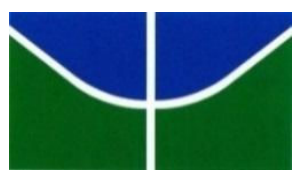

UNIVERSIDADE DE BRASÍLIA

INSTITUTO DE CIÊNCIAS BIOLÓGICAS

PROGRAMA DE PÓS-GRADUAÇÃO EM BIOLOGIA MICROBIANA

MORFOTAXONOMIA E FILOGENIA MOLECULAR DE PUCCINIALES DO CERRADO BRASILEIRO

ERICA SANTOS DO CARMO DE SOUZA

BRASÍLIA-DF 
Tese apresentada à Universidade de Brasília como requisito parcial para a obtenção do título de Doutora pelo Programa de Pós-Graduação em Biologia Microbiana.

Orientador: Prof. José Carmine Dianese

\section{BRASÍLIA-DF}

2016 
SOUZA, Erica Santos do Carmo

Morfotaxonomia e Filogenia Molecular de Pucciniales do Cerrado Brasileiro / Erica Santos do Carmo de Souza. - Brasília, DF [s.n.], 2016

Número de páginas p. 350: il.

Tese (doutorado). Instituto de Ciências Biológicas da Universidade de Brasília/ Programa de Pósgraduação em Biologia Microbiana.

Orientador: Dr. José Carmine Dianese

Bibliografia.

1. Micodiversidade. 2. Pucciniomycetes. 3. Análise Filogenética 4. Savana Brasileira

I. Título. II. Programa de Pós-graduação em Biologia Microbiana 
Trabalho realizado nos laboratórios dos Departamentos de Biologia Celular e Fitopatologia do Instituto de Ciências Biológicas da Universidade de Brasília, sob orientação do Professor José Carmine Dianese, com apoio da Coordenação de Aperfeiçoamento de Pessoal de Nível Superior (CAPES), do Conselho Nacional de Pesquisa e Desenvolvimento Tecnológico (CNPq), do Programa de Pesquisa em Biodiversidade (PPBio-Cerrado) e da Fundação de apoio à Pesquisa do Distrito Federal (FAPDF).

\title{
MORFOTAXONOMIA E FILOGENIA MOLECULAR DE PUCCINIALES DO CERRADO BRASILEIRO
}

\author{
ERICA SANTOS DO CARMO DE SOUZA
}

TESE APROVADA em 15 de dezembro de 2016 por:

Prof. Paulo Eduardo Aguiar Câmara

Examinador Externo

\section{Prof. Danilo Batista Pinho \\ Examinador}

\author{
Prof. Robert Neil Gerard Miller \\ Examinador
}

Prof. José Carmine Dianese

Orientador (Presidente)

\section{BRASÍLIA-DF}


Dedico este trabalho à minha família pelo amor incondicional, apoio e confiança. 
"As pessoas que vencem neste mundo, são as que procuram as circunstâncias de que precisam e, quando não as encontram, as criam."

(Bernard Shaw) 
Agradeço primeiramente a Deus pela minha vida, por ter me proporcionado integridade física e mental, por Ele abrir as portas para as minhas conquistas e por ser o condutor do meu caminho me dando uma vivência abençoada.

Ao meu orientador, Professor José Carmine Dianese, pela confiança em meu trabalho, pelos seus valiosos ensinamentos e por ser espelho de motivação e determinação pela carreira científica.

Ao professor Robert Neil Gerard Miller, pela amizade, ensinamentos e por disponibilizar o laboratório para a realização de parte deste trabalho.

À Universidade de Brasília, especialmente aos Departamentos de Fitopatologia e de Biologia Celular, pela oportunidade da execução deste trabalho.

À Coordenação de Aperfeiçoamento de Pessoal de Nível Superior (CAPES) pelo financiamento da bolsa de estudos.

Ao Conselho Nacional de Pesquisa e Desenvolvimento (CNPq) e ao Programa de Pesquisa em Biodiversidade - CNPq/MCTI (PPBio-Cerrado) pelo apoio financeiro ao projeto que possibilitou a realização da pesquisa.

À Fundação de Apoio à Pesquisa do Distrito Federal (FAPDF) pelo apoio nas despesas de publicações dos trabalhos em eventos nacionais e internacionais.

Ao Jardim Botânico de Brasília (JBB) e à Reserva Ecológica do Instituto Brasileiro de Geografia e Estatística (RECOR - IBGE) por autorizar a realização de coletas das plantas hospedeiras, contribuindo para a execução e êxito deste trabalho. 
Aos membros da banca examinadora: Prof. Robert Neil Gerard Miller, Prof. Danilo Batista Pinho, Prof. Paulo Eduardo Aguiar Câmara, Prof. Adalberto Corrêa Café Filho, pelas críticas que muito contribuíram para a melhoria do texto da tese.

Aos funcionários do Departamento de Fitopatologia: Kamila Araújo, Ribamar Frazão e, principalmente, ao José Cézar Castro pela amizade e por proporcionar condições favoráveis ao desenvolvimento deste trabalho e por me ajudar intensivamente nas coletas.

À Professora Mariza Sanchez (in memorian), ex curadora da Coleção Micológica do Herbário UB, por todo o seu carinho, cuidado e apoio para a realização deste trabalho.

Às alunas que realizaram estágio comigo: Monique Resende, Caroline Rodrigues e Fabíola Turiel, pela ajuda nas atividades rotineiras do laboratório e amizade conquistada.

Ao nosso grupo de estudos em Micologia: Bruno Souza, Débora Guterres, Leandro Agra, William Soares, Zuleide Chaves, Bianca Samay, Camila Pereira, Aline da Silva, Sérgio Zambrano, pela amizade, ajuda nas atividades de laboratório, coletas e pelo compartilhamento mútuo de conhecimentos.

À Glaucia Midorikawa, pela amizade, paciência e pelos ensinamentos técnicos na área molecular.

Ao Prof. José Elias (in memorian), Profa. Mariza Sanchez (in memorian), Prof. Juvenil Cares, Marcelo Kuhlmann e Jair Eustáquio pela ajuda na identificação das plantas hospedeiras.

À Ingrid e Shayene do laboratório de Microscopia Eletrônica de Varredura pela ajuda na execução das fotos.

Aos Professores dos Programas de Pós-graduação em Fitopatologia e de Pós-graduação em Biologia Microbiana, pela arte de ensinar e transferir experiências construtoras do caráter profissional, Adalberto Café, Beatriz Dolabela, Carlos Uesugi, Cecília Favali, Cláudio Costa, Cleber Furlanetto, Consuelo de Lima Danilo Pinho, Denise Vilela, Helson Vale, José Carmine Dianese, Juvenil Cares, Luiz Blum, Marisa Ferreira, Renato Resende, Ricardo Kruger, Rita de 
Cássia, Robert Miller e Tatsuya Nagata. A vocês, a minha admiração pela competência acadêmica.

À secretária Luciana Medeiros do IB pela amizade e ajuda nos processos burocráticos.

À Profa. e amiga Rita de Cássia pelo apoio e incentivo na área acadêmica e pessoal.

Ao Prof. Danilo Batista Pinho, pela amizade e ensinamentos relacionados aos trabalhos em filogenia molecular.

À Rafaela Borges, Pedro Verlage e Daniel Lage pelas amostras fúngicas coletadas e incluídas neste trabalho.

Ao William Soares pela amizade, parceria e incentivo, sobretudo nos momentos mais difíceis.

Aos amigos Justino Dias e Débora Guterres por sempre deixar o ambiente mais alegre e descontraído, pela amizade, apoio e pela prontidão em me ajudar sempre.

As amigas Fabiane Brito e Karina Nascimento, pela amizade e confiança.

As "migas" da UnB: Caroline Amaral, Catharine Abreu, Flávia Milene e Geisianny Augusta pelos grandes momentos de alegria, desabafos, conselhos e, principalmente, pela amizade e consideração.

Aos colegas de curso: Gláucia Figueiró, Daniela Rossato, Nancy Nino, Carina Lopes, Cristiano Silva, Cecília Rodrigues, Cléia Cabral, Luciane Reis, Josiane Goulart, Marcelo Rennó, Pollyana Hermenegildo, Elenice Barbosa e Maurício Rossato pela amizade e bons momentos de descontração.

Aos colegas do Laboratório de Interação Planta Praga (Microbiologia) do Departamento de Biologia Celular: Rosane Mansan e Gabriel Alves pela força, amizade e ajuda nas atividades do laboratório.

Aos meus amigos “Amanitas" Vanessa Alves, Thais Torquato, Milton Lima e Eduardo Lima por toda amizade verdadeira, bom humor e companheirismo. 
Ao meu amigo e incentivador Prof. Milton Lima, exemplo de empolgação, dedicação e amor à profissão. Muito obrigada por todos os conselhos, ensinamentos, motivação e pela ajuda nas coletas das plantas hospedeiras.

À minha mãe América e aos meus irmãos, Eduardo, Samuel, Simeão e Sizaltino, pelo amor incondicional, apoio e confiança em todos os momentos da minha vida.

Ao Helson Mário pelo carinho, companheirismo, conselhos, incentivo e apoio. Agradeço também pela companhia e ajuda na realização de algumas coletas.

À minha prima Edvânia por sempre me dar força e me apoiar, sobretudo nos momentos mais difíceis estando ao meu lado.

A minha tia Maria de Jesus e ao casal de primos Michele e Robson pela acolhida, admiração, incentivo e força em todos os momentos sempre colocando Deus a frente de tudo em nossas vidas.

Ao meu pai Sezinho pelas orações e torcida por meu sucesso.

A toda a minha família pela admiração e incentivo constante.

À minha amiga Raquel Alves, por compartilhar desafios, incertezas, e mais que isto, pelo companheirismo nas alegrias e tristezas, cumplicidade e crédito.

As amigas Eliane Lagasse e Daiane Aparecida, as quais tenho muita satisfação em compartilhar uma amizade intensa concretizada na confiança. Muito obrigada por torcerem e fazerem parte da minha história.

Aos meus padrinhos Izabel Lagasse e Edson Ferreira e a toda a nossa família, por todo cuidado, afeto e consideração.

A todos que de alguma maneira contribuíram para o êxito deste trabalho. 


\section{REVISÃO DE LITERATURA}

Tabela 1. Gêneros e espécies novas publicadas entre 1993-2016 em pesquisas desenvolvidas na Coleção Micológica do Herbário UB

Tabela 2. Número de espécies de Pucciniales pertencentes aos gêneros relatados no Brasil até 2016 . 22

\section{CAPÍTULO 1}

Tabela 1. Comparação entre coletas de Crossopsora byrsonimatis obtidas de diferentes espécies de Byrsonima...... 142

\section{CAPÍTULO 2}

Tabela 1. Espécies de Pucciniales do Cerrado e todas as outras espécies incluídas neste estudo utilizados na análise filogenética. .226

Tabela 2. Iniciadores utilizados para amplificação da região 28S do rDNA de Pucciniales.233

\section{CAPÍTULO 3}

Tabela 1. Números de acessos do GenBank de Uromyces hawkswothii e de todas as outras espécies incluídas no estudo

\section{CAPÍTULO 4}

Tabela 1. Iniciadores e respectivas temperaturas de anelamento utilizadas na PCR

Tabela 2. Acessos do GenBank de Colletotrichum truncatum (Endofítico e Acervular) e todas as outras espécies incluídas neste estudo

Tabela 3. Acessos do GenBank de Uromyces euphorbiae e de todas as outras espécies incluídas neste estudo 


\section{INTRODUCÃO GERAL}

Figura 1. Distribuição geral dos Biomas Brasileiros. 6

\section{REVISÃO DE LITERATURA}

Figura 2. Ciclo de vida macrocíclico heteroécio de Puccinia graminis tritici. 30

Figura 3. Cístron de genes e regiões espaçadoras do DNA ribossomal nuclear. 38

\section{CAPÍTULO 1}

Figura 4. Esquema adotado por Cummins \& Hiratsuka (2003) para facilitar a descrição dos espermogônios por meio de uma divisão em Grupos e Tipos e usado no presente trabalho....74

Figura 5. Designações e desenhos esquemáticos das fases assexuadas (écios e urédios) dos Paucciniales criados por Hiratsuka \& Hiratsuka (1980) e adotados por Cummins \& Hiratsuka (2003), para facilitar a descrição de famílias e gêneros e usados neste trabalho 75

Figura 6. Chaconia brasiliensis em folhas de Stryphnodendron adstringens. 80

Figura 7 (A-J). Chaconia ingae, fase assexual em folhas de Inga sessilis..... 83

Figura 8 (A-G). Chaconia ingae, fase sexual em folhas de Inga laurina. 84

Figura 9 (A-L). Chaconia maprouneae, forma assexual em folhas de Maprounea guianensis 86

Figura 10 (A-H). Aplopsora hennenii, fase uredínica em folhas de Qualea multiflora .... 90

Figura 11 (A-L). Kuehneola loeseneriana, fase uredínica em folhas de Rubus brasiliensis.. 97

Figura 12 (A-E). Skierka divinopolensis em folhas de Matayba guianensis. 101

Figura 13 (A-L). S. divinopolensis em folhas de Matayba guianensis. .102

Figura 14 (A-K). Kimuromyces cerradensis em folhas de Astronium fraxinifolium..... 107

Figura 15 (A-F). Forma espermogonial de Dasyspora gregaria em Xylopia aromatica . 112

Figura 16 (A-I). Formas ecídica e teliospórica de D. gregaria em Xylopia aromatica. 113

Figura 17 (A-H). Mimema venturae em Dalbergia micolobium. 117 
Figura 18 (A-H). Forma uredínica e télica de Porotenus memorae em Adenocalymma bipinnatum (=Memora bipinata)

Figura 19 (A-K). Prospodium impolitum em folha de Pyrostegia venusta.

Figura 20 (A-E). Forma uredínica de Phakopsora bluteri em folha de Kielmeyera coriácea 128

Figura 21 (A-D). Forma uredínica de Phakopsora chavesii em folhas de Terminalia phaeocarpa..... 130

Figura 22 (A-F). Fase uredínica de Phakopsora coca em folhas de Erythroxylum deciduum

Figura 23 (A-H). Batistopsora crucis-filii em folhas de Anonna tomentosa. 136

Figura 24 (A-H). Fase uredínica de Catenulopsora henneneae em folhas de Pouteria torta

Figura 25 (A-G). Fase uredínica de Crossopsora byrsonimatis em folhas de Byrsonima coccolobifolia......

Figura 26 (A-G). Crossopsora byrsonimatis em folhas de Byrsonima crassa

Figura 27 (A-D). Crossopsora byrsonimatis em folhas de Byrsonima crassa.

Figura 28 (A-K). Crossopsora byrsonimatis em folhas de Byrsonima verbacifolia teliósporos.

Figura 29 (A-K). Crossopsora byrsonimatis em folhas de Byrsonima laxiflora.. 150

Figura 30 (A-G). Crossopsora byrsonimatis em brotação jovem de Byrsonima pachyphylla

Figura 31 (A-F). Forma uredínica de Crossopsora hymeneae em folhas de Hymenaea stigonocarpa.

Figura 32 (A-H). Puccinia banisteriae em folhas de Banisteriopsis gardneriana. 157

Figura 33 (A-G). Puccinia barbatula em folhas de Heteropterys byrsonimifolia. 160

Figura 34 (A-G). Puccinia pipta em folhas de Piptocarpha macropoda. 163

Figura 35 (A-H). Puccinia pipta em folhas de Piptocarpha rotundifolia 164

Figura 36 (A-E). Puccinia arechavaletae em folhas de Serjania lethalis. 167

Figura 37 (A-F). Puccinia psidii em folhas de Syzygium cumini. 171

Figura 38 (A-F). Forma uredínica de Ravenelia geminipora em Platymaenia reticulata.... 179 
Figura 39 (A-G). Forma télica de Ravenelia geminipora em Platymaenia reticulata vista em microscopia de luz.

Figura 40 (A-G). Forma ecídica e télica de Ravenelia hieronymi em folhas de Acacia farnesiana vistas em microscopia de luz. 182

Figura 41 (A-J). Ravenelia sp. em folhas de Eriosema rigidum . 184

Figura 42 (A-J). Sphaerophragmium albiziae em folhas de Albizia lebeck. 187

Figura 43 (A-H). Diorchidium copaiferae em folhas de Copaifera langsdorffii 190

Figura 44 (A-G). Esalque holwayi em bagens de Poincianella ferrea. 193

Figura 45 (A-H). Cerradoa palmaea em folhas de Syagrus comosa. 196

Figura 46 (A-D). Desmella sp. em folha de Thelypteris sp. 198

Figura 47. Aecidium duguetiae em folhas de Duguettia furfuraceae. 200

Figura 48. (A-H). Uredo sp. em folhas de Pera glabrata. 202

Figura 49. (A-G). Uredo sp. em folhas de Pradosia brevipes 204

Figura 50. (A-G). Uredo sp. (UB 22345) em folhas de Solanum sp. 206

Figura 51. (A-D). Uredo sp. (UB22360) em folhas de Solanum sp. 207

\section{CAPÍTULO 2}

Figura 1. Localização dos iniciadores utilizados para amplificar uma região parcial do $28 \mathrm{~S}$ do rDNA. .233

Figura 2. Árvore filogenética inferida a partir da análise de Inferência Bayesiana com base nas sequências da região 28S do rDNA de representantes da ordem Pucciniales. .237

Figura 3. Representação da árvore filogenética de espécies da ordem Pucciniales subdividida em 6 setores. .238

Figura 4. Setor 1 da árvore filogenética mostrando em detalhe os clados de 1 a 4 e o subclado 5.1 do clado 5 . 240

Figura 5. Setor 2 da árvore filogenética ampliado mostrando em detalhe os subclados 5.2, 5.3 e 5.4 do clado 5 . Além disso também são mostrados os clados 6 e 7 . 245

Figura 6. Setor 3 da árvore filogenética ampliado mostrando em detalhe os clados de 8 a 13. 248 
Figura 7. Setor 4 da árvore filogenética ampliado mostrando em detalhe os clados 14 a 16.

Figura 8. Setor 5 da árvore filogenética ampliado mostrando em detalhe o clado 17.

Figura 9. Setor 6 da árvore filogenética ampliado mostrando em detalhe os clados 18 a 20 .

\section{CAPÍTULO 3}

Figura 1. Árvore filogenética inferida a partir da análise Bayesiana com base nas sequências de LSU de Uromyces e taxa relacionados. .270

Figura 2. Fase ecídica de Uromyces hawksworthii em folhas de Phthirusa stelis. .274

Figura 3. Fase telial de Uromyces hawksworthii (UB Mycol Col. 22875.) 275

\section{CAPÍTULO 4}

Figura 1. Árvore filogenética inferida a partir da análise de Máxima Verossimilhança e sob Inferência Bayesiana com base nas sequências concatenadas de ITS, TUB2, GAPDH e HIS de espécies do complexo $C$. truncatum e de espécies de Colletotrichum com conídios curvados. .293

Figura 2. Árvore filogenética inferida a partir da análise de Máxima Verossimilhança e sob Inferência Bayesiana com base nas sequências de LSU de Uromyces e taxa relacionados...296 Figura 3. Principais características de Colletotrichum truncatum em Euphorbia hirta........298 Figura 4. Fase ecial de Uromyces euphorbie em folhas de Euphorbia hirta .........................300 Figura 5. Uromyces euphorbiae em folhas de Euphorbia hirta........................................301 Figura 6. Colletotrichum truncatum e Uromyces euphorbiae em folhas de Euphorbia hirta. .304 


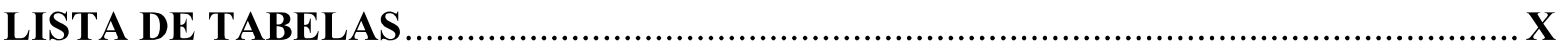

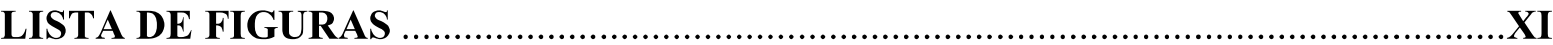

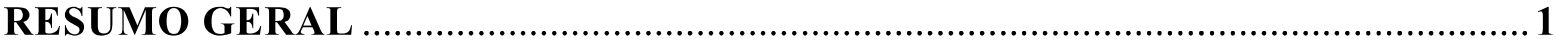

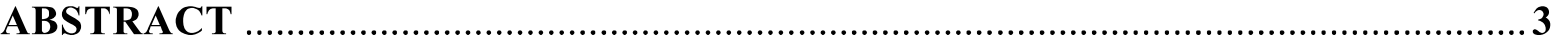

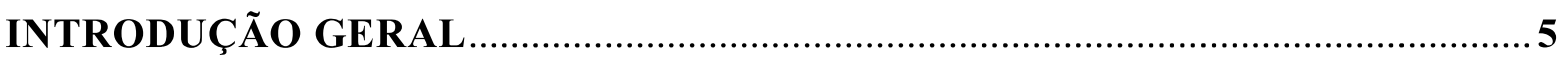

OBJETIVOS

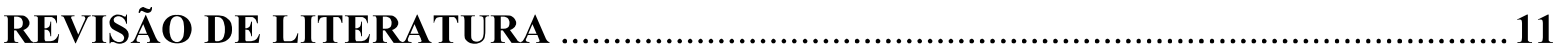

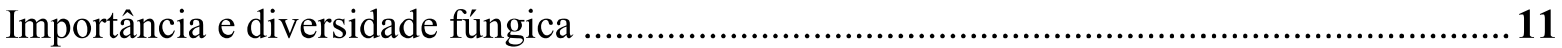

Os grandes repositórios de Pucciniales do Cerrado .........................................................25

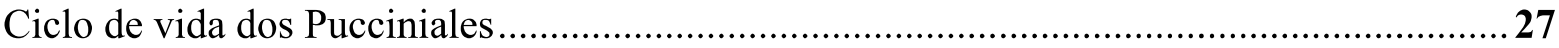

Parasitismo e Círculo de hospedeiros dos Pucciniales ............................................................31

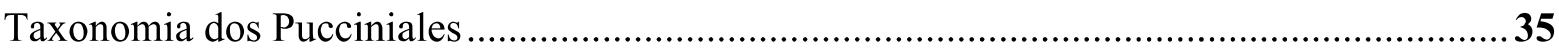

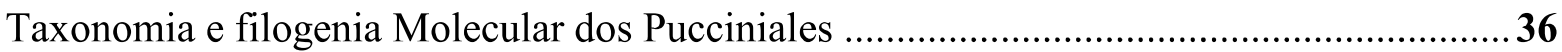

Taxonomia molecular e filogenia de Pucciniales............................................................... 41

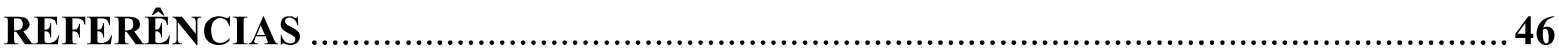

CAPÍTULO 1

CARACTERIZAÇÃO MORFOLÓGICA DOS PUCCINIALES DO CERRADO

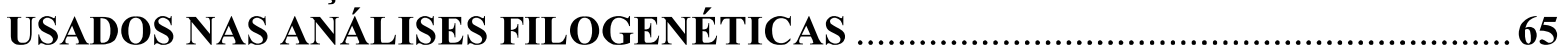

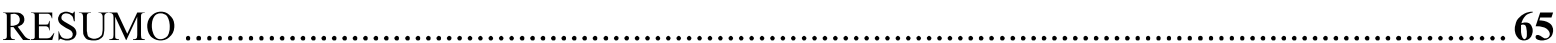

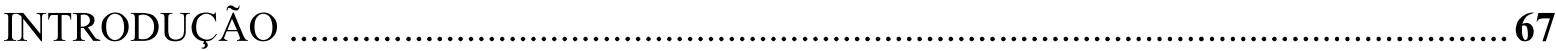

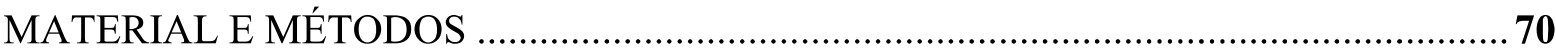

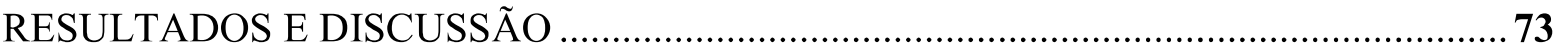

Membros da Família Chaconiaceae Cummins \& Y. Hiratsuka ..................................................76

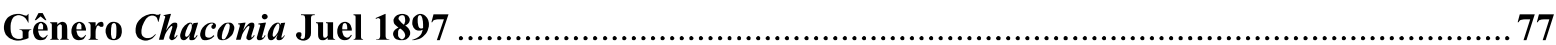




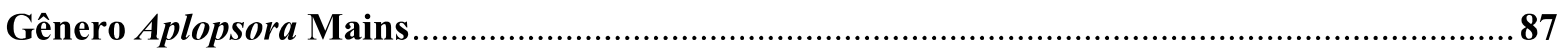

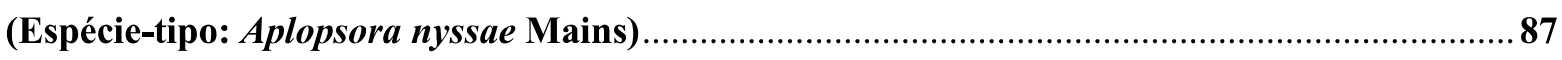

Membros da Família Phragmidiaceae Corda ...........................................................................

Kuehneola loeseneriana (=Uredo loeseneriana). Fig. 11 (A-L) .............................................94

Membros da Família Pileolariaceae (Arthur) Cummins \& Y. Hirats. no Cerrado .....................98

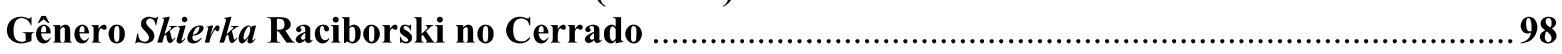

Membros da Família Uropyxidaceae (Arthur) Cummins \& Y. Hirats no Cerrado ................ 103

Gênero Kimuromyces Dianese, Santos, Medeiros \& C. Furlaneto …........................................103

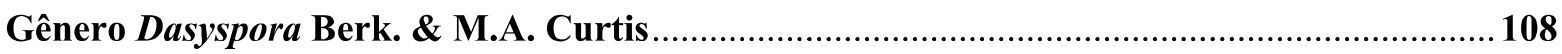

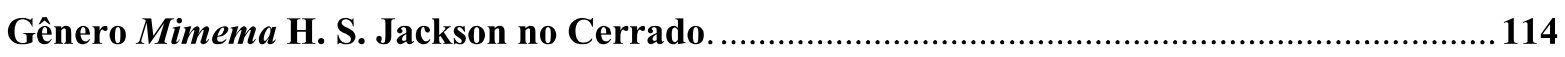

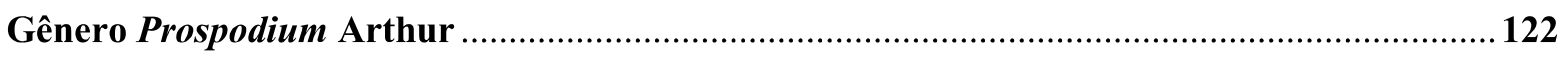

Membros da Família Phakopsoraceae (Arthur) Cummins \& Y. Hiratsuka ..............................125

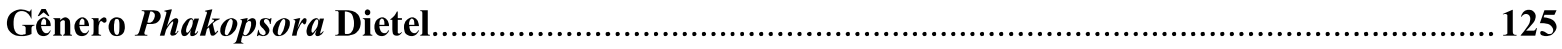

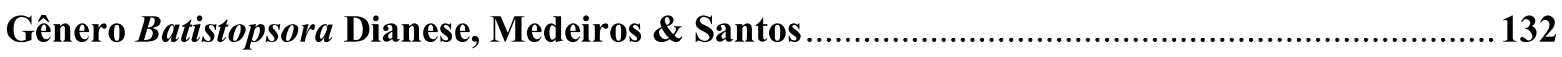

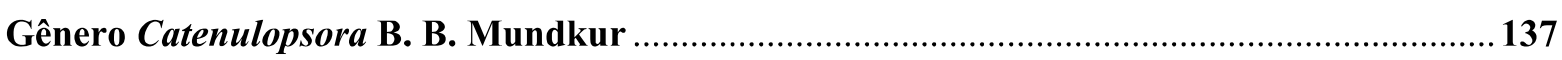

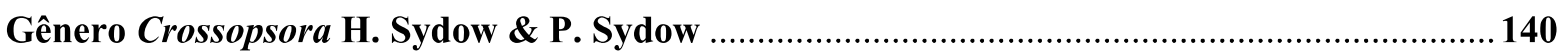

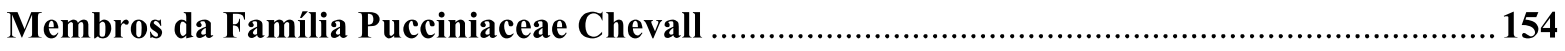

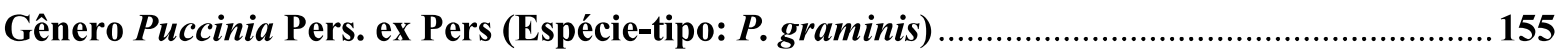

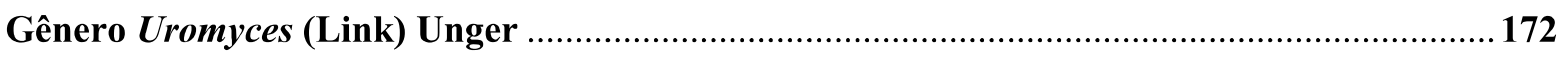

Membros da Família Raveneliaceae (= Sphaerophragmiaceae) .........................................173

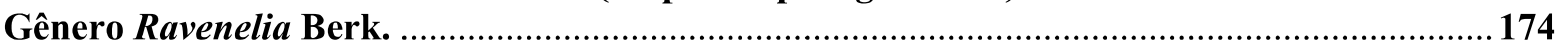

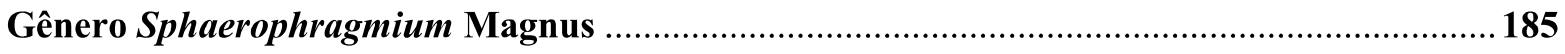

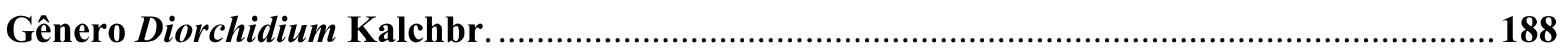

Gênero Esalque Hennen, Figueiredo \& Carvalho .................................................................. 191

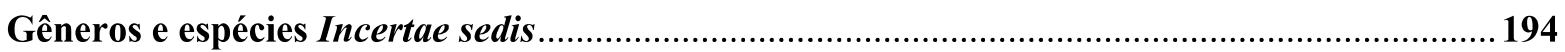

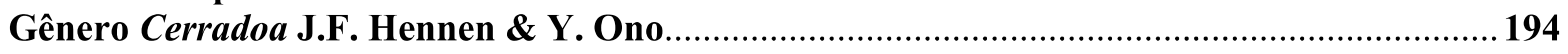

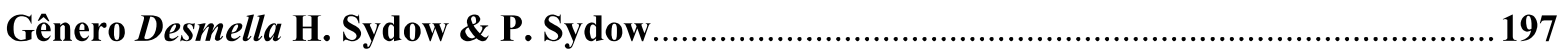

Formas assexuadas de Pucciniales incluídas na análise filogenética ........................................199

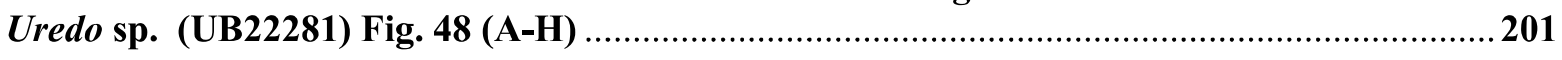

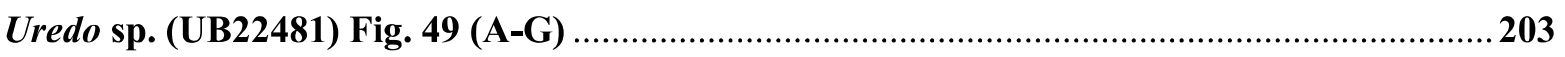




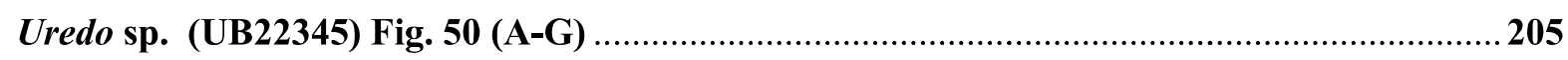

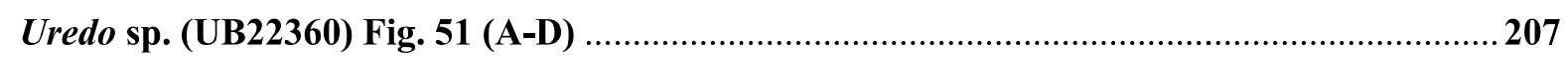

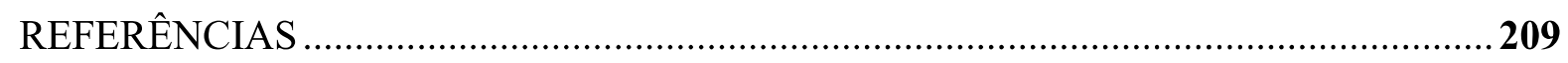

CAPÍTULO 2

RELACIONAMENTO FILOGENÉTICO DE ALGUNS PUCCINIALES DO

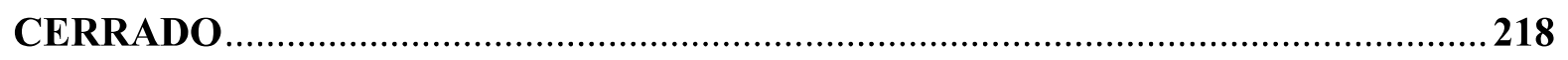

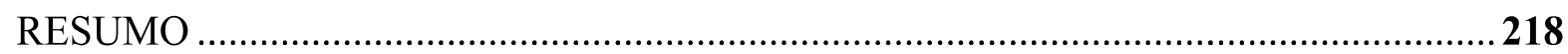

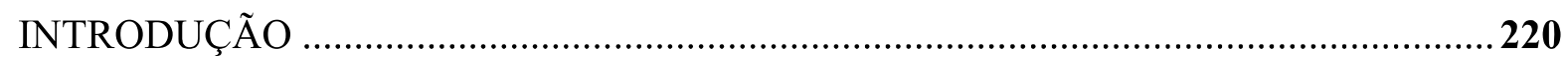

MATERIAL E MÉTODOS …....................................................................................... 225

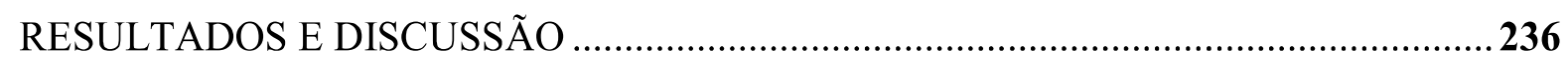

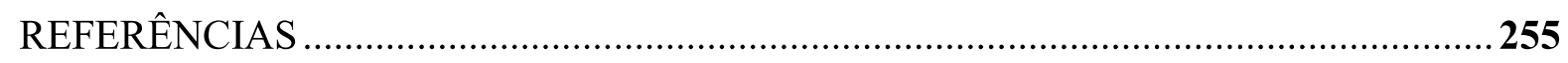

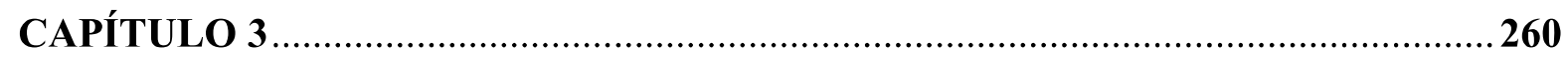

Uromyces hawksworthii UM NOVO NOME PARA Aecidium goyazense EM Phthirusa stelis (LORANTHACEAE) DO CERRADO BRASILEIRO (*) .............................. 260

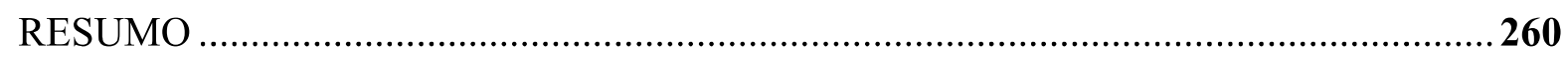

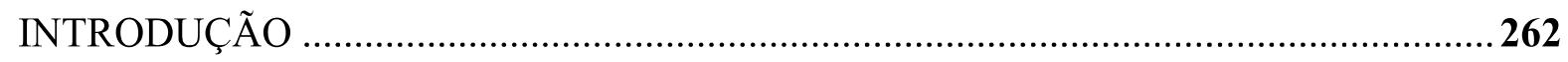

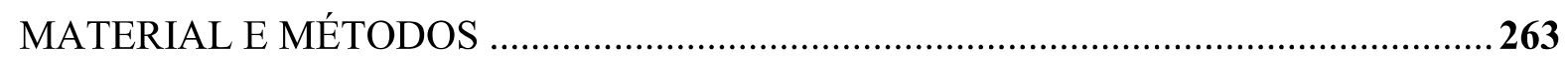

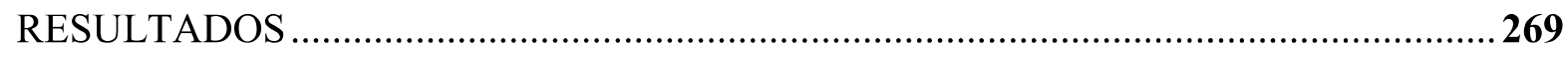

DISCUSSÃO

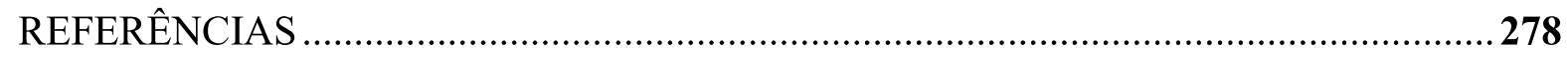

CAPÍTULO 4

INTERAÇÃO ENTRE Colletotrichum truncatum E Uromyces euphorbiae EM FOLHAS

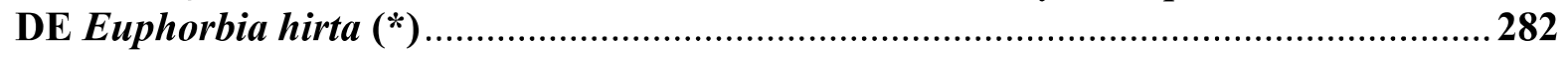


INTRODUÇÃO

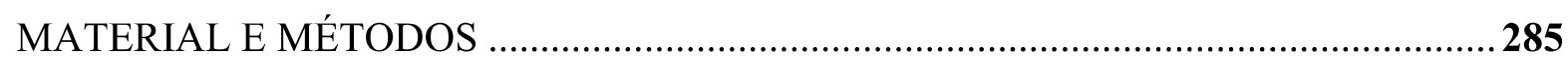

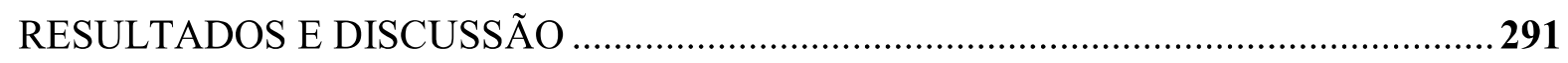

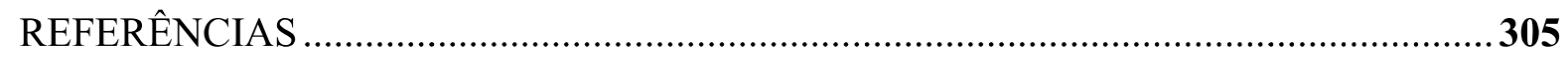

CONSIDERAÇÕES FINAIS E PERSPECTIVAS ...........................................................11

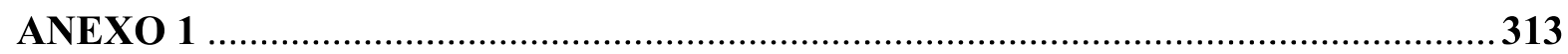

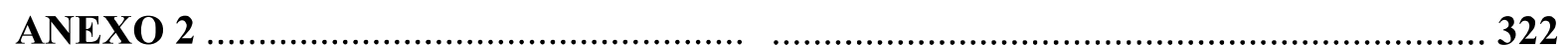


A ordem Pucciniales é um componente importante da micobiota do cerrado brasileiro, entretanto pouco se sabe sobre a sua diversidade e as informações até agora obtidas são quase que exclusivamente baseadas em aspectos morfológicos. Os estudos envolvendo a análise molecular e filogenética para fungos causadores de ferrugens no cerrado é escasso. Com o objetivo da ampliação do estudo em termos morfológicos bem como promover algum avanço em termos de suas relações filogenéticas, foram caracterizadas morfologicamente um total de 41 espécies de Pucciniales das quais destas 36 foram caracterizadas molecularmente, entre formas sexuadas e assexuadas, coletadas nos estados de Goiás, Mato Grosso, Maranhão, Minas Gerais e no Distrito Federal. No Cerrado, os fungos causadores de ferrugem foram encontrados em plantas hospedeiras das famílias Anacardiaceae, Annonaceae, Arecaceae, Asteraceae, Bignoniaceae, Clusiaceae, Combretaceae, Euphorbiaceae, Fabaceae, Lauraceae, Loranthaceae, Malpighiaceae Myrtaceae, Rosaceae, Sapindaceae, Sapotaceae, Solanaceae, Vochysiaceae e Thelypteridaceae. O trabalho consistiu na caracterização, ilustração e complementação de dados de vários espécimes já conhecidos ou não. Neste estudo foram incluídos membros representantes da família Pucciniaceae (Puccinia e Uromyces), Phakopsoraceae (Phakopsora, Batistopsora, Catenulopsora e Crossopssora), Raveneliaceae (Diorchidium, Esalque, Ravenelia e Sphaerophragmium), Uropyxidaceae (Dasyspora, Kimuromyces sp., Mimema, Porotenus e Prospodium) Chaconiaceae (Chaconia e Aplopsora), Pileolariaceae (Skierka) e Phragmidiaceae (Kuehneola). Além disso, foram incluídas no estudo espécies de classificação taxonômica incerta pertencentes aos gêneros Cerradoa e Desmella e alguns espécimes assexuais considerados simplesmente como Aecidium e Uredo. A análise filogenética foi realizada com base na região LSU do rDNA por meio de Inferência Bayesiana envolvendo os espécimes aqui estudados e demais retirados do GenBank 
relacionados filogeneticamente com as famílias e enraizada por Platygloea disciformis. Esta é a primeira vez que foi realizado um estudo baseado em análises moleculares filogenéticas de Pucciniales do cerrado numa dimensão ampla, envolvendo membros representantes de várias famílias. Aqui foi apresentada de forma inédita a caracterização molecular de vários espécimes fúngicos pertencentes a ordem Pucciniales encontradas em plantas endêmicas e introduzidas no cerrado que enriquecerá o banco de dados do NCBI e muito contribuirá para o estudo e compreensão da filogenia da ordem em estudos posteriores. De forma geral, os dados obtidos possibilitaram o entendimento do posicionamento filogenético de apenas alguns grupos em níveis de gênero e espécies como o caso de membros componentes da família Phakopsoraceae. No presente estudo a maioria das famílias de Pucciniales como Pucciniaceae, Raveneliaceae, Uropyxidaceae e Phakopsoraceae se mostraram polifiléticas, entretanto, os dados obtidos não foram suficientes para o esclarecimento das relações filogenéticas dos membros causadores de ferrugem do cerrado neste nível hierárquico dentro da ordem, havendo a necessidade de aprofundamento das análises filogenéticas principalmente com os grupos mais esclarecidos e atualização nomenclatural de alguns espécimes com classificação taxonômica indefinida. Além disso foi realizada caracterização morfo-molecular e nova nomeação de uma espécie de Uromyces encontrada em Phthirusa stelis (Loranthaceae) e um estudo sobre a interação entre $U$. euphorbiae com Colletotrichum truncatum, baseado em caracterização morfo-molecular de ambos os fungos envolvidos encontrados em folhas de Euphorbia hirta (Euphorbiaceae). Além de aumentar as informações sobre as espécies já conhecidas, o trabalho resultou em novos relatos de ocorrência de membros das Pucciniales em nova hospedeiras e novos locais, prováveis espécies novas, relatos de fase ou fases do ciclo de vida até então inéditas e, finalmente, algumas atualizações nomenclaturais e taxonômicas.

Palavras chave: Micodiversidade, Pucciniomycetes, Análise Filogenética e Savana Brasileira 
The order Pucciniales is an important component of Brazilian Cerrado micobiota, although few is known about its biodiversity and the existent information is almost exclusively based on morphological aspects. Studies of rust fungi involving molecular and phylogenetic analysis in the Cerrado are scarce. In order to increase the morphological knowledge and promote some advance in the understandment of their phylogenetic relationships, a total of 41 Pucciniales species were morphologically characterized, among which 36 were also mollecularly characterized, including sexual and assexual forms. The specimens were collected in the states of Goiás, Mato Grosso, Maranhão, Minas Gerais and Distrito Federal. In the Cerrado, the rust fungi were found inhabiting plants of the families Anacardiaceae, Annonaceae, Arecaceae, Asteraceae, Bignoniaceae, Clusiaceae, Combretaceae, Euphorbiaceae, Fabaceae, Lauraceae, Loranthaceae, Malpighiaceae Myrtaceae, Rosaceae, Sapindaceae, Sapotaceae, Solanaceae, Vochysiaceae and Thelypteridaceae. This study consisted in the characterization, illustration and complementation of data about many specimens previously known or unknown. In this study were included members of Pucciniaceae (Puccnia and Uromyces), Phakopsoraceae (Phakopsora, Batistopsora, Catenulopsora and Crossopsora), Raveneliaceae (Diorchidium, Esalque, Ravenelia and Sphaerophragmium), Uropyxidaceae (Dasyspora, Kimuromyces, Mimema, Porotenus and Prospodium) Chaconiaceae (Chaconia and Aplopsora), Pileolariaceae (Skierka) and Phragmidiaceae (Kuehneola). Besides, in this study they were included some species of uncertain taxonomic classification belonging to the genera Cerradoa and Desmella and some assexual specimens simply considered as Aecidium and Uredo. The phylogenetic analysis based on LSU region of rDNA was realized using Bayesian Inference and included the specimens studied here and more related species obtained from GenBank and the tree was 
rooted with Platygloea disciformis. This is the first time that a broad study based on molecular and phylogenetic analysis of Pucciniales from Cerrado is realized, including representative members of many families. Here it was presented the molecular characterization of many fungal specimens belonging to Pucciniales inhabiting endemic and exotic plants in the Cerrado, which will enrich NCBI database and contribute to study and comprehension of phylogeny of this order in posterior studies. In general, the data obtained enabled the understandment about phylogenetic placement of some groups at genera and species level, as observed in Phakopsoraceae. The majority of families as Pucciniaceae, Raveneliaceae, Uropyxidaceae and Phakopsoraceae were poliphyletic, although data were insufficient to clarify the phylogenetic relationship among rust fungi at this taxonomic level. So, it is necessary to intensify the phylogenetic analysis specially with groups more clarified and to update the nomenclature of some specimens with uncertain taxonomic classification. Furthermore, it was realized the morpho-molecular characterization and naming of a new species of Uromyces founded in Phthirusa stelis (Loranthaceae) and the study of interaction between $U$. euphorbiae and Colletotrichum truncatum based on morpho-molecular characterization of both fungi inhabiting leaves of Euphorbia hirta (Euphorbiaceae). In addition to increase the disponible information about species already known, this study resulted in new records of occurence of Pucciniales in new hosts and locals, problable new species, record of stadium or life cycle stadium unknown until now and, finally, some nomenclatural and taxonomic actualizations.

Key words: Mycodiversity, Puccniomycetes, Phylogenetic Analysis, Brazilian Savanna 
No Brasil, estudos sobre diversidade microbiana são limitados em escopo, inclusive os que se referem aos fungos. Poucos trabalhos fazem referência à riqueza das espécies de fungos que compõem a microbiota dos biomas nacionais. Muitas áreas nunca foram exploradas e, certamente, um grande número de novas espécies ainda serão relatadas, descritas e taxonomicamente definidas. Um dos biomas brasileiros onde pouco se conhece sobre a diversidade fúngica é o Cerrado (Forzza et al. 2010), apesar dos esforços mais recentes onde vários gêneros e mais 150 espécies novas foram descritas pelos pesquisadores da Universidade de Brasília a partir de 1993, conforme sumarizado em Dianese et al. (1997) e Véllez-Zambrano (2016). O Bioma Cerrado é a maior savana da América do Sul. Localizado na região central do Brasil é o segundo maior bioma do país, superado apenas pela Floresta Amazônica, ocupando originalmente mais de dois milhões de $\mathrm{km}^{2}$ (23 \% de toda a área do país) e abrangendo uma área contínua do Distrito Federal e dos estados de Goiás, Mato Grosso do Sul, Mato Grosso, Minas Gerais, São Paulo e Tocantins; uma parte dos estados da Bahia, Ceará, Rondônia, sul do Maranhão e do Piauí e áreas isoladas ao norte do Amapá, Amazonas, Pará e Roraima, contendo também áreas isoladas no Paraná (Ribeiro \& Walter 1998) (Figura 1).

O clima mostra duas estações bem definidas, uma seca e uma chuvosa com precipitação média anual de 1500 mm, com grandes variações intra-regionais (Klink et al. 1995).

A região do Cerrado exibe uma enorme heterogeneidade espacial, estendendo-se por mais de 20 graus de latitude, com altitudes variando de quase 0 a 1800 metros. A área do 


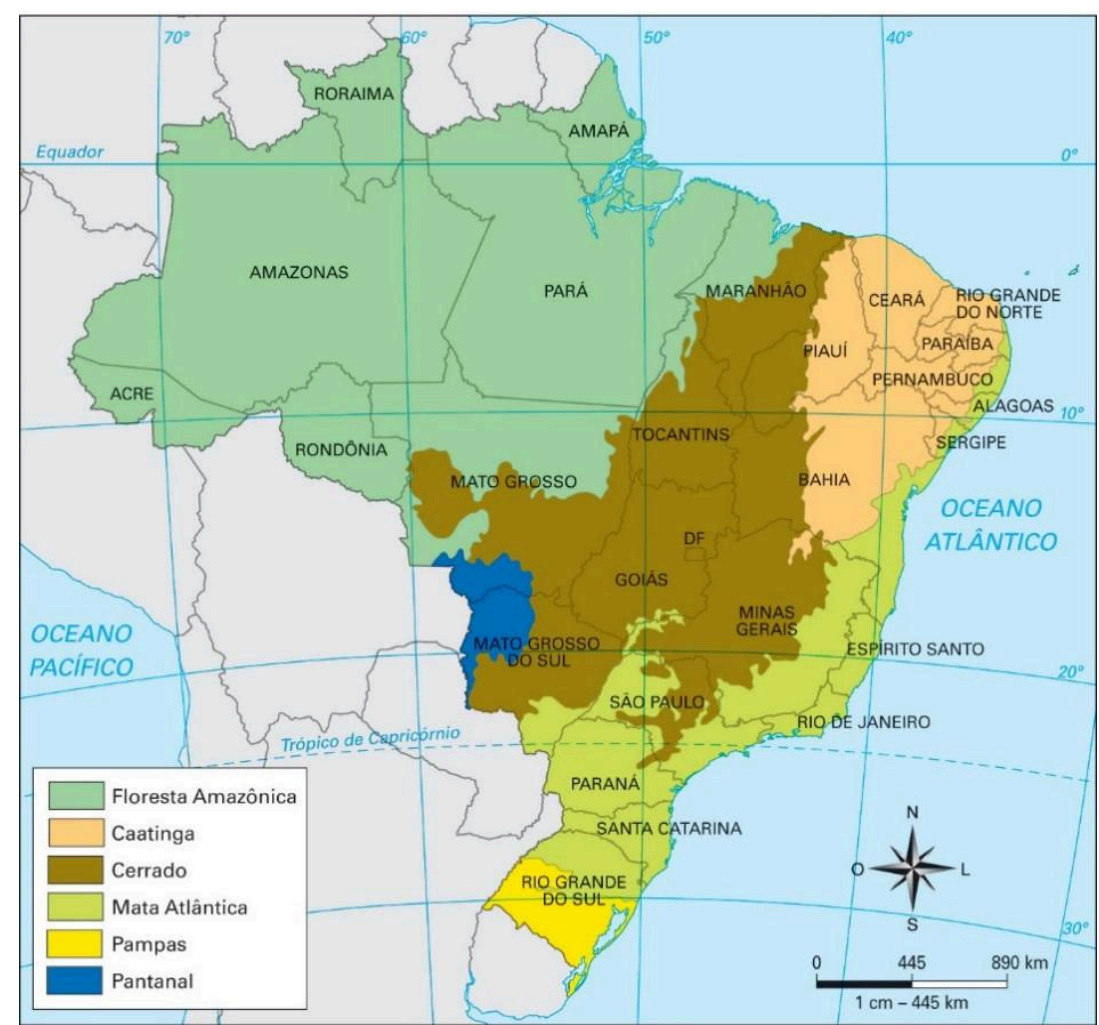

Figura 1. Distribuição geral dos Biomas Brasileiros. Encontrado em https://s-media-cacheak0.pinimg.com/originals/50/0a/6f/500a6f3ddba117196fce114e3f6e34a2.jpg. Acesso em dezembro de 2016.

Cerrado compõe diferentes bacias hidrográficas (Amazonas, Tocantins, Paraná, Paraguai, São Francisco e Parnaíba) e exibe uma grande diversidade de solos e climas que se refletem numa vasta e diversa biota (Cole 1986, Ribeiro \& Walter 2008). Este importante bioma abriga um rico patrimônio de recursos naturais adaptados às condições climáticas e edáficas que determinam a sua existência O Cerrado é uma savana tropical na qual uma vegetação rasteira, formada principalmente por gramíneas, coexiste com árvores e arbustos esparsos (Klink et al. 1995).

Esse bioma constitui a maior savana tropical do mundo em termos de diversidade apresentando 44\% de suas espécies endêmicas de plantas lenhosas (Klink \& Machado 2005). O Cerrado latu sensu apresenta vegetação com plantas lenhosas e aparência tortuosa com 
troncos e galhos retorcidos constituindo cerca de $12 \%$ de toda a flora brasileira (Ribeiro \& Walter 1998). Possui diversidade estimada em 12.000 espécies de plantas nativas vasculares já catalogadas sendo 4.400 endêmicas (Mendonça et al. 1998, Mendonça et al. 2008, MMA 2016).

Dentre as plantas do Cerrado, algumas possuem potencial econômico, podendo ser domesticadas e cultivadas para produção de alimentos, a exemplo do Pequi (Caryocar brasiliense), Maracujás nativos (Passiflora spp.), Cagaita (Eugenia dysenterica), Pêra-docerrado (Eugenia klostzchiana), Gabiroba (Campomanesia spp.), Pitanga-do-cerrado (Eugenia lutescens), Araçá (Psidium firmum), Jatobá (Hymenaea stigonocarpa), Mangaba (Hancornia speciosa), Bacupari (Salacia crassifolia), Cajuzinho do cerrado (Anacardium humile), Araticum (Annona crassifolia) e Barú (Dipteryx alata), entre outros. Além disso, mais de 200 espécies de plantas do Cerrado possuem uso como medicinal (Guarim-Neto \& Morais 2003). Acima de 400 espécies podem ser usadas na recuperação de solos degradados, como barreiras contra o vento, proteção contra a erosão, ou para criar habitat para a proliferação de predadores naturais de pragas (MMA 2016). Em contrapartida, plantas exóticas de interesse agronômico e ornamental, são comumente introduzidas no Cerrado tornando-se hospedeiras alternativas de vários fungos associados a plantas do Cerrado, como é o caso de Puccinia psidii, fungo oriundo do Neotrópico, causando ferrugem em Eucalipto (Eucalyptus spp.), Jambeiro rosa (Syzygium malaccense), Jamelão (S. cumini) e outras mirtáceas (Dianese et al. 1984, Dianese et al. 1984, Tessmann et al. 2001).

Os solos do Cerrado são profundos e bem drenados, ácidos e de baixa fertilidade, com altos níveis de ferro e alumínio. A paisagem apresenta relevos relativamente suaves, aptos à mecanização agrícola e florestal, favorecendo o processo de agricultura comercial e implantações florestais para fins econômicos (Bayma et al. 2003). 
A atividade agropecuária tem aumentado intensivamente no Cerrado nas últimas quatro décadas, resultando em uma extensa conversão e fragmentação dos espaços naturais. Aproximadamente $80 \%$ das áreas originais já sofreram alterações de alguma forma, restando apenas $20 \%$ totalmente preservada. Esta exploração desenfreada constitui algumas consequências como perdas da biodiversidade, invasão de espécies exóticas, erosão do solo, poluição de aquífero, degradação de ecossistemas, alterações no regime de queimadas e possivelmente alterações climáticas regionais. De acordo com Prevedello \& Carvalho (2006) estima-se que o Cerrado pode desaparecer até 2030, se medidas sustentáveis não forem tomadas.

Diante deste cenário, o Cerrado juntamente com a Mata Atlântica é considerado um hotspot mundial de biodiversidade por ser um dos biomas mais ricos e, também, um dos mais ameaçados do mundo (Myers et al., 2000).

Apesar do reconhecimento de sua importância biológica, de todos os hotspots mundiais, o Cerrado possui a menor porcentagem de áreas sob proteção integral. O Bioma apresenta $8,21 \%$ de seu território legalmente protegido por unidades de conservação; desse total, 2,85\% são unidades de conservação de proteção integral, 5,36\% unidades de conservação de uso sustentável, sendo que $0,07 \%$ dessas últimas são RPPNs - Reservas Particulares do Patrimônio Natural (MMA 2016).

Devido à ocupação antrópica acentuada nas últimas décadas, a degradação do Cerrado está acontecendo rapidamente e é provável a perda de ampla faixa da diversidade de plantas ali existentes e, consequentemente, imensusável perda da diversidade fúngica neste bioma, incapaz de sobreviver com a remoção das plantas hospedeiras (Ribeiro \& Walter, 1998). Juntamente com a vegetação, os fungos sofrem os mesmos efeitos associados a ela e ao solo do Cerrado. Portanto, estudos sobre as espécies fúngicas associadas a plantas nativas do 
Cerrado, têm grande urgência, pois muitas espécies para existir dependem das plantas hospedeiras.

Entre essas espécies destacam-se especialmente os fungos biotróficos, com destaque para os causadores de ferrugens pertencentes a ordem Pucciniales, parasitas de um grande números de espécies nativas do Cerrado. Cabe lembrar que a especificidade por hospedeira varia com fungos capazes de afetar espécies de diferentes gêneros, dentro de uma mesma família (e.g. P. psidii / família Myrtaceae), no entanto, na maioria dos casos a competência patogênica é limitada a uma única espécie hospedeira.

Sendo assim, uma vez que essas plantas hospedeiras endêmicas para o Cerrado encontram-se ameaçadas de extinção, os Pucciniales a elas associados também estarão correndo o risco de serem extintos, até mesmo antes de serem detectados e revelados à ciência.

Dados da Coleção Micológica do Herbário UB (Dianese 2000), revelam que membros da ordem Pucciniales mostram a maior incidência, entre os fungos biotróficos associados a plantas nativas do Cerrado, tornando clara a necessidade urgente de um estudo intensivo e moderno dessa importante fração da micobiota desse importante bioma. 


\section{GERAL}

- Ampliar o conhecimento sobre diversidade, taxonomia e filogenia dos fungos causadores de ferrugens (Pucciniales) em plantas nativas do Cerrado.

\section{ESPECÍFICOS}

- Identificar e posicionar filogeneticamente os espécimes de ferrugens coletados sobre plantas do Cerrado, com base em sequências da LSU do rDNA.

- Conduzir análise filogenética dos Pucciniales presentes no Cerrado com ênfase em espécies associadas a plantas endêmicas presentes neste Bioma.

- $\quad$ Estabelecer suas relações evolutivas utilizando os dados de sequências obtidas com os marcadores moleculares utilizados.

- Contribuir para o esclarecimento das relações co-evolutivas dos membros de Pucciniales e suas respectivas plantas hospedeiras.

- $\quad$ Ilustrar cada espécie estudada com fotos de alto padrão.

- Identificar, descrever e publicar possíveis novos taxa ou ocorrências de Pucciniales em plantas nativas e cultivadas no Cerrado com suporte de dados morfológicos e moleculares. 


\section{Importância e diversidade fúngica}

Os fungos são importantes para indústria alimentícia na fabricação de bebidas como cervejas e vinhos, na fabricação de queijos e fermentos para bolos e pães e no consumo de cogumelos comestíveis .

$\mathrm{Na}$ área médica e farmacêutica atuam como causadores de doenças graves em pessoas com imunidade baixa podendo levar a morte. São causadores de micoses em humanos e animais, porém, em contrapartida, são utilizados como componentes de vários medicamentos.

Em biotecnologia são potenciais produtores de metabólitos úteis, utilizados na fermentação para a produção de álcool.

Para a agricultura são potencialmente importantes no controle biológico de insetos, nematoides, aracnídeos, plantas invasoras e outros fungos. Além disso, estabelecem associações micorrízicas com várias famílias de plantas e também em simbioses com insetos. Entretanto, são responsáveis por mais de $70 \%$ das doenças em plantas cultivadas, são causadores de podridão em madeiras, além de gerar micotoxinas em grãos armazenados, nocivas ao homem e aos animais.

Ecologicamente, são os maiores responsáveis pela degradação e ciclagem de matéria orgânica (Alexopoulos et al. 1996, Maia \& Carvalho Júnior 2010, Cantrell et al., 2011).

A diversidade global de fungos é estimada de várias maneiras, variando de 1,5 milhões de espécies (Hawkswoth 1991, 2012), até aproximadamente 5,1 milhões (Blackwell 2011), com apenas aproximadamente 135.000 conhecidas e catalogadas (Mora et al., 2011; Hibbett et al., 2016). Lewinsohn \& Prado (2005) estimaram o número de espécies de fungos conhecidas no Brasil em cerca de 15.000 e estimaram o total para o país de aproximadamente 
264.000. Forzza et al. (2010) registraram 78 ordens, 924 gêneros e 3.608 espécies de fungos, sendo que Minter \& da Silva (2007) listaram 4.325 espécies de fungos estudados apenas por Augusto Chaves Batista e colaboradores.

Segundo Maia et al. (2015), foram relatadas para o Brasil, 5.719 espécies de fungos distribuídas em 1.246 gêneros e 102 ordens, consistindo em considerável aumento em relação a 2010. A maioria das espécies pertencem aos filos Basidiomycota $(2.741$ espécies, em 22 ordens) e Ascomycota (1.881 espécies, em 41 ordens). A Mata Atlântica possui a maior quantidade de registros, com 3.017 espécies, seguido pela Amazônia (1.050), Caatinga (999), Cerrado (638), Pampa (84) e Pantanal e (35). A região Nordeste tem a maior riqueza (2.617 espécies), seguida pelo Sudeste (2.252), Sul (1.995), Norte (1.301) e Centro-Oeste (488 espécies). Em relação aos Estados da Federação, São Paulo (1.846 espécies), Pernambuco (1.611) e Rio Grande do Sul (1.377) possuem o maior número de espécies conhecidas.

Hennen et al. (2005) demostraram que a diversidade dos Pucciniales em diferentes biomas brasileiros é incontestável, com base na realização de inventários em todos os tipos de vegetação, desde o semi-árido às florestas tropicais e equatoriais, incluindo o Cerrado.

O conhecimento da micobiota em diferentes habitats no bioma Cerrado está em expansão, com estudos incluindo leveduras, fungos filamentosos e endofíticos, em frutos e folhas de plantas do Cerrado (Sperandio 2012, Sperandio et al., 2015). Mais recentemente, surgiram estudos envolvendo metagenômica (Castro et al. 2008, Castro et al. 2016, Bruce et al. 2012, Araújo et al. 2012), a partir de amostras ambientais da comunidade microbiana do solo de diferentes fitofisionomias do Cerrado.

Valência \& Chambergo (2013) descreveram o progresso na pesquisa micológica brasileira com ênfase nas espécies produtoras de enzimas com potencial para a degradação da biomassa e aplicação produção de bioenergia. 
Seguramente uma grande contribuição para os estudos da micodiversidade do Cerrado foi realizada pela Universidade de Brasília com início em meados de 1993 (Dianese et al. 1993, Dianese et al. 1997, Véllez-Zambrano 2016), conforme mostra a Tabela 1. Com o apoio da Fundação Banco do Brasil e do Conselho Nacional de Desenvolvimento Científico e Tecnológico (CNPq) foi implantada a Coleção Micológica do Herbário UB (UB Col Micol), atualmente com mais de 23.000 exsicatas. A grande maioria do acervo da UB Col Micol está ainda em fase de estudo, com grande parte do material classificado apenas em termos de grandes grupos (basidiomicetos, ascomicetos e suas formas conidiais). 
Tabela 1. Gêneros e espécies novas publicadas entre 1993-2016 em pesquisas desenvolvidas na Coleção Micológica do Herbário UB.

\begin{tabular}{|c|c|}
\hline & Espécies-tipo de gêneros novos \\
\hline 1 & Batistopsora crucis-filli Dianese, Medeiros \& Santos, $1993^{3} \bullet$ \\
\hline 2 & Chaetothyriomyces brasiliensis Pereira-Carvalho, Dornelo-Silva, Inácio \& Dianese 200926 \\
\hline 3 & Echinocodiophorum cerradense Pereira-Carvalho \& Dianese $2009^{33}$ \\
\hline 4 & Globoconidiopsis cerradensis Sepúlveda-ChaveraPereira-Carvalho \& Dianese 200933 \\
\hline 5 & Globoconidium cerradense Sepúlveda-Chavera, Pereira-Carvalho \& Dianese, $2009^{33}$ \\
\hline 6 & Helminthosporiomyces cerradensis Sepúlveda-Chavera, Pereira-Carvalho \& Dianese $20099^{33}$ \\
\hline 7 & Plurispermiopsis cerradensis Pereira-Carvalho, Inácio \& Dianese $2009^{35}$ \\
\hline 8 & Kimuromyces cerradensis Dianese, Santos, Medeiros \& Furlaneto $1995^{7} \bullet$ \\
\hline 9 & Phaeostilbelloides velloziae Armando, Z.M Chaves \& Dianese $2015^{46}$ \\
\hline 10 & Phragmoconidium cerradense Sepúlveda-Chavera, Pereira-Carvalho \& Dianese $2009^{33}$ \\
\hline 11 & Trichomatomyces byrsonimae Dornelo-Silva \& Dianese $2004^{29}$ \\
\hline 12 & Trichosporodochium cerradensis Dornelo-Silva \& Dianese $2004^{23}$ \\
\hline 13 & Trichomatoclava cerradensis Sepúlveda-Chavera, Pereira-Carvalho \& Dianese 200933 \\
\hline 14 & Trichomatosphaera cerradensis Pereira-Carvalho, Sepúlveda-Chavera \& Dianese 200933 \\
\hline 15 & Velloziomyces ramosiconidialis Armando, Z.M Chaves \& Dianese $2015^{46}$ \\
\hline 16 & Vesiculohyphomyces cerradensis Armando, Pereira-Carvalho \& Dianese $2009^{33}$ \\
\hline \multirow[t]{2}{*}{17} & Wilmia brasiliensis Dianese, Inácio \& Dornelo-Silva, 200125 \\
\hline & Novos táxons \\
\hline 1 & Alternaria qualeae Dornelo-Silva \& Dianese $2003^{16}$ \\
\hline 2 & Anhelia tabebuiae Inácio \& Dianese $1998^{1}$ \\
\hline 3 & Aplopsora hennenii Dianese \& Santos $1995^{2} \bullet$ \\
\hline 4 & Asperisporium galactiae A Hern.-Gut., Z.M Chaves \& Dianese $2015^{45}$ \\
\hline 5 & Asteriolibertia bahiensis Firmino, Inácio \& Dianese $2015^{44}$ \\
\hline 6 & Asteriolibertia barrinhensis Firmino, Inácio \& Dianese $2015^{44}$ \\
\hline 7 & Asteriolibertia campograndensis Firmino, Inácio \& Dianese $2015^{44}$ \\
\hline 8 & Asteriolibertia licaniae Firmino, Inácio \& Dianese $2015^{44}$ \\
\hline 9 & Asterolibertia parinaricola Firmino, Inácio \& Dianese $2015^{44}$ \\
\hline 10 & Camarotella brasilienses Souza, Vitória, Bezerra, Luz, Inácio \& Dianese $2008^{31}$ \\
\hline 11 & $\begin{array}{l}\text { Cercospora jatrophyphila A Dianese, Vale, ECS Souza, Pereira-Carvalho, ZM Chaves, PEC Câmara, } \\
\text { Dianese } 41\end{array}$ \\
\hline 12 & Cercospora mimosae-sensitivae Hern.-Gut \& Dianese $2009^{34}$ \\
\hline 13 & Cercospora ochromae Hern.-Gut \& Dianese $2008^{27}$ \\
\hline 14 & Cercospora tabebuia-impetiginosae Inácio \& Dianese $1998^{1}$ \\
\hline 15 & Cerotelium giacometii Dianese, Santos \& Medeiros $1993^{3}$ \\
\hline 16 & Cirsosia splendida var laevigata Firmino, Inácio \&Dianese $2015^{44}$ \\
\hline
\end{tabular}




\begin{tabular}{|c|c|}
\hline 17 & Coniella costae Dianese, Medeiros, Santos \& Sutton $1993^{4}$ \\
\hline 18 & Crinipellis brasiliensis Arruda, Sepúlveda, Miller, Ferreira \& Felipe 200528 \\
\hline 19 & Crossopsora hymenaeae Dianese, Buriticá \& Hennen $1994{ }^{5} \bullet$ \\
\hline 20 & Dictyonella tabebuiae Inácio \& Dianese $1998^{1}$ \\
\hline 21 & Dinemasporium duguetia Furlanetto \& Dianese $1998^{6}$ \\
\hline 22 & Dothidasteroma psidii Inácio, Pereira-Carvalho, Souza \& Dianese ${ }^{36}$ \\
\hline 23 & Fumagospora tabebuiae Inácio \& Dianese $1998^{1}$ \\
\hline 24 & Harknessia qualeae Furlanetto \& Dianese $1998^{6}$ \\
\hline 25 & Harknessia salvertiana Furlanetto \& Dianese $1998^{6}$ \\
\hline 26 & Janetia salvertia Dornelo-Silva \& Dianese $2003^{16}$ \\
\hline 27 & Meliola albiziae-polyanthae Soares \& Dianese $2013^{38}$ \\
\hline 28 & Meliola andirae-humilis Soares \& Dianese $2013^{38}$ \\
\hline 29 & Meliola bodoquenensis Soares \& Dianese $2013^{38}$ \\
\hline 30 & Meliola eriosemae Soares \& Dianese $2013^{38}$ \\
\hline 31 & Meliola sweetiae Soares \& Dianese $2013^{38}$ \\
\hline 32 & Mimema venturae Dianese, Santos, Medeiros \& Sanchez $1994^{8} \bullet$ \\
\hline 33 & Mycovellosiella micranthae (Müller \& Chupp) Dianese \& Furlanetto $1996^{19}$ \\
\hline 34 & Mycovellosiella myracrodruonis Inácio \& Dianese $1999^{9}$ \\
\hline 35 & Mycovellosiella peixotae (Chupp \& Viégas) Furlanetto \& Dianese $1996^{19}$ \\
\hline 36 & Parastenella callisthenis-fasciculatae Dornelo-Silva, Pereira-Carvalho \& Dianese 200729 \\
\hline 37 & Passalora acosmii Hern.-Gut \& Dianese $2009^{34}$ \\
\hline 38 & Passalora brasilianensis A Hern.-Gut \& Dianese $2013^{39}$ \\
\hline 39 & Passalora caesalpiniae (Bhalla, Sarbhoy, Kulshr \& Kushwaha) Braun, Dianese \& Hern.-Gut $2009^{38}$ \\
\hline 40 & Passalora cerradensis A Hern-Gut \& Dianese $2013^{39}$ \\
\hline 41 & Passalora chamaecristae-orbiculatae Hern.-Gut \& Dianese $2009^{38}$ \\
\hline 42 & Passalora chamaecristicola Hern.-Gut \& Dianese $2009^{34}$ \\
\hline 43 & Passalora chapadensis A Hern.-Gut \& Dianese $2013^{40}$ \\
\hline 44 & Passalora dalbergiae (S.K Singh \& P.N Singh) U Braun, Dianese \& A Hern.-Gut $2009^{34}$ \\
\hline 45 & Passalora delamonicae A Hern.-Gut \& Dianese $2013^{40}$ \\
\hline 46 & Passalora eitenii Medeiros \& Dianese $1994^{10}$ \\
\hline 47 & Passalora guimaranhensis A Hern.-Gut \& Dianese $2013^{40}$ \\
\hline 48 & Passalora machaerii Hern.-Gut \& Dianese $2009^{34}$ \\
\hline 49 & Passalora peixotae-reticulatae A Hern-Gut \& Dianese 201339 \\
\hline 50 & Passalora peixotoae-goianae A Hern.-Gut \& Dianese $2013^{39}$ \\
\hline 51 & Passalora qualeae Dornelo-Silva \& Dianese $2003^{16}$ \\
\hline 52 & Passalora schefflerae Hern.-Gut \& Dianese $2008{ }^{27}$ \\
\hline 53 & Passalora tabebuiae-ochraceae Inácio \& Dianese $2006^{30}$ \\
\hline 54 & Periconiella campograndensis Dornelo-Silva \& Dianese $2003{ }^{16}$ \\
\hline
\end{tabular}




\begin{tabular}{|c|c|}
\hline 55 & Periconiella longispora Dornelo-Silva \& Dianese $2003^{16}$ \\
\hline 56 & Periconiella qualeae-grandiflorae Dornelo-Silva \& Dianese $2003^{16}$ \\
\hline 57 & Phaeoidiomyces qualeae Dornelo-Silva \& Dianese $2004{ }^{23}$ \\
\hline 58 & Phaeoramularia chupii Inácio \& Dianese, $1998{ }^{19}$ \\
\hline 59 & Phaeoramularia pyrostegiae (Viégas) Inácio \& Dianese $1996^{19}$ \\
\hline 60 & Phaeoramularia rubida (Müller \& Chupp) Inácio \& Dianese $1996{ }^{19}$ \\
\hline 61 & Phakopsora bluteri Dianese, Santos \& Medeiros, $1993^{3} \bullet$ \\
\hline 62 & Phakopsora chavessi Dianese, Santos \& Medeiros $1993^{3} \bullet$ \\
\hline 63 & Phakopsora rossmanii Dianese, Santos \& Tessmann $1993{ }^{3} \bullet$ \\
\hline 64 & Phloeosporella flavio-moralis Dianese, Sutton \& Tessmann $1993^{11}$ \\
\hline 65 & Phloeosporella kitajimae Dianese, Medeiros \& Santos $1993{ }^{12}$ \\
\hline 66 & Phomopsis amaranthophila Inácio, Dianese \& Carlos, $1999{ }^{17}$ \\
\hline 67 & Phyllachora cerradensis Santos, R.B Medeiros \& Dianese $2016^{47}$ \\
\hline 68 & Phyllachora ermidensis Santos, R.B Medeiros \& Dianese $2016^{47}$ \\
\hline 69 & Phyllachora furnasensis Santos, R.B Medeiros \& Dianese $2016^{47}$ \\
\hline 70 & Phyllachora myrciariae Santos, \& Dianese $2016^{47}$ \\
\hline 71 & Phyllachora nigerrima (Viégas) Santos, R.B Medeiros \& Dianese $2016^{47}$ \\
\hline 72 & Phyllosticta xylopiae-sericeae Furlanetto \& Dianese $1998^{6}$ \\
\hline 73 & Plurispermiopsis cerradensis Pereira-Carvalho, Inácio \& Dianese $2009^{35}$ \\
\hline 74 & Polychaeton tabebuiae Inácio \& Dianese $1998^{1}$ \\
\hline 75 & Prathigada austroplenckiae Hern.-Gut \& Dianese $2008^{27}$ \\
\hline 76 & Prathigada backmanii Furlanetto \& Dianese $1998^{13}$ \\
\hline 77 & Pseucercospora astroniiphila Hern.-Gut \& Dianese $2008^{27}$ \\
\hline 78 & Pseudocercospora acosmii-subelegantis A Hern.-Gut., Z.M Chaves \& Dianese $2015^{45}$ \\
\hline 79 & Pseudocercospora annellidica A Hern-Gut \&Dianese ${ }^{42}$ \\
\hline 80 & Pseudocercospora aquae-emendadasensis A Hern.-Gut., Z.M Chaves \& Dianese $2015^{45}$ \\
\hline 81 & Pseudocercospora aspidospermatis (Batista, Peres \& Garnier) Dianese \& Câmara $1994{ }^{18}$ \\
\hline 82 & Pseudocercospora astronii Hern.-Gut \& Dianese $2008^{27}$ \\
\hline 83 & Pseudocercospora austroplenckiae Her.-Gut \& Dianese $2008^{27}$ \\
\hline 84 & Pseudocercospora banisteriopsis-megaphyllae A Hern.-Gut \& Dianese $2014^{42}$ \\
\hline 85 & Pseudocercospora bolkanii Furlanetto \& Dianese $1999^{13}$ \\
\hline 86 & Pseudocercospora bonducella (Henn.) Braun, Dianese \& A Hern.-Gut.2009 ${ }^{34}$ \\
\hline 87 & Pseudocercospora byrsonimae-basilobae A Hern-Gut \& Dianese $2014^{42}$ \\
\hline 88 & Pseudocercospora byrsonimae-coccolobifoliae A Hern-Gut \& Dianese $2014^{42}$ \\
\hline 89 & Pseudocercospora byrsonimicola A Hern-Gut \& Dianese $2014^{42}$ \\
\hline 90 & Pseudocercospora byrsonimigena A Hern-Gut \& Dianese $2014^{42}$ \\
\hline 91 & Pseudocercospora caesalpiniicola Braun, Dianese \& A Hern.-Gut $2009^{42}$ \\
\hline 92 & Pseudocercospora campograndensis A Hern-Gut \& Dianese $2014^{42}$ \\
\hline
\end{tabular}




\begin{tabular}{|c|c|}
\hline 93 & Pseudocercospora chamaecristigena Hern.-Gut \& Dianese $2009^{34}$ \\
\hline 94 & Pseudocercospora eriothecae Hern.-Gut \& Dianese 200827 \\
\hline 95 & Pseudocercospora exilis Hern.-Gut \& Dianese $2009^{34}$ \\
\hline 96 & Pseudocercospora luzardii Furlanetto \& Dianese $1999^{13}$ \\
\hline 97 & Pseudocercospora luzianiensis Hern.-Gut \& Dianese $2009^{34}$ \\
\hline 98 & Pseudocercospora matogrossensis A Hern.-Gut \& Dianese $2014^{42}$ \\
\hline 99 & Pseudocercospora mutabiliconidiophorum A Hern-Gut \& Dianese ${ }^{42}$ \\
\hline 100 & Pseudocercospora passiflorae-setaceae A.C Dianese, Costa \& Dianese $2008^{32}$ \\
\hline 101 & Pseudocercospora pediformiconidiorum A Hern-Gut \& Dianese ${ }^{42}$ \\
\hline 102 & Pseudocercospora planaltinensis A Hern-Gut \& Dianese $2014^{42}$ \\
\hline 103 & Pseudocercospora protii Hern.-Gut \& Dianese $2008^{27}$ \\
\hline 104 & Pseudocercospora pseudobombacis Hern.-Gut \& Dianese $2008^{27}$ \\
\hline 105 & Pseudocercospora sennae A Hern.-Gut., Z.M Chaves \& Dianese $2015^{45}$ \\
\hline 106 & Pseudocercospora sennae-rugosae A Hern.-Gut., Z.M Chaves \& Dianese $2015^{45}$ \\
\hline 107 & Pseudocercospora stryphnodendri A Hern.-Gut., Z.M Chaves \& Dianese $2015^{45}$ \\
\hline 108 & Pseudocercospora subcuticularis A Hern.-Gut., Z.M Chaves \& Dianese $2015^{45}$ \\
\hline 109 & Pseudocercospora subhyalina A Hern-Gut \& Dianese $2014{ }^{42}$ \\
\hline 110 & Pseudocercospora tabebuiae-caraibae Inácio \& Dianese $2006^{30}$ \\
\hline 111 & Pseudocercospora tabebuiae-roseo-albae Inácio \& Dianese $1998^{1}$ \\
\hline 112 & Pseudocercospora urenae (Viégas \& Chupp) Hern \& Dianese $1996^{19}$ \\
\hline 113 & Pseudocercospora uwebrauniana A Hern.-Gut \& Dianese $2013^{40}$ \\
\hline 114 & Pseudocercospora zeyheriae (Henn.) Dianese, Furlanetto \& Santos $1999^{20}$ \\
\hline 115 & Ramularia crupinae Dianese, Hasan \& Sobian $1996^{26}$ \\
\hline 116 & Ravenellia bezerrae Dianese, Medeiros \& Furlanetto $1993^{3} \bullet$ \\
\hline 117 & Ravenellia cerradensis Rezende \& Dianese $2001^{21} \bullet$ \\
\hline 118 & Ravenellia chapadensis Rezende \& Dianese $2001^{21} \bullet$ \\
\hline 119 & Ravenellia emaensis Rezende \& Dianese $2001^{21} \bullet$ \\
\hline 120 & Ravenellia mineirosensis Rezende \& Dianese $2001{ }^{21} \bullet$ \\
\hline 121 & Ravenellia santos-costae Dianese, Medeiros, Santos \& A C Dianese $1993^{3} \bullet$ \\
\hline 122 & Ravenellia victoria -rossetii Dianese, Santos, Medeiros \& Sanchez $1993^{3} \bullet$ \\
\hline 123 & Rhinocladium abietina (Peck) Furlanetto \& Dianese $1995^{21}$ \\
\hline 124 & Rhinocladium magenotii (Reisinger) Furlanetto \& Dianese $1995^{21}$ \\
\hline 125 & Septoria tabebuiae-impetiginosae Inácio \& Dianese $1998^{1}$ \\
\hline 126 & Sirosporium sclerolobii A Hern.-Gut., Z.M Chaves \& Dianese $2015^{45}$ \\
\hline 127 & Skierka divinopolenis Dianese, Medeiros \& Santos $1993^{3} \bullet$ \\
\hline 128 & Stenella cyrtopodii Dornelo-Silva, Pereira-Carvalho \& Dianese 200729 \\
\hline 129 & Stenella erythroxyli-campestris Dornelo-Silva, Pereira-Carvalho \& Dianese 200729 \\
\hline 130 & Stenella erythroxylicola Dornelo-Silva \& Dianese $2007^{29}$ \\
\hline
\end{tabular}




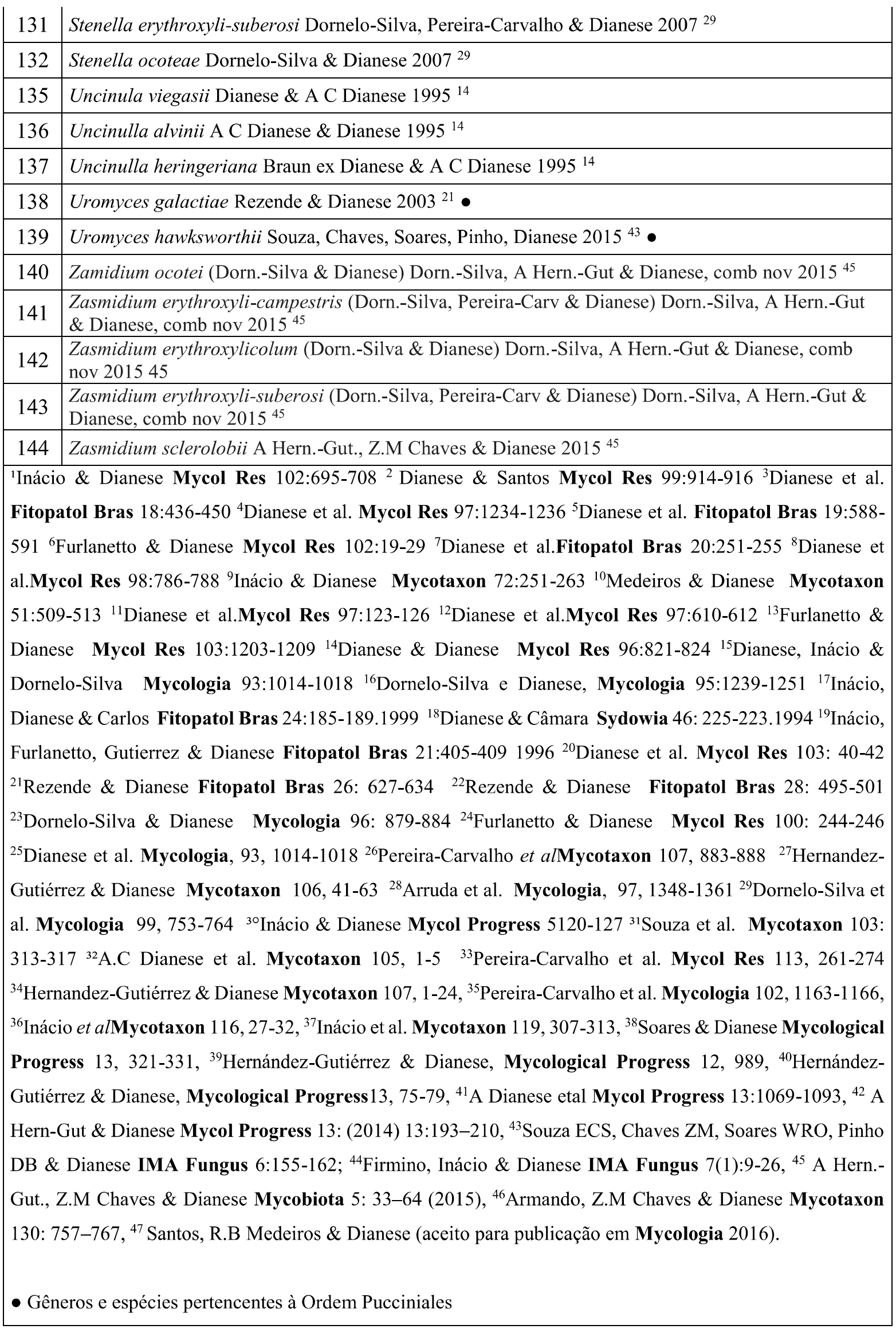


A relação fungo/planta no bioma Cerrado extrapola as estimativas sugeridas para o mundo por Hawksworth (1991, 2001), a qual se baseia na ocorrência de seis espécies de fungo para cada espécie de planta. Dianese et al. (1997) e Dianese (2000) argumentaram que este número é muito conservador quando se trata da savana tropical mais diversificada, o Cerrado, e sugeriram um mínimo de dez a vinte fungos por espécie de planta, com base no fato de algumas espécies abrigarem até 45 espécies diferentes de fungos apenas nas folhas (Santos 2011), sem considerar ramos, troncos, raízes, rizosfera, folhedo, insetos e solo.

Alguns exemplos que extrapolam Hawksworth (1991, 2001), constando a associação de mais de 18 fungos por espécie estão disponíveis em vários trabalhos (Dianese et al. 1997, Chaves 1998, Dornelo-Silva 1999, Pereira-Carvalho 2004, Armando 2004, Castro 2009 e Santos 2011). Assim, de forma conservadora, estima-se a ocorrência de 70 a 100 mil espécies de fungos associadas às plantas do Cerrado.

A lista de fungos para este bioma, em 1997 (Dianese et al. 1997), consistia de apenas 875 espécies de microfungos pertencentes a 301 gêneros, associados às plantas nativas do Cerrado. A maioria dessas espécies pertenciam às ordens Pucciniales (250), Dothideales (175), Phyllachorales (105), Meliolales (47), Hypocreales (7) e Erysiphales (9), além de 174 celomicetos, 96 hifomicetos.

Como visto, em termos de incidência sobre a vegetação nativa do Cerrado, destacam-se os fungos pertencentes à ordem Pucciniales. Com efeito, das 144 espécies listadas na Tabela 1, 18, ou seja mais de 10\%, são membros dessa ordem, justificando o foco dado ao grupo no presente trabalho. 
A Ordem Pucciniales Clem. \& Shear (= Uredinales G Winter).

A Ordem Pucciniales, inserida no Filo Basidiomycota, Subfilo Pucciniomycotina, Classe Pucciniomycetes, é monofilética (Maier et al. 2003, Wingfield et al. 2004, Aime et al. 2006, Hibbett et al. 2007, Zuluaga et al. 2011, Aime et al. 2014), caracterizando-se pela produção de esporos sexuados haploides denominados basidiósporos, produzidos externamente em estruturas septadas designadas metabasídios ou promicélios, os quais resultam da germinação meiótica de um probasídio dicariótico/diploide, especificamente designado teliósporo, no caso dos Pucciniales.

Os membros dessa ordem, são biotróficos por excelência, caracterizados por apresentar micélio endofítico, dicariótico e septado, sem grampos de conexão, poros simples nos septos, parasítico por meio de haustórios, originando células esporogênicas que levam à formação de probasídios (teliósporos), ou esporos disseminativos (urediniósporos) dicarióticos. Além disso, formam eciósporos igualmente dicarióticos, advindos da conjugação de micélio haploide resultante da germinação de basidiósporos compatíveis, muitas vezes compondo espermogônios contendo espermácias e hifas receptivas, onde ocorre a dicaritização dessas últimas. Essas hifas, agora dicarióticas, crescem parasiticamente para formar os écios e os eciósporos (Swann \& Taylor 1995a, Cummins \& Hiratsuka 2003). A ordem Pucciniales abriga, 13 famílias (Chaconiaceae, Coleosporaceae, Cronartiaceae, Melampsoraceae, Mikronegeriaceae, Phakopsoraceae, Phragmidiaceae, Pileolariaceae, Pucciniaceae, Pucciniastraceae, Raveneliaceae (=Sphaerophragmiaceae), Uncolaceae e Uropyxidaceae), 166 gêneros e cerca de 8.000 espécies (Cummins \& Hiratsuka 2003; Aime 2006, Kirk et al. 2008). Alguns gêneros ainda são mantidos em família incertae sedis, como por exemplo: Hiratsukamyces e Masseeëlla (Cummins \& Hiratsuka, 2003, Minnis et al. 2012). 
Para Rossman (1995) existiriam em torno de 50.000 fungos na Ordem Pucciniales no mundo, entretanto, Aime et al. (2014) reconheceram 7.458 espécies sendo: 75 na família Chaconiaceae, 313 na Coleosporiaceae, 90 na Melampsoraceae, 13 na Mikronegeriaceae, 205 na Phakopsoraceae, 164 na Phragmidiaceae, 34 na Pileolariaceae, 6.095 na Pucciniaceae, 323 na Raveneliaceae, 3 na Uncolaceae e 143 na Uropyxidaceae.

Pelo menos 68 formas sexuadas, oito gêneros assexuados e cerca de 750 espécies foram encontrados no Brasil das quais 36,5 \% são endêmicas (Tabela 2) (Hennen et al. 2005, Kirk et al. 2008, Carvalho Jr 2013, Maia et al., 2015). Em 1985, haviam registradas para o Brasil 538 espécies teleomórficas e atualmente existe o registro de 750 (Maia et al. 2015). Os gêneros com número igual ou maior que 10 espécies são Puccinia, Uromyces, Ravenelia, Prospodium, Phakopsora e Crosssopsora e, entre os anamórficos, encontram-se Uredo e Aecidium.

Os gêneros da ordem Pucciniales com maior número de espécies registrados para o país até 2016 foram: Puccinia (256), Uromyces (103), Uredo (75), Aecidium (67), Ravenelia (43) e Prospodium (37) (Maia et al. 2015)

A região Sudeste, onde esses fungos foram mais estudados, é a que apresenta maior número de espécies conhecidas, seguida pela região Sul, Norte, Centro-Oeste e Nordeste. São Paulo, Rio de Janeiro e Minas Gerais, em ordem decrescente, são os estados com maior número de coletas. Além disso, áreas de influência do bioma Mata Atlântica são mais bem amostradas que outras regiões brasileiras. Isso reflete um maior esforço de coleta nessa região em decorrência da presença de grandes centros urbanos e numerosos centros de pesquisa. Em coletas intensivas realizadas no Parque Nacional do Itatiaia (PNI), uma região de Mata Atlântica do Estado do Rio de Janeiro, foram coletadas 207 espécies (Salazar \& Carvalho Jr 2010). No Cerrado, apenas a partir de 1993 (Tabela 1), foram descritas 18 novas espécies, duas delas espécies-tipo de novos gêneros (Batistopsora e Kimuromyces). 
Tabela 2. Número de espécies de Pucciniales pertencentes aos gêneros relatados no Brasil até 2016.

\begin{tabular}{|c|c|c|}
\hline Gênero & Número de Espécies & Número de Espécies Endêmicas \\
\hline Aecidium & 67 & 43 \\
\hline Anthomyces & 1 & 1 \\
\hline Aplopsora & 1 & 1 \\
\hline Para & 1 & 0 \\
\hline Arthuria & 2 & 2 \\
\hline Atelocauda & 1 & 0 \\
\hline Batistopsora & 1 & 0 \\
\hline Botryorhiza & 1 & 0 \\
\hline Calidion & 1 & 1 \\
\hline Catenulopsora & 3 & 1 \\
\hline Cerotelium & 9 & 6 \\
\hline Cerradoa & 1 & 0 \\
\hline Chaconia & 5 & 1 \\
\hline Chrysocyclus & 2 & 0 \\
\hline Cionothrix & 2 & 1 \\
\hline Coleosporium & 6 & 0 \\
\hline Crossopsora & 10 & 2 \\
\hline Cumminsiella & 1 & 1 \\
\hline Dasyspora & 1 & 0 \\
\hline Desmella & 1 & 0 \\
\hline Desmosorus & 1 & 0 \\
\hline Diabole & 1 & 0 \\
\hline Dicheirinia & 7 & 2 \\
\hline Didymopsora & 3 & 3 \\
\hline Dietelia & 1 & 1 \\
\hline Diorchidiella & 2 & 1 \\
\hline Diorchidium & 4 & 3 \\
\hline Dipyxis & 1 & 1 \\
\hline Endophyllum & 2 & 0 \\
\hline Esalque & 1 & 1 \\
\hline Frommeëlla & 1 & 0 \\
\hline Hemileia & 2 & 0 \\
\hline Intrapes & 1 & 0 \\
\hline Kimuromyces & 1 & 0 \\
\hline Kuehneola & 1 & 0 \\
\hline Kweilingia & 1 & 0 \\
\hline Leptinia & 1 & 0 \\
\hline Malupa & 1 & 1 \\
\hline Maravalia & 8 & 6 \\
\hline
\end{tabular}




\begin{tabular}{lcc} 
Melampsora & 8 & 0 \\
Milesia & 1 & 1 \\
Olivea & 2 & 0 \\
Phakopsora & 29 & 8 \\
Phragmidiella & 4 & 0 \\
Phragmidium & 1 & 0 \\
Porotenus & 4 & 2 \\
Prospodium & 37 & 13 \\
Puccinia & 256 & 64 \\
Pucciniastrum & 3 & 0 \\
Pucciniosira & 2 & 1 \\
Ravenelia & 43 & 28 \\
Skierka & 2 & 1 \\
Sphaerophragmium & 2 & 0 \\
Sphenospora & 5 & 0 \\
Spumula & 1 & 0 \\
Tranzschelia & 1 & 0 \\
Uncol & 1 & 0 \\
Uredinopsis & 1 & 0 \\
Uredo & 75 & 41 \\
Uredopeltis & 1 & 1 \\
Uromyces & 103 & 32 \\
Uromycladium & 1 & 0 \\
Uropyxis & 1 & 0 \\
Ypsilospora & 1 & 0 \\
\hline Total / 64 gêneros & 743 & $271(36,5 \%)$ \\
\end{tabular}

Segundo Hennen et al. (2005) os principais coletores de fungos causadores de ferrugens no Brasil foram: Ernest Ule (1883-1910), Juan Puiggari (1887-1892), Arsene Puttemans (1892-1909), Eugênio Rangel (1912-1920), Edward Holway (1921-1922). O próprio Hennen, entre 1975 e 2002, coletou extensivamente no Brasil e principalmente no Cerrado, com espécimes depositados no Arthur Fungarium na Universidade de Purdue (Indiana, USA) e no Herbário do Instituto Biológico de São Paulo, então sob responsabilidade do Dr Mário Barreto Figueiredo.

No Cerrado os Pucciniales são representados por 19 espécies distribuídas em dez gêneros. Entre os gêneros existentes no Cerrado, destacam-se Batistopsora (Dianese et al. 
1993) e Kimuromyces (Dianese et al. 1995), que se constituíram na primeira contribuição brasileira a integrar a quarta edição do manual de Cummins \& Hiratsuka (2003), após a publicação pioneira de Porotenus Viégas em 1960 (Viégas 1960). Além disso, uma longa lista adicional de espécies novas de Pucciniales foi descrita (Tabela 1), incluindo novos membros dos gêneros Crossopsora, Phakopsora, Uromyces, Ravenelia, Aplopsora, Cerotelium, Skierka e Uromyces, a saber: Aplopsora hennenii Dianese \& Santos, em Qualea multiflora (Vochysiaceae), Batistopsora crucis-filli Dianese, Medeiros \& Santos em Annona tomentosa (Annonaceae), Cerotelium giacometii Dianese, Medeiros \& Santos em Caryocar brasiliense (Caryocaraceae), Crossopsora hymenaeae Dianese, Buriticá \& Hennen em Hymenaea stigonocarpa (Fabaceae), Kimuromyces cerradensis Dianese, Santos, Medeiros \& Furlanetto em Astronium fraxinifolium (Anacardiaceae), Mimema venturae Dianese, Santos, Medeiros \& Sanchez em Dalbergia miscolobium (Fabaceae), Phakopsora blutleri Dianese, Medeiros \& Santos em Kielmeyera coriaceae (Clusiaceae), Phakopsora chavessi Dianese, Medeiros \& Santos em Terminalia phaeocarpae (Combretaceae), Phakopsora rossmanii Dianese, Santos \& Tessmann em Campomanesia adamantium (Myrtaceae), Ravenelia bezerrae Dianese, Medeiros \& Furlanetto em Enterolobium ellipticum (Fabaceae), Ravenelia cerradensis Rezende \& Dianese em Chamaecrista clausenii var cyclophylla (Fabaceae), Ravenelia chapadensis Rezende \& Dianese em Chamaecrista decumbentes (Fabaceae), Ravenelia emaensis Rezende \& Dianese em Anadenanthera sp (Fabaceae), Ravenelia mineirosensis Rezende \& Dianese em Anadenanthera colubrina var colubrina (Fabaceae), Ravenelia santos-costae Dianese, Medeiros, Santos \& A C Dianese em Calliandra dysantha (Fabaceae), Ravenelia victoria-rossetii Dianese, Santos, Medeiros \& Sanchez em Mimosa radula var imbricata (Fabaceae), Skierka divinopolensis Dianese, Medeiros \& Santos em Matayba guianense (Sapotaceae), Uromyces galacticae Rezende \& Dianese em Galactia peduncularis (Fabaceae) e Uromyces hawksworthii Souza, Chaves, Soares, Pinho \& Dianese em Phthirusa 
stelis (Loranthaceae) (Dianese et al. 1993, Dianese et al, 1994, Dianese \& Santos 1995, Rezende \& Dianese 2001, 2002, 2003, Souza et al. 2015).

Castro (2012) estudou vinte e nove Pucciniales mencionando uma provável nova espécie de Crossopsora em Blepharodon pictum, ainda não publicada. Além disso, relatou oito Pucciniales em hospedeiras inéditas: Aecidium ipomoeae em Ipomoea cairica, Aecidium piptocarphae e Puccinia pipta em Piptocarpha rotundifolia, Puccinia malvacearum em Triumfetta rhomboidea, Puccinia inrecta em Peixotoa goiana e Cerotelium sabiceae em Sabicea brasiliensis.

\section{Os grandes repositórios de Pucciniales do Cerrado}

O Arthur Fungarium é o maior repositório de Pucciniales brasileiras, inclusive das espécies do Cerrado. Essa importante coleção está alojada no Departamento de Botânica e Fitopatologia da Universidade Purdue, Indiana, USA, e foi assim designada em homenagem ao seu fundador, o Prof. Joseph C. Arthur, um pioneiro da fitopatologia e da micologia americana falecido em 1915. Este Fungarium constitui-se na maior e mais importante coleção de fungos Pucciniales, não apenas das Américas, mas sim de todo o mundo, contendo mais de 110 mil exsicatas de espécimes coletadas por amplas áreas e seguindo uma longa linha de tempo histórico, conforme mostra a sequência de seus curadores a partir de 1887, considerados os maiores uredinologistas de todos os tempos, ou seja: J. C. Arthur (1887 1915), George B. Cummins (1938 -1971), Joe F. Hennen (1971 - 1995), R. Greg Thorn (1995 - 1996), A. L. Swinehart (1997 - 1998), M. Scholler (1999 - 2002), G. E. Shaner (2003 2008) e M. C. Aime, a partir de 2012, até o presente.

A contribuição do Arthur Fungarium começou com o seu fundador que em 1887 já havia descrito 29 gêneros e 309 espécies de Pucciniales da América do Norte, além de 50 
outras espécies de países como Índia, Filipinas, América Central e do Sul; tendo publicado 12 volumes da North American Flora (1907-1931), além de 289 publicações em periódicos. O continuador de Arthur, Prof. Cummins foi igualmente prolífico e influente, produzindo entre inúmeras obras importantes, inclusive o clássico, The Illustrated Genera de Rust Fungi, agora em sua quarta edição (Cummins \& Hiratsuka 2003). Não menos importante é a obra já consolidada realizada pelo Prof Joe F Hennen, hoje aposentado, sem dúvida o maior especialista em Pucciniales ainda vivo. Para o Brasil sua obra é o que pode ser considerada como essencial e referência obrigatória para quem queira estudar os Pucciniales do Brasil. Graças às coletas e aos estudos do Prof Hennen, sabe-se que no Arthur Fungarium, o Brasil é o terceiro país com maior número de espécimes de Pucciniales ali depositadas, ou seja, 4.625 coletas (Purdue Herbaria 2016), superado apenas pelos próprios Estados Unidos (52.866) e o vizinho México (5.285). É importante ressaltar que, o número é mais de duas vezes superior ao contido na Coleção Micológica do Herbário UB, da Universidade de Brasília (2.386). A coleção feita pelo Prof Hennen durante mais de 25 anos, montada a partir do Cerrado brasileiro, bem como as coletas anteriores feitas na América Latina, pelo botânico americano E W D Holway, na década de 1920-30, são extremante relevantes no que diz respeito a representatividade mundial de Pucciniales.

Em síntese, a razão de aqui se enfatizar a importância do Arthur Fungarium está no fato de ali estar depositada a maior coleção de Pucciniales do Cerrado, estabelecida pelo Prof. Joe F Hennen, a qual está disponível para uso internacional, mas o material nele depositado não foi estudado no presente trabalho. 


\section{Ciclo de vida dos Pucciniales}

Os Pucciniales possuem os ciclos de vida mais complexos dentro do reino Fungi e, provavelmente, entre os eucariontes (Petersen 1974). Eles são chamados de fungos causadores de ferrugens por produzirem em suas hospedeiras sintomas que se assemelham à ferrugem provocada pela oxidação do ferro. Em geral seus sintomas são caracterizados pela formação de pústulas ou soros de aspecto pulverulento de coloração que variam de esbranquiçadas, amareladas, laranja, ferruginosas, marrons, marron-escuras a tons negros.

Cummins \& Hiratsuka (2003) adotaram as seguintes definições para os cinco estágios esporíferos do ciclo de vida dos Pucciniales:

a) Espermogônios ou Pícnios (Estágio 0): são soros produzidos a partir de hifas haploides resultantes da infecção por basidiósporos (haploides), os quais produzem pequenas células fecundantes, denominadas espermácias ou picniósporos, além de hifas receptivas (haploides) susceptíveis de serem espermatizadas, passando com isto a uma condição dicariótica. Assim, as espermácias fecundam hifas receptivas compatíveis, resultando em hifa dicariótica, a qual irá formar um micélio igualmente dicariótico que irá colonizar as células da hospedeira, em geral em direção à face abaxial das folhas, e será responsável pela formação dos écios. O processo de fecundação de hifas receptivas pode ser intermediado pela ação e movimentação de insetos no local, ao serem atraídos pela massa adocicada que envolve os esporos produzidos pelos espermogônios.

b) Écios (estágio I): são frutificações de formato variado nas quais são produzidos os eciósporos $(n+n)$, os quais são responsáveis pela infecção de outros sítios susceptíveis na mesma hospedeira ou em um hospedeiro complementar. Quando ocorre a germinação do eciósporo, o tubo germinativo penetra a hospedeira através dos estômatos, e assim há a produção de hifas intercelulares e haustórios. A maioria causa infecção local. No entanto, há 
situações em que a fase ecídica de várias ferrugens assemelha-se a uma infecção sistêmica, por induzir alterações hormonais importantes que levam a formação de hiperplasia ou hipertrofia das células vegetais, onde são encontrados principalmente écios com eciósporos. Do micélio $(\mathrm{n}+\mathrm{n})$ resultante da germinação dos eciósporos irão ser formados os urédios.

c) Urédios ou Uredínios (Estágio II): é a fase em que são produzidos uediniósporos capazes de levar à repetição vegetativa com eventos mitóticos sucessivos. Os urediniósporos são formados em frutificações, na maioria dos casos, imersas, eruotivas, ou formados em soros mistos, contendo também um outro tipo de esporos, os teliósporos. Os urediniósporos ao germinarem produzem micélio dicarióticos que podem infectar a mesma hospedeira, através dos estômatos ou diretamente pela epiderme, nesse caso, com formação de apressório, como ocorre com Puccinia psidii Winter e Phakopsora pachyrhizi. O micélio endófítico e infectivo, irá formar novos urédios, resultando em multiplicação exponencial do número de esporos. Com isso, levando a ataques epidêmicos de relevância econômica. Assim, são responsáveis por multiciclos, resultando em epidemias, dada a facilidade de disseminação dos mesmos pelo ar. Possuem parede espessa e bem pigmentada, pouco sensível a radiação ultravioleta conseguindo sobreviver a longas distâncias quando levados pelo ar.

d) Télios (estágio III): são soros formados a partir do mesmo micélio dicariótico, pode ser o mesmo que formou os urédios. Porém nos télios são formados probasídios dicarióticos, no caso designados como teliósporos. Neles ocorre cariogamia (diploidização) seguida de meiose durante a germinação que consiste exclusivamente na formação de um metabasídio externo. Da meiose resultam 4 núcleos haploides migratórios, os quais passam a ocupar cada um uma célula do metabasídio. Os núcleos incorporam citoplasma e migram para pontas de esterigmas, onde amadurecem na forma de basidiósporos haploides, sendo daí lançados sempre por pressão. 
e). Basidiósporos (estágio IV): células indectivas haploides, em geral penetrando a hospedeira diretamente através da epiderme, por meio de formação de um apressório. Podem infectar e a hifa pode se conjugar com outra compatível, resultando hifa dicariótica capaz de formar écio, urédio, ou télio, dependendo do caso. Porém, muitas vezes, a hifa haploide dá origem às estruturas do Estágio 0, os espermogônios, formadores de espermácias e hifas receptivas.

Os cinco estágios descritos, em conjunto ocorrem nos Pucciniales de ciclo longo, ou macrocíclicos (Figura 2). No entanto, existem outros tipos de ciclos de vida nos quais variam o número de esporos e de frutificações. Os principais tipos de ciclos são conhecidos como macrocíclico, microcíclico e demicíclico (Cummins \& Hiratsuka 2003).

Os Pucciniales macrocíclicos (exemplo mostrado na Figura 2) mostram ciclo de vida com até cinco etapas diferentes, cada uma com um tipo de esporo (basidiósporos, espermácias ou picniósporos (fecundadores das hifas receptivas), eciósporos, urediniósporos e teliósporos), podendo envolver duas plantas hospedeiras (ciclo heteroécio) filogeneticamente não relacionadas (Cummins \& Hiratsuka 2003), para a conclusão do ciclo. Neste caso em uma hospedeira ocorrem espermogônios e écios e na outra urédios e télios. Entretanto, algumas espécies são capazes de concluir o seu ciclo de vida em uma única planta hospedeira, formando nela até 5 tipos de esporos (ciclo autoécio, macrocíclico).

No outro extremo, as espécies microcíclicas não possuem a fase uredínica e tampouco a ecídica, apenas teliósporos que germinam produzindo basidiósporos, quais completam o ciclo do fungo ao infectar indivíduos da mesma hospedeira, gerando micélio dicariótico capaz de formar novos télios diretamente, ou os formar a partir de hifa dicariótica resultante da espermatização de hifas receptivas. Germinados os teliósporos $(n+n / 2 n)$ fecha-se o microciclo. 
Já, os fungos demicíclicos não possuem estágio uredínico (II) e apresentam ou não o estágio espermacial (0). Neles a fase ecídica (I) funciona como fase uredínica. Possuem o estágio IV onde são produzidos os basidiósporos, o estágio 0 com formação de espermácias e hifas receptivas que vão produzir o écio e os eciósporos, com função de urédio e urediniósporos. Esses ao germinar penetram a hospedeira e formam o micélio dicariótico que irá produzir apenas télios, nunca urédios.

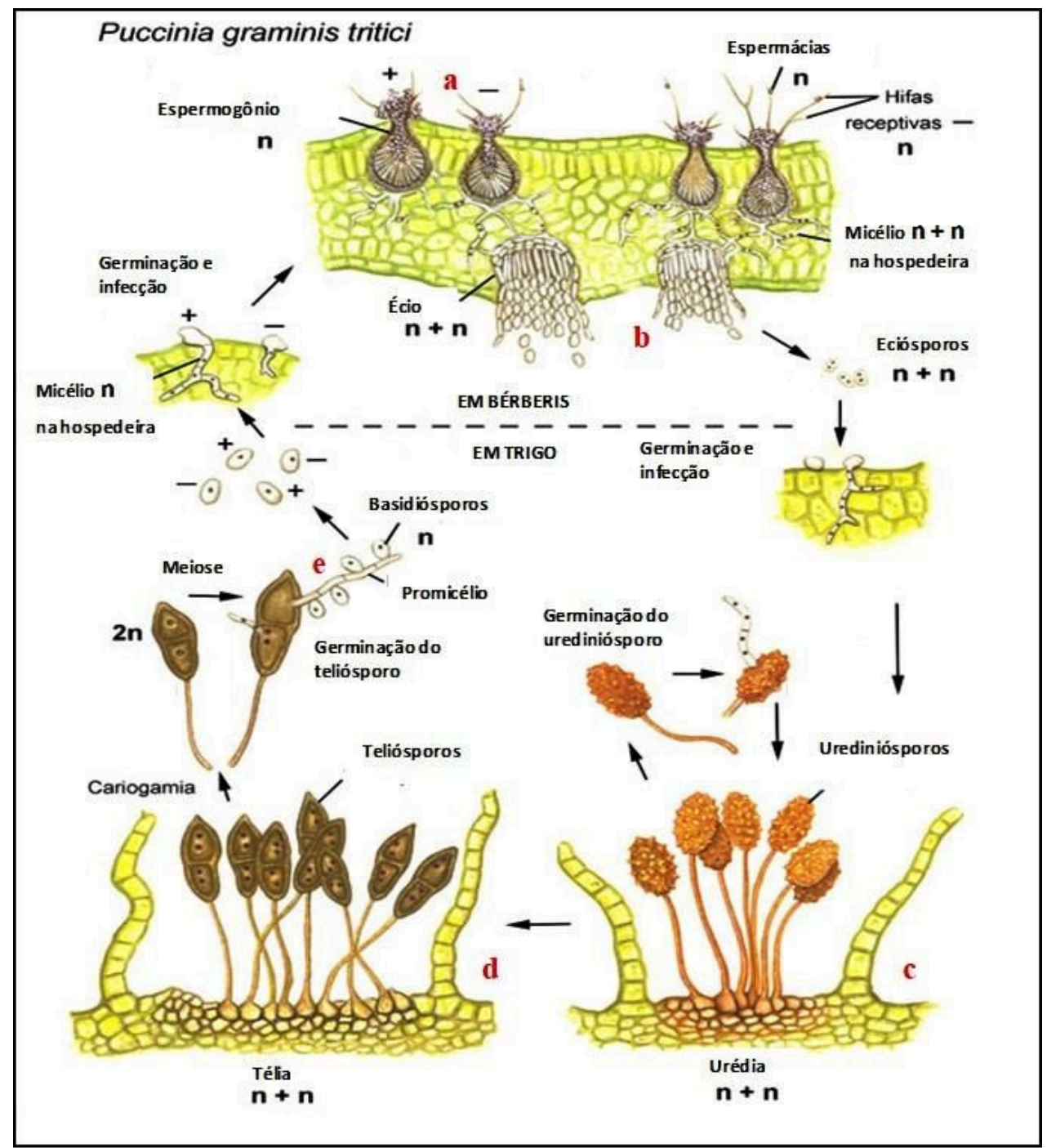

Figura 2. Ciclo de vida macrocíclico heteroécio de Puccinia graminis tritici. Adaptado de Ulloa (2016). 


\section{Parasitismo e Círculo de hospedeiros dos Pucciniales}

Pucciniales são biotróficos obrigatórios, o que significa que eles precisam de uma planta hospedeira viva para o seu desenvolvimento (Alexopoulos et al. 1996). Eles não sobrevivem saprofiticamente, porém alguns cresceram artificialmente de forma precária em meios de cultura (Williams et al. 1984, Fasters et al. 1993).

Assim, vários métodos foram desenvolvidos para facilitar o crescimento em cultura, inclusive inoculando-se urediniósporos em cultura de tecido da planta hospedeira. Algumas espécies de Pucciniales foram cultivadas com sucesso a partir da germinação de basidiósporos ou hifas em folhas; contudo, meios complexos são necessários, e a taxa de crescimento dessas culturas é extremamente lenta e limitada (Kinloch \& Dupper 1996; Moricca \& Ragazzi 2001).

Essses organismos formam o maior grupo de fungos patógenos de plantas. Constituem 95\% das espécies do Subfilo Pucciniomycotina e cerca de $8 \%$ de todos os fungos descritos (Kirk et al. 2008). Os Pucciniales formam o maior grupo de basidiomicetos fitopatogênicos representando cerca de um terço de todos os Basidiomycota (Aime et al. 2014). Podem ser encontrados até mesmo em locais de grandes altitudes e desertos, sendo abundantes nos trópicos e subtrópicos (Arthur 1934, Savile 1971, Smith et al. 2004, Aime et al. 2014).

Em agroecossistemas monoculturais esses fungos podem causar danos consideráveis aos seus hospedeiros e são, portanto, importantes patógenos em habitats florestais, agrícolas, hortícolas e industriais (Agrios 2005), podendo se constituir em importantes invasores biológicos de dimensão mundial (Carnegie et al. 2016).

Trata-se de um grupo de fitopatógenos importante tanto em plantas nativas, como em cultivadas. Alguns exemplos são: as ferrugens do trigo, milho e outros cereais; a ferrugem das mirtáceas; as ferrugens das forrageiras, gramíneas e cana-de-açúcar; as ferrugens das 
leguminosas como feijão, soja, amendoim e outras fabáceas; além das ferrugens de várias fruteiras, café e outras plantas.

A ferrugem do trigo (Puccinia graminis tritici) foi considerada uma das doenças mais graves para a agricultura na antiguidade sendo responsável por tragédias humanas, em consequência da falta de grãos (Schumann \& Leonard 2000). O fungo P. graminis tritici provoca ferrugem do colmo ou ferrugem negra do trigo, uma das doenças mais devastadoras que afetam o trigo mole e trigo duro, a cevada e o triticale (Leonard e Szabo, 2005; Park, 2007). O trigo fornece um quinto das calorias e proteínas de consumo humano em todo o mundo. De acordo com a FAO (2015) a produção de trigo do mundo para 2015 foi estimada em mais de 733 milhões de toneladas, um número que terá de ser duplicado para atender às demandas de abastecimento projetadas até o ano de 2050. Puccinia graminis tritici tem uma ampla distribuição geográfica, e pode destruir um campo de trigo inteiramente em menos de 3 semanas graças a capacidade de disseminação por meio de transporte a longa distâncias (Leonard e Szabo, 2005). Por essas razões, este agente causal foi classificado como uma das ameaças à segurança alimentar mundial (Dean et al., 2012).

Um caso singular é a invasão da Austrália por $P$. psidii, um fungo originário da América do Sul onde causa doença séria em goiabeira, e em várias mirtáceas nativas e exóticas (eucalipto, calistemon, jambeiros diversos, cravo-da-Índia e etc.). Conhecido em eucalipto a partir da década de 1980 (Ferreira 1983) e internacionalmente a partir de 1984 (Dianese et al. 1984), chegou à Austrália em 2010 (Carnegie et al. 2010).

Puccinia psidii disseminou-se pela América do Sul (Telechea et al. 2003), Caraíbas (Coutinho et al., 1998), America do Norte (Marlatt \& Kimbrough 1979), Havaí (Uchida et al. 2006), Japão (Kawanishi et al. 2009), Austrália (inicialmente relatado como Uredo rangelii) (Carnegie et al. 2010), China (Zhuang \& Wei 2011), África do Sul (Roux et al. 2013) e Nova Caledônia (Giblin 2013). Em julho de 2015, sintomas de ferrugem semelhantes aos de $P$. 
psidii foram observados em Eucalyptus pellita e em Melaleuca leucadendra no norte e sul de Sumatra e Indonésia.

Aspectos morfológicos e moleculares e uma abordagem filogenética com marcadores do rDNA foram utilizados para identificar os membros que causam ferrugens em Myrtaceae na Indonésia, confirmando a presença da espécie (McTarggart et al. 2016).

Porém, o mais relevante é o fato de que o fungo hoje ameaça provocar um amplo desequilíbrio ecológico no continente australiano, prevendo-se inclusive a extinção de várias espécies de Myrtaceae (Carnegie et al. 2016).

O patógeno tem uma ampla gama de hospedeiros, aproximadamente 450 espécies em 73 gêneros (Giblin e Carnegie 2014), sendo um dos fungos causadores de ferrugem que ocorrem em vários gêneros de hospedeiras. P. psidii foi descrita pela primeira vez no Brasil em Psidium guajava, e depois atingiu outras hospedeiras como espécies de Eucalyptus e Syzygium jambos (Castro et al., 1983, Tessmann et al. 2001). Porém, as populações de $P$. psidii em Eucalyptus e em Psidium divergiram há mais de 1000 anos atrás, e uma mudança de hospedeiro, mais provavelmente, não ocorreu após a introdução de eucalipto para o Brasil (Graça et al. 2013). Por isso mesmo, o genótipo de P. psidii em Eucalyptus e $S$. jambos tem uma origem ainda não explicada (Graça et al. 2013).

A ocorrência da ferrugem do cafeeiro (Hemileia vastatrix) encontrada hoje em todas as regiões onde ocorre a cafeicultura, em 1879 liquidou com a produção de café no Sri Lanka naquela ilha cessando a exportação do produto, forçando os ingleses a optarem pelo chá indiano, hoje uma tradição no país (Arneson 2000). Chegou às Américas em 1970 transportado por correntes aéreas sobre o Atlântico vinda de plantações de café da Angola.

Atualmente a ferrugem asiática da soja causada por Phakopsora pachyrhizi é considerada uma das doenças mais importantes para a cultura no Brasil, uma vez que esta representa uma das maiores fontes de divisas para o país (Yorinori et al. 2007). A doença tem 
origem na Ásia e recentemente se espalhou pelas América do Sul e do Norte (Kelly et al., 2015). No Brasil, a doença foi encontrada em 2001, no estado do Paraná, e vem aumentando sua área de ocorrência a cada ano, disseminando-se rapidamente para outros Estados do Brasil. Em 2002, a doença já estava presente nos Estados de Goiás, Mato Grosso, Mato Grosso do Sul, Minas Gerais, Rio Grande do Sul, Santa Catarina e São Paulo, e em quase todo o país a partir de 2004, causando prejuízos consideráveis em várias regiões produtoras. É atualmente um dos maiores problemas da cultura na região dos Cerrados Brasileiros, especialmente em Mato Grosso, onde têm sido necessário um excessivo número de pulverizações com fungicidas levando ao aumento de custos significativos e prejudicando a lucratividade da indústria da soja e contribuindo para a poluição ambiental. Segundo o Ministério da Agricultura, Pecuária e Abastecimento, com exceção de Roraima, todos os Estados que possuem cultivo de soja já foram atingidos pela doença, envolvendo uma área de 22 milhões de hectares. No sul do Brasil, epidemias severas têm sido esporádicas, porém está sendo detectada cada vez mais cedo durante a safra (Nunes 2016).

Os Pucciniales presentes em plantas úteis nativas do Cerrado são representados por espécies de vários gêneros como: Cerotelium em Caryocar brasiliense (Pequi), Puccinia em Psidium guajava (Goiaba), Eugenia dysenterica (Cagaita), Eugenia florida (Guamirim), Campomanesia adamantium (Gabiroba), Uredo em Dipterix alata (Baru), Batistopsora em Anonna tomentosa (Araticum), Crossopsora em Byrsonima sp (Murici), Hymenaea stigonocarpa (Jatobá) e Diorchidium copaiferae em Copaifera langsdorfii (Copaífera) e podem futuramente representar prejuízos econômicos significativos, uma vez que há um crescimento em potencial do cultivo dessas plantas para utilização com fins alimentícios, farmacêuticos, biotecnológicos e ornamentais.

As plantas hospedeiras dos fungos causadores de ferrugem variam de samambaias e coníferas a plantas monocotiledôneas e dicotiledôneas. Apesar da ampla variedade de 
hospedeiras, em geral, como um resultado de uma co-evolução com as plantas, a maioria dos Pucciniales são específicos para o hospedeiro ao nível de espécie (Saville 1971, Aime 2006, van der Merwe et al. 2008, Duplessis et al. 2011, Vialle et al. 2013, McTaggart et al. 2015), em que pese a existência de exceções envolvendo espécies com amplo aspecto de hospedeiras dentro de famílias, como é o caso de P. psiddi, P. graminis, Phakopsora pachyrhizi.

Já alguns gêneros mostram especificidade em termos de família de hospedeira, como Prospodium, Kernkampella e Ravenelia associados apenas a plantas das famílias Bignoniaceae, Euphorbiaceae e Fabaceae, respectivamente.

\section{Taxonomia dos Pucciniales}

A taxonomia clássica em Pucciniales é baseada, em grande parte, na morfologia dos esporos, principalmente a dos teliósporos (Petersen 1974, Sato \& Sato 1985, Cummins \& Hiratsuka 2003). Características como o arranjo dos teliósporos, se isolados ou em cadeia; a posição, se imersos ou eruptivos formando pústulas; o número ou orientação das células no esporo; se uni, bi- ou multicelulares; são importantes na classificação dos Pucciniales. Além das características dos teliósporos, o tipo, a posição e forma dos espermogônios, bem como forma das frutificações e dos esporos de origem assexuada (urédios, urediniósporos, écios e eciósporos) e especificidade de hospedeira também são importantes (Cummins \& Hiratsuka 2003).

A ornamentação da superfície dos esporos é fundamental para caracterizar gêneros e espécies e, além disso, também o arranjo e o número de poros germinativos dos urediniósporos são características importantes na identificação de espécies, principalmente nos casos de esporos bem pigmentados (Cummins \& Hiratsuka 2003). Em conjunto, o grau de afinidade filogenética, as características morfológicas, a ontogenia dos esporos, a evolução e a relação 
com os hospedeiros, são os critérios modernamente usados, principalmente para a organização supra genérica dos Pucciniales.

Características da morfologia, exclusivamente dos teliósporos, inicialmente foram utilizadas para definir originalmente duas famílias: Melampsoraceae com teliósporos não pedicelados (télios subepidérmicos) e Pucciniaceae com teliósporos pedicelados (télios eruptivos) (Dietel 1928). Subsequentemente, Gaumann (1949) acrescentou as famílias Pucciniastraceae (télios imersos), Cronartiaceae (télios colunares), Chrysomyxaceae (télios cupulares) e Coleosporiaceae (télios com basídio interno). Posteriormente, Cummins \& Hiratsuka (2003) propuseram 14 famílias para a ordem, que, em seguida, reduziram para 13, uma vez que as famílias Raveneliaceae e Sphaerophragmiaceae foram sinonimizadas (Cummins \& Hiratsuka 2003).

A taxonomia é baseada tradicionalmente na utilização de caracteres morfológicos e no caso de gêneros próximos, ou que reunam um grande número de espécies, utiliza frequentemente dados de filogenia molecular para definir e identificar espécies de forma segura. Felizmente a caracterização de Pucciniales por análise molecular, contribuiu fortemente para a validação dos resultados obtidos através de análises morfológicas, validando gêneros e todas as famílias tradicionalmente estabelecidas (Beenken et al. 2012, 2014, McTaggart et al. 2015).

\section{Taxonomia e filogenia Molecular dos Pucciniales}

A taxonomia dos fungos sofreu forte impacto com os avanços na área da filogenia molecular, instrumento importante, no caso dos Pucciniales, para a caracterização de novas espécies, e para elucidação de relações filogenéticas entre espécies, gêneros e famílias (Beeken et al. 2012, McTaggart et al. 2015). No aspecto técnico-laboratorial, protocolos de 
extração de DNA genômico de fungos e a técnica de amplificação em cadeia de fragmentos específicos do DNA (PCR), ainda permanecem complicados quando se trata de material herborizado. Comumente é usada a extração de DNA pelo método CTAB de Doyle \& Doyle (1990) e outros métodos como Fenol-clorofórmio estabelecido por Reader \& Broda (1985), bem como o uso de kits comerciais.

A PCR (Polymerase Chain Reaction), descrita em meados da década de 80, por Mullis e colaboradores (Mullis \& Faloona 1987), é uma técnica que permite obter in vitro várias cópias de um determinado segmento de DNA. Devido à sua especificidade e sensibilidade, a PCR é um método importante para identificação de fungos e estudos de filogenia. Ela pode ser utilizada para detectar grupos de linhagens, patotipos, espécies ou taxa superiores. Para a detecção de um determinado fungo em qualquer tipo de amostra é necessário iniciadores (iniciadores) que propiciem a amplificação de um gene ou segmento específico daquela espécie ou daquela função que se deseja identificar. Assim, o desenvolvimento de procedimentos de diagnóstico baseados em PCR requer o conhecimento de sequências de nucleotídeos de pelo menos parte da região alvo a fim de que iniciadores específicos possam ser desenhados. Neste sentido, algumas regiões tais como aquelas que codificam para RNA ribossômico têm sido bastante úteis (Fungaro 2001).

A filogenia molecular é o estudo, através de dados moleculares (principalmente sequências de DNA), da descendência, bem como das relações evolutivas de organismos que possuam ou não, a mesma ancestrabilidade. Além de ser uma ferramenta em que são considerados muitos caracteres evolutivos obtidos tem-se o fato das informações moleculares serem independentes de condições fisiológicas do organismo e do ambiente (Futuyama 2009, Ferreira \& Gratapaglia 1998, Faleiro 2007)

A filogenia molecular de fungos é realizada por meio do estudo de genes nucleares ribossomais (White 1990, Wanderlei-Silva et al. 2003, Crouch 2009, Feau et al. 2011, 
Hoshino 2012, Foltz et al. 2012, Pinho et al. 2012, Li \& Cui 2013), genes do DNA mitocondrial (Bruns \& Szaro 1992, Bullerwell \& Gray 2004, Seifert et al. 2007, Barroso et al. 2011, van de Sande 2012), entre outras regiões gênicas envolvidas em funções essenciais ao metabolismo celular. Essas regiões do genoma fúngico variam em grau de conservação e este pode ser um critério utilizado para separar níveis hierárquicos de classificação dos organismos. Com o avanço e sucesso de ferramentas moleculares envolvidas na análise molecular de fungos, tem se intensificado as discussões e critérios para eleger quais regiões do genoma fúngico são determinantes para cada grupo de fungos estudado.

O DNA que codifica para RNA ribossômico apresenta-se como um cluster gênico contendo três genes referentes às subunidades ribossomais: $18 \mathrm{~S}$ (small subunit - SSU), $5.8 \mathrm{~S}$ e 28S (large subunit - LSU), separados por dois espaçadores internos transcritos denominados ITS1 e ITS2, os quais são transcritos e processados para dar origem ao RNA ribossômico maduro. Toda essa composição gênica é caracterizada por um cístron e este se repete por centenas de vezes ao longo do DNA e são separados adjacentemente pelas regiões intergênicas não transcritas (IGS) (Figura 3).

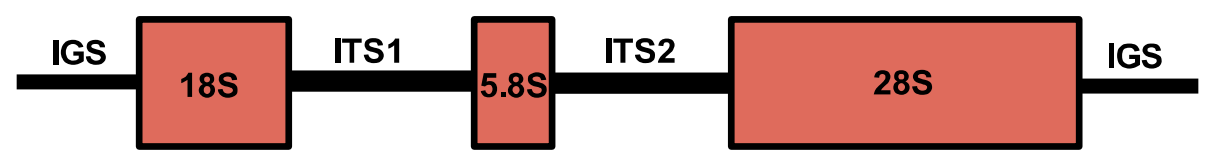

Figura 3. Cístron de genes e regiões espaçadoras do DNA ribossomal nuclear.

As sequências dos segmentos componentes do rDNA apresentam diferenças no que diz respeito a taxa de evolução, e isso permite o estudo acerca da micro e macro diversidade de organismos de interesse em decorrência do grau de polimorfismos presente em cada segmento (Oliveira 2001). O fato desse cluster gênico apresentar algumas regiões altamente 
conservadas e outras variáveis, tem permitido a análise de variação de diferentes níveis taxonômicos.

As regiões codificadoras para os genes rDNA nucleares, $18 \mathrm{~S}, 5.8 \mathrm{~S}$ e $28 \mathrm{~S}$, estão sob pressão seletiva e são altamente conservadas. Esses genes apresentam como característica, principalmente o $18 \mathrm{~S}$, uma lenta evolução nas suas sequencias codificadoras, são altamente conservados, possuem baixa taxa de mutação e são resistentes à transferência lateral de genes (Broccheri 2001). Portanto, para o estudo com fungos, apresentam baixa capacidade de discriminar espécies, são utilizadas apenas para comparação de organismos distantemente relacionados sendo mais utilizados para o estabelecimento de relações filogenéticas em nível hierárquico superior como famílias, classes e ordens (White et al. 1990, Fungaro 2000, Novaes et al. 2010, Schoch et al. 2012). A porção 28S, apesar de manter uma certa conservação, é mais variável graças a polimorfirmos existentes nas regiões D1 e D2 e, portanto, é apropriada para a comparação de diferentes gêneros ou mesmo de diferentes espécies (Fungaro 2000, Hyde 2014).

Ao contrário das regiões gênicas, as regiões ITS evoluem rapidamente, apresentando maior taxa de mutação e alto polimorfismo. Elas têm sido apropriadas para discriminar espécies relacionadas ou até mesmo variedades de uma mesma espécie (White et al. 1990, Fungaro 2000, Schoch et al. 2012). As regiões ITS são facilmente amplificadas e sequenciadas devido ao fato de serem flanqueadas por segmentos conservados, serem relativamente curtas (500 a 800 pb) e aparecerem em grande número de cópias no genoma. Como consequência disso, é grande o número de sequências ITS de diferentes fungos que estão atualmente disponíveis nos bancos de dados de sequências de nucleotídeos. Atualmente, a sequência da região ITS tem sido a proposta mais relevante a ser utilizada como código de barra universal, na identificação de fungos, pelo Consortium for Barcode of Life (Bellemain et al. 2010, Schoch et al. 2012). 
Entretanto, a identificação de espécies fúngicas utilizando apenas a região ITS, não tem mostrado muita eficiência na determinação em nível intraespecífico e, para tornar resoluções mais robustas, outros marcadores moleculares como $\beta$-Tubulina, Fator de Elongação, Histona e Calmodulina tem se tornado necessário para corroborar essas informações.

A escolha dos genes a serem utilizados na análise filogenética está relacionada ao grupo de fungos estudado. Em geral, cada grupo de fungos possui uma seleção preestabelecida de genes a ser empregada no estudo filogenético. Entre outras regiões gênicas utilizadas separadamente ou simultaneamente (concatenadas) para conferir a robustez dos dados podem ser citadas a Calmodulina (Cal), Histona (HIS), Actina (ACT), $\beta$ Tubulina (TUB), Fator de Elongação (EF), Gliceraldeído-3-Fosfato Desidrogenase (GAPDH), Glutamina Sintetase (GS), entre outras.

De acordo com Wade (2007) as sequências dos lócus para esses genes, em geral, são altamente conservadas nos eucariotos. Embora seja elevado o grau de conservação dessas proteínas, o polimorfismo de íntrons em seus genes, as tornam potencialmente úteis no estudo da filogenia de fungos (O'Donnell et al. 2000, Craven et al. 2001, Begerow et al. 2004, Ceresini et al. 2007, Kauserud \& Shalchian- Tabrizi, 2007, Konrad et al. 2007, Maciel et al. 2010).

Outro componente do genoma de organismos eucarióticos utilizado em filogenia de fungos é o DNA mitocondrial (mtDNA) Estes são elegíveis para inferir relações filogenéticas entre espécies relacionadas (Vialle et al. 2009, Barroso et al. 2011), bem como para a distinção entre gêneros (Bruns et al.1991). 


\section{Taxonomia molecular e filogenia de Pucciniales}

Nas últimas décadas, vários estudos envolvendo filogenia de fungos Pucciniales, utilizando-se sequências do DNA ribossômico (rDNA), tem se intensificado desempenhando um papel fundamental na inferência de relações evolutivas entre esses indivíduos (Sugiyama 1998; Maier et al. 2003, Wingfield et al. 2004, Aime 2006, Blackwell et al. 2006; Zualaga et al., 2011; Aime et al. 2014, Beenken \& Wood 2015, Kenaley et al., 2016). No entanto o número de estudos utilizando estas ferramentas moleculares para estudos taxonômicos em fungos causadores de ferrugens é muito pequena quando comparados com outros grupos de fungos (Zuluaga et al. 2009).

Para o estudo das relações filogenéticas dos membros de Pucciniales tem sido utilizado, principalmente os genes do rDNA (18S e 28S) e a região ITS. Entretanto, outros marcadores vêm sendo estabelecidos como a Btub ( $\beta$ tubulina) e o CO3 (Citocromo C oxidase, subunidade III) do mtDNA (Glass \& Donaldson 1995, Ayliffe et al. 2001, Wirsel et al. 2004, van der Merwe et al. 2007, Liu \& Hambleton 2013).

Assim, sabe-se que a análise da região ITS presta-se para a identificação de espécies de Pucciniales, conforme McTaggart et al. (2014) que utilizou a região ITS bem como 28S para identificar espécies de ferrugens das famílias Goodeniaceae e Stylidiaceae, na Austrália. Já, Beenken et al. (2012, 2014) separaram espécies de Dasyspora e Phakopsora em espécies de Annona através da análise conjunta da região ITS e do gene para CO3.

Apesar de possuir características de alta conservação, Maier et al. (2003), e, mais recentemente, Hyde (2014) revelaram que o uso do gene 28S é apropriado para separar, com boa resolução, níveis hierárquicos inferiores, gênero e espécie para membros de Pucciniales, dada a sua taxa de evolução, e grau de polimorfismo maior do que o gene $18 \mathrm{~S}$. 
Sequências da subunidade $28 \mathrm{~S}$ do rDNA são essenciais na determinação das relações filogenéticas entre membros de Pucciniales e muito utilizado para discriminar gêneros e espécies. Assim, Maier et al. (2003) estudaram 52 fungos causadores de ferrugem distribuídos em nove famílias com as análises confirmando que os fungos formavam um grupo natural e indicaram que Puccinia, Uromyces, Endophyllum e Cumminsiella formavam um grupo monofilético. Os gêneros de Pucciniales de rosáceas (Phragmidium, Kuehneola, Triphragmium e Trachyspora) igualmente formaram um grupo monofilético. Ao mesmo tempo mostraram que o gênero Ochropsora está intimamente relacionado com Tranzschelia. Dentro dos gêneros os seguintes se mostraram compostos por um conjunto monofilético de espécies: Chrysomyxa, Coleosporium, Cronartium, Gymnosporangium, Melampsora, Phragmidium e Tranzschelia, enquanto que os gêneros Puccinia, Pucciniastrum, Thekopsora e Uromyces não o são. A condição de polifilética dos gêneros de Puccinia e Uromyces foi confirmada em seguida por Van der Merwe et al. (2007), analisando sequências de genes do EF1 e $\beta$-tubulina 1.

Um estudo semelhante foi realizado por Wingfield et al., (2004), mas por análise da sequência do $18 \mathrm{~S}$ do rDNA em 64 espécies de 12 famílias de Pucciniales, mostrou que os gêneros com estágio ecídico em gimnospermas são filogeneticamente distantes de fungos que forma écios em angiospermas; determinando também que a condição de autoecismo ou heteroecismo não representa um caracter taxonômico válido para as famílias polifiléticas Pucciniaceae e Pucciniastraceae.

Trabalhos recentes mostram a adoção generalizada do uso combinado da caracterização morfológica com a análise filogenética na taxonomia dos Pucciniales. Assim, Souza et al. (2015), encontraram a fase télica de Aecidium goyazense infectando Phthirusa stelis (Loranthaceae) e baseados em caracterização morfológica suportada por análise de sequências da região $28 \mathrm{~S}$ do rDNA, puderam não apenas dar um novo nome à espécie, 
Uromyces hawksworthii Souza et al. (2015), mas também promover a epitypificação da espécie. A análise filogenética reforçou a convicção de que a espécie era a segunda do gênero Uromyces conhecida em hospedeiras do gênero Phthirusa. Da mesma forma, duas novas espécies de Phragmidium sp., P. zhouquensis e P. longissima, foram identificadas em duas plantas nativas, Rosa omeiensis e $R$. likiangensis respectivamente, no oeste da China por Yang et al. (2015). Além das evidências morfológicas observadas que as diferenciam, as análises filogenéticas com base em sequências de genes parcial 28S rRNA confirmaram a distinção dessas espécies de $P$. zhouquensis e $P$. longissima por formarem duas linhagens distintas. Phragmidium longissima foi a primeira espécie de Phragmidium sp. relatada em $R$. likiangensis.

Anteriormente, Aime et al. (2006), realizaram estudos filogenéticos baseados nos genes 18S e 28S do rDNA envolvendo diferentes famílias da Ordem Pucciniales, anteriormente propostas por Cummins e Hiratsuka (2003) com base em aspectos morfológicos. Das treze famílias propostas em 2003, oito (Coleosporiaceae, Melampsoraceae, Mikronegeriaceae, Phakopsoraceae, Phragmidiaceaeae, Pileolariaceae, Pucciniaceae e Raveneliaceae) mostraram-se bem suportadas pela análise com base nas sequências, enquanto que três não puderam ser segregadas (Cronartiaceae, Pucciniastraceae e Pucciniosiraceae), e para duas outras (Chaconiaceae e Uropyxidaceae) os estudos filogenéticos não permitiram uma resolução. Além disso, o autor concluiu que os dados de filogenia molecular indicaram uma correlação entre planta hospedeira e caraterísticas morfológicas das espécies. Mostram que a evolução dos fungos causadores de ferrugem foi, em grande parte, impulsionada por associações permanentes com as plantas hospedeiras, sem explicar o mecanismo por trás da ocorrência do heteroecismo nos Pucciniales (Aime 2006). Mais recentemente, McTaggart et al. (2015) reforçaram com ampla análise molecular as grandes coincidências entre a definição 
morfológica das famílias (Cummins \& Hiratsuka 2003) e a circunscrição das mesmas com o apoio também da filogenia molecular.

No Neotrópico, merece atenção os esforços de especialistas em Pucciniales de onde tem surgido contribuições importantes tanto em termos de taxonomia clássica (Buriticá 1991, Buritica 1994, Buritica 2000, Pardo-Cardona 2001, Salazar 2002, Buriticá 2003a) e mais recentemente utilizando-se também ferramentas moleculares. Assim, Zualaga et al. (2011) realizaram a análise filogenética de 40 Pucciniales parasitas de diferentes plantas na região andina colombiana, com base na região $28 \mathrm{~S}$ do rDNA, especificamente nos domínios D1 e D2. Os resultados mostraram que as famílias Pucciniaceae, Phakopsoraceae, Phragmidiaceae, Pileolariaceae, Mikronegeriaceae, Coleosporiaceae e Cronartiaceae estão bem suportadas e válidas taxonomicamente, enquanto que Pucciniastraceae e Pucciniosiraceae mostraram-se redundantes, repetindo a conclusão de Aime (2006). Além disso, as análises indicaram que Uropyxidaceae, Raveneliaceae, Chaconiaceae e Pucciniastraceae são polifiléticas, enquanto que Melampsoraceae mostrou-se um táxon basal para os Pucciniales, concordando com Wingfield et al. (2004).

As informações obtidas no estudo de Zualaga et al. (2011) contribuíram para incorporar um maior número de sequências de fungos causadores de ferrugem tropicais dentro esforços globais para redefinir a taxonomia da ordem Pucciniales. Além disso, há a necessidade de priorizar o estudo filogenético dos gêneros: Gerwasia, Hemileia, Phragmidium, Prospodium, Puccinia e Uromyces, gêneros que incluem um elevado número de fungos que causam ferrugem dos trópicos.

Estudos recentes feitos por McTaggart et al. (2015) baseados na combinação das regiões do rDNA (28S e $18 \mathrm{~S}$ ) e CO3, confirmam em geral, a classificação das famílias reconhecidas por Cummins \& Hiratsuka (2003), Aime (2006) e Zualaga et al. (2011). 
Até o momento, poucas espécies de fungos que causam ferrugem foram descritas com suporte de dados moleculares. Com tudo isso em foco, o presente trabalho, encarou a tarefa de estudar de forma ampla a diversidade, taxonomia e filogenia molecular dos Pucciniales do Cerrado, com base em amostras incorporadas à Coleção Micológica de Herbário UB, conforme consta nos capítulos seguintes. Neles reporta-se estudos morfo-taxonômicos (Capítulo 1. Caracterização morfológica de Pucciniales do Cerrado), filogenia molecular (Capítulo 2. Caracterização molecular e fillogenia de Pucciniales do cerrado), caracterização morfo-molecular de uma espécie de Uromyces (Capítulo 3. Novo nome para Aecidium goyazense em Phthirusa stelis (Loranthaceae) do Cerrado Brasileiro); interação entre um fungo causador de ferrugem encontrado no Cerrado com Colletotrichum truncatum, baseado em caracterização morfo-molecular de ambos os fungos envolvidos (Capítulo 4. Interação entre Colletotrichum truncatum e Uromyces euphorbiae em folhas de Euphorbia hirta). Assim, a meta central do trabalho é conhecer melhor os Pucciniales do Cerrado em termos morfológicos e contribuir com uma primeira abordagem ampla sobre a filogenia molecular desses organismos, incluindo também dois trabalhos enfocando aspectos específicos da taxonomia e patologia de duas espécies de Uromyces. 
Agrios G (2004) Plant Pathology. 5a ed. New York: Acad. Press. 952 pp.

Aime MC (2006) Toward resolving family-level relationships in rust fungi (Uredinales). Mycoscience 47: 112-122

Aime MC, Brandon MP, Henk DA, Frieders EM, Nilson RH, Piepenbring M, Mclaughlin DJ, Szabo LJ, Begerow D, Sampaio JP, Bauer R, Weib M, Oberwinkler FY, Hibbert D (2006) An overview of the higher level classification of Pucciniomycotina based on combined analyses of nuclear large and small subunit rDNA sequences. Mycologia 98: 896-905.

Aime MC, Toome M, McLaughlin D (2014) The Pucciniomycotina PP: 271-294 In: The Mycota VII Part A Systematics and Evolution 2nd Ed McLaughlin D, Spatafora JW (Eds), Springer-Verlag.

Alexopoulos CJ, Mims CW, Blackwell M (1996) Introductory Mycology 4 ed New York: John Wiley \& Sons 831.

Anikster Y \& Wahl I (1979) Coevolution of the rust fungi on Gramineae and Liliaceae and their host. Annual Review of Phytopathology 17: 367-403

Araujo JF, de Castro AP, Costa MM, Togawa RC, Junior GJ, Quirino BF, Bustamante M MC, Williamson L, Handelsman J \& Krüger RH (2012) Characterization of Soil Bacterial Assemblies in Brazilian Savanna-Like Vegetation Reveals Acidobacteria Dominance Microbial Ecology 64: 760-70

Armando EAS (2004) Micobiota associada a família Caryocaraceae. Dissertação de mestrado Universidade de Brasília. Brasília

Arneson, PA (2000) Coffee rust. The Plant Health Instructor http://www.apsnet.org/edcenter/intropp/lessons/fungi/basidiomycetes/pages/coffeerust .aspx, acessado em 02/12/2016.

Arthur JC (1934) Manual of the rusts in United States and Canadá Lafayette, Indiana Purdue Research Foundation 438 p. 
Ayliffe MA, Dodds PN \& Lawrence GJ (2001) Characterization of a $\beta$-tubulin gene from Melampsora lini and comparison of fungal $\beta$-tubulin genes. Mycological Research 105: 818-826.

Barroso G, Ferandon C Callac P (2011) From the comparative analysis of fungal mitochondria genes to the development of taxonomic and phylogenetic tools Proceedings of the 7 th International Conference on Mushroom Biology and Mushroom Products (ICMBMP7) 2011 Section: Diversity and Taxonomy 91-99

Bayma A, Santiago AMO, Miranda Jr A, Silvano D, Oliveira G, Vianna L, Pires MO (2003) Programa nacional de conservação e uso sustentável do Bioma Cerrado Ministério do Meio Ambiente Programa Cerrado Sustentável. Disponível em: http://www.mma.gov.br/estruturas/sbf/ arquivos/programa bioma cerrado. pdf Acessado em setembro de 2014.

Beenken L (2014) Pucciniales on Annona (Annonaceae) with special focus on the genus Phakopsora. Mycological Progress 13: 791-809

Beenken L, Wood AR (2015) Puccorchidium and Sphenorchidium, two new genera of Pucciniales on Annonaceae related to Puccinia psidii and the genus Dasyspora. Mycological Progress 14: 1-13.

Beenken L, Zoller S, Berndt R (2012) Rust fungi on Annonaceae II: The genus Dasyspora. Mycologia 104: 659-681.

Bellemain E, Carlsen T, Brochmann C, Coissac E, Taberlet P, Kauserud H (2010) ITS as an environmental DNA barcode for fungi: An in silico approach reveals potential PCR biases. BMC Microbiology 10:189.

Berndt R \& Beenken L (2013) Chaconia heliconiae and C. clusiae sp. novae from French Guiana with notes on the genus Chaconia (Uredinales) in the neotropics. Mycological Progress 12: 397-401.

Blackwell M (2011) The Fungi: 1, 2, 3 ... 5.1 million species? American Journal of Botany 98: 936-948 
Blackwell M, Hibbert D, Taylor JW, Spatafora JW (2006) Research Coordination Networks: a phylogeny or kingdom Fungi (Deep Hypha) Mycologia 98: 829-837 Broccheri 2001.

Bruns TD, Szaro TM (1992) Rate and mode differences between nuclear and mitochondrial small-subunit rDNA genes in mushrooms Molecular Biology and Evolution 9: 836-855.

Bruns TD, White TJ, Taylor JW (1991) Fungal molecular systematic Annual Review of Ecology Systematics 22: 525-564.

Bullerwell CE, Gray MW (2004) Evolution of the mitochondrial genome: protist connections to animals, fungi and plants Current Opinion in Microbiology 7: 528-534.

Buriticá P (1991) Familias del orden Uredinales con ciclo de vida completamente reducido Revista - Academia Colombiana de Ciências 18: 131-148.

Buriticá P (1994) Cambios taxonómicos y nuevos registros de Uredinales de la flora andina Rev I.C.N.E Univ Nacional Colombia, Medellín 5: 173-190

Buriticá P (2003) Centros naturales de diversificación en el orden Uredinales (Fungi, royas) Rev Fac Nal Agr Medellín 56: 1999-2019.

Cantrell AS, Dianese JC, Fell J, Gunde-Cimerman N, Zadar P (2011) Unusual fungi niches Mycologia 103: 1161-1174

Carnegie AJ, Kathuria A, Pegg GS, Entwistle P, Nagel M, Giblin FR (2016) Impact of the invasive rust Puccinia psidii (myrtle rust) on native Myrtaceae in natural ecosystems in Australia Biological Invasions 18: 127-144.

Carnegie AJ, Lidbetter, JR, Walker J, Horwood MA, Tesoriero L, Glen M and Priest M.J (2010) Uredo rangelii, a taxon in the guava rust complex, newly recorded on Myrtaceae in Australia Australasian Plant Pathology 39: 463-466.

Carvalho Jr AA (2013) Diversidade das Pucciniales do Brasil In: $36^{\circ}$ Congresso Paulista de Fitopatologia Summa Phytopathologica Botucatu: Sociedade Paulista de Fitopatologia 39 São Paulo.

Carvalho Jr AA, Hennen JF (2012) The species of Puccinia on Piptocarpha and Vanillosmopsis (Asteraceae-Vernonieae) in the Neotropics Mycologia 104: 557-568. 
Castro AP, Quirino BF, Pappas G, Kurokawa AS, Neto EL, Krüger RH (2008) Diversity of soil fungal communities of Cerrado and its closely surrounding agriculture fields Archives of Microbiology 190:129-139.

Castro AP, Silva MRSS, Quirino BF, Bustamante MMC, Krüger RH (2016) Microbial Diversity in Cerrado Biome (Neotropical Savanna) Soils Plos One 11: e0148785.

Castro H, Ogram A, Reddy KR (2004) Phylogenetic characterization of methanogenic assemblages in eutrophic and oligotrophic areas of the Florida Everglades Applied and environmental microbiology 70: 6559-6568.

Castro HA, Krügner TL, Ideriha CHF, Cappello MSC, Marchi AB (1983) Inoculação cruzada de Eucalyptus, goiaba (Psidium guajava) e jambeiro (Syzygium jambos) com Puccinia psidii. Fitopatologia Brasileira 8: 491-7.

Castro MT (2009) Fungos associados à Copaifera Monografia Universidade de Brasília. Brasília.

Castro MT (2012) Pucciniales em plantas nativas do cerrado brasileiro e em algumas exóticas. Dissertação de Mestrado. Universidade de Brasília. Brasília.

Ceresini PC, Shew HD, James TY, Vilgalys RJ, Cubeta MA (2007) Phylogeography of the Solanaceae-infecting Basidiomycota fungus Rhizoctonia solani AG-3 based on sequence analysis of two nuclear DNA loci. BMC Evolutionary Biology 7:163-184.

Chaves ZM (1998) Fungos associados à Mauritia flexuosa (Buriti) e Mauritiella armata (Buritirana) Tese de Mestrado Universidade de Brasília Brasília

Cole MM (1986) The Savannas - Biogeography and Geobotany Academic Press, London.

Coutinho TA, Wingfield MJ, Alfenas AC, Crous PW (1998) Eucalyptus rust: a disease with the potential for serious international implications Plant Disease 82: 819-25

Craven KD, Blankenship JD, Leuchtmann A, Hignight K, Schardl CL (2001) Hybrid fungal endophytes symbiotic with the endophyte effects is mainly caused by the endophyte grass Lolium pretense. Sydowia 53: 44-73. 
Crouch JA, Clark BB \& Hillman BJ (2009) What is the value of ITS sequence data in Colletotrichum systematics and species diagnosis? A case study using the falcate-spored graminicolous Colletotrichum group. Mycologia 101: 648-656

Cummins G, Hiratsuka Y (1983) Illustrated genera of rust fungi American Phytophatological Society, San Pablo, EEUU.

Cummins GB (1936) Phylogenetic significance of the pores in urediospores. Mycologia 28: 103-132.

Cummins GB, Hiratsuka Y (2003) Illustrated genera of rust fungi 3 ed The American Phytopathological Society, St Paul 225

Dean R, Van Kan JA, Pretorius ZA, Hammond-Kosack KE, Di Pietro A, Spanu PD, Rudd JJ, Dickman M, Kahmann R, Ellis J, Foster GD (2012) The Top 10 fungal pathogens in molecular plant pathology Molecular Plant Pathology 13: 414-430

Dianese AC, Costa AM, Dianese JC (2008) A new Pseudocercospora species on Passiflora setacea. Mycotaxon 105: 1-5

Dianese AC, Vale HMM, Souza ESC, Pereira-Carvalho RC, Chaves ZM, Câmara PEAS, Dianese JC (2014) New Cercospora species on Jatropha curcas in central Brazil. Mycological Progress 13: 1069

Dianese JC \& Santos LTP (1995) Aplopsora hennenii sp nov., the first rust fungus recorded in host-family Vochysiaceae. Mycological Research 99: 914-916 London.

Dianese JC (2000) Micodiversidade associada a plantas nativas do Cerrado In: TB, Cavalcanti; BMT, Walter (Org.) Tópicos atuais em Botânica $1^{\mathrm{a}}$ ed Brasília: Soc Bras Botânica / EMBRAPA: 109-115

Dianese JC, Buriticá P, Hennen JF (1994) The rust of jatobá: a new Crossopsora species from Neotropica on Hymenaea (Leguminosae). Fitopatologia Brasileira 19: 588-591.

Dianese JC, Medeiros RB, Santos LTP (1997) Biodiversity of microfungi found on native plants of the Brazilian cerrado In: K Hyde (Org.) Biodiversity of tropical microfungi: Hong Kong Uni Press 36-417. 
Dianese JC, Medeiros RB, Santos LTP, Furlanetto C, Sanchez M, Dianese AC (1993) Batistopsora gen nov and new Phakopsora, Ravenelia, Cerotelium, and Skierka species from the Brazilian Cerrado. Fitopatologia Brasileira 18: 436-450.

Dianese JC, Moraes TS, Haridassan M (1986) Screening Eucalipytus species for rust resistance in Bahia, Brazil. International Journal of Pest Management: 292-295, 1986.

Dianese, JC, Moraes, TS, Silva AR (1984) Response of Eucalyptus species to field infection by Puccinia psidii. Plant Disease 68: 314-316.

Dietel P (1928) Hemibasidii (Ustilaginales and Uredina-les), p 24-98 In A Engler \& K Plantl (eds) Die Natürlichen Pflanzenfamilien, vol 2 Engelmann, Leipzig, Alemania.

Dornelo-Silva D (1999) Fungos associados a plantas da família Vochysiaceae presentes no Cerrado. Dissertação de Mestrado. Universidade de Brasília. Brasília.

Dornelo-Silva D, Dianese JC (2004) New hyphomycete genera on Qualea species from the Brazilian Cerrado. Mycologia 96: 879-884.

Dornelo-Silva D, Pereira-Carvalho RC, Dianese JC (2007) New Stenella and Parastenella species from the Brazilian Cerrado. Mycologia 99: 753-764

Doungsa-ard C, McTaggart AR, Geering ADW, Dalisay TU, Ray J, Shivas RG (2015) Uromycladium falcatarium sp nov., the cause of rust on Paraserianthes falcataria in south-east Asia Australasian Plant Pathology 44: 25-30.

Doyle JJ, Doyle JL (1990) Isolation of plant DNA from fresh tissue. Focus 12: 13-15

Duplessis S, Cuomo CA, Lin Y-C, Aerts A, Tisserant E, Veneault-Fourrey C, Joly DL, Hacquard S, Amselem J, Cantarel BL, Chiu R, Coutinho PM, Feau N, Field M, Frey P, Gelhaye E, Goldberg J, Grabherr MG, Kodira CD, Kohler A, Kües U, Lindquist EA, Lucas SM, Mago R, Mauceli E, Morin E, Murat C, Pangilinan JL, Park R, Pearson M, Quesneville H, Rouhier N, Sakthikumar S, Salamov AA, Schmutz J, Selles B, Shapiro H, Tanguay P, Tuskan A, Henrissat B, Vande Peer Y, Rouzé P, Ellis JG, Dodds PN, Schein JE, Zhong S, Hamelin RC, Grigoriev IV, Szabo LJ, Martin F 2011. Obligate biotrophy features unraveled by the genomic analysis of rust fungi. Proceedings of the National Academy of Sciences 108: 9166-1971. 
Faleiro FG (2007) Marcadores genético-moleculares aplicados a programas de conservação e uso de recursos genéticos. Embrapa Cerrados Planaltina.

FAO (2015) World Food Situation. Disponível em: http://www.fao.org/worldfoodsituation/csdb/en/ acessado em 02setembro de 2015.

Fasters MK, Daniels U, Moershbacher BM (1993) A simple and reliable method for growing the wheat-stem rust fungus, Puccinia graminis $\mathrm{f}$ sp tritici in liquid culture. Physiol Mol Plant Pathol 42: 259-265.

Feau N, Vialle A, Allaire, M, Maier W, Hamelin RC (2011) DNA barcoding in the rust genus Chrysomyxa and the implications for the phylogeny of the genus. Mycologia 103: 12501266.

Ferreira FA (1983) Ferrugem do eucalipto. Revista Árvore 7: 91-109.

Ferreira ME, Grattapaglia D (1998) Introdução ao uso de marcadores moleculares em análise genética 3. Ed. Embrapa Cenargen Brasília.

Foltz MJ, Perez KE \& Volk TJ (2012) Molecular phylogeny and morphology reveal three new species of Cantharellus within $20 \mathrm{~m}$ of one another in western Wisconsin, USA. Mycologia 105:447-461

Forzza RC, Baumgratz JFA, Bicudo CEM, Canhos Dal, Carvalho Jr AA, Costa A, Costa DP, Hopkins M, Leitman PM, Lohmann LG, Lughadha EN, Maia, LC, Martinelli, G, Menezes M, Morim MP, Coelho, MAN, Peixoto AL, Pirani JR, Prado J, Queiroz LP, Souza S, Souza VC, Stehmann JR, Sylvestre LS, Walter BMT \& Zappi D (2010) Síntese da diversidade brasileira In: Forzza, R.C et al. (eds.) Catálogo de plantas e fungos do Brasil v 1 Andrea Jakobsson Estúdio: Instituto de Pesquisas Jardim Botânico do Rio de Janeiro. Rio de Janeiro 21-42.

Fungaro MHP (2000) PCR na micologia Biotecnologia Ciência e Desenvolvimento 14: 1216.

Fungaro MHP (2001) PCR na Micologia-Diagnóstico e Análise de Variabilidade Biotecnologia. Ciência \& Desenvolvimento 14: 12-16. 
Futuyma DJ (2009) Biologia evolutiva 3ª ed Editora Funpec Ribeirão Preto.

Giblin F \& Carnegie AJ (2014) Puccinia psidii (Myrtle Rust) - Australian host list. Acessado em outubro de 2014. Disponível em: http://www.anpc.asn.au/resources/Myrtle_Rust.html.

Giblin F (2013) Myrtle rust report: new Caledonia. University of the Sunshine Coast, Maroochydore.

Glass NL, Donaldson GC (1995) Development of primer sets designed for use with the PCR to amplify conserved genes from filamentous ascomycetes. Applied and Environmental Microbiology 61: 1323-1330.

Graça RN, Ross-Davis AL, Klopfenstein NB, Kim M-S, Peever TL, Cannon PG, Aun CP, Mizubuti ESG, Alfenas AC (2013) Rust disease of eucalypts, caused by Puccinia psidii, did not originate via host jump from guava in Brazil. Molecular Ecology 22: 6033-6047.

Guarim-Neto G, Morais RG (2003) Recursos medicinais de espécies do Cerrado de Mato Grosso: um estudo bibliográfico. Acta bot bras 17: 561-584

Gutiérrez AH, Dianese JC (2008) New cercosporoid fungi from the Brazilian Cerrado 1 Species on hosts of the families Anacardiaceae, Araliaceae, Bombacaceae, Burseraceae and Celastraceae Mycotaxon106: 41-63

Gutiérrez AH, Dianese JC (2009) New cercosporoid fungi from the Brazilian Cerrado 2 Species on hosts of the subfamilies Caesalpinioideae, Faboideae and Mimosoideae (Leguminosae s lat.). Mycotaxon 107: 1-24

Hawksworth DL (2012) Managing and coping with names of pleomorphic fungi in a period of transition. IMA Fungus 3: 15-24.

Hawksworth DL (1991) The fungal dimension of biodiversity: magnitude, significance, and conservation. Mycological Research 95: 641-655

Hawksworth DL (2001) The magnitude of fungal diversity: the 1.5 million species estimate revisited. Mycological Research 105: 1422-1432 
Hennen, JF, Figueiredo, MB, Carvalho Jr., AA, Hennen, PG (2005) Catalogue of plant rust fungi (Uredinales) of Brazil Hernández-Gutiérrez \& Dianese JC 2013 New Passalora species on Peixotoa (Malpighiaceae) from the Brazilian Cerrado. Mycological Progress 4 107-111.

Hernández-Gutiérrez A, Braun U, Dianese JC (2014) Cercosporoid hyphomycetes on malpighiaceous hosts from the Brazilian Cerrado: species of Pseudocercospora on hosts belonging to Byrsonima. Mycological Progress 13: 193-210.

Hibbett DS, Binder M, Bischoff JF, Blackwell M, Cannon F, Eriksson OE, Huhndorf S, James T, Kirk PM, Lucking R, Thorsenlumbschm H, Lutzoni F, Matheny PB, McLaughlin DJ, Powell MJ, Redhead S, Schoch CL, Spatafora JW, Stalpers JA, Vilgalys R, Aime MC, Aptroot A, Bauer R, Begerow D, Benny GL, Castlebury LA, Crous PW, Dai Y, Gams W, Geiser DM, Griffith GW, Gueidan C, Hawksworth DL, Hestmark G, Hosaka K, Humber RA, Hyde KD, Ironside JE, Köljalg U, Kurtzman CP, Larsson K, Lichtwardt, MozleyStandridge JS, Oberwinkler F, Parmasto E, Reeb V, Rogers JD, Roux C, Ryvarden L, Sampaio JP, Schübler V, Sugiyama J, Thorn RG, Tibell L, Untereiner WA, Walker C, Wang Z, Weir A, Wess M, White MM, Winka K, Yao Y, Zhang N (2007). A higher-level phylogenetic classification of the Fungi. Mycological Research 111: 509-547.

Hibbett D, Abarenkov K, Kõljalg U, Öpik M, Chai B, Cole J, Wang Q, Crous P, Robert V, Helgason T, Herr JR, Kirk P, Lueschow S, O'Donnell K, Nilsson RH, Oono R, Schoch C, Smyth C, Walker DM, Porras-Alfaro A, Taylor JW, Geiser DM. 2016. Sequence-based classification and identification of Fungi. Mycologia 108: doi: 10.3852/16-130.

Hoshino YT (2012) Molecular analyses of soil fungal community - methods and applications In: Soriano, M.C.H (ed.) Soil health and land use management In Tech Shanghai.

Hyde KD, Nilsson RH, S Alias A, Ariyawansa AH, Blair E \& Lei Cai \& Arthur WAM de Cock \& Dissanayake AJ \& Glockling SL \& Goonasekara ID \& Gorczak M \& Hahn M \& Jayawardena RS \& van Kan JAL \& Laurence MH \& Lévesque CA \& Li X \& Liu J-K \& Maharachchikumbura SSN \& Manamgoda DS \& Martin FN \& McKenzie EHC \& McTaggart AR \& Mortimer PE \& Nair PVR \& Pawłowska J \& Rintoul TL \& Shivas RG \& Spies CFJ \& Summerell BA \& Taylor PWJ \& Terhem RB \& Udayanga D \& Vaghefi N \& Walther G \& Wilk M \& Wrzosek M \& Xu J-C \& Yan J \& Zhou N (2014) One stop 
shop: backbones trees for important phytopathogenic genera: I (2014) Fungal Diversity 67: $21-125$.

Inácio CA, Pereira-Carvalho RC, Souza ESC, Dianese JC (2011) A new Dothidasteroma species on leaves of Psidium laruotteanum from the Brazilian Cerrado Mycotaxon 116: 27-32.

Inácio CA, Pereira-Carvalho RC, Souza ESC, Sales HB, Dianese JC (2012) A new Hysterostomella species from the Cerrado in Brasília National Park. Mycotaxon 119: 307-313.

Kauserud H, Shalchian-Tabrizi K (2007) Multilocus sequencing reveals multiple geographically structured lineages of Coniophora arida and C. olivacea in North America. Mycologia 99: 705-713.

Kawanishi T, Uemastu S, Kakishima M, Kagiwada S, Hamamoto H, Horie H, Namba S (2009) First report of rust disease on ohia and the causal fungus in Japan. Journal of Genetic Plant Pathology 75: 428-431.

Kenaley SC, Hudler GW, Bergstrom GC (2016) Detection and phylogenetic relationships of Puccinia emaculata and Uromyces graminicola (Pucciniales) on switchgrass in New York State using rDNA sequence information. Fungal biology 120: 791-806.

Kinloch BB Jr., Dupper GE (1996) Genetics of Cronartium ribicola I Axenic culture of haploid clones Canadian. Journal of Botany 74: 456-460.

Kirk PM, Cannon PF, Minter DW, Stalpers JA (2008) Ainsworth and Bisby's dictionary of the fungi 10th ed Wallingford, CAB International.

Klink CA, Macedo RF, Mueller CC (1995) De Grão em Grão, o Cerrado Perde Espaço (Cerrado - Impactos do Processo de Ocupação) WWF- Fundo Mundial para a Natureza Brasília.

Klink CA, Machado, RB (2005) A conservação do Cerrado brasileiro. Megadiversidade 1: 147-155. 
Konrad H, Stauffer C, Kirisits T, Halmschlager E (2007) Phylogeographic variation among isolates of the Sirococcus conigenus P group For. Pathol 37: 22-39.

Lee D, Redfern O, Orengo C (2007) Predicting protein function from sequence and structure Nature. Reviews Molecular Cell Biology 8: 995-1005.

Leonard KJ, Szabo LS (2005) Stem rust of small grains and grasses caused by Puccinia graminis. Molecular Plant Pathology 6: 99-111.

Li H \& Cui B (2013) Taxonomy and phylogeny of the genus Megasporoporia and its related genera. Mycologia 105: 368-383.

Liu M \& Hambleton S (2013) Laying the foundation for a taxonomic review of Puccinia coronata s.1 in a phylogenetic context. Mycological Progress 12:63-89.

Maia LC, Carvalho Jr AA (2010) Os fungos do Brasil In: Forzza, R.C et al. (Eds.) Catálogo de plantas e fungos do Brasil. V 1 Andrea Jakobsson Estúdio: Instituto de Pesquisas Jardim Botânico do Rio de Janeiro. Rio de Janeiro.

Maia LC, Carvalho Jr AA, Cavalcanti LH, Gugliotta AM, Drechslersantos ER, Santiago ALMA, Cáceres MES, Gibertoni TB, Aptroot A, Giachini AJ, Soares AMS, Silva ACG, Magnago AC, Goto BT, Lira CRS, Montoya CAS, Pires-Zottarelli CLA, Silva DKA, Soares DJ, Rezende DHC, Luz EDMN, Gumboski EL, Wartchow F, Karstedt F, Freire FM, Coutinho FP, Melo GSN, Sotão HMP, Baseia IG, Pereira J, Oliveira JJS, Souza JF, Bezerra JL, Araujo Neta LS, Pfenning LH, Gusmão LFP, Neves MA, Capelari M, Jaeger MCW, Pulgarín MP, Menolli Junior N, Medeiros PS, Friedrich RCS, Chikowski RS, Pires RM, Melo RF, Silveira RMB, Urrea-Valencia S, Cortez VG, Silva VF (2015) Diversity of Brazilian Fungi. Rodriguésia 66: 1033-1045

Maier W, Begerow D, Weiss M, Oberwinkler F (2003) Phylogeny of the rust fungi: an approach using nuclear large subunit ribosomal DNA sequences. Canadian Journal of Botany 81: 12-23

Marlatt RB, \& Kimbrough JW (1979) Puccinia psidii on Pimenta dioica in south Florida. Plant Disease Reporter 63: 510-512. 
McTaggart AR, Doungsa-ard C, Geering ADW, Aime MC, Shivas RG (2015) A co-evolutionary relationship exists between Endoraecium (Pucciniales) and its Acacia hosts in Australia. Persoonia 35: 50-62

McTaggart AR, Geering AD, Shivas RG (2014) The rusts on Goodeniaceae and Stylidiaceae. Mycological Progress 13: 1017-1025.

McTaggart AR, Shivas RG, Nest MA, Roux J, Wingfield BD, Wingfield MJ (2016) Host jumps shaped the diversity of extant rust fungi (Pucciniales). New Phytologist 209: 11491158 .

Mendonça R, Felfili J, Walter B, Silva JR, Rezende A, Filgueiras T, Nogueira P (1998) Flora vascular do Cerrado. In: S Sano \& S Almeida (eds.) Cerrado Ambiente e flora p 288-556. Empresa Brasileira de Pesquisa Agropecuária-Embrapa Cerrados, Planaltina, Brasil.

Minnis AM, McTaggart A, Rossman A, Aime MC (2012) Taxonomy of mayapple rust: the genus Allodus resurrected. Mycologia 104: 942-950.

Minter DW, da Silva, M (2007) Fungos do Brasil Disponível em: www.cybertruffle.org.uk/brazfung.

MMA (2016) Ministério do Meio Ambiente Disponível em: http://www.mma.gov.br/estruturas/sbf/ arquivos/programa bioma cerrado.pdf Acessado em abril de 2016.

Mora C, Tittensor DP, Adl S, Simpson AGB, Worm B (2011) How many species are there on earth and in the ocean. PLoS Biol 9:1001127.

Moricca S, Ragazzi A (2001) Establishment of single genotype axenic cultures from the haploid stage of the pine blister rust Cronartium flaccidum. Mycological Research 105: $1527-1532$.

Mullis K, Faloona F (1987) Specific synthesis of DNA in vitro via a polymerase catalyzed chain reaction. Methods in Enzymology 55: 335-350.

Myers N, Mittermeier CG, Mittermeier GABF, Kents J (2000) Biodiversity hotspots for conservation priorities. Nature 403: 853-858. 
Novaes CB, Souza FA \& Siqueira JO (2010) Caracterização fenotípica e molecular de fungos micorrízicos arbusculares mantidos em banco de germoplasma. Pesquisa Agropecuária Brasileira 45: 806-896.

Nunes JLS (2016) Ferrugem asiática. Disponível em Agro Link: http://www.agrolink.com.br/culturas/soja/ferrugem.aspx Acessado em julho de 2016.

O'Donnell K, Kistler HC, Tacke BK, Casper HH (2000) Gene genealogies reveal global phylogeographic structure and reproductive isolation among lineages of Fusarium graminearum, the fungus causing wheat scab. Proc Natl Acad Sci USA 97:7905-7910.

Oliveira MC (2001) Estudios de la macro y microbiodiversidad de las algas Secuenciamiento del RNA ribosomal (rDNA) In: Alveal, K.; Antezana, T (eds.) Sustentabilidade de la Biodiversidad, um problema atual Bases científico-técnicas, teorizaciones y proyeciones. Universidad de Concepsión Concepción 85-96.

Ono Y (2015) Kuehneola species (Phragmidiaceae, Pucciniales) on Vitaceae plants. Mycological Progress 14: 50.

Ono Y (2016) Phakopsora hornotina, an additional autoecious rust species on Meliosma in the Philippines and the Ryukyu Islands. Japan Mycoscience 57: 71-78.

Pardo-Cardona V (2001) Historia, estado actual y perspectivas de la investigación de los Uredinales en Colombia. Rev Fac Nal Agr Medellín 54: 1333-1350.

Park R (2007) Stem rust of wheat in Australia. Crop Pasture Sci 58: 558-566.

Perdomo-Sánchez O, Pierpenbring M (2014) Species of Uromyces (Pucciniales, Basidiomycota) on Loranthaceae. Tropical Plant Patology 39:141-153.

Pereira OL, Soares DJ (2012) Fungos Fitopatogênicos In: Laércio Zambolim; Waldir Cintra de Jesus Júnior; Olinto Liparini Pereira (Org.). O Essencial da Fitopatologia $1^{\mathrm{a}}$ ed Visconde do Rio Branco: Suprema Gráfica e Editora Ltda 01 225-307. 
Pereira-Carvalho RC (2004) Micobiota Foliícola associada a espécie de Blepharocalyx, Eugenia, Gomidesia e Psidium no Cerrado. Dissertação de Mestrado. Universidade de Brasília. Brasília.

Pereira-Carvalho RC, Dornelo-Silva D, Inacio CA, Dianese JC (2009a) Chaetothyriomyces: a new genus in family Chaetothyriaceae. Mycotaxon 107: 483-488

Pereira-Carvalho RC, Sepúlveda-Chavera G, Armando EA, Dianese JC (2009b) An overlooked source of fungal diversity: novel hyphomycete genera on trichomes of Cerrado plants. Mycological Research113: 261-274

Petersen R (1974) The rust fungus life cycle. The Botanical Review 40: 453-513.

Pinho DB, Honorato Junior J, Nicoli A, Hora Junior BT, Pereira OL (2012) Phylogenetic placement of the genus Anhellia and the description of a nectrandae sp. nov. Mycologia 104: $1291-1298$

Pretti VQ, Calcagnotto D, Toledo-Piza M, de Almeida-Toledo LF (2009) Phylogeny of the Neotropical genus Acestrorhynchus (Ostariophysi: Characiformes) based on nuclear and mitochondrial gene sequences and morphology: A total evidence approach. Molecular phylogenetics and evolution 52: 312-320.

Prevedello JA, Carvalho CJB (2006) Conservação do Cerrado brasileiro: o método panbiogeográfico como ferramenta para a seleção de áreas prioritárias. Natureza e conservação 4: 39-57. Paraná.

Purdue Herbaria - Botany and Plant Pathology. Disponível em: (https://ag.purdue.edu/btny/Herbaria/Pages/Arthur\%20Herbarium/Arthur Herbarium Overview.aspx). Acessado em novembro 2014.

Ramsbottom J (1912) Some notes on the history of the classification of the Uredinales Transactions of the British. Mycological Society 4: 77-105

Reader U, Broda P (1985) Rapid preparation of DNA from filamentous fungi Lett. Appl Microbiology 1: 17-20. 
Rezende DV, Dianese JC (2001) New species of Ravenelia from Brazilian Cerrado áreas. Fitopatologia Brasileira, SBF 26: 627-634 Fortaleza.

Rezende DV, Dianese JC (2002) Aspectos taxonômicos de Uredinales infectando leguminosas utilizadas na arborização urbana do Distrito Federal. Fitopatologia Brasileira. 27: 361-371 Brasília, DF.

Rezende DV, Dianese JC (2003) Espécies de Uromyces em Leguminosae do Cerrado com descrição de U. galactiae. Fitopatologia Brasileira 28: 495-501 Fortaleza, Ceará.

Ribeiro JF, Walter BMT (1998) Fitofisionomias do bioma Cerrado In: Cerrado: Ambiente e flora Sano, S.M \& Almeida, S.P (ed.), Planaltina, DF, Embrapa 87-166 p.

Ribeiro JF, Walter BMT (2008) As principais fitofisionomias do bioma Cerrado In: Sano SM, Almeida SP, Ribeiro JF (orgs.) Cerrado: ecologia e flora 151-212 Embrapa Brasília.

Rossman AY (1995) A strategy for an all-taxa inventory of fungal biodiversity. In: Biodiversity and Terrestrial Ecosystems C Peng \& Chou CH. eds Academia Sinica, Taiwan 169-194.

Roux KH (2003) Optimization and troubleshooting in PCR In: Dieffenbach, CW \& Dveksler GS (eds.) PCR primer: a laboratory manual 2ed Cold Spring Harbor Press New York.

Salazar M (2002) Uredinales (royas) en la zona cafetera colombiana Tesis Maestría, Universidad de Caldas, Manizales, Colombia.

Salazar MY, Carvalho Jr AA (2010) Novos registros de ferrugens (fungi, Uredinales) para o Brasil, coletados no Parque Nacional do Itatiaia Acta Botanica Brasilica 24: 378-385.

Santos LTP (2011) Micobiota foliícola de Salacia crassifólia. Dissertação de Mestrado. Universidade de Brasília. Brasília.

Santos MDM (2013) Morfotaxonomia e filogenia molecular de espécies dos gêneros Phyllachora e Ophiodothella em hospedeiras da família Myrtaceae nativas do cerrado. Tese de Doutorado. Universidade de Brasília. Brasília.

Sato T, Sato S (1985) Morphology of aecia of the rust fungi Transactions of the British. Mycological Society 85: 223-238. 
Savile DBO (1971) Coevolution of the Rust Fungi and Their Hosts. The Quarterly Review of Biology 46: 211-218.

Savile DBO (1976) Evolution of the rust fungi (Uredinales) as reflected by their ecological problems. Evol Biol 9:137-2.

Savile DBO (1979) Fungi as aids in higher plant classification. Bot Rev 45: 377-503.

Schoch CL, Seifert KA, Huhndorf S, Robert V, Spouge JL, Levesque CA, Chen W (2012) Nuclear ribosomal internal transcribed spacer (ITS) region as a universal DNA barcode marker for fungi Proccedings of the National Academy of Sciences USA 109: 62146246 .

Schumann GL, Leonard KJ (2000) Stem rust of wheat (black rust) The Plant Health Instructor.

Seifert KA et al. (2007) Prospects for fungus identification using CO1 DNA barcodes, with Penicillium as a test case. Proceedings of the National Academy of Sciences USA 104: 3901-3906.

Sjamsuridzal W, Nishida H, Ogawa H, Kakishima M, Sugiyama J (1999) Phylogenetic positions of rust fungi parasitic on ferns: evidence from 18S rDNA sequence analysis. Mycoscience 40:21-27.

Smith JA, Blanchette RA, Newcombe G (2004) Molecular and morphological characterization of the willow rust fungus, Melampsora epitea, from arctic and temperate hosts in North America. Mycologia 96: 1330-1338.

Soares WRO, Dianese JC (2014) New Meliola species on fabaceous hosts from the Brazilian Cerrado. Mycological Progress 13: 321-331.

Souza CAP, Vitória NS, Bezerra JL, Luz EDMN, Inácio CA, Dianese JC (2008) Camarotella brasiliensis sp nov (Phyllachoraceae) on Syagrus schizophylla (Arecaceae) from Brazil. Mycotaxon 103: 313-317.

Souza ESC, Chaves ZM, Soares WR, Pinho DB, Dianese JC (2015) Uromyces hawksworthii nom nov for Aecidium goyazense, on Phthirusa stelis (Loranthaceae) from the Brazilian Cerrado. IMA fungus 6: 155-162. 
Sperandio EM (2012) Ocorrência, diversidade e potencial biotecnológico de leveduras associadas a plantas do Cerrado. Dissertação de mestrado Universidade de Brasília. Brasília.

Sperandio EM, Vale HMM, Moreira GAM (2015) Yeasts from native Brazilian Cerrado plants: Occurrence, diversity and use in the biocontrol of citrus green mould. Fungal Biology 119: 984-993.

Sugiyama J (1998) Relatedness, phylogeny, and evolution of the fungi. Mycoscience 39: 487 511

Suneetha KB, Dahle G, Naevdal G (2000) Analysis of mitochondrial DNA sequences from two Maurolicus taxa: evidence for separate species? Journal of fish biology 57(6): 16051609.

Swann EA, Taylor JW (1995a) Phylogenetic diversity of yeast-producing basidiomycetes. Mycological Research 99: 1205-1210.

Telechea N, Rolfo M, Coutinho TA, Wingfield MJ (2003) Puccinia psidii on Eucalyptus globulus in Uruguay. Plant Pathology 52: 427-427.

Tessmann DJ, Dianese JC, Miranda, AC, Castro, LHR (2001) Epidemiology of a Neotropical rust (Puccinia psidii): periodical analysisof the temporal progress in a perenial host (Syzygium jambos). Plant Pathology 50: 725-731.

Ulloa M (2016). unibio.unam.mx/irekni/handle/123456789/32020?proyecto=Irekani. Acessado em 03/12/2016.

Uchida J, Zhong S, Killgore E (2006) First report of a rust disease on Ohia caused by Puccinia psidii in Hawaii. Plant Disease 90: 524-524.

Valencia EY, Chambergo FS (2013) Mini-review: Brazilian fungi diversity for biomas degradation Fungal. Genetics and Biology 60: 9-18.

Van de Sande WWJ (2012) Phylogenetic analysis of the complete mitochondrial genome of Madurella mycetomatis confirms its taxonomic position within the order Sordariales. Plos One 7:1-10. 
Van Der Merwe M, Ericson L, Walker J, Thrall PH, Burdon JJ (2007) Evolutionary relationships among species of Puccinia and Uromyces (Pucciniaceae, Uredinales) inferred from partial protein coding gene phylogenies Mycological Research 111: 163175.

Van Der Merwe MM, Walker J, Ericson L, Burdon JJ (2008) Coevolution with higher taxonomic host groups within the Puccinia/Uromyces rust lineage obscured by host jumps. Mycological Research 112: 1387-1408.

Vialle A, Feau N, Allaire M, Didukh M, Martin F, Moncalvo JM, Hamelin RC (2009) Evaluation of mitochondrial genes as DNA barcode for Basidiomycota. Mol Ecol Resour 9:99-113.

Vialle A, Feau N, Frey P, Bernier L, Hamelin, RC (2013) Phylogenetic species recognition reveals host-specific lineages among poplar rust fungi. Molecular phylogenetics and evolution 66: 628-644.

Véllez-Zambrano S (2016). Taxonomia de fungos associados a plantas do cerrado do Distrito Federal e Mato Grosso. Dissertação de Mestrado. Universidade de Brasília. Brasília.

Wade RH (2007) Microtubules: An overview. Meth Mol Med 137: 1-16

Wanderlei-Silva D, Neto E, Hanlin RT (2003) Molecular systematics of the Phyllachorales (Ascomycota, Fungi) based on $18 \mathrm{~S}$ ribosomal DNA sequences Brazil. Arch Biol Tech 46: 315-322.

White TJ, Bruns T, Lee S, Taylor J (1990) Amplification and direct sequencing of fungal ribosomal RNA genes for phylogenetics In: InnisMA, Gelfand DH, Sninsky JJ, White TJ (eds) PCR protocols: a guide to methods and applications. 315-322 Academic, San Diego.

Williams PG (1984) Obligate parasitism and axenic culture Pgs 399- 430 in: The Cereal Rusts Bushnell WR, Roelfs AP eds Academic Press Orlando.

Wingfield GD, Ericson L, Szaro T, Burdon JJ (2004) Phylogenetic patterns in the Uredinales. Australasian Plant Pathology 33: 327-335. 
Wirsel SG (2004) Homogenous stands of a wetland grass harbour diverse consortia of arbuscular mycorrhizal fungi FEMS. Microbiology Ecology 48: 129-138.

Yang T, Chang W, Cao B, Tian C, Zhao L \& Liang Y (2015) Two new Phragmidium species identified on Rosa plants native to China. Phytotaxa 217: 182-190.

Yorinori JT (2007) Controle da ferrugem "asiática" da soja da na safra 2006/2007. Disponível em: http://www.cnpso.embrapa.br Acessado em agosto de 2013.

Zhuang JY, Wei SX (2011) Additional materials for the rust flora of Hainan Province, China .Mycosystema 30: 853-860.

Zuluaga C, Buriticá P, Marín M (2009) Generalidades de los Uredinales (Fungi: Basidiomycota) y de sus relaciones filogenéticas. Acta Biol Colombiana 14: 39-54.

Zuluaga C, Buriticá P, Marín M (2011) Filogenia de hongos roya (Uredinales) en la zona andina colombiana mediante el uso de secuencias del ADN ribosomal 28S. Revista de Biología Tropical 59: 517-5402011 San José, Costa Rica. 


\section{CARACTERIZAÇÃO MORFOLÓGICA DOS PUCCINIALES DO CERRADO USADOS NAS ANÁLISES FILOGENÉTICAS}

\section{RESUMO}

A ordem Pucciniales representa um dos maiores grupos de fungos do Cerrado brasileiro (Dianese et al. 1997, Dianese 2000), entretanto o estudo acerca da sua biodiversidade ainda é insatisfatório. O que se tem de informações são principalmente refletidas em trabalhos de caracterização morfológica. Nessas condições, um total de 41 espécies entre formas sexuadas e assexuadas de Pucciniales foram aqui estudados, coletados nos estados de Goiás, Minas Gerais, Maranhão, Mato Grosso e no Distrito Federal. No Cerrado, os fungos causadores de ferrugem foram encontrados em plantas hospedeiras das famílias Anacardiaceae, Annonaceae, Arecaceae, Asteraceae, Bignoniaceae, Clusiaceae, Combretaceae, Euphorbiaceae, Fabaceae, Lauraceae, Loranthaceae, Malpighiaceae Myrtaceae, Rosaceae, Sapindaceae, Sapotaceae, Solanaceae, Vochysiaceae e Thelypteridaceae. O trabalho consistiu na caracterização, ilustração e complementação de dados de vários espécimes já conhecidos ou não. Neste estudo a família com a maior quantidade de membros representados foi a Pucciniaceae (gêneros: Puccinia e Uromyces) seguida das famílias Phakopsoraceae (gêneros: Phakopsora, Batistopsora, Catenulopsora e Crossopssora), Raveneliaceae (gêneros: Diorchidium, Esalque, Ravenelia e Sphaerophragmium), Uropyxidaceae (gêneros: Dasyspora, Kimuromyces sp., Mimema, Porotenus e Prospodium) Chaconiaceae (gêneros: Chaconia e Aplopsora), Pileolariaceae (gênero: Skierka) e Phragmidiaceae (gênero: Kuehneola). Além disso, foram incluídas no 
estudo espécies de classificação taxonômica incerta pertencentes aos gêneros Cerradoa e Desmella e alguns espécimes assexuais considerados simplesmente como Aecidium e Uredo. Além de aumentar as informações sobre as espécies já conhecidas, o trabalho resultou em novos relatos de ocorrência de membros das Pucciniales em nova hospedeiras e novos locais, prováveis espécies novas, relatos de fase ou fases do ciclo de vida até então inéditas e, finalmente, algumas atualizações nomenclaturais e taxonômicas.

Palavras chave: Morfologia, Ferrugens, Micodiversidade, Savana brasileira, Fungos da Neotropica 
A Ordem Pucciniales é um grupo de grande importância no Cerrado, todavia os conhecimentos acerca da ocorrência e diversidade de membros deste grupo ainda são escassos. Atualmente cerca de um terço dos gêneros de Pucciniales são conhecidos no Cerrado (Kirk et al. 2008, Hennen et al. 2005). A caracterização morfológica é uma ferramenta base para o conhecimento de tais fungos sendo primordial a continuidade de pesquisas voltadas para este grupo neste sentido. Com o objetivo de se estender as informações sobre Pucciniales do Cerrado, extensivas coletas foram realizadas em diversos estados brasileiros dentro do bioma, seja em áreas de preservação ambiental, seja em parques Nacionais, bem como em locais de fronteira de ocupação urbana e agrícola.

A caracterização morfológica dentro do grupo dos Pucciniales detém uma particularidade em relação aos outros grupos fúngicos. Neste caso, o grupo pode envolver em seu ciclo de vida até 5 estágios esporíferos distintos e a morfologia das estruturas, principalmente dos esporos sexuais (teliósporos) e assexuais de cada estágio é determinante para a caracterização de gêneros e também de muitas espécies (Cummins e Hiratsuka 2003). Cabe lembrar que, associada à análise morfológica temos a inferência de gêneros e espécies por meio da determinação da hospedeira, uma vez que os Pucciniales infectam grupos específicos de plantas sendo restritos principalmente a famílias.

Uma contribuição relativamente importante em termos da taxonomia do grupo, foi dada pelos micólogos da Universidade de Brasília, a qual se refletiu inclusive de forma sugnificativa no conteúdo da quarta edição do clássico Illustrated Genera of Rust Fungi, por Cummins \& Hiratsuka (2003), onde foram incorporados dois novos gêneros (Batistopsora e Kimuromyces) e reinstalado um terceiro (Mimema), todos os três encontrados sobre plantas endêmicas do Cerrado. Além disso, várias ilustrações importantes passaram a constar do 
referido manual (Dianese et al. 1993, 1995; Resende 1999). As principais famílias de hospedeiras dos fungos causadores de ferrugem no Cerrado são: Fabaceae, Vochysiaceae, Annonaceae, Anacardiaceae, Clusiaceae, Combretaceae, Myrtaceae, Sapotaceae, Salpindaceae, Loranthaceae, entre outras.

Em Fabaceae são relatadas as espécies Crossopsora hymenaeae em Hymenaea stigonocarpa, Mimema venturae em Dalbergia miscolobium, Ravenelia bezerrae em Enterolobium ellipticum, Ravenelia cerradensis em Chamaecrista clausenii var. cyclophylla, Ravenelia chapadensis em Chamaecrista decumbentes, Ravenelia emaensis em Anadenanthera sp., Ravenelia mineirosensis em Anadenanthera colubrina var. colubrina, Ravenelia santos - costae em Calliandra dysantha, Ravenelia victoria - rossetii em Mimosa radula var. imbricata, Uromyces galacticae em Galactia peduncularis. Na família Vochysiaceae é encontrada a espécie Aplopsora hennenii em Qualea multiflora. Em Annonaceae Batistopsora crucis - filli em Annona tomentosa. Em Caryocaraceae a espécie Cerotelium giacometii em Caryocar brasiliense. Para Anacardiaceae é relatada a espécie monotípica Kimuromyces cerradensis em Astronium fraxinifolium. Em Clusiaceae Phakopsora blutleri em Kielmeyera coriaceae. Em Combretaceae Phakopsora chavessi em Terminalia phaeocarpae. Em Myrtaceae Phakopsora rossmanii em Campomanesia adamantium. Na família Sapotaceae é descrita a espécie Skierka divinopolensis em Matayba guianense. Na família Loranthaceae Uromyces hawksworthii em Phthirusa stelis, uma planta parasita de outras árvores do Cerrado (Dianese et al. 1993, Dianese et al. 1994, Dianese \& Santos 1995, Rezende \& Dianese 2001, 2002, 2003 e Souza et al. 2015).

Os principais trabalhos envolvendo o estudo da taxonomia de Pucciniales do Cerrado foram realizados por Resende (1999) com espécies em plantas da família Fabaceae, revelando entre outras várias espécies do gênero Ravenelia. Castro em 2012 estudou vinte e nove Pucciniales sendo uma provável nova espécie de Crossopsora em Blepharodon pictum e 
relatou oito fungos em hospedeiras inéditas: Aecidium ipomoeae em Ipomoea cairica, Aecidium piptocarphae e Puccinia pipta em Piptocarpha rotundifolia, Puccinia malvacearum em Triumfetta rhomboidea, Puccinia inrecta em Peixotoa goiana e Cerotelium sabiceae em Sabicea brasiliensis.

Dada a abundância de membros da Ordem Pucciniales neste bioma faz-se necessário o aprimoramento de técnicas clássicas de identificação morfológica, como alicerce para posteriores inclusão de ferramentas moleculares e estudos em filogenia molecular. Assim, o objeto do presente trabalho é prover um avanço na caracterização morfológica de um grupo de espécies para servir de base para um estudo molecular eficiente, capaz de resolver pendências que eventualmente apareçam. 
As amostras de plantas hospedeiras contendo sinais de fungos causadores de ferrugens foram coletadas no Distrito Federal, principalmente nos seguintes locais: Jardim Botânico de Brasília (JBB), Reserva Ecológica do Instituto Brasileiro de Geografia e Estatística (RECOR — IBGE), Reserva da Fazenda Água Limpa da Universidade de Brasília (FAL - UNB), Reserva da Estação Experimental de Biologia da Universidade de Brasília (EEB - UNB) e Campus Darcy Ribeiro da Universidade de Brasília. Além do Distrito Federal, as coletas das amostras também foram realizadas em reservas no estado de Minas Gerais (Fazenda das Grotadas), Mato Grosso (Vila da Santíssima Trindade), Goiás (Rialma, Curralinho) e Maranhão (Chapada das Mesas - Carolina).

As plantas hospedeiras contendo sinais e sintomas de fungos característicos de membros da ordem Pucciniales, foram identificadas, processadas e submetidas ao processo de herborização. Posteriormente, essas plantas foram depositadas na Coleção Micológica do Herbário UB da Universidade de Brasília o qual receberam um código de referência (UB Col. Micol.), e um número seriado.

Aproximadamente 400 amostras frescas de plantas foram analisadas, no entanto, quase 3.000 espécimes de Pucciniales do Cerrado, estão incorporados à Coleção Micológica do Herbário UB (UB Col. Micol). Adicionalmente, algumas das amostras herborizadas contidas na UB Col. Micol foram utilizadas para a complementação da caracterização morfológica, quando necessária, a fim de ampliar o universo do estudo filogenético em Pucciniales do Cerrado.

Plantas mostrando sintomas/sinais de fungos causadores de ferrugens em folhas, caules, flores e frutos, foram submetidas primeiramente à análise em microscópio estereoscópico. As estruturas fúngicas foram retiradas através de estilete de ponta fina e 
colocadas em lâminas de vidro contendo corante a base de lactoglicerol, e, em seguida, sobrepostas com lamínulas de vidro e vedadas com camadas de esmalte para unhas. Essas montagens são caracterizadas como lâminas semipermanentes. Principalmente, nos materiais herborizados, fragmentos do tecido da planta contendo estruturas dos fungos foram separados e hidratados com etanol $10 \%(\mathrm{v} / \mathrm{v})$ e tween -20 a $0,1 \%$, por 30 minutos (material fresco) e por 3 horas (material herborizado). Para a análise da relação do fungo com o tecido vegetal da hospedeira, esses fragmentos foram submetidos a cortes histológicos com espessura entre 10 a $30 \mu \mathrm{m}$, realizados em criomicrótomo modelo Micron CM $1850-220 \mathrm{~V} / 60 \mathrm{~Hz}$ e os cortes montados em lâminas semipermanentes para observação em microscópio de luz.

O material assim tratado, foi examinado e fotografado em microscópio de luz Leica ${ }^{\circledR}$ DM 2500 provido de câmara Leica ${ }^{\circledR}$ DFC 490, acoplada a computador conectado a sistema eletrônico de captura de imagem. A mensuração das estruturas dos fungos foram realizadas através do programa Leica ${ }^{\circledR}$ QwinV3. As medidas referentes a cada estrutura fúngica foram realizadas com 20 a 50 repetições e foram consideradas as dimensões extremas e as de maior frequência.

Os sintomas e sinais dos respectivos fungos nas hospedeiras foram fotografados em um microscópio estereoscópico (Leica ${ }^{\circledR} \mathrm{M} 205 \mathrm{C}$ ) acoplada a uma câmara fotográfica digital (Leica ${ }^{\circledR}$ DFC 295) conectada a conectada a um computador e a um sistema eletrônico de captura de imagem que são processadas por meio do software Leica ${ }^{\circledR}$ LAS V4.4.

Os dados então gerados somados à identificação precisa da planta hospedeira, dada à especificidade patogênica dos Pucciniales, constituiu, em conjunto, em uma primeira fase obrigatória para chegar com sucesso a identificação precisa da espécie de fungo envolvida.

A literatura básica envolvida nos estudos morfológicos consistiu em primeiro plano na quarta edição do "Illustrated Genera of Rust Fungi" publicado pela American Phytopathological Society (Cummins \& Hiratsuka 2003) e no "Catalogue of the Species of 
Rust Fungi from Brazil" (Hennen et al. 2005), entre muitos outros artigos a serem mencionados quando no trato de material especificamete vinculado a cada gênero e/ou espécie. 


\section{RESULTADOS E DISCUSSÃO}

O presente estudo concentrou-se apenas em espécies de Pucciniales do Cerrado pertencentes as famílias Chaconiaceae, Phakopsoraceae, Uropyxidaceae, Pucciniaceae, Phragmidiaceae, Pileolaricaceae e Raveneliaceae. No entanto, também foram caracterizadas espécies Pucciniales com classificação taxonômica incerta (Incertae sedis) e formas assexuadas de ocorrência inédita para algumas das hospedeiras estudadas.

Assim, as coletas de membros de cada Família da Ordem Pucciniales estudada, foram caracterizadas morfologicamente através de descrição e ilustração precisas, acompanhadas da consequente classificação taxonômica precisa de cada uma.

As descrições de cada espécime seguiram os conceitos de Cummins \& Hiratsuka (2003), no que se refere aos 6 grupos e 12 tipos de espermogônios estabelecidos por Hiratsuka \& Hiratsuka (1980) (Figura 4), e as formas estabelecidas para a fase ecídica e uredínica conforme contidos em Cummins \& Hiratisuka (2003) e Hennen et al. (2005), conforme a Figura 5. 

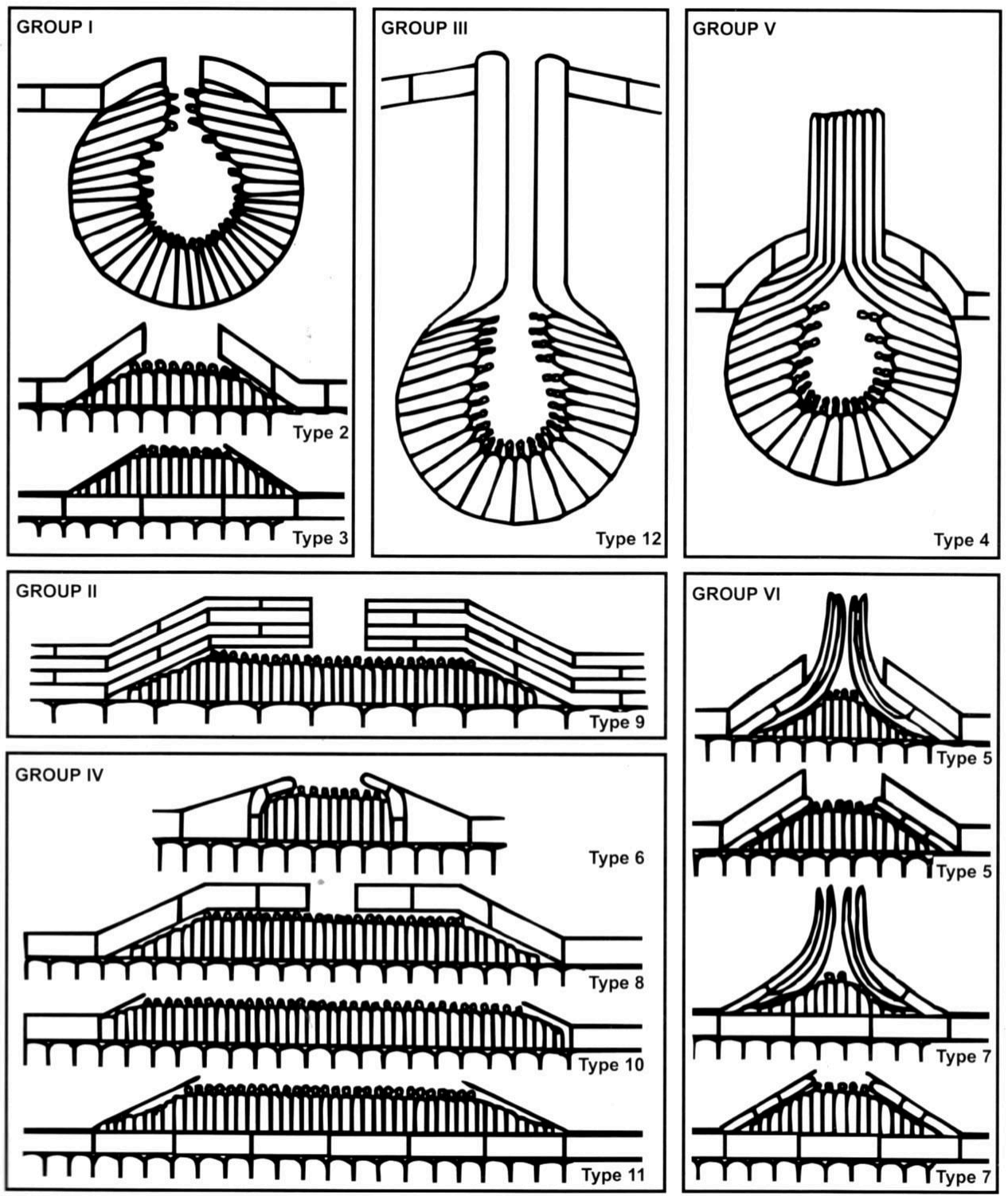

Figura 4. Esquema adotado por Cummins \& Hiratsuka (2003) para facilitar a descrição dos espermogônios por meio de uma divisão em Grupos e Tipos e usado no presente trabalho. 


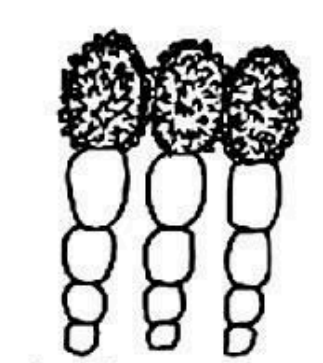

A
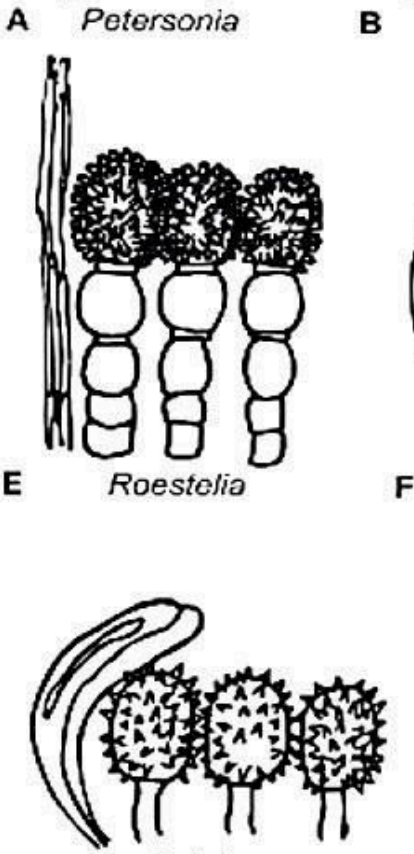

I

Calidion

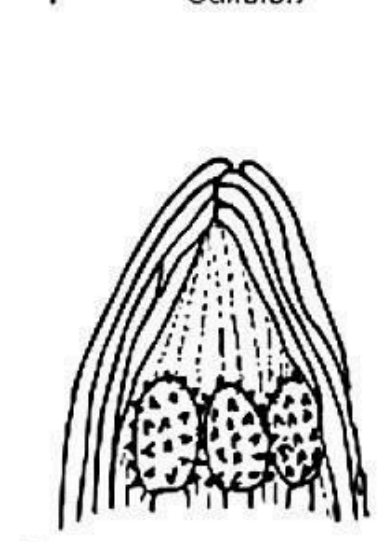

M Uredostibe

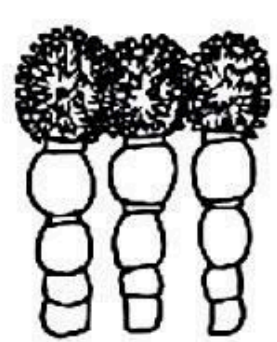

B

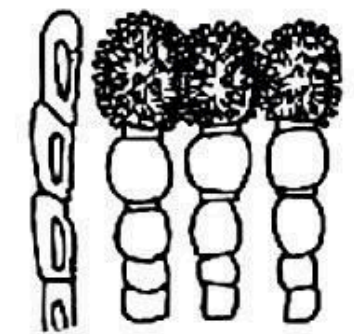

C
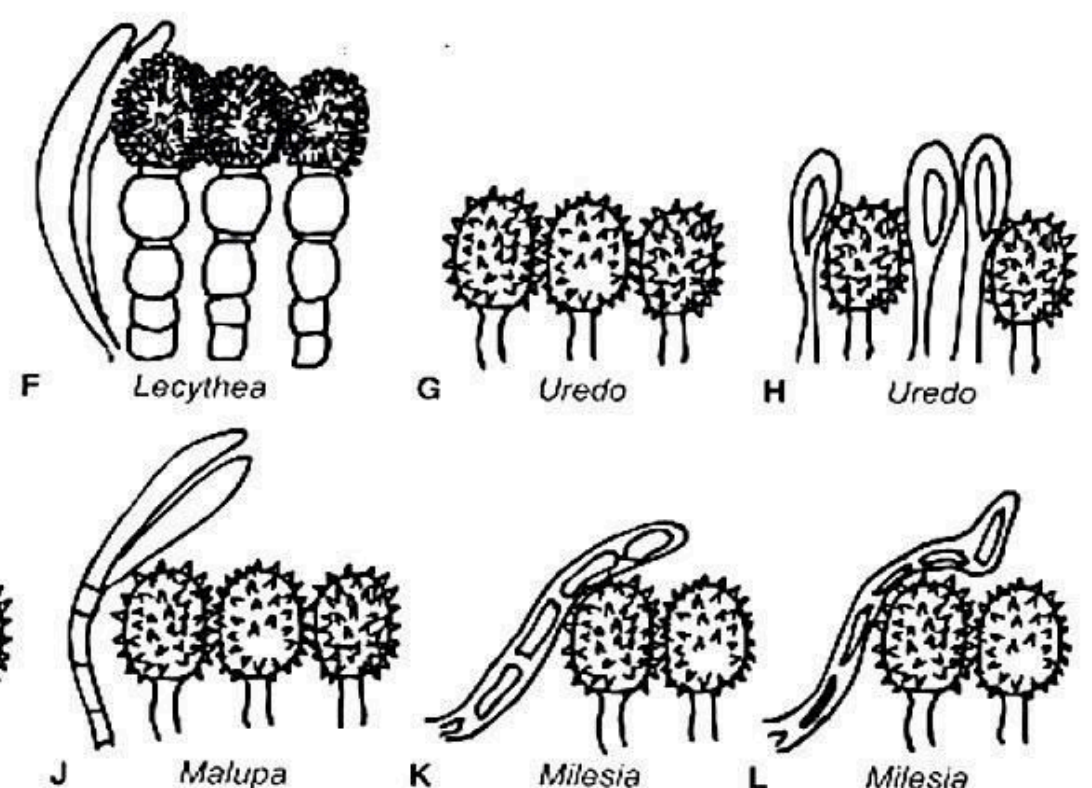

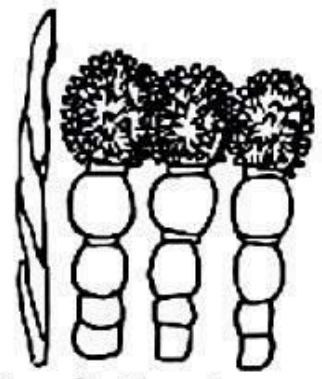

D Peridemium

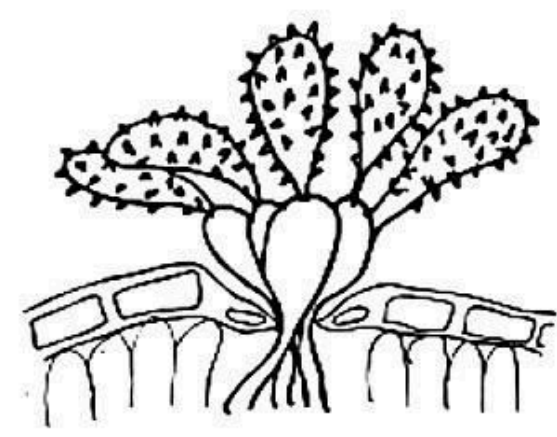

$\mathbf{N}$

Wardia

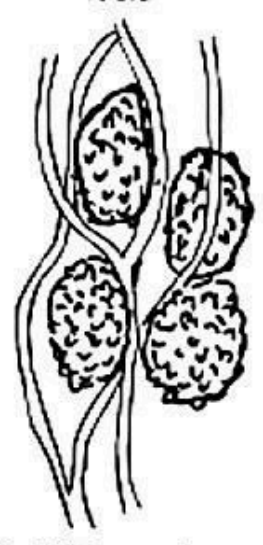

- Elateraecium

Figura 5. Designações e desenhos esquemáticos das fases assexuadas (écios e urédios) dos Paucciniales criados por Hiratsuka \& Hiratsuka (1980) e adotados por Cummins \& Hiratsuka (2003), para facilitar a descrição de famílias e gêneros e usados neste trabalho. 


\section{Membros da Família Chaconiaceae Cummins \& Y. Hiratsuka}

A Família Chaconiaceae é caracterizada morfologicamente por possuir Espermogônios Grupo VI (tipos 5 ou 7). Écios tipo Uraecium sensu Arthur, ou do tipo Aecidium, com ou sem perídio; eciósporos individuais ou catenulados, geralmente equinulados, poros germinativos variados. Urédios do tipo Uredo, com ou sem paráfises; urediniósporos solitários, curto - pedicelados, geralmente equinulados com poros germinativos distribuídos ao acaso. Télios irrompentess, teliósporos unicelulares, lateralmente livres, sésseis ou pedicelados, paredes finas, com ou sem poros germinativos conspícuos; germinam sem dormência; basídio externo ou interno (septados internamente). Autoécios ou heteroécios com hospedeiros variados.

Essa Família incluia os Gêneros: Achrotelium, Aplopsora, Botryorhiza, Ceraceopsora, Chaconia, Chrysocelis, Goplana, Maravalia, Olivea, Stomatisora, Telomapea, Acervulopsora, Angusia, Argomycetella, Bitzea, Desmotelium, Scopella, Scopellopsis, Tegillum e Mapea, sendo o Gênero Chaconia Juel designado como tipo (Cummins \& Hiratsuka 1983, Index Fungorum 2016, Mycobank 2016).

Os gêneros Achrotelium, Botryorhiza, Ceropsora, Maravalia e Scopella que produzem teliósporos pedicelados, foram excluídos da família Chaconiaceae, onde estavam anteriormente incluídos por Cummins e Hiratsuka (1983) e por Ono \& Hennen (1983), segundo Mycobank e Index Fungorum, acessados em 29/11/2016. Assim, atualmente, com a sinonimização de gêneros e recombinação de várias espécies, a família Chaconiaceae se limita aos gêneros que apresentam teliósporos unicelulares e sésseis como em Aplopsora, Chaconia, Chrysocelis, Goplana, Ochropsora e Olivea.

O gênero Hemileia era considerado por Cummins e Hiratsuka (2003) como membro de Chaconiaceae, porém atualmente permanece como gênero incertae sedis (Index Fungorum, 
Mycobank acessados em 29/11/2016, devendo estar vinculado ao grupo de espécies que formam teliósporos em cestas supra - estomatais.

Cummins \& Hiratsuka (2003) já haviam excluído Chrysocelis de Chaconiaceae por diferir de outros gêneros quanto ao tipo de espermogônio, e écios do tipo Petersonia-like alocando-o dentro de Mikronegeriaece. Até o presente, prevalece a observação de Ono \& Harada (1994) de que os gêneros atribuídos a Chaconiaceae não estão claramente estabelecidos devido ao conhecimento incompleto dos ciclos de vida e caracteres morfológicos dos soros.

Daí a ênfase dada no presente trabalho aos detalhes das diferentes formas de esporulação de espécies da família Chaconiaceae. No Cerrado brasileiro trabalhou-se aqui com espécies pertencentes aos Gêneros Chaconia e Aplopsora, ambas aqui caraterizadas em detalhe.

\section{Gênero Chaconia Juel 1897}

O gênero possui, segundo Cummins \& Hiratsuka (2003): Espermogônias subepidérmicos ou subcuticulares do grupo VI. Écios subepidérmicos, irrompentes, paráfises ausentes, do tipo Uredo ou periféricas e encurvadas, tipo Calidion sensu Cummins \& Hiratsuka (2003); eciósporos solitários, pedicelados, equinulados ou com verrugas em linhas, mais ou menos reticulados, poros germinativos equatoriais ou obscuros. Urédios similares aos écios mas não acompanhados por espermogônios; urediniósporos semelhantes aos eciósporos. Télios subepidérmicos, irrompentes; teliósporos unicelulares probasidiais, elipsoides ou clavados, de parede fina e lisa, lateralmente livres, sésseis, agrupados em células esporogênicas basais, poros germinativos inconspícuos de parede fina e coloração pálida; desenvolvendo metabasidios externos. Basidiósporos em esterimas formadas por 
alongamento apical dos teliósporos, germinando em grupos, sem dormência; mebasídios externos. Esses conceitos são também considerados em trabalhos mais recentes (Hennen et al., 2005, Berndt \& Beenken 2013).

O gênero Chaconia (espécie tipo: Chaconia alutacea Juel), foi descrito em Pithecellobium divaricatum (Borg.) Benth, originalmente identificado como Calliandra sp., no Paraguai (Juel 1897).

Atualmente são reconhecidas 12 espécies válidas para o gênero, encontradas em diversas famílias botânicas: Fabaceae (C. alutacea, C. brasiliensis, C. coaetanea e C. ingae), Euphorbiaceae (C. maprouneae), Oleaceae (C. butleri), Bignoniaceae (C. thailandica), Verbenaceae (C. berroana), Clusiaceae (C. clusiae), Heliconiaceae (C. heliconiae), Moraceae (C. hennenii) e Loranthaceae (C. texensis) (Index Fungorum e Mycobank, acessados em $29 / 11 / 2016$.

Todas as espécies de Chaconia spp. são autoécias. Como consequência, espécies de Chaconia podem na prática serem identificadas com base em características dos télios combinadas com a identificação precisa da espécie hospedeira.

As espécies C. africana (Y. Ono \& J.F. Hennen) Eboh e C. baphiae (Cummins) Thirum. \& Cummins, ambas descritas em Fabaceae, foram tratadas como espécies de Chaconia por Eboh (1979) e Thirum. \& Cummins (1948). No entanto, hoje, os próprios auroes das recombinações, alocaram ambas em Ypsilospora, família Raveneliaceae, designadas: $Y$. africana Ono \& J.F. Hennen e $Y$. baphiae Cummins. Nessas espécies, os teliósporos são unicelulares e sésseis, mas ligados em pares, por um único pedicelo, além de serem produzidos sucessivamente em células esporogênicas às vezes soldadas a outras adjacentes, Com isso, resultando em teliósporos arranjados em roseta ou em espiral.

Duas espécies de Chaconia foram recombinadas para os gêneros Maravalia e Olivea, ambos da mesma família, como foi o caso de C. millettiae Suj. Singh, encontrada em folhas 
de Millettia auriculata (Fabaceae) descrita em 1968 (Suj. Singh 1968) hoje M. milletticola Y. Ono \& J.F. Hennen (1984); e C. tectonae T.S. Ramakr. \& K. Ramakr, a partir de 1973, tratada como Olivea tectonae (T.S. Ramakr. \& K. Ramakr.) J.L. Mulder (T.S. Ramakr. \& K. Ramakr 1949, Mulder 1973).

\section{Espécies de Chaconia do Cerrado}

Chaconia brasiliensis Ono \& Hennen (1983). Figs. 6 (A-I)

De acordo com a descrição original de Ono \& Hennen (1983) e estudos feitos por Vilela (1999) a espécie mostrou: Lesões esbranquiçadas na presença de teliósporos, ou ferruginosas quando dominam os urédios. Espermogônios e Écios ausentes. Urédios anfígenos, maioria hipófilos, 0,2-0,5 $\mathrm{mm}$ de diâmetro, subepidérmicos, irrompentess, dispersos ou gregários, pulverulentos, de coloração canela a marrom, parafisados. Urediniósporos $23-38 \times 18-25 \mu \mathrm{m}$; paredes $1,5 \mu \mathrm{m}$ de espessura, pedicelados, subglobosos, obovoides a elipsoides, equinulados, coloração canela a marrom dourado; $5-7$ poros germinativos (maioria 6), dispersos, parafisados. Paráfises $28-44 \times 2-4 \mu \mathrm{m}$, himeniais, hialinas, cilíndricas a clavadas. Télios $0,2-0,5 \mathrm{~mm}$, hialinos, compactos, cerosos. Teliósporos cilíndricos $47-67 \times 9-14(-16) \mu \mathrm{m}$, paredes finas, hialinas, lisas, metabasídios formados pela germinação apical dos teliósporo. Basidiósporos hialinos, unicelulares, obovoides $10-13 \times 7-10 \mu \mathrm{m}$.

Espécimes examinados: em folhas de Stryphnodendron adstringens (Mart.) Coville (Fabaceae): Estação Experimental de Biologia da Universidade de Brasília, Brasília, Distrito Federal, 01 ago. 2012, leg. E.S.C. Souza 102, UB22333; Centro Olímpico da Universidade de Brasília, Brasília, Distrito Federal, 25 jun. 2012, leg. E.S.C. Souza 65, UB22270; Instituto 
Federal de Brasília, Planaltina, Distrito Federal, 20 ago. 2015, leg. E.S.C. Souza 248, UB23242.

Esta espécie já foi relatada em Stryphnodendron adstringens, S. barbatimam, $S$. cristalinae e Stryphnodendron sp. (Fabaceae) com ocorrência apenas nos estados brasileiros da Bahia, Maranhão, Mato Grosso, Mato Grosso do Sul, Minas Gerais, Pará, Piauí, Roraima, São Paulo e no Distrito Federal.

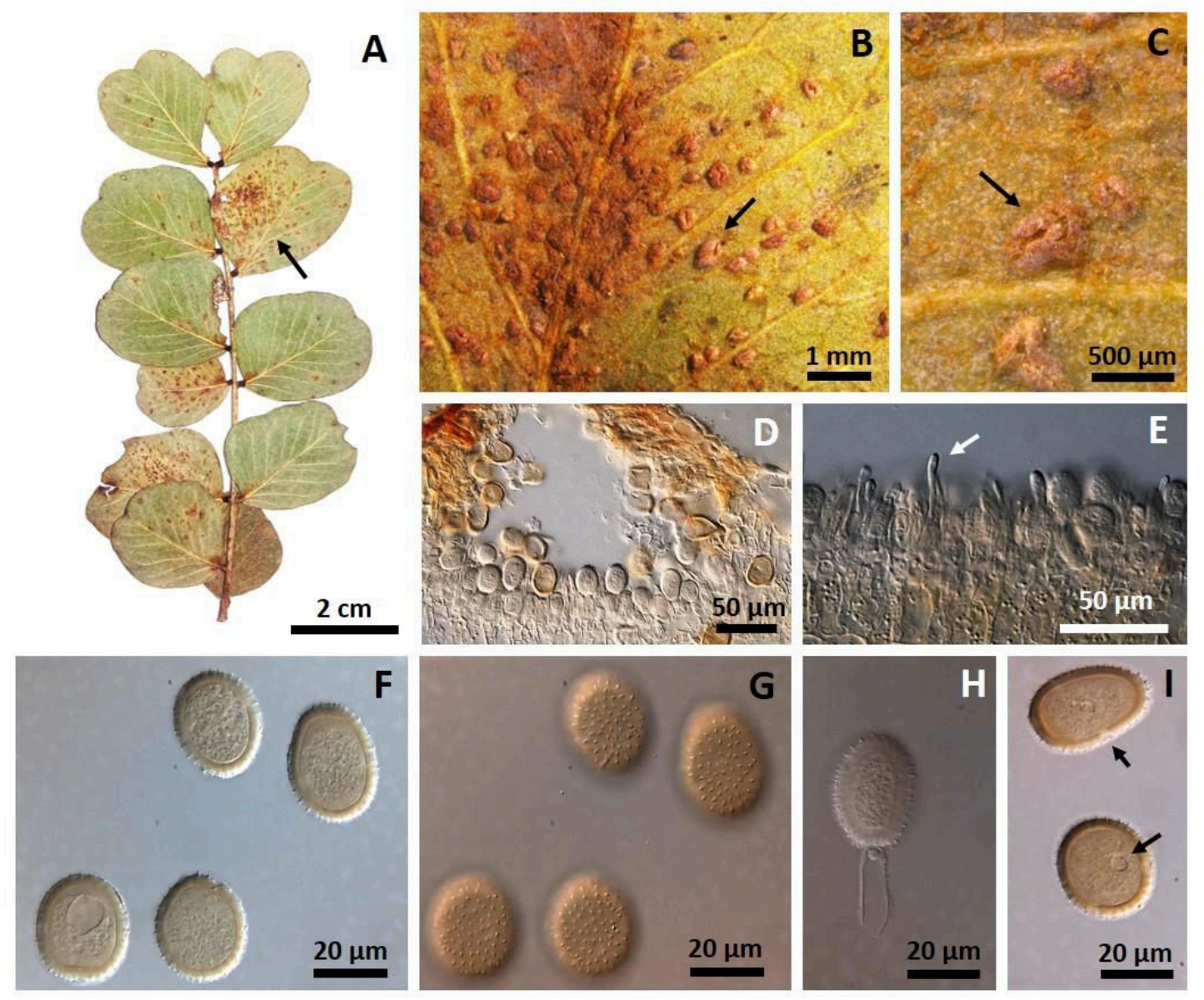

Figura 6. Chaconia brasiliensis em folhas de Stryphnodendron adstringens. A.

Ferrugem cersas nos folíolos. B e C. Urédios (setas) com soros de coloração canela a marrom distribuídas na face abaxial dos folíolos. D. Corte transversal de um urédio subepidérmico, incorporando parte do parênquima paliçádico, irrompente, parafisado. E. Detalhe das paráfises himeniais hialinas cilíndricas a clavadas (seta). F e G. Urediniósporos, subglobosos, obovoides a elipsoides, equinulados, coloração canela a marrom dourado, em diferentes profundidades de foco. H. Urediniósporo pedicelado. I. Poros germinativos dos urediniósporos (seta). 


\section{Chaconia ingae (Syd.) Cummins. Figs. 7 (A-J) e 8 (A-G)}

Espermogônios $(108-) 115(-145) \times(30-46)(-60) \mu \mathrm{m}$, profundos, irrompentes, anfígenos, subcuticulares, cilíndricos, hemisféricos. Écios $(0,2-) 0,5(-1,0) \times(0,1) 0,4(-0,7)$ $\mathrm{mm}$, sobre calos hipertrofiados, profundos, irrompentes, uredinioides, anfígenos, parafisados; Paráfises cilíndricas, clavadas no ápice, himeniais e periféricas, $28-55 \times 2-4 \mu \mathrm{m}$. Eciósporos (20-) $25(-31) \times(15-21(-25) \mu \mathrm{m}$, pedicelados, ovoides, obovoides a elipsoides ou irregulares, ligeiramente clavados com estreitamento em direção à base, marrom-canela, verrugosos na metade subequatorial, com projeções em estrias no terço distal do esporo, com sulcos longitudinais proeminentes, muitas vezes reticulados com menos sulcos transversais pronunciados; parede $2-4 \mu \mathrm{m}$ de espessura nos lados, $2-5 \mu \mathrm{m}$ no ápice $3-9 \mu \mathrm{m}$ na base; 3-4 poros germinativos, equatoriais. Urédios semelhantes aos écios, mas não associadas aos espermogônios. Urediniósporos smelhantes aos eciósporos. Télios $(0,3-)$ 0,6 $(-0,9) \times(0,2-)$ $0,5(-0,6) \mathrm{mm}$, hipófilos, dispersos ou pouco gregários, muitas vezes confluentes, subepidérmicos na origem, irrompendo precocemente. Teliósporos (103-) $129(-150) \times$ (12-) 16 (-21) $\mu \mathrm{m}$, cilíndricos, clavados, lisos, fasciculados, germinação externa, apical, sem dormência; paredes finas, hialinas, lisas. Metabasídios formados por germinação apical dos teliósporos. Basidiósporos obovoides $9-10 \times 7-8 \mu \mathrm{m}$.

Essas observações concordam com as descrições de Ono e Hennen (1983) e Hernández \& Hennen (2003).

Espécimes examinados: em folhas de Inga sessilis (Fabaceae): Quadra 23, rua $15 \mathrm{~S} / \mathrm{N}$ Centro, Rialma, Goiás, 22 set. 2013, leg. E.S.C. Souza 220, UB22559; Quadra 23, rua 15 S/N Centro, Rialma, Goiás, 19 jan. 2014, leg. E.S.C. Souza 223, UB22597. Em folhas de Inga laurina_(Vellozo) Martius (Fabaceae): Rancho Riacho, Lagoa da Prata, Minas Gerais, 01 ago. 2015, leg. Danilo Batista Pinho 111, UB23340. 
Os espécimes aqui estudados apresentaram urediniósporos com as mesmas características morfológicas que a descrição original, entretanto mostram maiores dimensões, $29-39 \times 20-24 \mu \mathrm{m}$, e mostrando quase sempre 2 poros germinativos. Já os teliósporos são menores $(100-122 \times 8-12 \mu \mathrm{m})$, porém possuem a mesma morfologia.

Assim como nas considerações feitas por Rezende (1999) as características morfológicas das estruturas e dos esporos estão de acordo com as descrições de Ono (1978), porém as ornamentações das paredes dos eciósporos e urediniósporos não se mostram sempre em linhas como nas descrições anteriores feitas por Viegas (1945) e por Cummins e Hiratsuka (1983). Rezende (1999) observou saliências, tuberculosidades ou projeções no topo do esporo, aparentando uma franja e, quando vistos em MEV, mostraram a superfície com pequenas depressões alveolares nos dois terços basais. Possuem também os quatro poros germinativos bem evidentes, mas no terço distal ocorrem tuberosidades em linha que recobrem até o topo do esporo.

No material aqui estudado, os eciósporos não foram vistos. A ornamentação da parede dos urediniósporos mostrou-se reticulada e fortemente estriada com projeções longitudinais dispostas irregularmente ao longo de toda a superfície do esporo, concordando com Ono \& Hennen (1983).

Ao germinar, os teliósporos produzem primeiramente o basidiósporo apical, diferentemente de Chaconia brasiliensis em que todos os quatro basidiósporos são formados simultaneamente no metabasídeo com a liberação de basidiósporos um a um (Ono \& Hennen 1984). Esta espécie também foi relatada infectando outras espécies hospedeiras do Gênero Inga em outros países como: Equador, El Salvador, Costa Rica, Argentina, Colômbia, Paraguai, Belize, Guatemala, Porto Rico, Ilhas Britânicas, Venezuela, México, Honduras, Panamá, Peru, Guiana Francesa, Guiana, Trinidad e Tobago (Farr \& Rossman 2016). 
A espécie foi reportada em Inga edulis, I. insignis, I. sessilis, I. vera e Inga sp. (Fabaceae) no Brasil, em registros diferentes nos estados de Minas Gerais, Pará, Paraíba, São Paulo, Amapá, Amazonas e Goiás, Rio de Janeiro e no Distrito Federal. No entanto, esta é a primeira vez que $C$. ingae foi encontrada em Inga laurina.
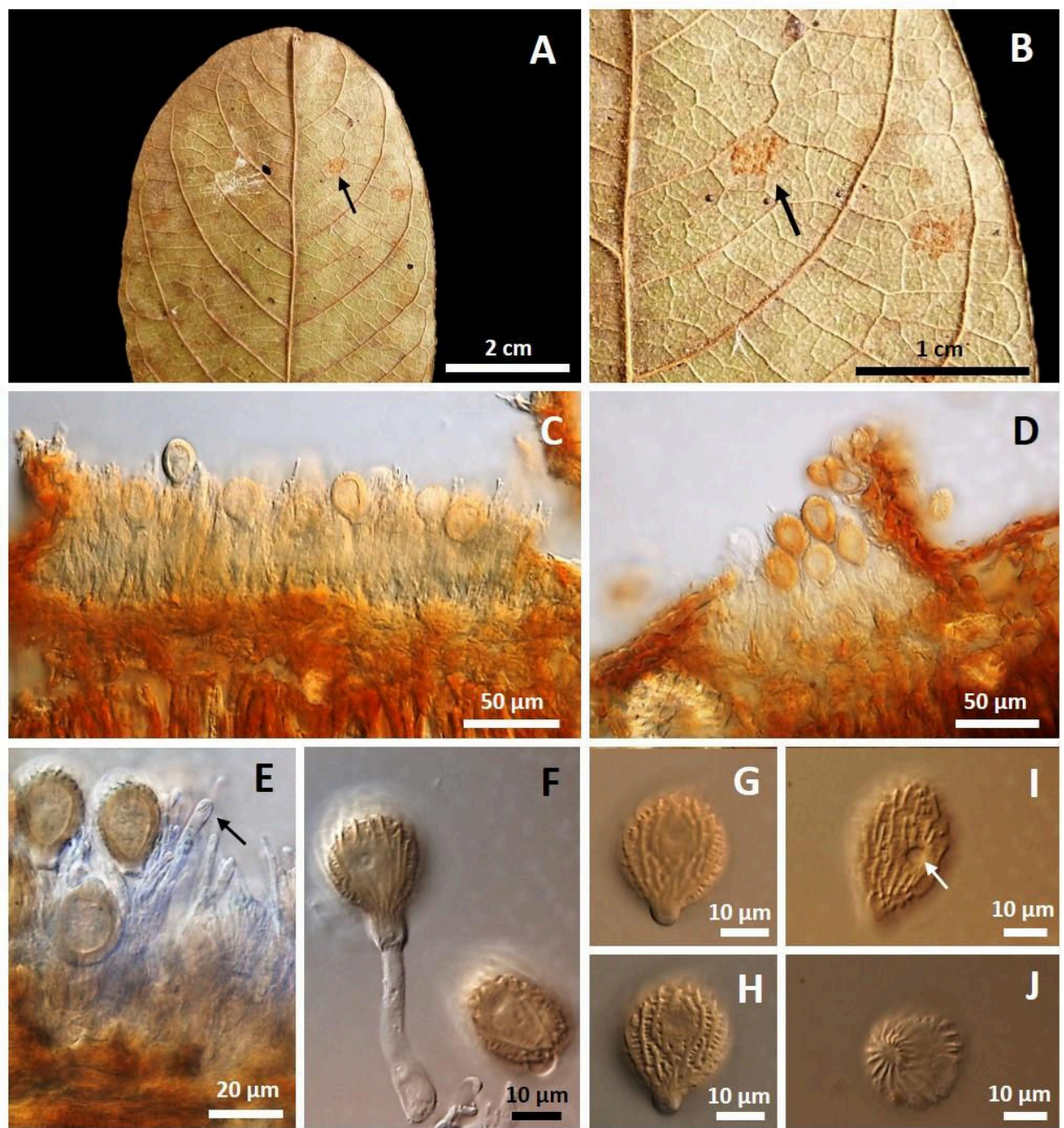

Figura 7 (A-J). Chaconia ingae, fase assexual em folhas de Inga sessilis. A-B. Sintoma de ferrugem com aspecto pulverulento e distribuição dos soros (setas) em grupo. C-D. Corte transversal de urédios subepidérmicos, irrompentes e parafisadas. E. Detalhe das paráfises himeniais hialinas cilíndricas a clavadas (seta). F. Urediniósporo pedicelado. G-H. Urediniósporos obovoides, subglobosos a subclavados, marrom-canela, verrugosos, com projeções em estrias no terço distal do esporo, com sulcos longitudinais proeminentes ou não, I. Poro germinativo (seta). J. Detalhe da base estriada do urediniósporo. 

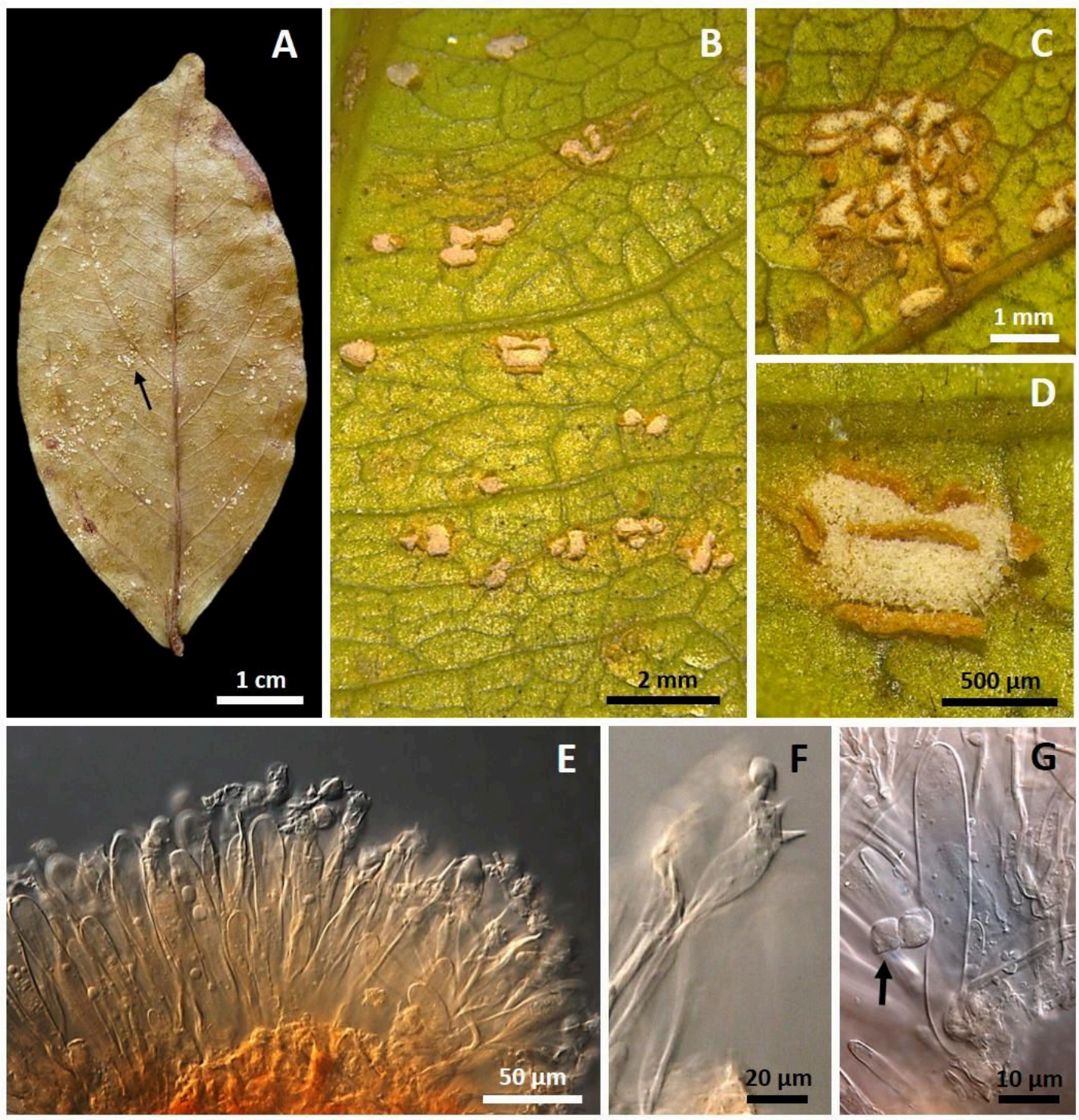

Figura 8 (A-G). Chaconia ingae, fase sexual em folhas de Inga laurina. A. Distribuição das pústulas (seta) na face abaxial da folha. B, C e D. Télios irrompentes, cerosas, esbranquiçadas e de aspecto brilhante. E. Télio em corte transversal mostrando agrupamento dos teliósporos hialinos, cilíndricos, clavados, lisos e fasciculados com germinação externa e apical. F. Metabasídio formados por alongamento apical dos teliósporos, mostando esterigmas e um basidiósporo. G. Teliósporo e basidiósporos dois livres (seta). 
Chaconia maprouneae (Viégas) Ono \& Hennen. Fig. 9 (A-L)

Essa espécie é caracterizada por: Espermogônios e écios não observados. Urédios 0,2 - 1,0 mm de diâmetro, hipófilos, dispersos a densamente agregados, subepidérmicos na origem, irrompentes (Fig.4.A - F). Urediniósporos $26-31(-35) \times 18-25(-27) \mu \mathrm{m}$, pedicelados, reniformes, assimetricamente obovoides a piriformes; parede $1-1,5 \mu \mathrm{m}$ de espessura, equinulados, castanho claros a castanho - amarelados, $5-6$ poros germinativos supraequatoriais, ou dispersos na metade superior do esporo. Télios $0,1-0,3 \mathrm{~mm}$ de diâmetro, hipófilos, espalhados ou em pequenos grupos, misturados com os urédios, subepidérmicos em origem, irrompentes. Teliósporos $27-41 \times(4-)$ 6-10 um, cilíndricos, parede fina, hialinos; metabasídeos formados pelo alongamento da região apical dos teliósporos; basidiósporos 7 $-8 \times 6-7 \mu \mathrm{m}$ obovoides a piriformes. Essa descrição concorda com a de Ono e Hennen (1983).

Espécimes examinados: em folhas de Maprounea guianensis (Euphorbiaceae): Reserva Ecológica (RECOR) do Instituto Brasileiro de Geografia e Estatística (IBGE), Brasília, Distrito Federal, 06 jun. 2012, leg. E.S.C. Souza 52, UB22226; Centro Olímpico da Universidade de Brasília, Brasília, Distrito Federal, 25 jun. 2012, leg. E.S.C. Souza 60, UB22264; Fazenda Água Limpa (FAL) da Universidade de Brasília na trilha do córrego da Capetinga, Brasília, Distrito Federal, 08 ago. 2013, leg. E.S.C. Souza 207, UB22541.

A forma assexuada de Chaconia maprouneae é a espécie Uredo maprouneae P. Hennings, encontrada em folhas de Maprounea brasiliensis em 1904 no Peru.

Chaconia maprouneae foi encontrada em folhas de Maprounea brasiliensis e $M$. guianensis no Brasil em Goiás, Distrito Federal, em Minas Gerais, no Mato Grosso, Pará e São Paulo. Além disso, C. maprouneae, já foi registrada na Guiana Francesa, Bolívia e Trinidad (Hennen et al. 2005, Farr \& Rossman 2016). 

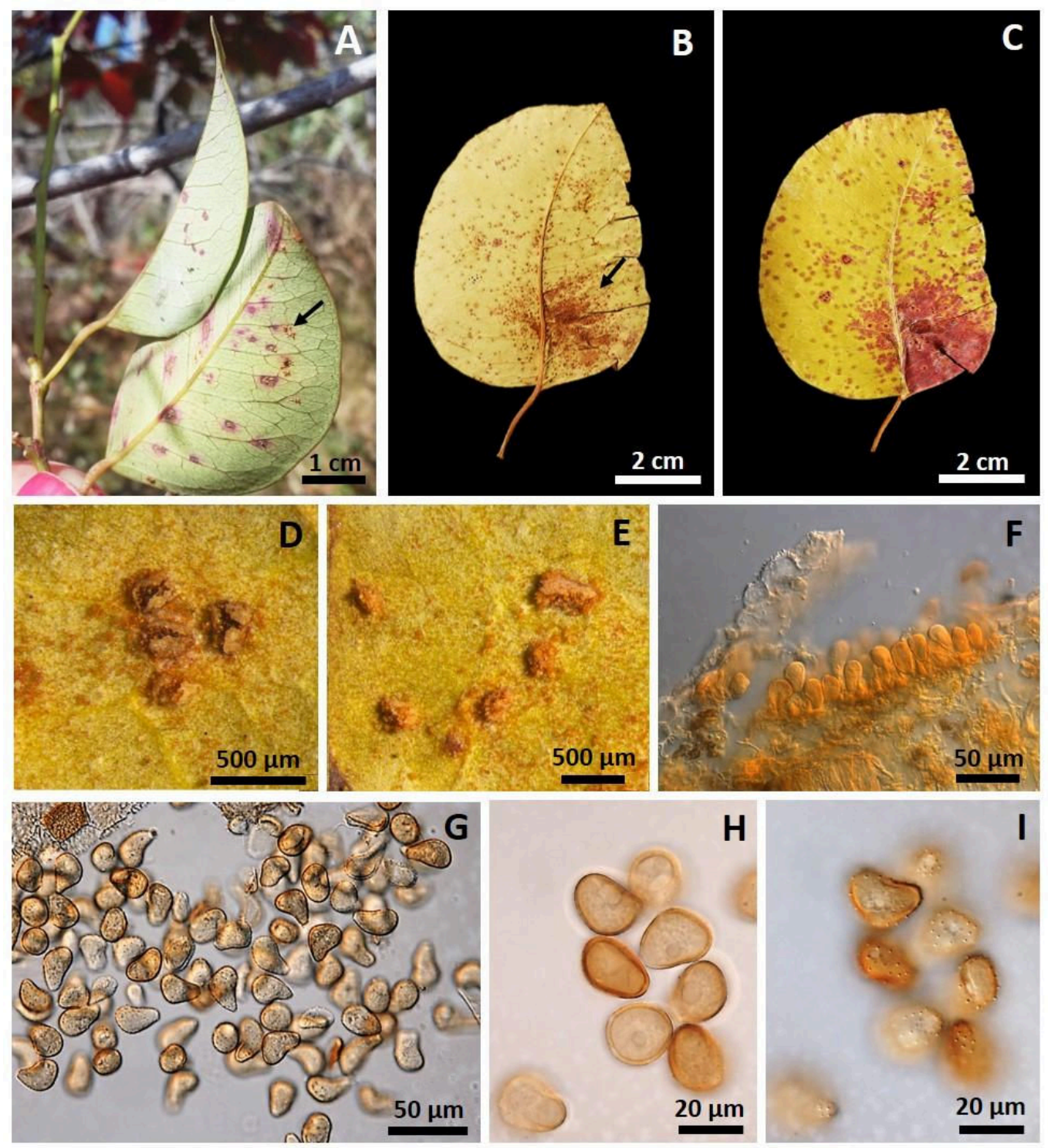

H
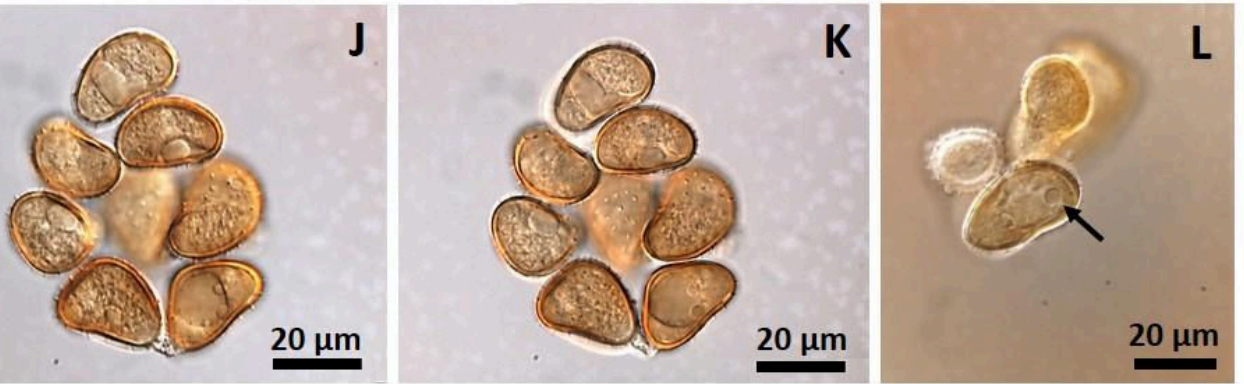

Figura 9 (A-L). Chaconia maprouneae, forma assexual em folhas de

Maprounea guianensis. A, B, C. Manchas avermelhadas anfígenas, contendo soros irrompentes (setas). D e E. Urédios irrompentes pulverulentos de coloração castanha. F. Corte transversal da urédio subepidermico. G. Massa de urediniósporos. H, I, J e K. Urediniósporos reniformes a piriformes, equinulados. L. Urediniósporo com seta mostrando poro germinativo. 


\section{Gênero Aplopsora Mains}

(Espécie-tipo: Aplopsora nyssae Mains)

Conforme Mains (1921) e Hennen et al., (2005), o gênero Aplopsora mostra as seguintes características: Espermogônios e écios não observados. Urédios subepidérmicos, irrompentes, paráfises periféricas fortes e recurvadas, unidas pela base. Urediniósporos pedicelados, poros germinativos inconspícuos. Télios subepidérmicos, imersos, irrompentes, sésseis, consistindo de uma camada de células adensadas cenocíticas. Teliósporos subhialinos, parede fina, às vezes, na parte central de um soro, formados em uma ou poucas camadas de uma a três células, poros germinativos são inconspícuos, germinação sem dormência; metabasídio basídio externo.

São conhecidas seis espécies dentro do gênero: $A$. corni Y. Ono \& Y. Harada, em Cornus controversa descrita do Japão; A. dicentrae (Mains \& H.W. Anderson) Buriticá \& J.F. Hennen, em Urticastrum divaricatum nos Estados Unidos; A. hennenii Dianese \& L.T.P. Santos (Sin= A. qualeae Buriticá \& Hennen) em Qualea multiflora (Vochysiaceae) no Cerrado; A. nyssae Mins em Nyssa aquatica (Nyssaceae) nos Estados Unidos; e A. tanakae em Falcata comosa no Japão.

A espécie tipo do gênero é Aplopsora nyssae Mains, coletada sobre Nyssa aquatica L. (Nyssaceae), no Mississippi (Cummins \& Hiratsuka, 2003).

Aplopsora dicentrae é a única espécie documentada claramente como sendo heteroécia com espermogônios e écios em Dicentra sp. (Fumariaceae), ao passo que urédios e télios são produzidos em Laportea $\mathrm{sp}$. (Urticaceae).

Aplopsora possui urédio semelhante ao de Phakopsora, porém os teliósporos são em poucas camadas e embora os sejam semelhantes aos de Melampsora, as paráfises dos urédios são diferentes. Em Aplopsora as paráfises são curvas e periféricas, já em Melampsora elas 
são muito mais numerosas, capitadas, não curvas, mais estreitas e com o ápice menos abaulado. Os teliósporos também são próximos aos do gênero Ochropsora sp. (antigamente dentro de Chaconiaceae e hoje em Uropyxidaceae), entretanto neste gênero os basídios são produzidos internamente, ao contrário aos de Aplopsora.

No Cerrado evidentemente o destaque é para $A$. hennenii, única espécie de Pucciniales conhecida em hospedeiros da família Vovhysiaceae.

\author{
Aplopsora hennenii Dianese \& L. T. P. Santos. Fig. 10 (A-H) \\ ( $\equiv$ Aplopsora qualeae Buriticá \& Hennen)
}

Aplopsora hennenii descrito por Dianese \& Santos (1995) mostra Urédios hipófilos, 75 - $150 \mu \mathrm{m}$ de diâmetro, irrompentes, pulverulentos, cinza claros a marrom-claros, solitários ou gregários, numerosos, cobrindo boa parte da folha. Paráfises $28-33 \mu \mathrm{m} \times 8-$ $12 \mu \mathrm{m}$, periféricas, numerosas, com as pontas dilatadas e encurvadas, hialinas a levemente pigmentadas, paredes lisas. Urediniósporos $13-20 \mu \mathrm{m} \times 11-15 \mu \mathrm{m}$ reniformes a subclavados, equinulados, pedicelados, parede com $1 \mu \mathrm{m}$ de espessura, levemente pigmentados, dois poros germinativos subequatoriais. Télios

As características morfológicas são as mesmas, quando comparado com o espécimetipo, entretanto o material aqui estudado apresenta urédios maiores em diâmetro (108 - 170 $\mathrm{mm})$, paráfises maiores e mais estreitas $(23-38 \times 8-9 \mu \mathrm{m})$, urediniósporos mais longos [16 - $22(19) \times 12-16(13) \mu \mathrm{m}]$, e ao contrário do mostrado acima, apresenta poros germinativos inconspícuos sendo a maioria apenas um por esporo.

Este é o primeiro registro do fungo em Qualea parviflora, uma vez que a espécietipo foi descrita em Q. multiflora. 
Espécimes examinados: em folhas de Qualea parviflora (Vochysiaceae): Jardim Botânico de Brasília, Brasília, Distrito Federal, 07 abr. 2014, leg. E.S.C. Souza 228, UB22891; em folhas de Qualea multiflora (Vochysiaceae): Jardim Botânico de Brasília, Brasília, Distrito Federal, 07 abr. 2014, leg. E.S.C. Souza 229, UB22895; Rancho Riacho, Lagoa da Prata, Minas Gerais, 01 ago. 2015, leg. D.B. Pinho 113, UB23329.

Esta foi a primeira vez que Aplopsora hennenii foi encontrada em Qualea parviflora no Cerrado. Aplopsora hennenii foi relatada no Brasil em Qualea multiflora, posteriormente por Buriticá (1998) em Qualea sp. (Farr \& Rossman 2016, Index Fungorum 2016, Mycobank 2016) e agora em Qualea parviflora. 


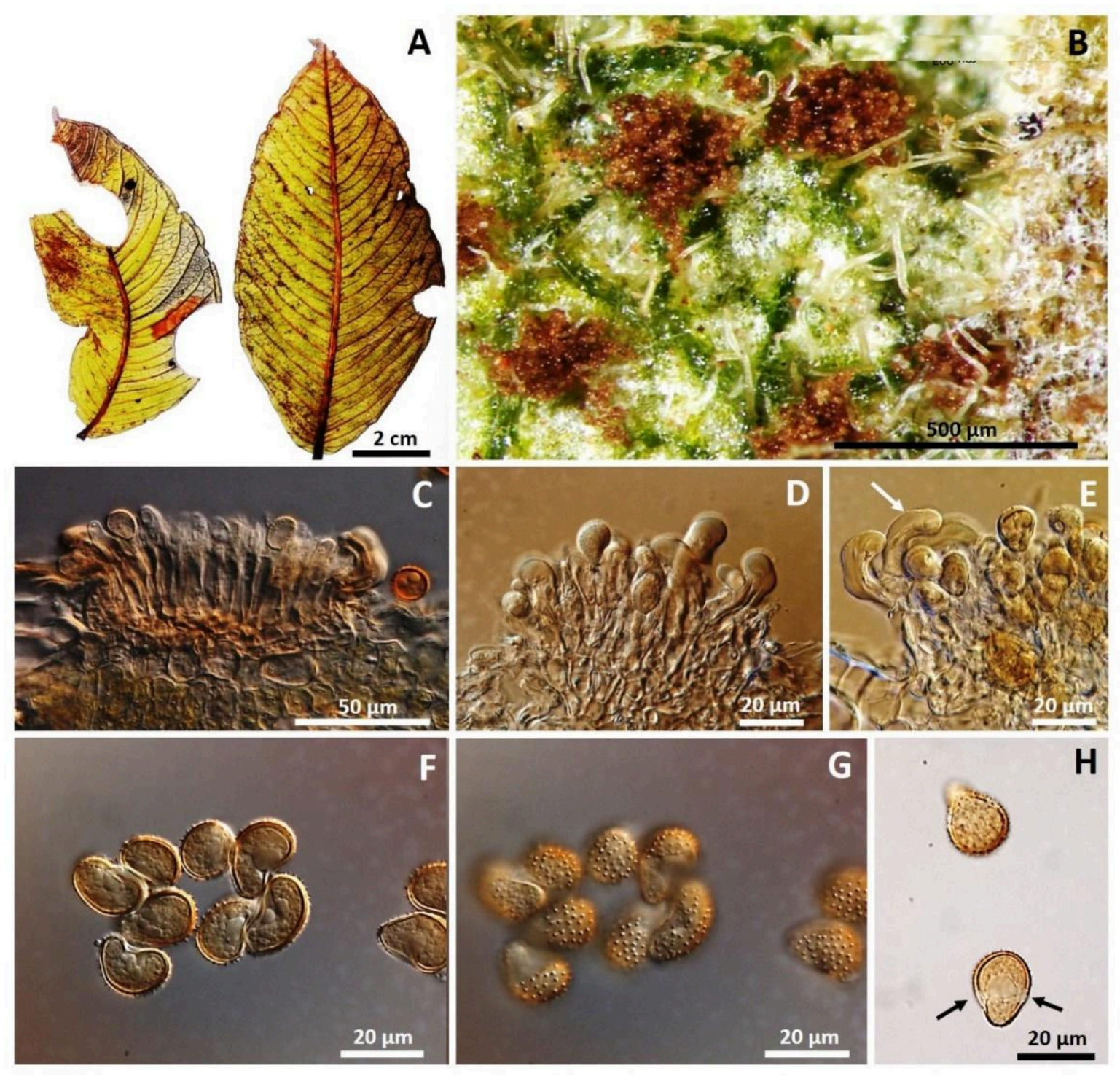

Figura $10(\mathrm{~A}-\mathrm{H})$. Aplopsora hennenii, fase uredínica em folhas de Qualea multiflora.

A. Sintoma na folha. B. Soros pulverulentos. C, D, E. Corte transversal de urédios mostrando paráfises periféricas recurvadas, fortes. F, G, H. Urediniósporos reniformes, equinulados e marrom claros em diferentes profundidades de foco em microscopia de luz, inclusive mostrando dois poros germinativos (setas). 


\section{Membros da Família Phragmidiaceae Corda}

Esta família é representada por treze gêneros autoécios que parasitam apenas plantas da família Rosaceae e normalmente produzem: espermogônios e écios de vários tipos com eciósporos catenulados ou pedicelados liberados solitariamente. Eciósporos verrugosos ou equinulados. Urédios na maioria das vezes com paráfises periféricas e encurvadas; urediniósporos geralmente equinulados com poros germinativos dispersos. Télios irrompentes com ou sem paráfises, teliósporos pedicelados com um a vários septos transversais e um ou mais poros germinativos por célula, metabasídio externo (Cummins \& Hiratsuka 2003, Zualaga et al. 2011).

Esta Família compreende os gêneros Arthuriomyces, Campanulospora, Frommeëlla, Gerwasia, Gymnoconia, Hamaspora, Joerstadia, Kuehneola, Morispora, Phragmidium, Scutelliformis, Trachyspora e Xenodochus e é composta por mais de mais de 164 espécies (Kirk et al. 2008, Mycobank: www.mycobank.org acessado em 29/11/2016.

Phragmidium é o gênero-tipo para a família, definido com base na espécie-tipo $P$. mucronatum (Pers.) Schltdl. infectando Rosa sp. na Europa.

O gênero Newinia já foi considerado anteriormente como membro de Phragmidiaceae por Cummins \& Hiratsuka (2003), entretanto atualmente ele está alocado em Phakopsoraceae (Mycobank 2016).

Já, o gênero Kuehneola Magnus (1898) abriga espécies com: Espermogônios subcuticulares ou intraepidérmicos, com crescimento determinado ou indeterminado, himênio plano ou ligeiramente côncavo, pertence ao Grupo 4 (tipo 11) estabelecido por Hiratsuka \& Hiratsuka (1980). Écios comumente produzem deformações no hospedeiro, são subepidérmicos na origem, irrompentes, tipo Uraecium, pulverulentos, eciósporos pedicelados. Urédios subepidérmicos na origem, irrompentes, tipo Uredo, pulverulentos; 
urediniósporos pedicelados, geralmente equinulados, poros germinativos subequatoriais ou inconspícuos. Télios subepidérmicos na origem, irrompente. Teliósporos produzido em soros mistos, juntamente com urediniósporos; teliósporos com pedicelos curtos, de duas a várias células divididas por septos transversais, parede lisa, pálida incolor, poro germinativo obscuro (um por célula), germinação ocorre sem dormência; metabasídios externos, bem diferenciados a partir das células probasidiais (Cummins \& Hiratsuka 2003, Hennen et al. 2005).

Embora a presença de pedicelos nos teliósporos seja uma característica essencial para a definição do gênero Kuehneola, é difícil determinar a sua presença em algumas espécies. Um representante comum deste gênero no neotrópico é Kuehneola loeseneriana (Arthur) H. S. Jackson \& Holway que pode incitar grande pulverulência de coloração laranja formando galhas em folhas e caules em espécies de Rubus sp.

O gênero Spirechina descrito em Rubus sp. na Bolívia (Arthur 1907) foi considerado como sendo sinônimo de Kuehneola (Jackson 1931). Thirumalachar (1960) considerou Catenulopsora como sinonímia de Kuehneola ao invés de Cerotelium (Cummins \& Hiratsuka 1983) e transferiu essas espécies de Catenulopsora para Kuehneola.

Phakopsora nishidana Ito, a ferrugem comum de Ficus carica foi impropriamente tida como Kuehneola fici Butler por Arhur (1917), sabendo-se hoje que se trata de Cerotelium fici (Butler) Arthur. Também, Phakopsora gossypii (Lagerheim) N. Hiratsuka, a ferrugem tropical de Gossypium hirsutum (algodoeiro), uma espécie bem estabelecida, foi anteriormente tratada como Kuehneola desmium (Berkeley \& Curtis) Butler e K. gossypii Arthur.

O gênero Kuehneola possui poucas espécies e são relatadas em hospedeiros de Rosaceae, Anarcadiaceae, Malvaceae, Verbenaceae e Celatracaeae (Bagyanarayana \& Rao 1985). Todas as espécies são autoécias e macrocíclicas. Kuehneola uredinis pode causar queda de folhas em framboesa e pode infectar também o caule (Cummins \& Hiratsuka 2003). 
A espécie tipo de Kuehneola é K. uredinis (=Oidium uredines $=$ Chrysomyxa albida =Kuehneola álbida) encontrada em Rubus fruticosus (Rosaceae) na Alemanha.

Para a identificação prática de espécies de Kuehneola atualmente, é considerada a apenas espécies com hospedeiros da família Rosaceae como Rosa sp. e Rubus sp. (Hennen et al. 2005). Hennen et al. (2005) possui uma chave para identificação de espécies de Kuehneola em Rosaceae para hospedeiras dos gêneros Dryas, Rosa e Rubus reproduzida a seguir:

1. Teliósporos com paredes uniformemente finas

2. Teliósporos com $3-4$ células nas linhas verticais

3. Teliósporos de $21-37 \times 10-20 \mu \mathrm{m}$ sobre Dryas Kuehneola dryadis

3. Teliósporos de $20-34 \times 17-22 \mu \mathrm{m}$ em Rosa Kuehneola japonica

2. Teliósporos com $4-6$ células nas linhas verticais sobre $R u b u s$

4. Ligação estreita entre as células dos teliósporos Kuehneola filipina

4. Ligação ampla entre as células dos teliósporos Kuehneola andina

1. Paredes dos teliósporos irregularmente espessada em Rubus

5. Eciósporos e urediniósporos equinulados

6. Urediniósporos de $18-28 \times 16-23 \mu \mathrm{m}$ Kuehneola albida

6. Urediniósporos de $23-27 \times 19-25 \mu \mathrm{m}$ Kuehneola guatemalensis

5. Eciósporos e urediniósporos com verrugas ou espinhos em espirais

7. Kuehneola loeseneriana (inclui Kuehneola arthurii e K. uleana) 


\section{Kuehneola loeseneriana (=Uredo loeseneriana). Fig. $11(\mathrm{~A}-\mathrm{L})$}

No Cerrado, foi encontrada apenas a fase uredínica de Kuehneola loeseneriana (=Uredo loeseneriana) apresentando: urédios $90-200 \mu \mathrm{m}$ subepidérmicos, irrompentes, sem paráfises, pulverulentos de coloração amarelada a esbranquiçada; urediniósporos $22-38$ (30) $\times 21-25 \mu \mathrm{m}$, pedicelados, elipsoides, verrugosos com verrugas distribuídas em forma de espiral, poros germinativos inconspícuos. As linhas em espirais espaçadas constituídas por conjunto organizado de pequenas verrugas, são bem características da espécie e, com isso facilitam a identificação de sua fase assexuada, ao se conhecer a identidade da hospedeira.

Espécime examinado: em folhas de Rubus brasiliensis (Rosaceae): Fazenda Água Limpa da Universidade de Brasília, Brasília, Distrito Federal, 27 jul. 2012, leg. H.M.M. Vale 177, UB22326.

O material tipo, anteriormente classificado como Spirechina loeseneriana, foi encontrado em Rubus bogotensis na Bolívia em 1890. Arthur (1912) e Gallegos \& Cummins (1981) relataram que espermogônios e écios de Kuehneola loeseneriana formavam galhas laranja-amareladas brilhantes em caules e folhas. Encontraram também espermogônios e écios associados com galhas, com massas de eciósporos tornando as galhas pulverulentas. $\mathrm{Na}$ maturidade as galhas nos troncos eram atingiam de 8 a10 $\mathrm{cm}$ de diâmetro. Acredita-se que todas as galhas produzidas por esta espécie são o resultado de infecções de basidiósporos e que geram espermogônios e écios, com os urédios espalhados pelas folhas.

Embora fungo seja relatado em várias espécies selvagens de Rubus, designadas amoras pretas no Brasil, principalmente na região da Mata Atlântica, ele também pode infectar algumas dessas espécies que são aqui cultivadas. Devido ao manejo de plantações cultivadas de Rubus em que as plantas são bem espaçadas, aumentando a circulação de ar e secagem da folha, a doença é de pouca importância no Brasil. 
Kuehneola loeseneriana foi primeiramente tratada como Uredo loeseneriana P. Hennings em 1898 a partir de material da Guatemala. Arthur (1907) foi o primeiro a relatar a fase sexuada. Ele encontrou a ferrugem em um espécime fanerogâmico de herbário, Rubus bogotensis, coletado na Bolívia e depositado no Field Herbarium do Museu de Chicago. Arthur designou este material como espécime-tipo de seu novo gênero Spirechina, uma vez que Spirechina loeseneriana era a única espécie no gênero. Assim, o espécime automaticamente se tornou a espécie-tipo do gênero Spirechina. Arthur publicou esta espécie como "Spirechina loeseneriana (P. Henn.) Arthur nom. novum ", indicando que era um novo nome para Uredo loeseneriana P. Hennings.

Arthur (1907) indicou que o gênero Spirechina possui teliósporos unicelulares encontrados na amostra da Bolívia citada acima. Mais tarde, Arthur (1912) incluiu cinco espécies no gênero, todos parasitas de espécies de Rubus. Três destas espécies são atualmente tratadas como membros de Gerwasia, um gênero que tem teliósporos unicelulares. As outras duas, S. loeseneriana e $S$. arthuri, foram colocadas em Kuehneola, um gênero que tem, pelo menos, alguns teliósporos multicelulares, com as células probasidiais enfileiradas.

Jackson (1931) transferiu S. loeseneriana para Kuehneola como K. loeseneriana (P. Henn.) Jackson \& Holway" por descobrir que os teliósporos de $S$. loeseneriana são, na sua maioria, unicelulares, mas duas ou mais células probasidiais enfileiradas também são produzidas.

O Código Internacional de Nomenclatura de Algas, Fungos e Plantas - Código de Melbourne (McNeil et. al. 2012) exige que o espécime-tipo da forma sexuada de um determinado táxon deve conter elementos dessa fase de seu ciclo. Para seguir esta exigência do Código foi ignorada designação de Spirachina loeseneriana Arthur como um novo nome ou como uma derivação de Uredo loeseneriana P. Hennings. Com isso o nome aceito é Kuehneola loeseneriana (Arthur) H. S. Jackson \& Holway. 
A fase assexuada de $K$. loeseneriana é $U$. loeseneriana e já foi relatado em Rubus sp. na Guatemala em 1896, em Rubus imperialis na Argentina em 1899, em Rubus urticaefolius no Brasil em São Paulo em 1908 (Hennen et al. 2005).

Ainda em Rosaceae a espécie já foi encontrada no Brasil infectando $R$. brasiliensis em Minas Gerais e São Paulo; em R. erythroclados em São Paulo; em R. sellowii no Rio Grande do Sul; em R. urticaefolius em São Paulo e em Rubus sp. no Espírito Santo, Minas Gerais, Paraná, Rio de Janeiro, Rio Grande do Sul, Santa Catarina, São Paulo. Kuehneola loeseneriana é também conhecida na Argentina, América Central e no México (Farr \& Rossman 2016).

Esta é a primeira vez que a fase uredínica de $K$. loeseneriana foi encontrada em $R$. brasiliensis no Distrito Federal. 

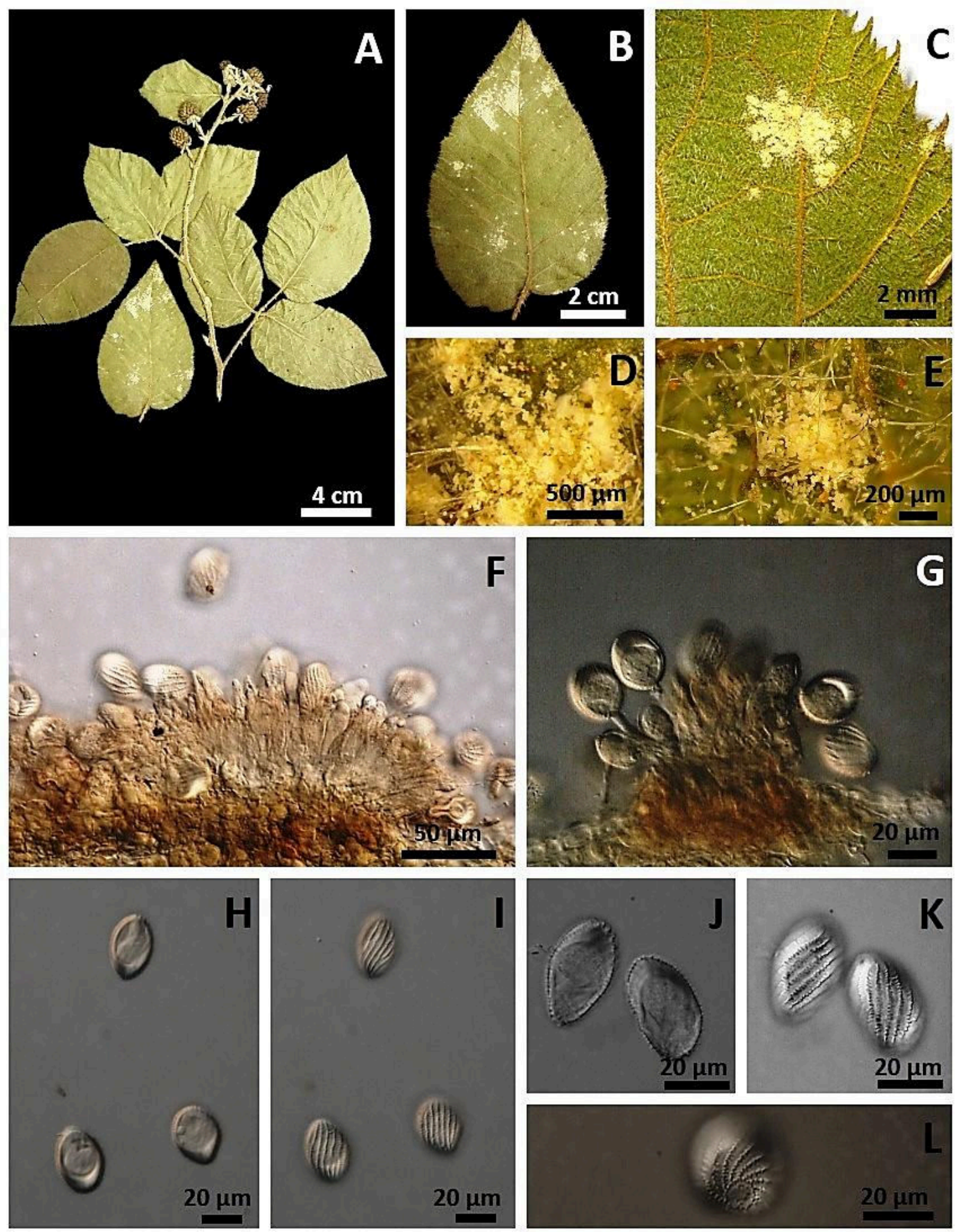

Figura 11 (A-L). Kuehneola loeseneriana, fase uredínica em folhas de Rubus

brasiliensis. A e B Hospedeira herborizada e folha com sintoma de ferrugem. C, D, E. Soros irrompentes pulverulentos de coloração amarelada na face abaxial das folhas. F e G. Urédios subepidérmicos em corte transversal. H-I. Urediniósporos elipsoides em dois planos de foco. J-K. Detalhe da superfície dos urediniósporos em profundidades de foco diferentes mostrando verrugas em espiral. L. Detalhe da base de um urediniósporo. 


\section{Membros da Família Pileolariaceae (Arthur) Cummins \& Y. Hirats. no Cerrado}

Os membros dessa família caracterizam-se por: Espemogônios epifilos, Grupo VI (tipo 5 ou 7), Écios do tipo Uraecium. Eciósporos solitários liberados um a um, usualmente reticulados, rígidos, verrugosos ou com marcações em espiral, poros germinativos zonados. Urédios semelhantes aos écios, mas não acompanhados por espermogônios. Télios irrompentes, teliósporos unicelulares, com um ou poucos esporos pedicelados, como pode também conter cistos estéreis lateralmente, um poro germinativo por esporo, germinação por metabasídio externo. Todas as espécies conhecidas são autoécias em plantas hospedeiras da família Anarcadiaceae e Fabaceae (Cummins \& Hiratsuka 2003).

A família Pileolariaceae abriga os gêneros Atelocauda, Endoraecium, Pileolaria, Racospermyces, Skierka e Uromycladium com mais de 34 espécies descritas (Kirk et al. 2008, Mycobank 2016).

O gênero tipo da família (Pileolaria), tem Pileolaria terebinthi (DC.) Castagne (1842) como sua espécie-tipo, sendo sua forma assexuada Uredo terebinthi, encontrado em Pistacia terebinthus (Anarcadiaceae), descrito em 1815 na Hungria.

Alguns gêneros anteriormente classificados em Pileolariaceae foram sinonimizados, como é o caso de Ctenoderma que foi incorporado a Skierka, Discospora a Pileolaria, e Macalpinia a Uromycladium (Mycobank 2016).

\section{Gênero Skierka Raciborski no Cerrado}

A espécie-tipo do gênero, Skierka canarii Raciborski em Canarium commune (Burseraceae) foi coletada na ilha Java na Indonésia em 1990.

O gênero Skierka é prontamente caracterizado por possuir urediniósporos com paredes duplas e verrugosas, formados em urédios subepidérmicos. Os teliósporos são unicelulares, 
muitas vezes com uma estreita extensão apical similar por onde germinam dando origem a um metabasídio externo. Os teliósporos são produzidos em sucessão, fortemente aderidos uns aos outros formando télios colunares longos esbranquiçados, semelhantes a pelos, a partir de urédios após descarga dos urediniósporos.

Cerca de quinze espécies foram relatadas com ocorrência em áreas tropicais. Mains (1939b) incluía dez espécies e as considerava pertencentes a uma família incerta (Cummins \& Hiratsuka, 1983). Atualmente o gênero Skierka é alocado na família Pileolariaceae (Mycobank 2016, Index Fungorum 2016).

O gênero conta com as espécies S. agallocha, S. canarii, S. clemensiae, S. congensis, S. cristata, $S$. diploglottidis, $S$. divinopolensis, $S$. holwayi, $S$. nephelii, $S$. petchii, $S$. philippinensis, S. robusta e S. toddaliae (Micobank 2016).

Skierka divinopolensis J. C. Dianese, Medeiros \& Santos. Figs 12 (A-E) e 13 (A-L).

Espermogônios e Écios são desconhecidos. Urédios 216 - $260 \mu \mathrm{m}$ de diâmetro, hipófilos, subepidérmicos, solitários ou gregários, irrompentes, circulares, amarelados a marrom-claros, imersos, subepidérmicos, profundos, ostiolados, himênio côncavo, (Fig.8.D). Urediniósporos $(50-) 55-57(-64) \times(24-) 28-32(-34) \mu \mathrm{m}$, elipsoides a fusoides, truncados na base, amarelados a marrons claros, parede com $1 \mu \mathrm{m}$ de espessura, formando franjas laterais na superfície de $5-7 \mu \mathrm{m}$ de largura, moderadamente rugosas, poros germinativos indistintos. Télios colunares, com a base subepidérmica, gregários, hipófilos, amarelados a marrom-claros, surgindo de urédios já vasios. Teliósporos (35-) $43-48(-50)$ $\times(15-) 17-20 \mu \mathrm{m}$, fusoides, acuminados na parte apical e base truncada, esbranquiçados, hialinos a marrom-claros, catenulados, aderidos uns aos outros em sequência acropetal, formando colunas de $1.4-1.8 \mathrm{~mm}$ de comprimento por $48-60 \mu \mathrm{m}$ de diâmetro; parede 2 
$-4 \mu \mathrm{m}$ de espessura, lisa, com um poro germinativo apical; metabasídios cilíndricos $48-52$ $\mu \mathrm{m} \times 7-8 \mu \mathrm{m}$, externos.

Espécimes examinados: em folhas de Matayba guianensis (Sapindaceae): Reserva da Embrapa Cerrados (CPAC) Planaltina, Distrito Federal, 05 set. 2012, leg. E.S.C. Souza 136, UB22373; em folhas de Cupania rugosa (Sapindaceae): Divinópolis, Minas Gerais, 04 ago. 2015, leg. D.B. Pinho 157, UB23331.

Skierka divinopolensis é claramente diferente de S. cristata (Mains 1931) e das espécies de Skierka reportadas para o Brasil (Hennen et al. 1982) em termos de morfologia e tamanho dos teliósporos e basidiósporos.

A espécie foi originalmente encontrada em folhas de Matayba guianensis no município de Araguarí, Minas Gerais em 1993. Ela também foi relata em folhas de Cupania rugossa em Minas Gerais no mesmo ano.

Primeira vez foi relatada em folhas de Mataybae guianensis no Distrito Federal em 2012. 


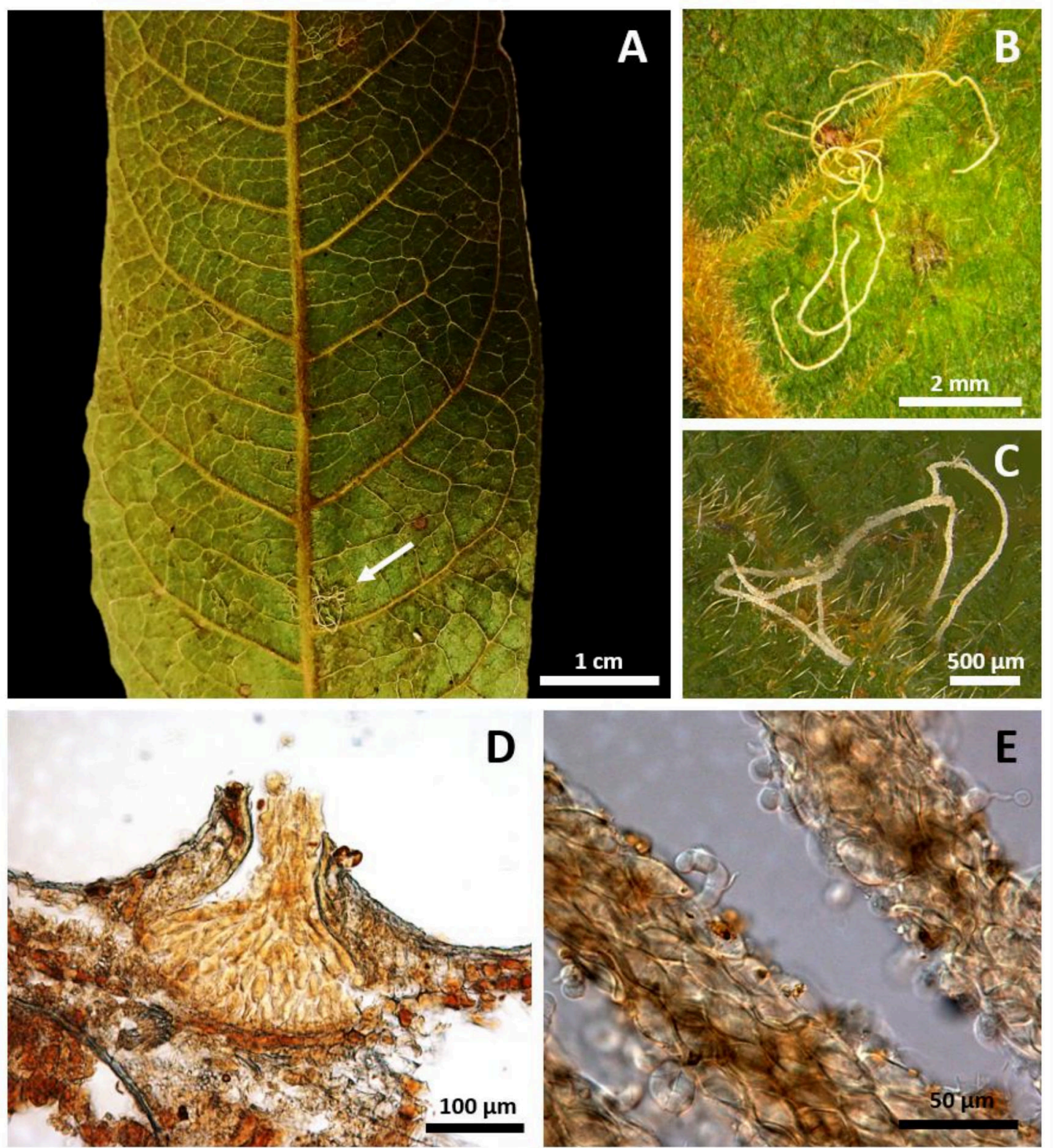

Figura 12 (A-E). Skierka divinopolensis em folhas de Matayba guianensis. A. Sintoma na face abaxial da folha. B-C. Vistas dos télios colunares. D. Base do télio colunar. E. Télio com alguns teliósporos germinados, ou seja, produzindo metabasídios. 

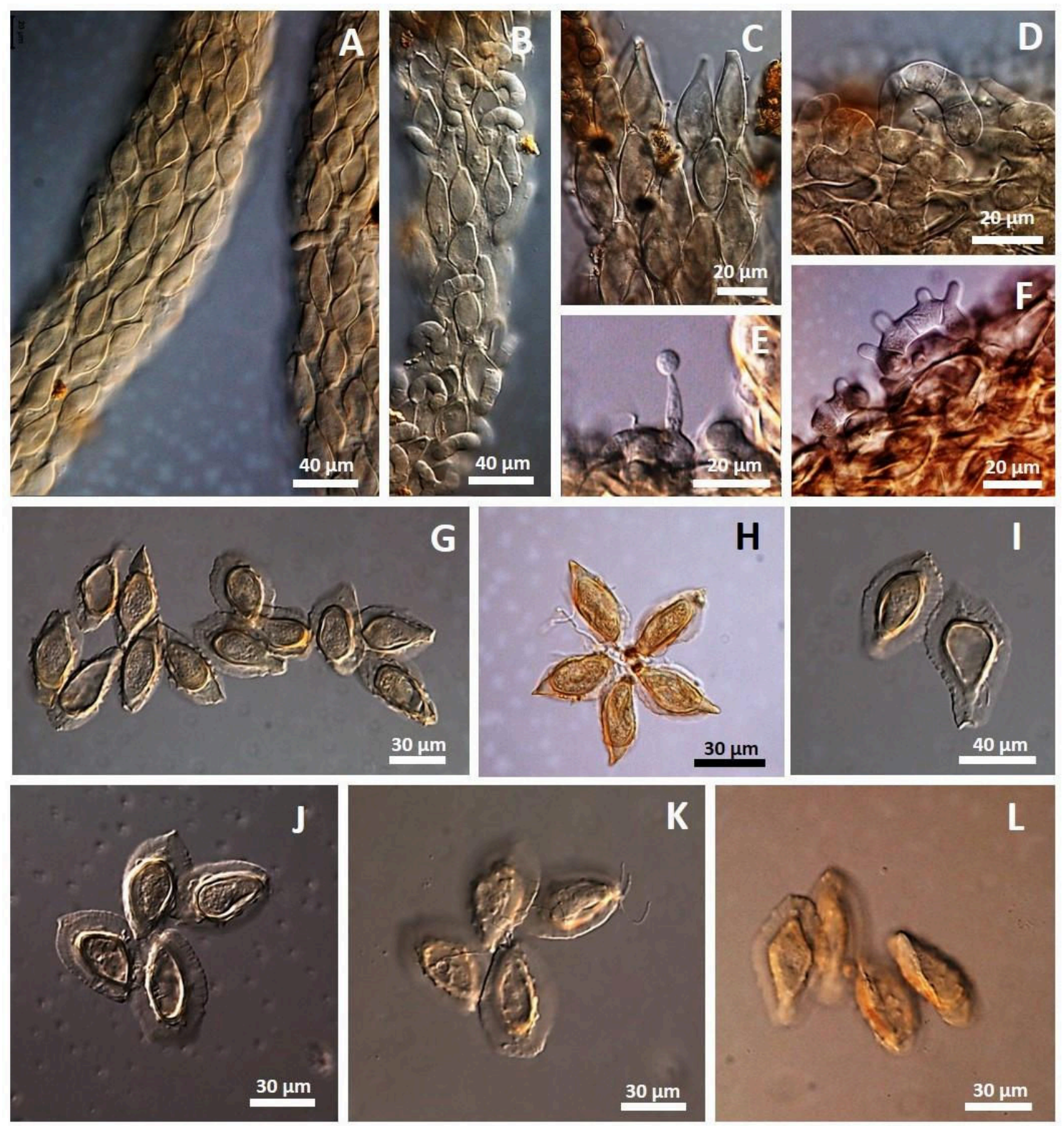

Figura 13 (A-L). Skierka divinopolensis em folhas de Matayba guianensis. Detalhe das colunas mostrando os telíosporos aderidos e formação de metabasídios. A. Teliósporos vistos isoladamente. B. Metabasídio em formação. C. Basidiósporo preso ao metabasídio. D. Basídios com esterigmas formados. E. Massa de urediniósporos. F. Urediniósporos acuminados de coloração marrom. G-L. Urediniósporos com faixas laterais rugosas vistas em profundidades de foco diferentes e detalhes da superfície. 


\section{Membros da Família Uropyxidaceae (Arthur) Cummins \& Y. Hirats no Cerrado}

A família possui membros com: Espermogônios do Grupo IV (tipo 5). Écios do Tipo Aecidium ou Caeoma, ou mais comumente do tipo Uredo com ou sem perídio, paráfisados ou não. Eciósporos catenulados ou não, verrugosos ou equinulados. Urédios do tipo Calidion, Malupa ou Uredo, com ou sem paráfises, ou do tipo Wardia (supraestomatal), sensu Hennen et al. (2005). Urediniósporos não catenulados, geralmente equinulados, poros germinativos dispersos. Télios com ou sem paráfises; teliósporos de duas ou mais células separadas por septo vertical, muitas vezes com a parede bilaminar e camada exterior higroscópica, um ou mais poros germinativos por célula. Teliósporos pedicelados, frequentemente higroscópicos, basídio externo. Os membros da família podem ser autoécios ou heteroécios e possuem amplo espectro de hospedeiras (Cummins \& Hiratsuka 2003).

Os gêneros válidos para a família incluem: Dasyspora, Didymopsorella, Dipyxis, Kimuromyces, Leucotelium, Macruropyxis, Mimema, Ochropsora, Phragmopyxis, Poliomopsis, Porotenus, Prospodium, Sorataea, Tranzschelia e o gênero tipo Uropyxis (Mycobank 2016). A família Uropyxidaceae é composta por mais de 143 espécies descritas (Kirk et al. 2008).

Gênero Kimuromyces Dianese, Santos, Medeiros \& C. Furlaneto

O gênero é assim caracterizado: Espermogônios e écios desconhecidos. Urédios subepidérmicos irrompentes, paráfises densas e geralmente periféricas, do tipo Calidion. Urediniósporos marrons, não catenulados, desenvolvem-se em células esporogênicas de proliferação simpodial, equinulados, reniformes, com dois poros germinativos equatoriais. Télios irrompentes, marrons, às vezes se apresentando como soros mistos mostrando tanto teliósporos como urediniósporos, parafisados; paráfises semelhantes às dos urédios, com 
ápice verrugoso quando vistas em MEV. Teliósporos pedicelados, bicelulares, septados transversalmente, ambas as células dos teliósporos com proeminências simples e com apêndices ramificados e salientes, um poro germinativo por célula; metabasídios externos (Dianese et al. 1995. Cummins \& Hiratsuka 2003).

O gênero é monotípico representado pela espécie Kimuromyces cerradensis encontrada em folhas de Astronium fraxinifolium (Anarcadiaceae) (Dianese et al. 1995).

Outras espécies de fungos causadores de ferrugem como Leptinia brasiliensis (=Puccinia brasiliensis) já foram relatadas para Astronium, entretanto são claramente diferentes de $K$. cerradensis com relação a morfologia dos teliósporos. Kimuromyces foi relatado apenas nas amostras tipo descritas abaixo. Dianese et al. (1995) julgaram mais apropriado tentativamente colocar o gênero na família Uropyxidaceae.

Kimuromyces cerradensis Dianese, Santos, Medeiros, \& C. Furlaneto Fig. 14 (A-K)

A descrição da espécie realizada por Dianese et al. (1995) consta de: Urédios $60-$ $160 \mu \mathrm{m}$ de diâmetro, subepidérmicos na origem e irrompentes com o desenvolvimento, hipófilos, marrons e parafisados. Paráfises $25-35 \times 8-12 \mu \mathrm{m}$, a maioria periféricas ou as vezes himeniais, levemente clavadas a clavadas, retas ou curvadas, cada uma com a ponta enrugada ou rugosa. Urediniósporos $20-25 \times 14-21 \mu \mathrm{m}$, marrons, elipsoide transversalmente em vista plana, originados individualmente com proliferação simpodial das células esporogênicas, equinulados na maioria das vezes, mas algumas vezes com a superfície lisa, dois poros germinativos equatoriais localizados nos ângulos laterais. Télios $60-160 \mu \mathrm{m}$ de diâmetro, marrom a marrom-escuros, subepidérmicos, irrompentes, solitários ou as vezes coalescentes, à semelhança dos urédios, parafisados. Paráfises idênticas às dos urédios em formato, tamanho e localização. Teliósporos $22-32 \times 11-16 \mu \mathrm{m}$, formados por proliferação 
simpodial das células esporogênicas, bicelulares com septo transversal, parede fina, marrom clara, pedicelados, ambas células com apêndices salientes a maioria ramificados, um poro germinativo por célula. Metabasídio externo $58-62 \times 5-6 \mu \mathrm{m}$. Basidiósporos $5-7 \mu \mathrm{m}$ de diâmetro, hialinos e globoides.

Hennen et al. (2005) descreveram a fase assexuada de Kimuromyces, Uredo rhombica Speg. e ao mesmo tempo, validaram a espécie K. cerradensis descrita por Dianese et al. (1995)

Espécimes examinados: em folhas de Astronium fraxinifolium (Anacardiaceae): Mineradora Rio do Sal, Padre Bernardo, Curralinho, Goiás, 05 jul. 2012, leg. C. Pietrani 01, UB23337; Santo Antônio do Monte, Minas Gerais, 05 ago. 2015, leg. D.B. Pinho 176, UB23333.

O espécime descrito por Dianese et al. (1995) é claramente diferente da espécie Leptinia brasiliensis que possui teliósporos lisos e fase uredínica desconhecida como também dos outros gêneros com teliósporos bicelulares e septo transversal reportados na família Pucciniaceae (Puccinia e Cleptomyces) e Uropyxidaceae (Prospodium, Dasyspora, Soratea, Porotenus, Uropyxis e Dipyxis).

O gênero Kimuromyces é separado de todos os outros fungos neotropicais independentemente do tipo dos espermogônios, graças a morfologia clara dos teliósporos, espécies hospedeiras e características do formato da urédio e dos urediniósporos (Dianese et al. 1995). O gênero mais próximo morfologicamente de Kimuromyces é Porotenus, em termos da forma e do tipo de germinação dos teliósporos (Dianese et al. 1995), porém claramente diferenciado pelas ornamentações dos telióporos, distância filogenética entre as hospedeiras e formação de uma saliência na célula inferior, junto ao septo do teliósporo de Porotenus, por onde o mesmo germina.

Erroneamente Sotão et al. (2006) consideraram um espécime de herbário de 1997 como K. cerradensis, encontrado no Pará em folhas de Astronium sp.. Eles admitiram o 
espécime como sendo uma variação da espécie por conter teliósporos com três células, conforme a descrição original. Entretanto, os teliósporos do material estudado por Sotão et al. (2006) não apresentaram apêndices na superfície das células, característica essencial do gênero Kimuromyces.

Segundo Hennen et al., Uredo rhombica foi encontrado em folhas de Astronium urundeuva na Argentina em 1884, e antes reportado em Astronium juglandifolium no Paraguai em 1883, além de relatar a ocorrência em outras anacardiáceas, como inclusive Astronium fraxinifolium no Ceará, Goiás, Mato Grosso, Mato Grosso do Sul, Minas Gerais, Pará e São Paulo, e sobre Astronium lecointe no Pará. Além disso Uredo rhombica é conhecido na Venezuela e na Costa Rica (Hennen et al. 2005). 

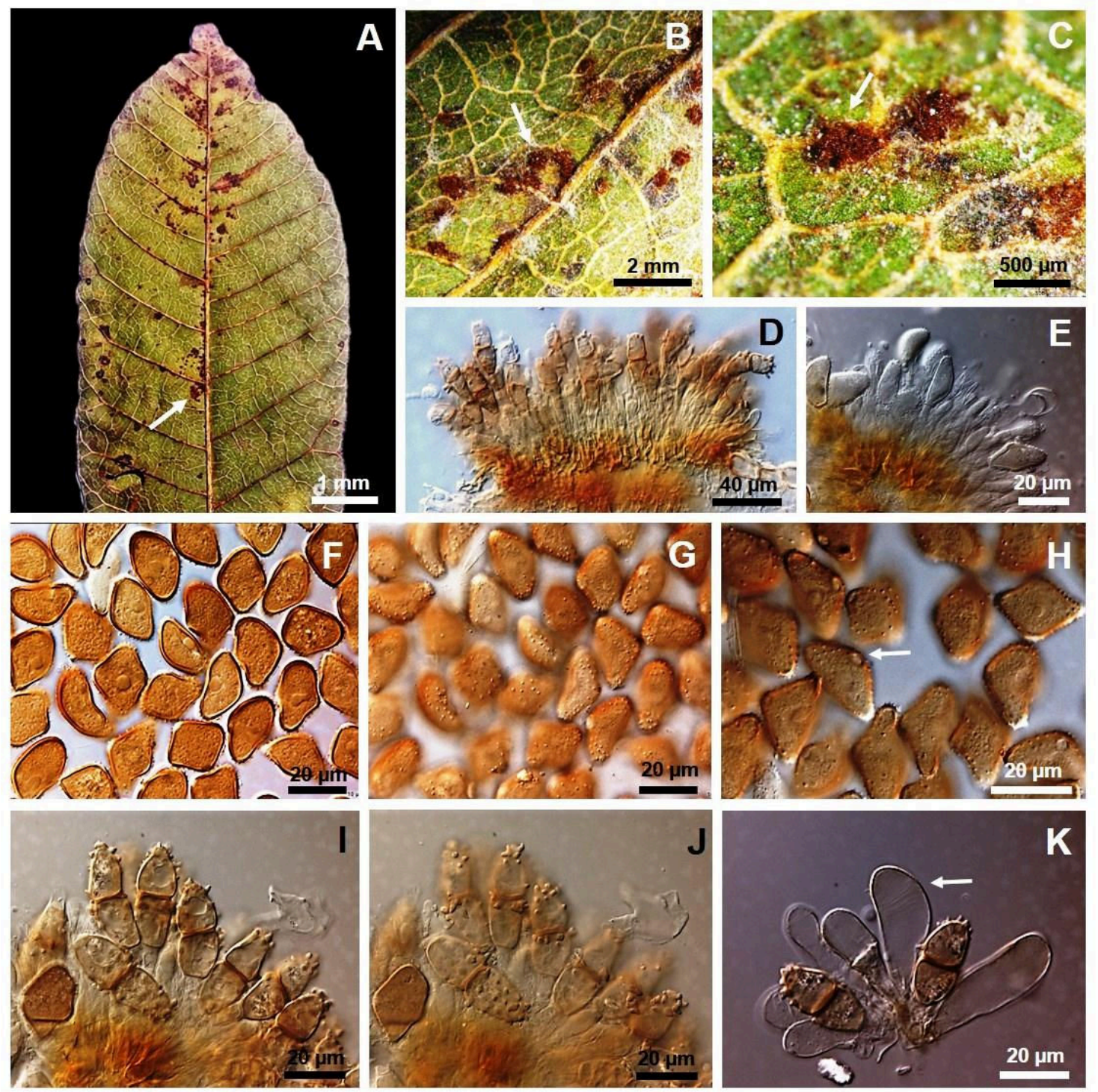

Figura 14 (A-K). Kimuromyces cerradensis em folhas de Astronium fraxinifolium.

A. Sintoma e distribuição dos soros (seta) na face abaxial da hospedeira. B, C. Pústulas pulverulentas de coloração marrom. D. Disposição de teliósporos em um télio. E. Urediniósporos com pedicelos em um urédio. F e G. Massa de urediniósporos vistos em diferentes profundidades de foco. H. Poro germinativo (seta) de um urediniósporo. I, J. Teliósporos bicelulares com parede contendo apêndices salientes, sob diferentes profundidades de foco. K. Teliósporos e paráfises (seta) grossas cilíndricas com porção apical mais larga. 


\section{Gênero Dasyspora Berk. \& M.A. Curtis}

Com base na espécie Dasyspora foveolata Berk. \& Curt, uma espécie microcíclica (com fase uredínica até o presente desconhecida) encontrada em espécies de Xylopia L. (Annonaceae) no Neotrópico, Berkeley e Curtis (1853) propuseram Dasyspora como um novo gênero de Pucciniales. Como a espécie fora anteriormente designada Puccinia gregaria Kunze, em 1827, D. foveolata, publicada em 1853 passou a ser seu sinônimo. Assim, o nome da espécie-tipo do gênero Dasyspora, D. gregaria (Kunze) Henn, resultou de recombinação a partir do nome mais antigo (P. gregaria). Dasyspora geranii-silvatici Arthur e $D$. malvacearum Arthur foram descritas em 1906 (Mycobank 2016, Index Fungorum 2016).

Beenken \& Berndt (2010), em um estudo monográfico sobre fungos causadores de ferrugem em anonáceas, investigaram inúmeros espécimes de Dasyspora a partir de uma ampla faixa geográfica e diferentes espécies hospedeiras. Através de comparações por morfologia e análise filogenética descreveram nove novas espécies para o gênero Dasyspora: D. amazonica, D. echinata, D. emarginatae, D. ferrugineae, D. frutescentis, D. guianensis, D. mesoamericana, D. nitidae e D. segregaria. Já Beenken et al. (2012) recombinaram Puccinia winteri Pazschke, sendo agora tratada como Dasyspora winteri (Pazschke) Beenken. Com isso, chega-se ao número de 13 espécies de Dasyspora conhecidas até o presente (Index Fungorum 2016, Mycobank 2016).

O gênero Dasyspora, segundo Cummins \& Hiratsuka (2003) é caracterizado por: Espermogônios subepidérmicos, Grupo VI (tipo 5). Écios subepidérmicos hipófilos, irrompentes, cupulados. Urédios desconhecidas. Télios subepidérmicos, irrompentes; Teliósporos bicelulares, pedicelados, paredes pigmentadas, verrugosos, um poro germinativo por célula, metabasídios externos. 
A verrugosidade extrema dos teliósporos bicelulares com projeções em formato cilíndrico, muitas vezes ramificadas na porção apical constitui em caráter fundamental na definição do gênero. Além disso, Dasyspora é separada de Puccinia, que também forma teliósporos bicelulares às vezes ornamentados, pelo tipo de espermogônio. Em espécies de Puccinia os espermogônios pertencem ao Grupo V (tipo 4), segundo Cummins \& Hiratsuka (2003). Na verdade, modernamente inclusive com dados de filogenia molecular (Beenken et al. 2012), o gênero Dasyspora está alocado distante de Pucciniaceae, na família Uropyxidaceae, confirmando Cummins e Hiratsuka (2003).

Assim, o gênero Dasyspora foi por algum tempo, tratado como monotípico distribuído pelas Américas tropicais (Arthur 1927, 1929, Buriticá \& Pardo-Cardona 1996; Dennis 1970; Hennings 1895; Hennen e Figueiredo 1981; Hennen et al. 2005, Jorstad 1956; Mains 1935, 1939; Sydow 1925; Viégas 1945).

As plantas hospedeiras pertencem ao gênero Xylopia (Annonaceae) com aproximadamente de 100 a 160 espécies e distribuídas pela Neotropica (Kessler 1993), porém apenas cerca de 50 espécies têm sido acometidas por Dasyspora até agora, com destaque para X. aromatica (Lam.) Mart, X. frutescens Aubl., X. ochranta Mart., e várias outras espécies de Xylopia listadas por Hennen et al. (2005).

\section{Dasyspora gregaria (Kunze) Henn. Fig. 15 (A-E) e Fig. 16 (A-I)}

Espermogônios 100- $200 \mu \mathrm{m}$ de diâmetro, subepidérmicos, globosos, predominantemente epífilos com massa de espermácias de coloração amarelada. Hifas receptivas cilíndricas e numerosas. Espermácias ou Piciniósporos 3-5 $\mu \mathrm{m}$ diam., elipsoides, subglobosos, hialinos. Écios 180-200 $\mu \mathrm{m}$, hipófilos, gregários, esbranquiçados a amarelados, pulverulentos, irrompentes, cobrindo grande parte da folha, cupulados; células peridiais 25 - 
$30 \mu \mathrm{m} \times 16-22 \mu \mathrm{m}$, romboides a hexagonais, grossas verrugosas. Eciósporos de tamanho menor que as células peridiais, $18-22 \mu \mathrm{m} \times 14-16 \mu \mathrm{m}$, globosos a irregulares, hialinos, catenulados; parede verrugosa a tuberculada, com grânulos superficiais de até $4 \mu \mathrm{m}$ de diâmetro cobrindo os poros germinativos, às vezes se destacando do esporo. Télios 270 - 350 $\mu \mathrm{m}$, hipófilos, subepidérmicos, irrompentes, castanho escuros a negros, dispostos em círculos concêntricos ou dispersos, parafisados. Paráfises periféricas, raramente himeniais, cilíndricas a ligeiramente clavadas. Teliósporos bicelulares septados transversalmente, constritos no septo, pedicelados (pedicelos hialinos e frágeis), oblongos a elipsoides, $30-35 \times 15-20$ $\mu \mathrm{m}$, marrom-escuros, parede dupla, verrugosos e com projeções numerosas cilíndricas distribuídas principalmente nas regiões apical e basal, um poro germinativo por célula.

Espécimes examinados: em folhas de Xylopia aromatica (Annonaceae): Embrapa Cerrados (CPAC), Planaltina, Distrito Federal, 05 set. 2012, leg. E.S.C Souza 135, UB22371; Barra do Garça, Mato Grosso, 18 ago. 2014, leg. Z.M. Chaves A73, UB22969; Divinópolis, Minas Gerais, 29 jul. 2015, leg. D.B. Pinho A19, UB23339; Reserva do Instituto Federal de Brasília Campus Planaltina, Distrito Federal, 20 ago. 2015, E.S.C Souza 250, UB.

O espécime aqui estudado é claramente pertencente à espécie D. gregaria, uma vez que além de infectar a mesma hospedeira já descrita em literatura, ele possui morfologia (forma e distribuição das projeções da parede dos teliósporos) e dimensões compatíveis com a espécie quando comparados com as espécies descritas e ilustradas por Beenken et al. (2012).

As infecções causadas pela fase ecídica de D. gregaria (三Aecidium xylopiae) ocorrem em brotações e em tecidos jovens e são raramente locais, pois, em geral, produzem efeitos sistêmicos, resultando em sintomas de "vassouras-de-bruxa" avantajadas, assumindo coloração amarela a laranja. A fase sexuada de Dasyspora gregaria (Kunze) Henn, pode apresentar clorose ao redor dos soros, e muitas vezes associada com a alga Cephaleuros virescens Kunze (Hennen \& Figueiredo, 1981). 
Dasyspora gregaria é relatada em folhas de $X$. aromatica em Goiás, Mato Grosso e São Paulo; em $X$. frutescens em Pernambuco; em $X$. grandiflora no Mato Grosso, Rio de Janeiro e São Paulo; em X. ocrantha na Bahia; em Xylopia sp., no Amapá, Amazonas, Distrito Federal, Goiás, Maranhão, Mato Grosso do Sul, Minas Gerais, Pará, Pernambuco e São Paulo (Hennen et al. 2005, Farr \& Rossman 2016).

Além disso a espécie é reportada em folhas de Annona na Guiana, em Polyalthia longifolia e em X. aromatica na Índia; em X. aromatica em Trinidade e Tobago e Venezuela; em $X$. cayennensis na Guiana Francesa e Suriname; em X. frutescens em Belize, Guatemala e México; em X. grandiflora no Panamá e no Peru; em Xylopia sp. na Colômbia, Costa Rica e Suriname (Beenken et al. 2012, Farr \& Rossman 2016).

Esta é a primeira vez que $D$. gregaria é relatada em folhas de $X$. aromatica no Distrito Federal e em Minas Gerais. 

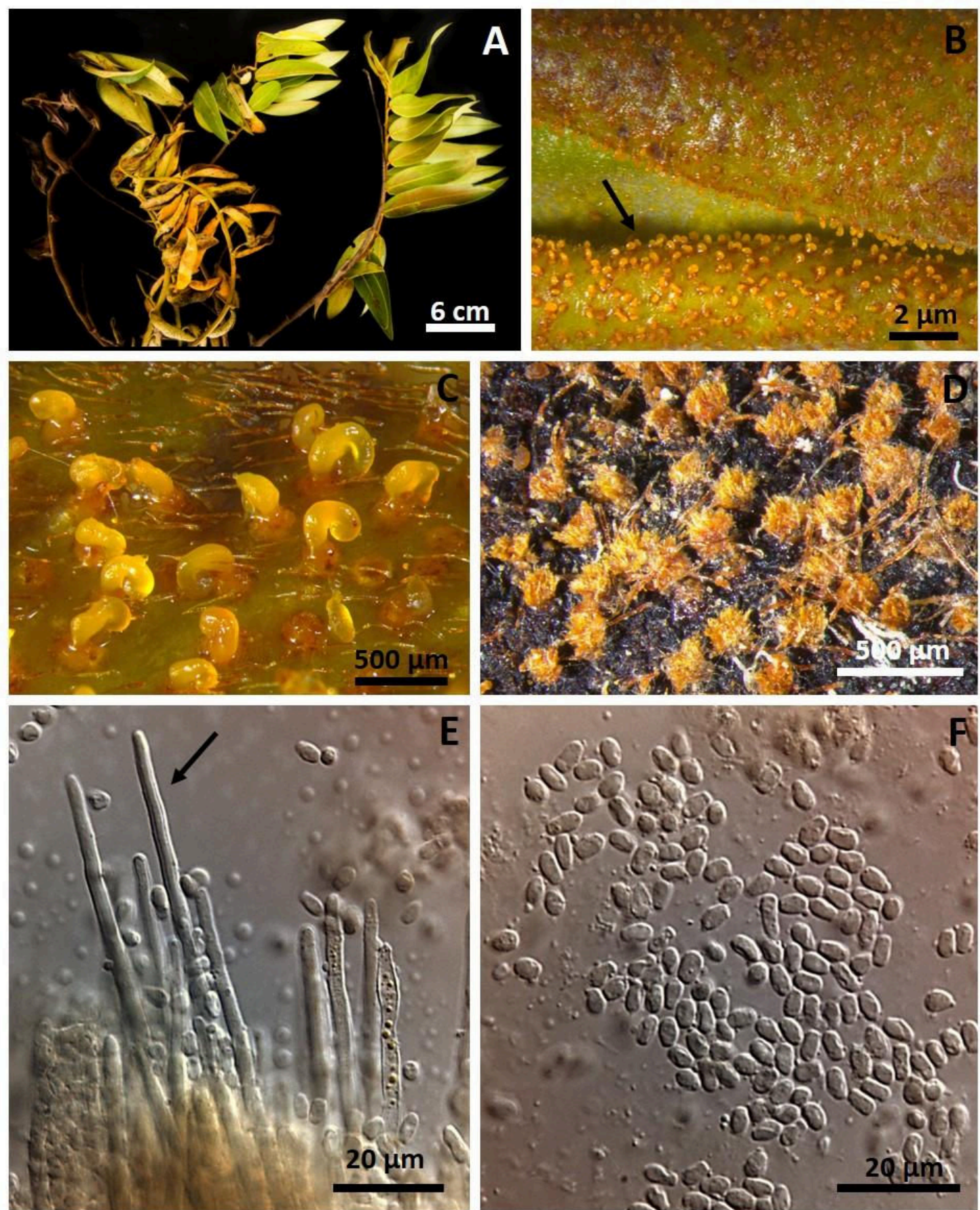

Figura $15(\mathrm{~A}-\mathrm{F})$. Forma espermogonial de Dasyspora gregaria em Xylopia

aromatica. A. Sintomas. B-C. Espermogônios exsudanto cirros contendo espermácias.

D. Espermogônios secos mostrando hifas receptivas. E. Hifas receptivas cilíndricas e espermácias oblongas. F. Espermácias. 

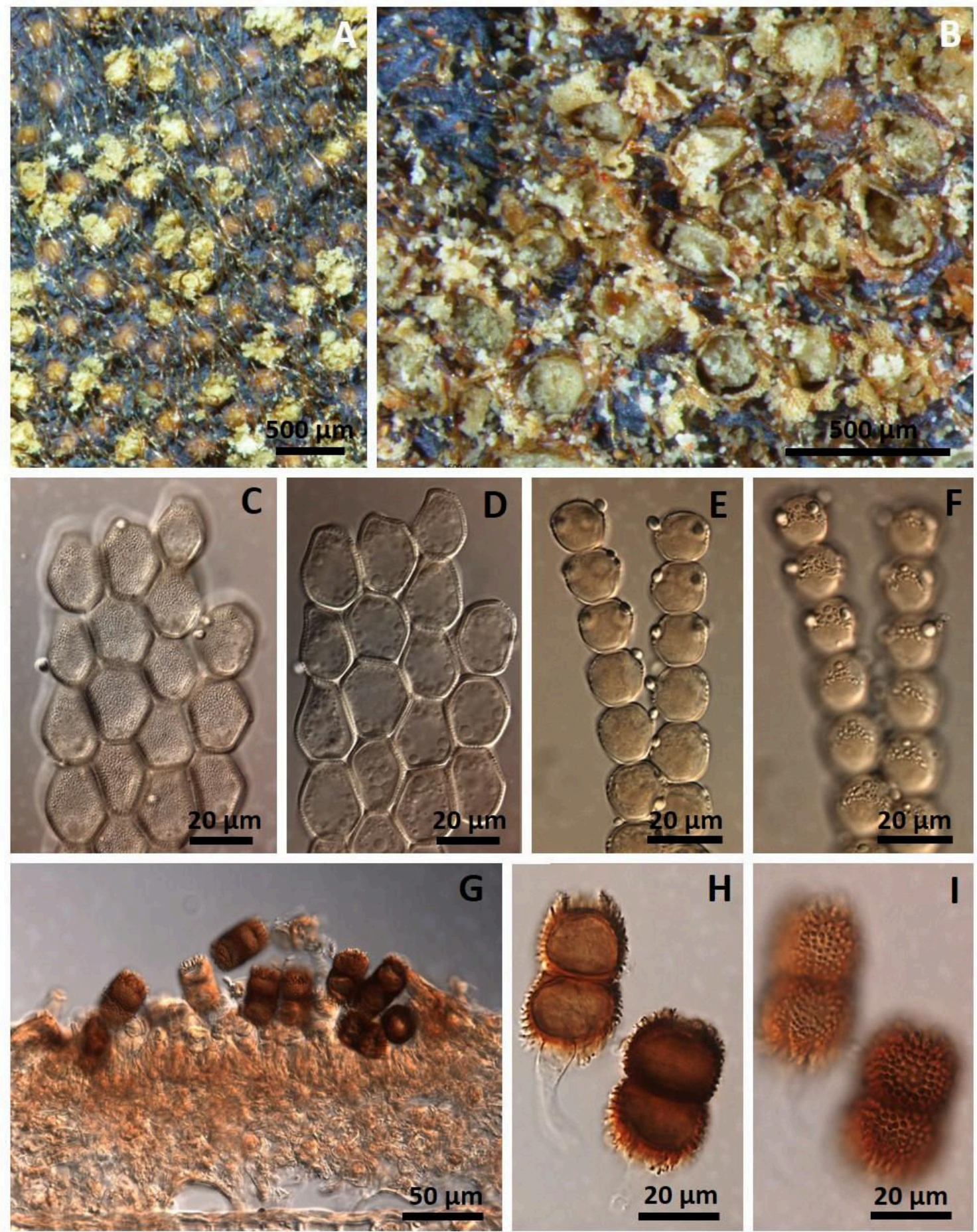

Figura 16 (A-I). Formas ecídica e teliospórica de Dasyspora gregaria em Xylopia

aromatica. A-B. Écios em amostra herborizada. C-D. Células do perídio. E-F.

Eciósporos catenulados, mostrando até 2 poros germinativos. G. Corte de um Télio.

H-I. Teliósporos. 


\section{Gênero Mimema H. S. Jackson no Cerrado.}

O gênero Mimema, pode ser assim descrito: Epermogônios e Écios não observados. Urédios com paráfises periféricas abundantes, tipo Calidion. Urediniósporos equinulados, poros germinativos $1-6$, equatoriais. Télios colunares, instáveis, produzidos a partir de urédios já sem urediniósporos, com paráfises periféricas menores do que as uredínicas, formadas na base das colunas. Teliósporos cilíndricos ou fusiformes, multicelulares, geralmente tetracelulares, variando entre 3 e 6 células, com pedicelos não celulares afilados longos, reponsáveis pela conexão entre teliósporos nas colunas, com germinação simultânea em várias células através poros germinativos discretos, metabasídio externo (Cummins \& Hiratsuka, 2003, Dianese et al. 1994).

O gênero Mimema anteriormente considerado sinônimo de Sorataea, foi reinstituído por Cummins e Hiratsuka (2003), com base na descrição de M. venturae por Dianese et al. (1994). Em Mimema ocorre um poro germinativo em cada célula probasidial através do qual o metabasídio emerge. Em Sorataea o metabasídio desenvolve-se pelo alongamento do ápice do probasídio. Além disso, os teliósporos em Mimema são formados e liberados a partir dos soros como uma coluna, uma característica não relatada para Sorataea. Além disso, Cummins e Hiratsuka (2003) incluíram Mimema na família Uropyxidaceae, mas não o incluíram na chave para gêneros da família. Dianese et al. (1994) admitiram que a morfologia dos teliósporos e a maneira como os basídios são formados claramente separa Mimema de Soratea. Os teliósporos de Mimema são semelhantes aos de Hamaspora que ocorre apenas em Rubus (Rosaceae) e possui espermogônia do Grupo IV tipo 8 ou 9, mas eles podem não estar intimamente relacionados. Como espermogônia e écio em Mimema não são conhecidos, somente quando descobertos, tornariam mais clara a relação com Hamaspora. Superficialmente as colunas dos teliósporos em Mimema são relativamente similares em 
muitas espécies de Crossopsora por apresentar paráfises periféricas e colunas a partir de urédios antigos. Porém, a semelhança cessa por aí, uma vez que em Crossopsora os teliósporos são unicelulares.

Existem apenas duas espécies descritas para o gênero sendo que Mimema holwayi H. S. Jackson a espécie-tipo do gênero, foi coletada na Bolívia em 1920 (Jackson 1931), em uma espécie de Dalbergia (Fabaceae), na época identificada erroneamente como Cassia versicolor (Hennen et al. 2005). Somente em 1994, foi descrita a segunda espécie, Mimema venturae, reportada em Dalbergia miscolobium no Brasil em 1994 (Dianese et al. 1994).

Mimema venturae Dianese, L. T. P. Santos, R. B. Medeiros \& M. Sanchez. Fig. 17 (A-H)

O espécime aqui estudado mostrou: Espermogônios e Écios ausentes. Urédios hipófilos, em manchas amareladas da folha, dispersos ou em grupos densos até $4 \mathrm{~mm}$ de diâmetro, castanho-canela, irrompontes, pulverulentos, parafisados; paráfises $40-55 \times 5-$ $7 \mu \mathrm{m}$, numerosas, sempre periféricas, encurvadas, pontiagudas, parede incolor a pouco pigmentada. Urediniósporos $16-23 \times 9-12 \mu \mathrm{m}$, subgloboides, ovoides, a piriformes, ligeiramente reniformes, marrom-claros, equinulados, poros germinativos provavelmente numerosos, obscuros. Télios colunares, $80-150 \mu \mathrm{m}$ de comprimento, hipófilos, emergindo como colunas frágeis a partir de urédios velhos. Teliósporos até $65-110 \times 8 \mu \mathrm{m}$, aciculares, com 4 septos, extremidades agudas, paredes incolores, pedicelos viscosos, responsáveis pela conexão entre teliósporos nas colunas.

Espécimes examinados: em folhas de Dalbergia sp. (Fabaceae): Fazenda Água Limpa da Universidade de Brasília (FAL - UnB), Brasília, Distrito Federal, 27 jul. 2012, leg. E.S.C Souza 99, UB22323; em folhas de Dalbergia sp. (Fabaceae): Reserva do IBGE (RECOR) 
próximo à nascente do Taquara, Brasília, Distrito Federal, 04 set. 2012, leg. M. Sanchez 4665, UB22364.

O material tipo foi encontrado em folhas de Dalbergia miscolobium no Distrito Federal em 1994. Além do material-tipo a espécie já foi relatada em Dalbergia sp. no Amazonas; em D. foliolosa na Bolívia; em D. variabilis em Santa Catarina; em Dalbergia sp. em Goiás e Mato Grosso (Hennem et al. 2005). 

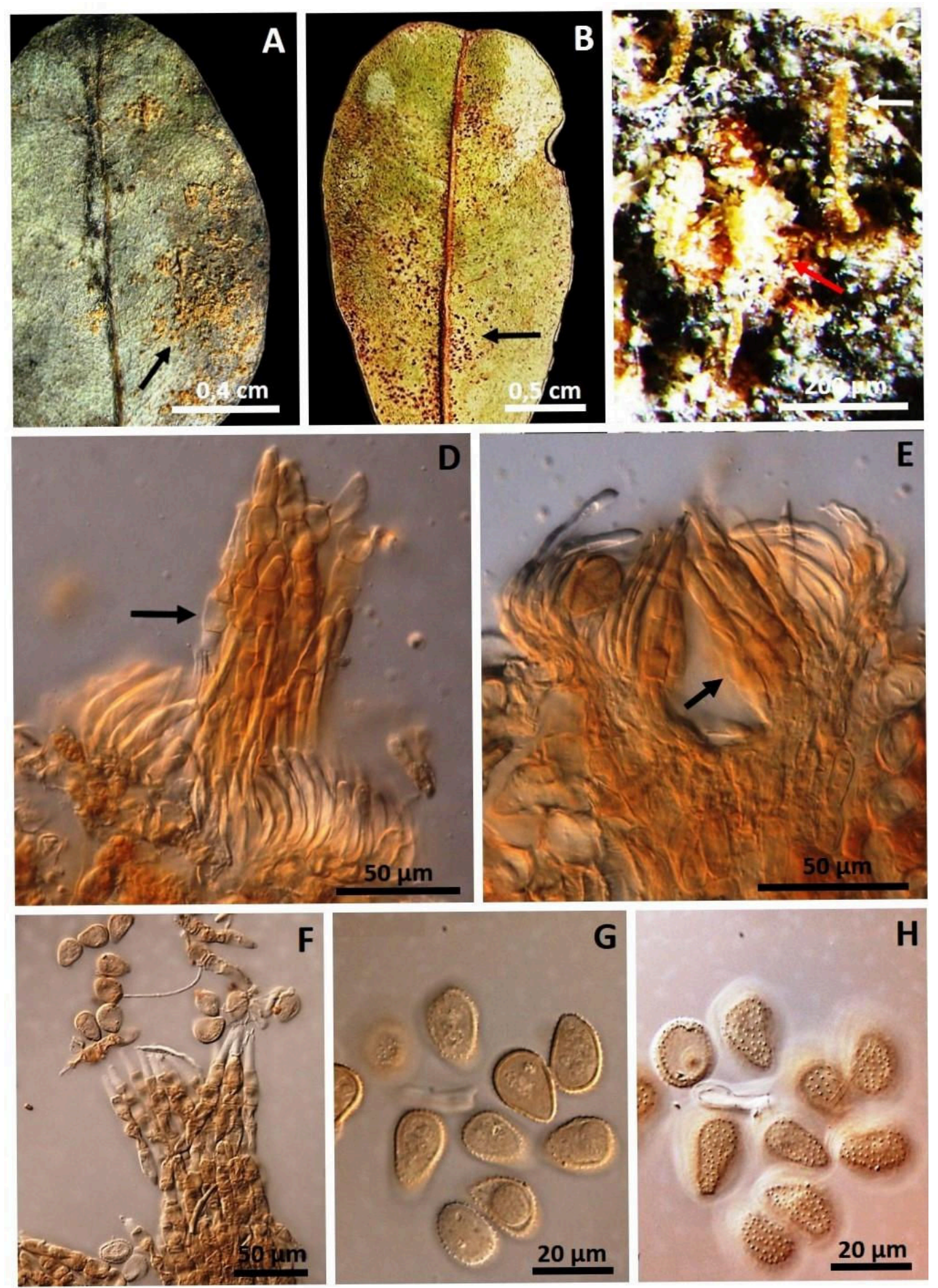

Figura 17 (A-H). Mimema venturae em Dalbergia micolobium. A-B. Sintomas.

C. Télio colunar indicado por uma seta branca, e urédio por uma seta vermelha. D. Base de um télio em início de formação, circundado por paráfises cilíndricas de pontas afiladas. E. Urédio senescente onde se inicia a formação de um télio, com telióspro indicados por seta. F. Télio colunar rompido com telióosporos multiseptados (seta). G-H. Urediniósporos em profundidades de foco diferentes. 


\section{Gênero Porotenus Viégas}

Espécie do gênero Porotenus mostra: Espermogônios do Grupo VI tipo 5 ou 7. Écios subepidérmicos, irrompentes. Eciósporos solitários pedicelados, radialmente assimétricos, equinulados, poros germinativos equatoriais ou basais, geralmente no lado encurvado do eciósporo. Urédios subepidérmicos, irrompentes. Urediniósporos semelhantes aos eciósporos. Télios subepidérmicos, irrompentes. Teliósporos bicelulares com septos transversal, pedicelados, célula superior com germinação apical e a inferior lateralmente junto ao septo do esporo, ambas originando metabasídio hialino, com ou sem um poro diferenciado na parede (Cummins \& Y. Hiratsuka (1983).

A espécie-tipo, Porotenus concavus Viégas, foi descrita no Brasil em Memora glaberrima (atualmente Adennocalyma sp.) da família Bignoniaceae, hoje conhecida em espécies de Adennocalyma e Amphilophium (Bignoniaceae) e de Lippia (Verbenaceae).

Porotenus memorae F.C. Albuq. foi descrita na Amazônia por Albuquerque (1971). Três outras espécies primeiramente classificadas como Puccinia e Prospodium foram transferidas para Porotenus: P. elatipes (Arthur \& Holw.) Cummins \& Y. Hirats., P. permagnus (Arthur \& Holw.) Cummins \& Y. Hirats., e P. depallens (Arthur \& Holw.) Cummins \& Y. Hirats. 1983. Hennen \& Sotão (1996) adicionaram duas novas espécies relatadas em Memora no Brasil (P. bibasiporulus J.F. Hennen \& Sotão e P. biporus J.F. Hennen \& Sotão. Porotenus possui características comuns com Prospodium e os teliósporos de $P$. concavus guardam semelhanças com os de Soratea.

Atualmente existem sete espécies dentro do gênero Porotenus. Cinco espécies em Bignociaceae: P. bibasiporulus em Memora nodosa, P. biporus em Memora flavida, P. concavus em Memora glaberrima, P. memorae em Memora consanguinea e $P$. depallens em 
Pithecoctenium muricatum, e duas em Verbenaceae ( $P$. elatipes em Lippia sp. e P. permagnus em Lippia myriocephala) (Index Fungorum 2016).

As espécies de Porotenus conhecidas em Memora possuem características e tamanhos dos teliósporos muito semelhantes e não são consideradas úteis para a diferenciação entre elas. As variações das características presentes nos anamorfos são mais úteis do que os as características presentes na fase telial para caracterizar estas espécies de Porotenus.

\section{Porotenus memorae F. C. Abuq. (Fig. 18. (A-E)}

Espermogônios e Écios não vistos. Urédios hipófilas, subepidérmicas irrompentess, gregárias, marrons, pulverulentas e mistas contendo urediniósporos e teliósporos. Urediniósporos $30-45 \times 17-25 \mu \mathrm{m}$, reniformes a elipsoides, curvados, pedicelados, marrons, equinulados ora na parte côncava, ora na convexa, geralmente um poro germinativo, ocasionalmente dois próximos a região basal. Télias mistas e semelhantes às urédios. Teliósporos $45-55 \times 16-22 \mu \mathrm{m}$, bicelulares, oblongo - elipsoides, constritos, lisos, quase incolores a subhialinos, um poro germintivo em cada célula dispostos na porção apical.

Espécime examinado: em folhas de Adenocalymma bipinnatum (Bignoniaceae): Barra do Garça, Mato Grosso, 18 ago. 2014, leg. L.A.N.N Agra 309, UB23198.

Em comparação com as espécies já descritas em espécies hospedeiras em Bignoniaceae, o espécime aqui estudado é semelhante em morfologia a $P$. memorae. As principais características semelhantes é a predominância do formato reniforme dos urediniósporos e a presença de equinulações nos urediniósporos predominentemente na porção convexa.

Em termos de dimensões o espécime encontrado em A. bipinnatum apresentou as medidas dos urediniósporos e teliósporos muito próximas das espécies $P$. bibasiporulus, $P$. 
biporus e $P$. memorae. $P$. concavus mostrou urediniósporos menores e mais largos $(28-35$ $\times 24-26 \mu \mathrm{m})$ e teliósporos entre os maiores $(53-75 \times 15-18 \mu \mathrm{m})$ para as espécies e $P$. depallens não possui fase de urédio descrita e mostrou teliósporos consideravelmente maiores do que todas as espécies $(45-96 \times 16-17 \mu \mathrm{m})$.

Porotenus bibasiporulus já foi relatado em M. nodosa e em Memora sp. no Brasil; $P$. biporus em M. flavida no Brasil e na Guiana Francesa; P. concavus em M. flavidula e em $M$. glaberrima no Brasil; P. memorae em M. allamandiflora, M. axillaris, M. consanguinea, $M$. peregrina no Brasil e em M. racemosa na Guiana Francesa.

Este é o primeiro relato de Porotenus memorae na espécie hospedeira Adenocalymma bipinnatum. 

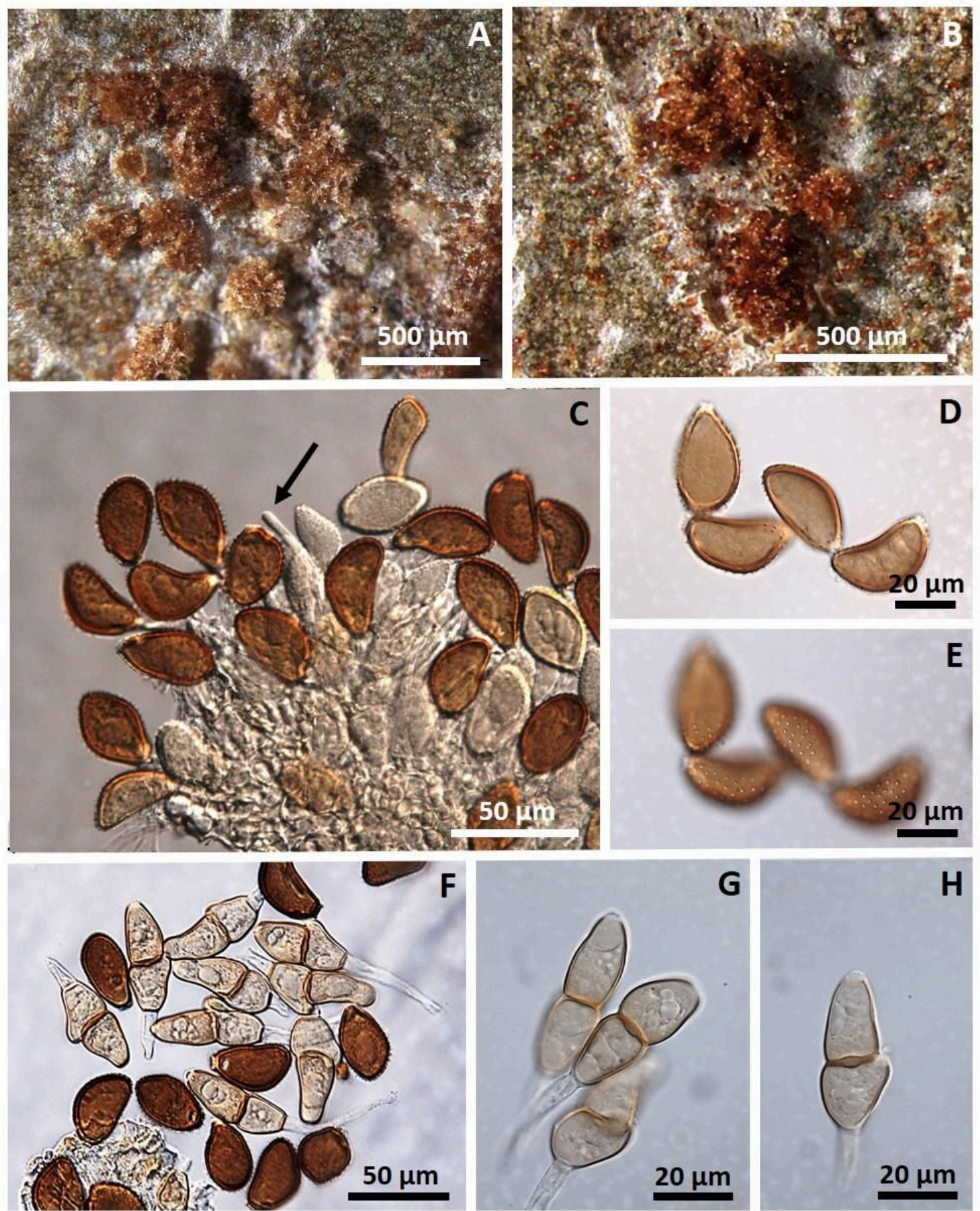

Figura $18(\mathrm{~A}-\mathrm{H})$. Forma uredínica e télica de Porotenus memorae em

Adenocalymma bipinnatum (=Memora bipinata). A-B. Soros mistos. C. Urédio, seta mostra resíduo de pedicelo. D. Urediniósporos motrando poros germinativos próximos ao hilo. E. Urediniósporos com foco nas ornamentações superficiais. F. Teliósporos e urediniósporos. G-H. Teliósporos em detalhe. 


\section{Gênero Prospodium Arthur}

Descrição: Espermogônios subcuticulares, Grupo VI (tipo 7). Écios subepidérmicos na origem, irrompentes. Eciósporos solitários, pedicelados, principalmente equinulados. Urédios subepidérmicos, irrompentes, com paráfises periféricas, ou supra-estomatais, formando um cesto de células esporogênicas com paráfises periféricas; Urediniósporos solitários e pedicelados, equinulados, alguns assimétricos, parede simples ou com uma camada exterior mais clara, com dois poros germinativos equatoriais; pedicelos higroscópicos. Télios semelhantes aos urédios, sendo que nas espécies microcíclicas os télios são sempre subepidérmicos, irrompentes e associados com espermogônios, ou formando cestas supraestomatais nas macrocíclicas. Teliósporos bicelulares com um septo transversal, solitários, pedicelados, parede pigmentada, muitas vezes obviamente bilaminada e geralmente equinulada ou verrugosa, poucas espécies possuem teliósporos com parede pálida ou incolores e lisas, um poro germinativo em cada célula, metabasídio externo (Cummins \& Hiratsuka 2003).

Todas as espécies de Prospodium são autoécias e a maioria são de ciclos longos, algumas são microcíclicas e todas nativas das Américas. Cerca de 60 espécies infectam hospedeiros em Bignoniaceae e oito espécies infectam plantas da família Verbenaceae. Pelo menos três espécies de Prospodium foram relatadas na África e na Índia.

A espécie-tipo do gênero é Prospodium appendiculatum (Winter) Arthur (=Puccinia appendiculata Winter) relatada em uma bignoniácea não identificada, em 1940 no México (Jackson 1932). 


\section{Prospodium impolitum H. S. Jackson \& Holway Fig. 19 (A-K)}

A espécie forma: Espermogônios escassos. Écios anfígenos, envolvendo os espermogônios, com poucas paráfises dispersas. Eciósporos semelhantes aos urediniósporos. Urédios hipófilos, gregarios, marrons, supraestomatais, com perídio marrom dourado, suportando células esporogênicas recurvadas. Paráfises periféricas de $90 \mu \mathrm{m}$ de comprimento. Urediniósporos $28-33 \times 28-30 \mu \mathrm{m}$ globoides ou obovoides, castanhos a castanho-escuros, com dois poros germinativos equatoriais. Télios formando setas supra-estomatais como as urédias, porém com coloração castanho escura. Teliósporos 35-47,5 x 21-28 $\mu \mathrm{m}$, elipsoides, oblongos, constritos ou não no septo, marrons, verrugosos com verrugas espaçadas, pedicelados. Pedicelos hialinos, higroscópicos, com um par de apêndices laterais ramificados.

A amostra do fungo causador de ferrugem aqui estudada foi identificada como pertencente à espécie Prospodium impolitum por possuir características morfométricas compatíveis com as do material tipo e por infectar a mesma planta hospedeira do material tipo da espécie.

Espécime examinado: em folhas de Pyrostegia venusta (Bignoniaceae): Fazenda Jonas Filgueiras próximo ao Distrito de Marilândia, Município de Itapecerica, Minas Gerais, 04 ago. 2015, leg. D.B. Pinho, UB23334.

O espécime-tipo foi encontrada em folhas de Pyrostegia venusta em São Paulo no ano de 1922 (Jackson 1932), porém Prospodium impolitum encontrada no Brasil nos estados de São Paulo, Minas gerais e Rio Grande do Sul. 

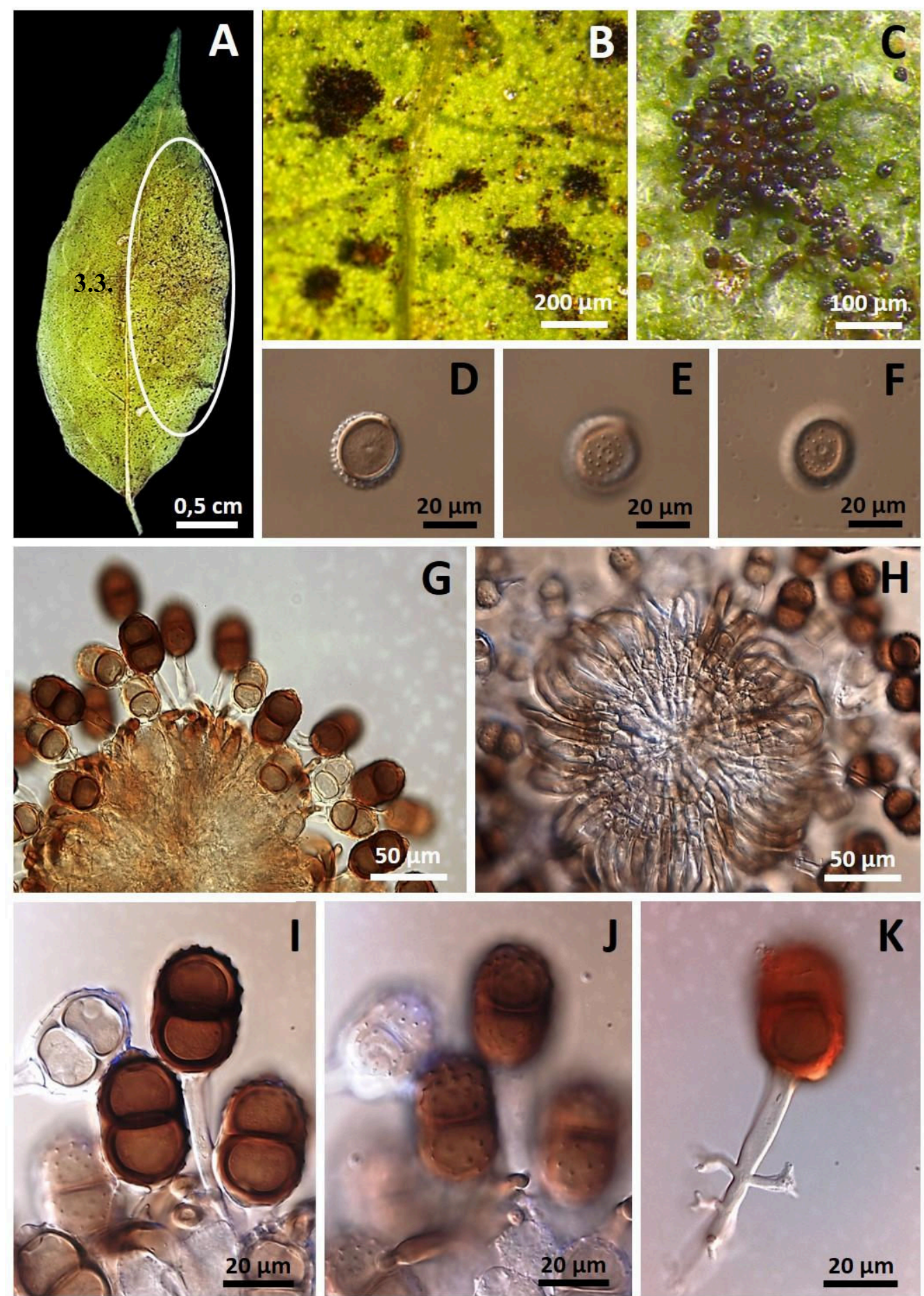

Figura 19 (A-K). Prospodium impolitum em folha de Pyrostegia venusta. A.

Aspecto geral da área abaxial da folha tomada por frutificações do fungo. B, C. Télios vistos em estereomicroscópio. D, E, F. Urediniósporos. G. Télio com teliósporos pedicelados. H. Cesta supraestomatal com foco dirigido à sua base mostrando individualmente as células esporogênicas. I, J, K. Teliósporos. 


\section{Membros da Família Phakopsoraceae (Arthur) Cummins \& Y. Hiratsuka}

Esta família possui 18 gêneros, dos quais 13 tem sua forma sexuada conhecida, abrangendo aproximadamente 205 espécies (Cummins \& Hiratsuka 2003, Kirk et al. 2008). Pelo menos 10 formas assexuadas receberam nomes (Buriticá \& Hennen 1994), hoje em desuso dadas as mudanças advindas do Código de Melbourne de 2011.

Os membros da família Phakopsoraceae infectam grande diversidade de plantas mono e dicotiledôneas. Eles são assim caracterizados: Espermogônios do Grupo VI (tipo 5 ou 7). Écios do tipo Aecidium, Caeoma ou Uredo, com ou sem perídio, eciósporos catenulados ou solitários, verrugosos ou equinulados. Urédios geralmente com paráfises unidas na base, sendo as paráfises periféricas fortes e recurvadas, com a parede fina na parte dorsal. Urediniósporos solitários, exceto em Anthuria onde eles são catenulados, equinulados, poros germinativos obscuros e dispersos. Télios irrompentes ou imersos no tecido da hospedeira, com duas a várias camadas profundas de teliósporos. Teliósporos unicelulares, sésseis, catenulados ou organizados irregularmente, um poro germinativo por célula geralmente inconspícuos metabasídio externo (Cummins \& Hiratsuka 2003).

A família é representada atualmente pelos gêneros Aeciure, Arthuria, Batistopsora, Cerotelium, Crossopsora, Dasturella, Macabuna, Monosporidium, Newinia, Nothoravenelia, Phragmidiella, Pucciniostele, Scalarispora, Uredendo, Uredopeltis, Uredostilbe e Phakopsora (espécie-tipo: P. punctiformis), sendo este último o gênero-tipo da família.

\section{Gênero Phakopsora Dietel}

Esse gênero mostra: Espermogonios subcuticulares, Grupo VI, tipo 7 (Hiratsuka e Hiratsuka, 1980). Écios subepidérmicos, irrompentes. Eciósporos solitários e semelhantes aos urediniósporos. Urédios subepidérmicos, irrompentes, com paráfises encurvadas, fortes, mas 
de parede fina na porção dorsal. Urediniósporos solitários, fortemente equinulados, marrons a quase incolores, poros germinativos espalhados ou equatoriais. Télios subepidérmicos, imersos, compostos de duas a várias camadas irregulares ou regulares de células probasidiais (teliósporos), aderidas umas às outras lateralmente formando um bloco tridimensional, de textura angular quando em cortes transversais. Teliósporos unicelulares, sésseis, marrons a castanhos, um poro germinativo apical, catenulados ou irregularmente dispostos, com paredes espessadas e pigmentadas, compostos por duas ou mais camadas profundas.

Presume-se que a germinação dos teliósporos ocorra após a vencido um período de dormência; metabasídios externos (Cummins \& Hiratsuka 2003, Hennen et al. 2005).

A partir da contribuição de Ono et al. (1992), em que incluiu Physopella em Phakopsora, cerca de 50 espécies foram confirmadas no Novo Mundo e 50 no Velho. Isso faz com que o gênero Phakopsora chegue a cerca de 100 espécies, sendo o terceiro ou quarto maior gênero entre os Pucciniales, superado apenas por Puccinia, Uromyces e Ravenelia. As espécies de Phakopsora ocorrem em todas as regiões mais quentes do mundo em plantas monocotiledôneas e dicotiledôneas. A maioria é provavelmente autoécia mas espermogônios e écios são desconhecidos para a maioria de espécies. Buriticá (1999), Cummins (1971), Ono, Buriticá \& Hennen (1992) e Hennen et al. (2005), são trabalhos básicos indispensáveis nos estudos sobre taxonomia e diversidade do gênero Phakopsora na Neotrópica. No Brasil, foram relatadas cerca de 30 espécies. Phakopsora euvitis Ono em Vitis sp., conhecida no Brasil a partir do registro de Tessmann et al. (2004), P. gossypii (Lagerheim) N. Hiratsuka em espécies de Gossypium, cabendo lembrar a importância de $P$. pachyrhizi infectando vários gêneros de leguminosas, causando inclusive a ferrugem asiática da soja (Glycine max), essa também atacada por P. meibomiae (Arthur) Arthur (Cummins \& Hiratsuka 2003, Hennen et al. 2005, Kirk et al. 2008). 
Phakopsora butleri Dianese, Santos \& Medeiros Fig. 19 (A-E)

Descrita por Dianese et al. (1993), mostra: Espermogônios e Écios não observados. Urédios 280-616 $\mu \mathrm{m}$, geralmente hipófilos, às vezes epifilos, subepidérmicos, irrompentes, com um perídio com textura intricata no topo, parafisados; paráfises himeniais cilíndricas com as pontas arredondadas, solitárias, hialinas, $26-42 \times 10-12 \mu \mathrm{m}$. Urediniósporos sésseis, marrom-claros a marrons, obovóides com a base truncada, $18-30 \times 17-22 \mu \mathrm{m}$, parede com 1-2 $\mu \mathrm{m}$ de espessura, equinulados, 2-4 poros germinativos supra-equatoriais. Télios epifilos, amarelas, esbranquiçadas, cerosas, originalmente subcuticulares, tornando-se tipicamente intra-epidérmicos. Teliósporos organizados em 4-9 camadas, variando de cilíndricos, ovoides e obovoides a elipsoides $21-32 \times 12-14 \mu \mathrm{m}$.

O espécime aqui estudado apresentou apenas urédios sendo os urediniósporos pouco maiores $(26-33 \times 18-22)$ do que os do espécime-tipo.

Espécimes examinados: em folhas de Kielmeyera coriacea (Clusiaceae): Reserva Ecológica do IBGE (Projeto Fogo), Brasília, Distrito Federal. 06 jun. 2012, leg. E.S.C Souza 49, UB22223; em folhas de Kielmeyera coriacea (Clusiaceae): Parque Ecológico Ermida Dom Bosco, Asa Sul, Brasília, Distrito Federal. 27 jul. 2013, leg. E.S.C Souza 198, UB22520. 

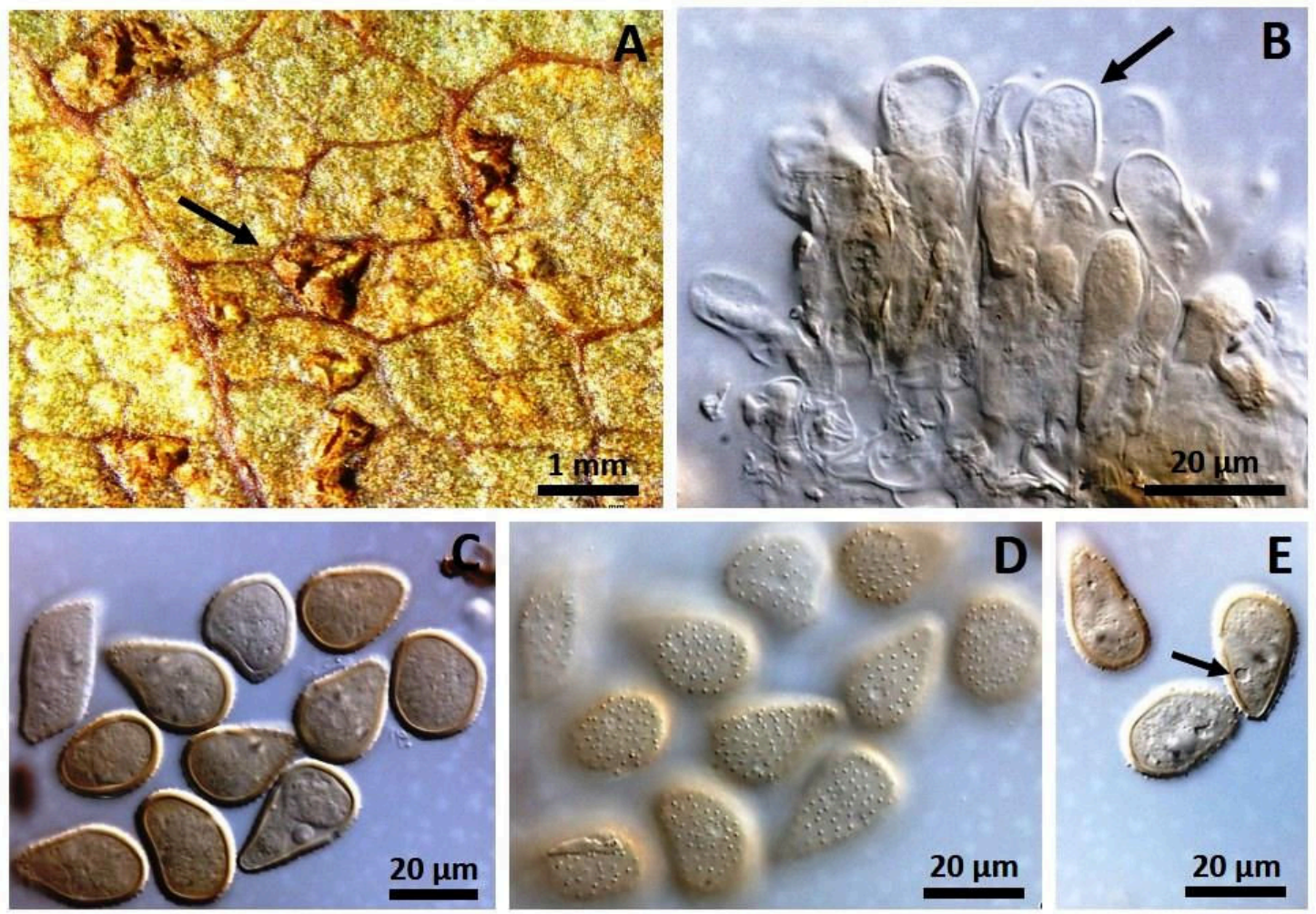

Figura 20 (A-E). Forma uredínica de Phakopsora bluteri em folha de Kielmeyera coriácea. A. Soro (seta). B. Corte de um urédio, mostrando urediniósporos e paráfises. C-E. Urediniósporos em diferentes profundidades de foco, com seta mostrando poro germinativo.

A espécie tipo P. butleri infecta Kielmeyera coriacea Martius (Clusiaceae), espécie endêmica do Cerrado e foi descrita em de Brasília, Distrito Federal, em 1992 (Dianese et al. 1993).

Phakopsora chavesii Dianese, Santos \& Medeiros. Fig. 21 (A-D)

Essa espécie foi assim descrita por Dianese et al. (1993): Espermogônios e Écios desconhecidos. Urédios 118-132 $\mu \mathrm{m}$ de diâmetro, anfígenos, maioria das vezes hipófilos, em pequenos grupos, redondos, amarelados a marrons, irrompentes, subepidérmicos. Urediniósporos sésseis, hialinos a amarelados, elipsoides a obovoides com a base truncada, 21-26 x 16-19 $\mu \mathrm{m}$; fortemente equinulados, 3 poros germinativos obscuros. Télios 
anfígenos, marrons a amarelados, cerosos, subepidérmicos, 2-4 camadas de teliósporos. Teliósporos irregularmente distribuídos em camadas imersas, cilíndricos ou as vezes ovoides, obovoides a fusiformes, $14-38 \times 7-13 \mu \mathrm{m}$; parede com $2-3 \mu \mathrm{m}$ de espessura.

Nas amostras aqui estudadas foi encontrada apenas a fase uredínica com urediniósporos maiores do que os do espécime-tipo, e, além disso, tendo mostrado poros germinativos numerosos.

Espécimes examinados: em folhas de Terminalia phaeocarpa (Combretaceae): Câmpus Darcy Ribeiro Universidade de Brasília, ao lado direito da entrada do CESPE, Brasília-Distrito Federal, 21 jun. 2013, leg. E.S.C Souza 184, UB22487; em folhas de Terminalia phaeocarpa (Combretaceae): Campus Darcy Ribeiro Universidade de Brasília, Brasília-Distrito Federal, 11 jul. 2013, leg. E.S.C Souza 186, UB22502; em folhas de Terminalia argentea (Combretaceae): Jardim Botânico de Brasília, próximo à portaria privativa, Brasília-Distrito Federal, 07 jul. 2014, leg. E.S.C Souza 230, UB22896.

Há relatos de $P$. chavesii em Terminalia argentea em Goiás e em Minas Gerais e em Terminalia phaeocarpa no Distrito Federal, entretanto é a primeira vez que $P$. chavesii é relatada em T. argentea no Distrito Federal. Phakopsora chavesii foi reportada apenas no Brasil. 


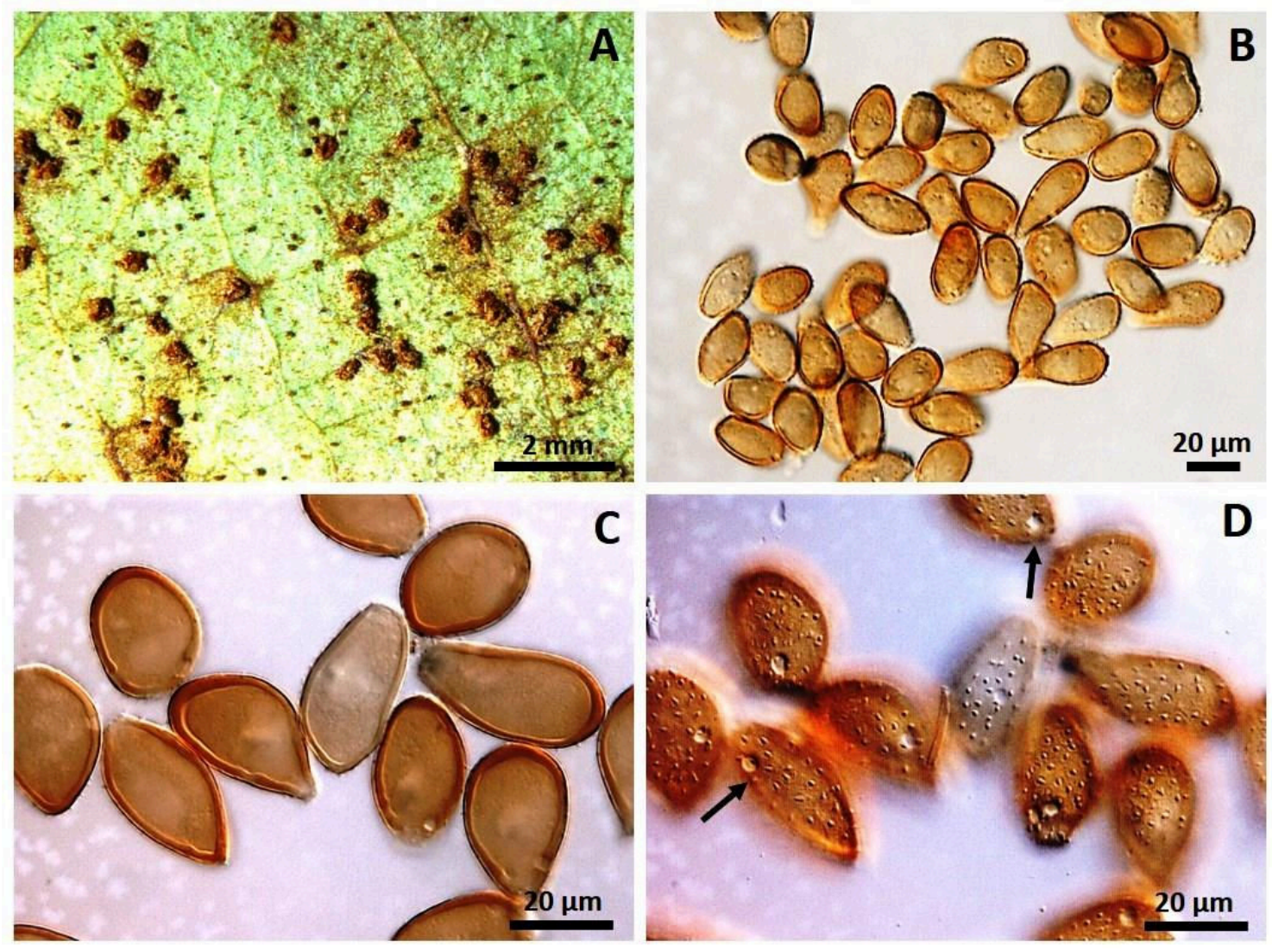

Figura 21 (A-D). Forma uredínica de Phakopsora chavesii em folhas de Terminalia phaeocarpa. A. Urédios pustulares arredondados, amareladas a marrons, irrompentes. B-D. Urediniósporos vistos em diferentes profundidades de foco, com setas indicando poros germinativos.

Phakopsora coca Buriticá \& Hennen in Buriticá. Fig. 22 (A-F)

Espermogônios e écios não bservados. Urédios hipófilos, dispersos ou em pequenos grupos, subepidérmicos, pulverulentos, parafisadois; paráfises himeniais, hialinas, clavadas a cilíndricas 15-25 × 7-9 $\mu \mathrm{m}$, Urediniósporos com pseudopedicelos curtos, obovoides a elipsoides, $22-30 \times 16-20 \mu \mathrm{m}$, equinulados, marrons; 2-4 poros germinativos equatoriais ou em ângulos. Télios e teliósporos não observados.

Espécime examinado: em folhas de Erythroxylum deciduum (Erythroxylaceae): Campus Universitário Darcy Ribeiro da Universidade de Brasília, ao lado direito da entrada 
do CESPE, Asa Norte, Brasília-Distrito Federal, 20 jun. 2013, leg. E.S.C Souza 170, UB22470.

Existem três espécies de fungos causadores de ferrugem que infectam plantas da família Erythroxylaceae na América Latina a saber: Maravalia erythroxyli, Phakopsora erythroxylonis e Phakopsora coca.

Uma chave proposta para a identificação para essas espécies, disponível Hennen et al. (2005), mostrou que, de acordo apenas com a fase uredínica a espécie que mais se aproximou do espécime aqui estudado foi a espécie Phakopsora coca por conter os urediniósporos praticamente com as mesmas medidas, formatos e número de poros germinativos que o espécime aqui estudado.

Phakopsora coca Buriticá \& Hennen foi relatada pela primeira vez em folhas de Erythroxylum engleri em Goiás no ano de 1979, sendo que a sua fase uredínica foi encontrada originalmente na Bolívia e no Peru (Hennen et al. 2005).

Pelo menos 12 outras espécies de Erythroxylum, incluindo E. coca Lamarck, foram listadas como hospedeiras dessa espécie causadora de ferrugem.

A espécie $P$. coca é relatada em E. campestre (São Paulo), em E. citrifolium (Minas Gerais), E. daphnites (Minas Gerais), E. deciduum (São Paulo), E. engleri (Distrito Federal, Goiás e Minas Gerais), E. ovalifolium (Minas Gerais e Rio de Janeiro), E. pelleterianum (Minas Gerais e São Paulo), E. suberosum (São Paulo), E. tortuosum (Distrito Federal e Minas Gerais), Erythroxylum sp., (Distrito Federal, Goiás, Minas Gerais e Rio de Janeiro) E. vaccinifolium (Distrito Federal).

Além desses relatos $P$. coca também foi reportada infectando $E$. areolatum na Guatemala, E. brevipes no Porto Rico, E. coca na Argentina e no Peru e E. mexicanum no México. 
Esta é a primeira vez que $P$. coca é encontrada em folhas de $E$. deciduum no Distrito Federal.
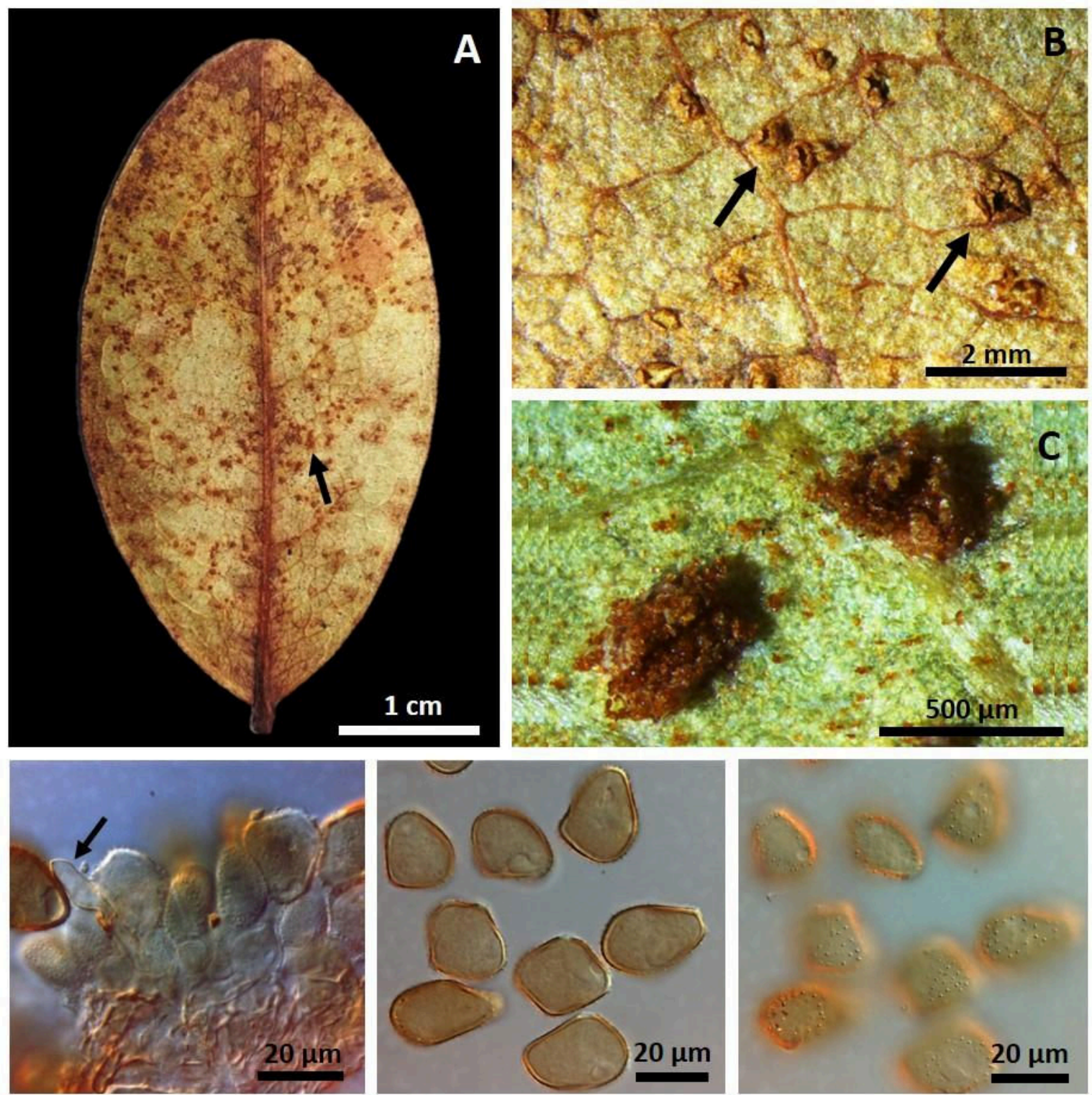

Figura 22 (A-F). Fase uredínica de Phakopsora coca em folhas de Erythroxylum deciduum. A-C. Aspectos da infecção das folhas resultando na produção de soros uredínicos. D-F. Urediniósporos em diferentes profundidades de foco.

\section{Gênero Batistopsora Dianese, Medeiros \& Santos}

Descrição: Espermogônios subepidérmicos, formando hifas recepotivas e espermácias facilmente observados Grupo VI (tipo5). Écios não observados. Urédios subepidérmicos, 
irrompentes, parafisados; paráfises periféricas longas em paliçada, unidas lateralmente formando um cilindro na saída dos urédios, onde os esporos se acumulam e emergem. Urediniósporos equinulados com a vase truncada, sésseis, marrom-claros. Télios subepidérmicos, marrons de aparência crustosa, composta de várias camadas (3-4) de esporos de paredes finas, com textura firme. Teliósporos unicelulares, sésseis, formados em camadas superpostas, paredes finas, incolores ou ligeiramente pigmentados (Dianese et al. 1993, Cummins \& Hiratsuka 2003).

A posição das espermogônios e a paliçada cilíndrica de paráfises soldadas ao redor dos urédios auxilia na identificação do gênero. Dianese et al. (1993) encontraram espermogônios do Grupo VI (tipo 5).

Há controvérsias com relação a permanência do gênero Batistopsora separado de Phakopsora uma vez que, recentemente Beenken (2014), através de estudos filogenéticos, os considera como sendo um gênero único com permanência para Phakopsora.

A espécie tipo para o gênero é Batistopsora crucis-fili encontrada em Annona tomentosa (Anonnaceae) no Brasil (Minas Gerais) em 1993.

Além de Batistopsora crucis-filii, uma outra espécie foi relatada, Batistopsora pistila Buriticá \& Hennen, reportada em Annona nolosericea de Honduras e do Panamá (Buriticá, 1999).

Batistopsora crucis-filii Dianese, Medeiros \& Santos. Fig. 23 (A-H)

Descrição: Espermogônios subepidérmicos na origem, 100-150 $\mu \mathrm{m}$ de largura, 75-115 $\mu \mathrm{m}$ de altura no centro, Grupo VI (tipo5). Écios imaturos, não observados. Urédios hipófilos, subepidérmicos, esbranquiçados a amarelados a marrom-claros, paráfises periféricas (40-) 75-80 × 7-12 $\mu \mathrm{m}$, cilíndricas planas, pontas arredondadas, capitadas, 
aderidas lateralmente formando uma paliçada cilíndrica. Urediniósporos sésseis, (17-) 20-24 (-26) $\times(12-)$ 16-18 $\mu \mathrm{m}$, elipsoides a globoides, truncados na base, paredes finas com $1 \mu \mathrm{m}$ de espessura, densamente equinulados, marrom-claros, poros germinativos inconspícuos. Télios subepidérmicos, hipófilos, 140-160 $\mu \mathrm{m}$ de largura x 70-80 $\mu \mathrm{m}$ de altura, lenticulares, cerosas, amarelados, com 3 a 5 camadas de teliósporos. Teliósporos (8-12) 14-18 × (5-) 8-10 $\mu \mathrm{m}$, sésseis, cilíndricos curtos, em camadas de 3-4 (-5) esporos, parede com 1-2 $\mu \mathrm{m}$ de espessura, subhialinos a marrom-claros (Dianese et al., 1993; Buriticá, 1999).

A amostra analisada possui características morfológicas e dimensionais semelhantes às do material tipo com urediniósporos, entretanto, os urédios $(127-240$ x 80-240 $\mu \mathrm{m})$ e os Télios (190-347 x 59-70) apresentam valores muito maiores que a os descritos para o holótipo da espécie (Dianese et al. 1993).

Espécimes examinados: em folhas de Anonna tomentosa (Anonnaceae): Jardim Botânico de Brasília, Brasília-Distrito Federal, 23 abr. 2012, leg. E.S.C Souza 16, UB22180; em folhas de Anonna tomentosa (Anonnaceae): Proximidades do Centro Olímpico da Universidade de Brasília (UnB), Brasília-Distrito Federal, 25 jun. 2012, leg. E.S.C Souza 62, UB22266; em folhas de Anonna tomentosa (Anonnaceae): Jardim Botânico de Brasília, próximo à portaria principal, Brasília-Distrito Federal, 07 jul. 2014, leg. E.S.C Souza 234, UB22902.

O material tipo foi reportado em Annona tomentosa Fries no Brasil, em Minas Gerais em 1993 e possui como anamorfo Uredostilbe crucis-filii Buriticá encontrado na Colômbia em 1999.

Batistopsora crucis-filii também foi encontrada em outros locais e hospedeiras da família Annonaceae como A. crassifolia em Minas Gerais; A. glaucophylla em Goiás, A. tomentosa em Goiás, Mato Grosso e Minas Gerais; A. squamosa no Ceará e Annona sp., em 
Goiás, Mato Grosso, Mato Grosso do Sul, Minas Gerais e São Paulo (Hennen et al. 2005, Beenkem 2014).

Batistopsora crucis-filii foi reportada apenas no Brasil, entretanto a espécie também é relatada sobre A. paludosa em diversas regiões da Guiana Francesa (Hennen et al. 2005, Beenkem 2014). 

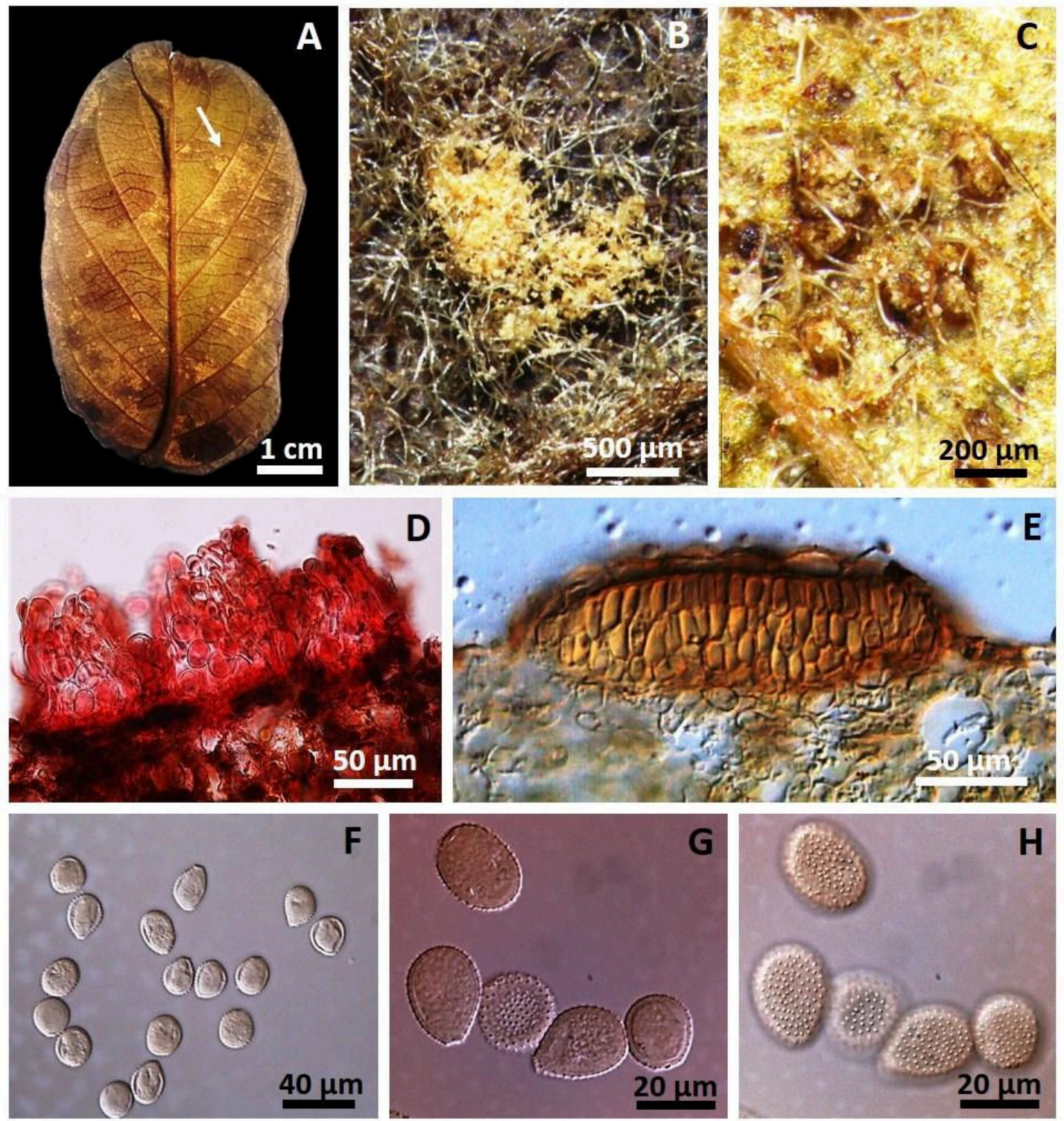

Figura 23 (A-H). Batistopsora crucis-filii em folhas de Anonna tomentosa. A-C.

Sintoma na folha e soros em diferentes aumentos em estereomicroscópio. D. Urédios com paráfises formando paliçada. D. Télio subepidérmico, com teliósporos sésseis em três camadas mais ou menos organizadas. F-H. Urediniósporos em diferentes profundidades de foco. 
Gênero Catenulopsora B. B. Mundkur

Descrição: Espermogônios do tipo IV. Urédios hipófolos, irrompentes. Urediniósporos obovoides a reniformes, equinulados, marrons a marrom-claros, com poros germinativos dispersos. Télios com teliósporos produzidos em fileiras verticais lateralmente livres de células basais esporogênicas, estes às vezes se assemelham a um pedicelo (Buriticá, 1998).

Cummins \& Hiratsuka (2003), colocaram Catenulopsora como sinônimo de Kuehneola, mas Buriticá e Hennen (1994) e Buriticá (1999) o reconheceram como um gênero à parte. Além das espécies C. praelonga e C. henneneae, Buriticá (1999) registrou nove outras espécies dos Trópicos de África, Índia, Birmânia, Tailândia e Filipinas em uma lista não publicada.

Atualmente o gênero está sinonimizado como Kuehneola por por Cummins \& Hiratsuka (2003), embora outros autores, considerem o gênero como sinônimo de Cerotelium.

A espécie-tipo do gênero, C. flacourtiae, foi descrita em Flacourtia sepiaria (Flacourtiaceae) em 1943, na Índia (Hennen et al. 2005).

Catenulopsora henneneae Buriticá Fig. 23 (A-H)

Descrição: o material estudado continha apenas urédios e urediniósporos, a saber: Urédios 87-145 $\mu \mathrm{m}$ de diâmetro, hipófilas, subepidérmicos tornando-se irrompentes quando velhos, pulverulentos, amarelados a amarronzados Paráfises 18-34 $\mu \mathrm{m} \times 4-10 \mu \mathrm{m}$, curvadas, lisas, hialinas a levemente pigmentadas, paredes grossas com até $3,5 \mu \mathrm{m}$ de espessura, numerosas. Urediniósporos $22-32 \mu \mathrm{m} \times 19-27 \mu \mathrm{m}$, obovoides a reniformes, marrons, parede grossa com até $3 \mu \mathrm{m}$ de espessura, equinulações grandes e uniformes, poros germinativos espalhados, podendo chegar até 4 . 
Espécime examinado: em folhas de Pouteria torta (Sapotaceae): Centro Olímpico da Universidade de Brasília, Brasília-Distrito Federal, 25 jun. 2012, leg. E.S.C Souza 61, UB22265.

Cummins \& Hiratsuka (2003) consideraram Catenulopsora como sinônimo de Kuehneola, mas Buriticá \& Hennen (1994) e Buriticá (1999) separaram os gêneros. Buriticá (1999) reconheceu 11 espécies para o gênero, sendo que duas ocorrem no Brasil, a saber: Catenulopsora henneneae Buriticá e Catenulopsora praelonga (Speg.) Buriticá, em Sapotaceae e Malvaceae, respectivamente.

A forma uredínica de Catenulopsora henneneae, embora hoje em desuso, foi designada Macabuna hennenae Buriticá, encontrado no mesmo material que a espécie tipo, segundo Buriticá (1999).

Aquela descrição da fase uredínica é semelhante à do espécime estudado e também está associada à mesma hospedeira. Castro (2012) também encontrou a mesma fase uredínica em Pouteria sp.

Catenulopsora henneneae foi anteriormente relatada em São Paulo e Minas Gerais (Buriticá, 1999) e sua fase uredínica em Goiás e Mato Grosso do Sul (Castro 2012) e agora no Distrito Federal. 

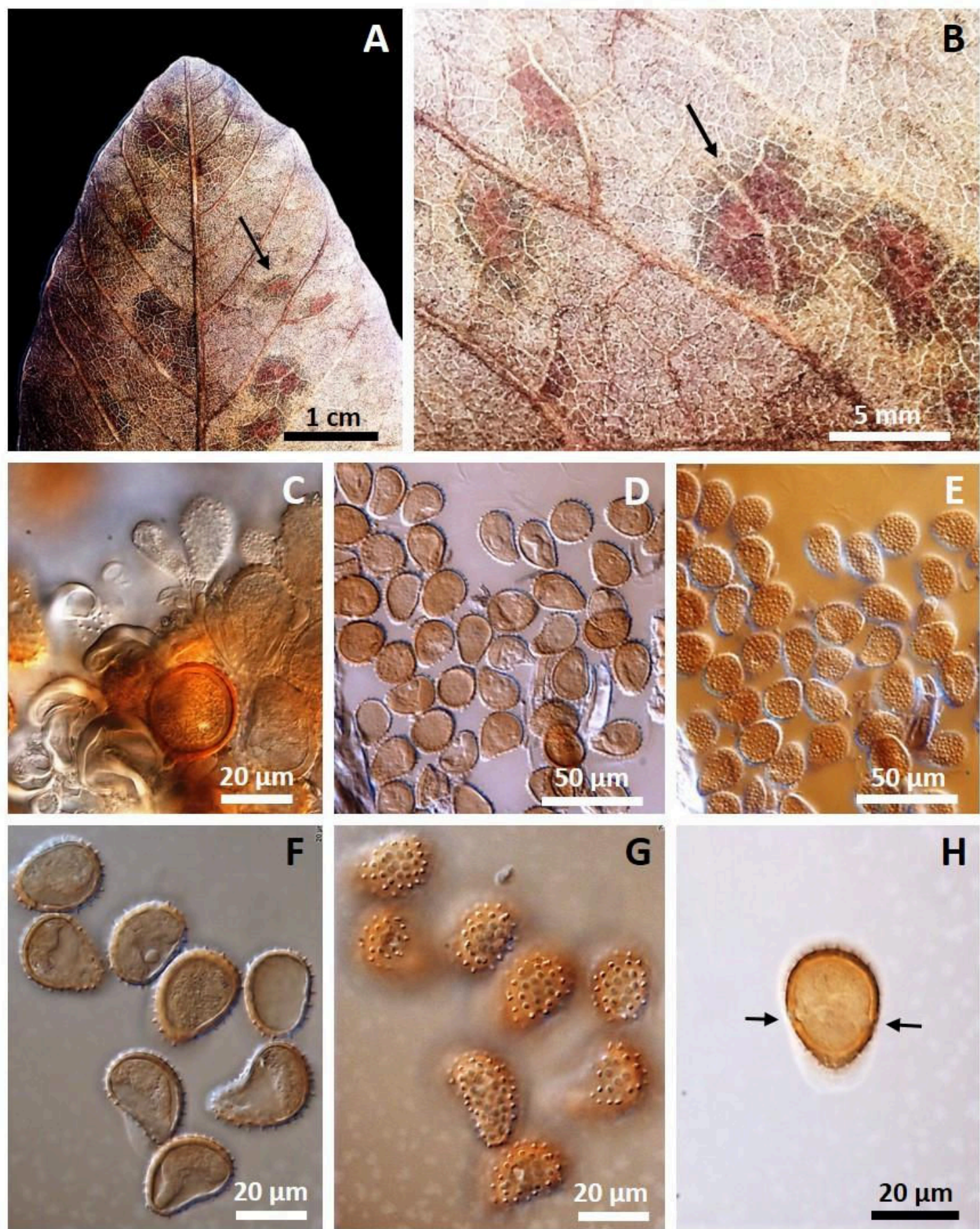

Figura $24(\mathrm{~A}-\mathrm{H})$. Fase uredínica de Catenulopsora henneneae em folhas de

Pouteria torta. A-B. Sintomas. C-G. Urediniósporos vistos em diferentes profundidades de foco. H. Urediniósporo com setas indicando posição dos poros germinativos. 


\section{Gênero Crossopsora H. Sydow \& P. Sydow}

Descrição: Espermogônios subcuticulares, Grupo VI, tipo 7. Écios subepidérmicos, sem perídio, irrompentes, tipo Caeoma. Eciósporos catenulados e equinulados. Urédios subepidérmicos, irrompentes, parafisados; paráfises geralmente septadas e unidas na base. Urediniósporos pedicelados, equinulados, poros dispersos, inconspícuos. Télios subepidérmicos, irrompentes, depois colunares, com teliósporos fortemente ligados formando filamentos longos e estáveis. Teliósporos unicelulares, cilíndrico-elípticos, catenulados, fortemente aderidos uns aos outros, formando coluna ereta ou recurvada, com um poro germinativo lateral, germinação sem dormência, basídio externo (Cummins \& Hiratsuka 2003, Hennen et al. 2005).

A espécie tipo do gênero é C. zizyphi encontrada em folhas de Zizyphus oenopilia e de Z. rugosa (Rhamnaceae) reportada em 1919 na Índia.

As espécies ocorrem em regiões de clima tropical e subtropical, com 11 espécies no Neotrópico Buriticá (1999).

Dodge (1925) relatou que os télios colunares de Crossopsora são semelhantes aos de Cronartium tanto na estrutura quanto na ontogenia, principalmente nas células que ficam ao redor do ápice da coluna. As paredes do ápice das células adjacentes são fundidas com as de outras células em um arranjo vertical e incorporadas em uma matriz gelatinosa que lhes dão coesão lateral, principalmente depois de secar. Em Crossopsora essa coluna tem origem em urédios que já liberaram os urediniósporos, fato não demonstrado em Cronartium.

Outro fato é que os télios de Crossopsora se assemelham superficialmente aos de Cronartium, mas é duvidoso de que os dois gêneros estejam relacionados pois as espermogônios são diferentes, os écios de Crossopsora não são peridiados, os seus urédios possuem paráfises em vez de perídio, e os teliósporos não são incorporados em uma matriz 
comum com os urediniósporos. Mundkur \& Thinrumalachar (1946) descreveram e ilustraram urédio supraestomatal em C. zizyphi, mas a maioria das espécies tem soros imersos e irrompentes. Todas as espécies provavelmente são autoécias (Cummins \& Hiratsuka 2003).

Atualmente há 19 espécies membros do gênero Crossopsora: C. aganosmae, C. angusta e C. stevensii em Apocynaceae; C. asclepidiaceae e C. mateleae em Asclepiadaceae, C. bixae em Bixaceae, C. byrsonimatis em Malpighiaceae, C. clemensiae em Euphorbiaceae, C. crassa em Bignoniaceae, C. fici em Moraceae, C. gilgiana em hospedeira não determinada, C. hymenaeae em Fabaceae, C. opposita em Solanaceae, C. perscita em Asteraceae, C. piperis em Piperaceae, C. premnae e C. premnae-tomentosae em Verbenaceae, C. symphorematis em Lamiaceae e C. ziziphi em Rhamnaceae (Index fungorum 2016).

Das nove espécies antes consideradas em Crossopsora oito foram transferidas para o gênero Cronartium: C. antidesmae-dioicae e C. malloti em Euphorbiaceae, C. byrsonimae e C. notata em Malpighiaceae, C. kemangae em Anacardiaceae, C. sawadae, C. uleana (Solanaceae) e C. wilsoniana em Vitaceae e C. caucensis para o gênero Physopella (Index Fungorum 2016, Mycobank 2016).

\section{Espécies de Crossopsora encontradas no Cerrado}

Crossopsora byrsonimatis $(\mathrm{P}$. Hennings $)=$ Cronartium byrsonimatis $=$ Crossopsora byrsonimae Fig. 24 (A-G), Fig. 25 (A-G), Fig. 26 (A-D), Fig. 27 (A-K), Fig. 28 (A-K) e Fig. $29(\mathrm{~A}-\mathrm{G})$

Espermogônios densamente e igualmente distribuídas em ambos os lados das folhas e em caules deformados, infectados sistematicamente, subcuticulares, inicialmente castanhoamarelados e finalmente castanhos. Écios espalhados entre os espermogônios, distribuídos em fileiras em torno da folha, cilíndricos, brancos a marrom-claros; células peridiais firmemente 
unidas em linhas regulares, 48-66 (53) $\times$ 24-31,5 (24) $\mu \mathrm{m}$, romboides, grosseiramente verrugosas. Eciósporos 35-48 (46) $\times$ 27-33,5 (32) $\mu \mathrm{m}$, angulares a ovoides, elipsoides ou oblongos, muitas vezes apiculados, marrom-amarelados. Urédios hipófilos, subepidérmicos, dispersos ou gregários, paráfises longas e espessas, acuminadas, sobrepostas, hialinas ou levemente pigmentadas. Urediniósporos hialinos, marrom-claros a marrons, clavados a obovóides, curto-pedicelados, equinulados de forma homogênea por toda a superfície, 3-4 esporos germinativos. Télios colunares, capiliformes, cilíndricos, longos, hipófilos, gregários a dispersos, formados a partir de urédios senescentes, côr de palha a marrom-escuros. Teliósporos unicelulares, lisos, solidamente catenulados formando colunas tridimensionais, geralmente oblongo-cilíndricos, ápice e bases obtusos, mais largos na base, germinação lateral. Metabasídios reniformes a alantoides, 3 septos transversais, hialinos, as vezes com probasídios largos na base. A Tabela 1 mostra as dimensões das estruturas de $C$. byrsonimatis encontradas nas diferentes espécies do gênero Byrsonima.

A espécie C. byrsonimatis foi encontrada pela primeira vez em Byrsonima coccolobifolia no estado de São Paulo em 1904 (Hennen et al. 2005).

Tabela 1. Comparação entre coletas de Crossopsora byrsonimatis obtidas de diferentes espécies de Byrsonima.

\begin{tabular}{|c|c|c|c|c|}
\hline Hospedeiras & Eciósporos $(\mu \mathrm{m})$ & $\begin{array}{c}\text { Urediniósporos } \\
(\mu \mathrm{m})\end{array}$ & $\begin{array}{l}\text { Télios } \\
(\mu \mathrm{m})\end{array}$ & Teliósporos $(\mu \mathrm{m})$ \\
\hline Byrsonima verbascifolia (UB22347) & - & $39-53 \times 28,5-35$ & 95-257 & $43-69 \times 25-35$ \\
\hline Byrsonima laxiflora (UB22202) & - & $37-50 \times 27-38$ & - & - \\
\hline Byrsonima coccolobifolia (UB22259) & - & $29-47,5 \times 22-36$ & - & - \\
\hline Byrsonima pachyphylla (UB23344) & $35-48,5 \times 27-33,5$ & - & - & - \\
\hline Byrsonima pachyphylla* & - & $34-42 \times 21-27$ & - & $35-66 \times 20-26$ \\
\hline Byrsonima coccolobifolia ** & - & $36-44,4 \times 24-30$ & $90-150$ & $40-76 \times 18-29$ \\
\hline Byrsonima crassifolia $* * *$ & $28-55 \times 22-35$ & - & - & - \\
\hline
\end{tabular}

* Castro (2012), ** Peterson (1973), *** P. \& H. Sydow (1923)

As amostras aqui estudadas foram comparadas com o material tipo e se encaixam na descrição original para a espécie, principalmente quanto aos aspectos morfológicos, embora 
apresentem dimensões com poucas variações. Conforme mostrado na Tabela 1, o espécime sobre folhas de $B$. verbascifolia foi o que apresentou maiores dimensões em termos de urediniósporos, teliósporos e télios. Em B. coccolobifolia o urédio não apresentaram paráfises e os urediniósporos são mais curtos, porém mais largos, o mesmo ocorrendo com o espécime de $B$. laxiflora. Embora na espécie-tipo a fase ecídica não tenha sido descrita, ela está presente em nossa amostra de C. byrsonimatis em B. pachyphylla e já foi reportada em B. crassifolia (P. \& H. Sydow 1923). Porém, nessa hospedeira as formas uredínica e telial não foram aqui encontradas, as quais, no entanto, já foram observadas e descritas por Castro (2012).

Espécimes examinados: em folhas de Byrsonima coccolobifolia (Malpighiaceae): Proximidades do Centro Olímpico da Universidade de Brasília, Brasília-Distrito Federal, 21 jun. 2012, leg. M. Sanchez 4662, UB22259; em folhas de Byrsonima crassa (Malpighiaceae): Parque Ecológico Olhos D`Água de Brasília na SQN 413 (Asa Norte), Brasília- Distrito Federal, 12 set. 2012, leg. E.S.C Souza 144, UB22384; em folhas de Byrsonima laxiflora (Malpighiaceae): Jardim Botânico de Brasília, Brasília-DF, 30 mai. 2012, leg. E.S.C Souza 28, UB22202; em folhas de Byrsonima verbascifolia (Malpighiaceae): Fazenda Água Limpa da Universidade de Brasília (FAL-UnB), Brasília- Distrito Federal, 03 set. 2012, leg. E.S.C Souza 119, UB22347; em folhas de Byrsonima pachyphylla (Malpighiaceae): Parque Nacional Chapada das Mesas, Maranhão, 29.10.2015, leg. D.B. Pinho UB23344.

Hennen et al. (1982) citaram cinco espécies de Pucciniales sobre Byrsonima: Aecidium byrsonimatis P. Hennings, Aecidium vinnulum H. S. Jackson \& Holway, Crossopsora byrsonimatis (P. Hennings) R.S. Peterson, Crossopsora notata Arthur e Uredo uberabensis P. Hennings. Essa última teve o hospedeiro erroneamente identificado como Byrsonima, quando se tratava do gênero Caryocar (Caryocaraceae), tratando-se provavelmente da fase uredínica de Cerotelium giacomettii (Dianese et al. 1973). De acordo com Buriticá (1999c), C. byrsonimatis diferencia-se de C. notata por apresentar soros anamórficos (urédios) com 
paráfises largas e grossas e esporos com uniformemente equinulados, enquanto que as paráfises dos soros de $C$. notata seriam curtas e os esporos irregularmente ornamentados, com áreas lisas e outras verrugosas. Aecidium byrsonimatis e A. vinnulum anteriormente eram diferenciados de C. byrsonimatis pelos tipos de soros e esporos. Nas duas espécies de Aecidium os soros encontrados eram de espermogônios e écios com eciósporos de parede verrugosa, enquanto que em $C$. byrsonimatis eram conhecidos soros uredínicos com urediniósporos de parede equinulada e télios com teliósporos catenulados. Cummins \& Hiratsuka (2003) já citavam que havia a possibilidade de $A$. byrsonimatis ser o estágio ecídico de Crossopsora, uma vez que esta espécie apresentava espermogônio do tipo 7, característico da família Phakopsoraceae (Cummins \& Hiratsuka 2003).

A fase anamórfica ecídica (Aecidium byrsonimatis) é relatada em Byrsonima sp., em Byrsonima crassifolia, em Byrsonima sericea e agora em Byrsonima pachyphylla. A correlação do anamorfo ecídico com o teleomorfo do fungo em questão era questionada sendo aqui esclarecida por ser encontrada as duas fases correspondentes na mesma espécie hospedeira, Byrsonima pachyphylla.

Crossopsora byrsonimatis é relatada nas seguintes hospedeiras e locais: $B$. affinis e $B$. fagifolia em Minas Gerais; B. coccolobifolia em Minas Gerais e em São Paulo; B. crassifolia no Acre e no Pará; $B$. densa no Maranhão e em Minas Gerais; B. intermedia no Mato Grosso do Sul, em Minas Gerais e em São Paulo; B. pachyphylla no Distrito Federal em Goiás; $B$. sericea no Rio de Janeiro e Byrsonima sp. no Amapá, no Amazonas, em Goiás, no Maranhão, no Mato Grosso, em Minas Gerais, no Pará e em São Paulo (Castro 2012, Farr \& Rossman 2016; Hennen et al. 2005).

Além do Brasil, a fase ecídica de $C$. byrsonimatis foi encontrada em folhas de Byrsonima sp. no México, em Byrsonima crassifolia na Guatemala e em Byrsonima 
crassifolia na Guiana Francesa. Aecidium byrsonimatis tem sido reportada também na Venezuela, em Trinidade e na América Central (Hennem et al. 2005; Farr \& Rossman 2016). Crossopsora byrsonimatis foi relatada também em Byrsonima sericea e Byrsonima crassifolia na Bolívia, Costa Rica, Cuba, Guatemala, Honduras, México, Panamá, Porto Rico, Venezuela (Hennen et al., 2005, Farr et al., 2009).

Esta é a primeira vez que a espécie Crossopsora byrsonimatis infectando Byrsonima pachyphylla e B. coccolobifolia foi encontrada no Maranhão e no Distrito Federal, respectivamente. Crossopsora byrsonimatis é também relatada aqui, pela primeira vez, em Byrsonima verbascifolia, Byrsonima laxiflora e Byrsonima crassa, todas no Distrito Federal. 

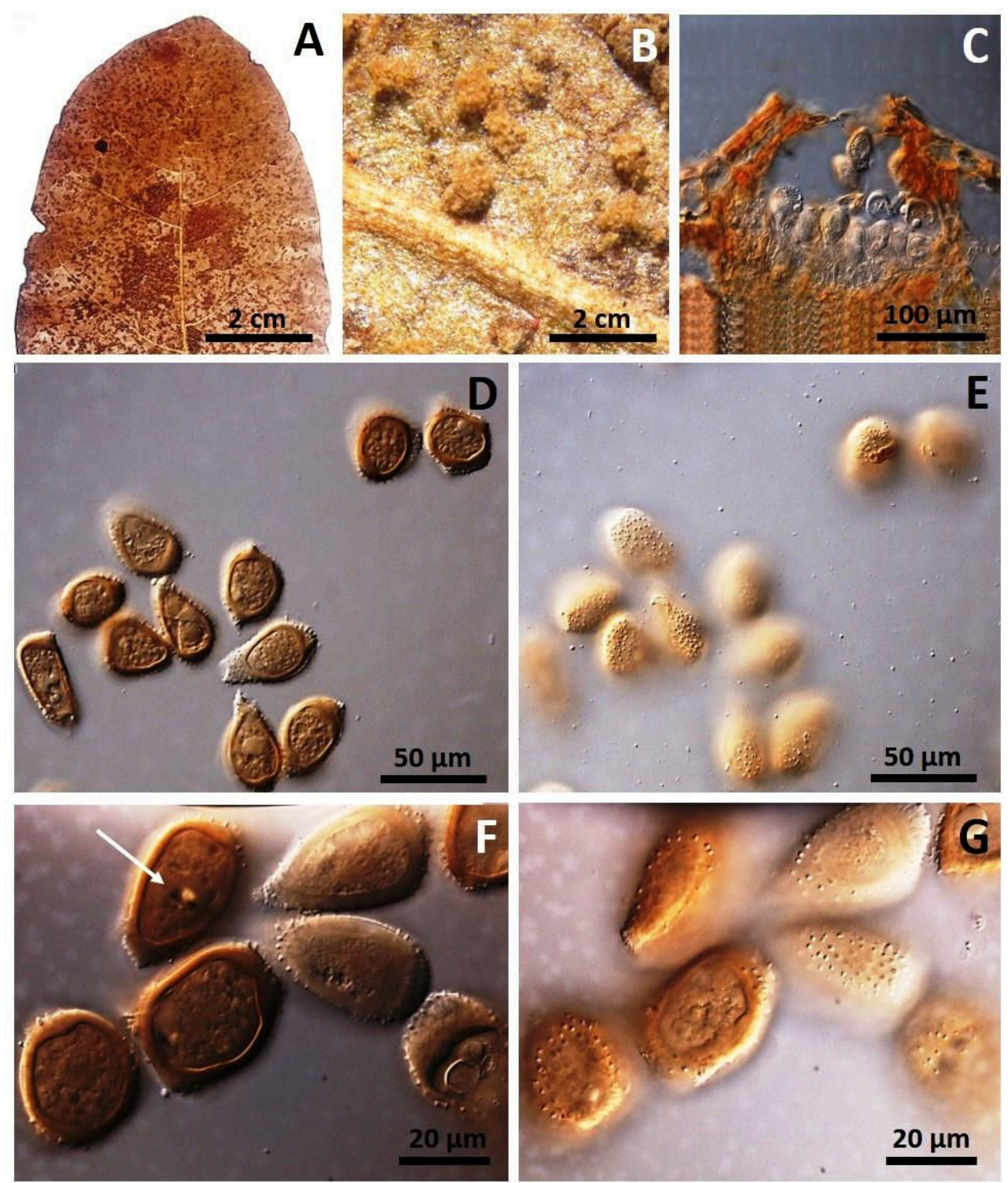

Figura 25 (A-G). Fase uredínica de Crossopsora byrsonimatis em folhas de Byrsonima coccolobifolia. A-B. Sintomas. C. Corte de um urédio. D-G. Urediniósporos vistos em diferentes aumentos e profundidades de foco. 

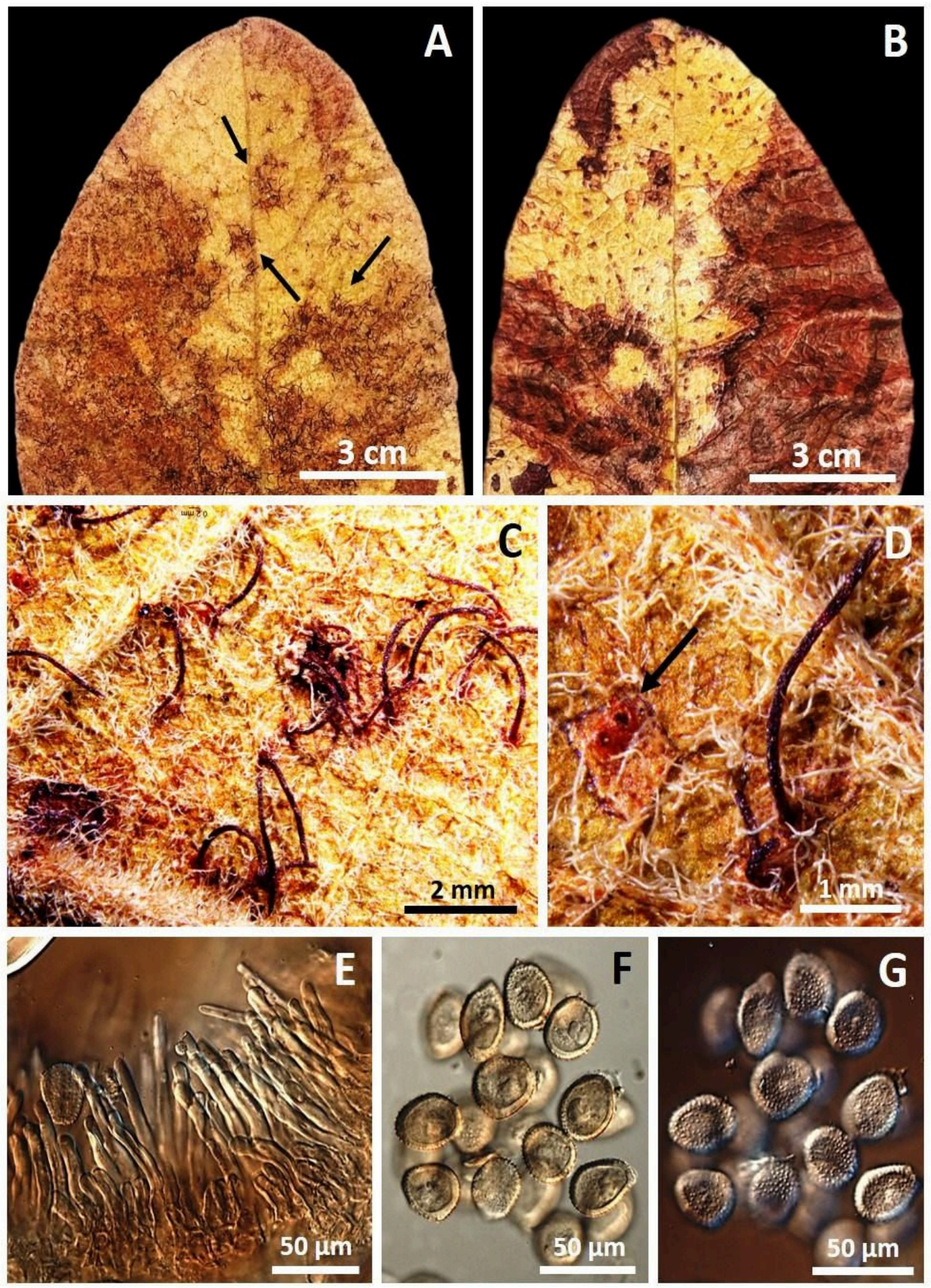

Figura 26 (A-G). Crossopsora byrsonimatis em folhas de Byrsonima crassa.

A-B. Sintomas. C-D. Télios colunares. E. Paráfises localizadas na base dos télios colunares. F - G. Urediniósporos vistos em diferentes profundidades de foco. 

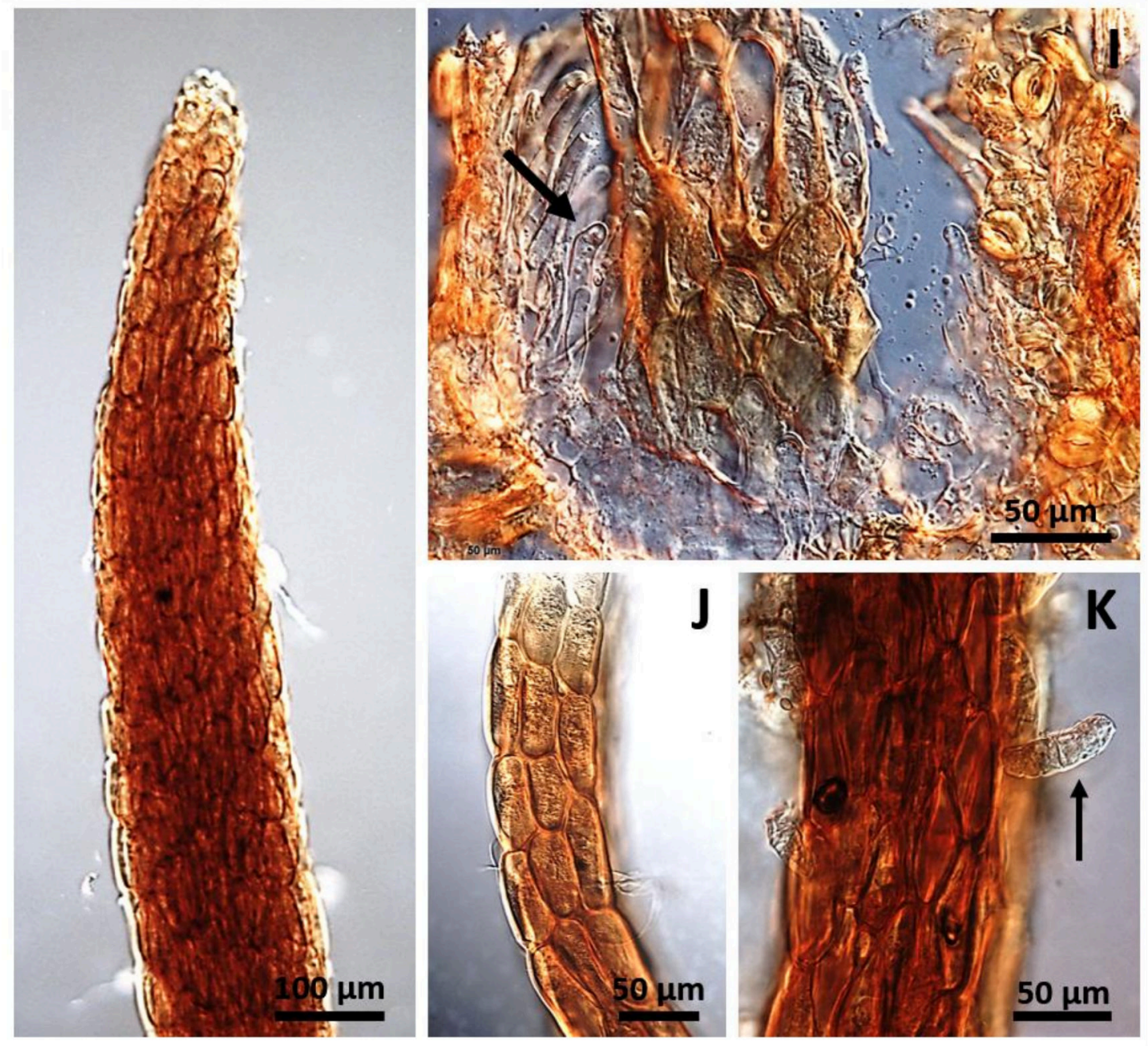

Figura 27 (A-D). Crossopsora byrsonimatis em folhas de Byrsonima crassa. A. Télio colunar. B. Base de um télio colunar, mostrando posição das paráfises (seta). C. Telio colunar com teliósporos unicelulares. D. Teliósporo e um metabasídio (seta) ainda sem basidiósporos. 

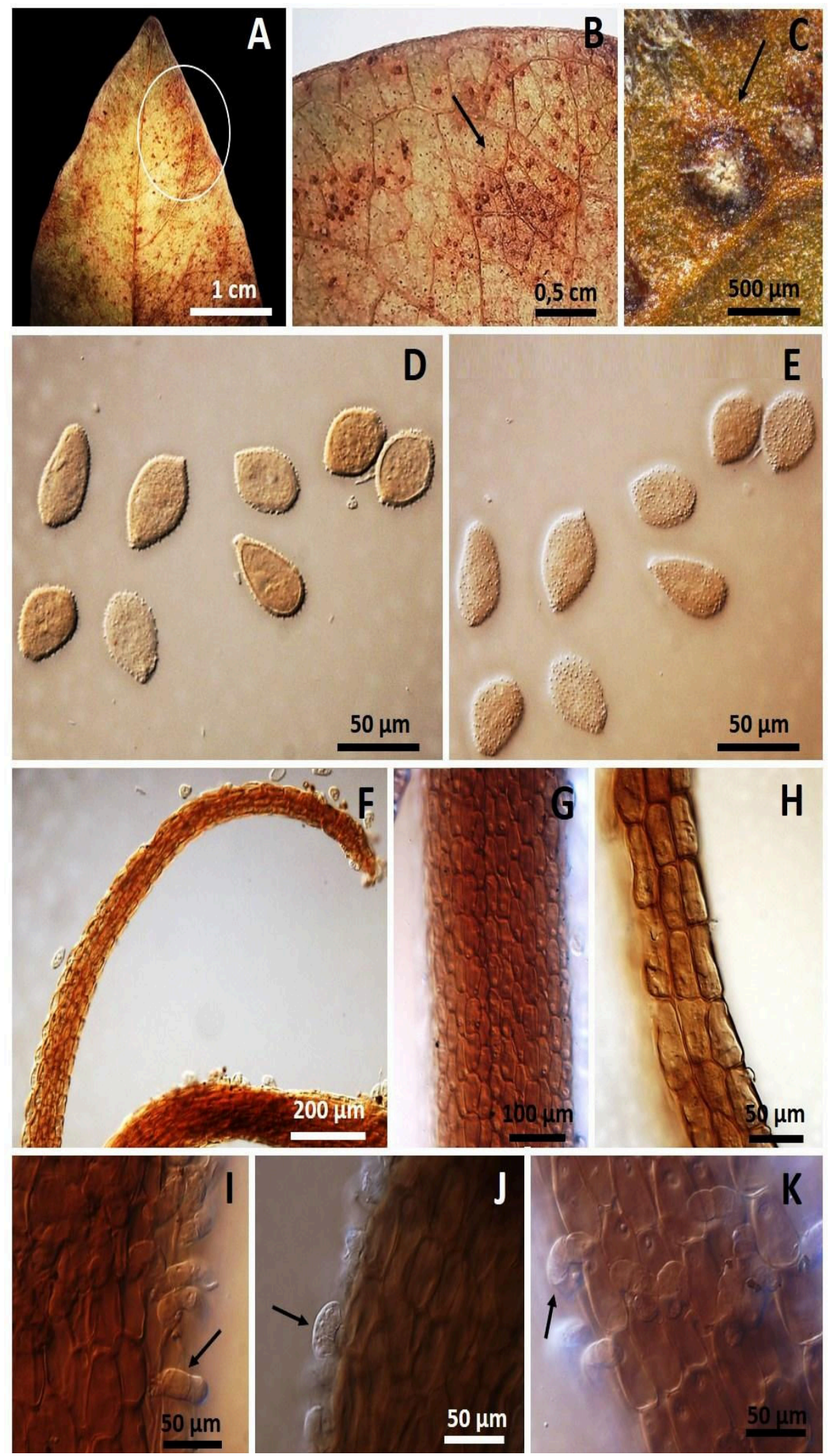

Figura 28 (A-K). Crossopsora byrsonimatis em folhas de Byrsonima

verbacifolia. A-B. Sintomas. C. Urédio. D-E. Urediniósporos vistos em diferentes profundidades de foco. F-H. Télios colunares compostos por telióosporos unicelulares. I-K. Germinação de teliósporos em télio colunar. 

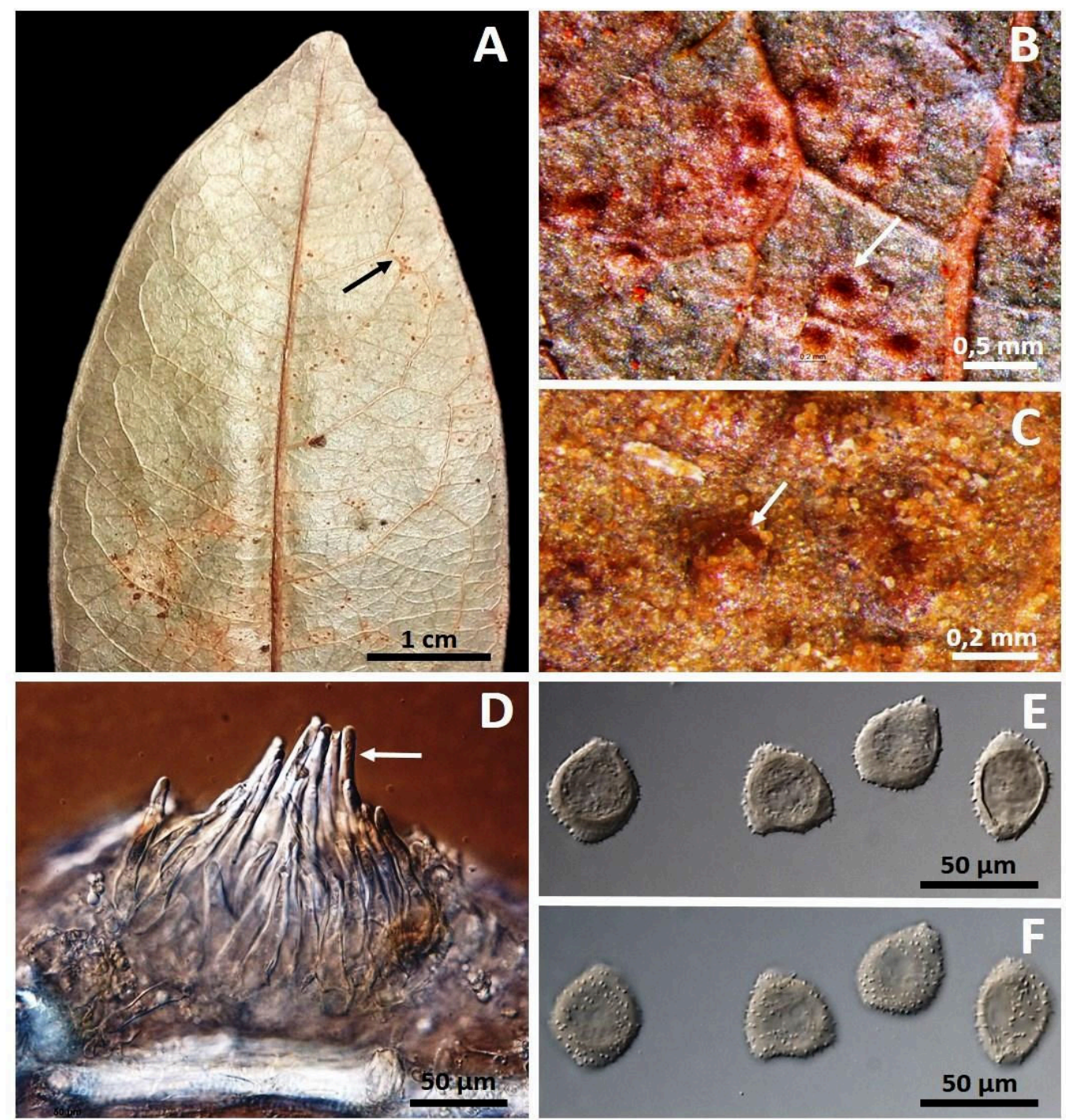

Figura 29 (A-K). Crossopsora byrsonimatis em folhas de Byrsonima laxiflora.

A. Sintomas consistindo de urédios na forma de pontos marrom-avermelhados. B-C. Urédios. D. Urédio coberto de paráfises afiladas. E-F. Urediniósporos vistos em diferemtes profundidades de foco. 

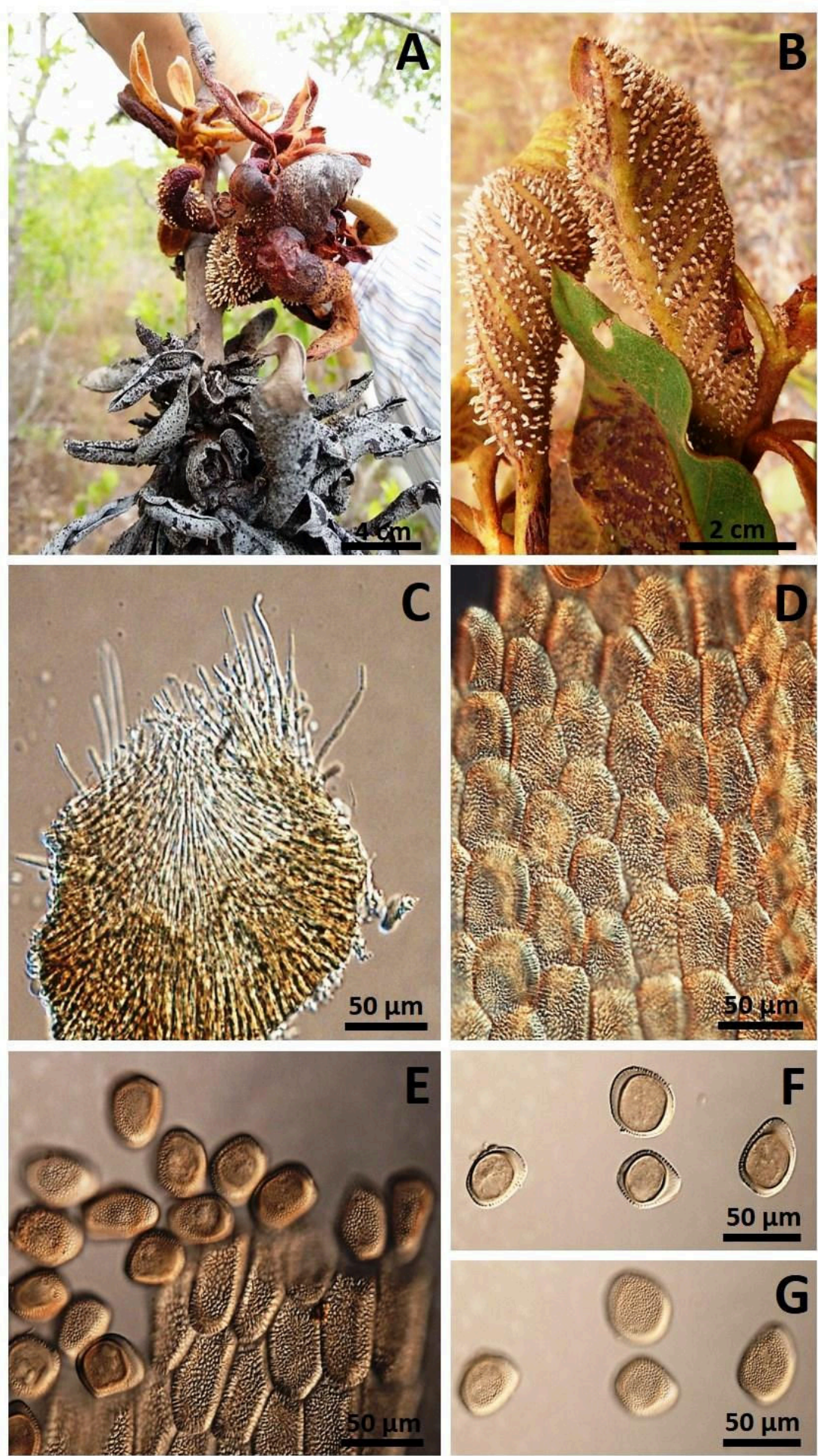

Figura 30 (A-G). Crossopsora byrsonimatis em brotação jovem de Byrsonima pachyphylla. A. Sintomas de deformação foliar e envassouramento. B. Formação abundante de écios na face abaxial das folhas. C. Detalhe de um espermogônio mostrando uma profusão de hifas receptivas. D. Textura do perídio de um écio, mostrando a verrugosidade de suas células. E. Eciósporos e parte do perídio do écio. F-G. Ecióspros visto em diferentes profundidades de foco. 
Crossopsora hymenaeae Dianese, Buriticá \& Hennen Fig. 30 (A-E)

Espermogônios e écios não observados. Urédios 0,3-0,7 mm de diâmetro, hipófilos, dispersos a gregários, em manchas castanho-canela, subepidérmicos, irrompentes, abrindo-se em formato de urnas, pulverulentos, parafisados; paráfises himeniais, 40-48 x 9-12 (-17) $\mu \mathrm{m}$, cilíndricas com pontas afiladas, flexuosas, parede fina, ocasionalmente $2-3 \mu \mathrm{m}$ de espessura no ápice. Urediniósporos (26-) 29-33 (-39) x (13-) 16-17 (-20) $\mu \mathrm{m}$, obovoides ou elipsoides, parede com $1 \mu \mathrm{m}$ de espessura, porém com $2-4 \mu \mathrm{m}$ de espessura no ápice, moderadamente equinulados, (2-) 3-4 poros germinativos, supra-equatoriais. Télios hipófilos, subepidémicos, irrompentes, colunares, filiformes, originando-se urédios senescentes, marrom-claro a marrom escuros. Teliósporos 26-32 x 7-10 $\mu \mathrm{m}$, cilíndricos, castanho-canela, unidos apical e lateralmente formando coluna cilíndrica, parede cerca de 1 $\mu \mathrm{m}$ de espessura, com 1 poro germinativo (Dianese et al. 1994, Buriticá et al. 1996).

O material aqui estudado apresentou as mesmas características morfológicas do material tipo (Dianese et al. 1994).

Espécimes examinado: em folhas de Hymenaea stigonocarpa Martius (Fabaceae): Fazenda Água Limpa da Universidade de Brasília (FAL-UnB) na trilha da cachoeirinha, Brasília-Distrito Federal, 03 set. 2012, leg. E.S.C Souza 120, UB22349; em folhas de Hymenaea stigonocarpa Martius (Fabaceae): Campus universitário Darcy Ribeiro da Universidade de Brasília ao lado da entrada do CESPE, Brasília-Distrito Federal, 20 jun. 2013, leg. E.S.C Souza 171, UB22472.

O espécime-tipo foi encontrada em folhas de Hymenaea stigonocarpa Martius (Fabaceae) entre os municípios de Rialma e Rianápolis (Goiás) em 1979. Além de Goiás o fungo causador de ferrugem também foi relatado no Distrito Federal, Mato Grosso, Mato Grosso do Sul e Minas Gerais. 

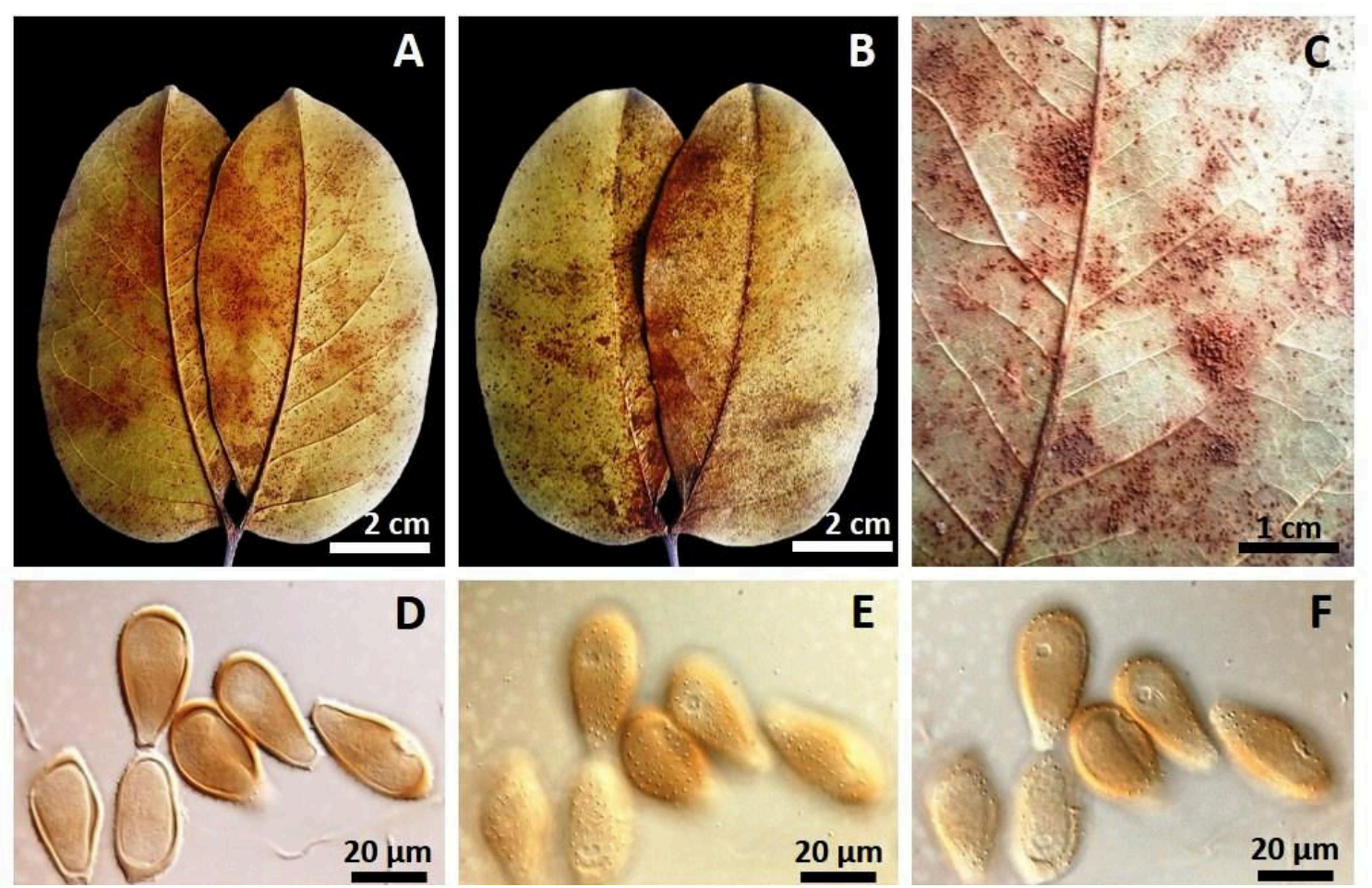

E

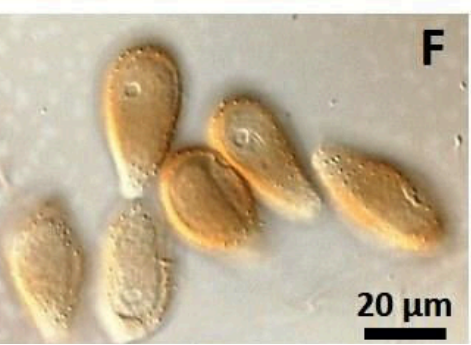

Figura 31 (A-F). Forma uredínica de Crossopsora hymeneae em folhas de Hymenaea stigonocarpa. A-B. Sintomas nas duas faces de uma mesma folha. C. Urédios gregários. D-F. Grupo de urediniósporos vistos em três diferentes profundidades de foco. 


\section{Membros da Família Pucciniaceae Chevall}

Descrição: Espermogônios Grupo VI, Tipo 4. Écios do tipo Aecidium ou Caeoma, com ou sem perídio, eciósporos catenulados, verrugosos; ou do tipo Uraecium com perídio e com eciósporos solitários, ou raramente com perídio, mas com esporos catenulados. Urédios do tipo Uredo com ou sem paráfises, ou do tipo Uredostilbe com perídio em paliçada. Urediniósporos solitários, frequentemente equinulados, poros germinativos numerosos, conspícuos. Télios com ou sem paráfises, mas raramente com perídio em paliçada, ou télios algumas vezes separados em lóculos por paráfises. Teliósporos solitários, geralmente pedicelados, com uma ou duas células (raramente mais), com septo transversal, raramente oblíquo, um poro germinativo em cada célula, germinação geralmente por basídios externos, raramente por basídios internos.

Essa família inclui o maior número fungos de causadores de ferrugem da ordem Pucciniales, com cerca de 7000 espécies e 18 gêneros. Os gêneros Puccinia e Uromyces são os mais comuns, com mais de mais de 3000 e cerca de 600 espécies, respectivamente (Kirk et al. 2008, Cummins \& Hiratsuka 2003).

Além dos gêneros Puccinia (gênero-tipo) e Uromyces, outros gêneros que compõe essa família são: Cumminsiella, Gymnosporangium, Chrysella, Chrysocyclus, Chrysopsora, Cleptomyces, Corbulopsora, Endophyllum, Kernia, Miyagia, Polioma, Puccorchidium e Sphenorchidium, Stereostratum, Zaghouania (Index Fungorum 2016, Mycobank 2016).

Membros desta família podem ser heteroécios ou autoécios e, em conjunto, possuem ampla gama de hospedeiras. 


\section{Gênero Puccinia Pers. ex Pers (Espécie-tipo: P. graminis)}

Descrição: Espermogônios subepidérmicos, Grupo V, tipo 4. Écios subepidérmicos, eruptivos, do tipo Aecidium com perídio e eciósporos catenulados e verrugosos ou do tipo Uraecium com os eciósporos na maioria das vezes equinulados, solitários e pedicelados. Urédios subepidérmicos, eruptivos, sem perídio, com ou sem paráfises, tipo Uredo ou as vezes do tipo Aecidium. Urediniósporos solitários, pedicelados, geralmente equinulados, verrugosos, raramente catenulados, poros germinativos numerosos. Télios subepidérmicos, eruptivos na maioria das espécies, inicialmente cobertos pela epiderme e divididos em lóculos por paráfises em muitas espécies. Teliósporos tipicamente bicelulares com um septo transversal, em poucas se mostram unicelulares, ou com três a quatro células, solitários, pedicelados, paredes pigmentadas, nunca hialinos, mas com grau de pigmentação amplamente variado, lisos ou ornamentados, um poro germinativo por célula, mas inconspícuos em poucas espécies, os quais germinam por metabasídio externo, com quatro células com esterigmas.

As espécies de Puccinia podem heteroécias ou autoécias e acometem tanto famílias monocotiledôneas como dicotiledôneas, por exemplo, membros das Asteraceae, Cyperaceae, Fabaceae, Poaceae, Liliaceae, Malvaceae, entre outras.

Espécies em Puccinia causam sérias doenças importantes como a ferrugem do colmo das gramíneas ( $P$. graminis), a ferrugem da aveia e cevada ( $P$. coronata), ferrugem da cana de açúcar (P. kuehnii), a ferrugem do algodoeiro (P. cacabata), entre outras.

\section{Puccinia banisteriae Henn. Fig. 31 (A-E)}

Descrição: Espermogônias e Écios não observados. Urédios hipófilos, castanho escuros, eruptivos, pulverulentos, dispersos ou gregários, causando lesões cloróticas ou necróticas na face adaxial das folhas. Urediniósporos 30-35 $\times 22-25 \mu \mathrm{m}$ globosos, parede 
espessa, equinulados e marrons. Télios semelhantes aos urédios. Teliósporos 40-55 × 21-25 $\mu \mathrm{m}$, elipsoides a cilíndricos, arredondados em ambas as extremidades, ligeiramente constritos no septo, com superfície reticulada e pedicelados; pedicelos hialinos, paredes finas, geralmente rompidos junto ao esporo.

Os traços úteis para a identificação de $P$. banisteriae incluem: teliósporo com paredes reticuladas, pontilhadas, com dois poros germinativos um no ápice da célula superior, e outro na célula inferior junto ao septo, pedicelos decíduos cujo resíduo permanece ligado ao esporo. Os grandes grupos irregulares de télios pulverulentos de coloração escura no lado abaxial das folhas são especialmente óbvios no campo pelo contraste com o cinza prateado na face abaxial das folhas das hospedeiras.

Espécime examinado: em folhas de Banisteriopsis gardneriana (Malpighiaceae): Jardim Botânico de Brasília, Brasília-Distrito Federal, 30 mai. 2012, leg. E.S.C Souza 41, UB22210.

O material tipo de P. banisteriae foi encontrado em Banisteriopsis sp. no Estado de Goiás em 1892, e também em B. anisandra em Goiás e Minas Gerais; em B. clauseniana em Goiás e São Paulo; em B. gardneriana em Goiás; em B. nummifera em São Paulo; em Banisteriopsis sp., em Goiás e Minas Gerais. Este é o primeiro relato de P. banisteriae, em Banisteriopsis gardneriana para o Distrito Federal e a primeira vez que a fase uredínica é descrita e ilustrada para esta espécie. 


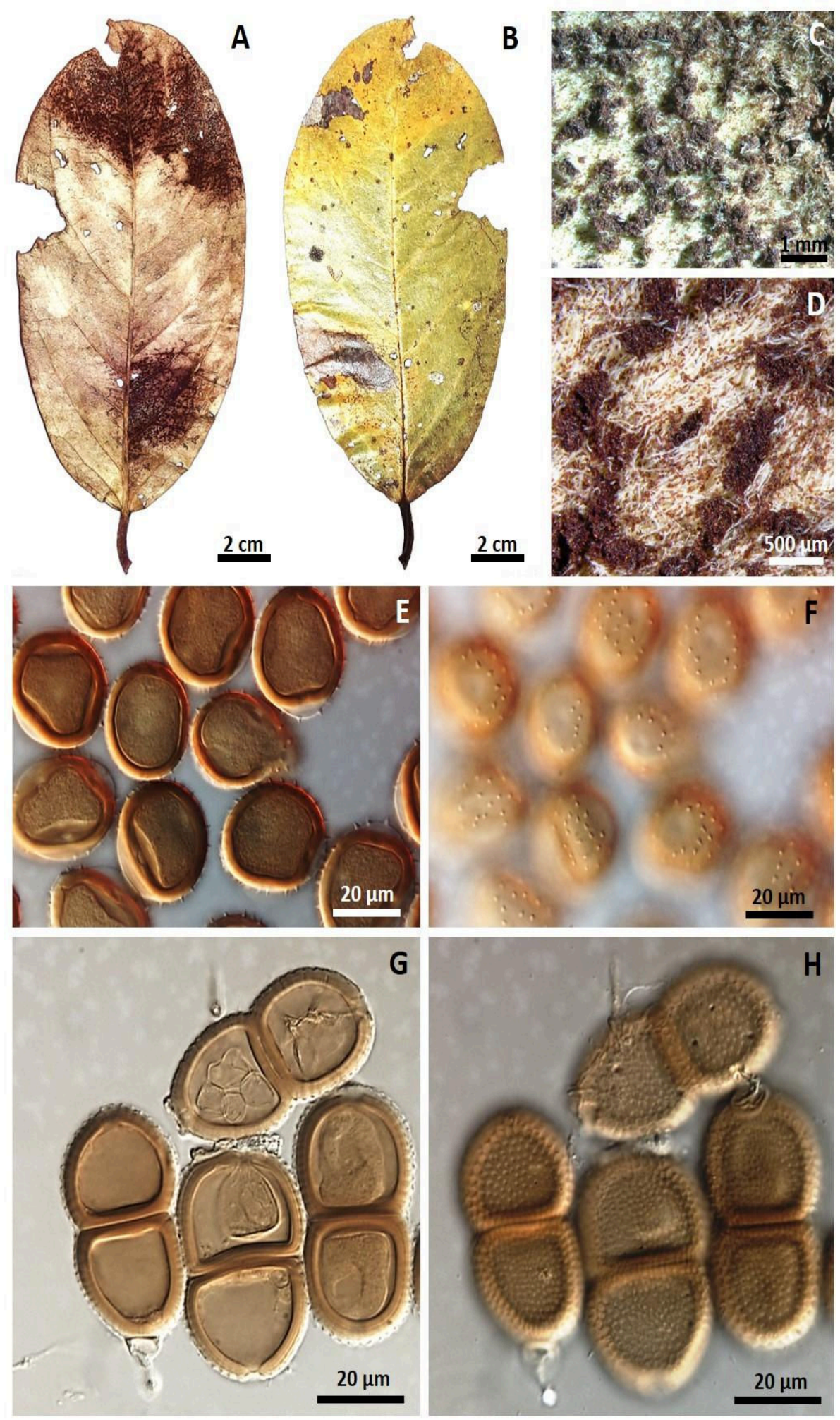

Figura 32 (A-H). Puccinia banisteriae em folhas de Banisteriopsis gardneriana. A. Sintoma na folha, áreas hipófilas contendo esporulação marrom. B. Áreas necrosadas na face adaxial. C-D. Soros (urédios e télios) hipófilos. E-F. Urediniósporos vistos em duas profundidades de foco. G-H. Teliósporos visto em duas profundidades de foco. 
Puccinia barbatula Arthur \& J. R. Johnston. Fig. 32 (A-G)

Descrição: Espermogônios hipófilos, em pequenos grupos, tons acastanhados a marrom-claros, 1-3 mm de diâmetro. Écios circundando os espermogônios, 0,2-0,8 mm de diâmetro, profundos, eruptivos, parcialmente recobertos por tecido epidérmico, pulverulentos, castanho-canela escuros. Eciósporos pedicelados, 39-45 × 25-32 $\mu \mathrm{m}$, amplamente elipsoides ou obovoides, com parede de $2-2,5 \mu \mathrm{m}$ de espessura, equinulados, com 2 poros germinativos equatoriais. Urédios hipófilos, subepidérmicos, eruptivos, pulverulentos, castanho escuros, parafisados. Paráfises 40-65 × 3-5 $\mu \mathrm{m}$, cilíndricas com a ponta arredondada, hialinas. Urediniósporos 35-45 × 24-33 $\mu \mathrm{m}$, amplamente obovoides ou elipsoides, equinulados e pedicelados. Télios hipófilos, sobre áreas de cor mais ou menos clara, geralmente aglomerados em torno dos urédios ou écios, esbranquiçados ou marrons pálidos, geralmente longos. Teliósporos 40-55 × 18-28 $\mu \mathrm{m}$, oblongos-clavados a elipsoides, arredondados na extremidade apical ou ligeiramente estreitado na porção basal, constritos no septo, lisos, incolores a subhialinos, pedicelados; pedicelos longos 40-60 × 13-18 $\mu \mathrm{m}$.

Características relevantes para a identificação de Puccinia barbatula incluem: écios e eciósporos e urédios e urediniósporos grandes e castanhos, fortemente equinulados, com dois poros germinativos equatoriais e teliósporos com paredes incolores a ligeiramente pigmentados e lisas. Na descrição original para a espécie não consta a presença de paráfises himeniais nos urédios, ao contrário do que foi observado aqui.

Apesar de não terem sido observados écios e eciósporos, outras características que permitiram a identificação do espécime aqui estudado foram as dimensões, formatos e textura da parede dos urediniósporos e teliósporos e pedicelos característicos (consideravelmente mais longos), semelhantes aos encontrados na descrição do material tipo da espécie. Além disso, o espécime foi encontrado infectando a mesma hospedeira já relatada para a espécie e, 
de acordo com a chave de identificação disponível em Hennen et al. (2005) para espécies de Puccinia em membros de Malpighiaceae, o espécime se enquadrou em Puccinia barbatula por ser a única espécie com teliósporos lisos, pouco pigmentados. A maioria das espécies descritas em membros de Malpighiaceae possuem teliósporos reticulados e algumas verrugosos.

Espécimes examinados: em folhas de Heteropterys byrsonimifolia (Malpighiaceae): Jardim Botânico de Brasília, Brasília-Distrito Federal, 20 set. 2012, leg. E.S.C Souza 149, UB22390; em folhas de Heteropterys byrsonimifolia (Malpighiaceae): Jardim Botânico de Brasília, Brasília-Distrito Federal, 20 set. 2012, leg. E.S.C Souza 157, UB22400.

O material tipo foi encontrado em folhas de Heteropterys laurifolia (reportado originalmente em Banisteria laurifolia) em Cuba (Arthur \& J. R. Johnston (1916). A espécie foi também encontrada em outras hospedeiras em Malpighiaceae como Diplopterys sp. no Distrito Federal; H. byrsonimifolia em Minas Gerais e São Paulo; H. coriacea no Distrito Federal; H. escalloniifolia na Bahia e Heteropterys sp. em Goiás, Mato Grosso, Minas Gerais e São Paulo. Além disso, a espécie ocorre em Belize, Cuba e México (Hennen et al. 2005). 

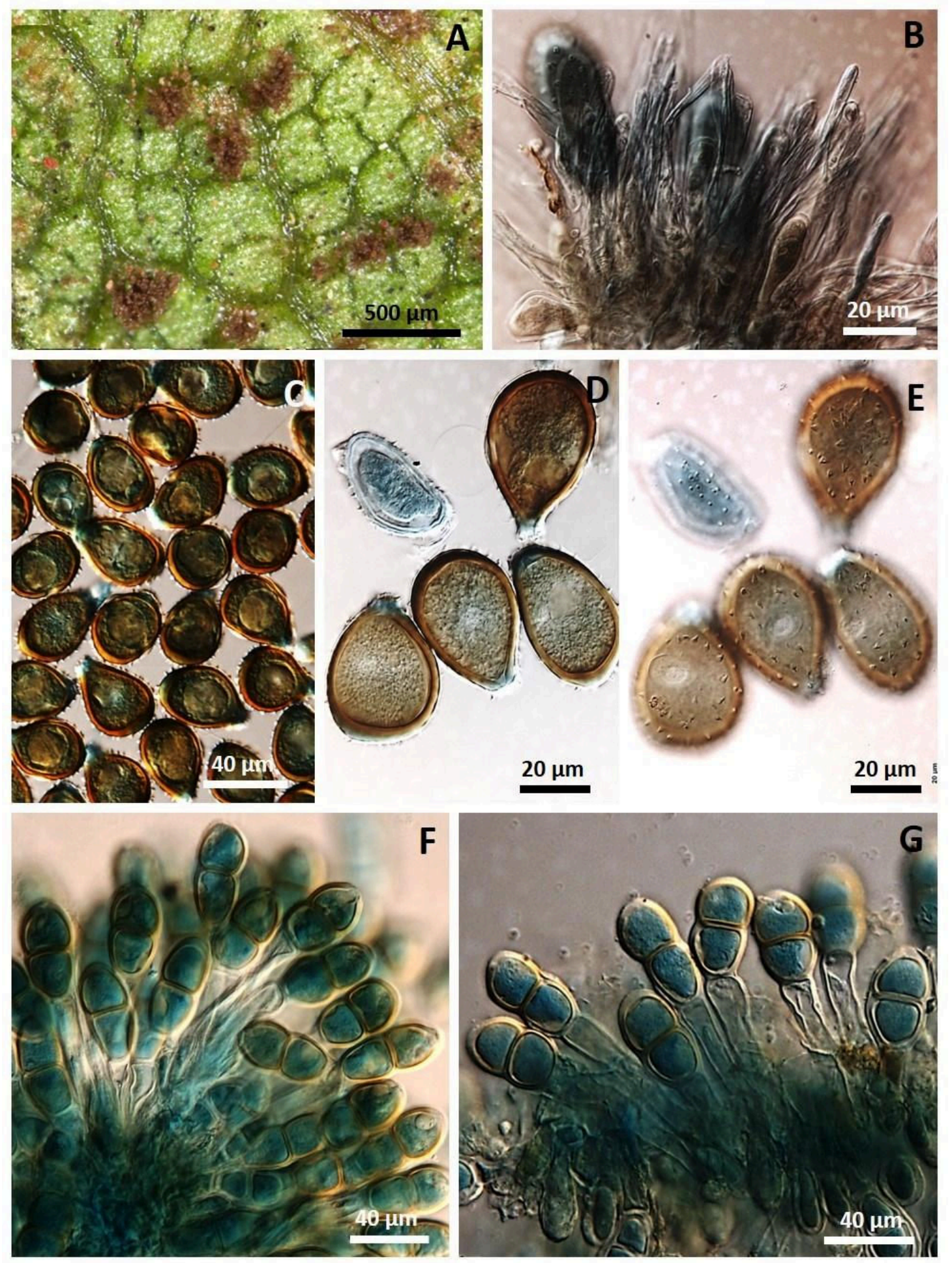

Figura 33 (A-G). Puccinia barbatula em folhas de Heteropterys byrsonimifolia. $A$.

urédios irrompentes, pulverulentos e marrons claros. B. Paráfises himeniais hialinas dos urédios e alguns urediniósporos em formação. C. Massa de urediniósporos marrons. D-E. Urediniósporos obovoides marrons, equinulados. F-G. Teliósporos pedicelados, oblongo-elipsoides, subhialinos. 
Puccinia pipta A.A. Carvalho \& J. F. Hennen. Fig. 33 (A-G) Fig. 34 (A-H)

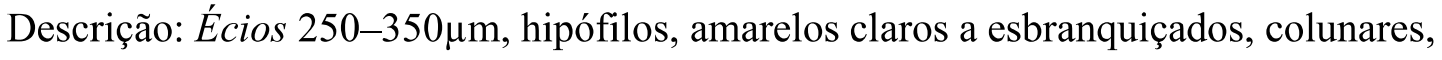
pequenos, pulverulentos. Eciósporos $18-20 \mu \mathrm{m} \times 16 \mu \mathrm{m}$, circulares a ovóides, hialinas, equinuladas. Urédios $100-300 \mu \mathrm{m}$ hipófilos, subepidérmicos, eruptivos, pulverulentos, marrons. Urediniósporos $33-35 \times 30 \mu \mathrm{m}$, globoides, marrons, equinulados, um poro germinativo na porção central. Télios numerosos, epífilos em Piptocarpha rotundifolia e hipófilos em Piptocarpha macropoda, dispersos amplamente na superfície da folha, marrons a negros, de diâmetro pequeno $(250 \mu \mathrm{m}$, em média), sem paráfises himeniais ou periféricas, pulverulentos. Teliósporos $37-42 \times 23-27 \mu \mathrm{m}$ (em Piptocarpha macropoda) e $36-45 \times$ 33 - $35 \mu \mathrm{m}$ (em Piptocarpha rotundifolia), bicelulares, ligeiramente constritos no septo, elípticos a subgloboides, marrons, reticulados e pedicelados: pedicelos não persistentes, deixando fragmento remanescente preso aos teliósporos, hialinos. Poro germinativo no ápice da célula apical.

Espécimes examinados: em folhas de Piptocarpha macropoda (Asteraceae): Fazenda Água Limpa da Universidade de Brasília (FAL-UnB), Brasília-Distrito Federal, 27 jul. 2012, leg. H.M.M Vale 178, UB22327; em folhas de Piptocarpha rotundifolia (Asteraceae): Fazenda Água Limpa da Universidade de Brasília (FAL-UnB), Brasília-Distrito Federal, 27 jul. 2012, leg. E.S.C Souza 100, UB22328; em folhas de Piptocarpha rotundifolia (Asteraceae): Jardim Botânico de Brasília, Brasília-Distrito Federal, 20 set. 2012, leg. E.S.C Souza 152, UB22395.

Puccinia pipta foi descrita recentemente por Carvalho Jr \& Hennen (2011) em folhas de Piptocarpha sellowii e sobre P. rotundifolia descreveram: P. manuelensis A.A. Carvalho \& J. F. Hennen e P. calida A.A. Carvalho \& J.F. Hennen. As duas últimas, possuem teliósporos faveolados, porém P. manuelensis possui urediniósporos equinulados, e não 
mostra constrição no septo dos teliósporos, enquanto que $P$. calida possui urediniósporos verrugosos e $P$. pipta urediniósporos equinulados, teliósporos faveolados e constritos no septo, além do mais se trata de uma espécie microcíclica.

Os espécimes aqui estudados, foram identificados como $P$. pipta por serem também autoécios e morfologicamente idênticos a ela, afetando $P$. rotundifolia e, pela primeira vez observada em P. macropoda.

O holótipo de $P$. pipta apresenta télios epífilos, paráfises himeniais clavadas, amarelas pálidas a hialinas, geralmente grossas e espessas no ápice, com $40-60 \times 5-7(-10) \mu \mathrm{m}$ de tamanho e paredes com $0,5 \mu \mathrm{m}$ de espessura, em média, entretanto nos materiais ora estudados as paráfises não foram encontradas. Castro (2012) também estudou um espécime de Puccinia sobre folhas de $P$. rotundifolia que apresentou características semelhantes e ausência de paráfises, assim como os espécimes aqui analisados. Castro (2012) observou em P. pipta écios amarelo-amarronzados, cupulados, com eciósporos $26-37 \mu \mathrm{m} \times 19-22 \mu \mathrm{m}$, elipsoides, ligeiramente amarelados e verrugosos. 

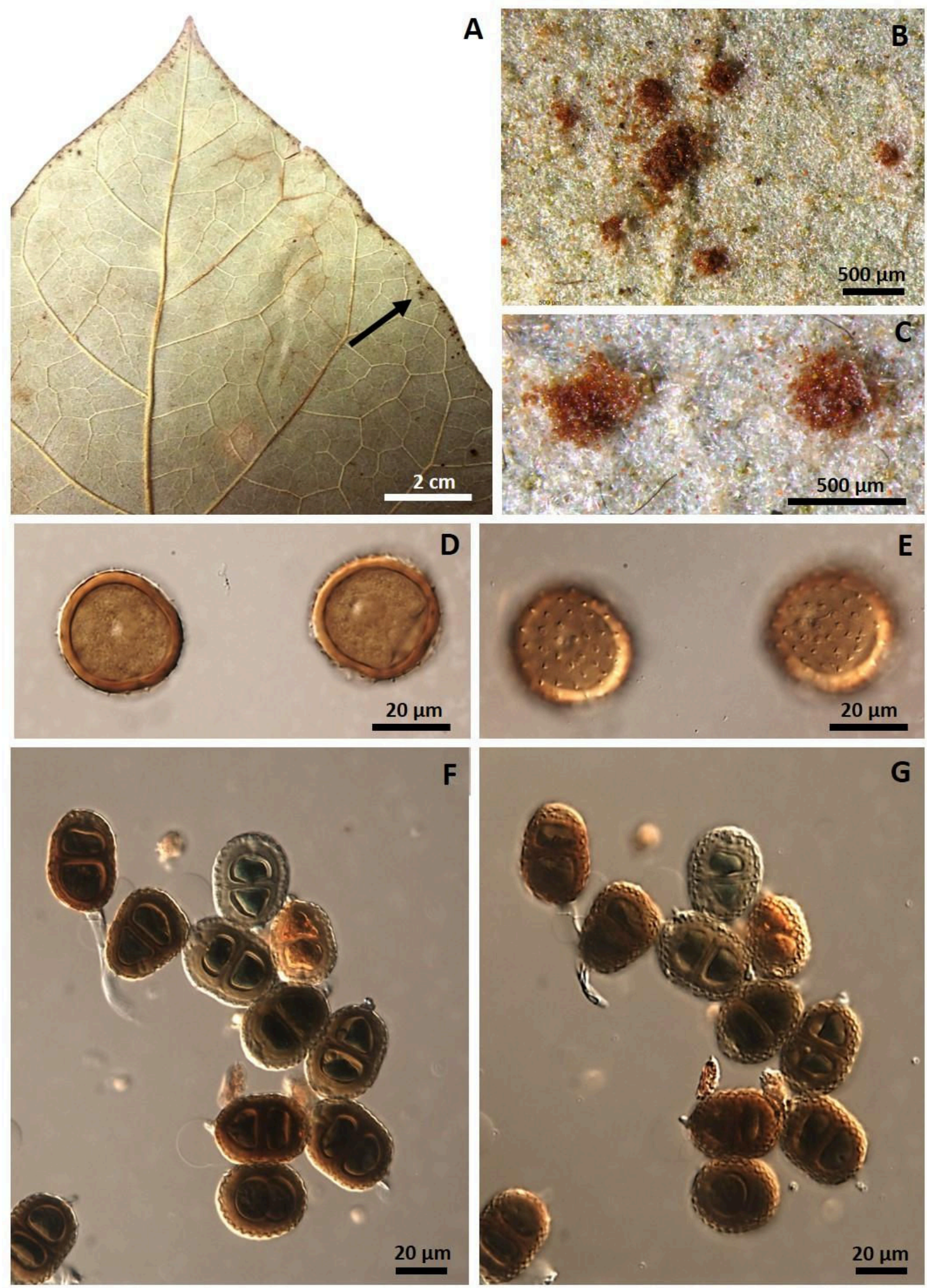

Figura 34 (A-G). Puccinia pipta em folhas de Piptocarpha macropoda. A. Folha com pontos escuros nas bordas em sua face abaxial contendo urédios e télios. B-C. Urédios. D-E. Urediniósporos vistos em duas profundidades de foco, uma delas mostrando poros gerinativos. F-G. Teliósporos em duas profundidades de foco. 

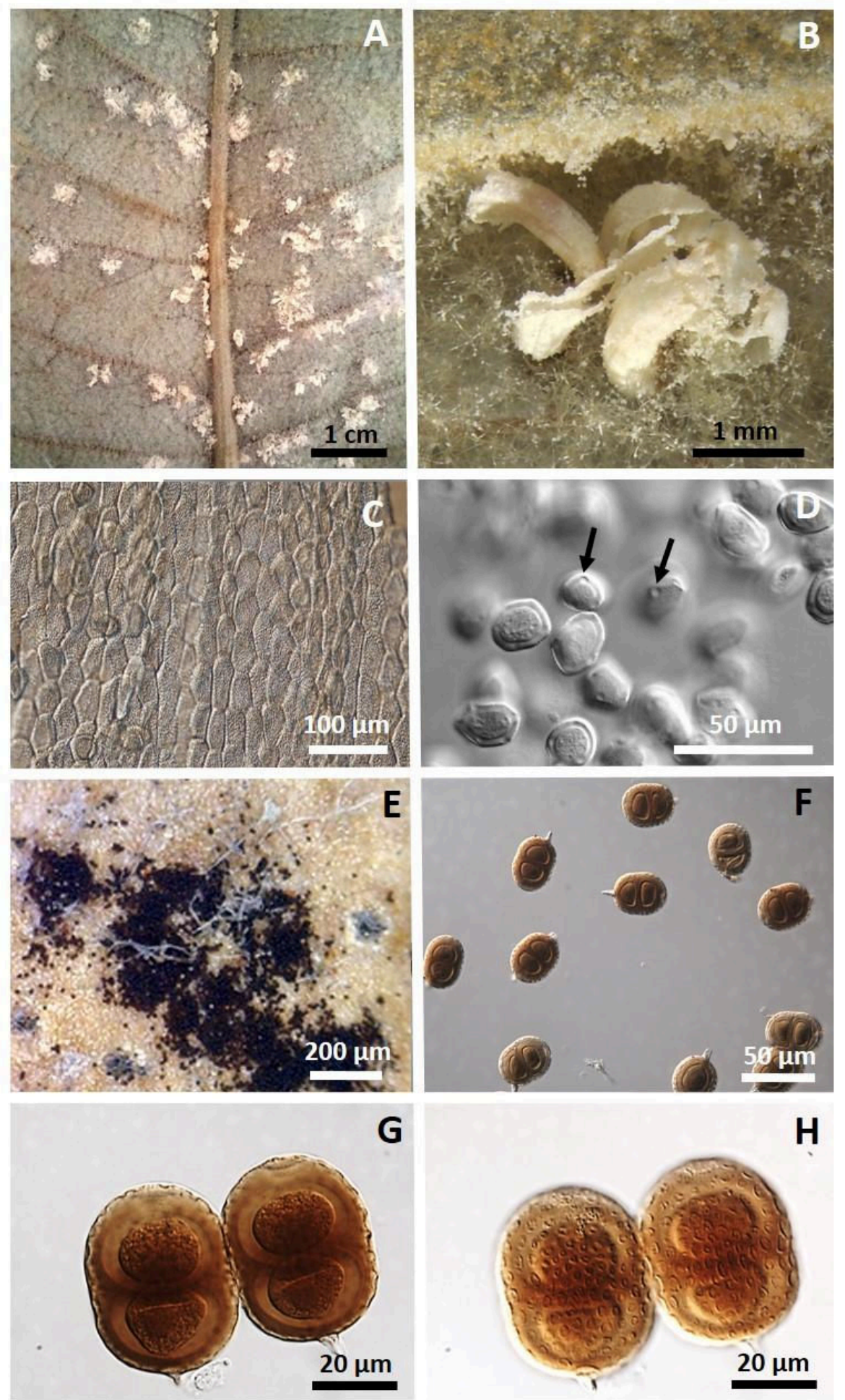

G

H

Figura 35 (A-H). Puccinia pipta em folhas de Piptocarpha rotundifolia. A.

Écios esbranquiçados na face abaxial da folha. B. Detalhe de um écio rompido. C. Textura do perídio do écio. D. Eciósporos com parede espessa e presença de poros germinativos (setas). E. Massa de teliósporos sobre um grupo de soros, na superfície adaxial da folha. $\mathbf{F}-\mathbf{H}$. Teliósporos. 
Descrição: Espermogônios, Écios e Urédios não observados. Télios 150-200 $\mu \mathrm{m}$, hipófilos, pulverulentos, marrons, marrom-escuros a negros, gregários dispostos em anéis concêntricos na lesão, parafisados; paráfises clavadas e hialinas. Teliósporos, 20-26 × 15-18 $\mu \mathrm{m}$, unicelulares ou bicelulares, globosos, elipsoides ou oblongos, ligeiramente constritos no septo, castanhos, lisos, pedicelados; pedicelos longos, hialinos e persistentes.

Espécime examinado: em folhas de Serjania lethalis (Sapindaceae): Reserva Ecológica do Instituto Brasileiro de Geografia e Estatística (RECOR-IBGE), Brasília-Distrito Federal, 06 jun. 2012, leg. J.C. Castro 436, UB22227.

Puccinia arechavaletae foi relatada na Argentina e no Texas em pelo menos seis gêneros de Sapindaceae. O material tipo foi encontrado em Cardiospermum velutinum no Paraguai (Spegazzini 1881).

Uma comparação da morfologia telial de $P$. arechavaletae, $P$. heterospora Berk. \& M.A. Curtis, que parasita gêneros em Malvaceae e P. lantanae Farl, nas famílias Acanthaceae e Verbenaceae, revela que estas três espécies microcíclicas são notavelmente semelhantes. As três não mostram espermogônios, écios e tampouco urédios. Os télios são hipófilos, dispersos ou, em geral, em grupos concêntricos, castanho escuros. Os teliósporos são principalmente unicelulares, todos muito variáveis quanto à forma e tamanho. O espécime aqui estudado apresentou características morfológicas semelhantes ao holótipo, embora com teliósporos um pouco menores. Aparentemente, o que separa as espécies descritas acima é a planta hospedeira. Trata-se de um caso típico em que se faz necessário o uso de ferramentas moleculares incluindo-se sequências dos outros materiais, pois até o presente, somente o espécime aqui descrito teve sua sequência do segmento 28S incorporada ao GenBank.

Segundo (Hennen et al. 2005), P. arechavaletae já foi relatada no Brasil, em várias Sapindaceae como: Cardiospermum grandiflorum no Mato Grosso, Minas Gerais e São Paulo; C. halicacabum em Minas Gerais, Santa Catarina e São Paulo; Cardiospermum sp. na Paraíba 
e em São Paulo; Paullinia sp., no Pará, Paraíba, Pernambuco, Rio de Janeiro e São Paulo; Serjania communis em Santa Catarina; S. cuspidata no Rio de Janeiro; S. fuscifolia na Bahia e Rio de Janeiro; S. glabrata na Paraíba; S. mansiana em Minas Gerais; S. perulaceae no Mato Grosso; Serjania sp. na Bahia, Espírito Santo, Goiás, Mato Grosso, Minas Gerais, Paraíba, Rio de Janeiro, Santa Catarina, São Paulo; Thouinia sp., Rio de Janeiro; Urvillea sp., São Paulo; Sapindaceae indeterminada no Ceará, Goiás, Mato Grosso do Sul, Minas Gerais, Rio de Janeiro e São Paulo. Além disso, há relatos de P. arechavaletae na Colômbia, Venezuela, México, Panamá, República Dominicana, Costa Rica e Peru (Farr \& Rossman 2016).

No entanto, pela primeira vez $P$. arechavaletae foi encontrada parasitando Serjania lethalis. 

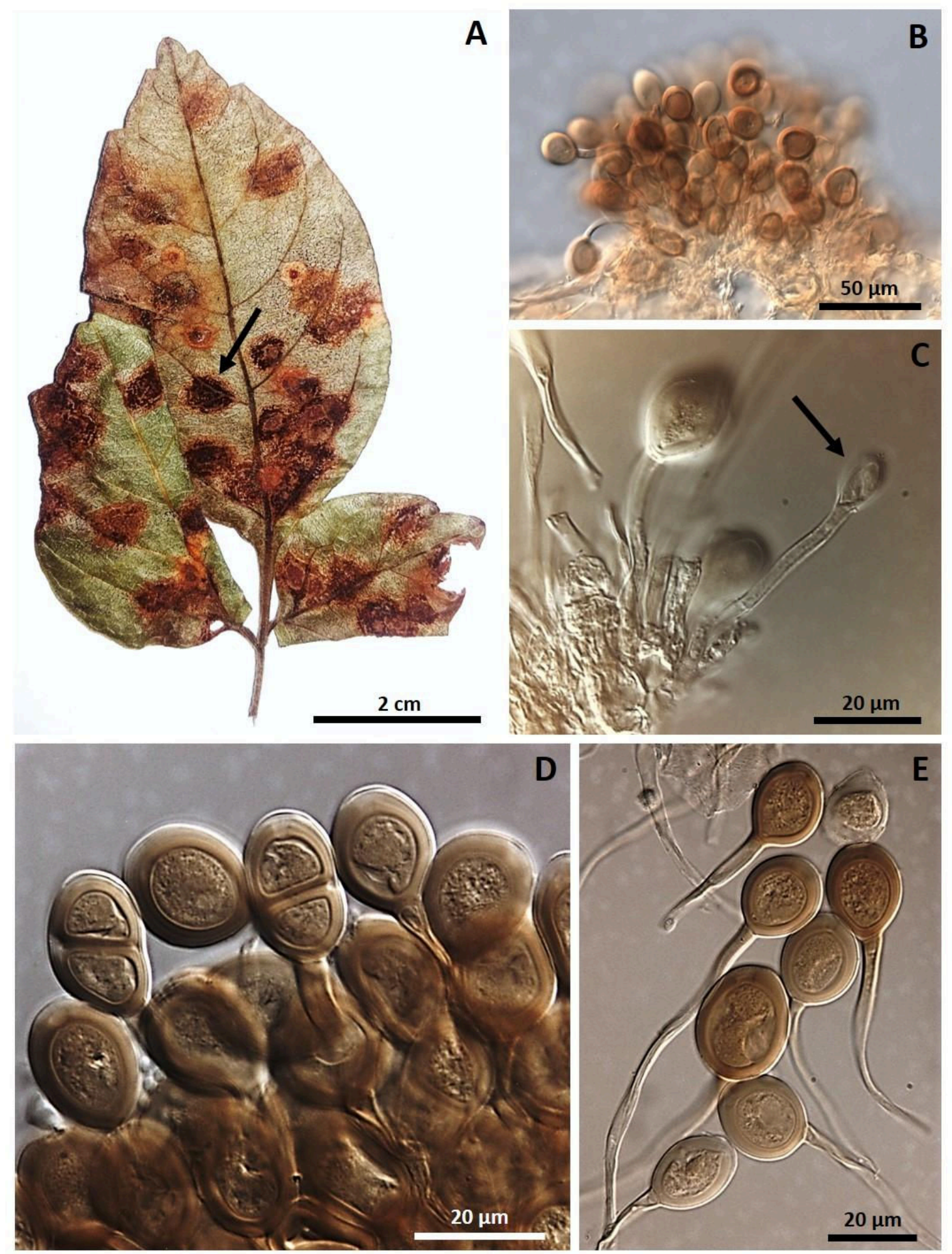

Figura 36 (A-E). Puccinia arechavaletae em folhas de Serjania lethalis. A. Sintoma de ferrugem na face abaxial de folha da hospedeira. B-E. Teliósporos unicelulares e bicelulares, vistos em diferentes aumentos e profundidades de foco. 
Puccinia psidii Winter. Fig. 36 (A-F)

Descrição: Espermogônios e Écios não observados. Soros mistos contendo urediniósporos e teliósporos, hipófilos, subepidérmicos, gregários, numerosos, eruptivos, pulverulentos, amarelos. Urediniósporos, $18-30 \times 13-15 \mu \mathrm{m}$, predominantemente elipsoides, amarelados, equinulados, poros germinativos obscuros. Teliósporos $41-52 \times 21$ - $23 \mu \mathrm{m}$, bicelulares, ligeiramente constritos no septo, elípticos a cilíndricos, castanho $=$ amarelados a castanhos, lisos e pedicelados. Um poro germinativo em cada célula disposto no ápice da célula apical e lateralmente próximo ao septo, na célula basal. Metabasídios, 45- $62 \times 6-8 \mu \mathrm{m}$, cilíndricos, hialinos, com 3 septos e um esterigma por célula. Basidiósporos, $6-8 \mu \mathrm{m}$, esféricos, hialinos.

Espécimes examinados: em folhas de Syzygium jambos (Myrtaceae): Campus Darcy Ribeiro da Universidade de Brasília, próximo a entrada do ICC Sul, Brasília-Distrito Federal, 25 jun. 2012, leg. E.S.C. Souza 67, UB22272; em folhas de Myrcia linearifolia (Myrtaceae): Reserva Ecológica do Instituto Brasileiro de Geografia e Estatística (RECOR-IBGE), Nascente do Roncador, Brasília-Distrito Federal, 04 set. 2012, leg. E.S.C. Souza 131, UB22366; em folhas de Psidium guajava (Myrtaceae): Reserva Ecológica do Instituto Brasileiro de Geografia e Estatística (RECOR-IBGE) próximo ao restaurante, BrasíliaDistrito Federal, 04 set. 2012, leg. E.S.C. Souza 131, UB22366; em folhas de Syzygium cumini (Myrtaceae): Segunda Avenida, Bloco 801, casa 01, Núcleo Bandeirante-Distrito Federal, 05 mai. 2013, leg. E.S.C. Souza 167, UB22462; em folhas de Syzygium malaccense (Myrtaceae): Super Quadra Norte 312 entre os Blocos D e K, Brasília-Distrito Federal, 04 mai. 2013, leg. M. Sanchez 4667, UB22460; em folhas de Callistemon rigidus (Myrtaceae): Canteiro próximo ao estacionamento do Instituto de Ciências Biológicas da Universidade de Brasília, 18 fev. 2013, leg. E.S.C. Souza 162, UB22424; em folhas de Eugenia florida (Myrtaceae): 
Fazenda Barrinha, Divinópolis, Minas Gerais, 05 mai. 2013, leg. J.C. Dianese, UB23336; em folhas de Syzygium aromaticum (Myrtaceae): Fazenda Campo Largo, Santo Antônio do Descoberto, 11 ago. 2013, leg. J.C. Castro, UB2.2537; em folhas de Eucalyptus ficifolia (Myrtaceae): NOVACAP Viveiro 2, Asa Norte, Brasília-Distrito Federal, 24 mar. 2014, leg. C.A Souza 01, UB22876; em folhas de Eucalyptus sp. (Myrtaceae): Condomínio Jardim Botânico de Brasília, Brasília-Distrito Federal, 03 mai. 2014, leg. R.F. Borges 03, UB22878; em folhas de Eucalyptus ficifolia (Myrtaceae): NOVACAP Viveiro 2, Asa Norte, BrasíliaDistrito Federal, 24 mar. 2014, leg. C.A Souza 01, UB22876; em folhas de Eugenia dysenterica (Myrtaceae): Super Quadra Norte 616 em frente à Estação Experimental de Biologia da Universidade de Brasília, Brasília-Distrito Federal, 09 set. 2014, leg. J.C. Castro 551, UB23211.

O material tipo da espécie $P$. psidii foi descrita originalmente causando ferrugem em Psidium guajava, em Santa Catarina (Winter 1884). Além disso, infecta outras espécies nativas da região do Cerrado como: Eugenia dysenterica, E. florida, Campomanesia adamantium, Maliera sp., Plinia cauliflora, entre outras. Na goiabeira (Psidium guajava), causa grande prejuízo por infectar preferencialmente os frutos e folhas jovens. Das hospedeiras nativas $P$. psidii passou a infectar com grande intensidade espécies introduzidas no Brasil do continente indiano (jamelão - Syzygium cumini, o jambeiro rosa - S. jambos, jambo vermelho - S. malaccense (L.) Merr. \& L.M. Perry) e da Oceania (eucalipto Eucalyptus spp., Melaleuca spp. e Callistemon rigidus). A ferrugem do eucalipto, conhecida no Brasil através de Ferreira (1983), foi divulgada internacionalmente a partir de 1984 (Dianese et al. 1984), o que levou a quarentena australiana a publicar um folheto (Commonwealth Department of Primary Industry 1985), no qual se circulou pela primeira vez naquele país, fotos dos sintomas da doença em eucalipto fornecidas por J.C. Dianese (comunicação pessoal). Somente quase uma década e meia depois que Coutinho et al. (1998) 
voltaram a expor ao mundo a ferrugem do eucalipto. A epidemiologia dessa ferrugem em Jambeiro foi detalhadamente estudada por Tessman et al. (2001).

Assim, a Austrália, onde a flora é predominantemente de espécies da família Myrtaceae, àquela época já revelava preocupação com a invasão por $P$. psidii. Porém, antes de chegar à Austrália, o patógeno percorreu amplas áreas envolvendo quatro continentes, América, Ásia, Oceania e posteriormente a África, China, Nova Caledônia e Indonésia. Descoberta no Brasil, P. psidii, atingiu vários países da America Sul e Central, os Estados Unidos (Marlatt \& Kimbrough, 1979), a maioria das ilhas havaianas (Uchida et al., 2006), Japão (Kawanishi et al., 2009), Austrália (Carnegie et al., 2010), China (Zhuang \& Wei, 2011), África do Sul (Roux et al., 2013), Nova Caledônia e Indonésia (Buys et al. 2016). A invasão da Austrália já completou seis anos (Carnegie et al., 2010) e é hoje uma realidade candente (Carnegie et al. 2016). Antes do estabelecimento do fungo na Austrália o número de hospedeiras já era amplo, contando com espécies de Callistemon, Eucalyptus e Melaleuca da Austrália, de Syzygium da Índia, e de Campomanesia, Eugenia, Marliera, Myrcia, Phyllocalyx, Pimenta, Pseudomyrcianthes, e Psidium do continente americano (Farr \& Rossman 2016, Hennen et al. 2005). Porém, gama de hospedeiros de P. psidii expandiu-se exponenencialmente desde a sua introdução na Austrália, infectando 250 espécies membros da família Myrtaceae distribuídos em 56 gêneros (Carnegie, 2015; Machado et al., 2015b). Cabe destaque para a ocorrência de morte de Rhodamnia rubescens e de Rhodomyrtus psidioides em áreas de floresta nativa da Austrália (Carnegie et al. 2016).

Aqui é relatada de forma inédita a ocorrência no Distrito Federal de $P$. psidii em Callistemon rigidus, Corymbia ficifolia, Myrcia linearifolia, S. malaccence; Syzigium aromaticum em Goiás e Eugenia florida em Minas Gerais. 

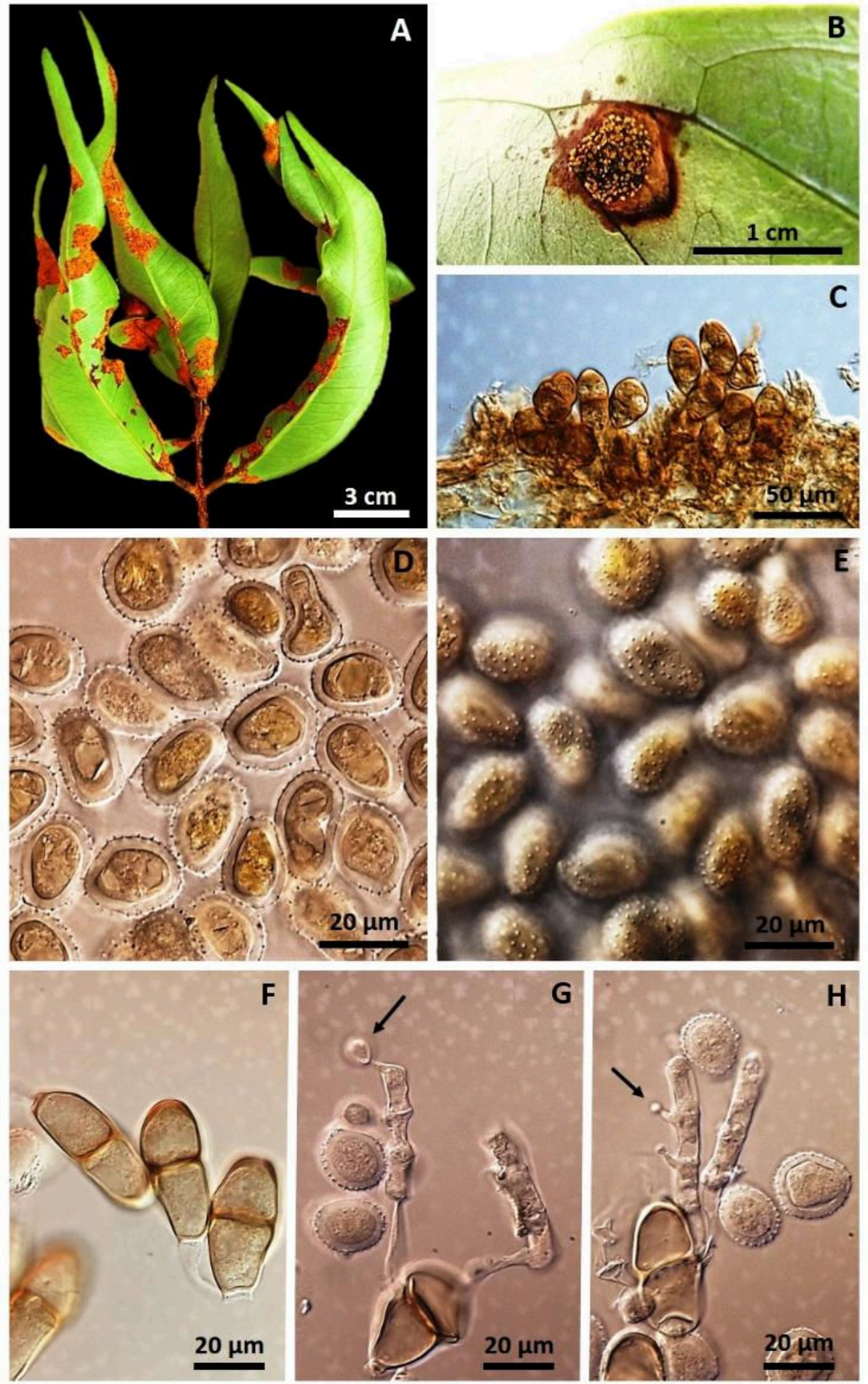

Figura 37 (A-F). Puccinia psidii em folhas de Syzygium cumini.

A-B. Sintomas de queima de folha. C. Télio. D-E. Urediniósporos vistos em duas profundidades de foco distintas. F. Teliósporos na superfície da folha. G-H. Teliósporos terminados com promicélios septados e com esterigmas suportanto basidiósporos. 


\section{Gênero Uromyces (Link) Unger}

Descrição: Espermogônios subepidérmicos, Grupo V (tipo 4). Écios subepidérmicos, irrompentes, do tipo Aecidium com perídio e eciósporos catenulados e verrugosos ou do tipo Uredo com os eciósporos na maioria das vezes equinulados, solitários e pedicelados. Urédios subepidérmicos, irrompentes, sem perídio, tipo Uredo ou as vezes do tipo Aecidium. Urediniósporos solitários, pedicelados, geralmente equinulados, poros germinativos numerosos e evidentes, Télios subepidérmicos, irrompentes na maioria das espécies, mas permanecendo coberto pela epiderme. Teliósporos unicelulares, solitários, pedicelados, paredes pigmentadas, um poro germinativo por célula, mas não diferenciado em poucas espécies. Basídio externo (Cummins \& Hiratsuka 2003).

Uromyces é o segundo gênero com o maior número de espécies da ordem Pucciniales, com mais de 600 espécies reportadas, ficando atrás, em número, apenas para Puccinia.

As espécies parasitam monocotiledôneas e dicotiledôneas por todo o mundo representadas nas famílias Asteraceae, Poaceae, Liliaceae, Euphorbiaceae, Fabaceae, entre outras (Cummins \& Hiratsuka 2003).

Uromyces se difere de Puccinia apenas com relação aos teliósporos. Puccinia possui teliósporos bicelulares e em algumas espécies unicelulares, enquanto que Uromyces apresenta teliósporos restritamente unicelulares. Alguns pesquisadores (Hennen et al. 2005) consideram esses dois gêneros como sinônimos e, atualmente existem trabalhos envolvendo análise molecular afim de esclarecer essa evidência (Van der Merve et al. 2007, Van der Merve et al. 2008).

O gênero possui espécies economicamente importantes que causam severas doenças como a ferrugem do feijão (U. appendiculatus (Pers.) Link 1816), da ervilha (U. pisi (Pers.) de Bary) e da beterraba (U. betae (Pers.) J. Kickx) (Cummins \& Hyratsuka 2003). 


\section{Espécies de Uromyces encontradas no Cerrado}

Duas espécies de Uromyces foram encontradas infectando plantas no Cerrado: Uromyces hawkworthii E.S.C. Souza, Z.M. Chaves, W.R.O. Soares, D.B. Pinho \& Dianese em uma lorantácea nativa, Phthirusa stelis; e U. euphorbiae Cooke \& Peck em folhas de Euphorbia hirta (Euphorbiaceae), planta invasora pantropical e de uso medicinal. As duas espécies de Uromyces (U. hawksworthii e U. euphorbiae) são objetos de estudo detalhado, incluindo aspectos da filogenia molecular, taxonomia e de morfologia baseada em ilustrações de qualidade, nos Capítulos 3 e 4 respectivamente.

\section{Membros da Família Raveneliaceae (= Sphaerophragmiaceae)}

Descrição: Espermogônios Grupo IV, VI (tipo 5, 7, 11). Écios do tipo Aecidium ou Caeoma, com ou sem perídio ou do tipo Uredo com ou sem paráfises. Eciósporos não catenulados, pedicelados, maioria equinulados ou catenulados e verrugosos. Urédios do tipo Malupa, Calidion, ou do tipo Uredo. Urediniósporos não catenulados, maioria equinulados, vários poros germinativos em geral evidentes. Télios subepidérmicos, erptivos, com ou sem paráfises. Teliósporos dois ou mais em um pedicelo composto, suportando dois ou mais esporos em célula no ápice do pedicelo, ou formando uma cabeça composta de muitos esporos, nessecaso com cistos pendentes ou aderentes à base dos esporos verticalmente aderidos podendo ser septados, radialmente arranjados no topo de pedicelo composto por multifilamentos compactamente soldados uns aos outros; cistos pendentes e higroscópicos, ou achatados e aderidos à base dos esporos em torno do topo do pedicelo; poros germinativos um ou dois por célula ou por esporo; basídios externos (metabasídios).

São Pucccinilaes autoécios, na maioria das vezes parasitando membros das famílias Fabaceae, Rosaceae, Euphorbiaceae, Apiaceae, Tiliaceae e Dioscoreaceae (Cummins \& 
Hiratsuka 2003). Raveneliaceae inclui mais de 323 espécies (Kirk et al. 2008), distribuídas nos seguintes gêneros: Allotelium, Anthomyces, Anthomycetella, Apra, Bibulocystis, Cumminsina, Cystomyces, Diabole, Diabolidium, Dicheirinia, Diorchidiella, Diorchidium, Kernkampella, Lipocystis, Ravenelia, Sphenospora, Spumula, Ypsilospora (Mycobank 2016, Index Fungorum 2016).

\section{Gênero Ravenelia Berk.}

Descrição: Espermogônios principalmente subcuticulares (Grupo VI, tipo 7) e subepidérmicos em poucas espécies (Grupo VI, tipo 5). Écios subepidérmicos ou, às vezes, subcuticulares, eruptivos. Eciósporos em geral pedicelados (forma de Uredo), ou, em algumas espécies, com esporos catenulados (forma Aecidium ou Caeoma). Urédios principalmente subepidérmicos ou às vezes subcuticulares, eruptivos, pulverulentos, (forma Uredo), muitas vezes bem desenvolvidos, parafisados; paráfises periféricas. Urediniósporos solitários, pedicelados, principalmente equinulados, alguns com ornamentação em espiral. Télios subepidérmicos ou às vezes subcuticulares na origem, eruptivos, marrom-escuros a quase negros. Teliósporos formando cabeças compostas, com até quatro tipos de células, discoide e multicelular quando vistas de topo, por cabeça com até 80 ou mais células que operam como probasídios, as quais se mostram aderidas lateralmente, chegando a ter duas camadas de células na parte central da cabeça, graças à presença de septo transversal ou oblíquo nos esporos, superfície distal dos teliósporos lisa ou ornamentada e com contornos poligonais nas paredes das células probasidiais, podendo ser ornamentadas (equinuladas, verrugoas, tuberculadas), com fendas germinativas obscuras ou raramente com poros germinativos, um em cada célula, células probasidiais com fendas pouco vivíveis; células estéreis, intercalares, ligadas a cistos; cistos higroscópicos, hialinos, unisseriados ou multiseriados, pendentes ou 
aderidos à face inferior da cabeça de esporos pedicelada; pedicelos compostos, constituídos por cordões de hifas unidas em colunas. Metabasídios externos.

O espécie-tipo do gênero é Ravenelia epiphylla (Schwein.) Dietel, (=Ravenelia glandulosa Berk. \& M.A. Curtis ex Sacc) descrita em Tephrosia virginiana nos Estados Unidos da América (Berkeley 1874).

Os teliósporos de Ravenelia são na verdade cabeças complexas, sendo essas maiores do que os esporos dos demais Pucciniales, muitas vezes visíveis a olho nu. Essas cabeças contêm quatro tipos de células. Normalmente, oito ou mais chegando a quase 80) células probasidiais unidas lateralmente formando uma camada discoide quando vista do topo. Em algumas espécies duas camadas de células probasidiais podem ocorrer na parte central do esporo. $\mathrm{Na}$ superfície da cabeça de esporos, as células probasidiais mostram formato poligonal. Algumas espécies produzem poros germinativos, difícil de serem observados, e ranhuras por onde o metabasídio emerge, igualmente difícil de serem vistas, devido à pigmentação e à refração provocada pelas paredes das células abaixo. Para a maioria das espécies fendas e poros germinativos não foram demonstrados, mas pode se presumir que um ou ambos ocorrem. As células probasidiais estão assentadas sobre uma camada de células intercalares estéreis, às quais se ligam os cistos higroscópicos. Na água, os cistos se expandem, podem explodir e liberar uma substância pegajosa gelatinosa. A cabeça complexa, ou esporo composto, é suportada por pedicelo composto de um cordão de hifas alongado, contendo vários elementos soldados uns aos outros formando uma coluna. Esses pedicelos estão ligados fortemente ou frouxamente à base do esporo composto e, em torno do ápice deles se distribuem células intercalares e os cistos, ou diretamente as células probasidiais. Os pedicelos das cabeças, são cordas hifálicas composta por um conjunto de hifas soldadas (Cummins \& Hiratsuka 2003, Hennen et al. 2005) 
As paráfises encontradas em urédios de espécies de Ravenelia são geralmente bem diferenciadas e, principalmente periféricas. Cada célula esporogênica produz urediniósporos pedicelados que são decíduos, deixando um longo pedicelo ainda ligado à célula esporogênica. Depois de alguns esporos serem produzidos, a célula esporogênica permanece nos soros com os pedicelos antigos ainda ligados. Estes podem parecer paráfises e ocorrem com todos os urediniósporos pedicelados de Ravenelia.

Na natureza muitas espécies de Ravenelia não causam danos significativos em suas hospedeiras, mas algumas espécies incitam galhas e vassouras de bruxas espetaculares, como é o caso de $R$. argentinica, R. hieronymi, R. papillosa e R. spegazziniana (Hernández \& Hennen 2003).

\section{Hospedeiras e distribuição geográfica das espécies de Ravenelia}

Embora algumas espécies de Ravenelia tenham sido reportadas em outras famílias, hoje apenas as espécies parasitas em Fabaceae, são aceitas no gênero. Suas espécies são numerosas nas regiões áridas, tropicais e subtropicais, onde espécies hospedeiras ocorrem de forma abundante, porém mesmo em desertos muito secos e até mesmo florestas tropicais elas são encontradas. A região Neotropical possui a maioria das espécies, seguida pelas regiões tropicais e subtropicais da África e Ásia.

Cerca de 115 espécies de Ravenelia são conhecidas no Hemisfério Ocidental sendo que destas, aproximadamente de 40 a 45 ocorrem no Brasil infectando espécies de Acacia, Calliandra, Cassia (incluindo Senna e Chamaecrista), Lonchocarpus Pithecellobium, Mimosa, Derris, Enterolobium, Anadenanthera, Cenostigma, Poincianella, Sesbania, Plathymenia, Andira, Piptadenia, Indigofera, Leucaena, Cratylia e Parkia (Hennen et al. 2005, Farr \& Rossman 2016). 
Nenhuma espécie foi relatada na Europa até o momento. Há registros de espécies de Ravenelia na Austrália (R. neocaledoniensis B. Huguenin em Acacia sp. e em Vachellia farnesiana, e R. sessilis Berk em Albizia procera) (Farr \& Rossman 2016). A maioria das espécies de Ravenelia são conhecidas apenas com base nos materiais tipo ou em poucas coletas.

O gênero Kernkampella Rajendren é um gênero causador de ferrugem em Euphorbiaceae, que foi anteriormente incluído em Ravenelia. Apenas uma espécie foi relatada em plantas de família diferente, K. appendiculata (Lagerh. \& Dietel) G.F. Laundon em Phyllanthus spp. (Phyllanthaceae), encontrada na Bolívia, México e no Cerrado do Distrito Federal (Chaves et al. 2008). As outras espécies são da Ásia, principalmente da Índia.

Asssim, existem três gêneros morfologicamente próximos, Ravenelia, Spumula e Kernkampella e nenhum outro gênero de Pucciniales tem esporos formando cabeça. Porém, embora espécies pertencentes aos três formem cistos higroscópios, a segregão dos três é simples: em Spumula o pedicelo é sempre simples, sendo composto em Ravenelia e Kernkampellaa; apenas nesse último gênero as cabeças complexas possuem sempre uma camada de células pateliformes (achatadas) entre os esporos e os cistos.

Os teliósporos compostos são demasiadamente grandes para disseminação a longa distância pelo vento. Além disso, o material gelatinoso dos cistos higroscópicos absorve e retém água suficiente, que se suspeita, poderiam ajudar na germinação das células probasidiais. Este processo de germinação resulta na formação de vários metabasídios e basidiósporos, estes lançados por pressão, a partir do mesmo teliósporo multicelular, assegurando assim a disseminação eficiente do fungo. 


\section{Ravenelia geminipora Hennen \& Cummins}

Descrição sensu Hennen \& Cummins (1990): Espermogônios epífilos, gregários. Écios anfígenos ou principalmente epifilos, ao redor e do lado oposto dos espermogônios, subepidérmicos, eruptivos, marrons, parafisados; paráfises abundantes, com pontas mais escuras, espatuladas, cilíndricas ou alongadas, principalmente periféricas, parede mais grossa na região apical, fina e mais clara na base. Eciósporos, $16(24) 28-33(-36) \times(20-) 22-25$ $(-27) \mu \mathrm{m}$, pedicelados, fortemente equinulados, principalmente obovoides, menos equinulados junto aos poros; poros germinativos, quatro, equatoriais, em 2 pares gêmeos em lados opostos do esporo, poros frontais muito mais estreitos e elipsoides do que os poros opostos; parede lateral medindo (2-) 3-4,5 $\mu \mathrm{m}$ de espessura, apical com 4-7 $\mu \mathrm{m}$, amarelada ou marrom dourada. Urédios epífilos, semelhantes aos écios, exceto por serem dispersos e não associados com espermogônios. Urediniósporos idêndicos aos eciósporos. Télios a maioria epífilos, castanho-escuras, subepidérmicas na origem, eruptivas. Teliósporos (55-) 80-112 (-120) um de diâmetro, marrom escuros, mais opacos quando maduros, parede exterior fina, lisa, (5) 6 ou 7 (8) $\mu \mathrm{m}$ entre as células probasidiais; células centrais (15) 16-20 (-22) $\mu \mathrm{m}$, em uma única camada; cistos unisseriados do mesmo número que as células periféricas do esporo composto; pedicelo incolor a acastanhado, multihifálicos e decíduos.

A amostra analisada neste estudo, quando comparada com a descrição original, apresentou urediniósporos $(21-30 \times 19-21 \mu \mathrm{m})$ e teliósporos $(88-104 \mu \mathrm{m}$ de diam.) um pouco menores e paráfises $73-102 \times 6-15 \mu \mathrm{m}$, lisas (medidas e característica não mencionada na descrição original). No geral, as características morfológicas são as mesmas, porém qui não foram encontrados espermogônios, nem tampouco écios.

Espécimes examinados: em folhas de Plathymenia reticulata (Fabaceae): Jardim Botânico de Brasília, Brasília, Distrito Federal.07 jul. 2014, leg. E.S.C Souza 232, UB22899; 
Santo Antônio do Monte, Minas Gerais, Rancho Riacho, 29 jul. 2015, leg. D.B. Pinho 21, UB23328.

Os dois pares de poros germinativos, localizados em lados opostos da parede dos urediniósporos, é característica importante na identificação da espécie e é a razão para o epíteto (geminipora). Quando jovens, os teliósporos são menos pigmentados e a superfície da parede exterior por baixo da camada exterior é pálida e sinuosamente estriada, não lisa.
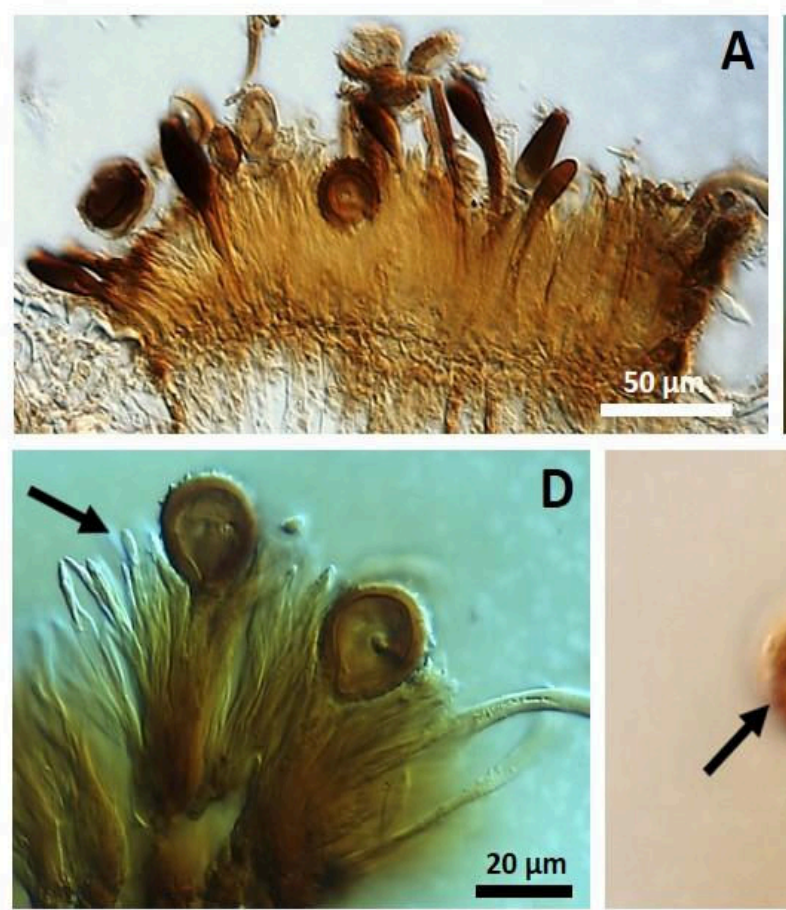
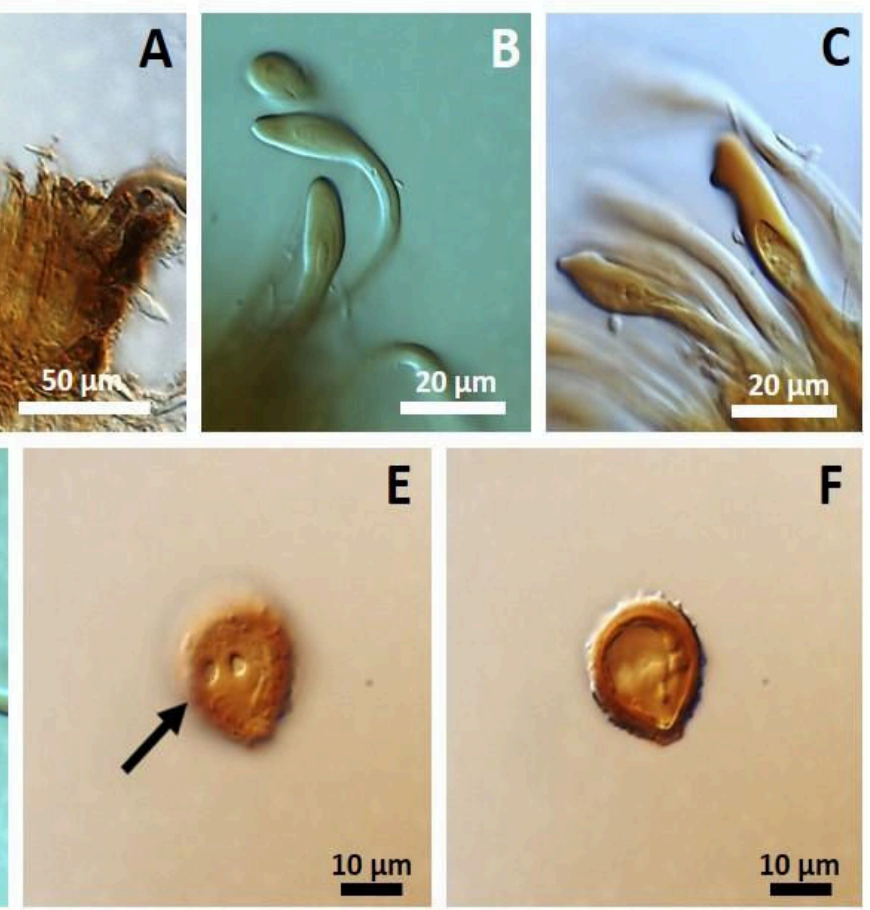

E

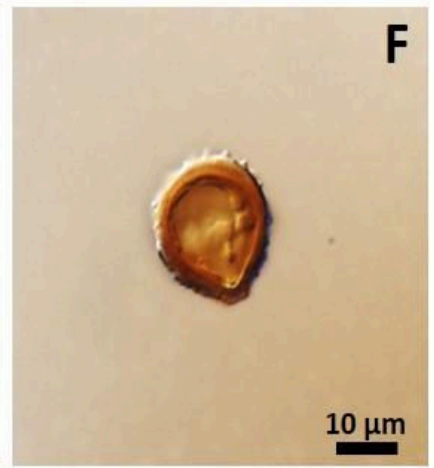

Figura 38 (A-F). Forma uredínica de Ravenelia geminipora em Platymaenia reticulata. A. Urédia em corte transversal mostrando a disposição dos urediniósporos e das paráfises. B-C. Paráfises. D. Urediniósporos ligados aos pedicelos cercados por paráfises himeniais numerosas (seta), ambos mostrando par de poros característicos. E-F. Urediniósporos em diferentes profundidades de foco. 


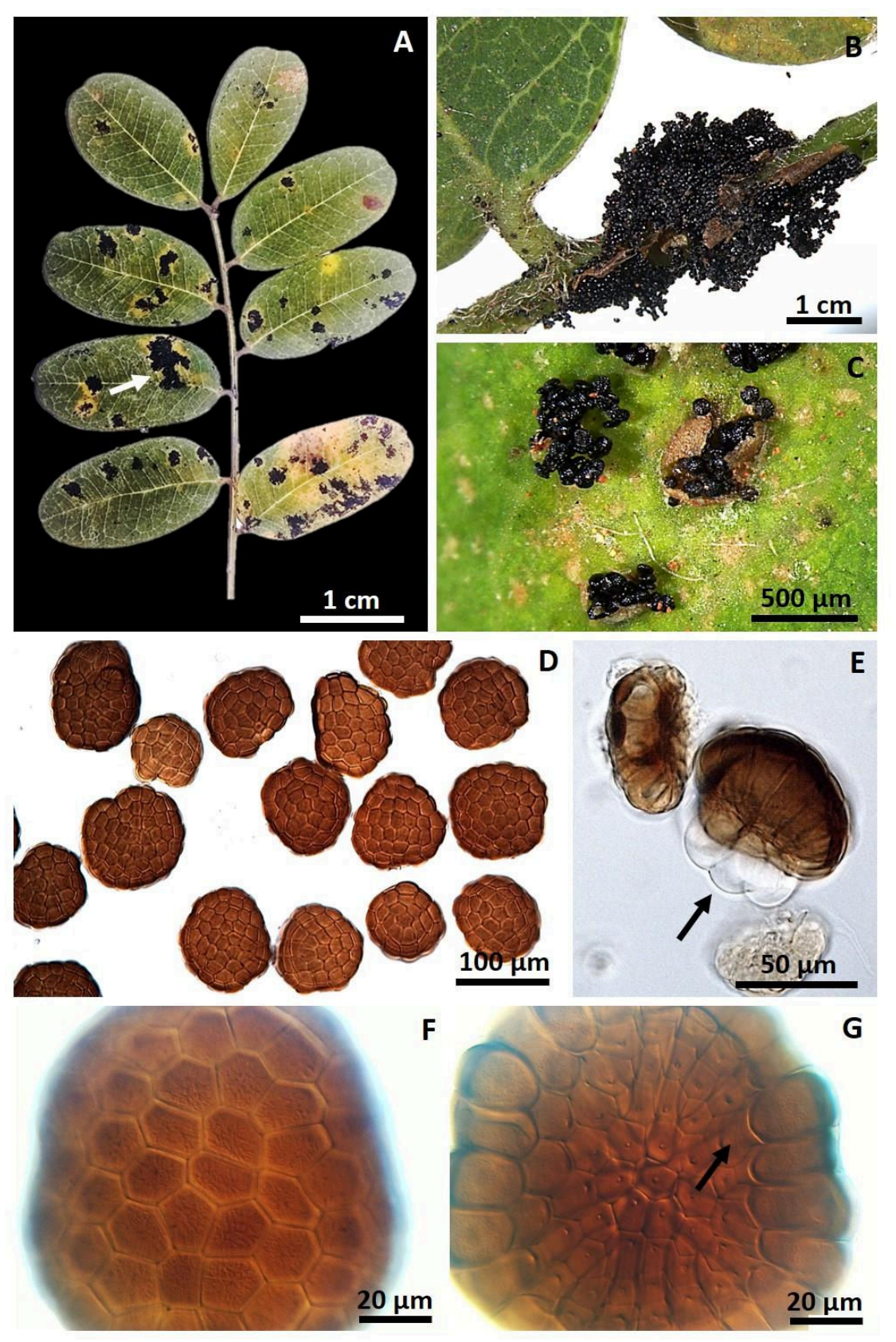

Figura 39 (A-G). Forma télica de Ravenelia geminipora em Platymaenia reticulata vista em microscopia de luz. A. Sintoma na face adaxial dos folíolos (seta). B. Massa pulverunta escura de teliósporos formados em um pecíolo. C. Soros eruptivos pulverulentos. D. Grupo de teliósporos compostos multicelulareslisos, vistos de topo. E. Teliósporo com cistos (seta) higroscópicos. F. Teliósporo liso, visto de topo mostrando células de perfil pentagonal e hexagonal e textura angular. G. Vista da base do teliósporo composto, sem os cistos, mostrando células em disposição radiada, onde se inserem os teliósporos individuais (seta). 


\section{Ravenelia hieronymi Speg. (=R. deformans (Maublanc) Dietel, Fig. 140 (A-G).}

Descrição: Epermogônios subcuticulares, irregulares, hemisféricos ou em forma de almofada, Écios com longos perídios cilíndricos; células peridiais $27-40 \times 15-21 \mu \mathrm{m}$, romboides, cilíndricas, hexagonais, irregulares, verrugulosas. Eciósporos catenulados, (18-) 20-26 (-28) x (13-) 15-20 $\mu \mathrm{m}$, variáveis em tamanho e forma, amplamente elipsoides ou oblongo-elipsoides, amarelo pálidos em massa, verrugosos, poros germinativos numerosos, dispersos, relativamente obscuros. Urédios e urediniósporos semelhantes aos ecios e eciósporos. Télios espalhados entre os écios, subepidérmicos, eruptivos, castanhos. Teliósporos (65-) 75-20 (-140) $\mu \mathrm{m}$ diam, castanho claros a marrons avermelhados, lisos, até 12 células probasidiais. Cistos aparentemente unisseriados, adaptadas à parte inferior do teliósporo, coerentes. Pedicelos multihifais, hialinos, persistentes.

Espécime examinado: em folhas de Acacia farneziana (Fabaceae): Universidade de Brasília, Campus Darcy Ribeiro, próximo ao Memorial Darcy Ribeiro, Brasília, Distrito Federal. 22 out. 2013, leg. E.S.C Souza 221, UB22560.

Ravenelia hieronymi foi anteriormente descrita em Brasília por Rezende \& Dianese (2002).

O fungo é conhecido nas seguintes hospedeiras: Acacia caven na Argentina, Brasil, Chile, Paraguai e Uruguai; A. cavenia na Argentina e Chile; A. farnesiana na Argentina, Brasil, Chile, Texas, Uruguai; A. farnesiana var. cavenia na Bolívia; A. fernandeziana no Chile e Acacia sp. em Moçambique e em Mimosa sp. no Brasil (Farr \& Rossman 2016, Hennen et al 2005).

A planta hospedeira é uma espécie exótica oriunda da América Central, usada na arborização de Brasília, porém mesmo assim o fungo foi agora incluído na análise filogenética objeto do Capítulo 2. 

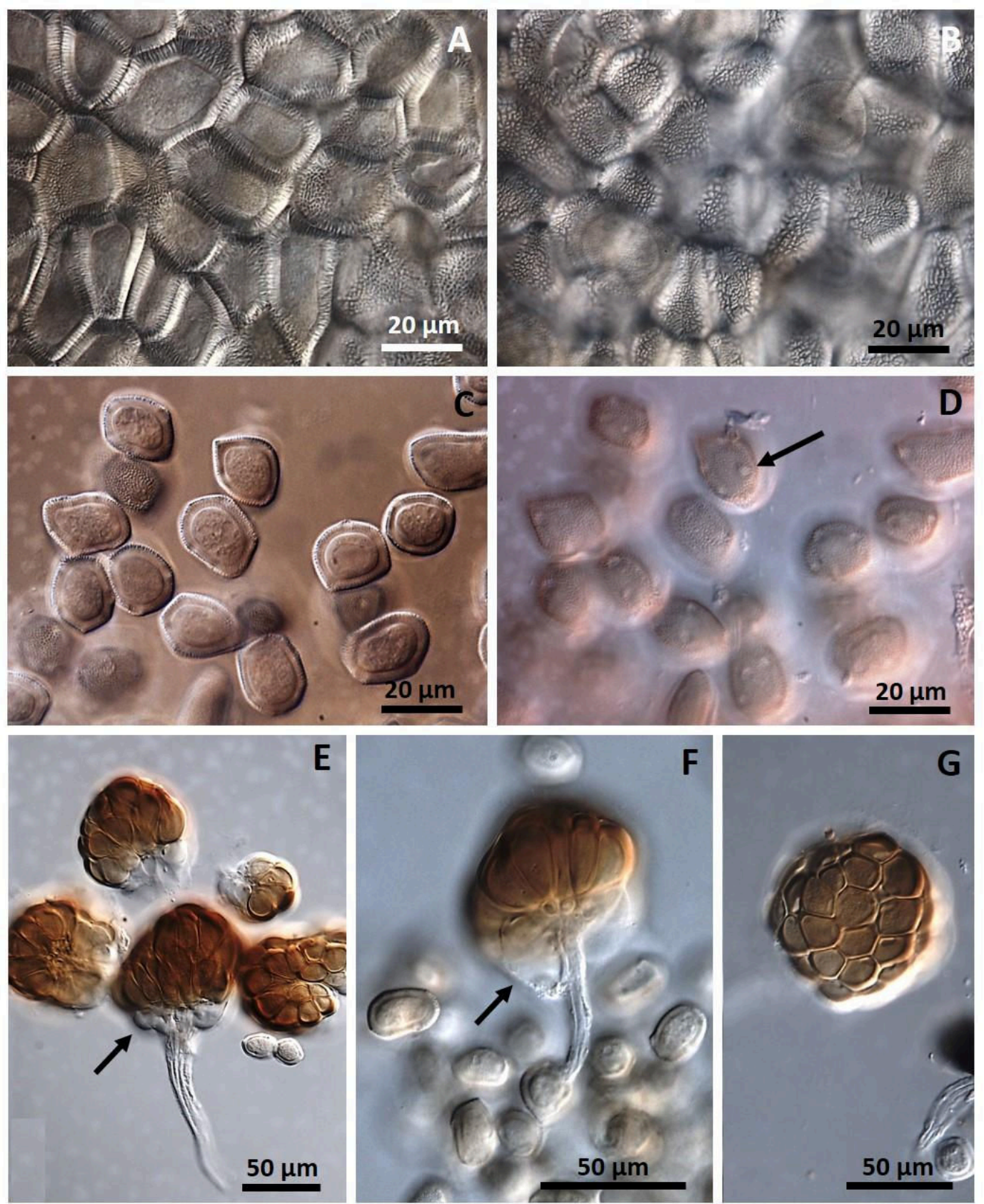

Figura 40 (A-G). Forma ecídica e télica de Ravenelia hieronymi em folhas de Acacia farnesiana vistas em microscopia de luz. A-B. Textura do perídio dos écios em diferentes profundidades de foco. C-D. Eciósporos visto em diferentes profundidades de foco. E-F. Teliósporos compostos com cistos aderidos (setas). G. Textura superficial das células centrais de um teliósporo composto. 


\section{Ravenelia possível sp. nov.}

Descrição: Espermogônios e Écios não observados. Urédios hipófilos, subepidérmicos, pulverulentos, eruptivos, marrons. Urediniósporos $21-26 \times 15-18 \mu \mathrm{m}$ limoniformes, equinulados, marrom-claros, poros germinativos equatoriais. Télios hipófilos, marrons, subepidérmicos, eruptivos. Teliósporos 50 - $67 \mu \mathrm{m}$ de diâmetro, marrom-claros, paredes ornamentadas com projeções espiculares, cerca de nove células probasidiais distribuídas em uma camada única, cistos unisseriados, hialinos, com a mesma proporção das células dos teliósporos, pedicelos hialinos, multihifálicos, decíduos.

Espécime examinado: em folhas de Eriosema rigidum (Fabaceae): Estação Experimental da Universidade de Brasília, Brasília, Distrito Federal. 11 jul. 2012, leg. E.S.C Souza 81, UB22289.

Várias espécies de Ravenelia são listadas em diversas espécies de plantas hospedeiras membros de Fabaceae (Farr \& Rossman 2016, Hennen et al 2005), entretanto esta é a primeira vez que foi encontrado um espécime em folhas de Eriosema rigidum. Em outras espécies de Eriosema são conhecidas as seguintes: Phakopsora meibomiae, P. pachyrhizi, Uromyces dolichi, U. phaseoli, U. rhynchosiae, Aecidium eriosematis, A. medellinense, Uredo eriosemiae e Uredo sp.

Portanto existe grande possibilidade de se tratar de uma nova espécie de Ravenelia, por isso mesmo foi incluída entre os espécimes que tiveram o segmento $28 \mathrm{~S}$ sequenciado e filogeneticamente analisado (Capítulo 2). 

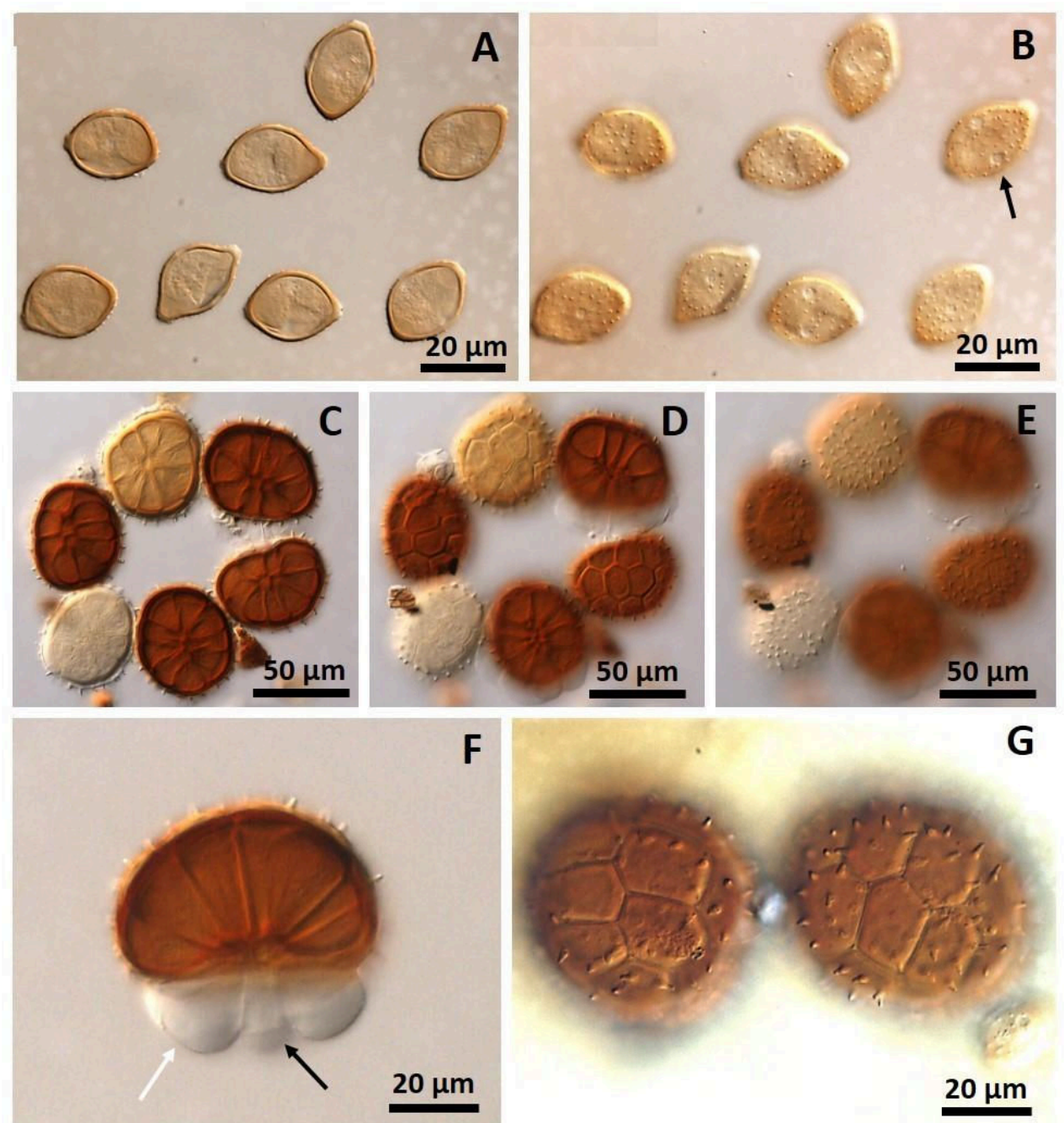

G

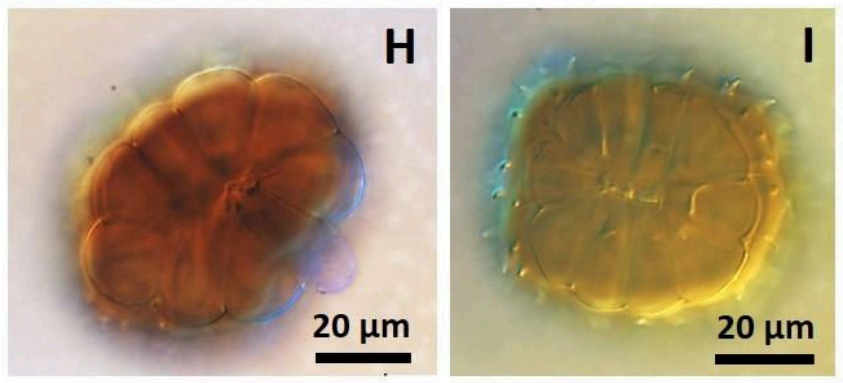

$20 \mu \mathrm{m}$

Figura 41 (A-J). Ravenelia sp. em folhas de Eriosema rigidum. A-B. Urediniósporos em diferentes profundidades de foco mostrando dois poros equatoriais. C-E. Uma mesma amostra de teliósporos de diferentes estágios de maturação, focados em três profundidades distintas, mostrando características da superfície e estrutura dos esporos compostos. F. Teliósporo composto com cistos pedentes (seta branca) e resíduo do pedicelo (seta negra). G. Células centrais de dois teliósporos compostos com poucas equinulações. H. Teliósporo composto com cistos higroscópicos. I-J. Mesmo teliósporo composto em duas diferentes profundidades de foco. 


\section{Gênero Sphaerophragmium Magnus}

Descrição: Espermogônios subepidérmicos, Grupo VI (tipo 5). Écios subepidérmicos, eruptivos, peridiados, tipo Aecidium. Eciósporos catenulados, verrugosos. Urédios subepidérmicos, eruptivos, a maioria com paráfises periféricas. Urediniósporos solitários, assimétricos e reniformes, pedicelados, equinulados. Télios subepidérmicos, eruptivos. Teliósporos solitários, pedicelados, multicelulares com septos verticais e horizontais (muriformes), globosos, pigmentados, ornados por grande número de projeções tubulares medianas a longas, poros germinativos obscuros; basídio externo.

Sphaerophragmium é um gênero com a maioria das espécies infectando Fabaceae e outras em Annonaceae, com registros na Nigéria, China, Austrália, Cuba e Brasil (Farr \& Rossman 2016).

\section{Sphaerophragmium acaciae}

Descrição: Espermogônios e Écios não observados. Urédios subepidérmicos, eruptivos, gregários, pulverulentos, marrom-claros. Urediniósporos 20-22 × 15-18 $\mu \mathrm{m}$ solitários, reniformes, castanhos, pedicelados, equinulados, poros germinativos equatoriais. Télios subepidérmicos, eruptivos, gregários, pulverulentos, marrons a negros. Teliósporos 27$30 \mu \mathrm{m}$ solitários, multicelulares, muriformes, globosos, marrons, ornados por projeções numerosas e cilíndrico-captadas, poros germinativos obscuros, longo-pedicelados; Pedicelos persistentes e hialinos.

Espécime examinado: em folhas de Albizia lebeck (Fabaceae): Universidade de Brasília, Campus Darcy Ribeiro, Jardim da Reitoria, Brasília, Distrito Federal. 20 jun. 2013, leg. E.S.C Souza 174, UB22477. 
Essa espécie já foi descrita e ilustrada em coleta feita em Brasília (Rezende \& Dianese 2002). As infecções provocadas por esse fungo provocam manchas foliares pontuais cloróticas nos locais de infecção e pontos escuros que indicam a presença de télios.

Espécies de Sphaerophragmium ocorrem em uma ampla gama de hospedeiras distribuídas em grande maioria na família Fabaceae (Farr \& Rossman 2016) e nove em Annonaceae (Beeken \& Berndt (2010). Em Fabaceae, Sphaerophragmium spp. são parasitas em membros dos gêneros: Acacia, Albizia, Cassia, Dalbergia, Calliandra, Milettia, Strongylodon, Mucunae e Parkia. 

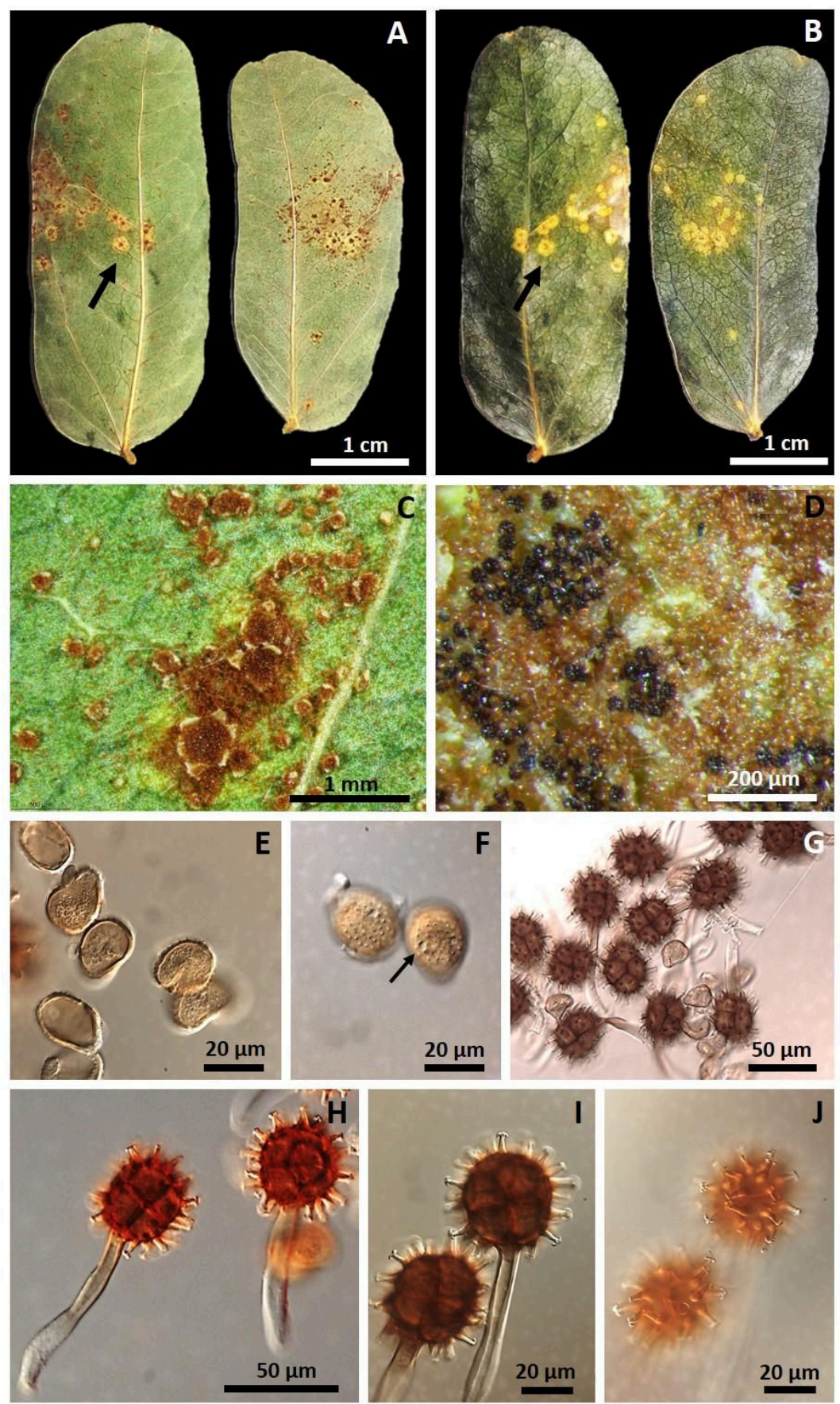

Figura 42 (A-J). Sphaerophragmium albiziae em folhas de Albizia

lebeck. A. Sintomas na face abaxial da folha mostrando áreas cloróticas com pontos ferruginosos, onde o fungo esporula. B. Sintomas de clorose vistos na face adaxial da folha. C-D. Soros mistos contendo teliósporos e urediniósporos. E. Grupo de urediniósporos. F. Urediniósporos mostrando dois poros germinativos equatoriais. G. Grupo de teliósporos. H. teliósporos com peidelos higroscópicos dilatados. I-J. Detalhe das projeções cilíndrica com a extremidade bifurcada, ornando os teliósporos. 


\section{Gênero Diorchidium Kalchbr.}

Descrição segundo Cummins \& Hiratsuka (2003): Espermogônios subcuticulares, Grupo VI (tipo 7). Écios subepidérmicos, eruptivos, do tipo Uredo. Eciósporos solitários, equinulados, pedicelados, poros germinativos equatoriais. Urédios subepidérmicos, eruptivos, tipo Uredo. Urediniósporos como os eciósporos. Télios subepidérmicos, eruptivos. Teliósporos geralmente bicelulares, com um septo vertical, solitários, pedicelados, paredes pigmentadas, mas com grau de pigmentação amplamente variado, lisos ou ornamentados, um poro germinativo por célula na porção apical; basídio externo.

O gênero conta com aproximadamente 23 espécies (Index Fungorum 2016) tendo como tipo a espécie D. woodii Kalchbr. \& Cooke encontrada em Milletia sp. (Fabaceae) na África do Sul (Kalchbrenner 1882). Outras espécies foram encontradas no Siri Lanka, Indonésia, Brasil e Argentina (Cummins \& Hiratsuka 2003, Farr \& Rossman 2016).

Cummins \& Hiratsuka $(1983,2003)$ diferenciaram Diorchidium de Puccinia por ter espermogônios do grupo VI, tipo 7, em contraste com o grupo V, tipo 4 de Puccinia. No entanto, espermogônios nunca foram relatados para a espécie-tipo de Diorchidium, D. woodii (Kalchbrenner \& Cooke 1882; Hennen et al. 1998).

Considerando isso, Beenken \& Wood (2015), baseados em dados moleculares, consideram que o tipo $D$. woodii se trata de uma espécie de Puccinia pois não há evidência morfológica contra o resultado molecular.

Em Diorchidium, os espermogônios são conhecidos apenas para D. puiggarii Speg. e D. taiwanensis R. Berndt, que são do tipo 7 em ambas as espécies (Hennen et al., 1998; Berndt 1996). Estas duas espécies, bem como D. koordersi Wurth [= Diphragmium koordersi (Wurth) Boedijn] se assemelha ao gênero Hapalophragmium Syd. \& Syd. (Berndt 1996, 
Hennen et al., 1998), que tem espermogônios do tipo 7 e teliósporos com três células (Lohsomboon et al. 1992).

Diorchidium como definido por Cummins e Hiratsuka (2003) é polifilético, com membros pertencentes a pelo menos três linhagens distantes dentro dos Pucciniales (Beenken $\&$ Wood 2015)

Diorchidium copaiferae (P. Sydow \& H. Sydow) Cummins \& Y. Hiratsuka

Descrição: Espermogônios e Écios não observados. Urédios hipófilos, subepidérmicos, eruptivos, dispersos, pulverulentos, castanhos, parafisados; Paráfises 43 - 65 $\times 10-12 \mu \mathrm{m}$, grossas, periféricas abundantes, unidas pela base, encurvadas, pálidas. Urediniósporos $34-44 \times 13-18 \mu \mathrm{m}$ de tamanhos e formas variáveis, alantoides, estreitamente elipsoides ou raramente ovoides, canela ou castanho-castanho, pálidos, moderadamente equinulados, um poro germinativo na base. Télios como os urédios, marrom amarelados. Teliósporos $34-44 \times 15-22 \mu \mathrm{m}$, bicelulares, oblongo-elipsoides, lisos, dourado pálidos ou quase incolores, um poro germinativo na porção apical de cada célula, a germinação ocorre sem dormência, pedicelos incolores, persistentes.

Espécime examinado: em folhas de Copaifera langsdorffii (Fabaceae): Parque Olhos D’Água de Brasília, Brasília, Distrito Federal. 12 set. 2012, leg. E.S.C Souza 145, UB22385. Cummins \& Hiratsuka (1983) transferiram Sphenospora copaifera (Henn.) P. Syd. \& Syd. para Diorchidium porque em sua fase telial faltava a matriz gelatinosa característica de outras espécies de Sphenospora, entretanto os urediniósporos longos, estreitos e curvos com um poro germinativo basal são característicos.

Rezende \& Dianese (2002) observaram a presença de paráfíses curvadas nos urédios e télios de D. copaiferae, com urediniósporos reniformes, teliósporos bicelulares, lisos, com 
projeções nos ápices e com um poro germinativo por célula do teliósporo. Essas características são as mesmas descritas para D. copaiferae por Cummins (1960) e também as mesmas observadas na amostra aqui estudada.

É importante notar que Diorchidium copaiferae foi relatada apenas no Brasil sempre sobre Copaifera langsdorfii (Cummins \& Hiratsuka 2003, Farr \& Rossman 2016).
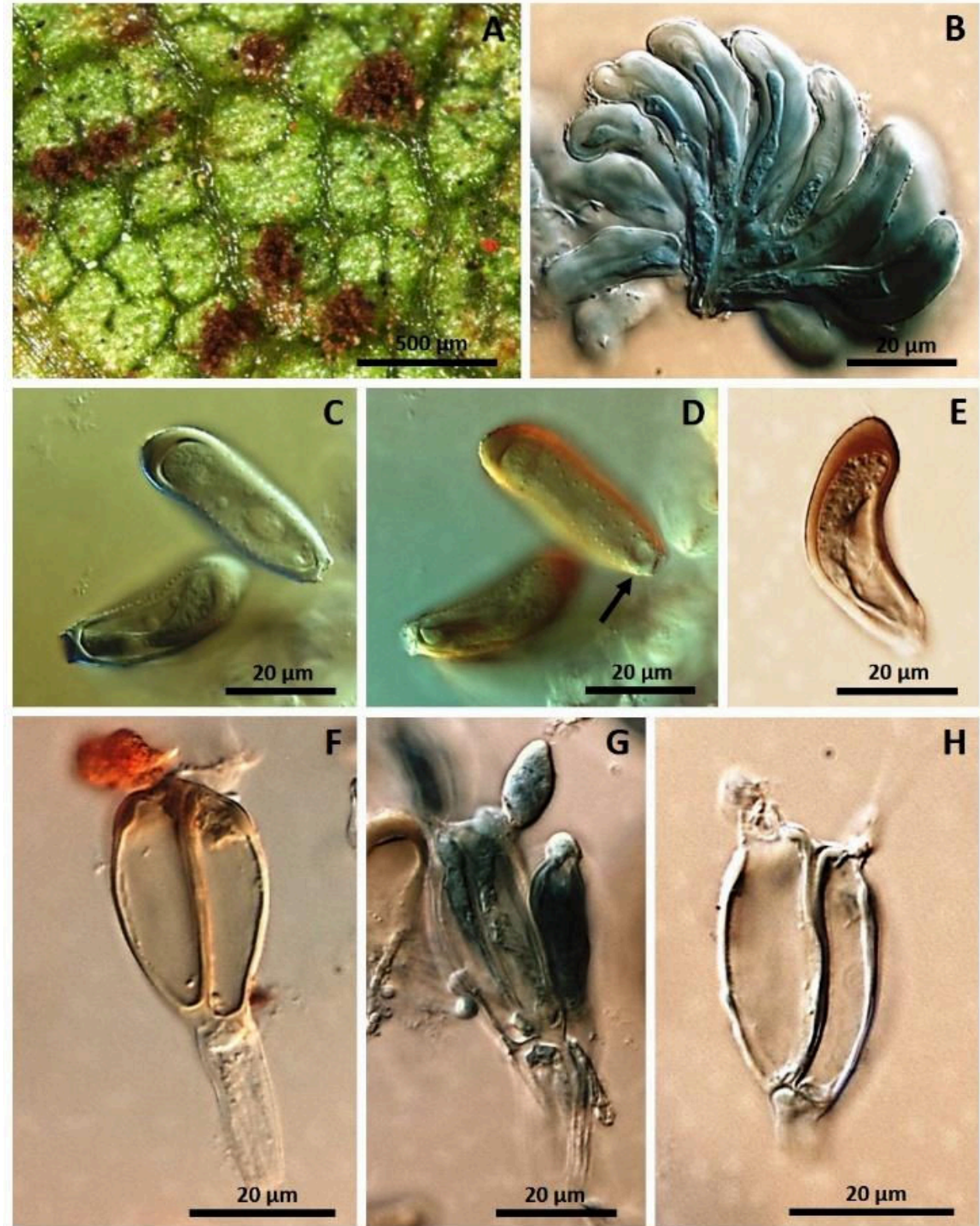

Figura 43 (A-H) Diorchidium copaiferae em folhas de Copaifera

langsdorffii. A. Soros na face abaxial de folíolos. B. Paráfises uredínicas fortes e recurvadas. $\mathbf{C}-\mathbf{E}$. Urediniósporos. F-H. Teliósporos bicellares, pedicelados. 


\section{Gênero Esalque Hennen, Figueiredo \& Carvalho}

Descrição: Espermogônios e Écios desconhecidos. Urédios anfígenos, subepidérmicos, dispersos, eruptivos, tipo Uredo. Urediniósporos unicelulares, pedicelados, equinulados, de um a dois poros germinativos. Télios subepidérmicos, eruptivos, mistos (presença de teliósporos junto aos urediniósporos). Teliósporos com três células sendo uma basal próxima ao pedicelo e duas distais, solitários, pedicelados, poros germinativos obscuros, basídio externo (Hennen et al. 2000).

Em estudos sobre fungos causadores de ferrugem em leguminosas do Brasil, Hennen et al (1982) registraram quatro espécies de fungos nos gêneros Anthomyces Grüss, Hapalophragmium Syd. \& P. Syd., Ravenelia Berk e Triactella Syd. infectando Poincianella ferrea (=Caesalpinia ferrea). Duas dessas espécies, Hapalophragmium holwayi (H. Jackson) H. Sydow e Triactella holwayi H. S. Jackson, foram incialmente consideradas sinônimas uma vez que as espécies-tipo de Triactella foi recombinada em Hapalophragmium. Porém, devido ao arranjo das células probasidiais nos teliósporos, $T$. holwayi esta não pode ser alocada em Hapalophragmium. De imediato, Hennen et al (2000), verificaram que T. holwayi do Brasil não se tratava de uma espécie de Hapalophragmium, mas sim de um novo gênero. Assim a espécie foi recombinada para Esalque holwayi. Trata-se de um gênero monotípico com a espécie-tipo Esalque holwayi (H. S. Jackson) Hennen, Figueiredo \& Carvalho (Cummins \& Hiratsuka 2003, Hennen et al 2005, Index Fungorum 2016). 
Esalque holwayi (H. S. Jackson) Hennen, Figueiredo \& Carvalho

Existe apenas como espécie-tipo do gênero, a qual já foi descrita acima.

Espécime examinado: Esalque holwayi em folhas de Poincianella ferrea (Fabaceae): Super Quadra Norte 209, próximo à passagem subterrânea do Eivo W, Brasília, Brasília, Distrito Federal. 10 jul. 2012, leg. E.S.C Souza 79, UB22286.

O material aqui estudado apresentou somente a fase uredínica com urédios densamente pulverulentos, fortemente amarelados, encontrados infectando vagens da hospedeira. Os aspectos morfológicos e métricos dos urediniósporos foram comparados com a descrição original da espécie e apresentou urediniósporos pouco maiores e mais largos (18-25 × 13-17 $\mu \mathrm{m})$. Esalque holwayi além de relata em P. ferrea, também foi encontrada em outra espécie do mesmo gênero da hospedeira, $P$. punctata (Hennen et al.2005) e já reportada em Brasília por Rezende \& Dianese (2002). 

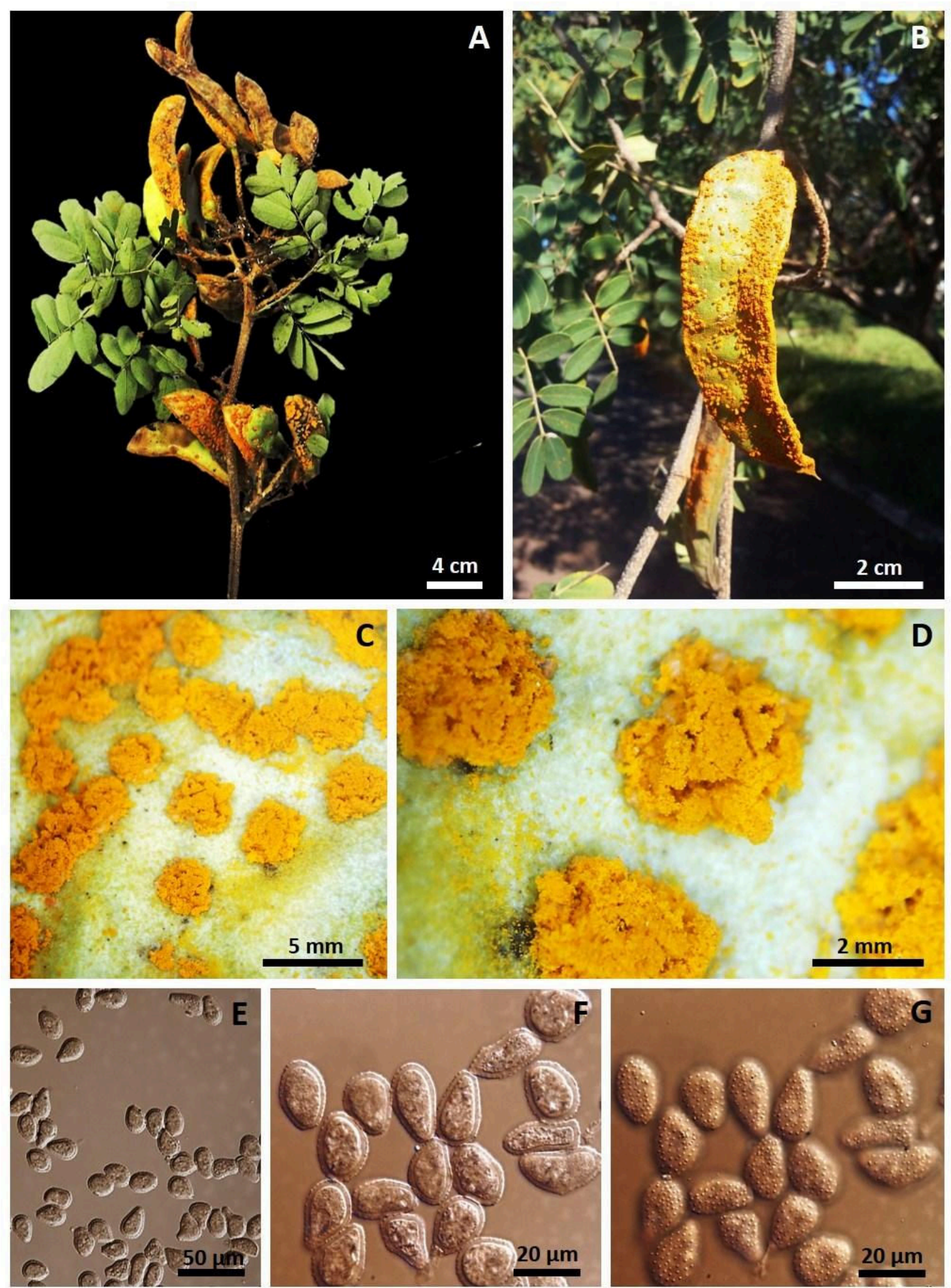

Figura 44 (A-G). Esalque holwayi em vagens de Poincianella ferrea. A-B.

Sintomas em vagens. C-D. Urédios. E. Grupo de urediniósporos. F-G. Urediniósporos vistos em duas profundidades de foco diferentes. 


\section{Gêneros e espécies Incertae sedis}

\section{Gênero Cerradoa J.F. Hennen \& Y. Ono}

Descrição: Espermogônios e Écios desconhecidos. Urédios subepidérmicos, supraestomatais, pulverulentos, castanho-claros a castanhos. Urediniósporos unicelulares, equinulados, pedicelados, decíduos. Télios como os urédios. Teliósporos solitários, bicelulares com as duas células probasidiais unidas lateralmente, septo vertical, cada célula com um poro ao lado do septo, longo-pedicelados. Basídio externo (Cummins \& Hiratsuka 2003, Hennen et al 2005).

Cummins \& Hiratsuka $(1983,2003)$ colocaram este gênero como sinônimo de Edythea H.S. Jacks. Eles consideraram que a diferença entre os dois gêneros se dava no grau de pigmentação da parede dos teliósporos. Os télios destes dois gêneros são morfologicamente semelhantes com relação a formação e alongamento das células esporogênicas e a forma como são emergidas através dos estômatos, entretanto, apesar de serem bicelulares, o formato dos teliósporos é completamente diferente. Em Cerradoa os teliósporos são oblongos, possuem septos verticais suportados por pedicelos finos inseridos na base dos septos. Já em Edythea os teliósporos são elipsoides, alguns com as células basais e apicais proeminentes lateralmente e apicalmente, respectivamente. Além disso, possuem septos transversais e pedicelos solidamente aderidos à base do teliósporo. Hennem et al (2005) também consideraram esses dois gêneros como distintos.

Edythea ocorre em Berberis spp. (Berberidaceae - dicotiledônea) no Equador, enquanto que Cerradoa, reportada no Brasil, é o único fungo em Arecaceae (monocotiledônea) mostrando a forma sexuada (Cummins \& Hiratsuka 2003, Hennem et al 2005). 
Trata-se da espécie-tipo do gênero, a qual já foi descrita acima.

Espécimes examinados: em folhas de Syagrus comosa (Arecaceae): Jardim Botânico de Brasília, Brasília-Distrito Federal, 29 set. 2012, leg. E.S.C Souza 150, UB22391; em folhas de Syagrus flexuosa (Arecaceae): Estação Experimental de Biologia da Universidade de Brasília, Brasília-Distrito Federal, 05 set. 2013, leg. E.S.C Souza 214, UB22550.

Na descrição original de C. palmaea a hospedeira foi identificada erroneamente como Attalea ceraensis (Arecaceae) (Hennen \& Ono 1978), posteriormente verificou-se que se tratava de Syagrus comosa, além de ter sido também encontrada em S. flexuosa (Dianese et al. 1992, Mendes et al. 1998).

Este foi o primeiro fungo reportado causando ferrugem em Arecaceae. Mais tarde registrou-se Uredo crusa J. Hennen \& J. McCain em planta não identificada do México $2 \mathrm{~mm}$ Chamaedorea sp. e Geonoma da Guatemala (Hennen \& McCain, 1993). 

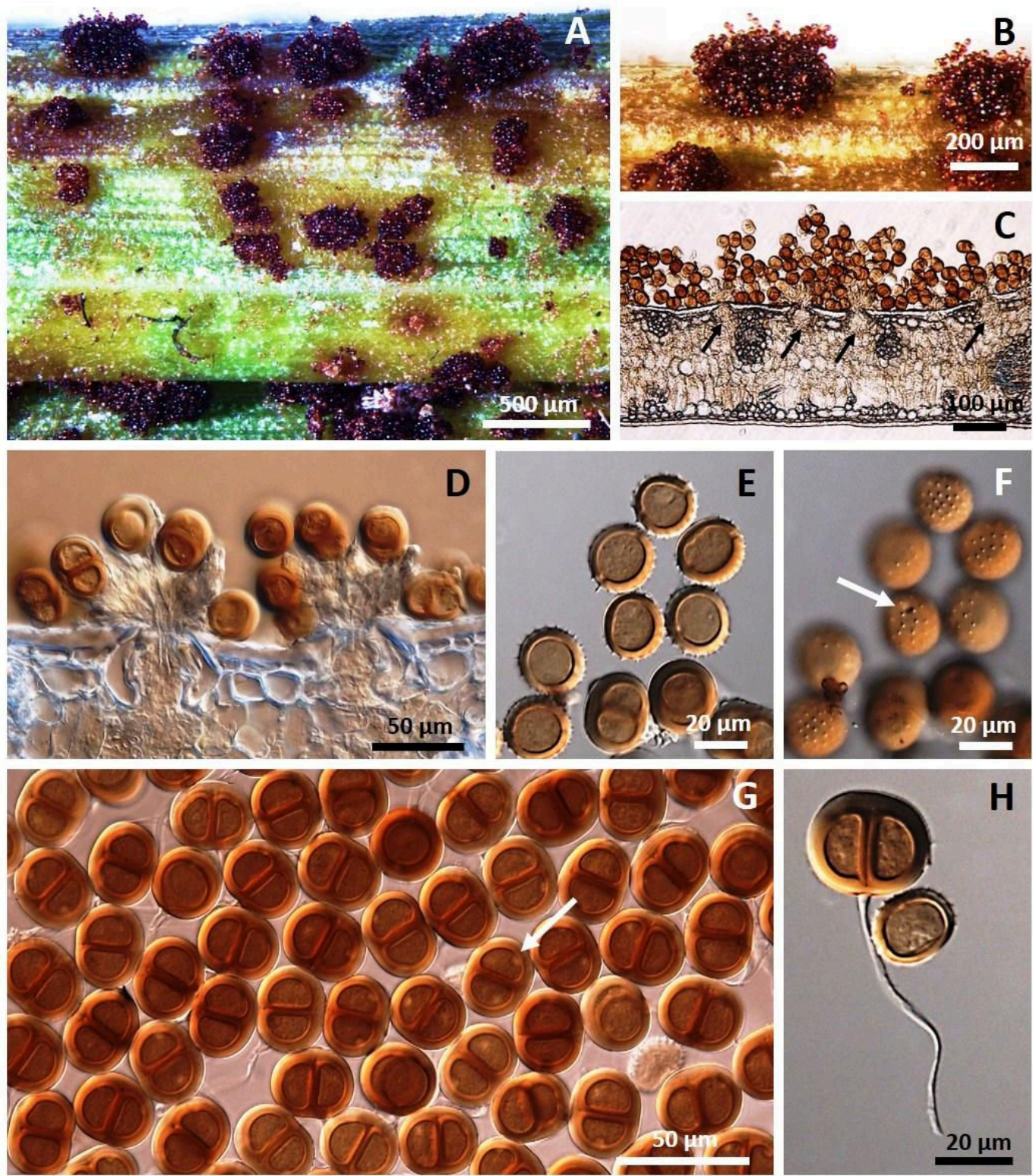

Figura 45 (A-H). Cerradoa palmaea em folhas de Syagrus comosa. A. Soros

mistos na superfíe abaxial da folha. B. Corte de um soro misto. C. Corte mostrando (setas) detalhes da frutificação trans-estomatal. D. Corte mostrando células esporogênicas através dos estômatos, suportando esporos. E-F. Urediniósporos em duas profundidades de foco, com seta indicando poro germinativo. G. Grupo de teliósporo com seta indicando um poro germinativo. $\mathbf{H}$. Teliósporo pedicelado e um urediniósporo. 


\section{Gênero Desmella H. Sydow \& P. Sydow}

Descrição: Espermogônios e Écios desconhecidos. Urédios supraestomatais do tipo Wardia. Urediniósporos solitários, equinulados, pedicelados. Télios subestomatais emergindo dos estômatos através das poucas células esporogênicas dos quais cada uma pode produzir vários esporos, os soros quando maduros são supraestomatais. Teliósporos solitários, bicelulares, com septos transversais, oblíquos ou verticais, pedicelados, parede pálida ou pigmentada, um poro germinativo em cada célula, germinação sem dormência; basídio externos (Cummins \& Hiratsuka 2003).

O gênero conta com quatro espécies: Desmella aneimiae Syd. \& P. Syd., D. gymnogrammes Syd. \& P. Syd., D. mbatobiensis (Speg.) Syd. \& P. Syd. e D. superficialis Syd. \& P. Syd., com ocorrência em mais de 21 gêneros diferentes de samambaias [Pteridophyta] (Index Fungorum 2016, Hennem et al. 2005).

Dentre as espécies relacionadas, $D$. aneimiae é a espécie-tipo do gênero encontrada em folhas de Anemia tomentosa (Schizaeceae) no Brasil em 1919 (Cummins \& Hiratsuka 2003, Hennem et al. 2005).

\section{Desmella sp.}

Descrição: Espermogônios e Écios não observados. Urédios supraestomatais, subepidérmicos, gregários ou dispersos, pulverulentos, amarelados. Urediniósporos 19- 42 $\mu \mathrm{m}$ de diâmetro, solitários, globoides, equinulados, marrom-claros, palha, pedicelados. Télios não observados.

Espécime examinado: em folhas de Thelypteris (Thelypteridaceae): Parque Olhos D Água de Brasília, Brasília-Distrito Federal, 17 set. 2013, leg J.C. Castro 443, UB22553. 
Já foram relatadas duas espécies de Desmella em diferentes espécies de Thelypteris. D. aneimiae foi encontrada em T. abrupta, T. hispidula e T. poiteana na Guiana Francesa; T. opulenta na Guiana; T. quadrangularis na Argentina; T. rudis na Costa Rica e Thelypteris sp. na Argentina, Brasil, Costa Rica, Guiana, Panamá e Venezuela. D. superficialis foi relatada em Goniopteris guadalupensis em Porto Rico e Ilhas Virgens e T. patens na Jamaica, T. tetragona em Porto Rico e Ilhas Virgens (Farr \& Rossman 2016).
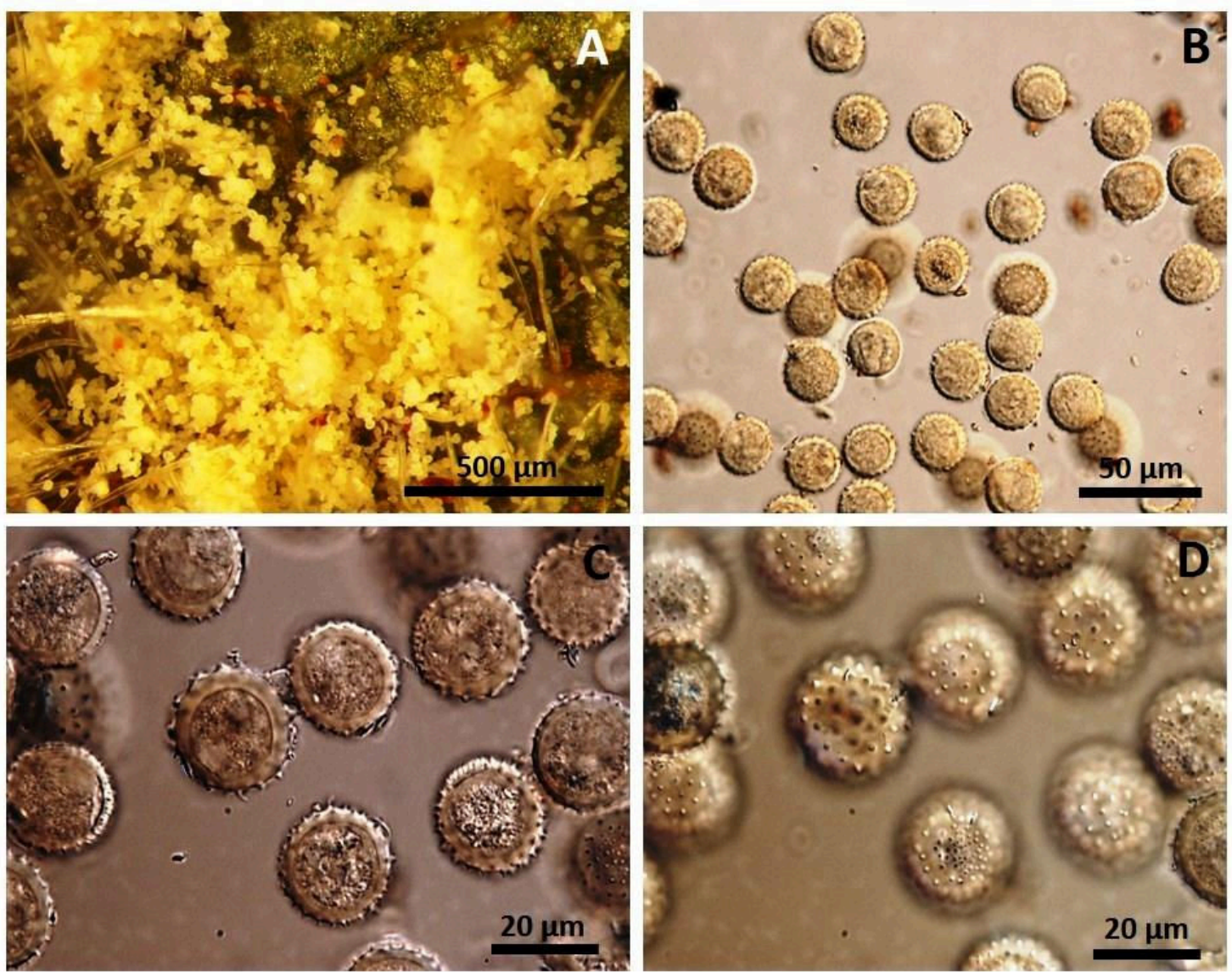

Figura 46 (A-D). Desmella sp. em folha de Thelypteris sp. A. Massa amarelada de urediniósporos em lesão eruptiva abaxial. B. Grupo de urediniósporos. C-D. Uredinióspros em duas profundidades de foco diferentes. 


\section{Formas assexuadas de Pucciniales incluídas na análise filogenética}

Amostras de uma espécie de Aecidium e quatro de Uredo foram incluídas nas análises filogenéticas e são, a seguir, morfologicamente caracterizadas.

Aecidium duguetiae P. Hariot (=Dietelia duguetiae (Thurst.) Buriticá \& J.F. Hennen)

Fig. 47 (A-F)

Descrição: Epermogônios não observados. Écios $\times$ 300-350 $\mu$ m predominantemente epífilos, colunares, fortemente amarelados, desenvolvidos em galhas decorrentes da infecção ou em manchas marrons irregulares, podendo cobrir quase toda a folha. Células peridiais 23$33 \times 12-16 \mu \mathrm{m}$ oblongas-poligonais, firmemente unidas, lisas. Eciósporos 18-23 ×14-19 $\mu \mathrm{m}$, globoides, parede fina, lisa, quase incolor.

Espécimes examinados: em folhas de Duguetia furfuracea (Annonaceae): Parque Ecológico Ermida Dom Bosco, Asa Sul, Brasília, Brasília-Distrito Federal, 25 jul. 2013, leg E.S.C. Souza 201, UB22524; em folhas de Duguetia furfuracea (Annonaceae): Vila Bela de Santíssima Trindade, Barra do Garça, Mato Grosso, 18 ago. 2014, leg Z.M. Chaves A161, UB23057.

Aecidium duguetiae é relatada apenas no Brasil, à semelhança de Dietelia duguetiae (Thurst.) Buriticá \& J.F. Hennen, conforme Burticá \& Hennen (1980). Pendendo revisão adicional $D$. dugueriae será ora tratada como sinônimo de $A$. duguetiae. 

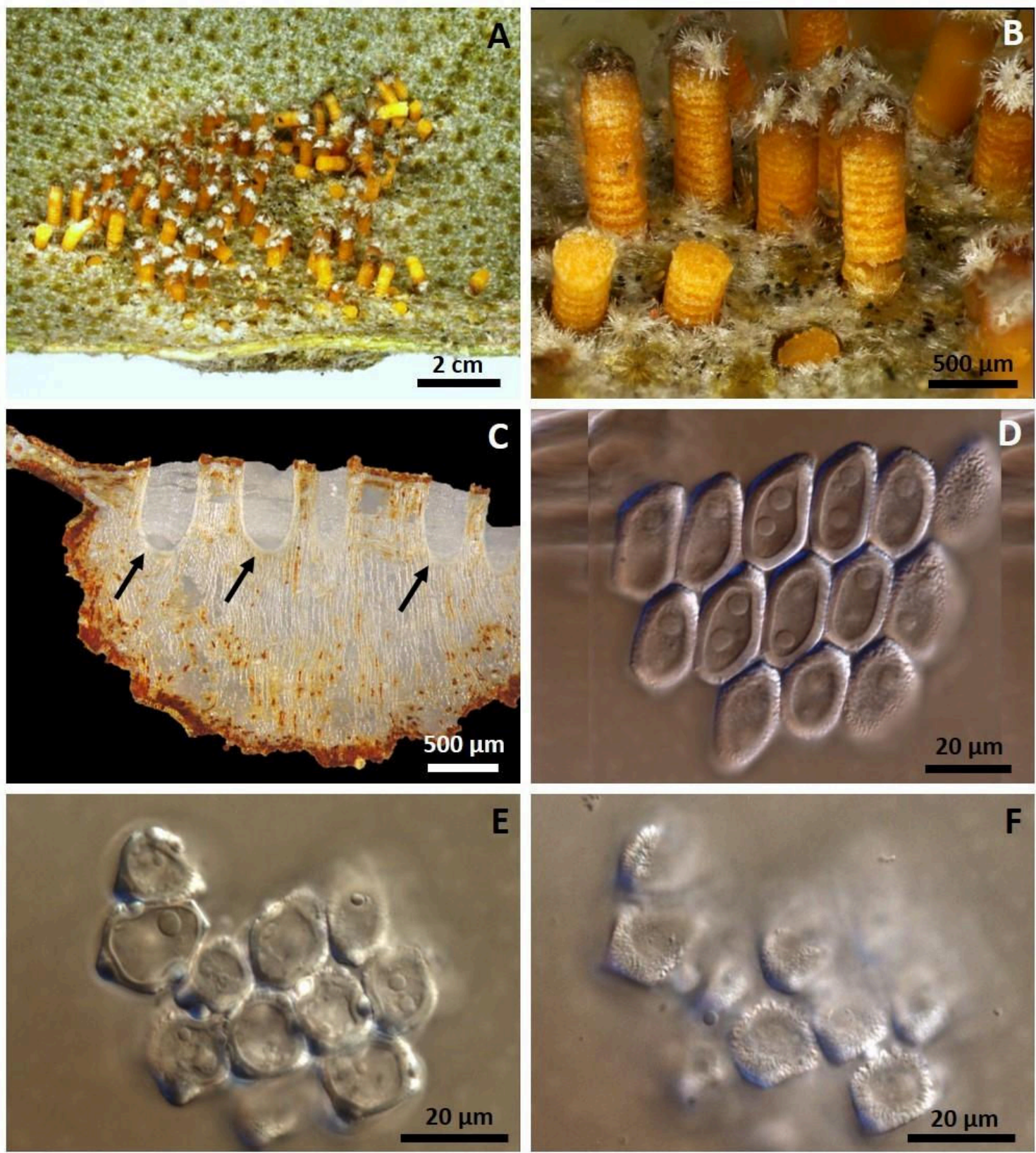

Figura 47. Aecidium duguetiae em folhas de Duguettia furfuraceae. A. Galha recoberta por écios colunares. B. Detalhe do formato dos écios. C. Corte de uma galha mostrando as bases (setas) de um grupo de écios. D. Células do perídio dos écios. E-F. Eciósporos em duas profundidades de foco diferentes. 
Uredo sp. (UB22281) Fig. 48 (A-H)

Descrição: Urédios 320-500 $\mu \mathrm{m}$ de diâmetro, subepidérmicos, hipófilos, eruptivos, com crosta brilhante, dispersos ou gregários, pulverulentos, marrons escuros. Urediniósporos $62-78 \times 22-30 \mu \mathrm{m}$, unicelulares, solitários, obovoides a elipsoides, muitas vezes com um dos lados côncavo, ápice arredondado e papilados, estreitos próximo à base truncada, marrons claros, equinulados, dois a três poros germinativos supraequatoriais, pedicelados; pedicelos curtos e decíduos.

Espécime examinado: em folhas de Pera glabrata (Peraceae): Jardim Botânico de Brasília, Brasília-Distrito Federal, 25 jul. 2013, leg. E.S.C. Souza 75, UB22281.

Há apenas um relato de membro dos Pucciniales para o gênero Pera, a espécie Maravalia perae A.A. Carvalho \& J.F. Hennen em Pera sp. (Carvalho et al. 2009, Farr \& Rossman 2016).

Esta espécie apresenta urediniósporos obovoides assimétricos a estreitamente elipsoides, muitas vezes com um lado côncavo, ápice em grande parte papilado, estreitos próximo à base truncada, marrons claros, equinulados, dois a quatro poros germinativos equatoriais e pedicelos curtos e decíduos. Os seus urédios são hipófilos como no material aqui analisado. As características morfológicas da forma uredínica descritas em M. perae por Carvalho et al (2009), são exatamente as mesmas do espécime aqui estudado o qual apenas forma urediniósporos um pouco maiores.

Diante disso, pode-se considerar a possibilidade de o espécime aqui estudado pertencer a $M$. perae necessitando de maiores estudos na tentativa de encontrar a forma télica para esclarecer este fato. Além do mais, este estudo se trata do primeiro relato de membro de Pucciniales em Pera glabrata. 

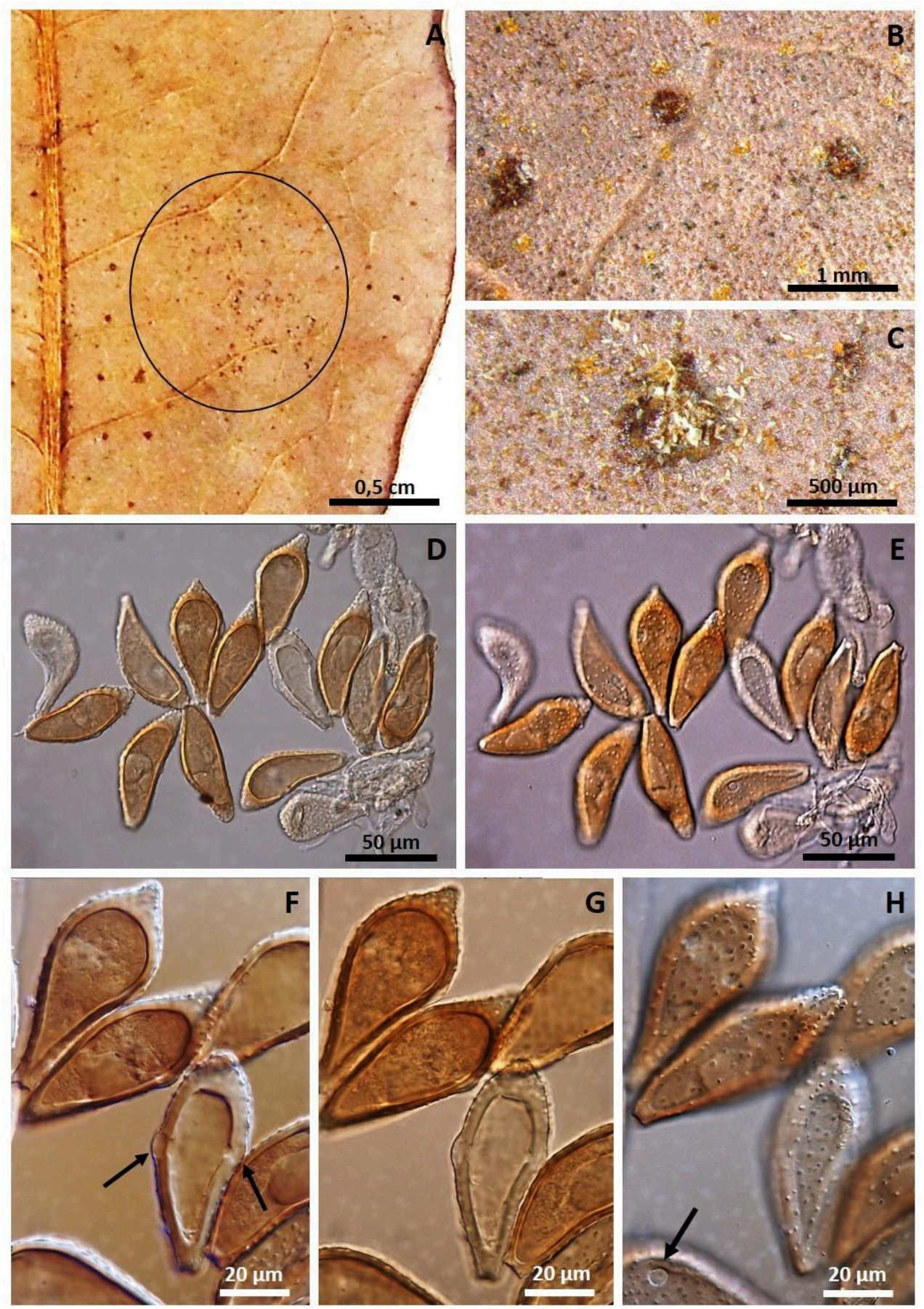

Figura 48. (A-H). Uredo sp. em folhas de Pera glabrata. A. Sintoma na forma de pontos escuros na face abaxial da folha. B-C. Urédios. D-H. Urediniósporos em diferentes profundidades de foco, com seta indicando poros germinativos equatoriais. 
Uredo sp. (UB22481) Fig. 49 (A-G)

Descrição: Urédios 100-50 $\mu \mathrm{m}$ de diâmetro, subepidérmicos, hipófilos, eruptivos, dispersos ou gregários, pulverulentos, marrons claros brilhantes, parafisadas; Paráfises 23$39 \times 5-7 \mu \mathrm{m}$, cilíndricas, encurvadas, hialinas. Urediniósporos 17-28 $\times 16-25 \mu \mathrm{m}$, solitários, reniformes, marrons claros, equinulados, poros germinativos obscuros, pedicelados; Pedicelos curtos e decíduos.

Espécime examinado: em folhas de Pradosia brevipes (Sapotaceae): Universidade de Brasília, Campus Darcy Ribeiro, próximo ao CEBRASPE, Brasília-Distrito Federal, 21 jun. 2013, leg. E.S.C. Souza 75, UB22481.

Não há nenhum relato de membro de Pucciniales infectando $P$. brevipes, entretanto há espécie de Catenulopsosa em espécies de Pouteria e ambas hospedeiras são da família Sapotaceae (Farr \& Rossman 2016, Hennen et al. 2005).

A forma uredínica aqui observada possui as mesmas características da espécie de Catenulopsora já relatada no que diz respeito ao formato dos urediniósporos e das paráfises. Sendo assim, o espécime em estudo pode corresponder à forma assexuada de Catenulopsora e mais estudos devem ser realizados afim de solucionar essa questão. 

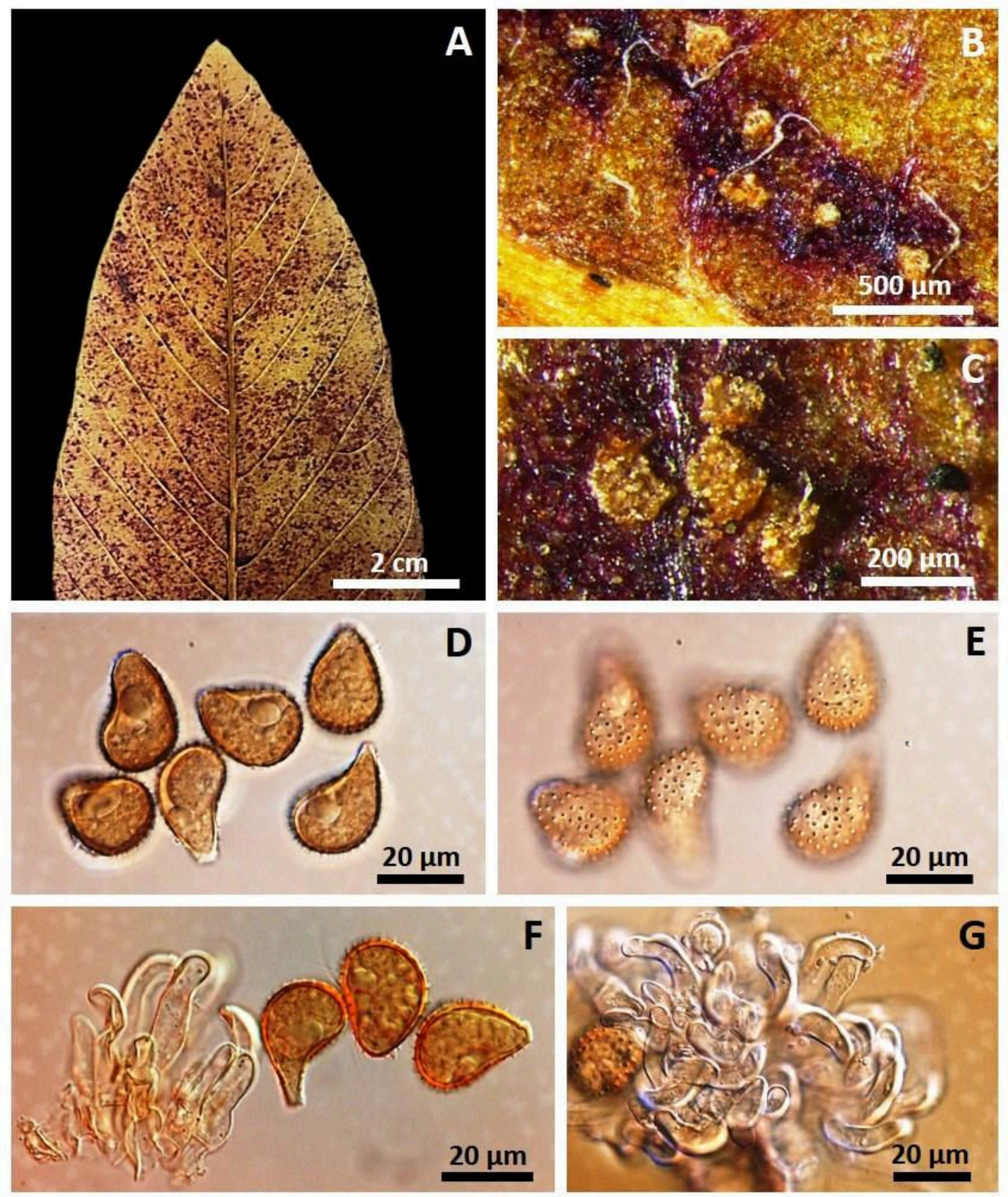

Figura 49. (A-G). Uredo sp. em folhas de Pradosia brevipes. A. Sintoma na forma de ampla área marrom-avermelhada na face abaxial da folha. B-C. Urédios. D-E. Urediniósporos obpiriformes a reniformes, em duas profundidades de foco diferentes. F. Paráfises ao lado de três urediniósporos. G. Paráfises recurvadas. 
Uredo sp. (UB22345) Fig. 50 (A-G)

Descrição: Urédios 100-150 $\mu \mathrm{m}$ de diâmetro, tipo subepidérmicos, hipófilos, eruptivos, dispersos ou gregários, pulverulentos, marrons, parafisadas; Paráfises, cilíndricas, pouco encurvadas, hialinas. Urediniósporos $17-28 \times 16-25 \mu \mathrm{m}$, solitários, globoides, marrons claros, equinulados, poros germinativos obscuros, pedicelados; Pedicelos decíduos.

Espécime examinado: em folhas de Solanum sp. (Solanaceae): Fazenda Água Limpa da Universidade de Brasília (FAL-UnB), Brasília-Distrito Federal, 03 set. 2012, leg. E.S.C. Souza 117, UB22345. 

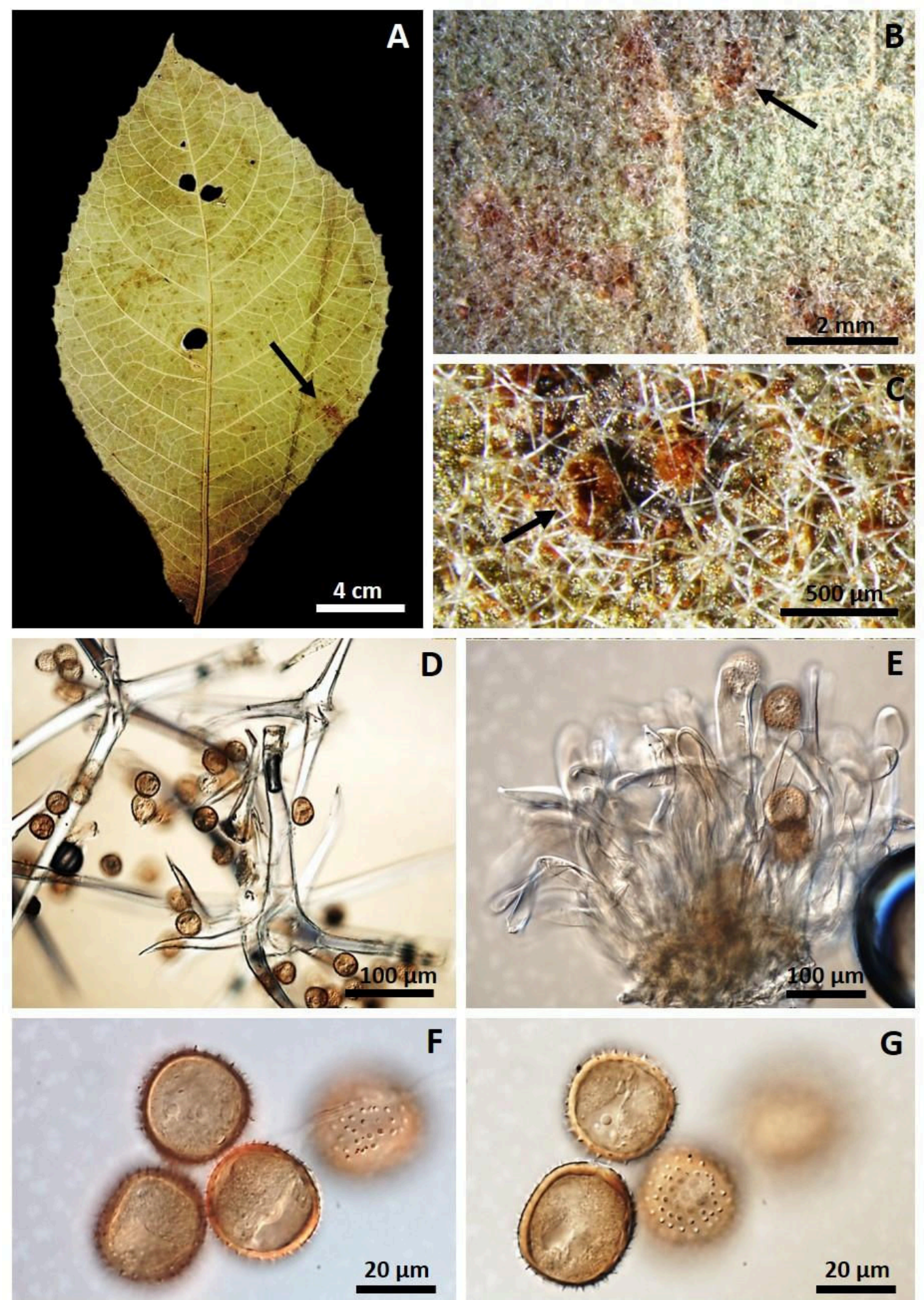

Figura 50. (A-G). Uredo sp. (UB 22345) em folhas de Solanum sp. A. Sintoma de pontos ferruginosos na face abaxial da folha. B-C. Urédios. D. Urediniósporos livres entre tricomas. E. Paráfises presentes na periferia dos urédios. F-G. Urediniósporos vistos em profundidades de foco diferentes, sem revelar os poros germinativos. 
Uredo sp. (UB22360) Fig. 51 (A-D)

Descrição: Urédios 100-200 $\mu \mathrm{m}$ de diâmetro, tipo subepidérmicos, hipófilos, eruptivos, dispersos ou gregários, pulverulentos, marrons. Urediniósporos $26-32 \times 24-26$ $\mu \mathrm{m}$, solitários, predominantemente globosos, marrons claros, equinulados, poros germinativos obscuros, pedicelados; Pedicelos decíduos.

Espécime examinado: em folhas de Solanum sp. (Solanaceae): Fazenda Água Limpa da Universidade de Brasília (FAL-UnB), Brasília-Distrito Federal, 03 set. 2012, leg. E.S.C. Souza 126, UB22360.
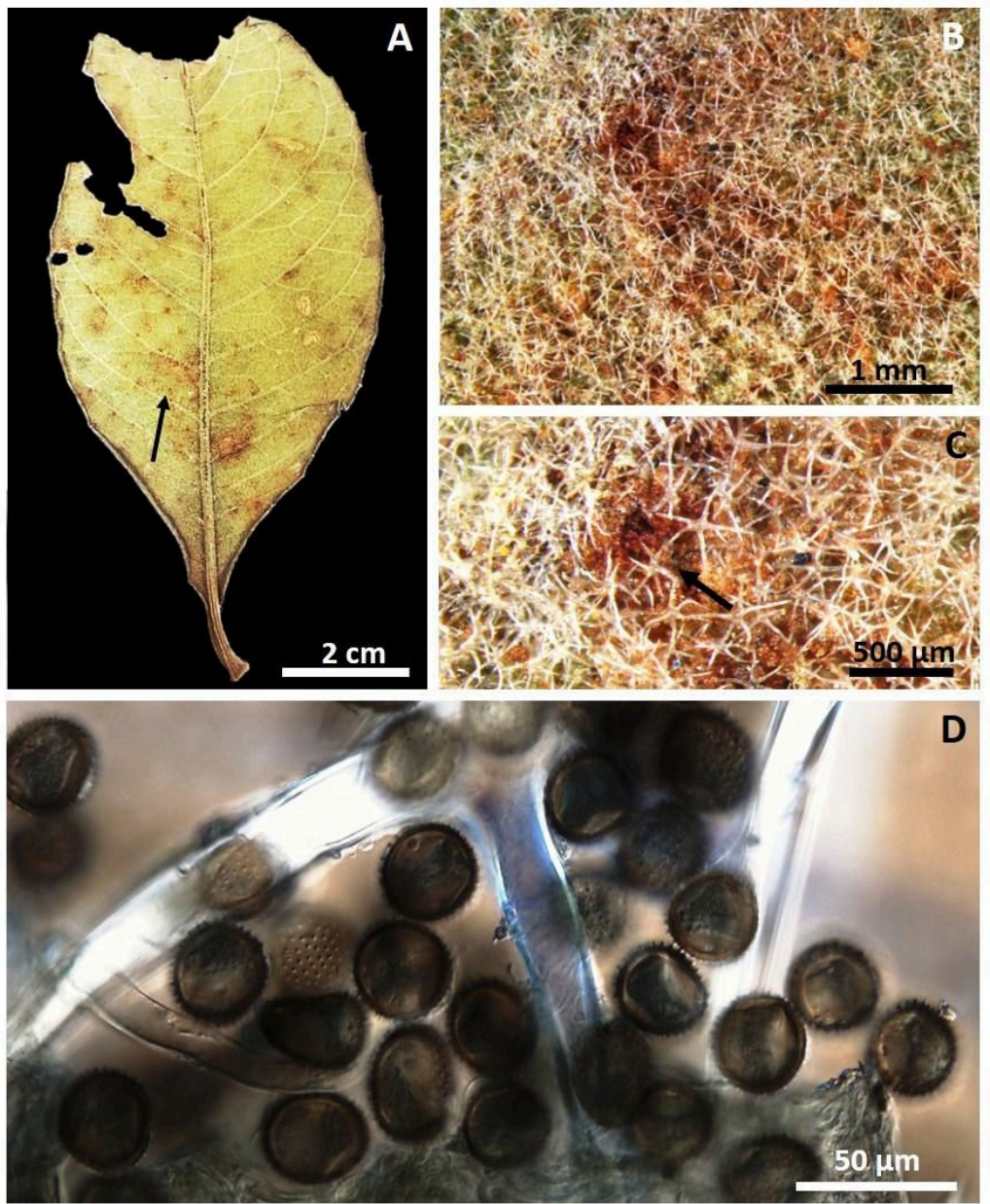

Figura 51. (A-D). Uredo sp. (UB22360) em folhas de

Solanum sp. A. Sintoma na forma de pequenas áreas escurecidas na face abaxial da folha. B-C. Urédios aparafisados. D. Urediniósporos livres entre tricomas. 
Os dois espécimes encontrados em Solanum sp. são muito parecidos quanto a forma e distribuição dos urédios e formato dos urediniósporos. Porém, o primeiro forma urédios parafisados. Há vários relatos de membros de Pucciniales em espécies de Solanum sp. Entre eles formas assexuadas como algumas espécies de Aecidium e de Uredo. As espécies de Uredo relatas são: $U$. invisa em $S$. fernandezianum no Chile; $U$. minitans em $S$. commersonii na Argentina; U. solaninum em Solanum sp. na Tanzania; Uredo sp. em S. verbascifolium em Hong Kong e U. tolimensis em Solanum sp. na Colômbia.

Além disso, algumas espécies em gêneros correspondentes à forma sexuada também foram relatadas em Solanum spp. como espécies de Chrysocyclus, Crossopsora, Didymopsora, Puccinia e Uromyces (Farr \& Rossman 2016). 


\section{REFERÊNCIAS}

Aime MC (2006) Toward resolving family-level relationships in rust fungi (Uredinales). Mycoscience. 47: 112-122.

Aime MC, Toome M, McLaughlin DJ. 2014. Pucciniomycotina. In: McLaughlin DJ, Spatafora JW, eds. The Mycota, systematics and evolution, 2 ed, 7A. Berlin, Germany: Springer-Verlag, in press.

Arthur JC (1922) Uredinales - Aecidiaceae. N Am Flora 7:481-540.

Arthur JC (1907) Aecidiaceae. North American Flora. 7(Part 2): 129-160.

Arthur JC (1907) Coleosporiaceae. North American Flora. 7: 85-95.

Arthur JC (1912) Uredinales. North American Flora. 7: 161-268.

Arthur JC (1917) Relationship of the genus Kuehneola. Bull. Torrey bot. Club 44: 501-511.

Arthur JC, Johnston JR (1918) Uredinales of Cuba. Memoirs of the Torrey Botanical Club. 17:97-175.

Bagyanarayana G, Rao KN (1985) A new species of Kuehneola on Gymnosporia montana from India. Canadian Journal of Botany. 63(4):762-764.

Beenken L, Berndt R (2010) Rust fungi on Annonaceae: the genus Sphaerophragmium. Mycologia 102:650-663.

Beenken L, Zoller S, Berndt R (2012) Rust fungi on Annonaceae II: The genus Dasyspora. Mycologia.104:659-681.

Beenken L (2014) Pucciniales on Annona (Annonaceae) with special focus on the genus Phakopsora Mycological Progress. 13:791-809.

Beenken L, Wood AR (2015) Puccorchidium and Sphenorchidium, two new genera of Pucciniales on Annonaceae related to Puccinia psidii and the genus Dasyspora. Mycological Progress 14: 1-13.

Berkeley MJ (1853) Ravenelia glandulae formis. Gardeners' Chronicle. 1853:132. 
Berkeley MJ (1874) Notices of North American fungi. Grevillea. 3:49-64.

Berndt R, Beenken L (2013) Chaconia heliconiae and C. clusiae sp. novae from French Guiana with notes on the genus Chaconia (Uredinales) in the neotropics. Mycological Progress. 12:397-401.

Berndt R (1996) Diorchidium taiwanensis $\mathrm{sp}$. nov. (Uredinales) a new Diorchidium from Taiwan. Mycotaxon 59:253-257.

Buriticá CP (1998) La familia Phakopsoraceae en el Neótropico-II. Generos Arthuria, Nothoravenelia, Uredopeltis, Kweilingia, Aplopsora, y Pucciniostele. Rev. Acad. Colomb. Cienc. 22: 325-334.

Buriticá P, Hennen JF (1980) Pucciniosireae (Uredinales, Pucciniaceae). Flora Neotropica 24: $1-48$.

Buys H, Flint H J, Miller EM, Yao H, Caird AR, Ganley R.J (2016) Preparing for the invasion: efficacy of DNA barcoding to discern the host range of myrtle rust (Puccinia psidii) among species of Myrtaceae. Forestry, 17.

Carnegie AJ, Cooper K (2011) Emergency response to the incursion of an exotic myrtaceous rust in Australia. Australasian Plant Pathology 40: 346359.

Carnegie AJ, Lidbetter JR, Walker J, Horwood MA, Tesoriero L, Glen M, Priest MJ (2010) Uredo rangelii, a taxon in the guava rust complex, newly recorded on Myrtaceae in Australia. Australas Plant Pathol $39: 463-466$.

Carvalho AA, Hennen JF (2009) Maravalia perae, a new species of rust fungus on Pera from Brazil. Mycologia, 101: 239-242.

Castro MT (2012) Pucciniales em plantas nativas do cerrado brasileiro e em algumas exóticas. Dissertação de Mestrado. Universidade de Brasília. Brasília. 
Chaves ZM_Fonseca MEN, Boiteux LS, Junqueira KP, (2008)_First record of Kernkampella (Uredinales) in Brazil, and its relationship to Ravenelia species. In: 2008 Meetings Mycological Soc. of America, 2008, State College Pennsylvania. Inoculum, 2008.

Coutinho TA, Wingfield MJ, Alfenas AC, Crous PW (1998) Eucalyptus rust: a disease with the potential for serious international implications. Plant Disease 82:819-825.

Cummins GB, Hiratsuka Y (2003) Illustrated genera of rust fungi. 3 ed. The American Phytopathological Society, St. Paul. 225p.

Cummins GB, Stevenson JA (1956) A check list of North American rust fungi (Uredinales). U.S.D.A. Plant Disease Reporter. 240 (suppl): 109-193.

Cummins GB, Y. Hiratsuka (1983) Illustrated genera of rust fungi. Revised Edition. American Phytopathological Society. St. Paul. 152 pp.

Deadman ML, Al Sadi AM, Al Maqbali YM, Farr DF, Aime MC (2011) Additions to the rust fungi (Pucciniales) from northern Oman. Sydowia 63: 155-168.

Dianese JC \& Santos LTP (1995) Aplopsora hennenii sp. nov., the first rust fungus recorded in host-family Vochysiaceae. Mycological Research. 99: 914-916. London.

Dianese JC Buriticá P, Hennen JF (1994) The rust of jatobá: a new Crossopsora species from Neotropical on Hymenaea (Leguminosae). Fitopatologia Brasileira. 19: 588-591.

Dianese JC, Medeiros RB, Santos LTP, Furlanetto C, Sanchez M \& Dianese AC (1993) Batistopsora gen. nov. and new Phakopsora, Ravenelia, Cerotelium, and Skierka species from the Brazilian cerrado. Fitopatologia Brasileira 18:436-450.

Dianese JC, Medeiros RB, Santos LTP (1992) Cerradoa palmaea Hennen \& Ono found in two new hosts, Syagrus commosa (Mart.) Mart. and S. flexuosa Becc. In: Congresso Brasileiro de Fitopatologia, 1992. Fitopatologia Brasileira. (Suplemento): 123.

Dianese JC, Medeiros RB, Santos LTP, Furlanetto C, Sanchez M, Dianese AC (1993) Batistopsora gen. nov. and new Phakopsora, Ravenelia, Cerotelium, and Skierka species from the Brazilian cerrado. Fitopatololgia Brasileira. 18: 436-450. 
Dianese JC, Santos LTP, Medeiros RB, Sanchez M (1994) Mimema venturae sp. nov. on Dalbergia miscolobium in Brazil. Mycological Research. 98:786-788.

Dietel P (1894) Die Gattung Ravenelia. Hedwigia 33: 22-48.

Dodge BO (1925) Organization of the telial sorus in the pine rust Gallowaya pinicola. Journal Agricculture Reserch. 31: 641-651.

Eboh DO (1985). A re-evaluation of Ypsilospora. Transactions of the British Mycological Society. 85(1): 39-64.

Farr DF, Rossman AY (2016) Fungal Databases, Systematic Mycology and Microbiology Laboratory, ARS, USDA. Access in July 2016, available at http: //nt.ars grin.gov/fungaldatabases/.

Figueiredo MB, L Coutinho, J F Hennen (1984) Estudo para determinação do ciclo vital de Puccinia psidii Winter. Summa Phytopathologica 10: 53-54. (Abstracts).

Gallegos ML, Cummins GB (1981) Uredinales (Royas) de Mexico. Vol. 2. Culiacan, Mexico. Instituto Nacional de Investigaciones Agrícolas.

Hennen J, M Hennen, M Figueiredo. 1982. Índice das ferrugens (Uredinales) do Brasil. Arquivos do Instituto Biológico. (São Paulo) 49: 1-201.

Hennen JF, Cummins GB (1990) New species and nomenclature of Ravenelia in Neotropical. Reports of the Tottori Mycological Institute. 28:1-14.

Hennen JF, Figueiredo MB, Carvalho Jr AA (2000) Esalque holwayi, gen.et comb. nov., a rust of Brazilian ironwood (Caesalpinia species). Mycologia 92: 312-316.

Hennen JF, Sotão HMP, Winkler Hennen MM (1998) The genus Diorchidium in the Neotropics. Mycologia 90:1079-1086.

Hennen JF, Sotão HMP (1996) New species of Uredinales on Bignoniaceae from Brazil. Sida 17:173-184. 
Hennen JF, Y Ono (1978) Cerradoa palmaea: The first rust fungus on Palmae. Mycologia 70: 569 .

Hennen JF, Figueiredo MB, Carvalho Jr. AA, Hennen PG (2005) Catalogue of plant rust fungi (Uredinales) of Brazil.

Hernández JR, Hennen JF (2003) Rust fungi causing witches' brooms, and other abnormal plant growths in northwest Argentina. Mycologia 95: 728-725.

Hiratsuka Y, Hiratsuka N (1980) "family classification" spermogonia.

Hyde KD, Nilsson RH, S Alias A, Ariyawansa AH, Blair E, et al. (2014) One stop shop: backbones trees for important phytopathogenic genera: I (2014). Fungal Diversity 67: 21125.

Index Fungorum (2016) Disponível em: www.indexfungorum.org. Acessado em dezembro de 2016.

Hennen JF, Ono Y (1978) Cerradoa palmaea: the first rust fungus on Palmae. Mycologia 70: $569-576$.

Jackson HS (1931) The rusts of South America based on the Holway collections. Mycologia 23:463-503.

Juel HO (1897) Die Ustilagineen und Uredineen der Ersten Regnell`s Expedition. Bih. K. svenska VetenskAkad. Handl., Afd. 3 23: 1-30.

Kalchbrenner C, Cooke MC (1882) Fungi Macowaniani. Grevillea 11: $18-27$.

Kalchbrenner C (1882) Fungi macowaniani. Grevillea 11:18-27.

Kawanishi T, Uematsu S, Kakishima M, Kagiwada S, Hamamoto H, Horie H, Namba S (2009) First report of rust disease on ohia and the causal fungus, Puccinia psidii, in Japan. J Gen Plant Pathol 75:428-443.

Kirk PM, Cannon PF, Minter DW, Stalpers JA (2008) Ainsworth and Bisby's dictionary of the fungi. 10th ed. Wallingford, CAB International. 
Kropp BR, Hansen DR, Wolf PG, Flint KM, Thomson SV (1997) A study on the phylogeny of the dyer's woad rust fungus and other species of Puccinia from Crucifers. Phytopathology 87: 565-571.

Lohsomboon P, Kakishima OY (1992) A monogroph of Hapalophragmium. Mycological Researh 96: 461-472.

López-Franco RM, Hennen JF (1989) The slit and other sorts of metabasidia exits in rust fungi probasidia. Mycological Society of America Newsletter. 40: 37.

Machado PDS, Glen M, Pereira OL, Silva AA, Alfenas AC (2015) Epitypification of Puccinia psidii, causal agent of guava rust. Tropical Plant Pathology. 40: 5-12.

Maier W, Begerow D, Weiss M, Oberwinkler F (2003) Phylogeny of the rust fungi: an approach using nuclear large subunit ribosomal DNA sequences. Canadian Journal of Botany 81: 12-23.

Mains EB (1921) Unusual rusts on Nyssa and Urticastrum. American Jornal Botanic. 8: 442451.

Mains EB (1939 b) The genera Skierka and Ctenoderma. Mycologia. 31: 175-190.

Marlatt RB, Kimbrough JW (1979) Puccinia psidii on Pimento dioica in south Florida. Plant Disease 68:510-512.

McNeill J, Barrie FR, Buck WR, Demoulin V, Greuter W, Hawksworth DL, Herendeen PS, Knapp S, Marhold K, Prado J, Prud'homme Van Reine WF, Smith GF, Wiersema JH, Turland NJ (2012) International Code of Nomenclature for algae, fungi and plants (Melbourne Code) adopted by the eighteenth international botanical congress Melbourne, Australia, July 2011. Regnum Vegetabile 154. Hamburg, Germany. Koeltz scientific books.

McTaggart AR, Geering ADW, Shivas RG (2014) Uredinopsis pteridis and Desmella aneimiae, the first rust fungi (Pucciniales) reported on ferns (Pteridophyta) in Australia. Australasian Plant Disease Notes 9: 149. 
McTaggart AR, Shivas RG, Nest MA, Roux J, Wingfield BD, Wingfield MJ (2016) Host jumps shaped the diversity of extant rust fungi (Pucciniales). New Phytologist 209: 11491158.

Mendes MAS, Silva VL, Dianese JC, Ferreira MASV, Santos CEN, Gomes-Neto E, Urben AF, Castro C (1999) Fungos em Plantas no Brasil. Embrapa-SPI/Embrapa-Cenargen, Brasília, 555 pp.

Moncalvo JM, Wang HH, Hseu RS (1995) Phylogenetic relationships in Ganoderma inferred from the internal transcribed spacers and 25S ribosomal DNA sequences. Mycologia 87: $223-238$.

Mycobank (2016) Mycobank database. Disponível em: http://www.mycobank.org/. Acessado em agosto de 2016.

Ono Y, Hennen JF (1983) Taxonomy of the chaconiaceous genera, Uredinales. Trans. Mycol. Soc. Japan 24: 369-402.

Ono Y (1978) Taxonomic Revision of the tribe Oliveae and morphologically related genera (Uredinales). Ph. D. Thesis, Purdue University. 254.

Rezende DV, Dianese JC (2001) New species of Ravenelia from Braziliam Cerrado areas. Fitopatologia Brasileira, SBF. 26: 627-634. Fortaleza.

Rezende DV, Dianese JC (2003) Espécies de Uromyces em Leguminosae do Cerrado com descrição de U. galactiae. Fitopatologia Brasileira. 28: 495-501. Fortaleza, Ceará.

Rezende DV, Dianese JC (2002) Aspectos taxonômicos de Uredinales infectando leguminosas utilizadas na arborização urbana do Distrito Federal. Fitopatologia Brasileira. 27: 361-371. Brasília, DF.

Rezende DV (1999) Taxonomia de Uredinales em plantas da Família Leguminosae do Cerrado Brasileiro. Tese de doutorado. Universidade de Brasília. Brasília.

Rodas CA, Roux J, Maier W, Granados GM, Bolaños MD, McTaggart AR, Wingfield, MJ (2015) First report of Puccinia psidii on Corymbia citriodora and Eucalyptus in Colombia. Forest Pathology. 45: 534-536. 
Roux J, Greyling I, Coutinho TA, Verleur M, Wingfield MJ (2013) The myrtle rust pathogen, Puccinia psidii, discovered in Africa. IMA Fungus 4:155-159.

Simpson JA, Thomas K, Grgurinovic CA (2006) Uredinales species pathogenic on species of Myrtaceae. Australasian Plant Pathology 35: 549-562.

Sotão HMP, França IF, Hennen JF (2006) Fungos das famílias Phakopsoraceae e Uropyxidaceae (Uredinales) da Floresta Nacional de Caxiuanã, Pará, Brasil. Hoehnea. 33: 407-417.

Souza ESC, Chaves ZM, Soares WR, Pinho DB, Dianese JC (2015) Uromyces hawksworthii nom. nov. for Aecidium goyazense, on Phthirusa stelis (Loranthaceae) from the Brazilian Cerrado. IMA fungus 6: 155-162.

Thirumalachar MJ, Mundkur BB (1950) Genera of rusts. Indian Phytopathology. 3, 4-42. 203 204.

Thirumalachar MJ (1960) Critical notes on some plant rusts. III. Mycologia. 52: 688-693.

Tommerup IC, Alfenas AC, Old KM (2003) Guava rust in Brazil - a threat to Eucalyptus and other Myrtaceae. N Z J For Sci 33:420-428

Uchida J, Zhong S, Killgore E (2006) First report of a rust disease on Ohi'a caused by Puccinia psidii in Hawaii. Plant Dis 90:524.

Viégas A P (1945) Alguns fungos do Brasil IV. Uredinales. Bragantia. 5: 1-144.

Viégas AP (1961) Índice de Fungo da América do Sul. Instituto Agronômico, Campinas, São Paulo, Brasil. 921.

Walker J (1983) Pacific mycogeography: deficiencies and irregularities in the distribution of plant parasitic fungi. Aust J Bot Suppl Ser 10:89-136.

Wingfield GD, Ericson L, Szaro T, Burdon JJ (2004) Phylogenetic patterns in the Uredinales. Australasian Plant Pathology. 33: 327-335.

Winter G (1884) Repertorium. Rabenhorstii fungi europaei et extraeuropaei exsiccati cura Dr. G. Winter, Centuria XXXI et XXXII. Hedwigia 23:164-172 
Zhuang J-Y, Wei S-X (2011) Additional materials for the rust flora of Hainan Province, China. Mycosystema 30:853-860

Zuluaga C, Buriticá P \& Marín M. 2011. Filogenia de hongos roya (Uredinales) en la zona andina colombiana mediante el uso de secuencias del ADN ribosomal 28S. Revista de Biología Tropical. 59: 517-5402011 San José, Costa Rica. 


\section{CAPÍTULO 2}

\section{RELACIONAMENTO FILOGENÉTICO DE ALGUNS PUCCINIALES DO CERRADO}

\section{RESUMO}

A ordem Pucciniales é um componente importante da micobiota do cerrado brasileiro, entretanto pouco se sabe sobre a sua diversidade e as informações obtidas até o momento são baseadas principalmente em características morfológicas. Os estudos envolvendo análises filogenéticas de fungos causadores de ferrugens no cerrado é escasso. Com o objetivo de compreender as relações filogenéticas desse grupo, foram caracterizadas molecularmente 36 espécies de Pucciniales, entre formas sexuadas e assexuadas, coletadas nos estados de Goiás, Mato Grosso, Maranhão, Minas Gerais e no Distrito Federal. Neste estudo a família Pucciniaceae é representada por sete espécies sendo cinco Puccinia spp. e duas Uromyces spp., com hospedeiras das famílias Annonaceae, Myrtaceae, Malpighiaceae, Euphorbiaceae, Asteraceae, Sapindaceae e Loranthaceae; Phakopsoraceae com sete espécies dos gêneros Phakopsora (três espécies), Batistopsora (uma espécie), Catenulopsora (uma espécie) e Crossopsora (duas espécies) encontradas em Annonaceae, Sapotaceae, Malpighiaceae, Fabaceae, Clusiaceae e Combretaceae; Raveneliaceae com seis espécies dos gêneros Ravenelia (três espécies), Sphaerophragmium (uma espécie), Diorchidium (uma espécie) e Esalque (uma espécie), todas em hospedeiras da família Fabaceae; Uropyxidaceae com cinco espécies distribuídas nos gêneros Dasyspora (uma espécie), Kimuromyces (uma espécie), Mimema (uma espécie), Porotenus (uma espécie) e Prospodium (uma espécie), ocorrendo em Annonaceae, Anacardiaceae, Fabaceae e Bignoniaceae; Chaconiaceae com três espécies sendo uma Aplopsora e duas em Chaconia, , encontradas em Vochysiaceae e Fabaceae; 
Pileolariaceae apenas com uma espécie de Skierka, parasita em pindaceae. Além disso, foram incluídas uma espécie de Desmella sobre Pteridophyta da família Thelypteridaceae, Cerradoa palmaea em Syagrus (Arecaceae), uma espécie de Aecidium e 4 de Uredo em plantas das famílias Annonaceae, Lauraceae, Solanaceae e Sapotaceae. A análise filogenética foi realizada com base na região $28 \mathrm{~S}$ do rDNA por meio de Inferência Bayesiana envolvendo os espécimes coletados e aqueles filogeneticamente relacionados disponíveis no GenBank. Esta é a primeira vez que foi realizado um estudo baseado em análises filogenéticas de Pucciniales do cerrado envolvendo membros de várias famílias. Neste estudo foi esclarecido de forma inédita a caracterização molecular de vários espécimes pertencentes à ordem Pucciniales encontrados em plantas endêmicas e introduzidas no cerrado, enriquecendo o banco de dados do NCBI e contribuindo para o estudo e compreensão da filogenia da ordem em estudos posteriores. De forma geral, os dados obtidos possibilitaram o entendimento do posicionamento filogenético de alguns grupos em níveis de gênero e espécies como o caso de membros da família Phakopsoraceae. No presente estudo a maioria das famílias de Pucciniales como Pucciniaceae, Raveneliaceae, Uropyxidaceae e Phakopsoraceae se mostraram polifiléticas, entretanto, os dados obtidos não foram suficientes para o esclarecimento das relações filogenéticas dos fungos causadores de ferrugens no cerrado quanto à alocação no nível de ordem, havendo a necessidade de aprofundamento das análises.

Palavras chave: Análise Filogenética, Ferrugens, LSU, Micodiversidade, Savana Brasileira 
Apesar de ser o maior grupo de fungos representados para o Cerrado pouco se sabe sobre a diversidade de Pucciniales neste bioma. As informações que se tem são baseadas quase que exclusivamente em estudos envolvendo a caracterização morfológica, com raros estudos envolvendo a filogenia molecular. Entre as contribuições existentes podem-se citar os trabalhos de Beenken (2012) e Beenken et al. (2014) na identificação e caracterização filogenética de fungos causadores de ferrugem em plantas hospedeiras da família Annonaceae sendo algumas espécies de Xylopia sp. e Annona sp., encontradas em regiões do Cerrado brasileiro nos estados de Goiás, Mato Grosso, Minas Gerais, São Paulo, Tocantins e no Distrito Federal. Beenken et al. (2012) e Beenken (2014) separaram espécies de Dasyspora e Phakopsora, parasitas de Annonaceae, através da análise conjunta da região ITS (internal transcribed spacer region) e do gene para CO3 (mitochondrial cytochrome oxidase subunit 3 ).

Recentemente, Souza et al. (2015), identificaram molecularmente e morfologicamente uma espécie de Uromyces, até então, conhecida apenas em sua fase assexuada (Aecidium goyazense). Foi caracterizada a fase teleomórfica, uma espécie de Uromyces encontrada causando galhas em uma planta hemiparasita (Phthirusa stelis -Loranthaceae) comum no Cerrado. A análise filogenética foi realizada com base na região $28 \mathrm{~S}$ do rDNA, uma região atualmente recomendada no estudo de fungos que causam ferrugens (Hyde 2014).

Tradicionalmente, a taxonomia dos fungos causadores de ferrugem foi baseada no estudo de caracteres morfológicos (Cummins \& Hiratsuka 2003, Hennen et al. 2005), entretanto estudos filogenéticos recentes baseados no rDNA e alguns genes nucleares (Maier et al. 2003, Wingfield et al. 2004, Aime 2006, Bauer et al. 2006, van Der Merwe et al. 2007, Dixon et al. 2010, Zualaga et al. 2011, Beenken et al. 2012, Beenken 2014, Beenken \& Wood 
2015), contribuíram para o esclarecimento dessas relações em diversos níveis hierárquicos de classificação taxonômica.

As relações filogenéticas dentro do grupo não estão consolidadas. Um dos primeiros trabalhos sobre filogenia dos fungos causadores de ferrugem (Maier et al. 2003) baseou-se na comparação de sequências da região $28 \mathrm{~S}$ do rDNA. Nesta análise foram incluídos 52 espécimes pertencentes a várias famílias da ordem por meio da Inferência Bayesiana. Com isso os autores confirmaram a existência de um ancestral comum para os membros dos gêneros Puccinia, Uromyces, Endophyllum e Cumminsiella. Os Pucciniales autoécios infectando Rosaceae como Phragmidium, Kuehneola, Triphragmium e Trachyspora formaram também um grupo monofilético. O gênero Ochropsora foi filogeneticamente relacionado com Tranzschelia. Pucciniastraceae sensu Dietel (1938) se mostrou monofilético e próximo de Pucciniaceae s.l. (Dietel 1928). Neste estudo (Maier et al. 2003), previam-se que os gêneros Chrysomyxa, Coleosporium, Cronartium, Gymnosporangium, Melampsora, Phragmidium e Tranzschelia seriam monofiléticos, ao contrário de Puccinia, Pucciniastrum, Thekopsora e Uromyces de filogenia polifilética.

Estudos envolvendo filogenia da ordem Pucciniales em grande escala foram pioneiramente desenvolvidos por Wingfield et al. (2004) utilizando amostras de vários locais do mundo, mas principalmente de regiões de clima temperado. Este estudo foi baseado em dados da região 18S do rDNA utilizando Máxima Parcimônia e mostrou a evidente divisão entre espécimes com estágios eciais em hospedeiras gimnospermas e aquelas com esta mesma fase em angiospermas. Os dados obtidos, mostraram que famílias taxonomicamente definidas por meio da morfologia estavam de acordo com a taxonomia preestabelecida por Cummins \& Hiratsuka (2003), uma vez que, dentro dos clados houveram evidências morfológicas e congruência entre as famílias. Os gêneros Racospermyces, Maravalia, Hemileia e Caeoma se mostraram basais para a principal sub-divisão filogenética e, provavelmente, representavam a 
forma mais antiga das linhagens de fungos causadores de ferrugem. Usando esses dados de sequências, estimaram que as ferrugens divergiram em torno de seus parentes mais próximos a 150 milhões de anos atrás.

Aime (2006) no sentido de resolver as relações em nível de família dos fungos causadores de ferrugem utilizaram dois genes do rDNA (18S e 28S) para resolver alguns conflitos e estruturar a sistemática. Nesta análise três suborders de ferrugens foram reestabelecidas e das 13 famílias amplamente aceitas pela morfologia, 8 foram suportadas no todo ou parcialmente (Coleosporiaceae, Melampsoraceae, Mikronegeriaceae, Phakopsoraceae, Phragmidiaceae, Pileolariaceae, Pucciniaceae, Raveneliaceae), 3 foram redundantes (Cronartiaceae, Pucciniastraceae, Pucciniosiraceae), e a situação de 2 (Chaconiaceae, Uropyxidaceae) não pôde ser resolvida. A família Mikronegeriaceae e Caeoma torreyae se mostraram como basais. Aime (2006) concluiu que a morfologia por si só não possibilita o estabelecimento das relações de Pucciniales em níveis hierárquicos mais elevados como famílias e, por outro lado, a especificidade de hospedeira tem desempenhado um papel significativo na evolução dos fungos causadores de ferrugens.

Zualaga et al. (2008) realizaram uma importante revisão sobre aspectos gerais dos fungos causadores de ferrugem e atentaram sobre a necessidade do estudo desse grupo fúngico em termos filogenéticos, principalmente nas regiões tropicais, consideradas como as maiores em concentração de diversidade de plantas hospedeiras e consequentemente espécies fúngicas devido ao clima favorável que contribui para o desenvolvimento de todos os estágios do ciclo de vida.

Zualaga et al. (2011), com base em dados da região 28S (especificamente domínios D1/D2) em análise sob Máxima Parcimônia, fizeram um estudo sobre a relação filogenética de membros de Pucciniales em diferentes regiões da Colômbia e os resultados sustentaram a validade taxonômica das famílias Pucciniaceae, Phakopsoraceae, Phragmidiaceae, 
Pileolariaceae, Mikronegeriaceae, Coleosporiaceae e Cronartiaceae, enquanto Pucciniosiraceae representa um grupo redundante com Pucciniaceae. As análises indicaram que Uropyxidaceae, Raveneliaceae, Chaconiaceae e Pucciniastraceae correspondem a famílias polifiléticas. Melampsoraceae formou um grupo basal para os Pucciniales. Eles sugeriram análises adicionais com uma maior quantidade de sequências de fungos causadores de ferrugem tropicais dentro de esforços globais para redefinir a taxonomia da ordem Pucciniales. Além disso, propuseram priorizar estudos filogenéticos de gêneros que incluem um grande número de espécies de fungos causadores de ferrugem nos trópicos como: Gerwasia, Hemileia, Phragmidium, Prospodium, Puccinia e Uromyces.

Conforme já mostrado o estudo da filogenia da ordem Pucciniales para o esclarecimento das relações filogenéticas entre famílias tem sido realizado com o uso de regiões gênicas do rDNA (18S e 28S) por serem mais conservadas, permitindo a comparação entre grupos filogeneticamente distantes.

Se tratando do estudo filogenético para a discriminação em nível de gêneros e espécies, além das regiões mencionadas, são utilizadas também outras regiões com melhor sinal fillogenético como $\beta$-tubulina, Fator de Elongação, ITS e CO3 do mDNA, permitindo uma separação robusta a nível específico e distinção intraespecífica.

A exemplo temos o trabalho recente de McTaggart et al (2016) que utilizaram, além das regiões $18 \mathrm{~S}$ e $28 \mathrm{~S}$ do rDNA, a região $\mathrm{CO} 3$ do mDNA para determinar membros de Pucciniales em níveis de família, gêneros e espécies e analisar a co-evolução entre esses taxa com os seus respectivos hospedeiros. Neste trabalho foi observado que a colonização dos fungos causadores de ferrugem em hospedeiras alternativas pode ter contribuído para a especiação de muitos membros de Pucciniales e que a maioria pode ter co-evoluído juntamente com seus hospedeiros. 
Maier et al. (2007) e Van Der Merve et al. $(2007,2008)$ determinaram que os gêneros Puccinia e Uromyces são polifiléticos com base em sequências parciais das regiões $\beta$-tubulina e Fator de Elongação e, além disso, analisaram a co-evolução destes gêneros com seus grupos de hospedeiros considerando a alternância dos mesmos, o que, muitas vezes, dificulta o entendimento desta relação.

Yang et al. (2015) usaram sequências de 28S e de ITS para discriminar e publicar novas espécies de Thekopsora em Cornus (Cornaceae) na China e Padamsee \& Mckenzie (2015) determinaram uma nova espécie, Pucciniastrum myosotidii encontrada em Myosotidium hortensium, baseados nas regiões $18 \mathrm{~S}$ e 28S.

Considerando a importância desses fungos não somente por infectar plantas nativas do Cerrado e outros biomas, como também causando grandes problemas em plantas cultivadas, é imprescindível que seja realizado um estudo filogenético dos Pucciniales brasileiros nos moldes do que foi feito por Zualaga et al. (2011) para a Colômbia.

Assim, o presente trabalho, se constituiu em uma tentativa de se proceder uma ampla análise filogenética de um grupo de Pucciniales, representativos da ordem no Cerrado. 
Todas as plantas com sintomas típicos de ferrugens foram coletadas durante as expedições realizadas em áreas do Cerrado Brasileiro. Os espécimes primeiramente foram caracterizados e identificados morfologicamente (capítulo 1) e somente amostras com DNA de boa qualidade foram utilizadas nas análises filogenéticas.

Um total de 64 espécimes de Pucciniales do Cerrado foram selecionados para compreensão do relacionamento filogenético, incluindo fungos na sua forma assexuada e sexuada distribuídos em seis famílias diferentes (Chaconiaceae, Phakopsoraceae, Pileolariaceae, Pucciniaceae, Raveneliaceae e Uropyxidaceae). Entre os 64 taxa, alguns pertencem a mesma espécie coletada em períodos ou localidades diferentes. No total, 36 espécies distintas foram coletadas nos estados de Goiás, Maranhão, Mato Grosso, Minas Gerais e no Distrito Federal (Tabela 1).

A Tabela 1 contêm as informações (espécie, hospedeira e código de acesso) dos espécimes coletados no Cerrado e os códigos de acesso das sequências da região parcial do 28S do rDNA obtidos no GenBank para a análise filogenética.

A análise foi baseada em Inferência Bayesiana (IB), envolvendo 122 OTUs, sendo 65 taxa de espécimes coletados no Cerrado e 57 cujas sequências foram obtidas do GenBank. A árvore filogenética foi enraizada com Platygloea disciformis, um basidiomiceto da ordem Platygloelales (Figura 2). 


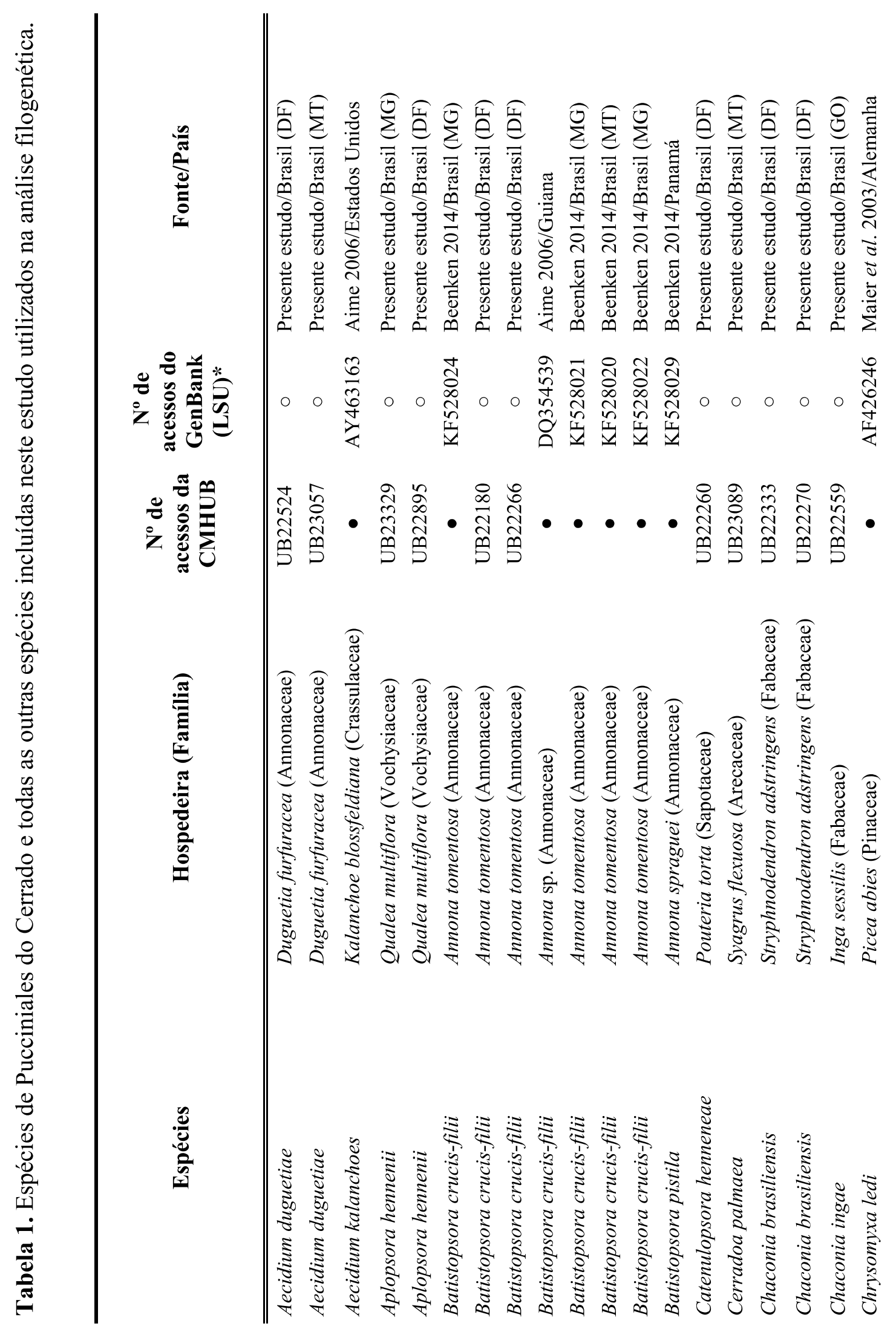


量

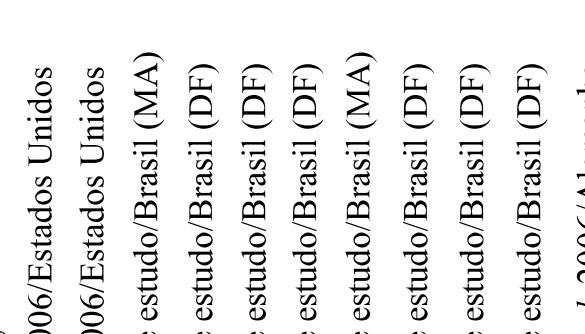

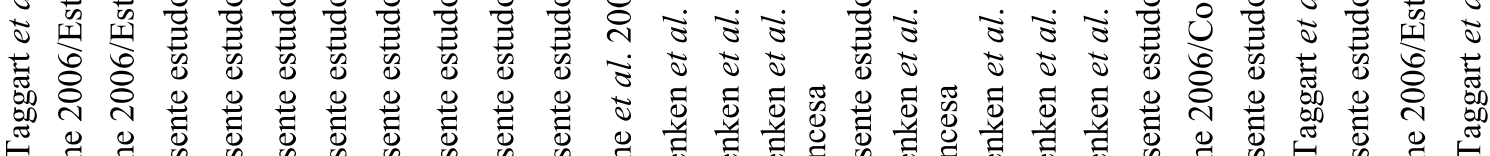

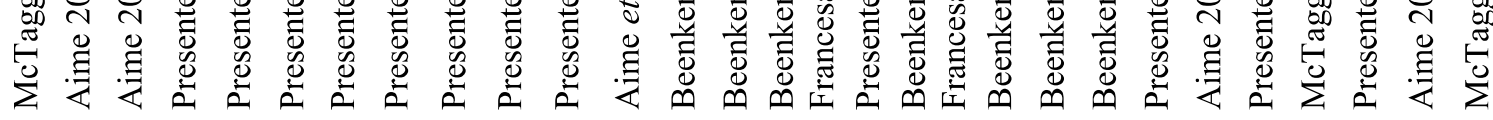

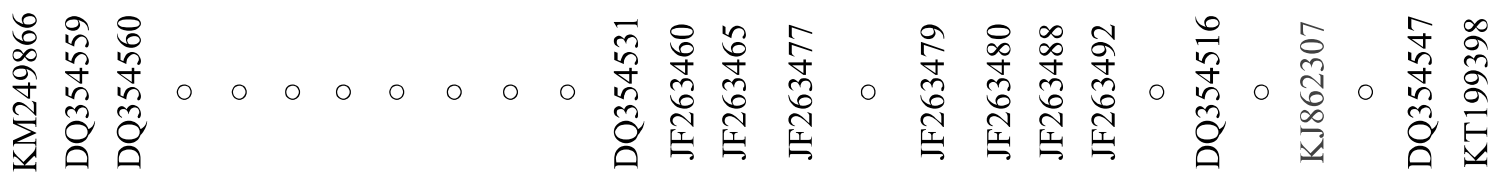

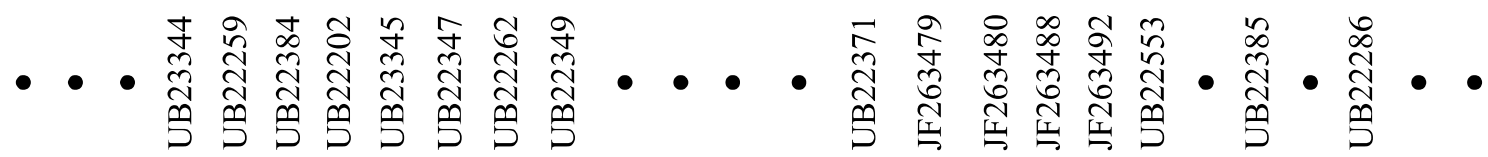

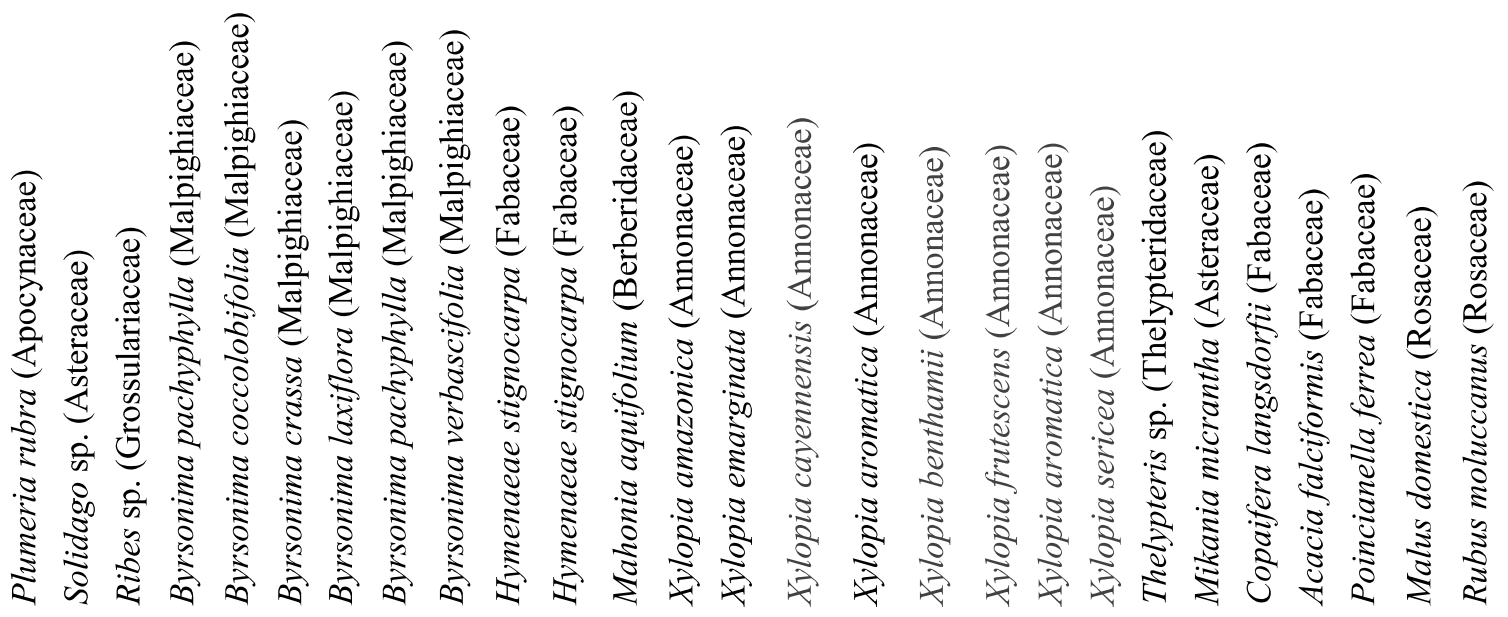

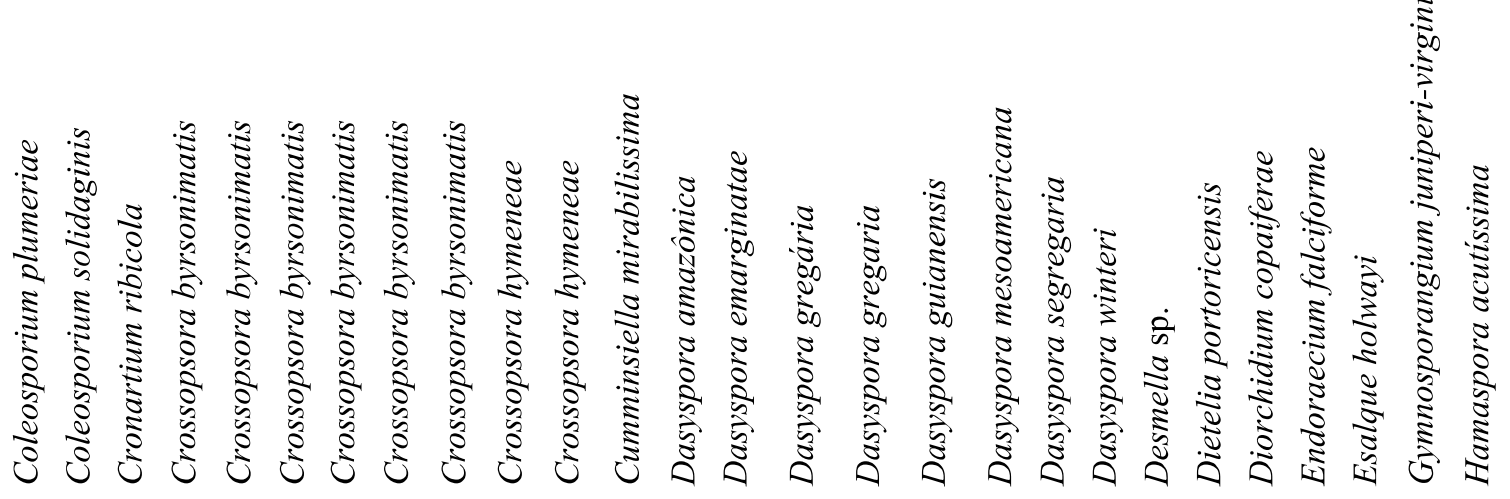




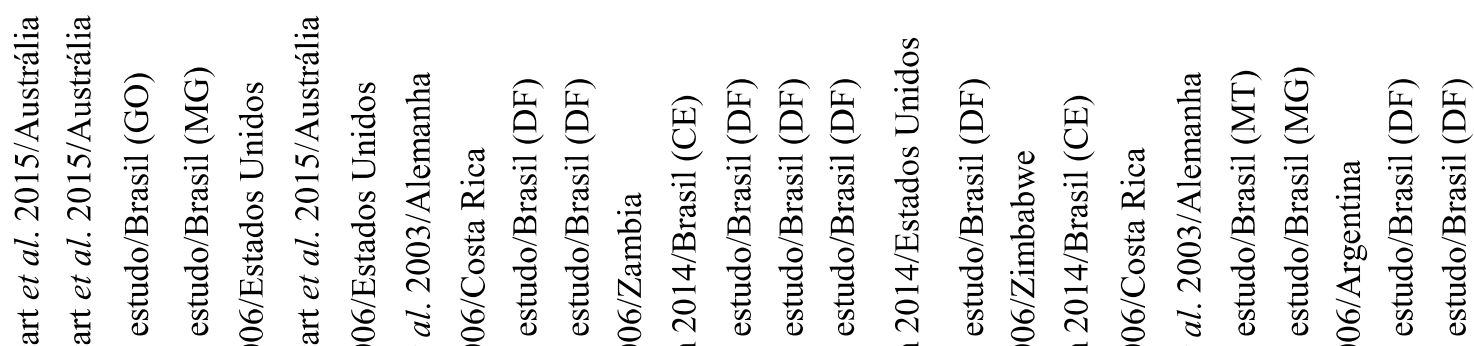

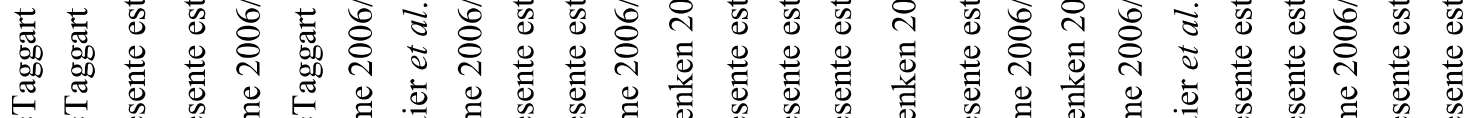

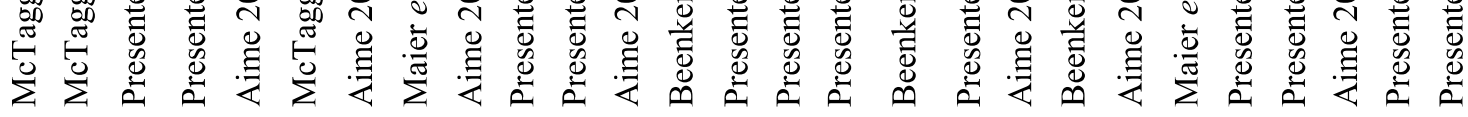

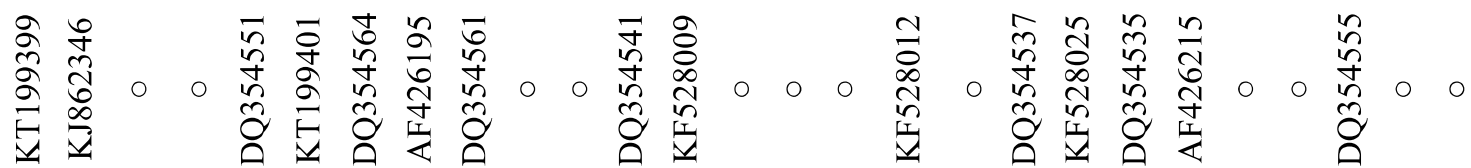

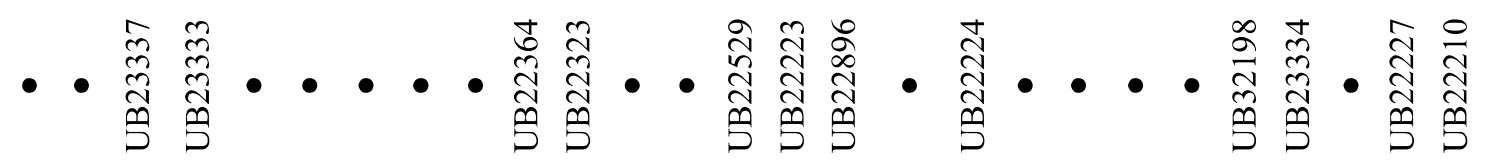

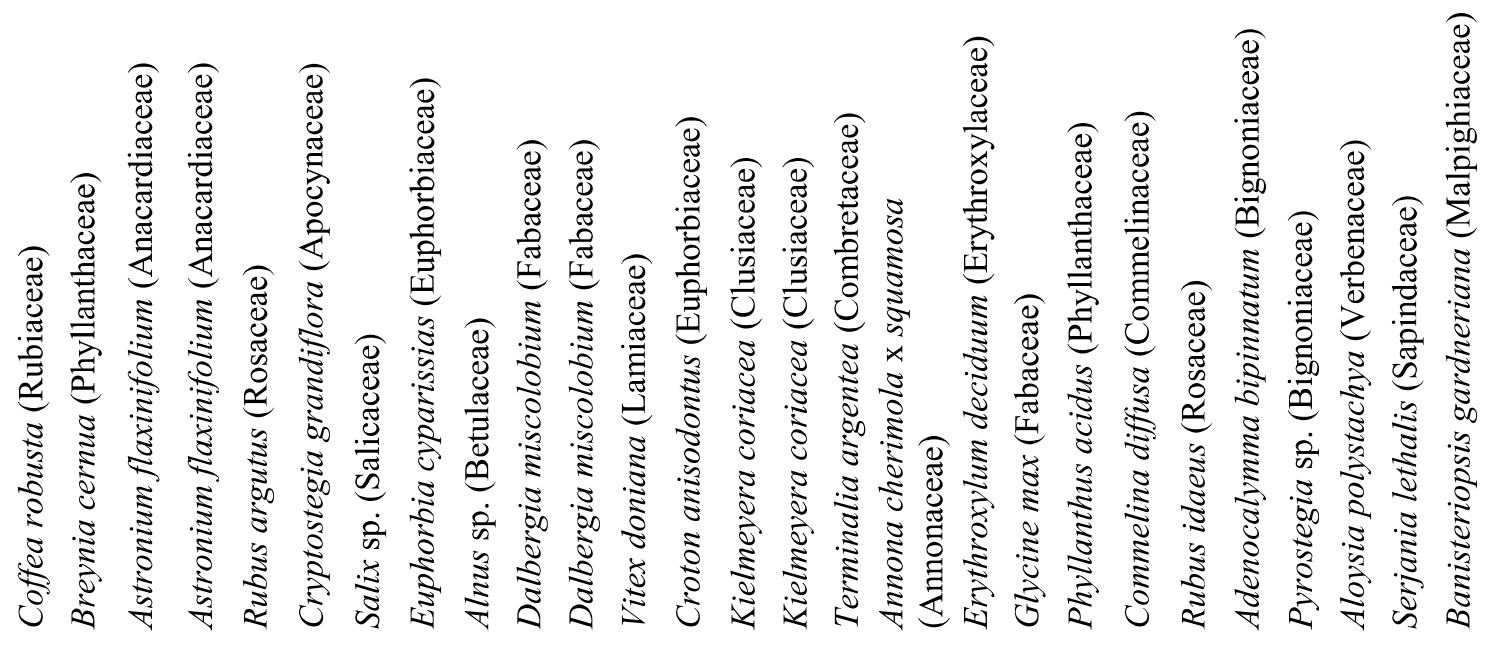

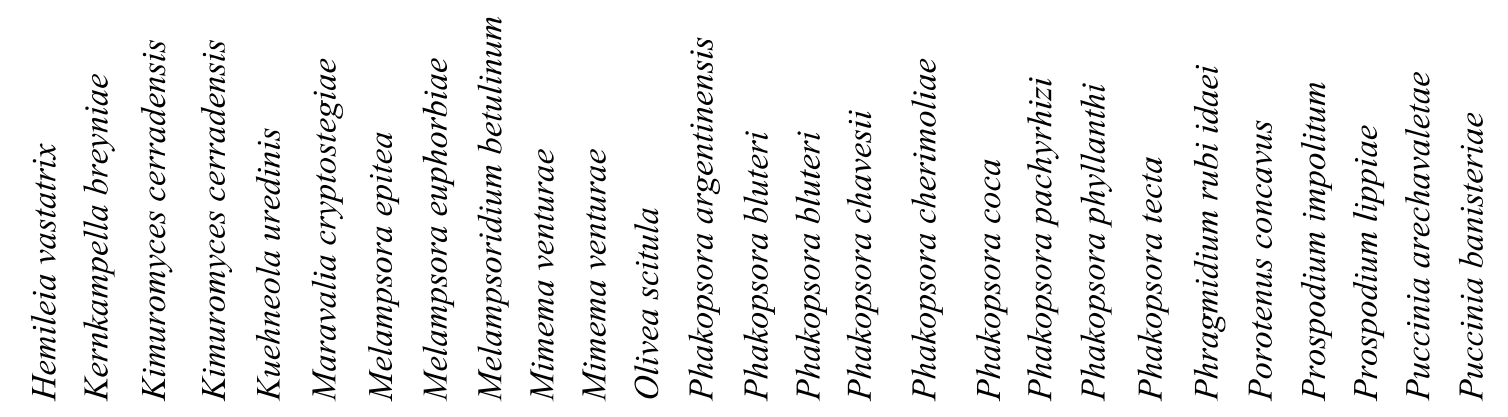




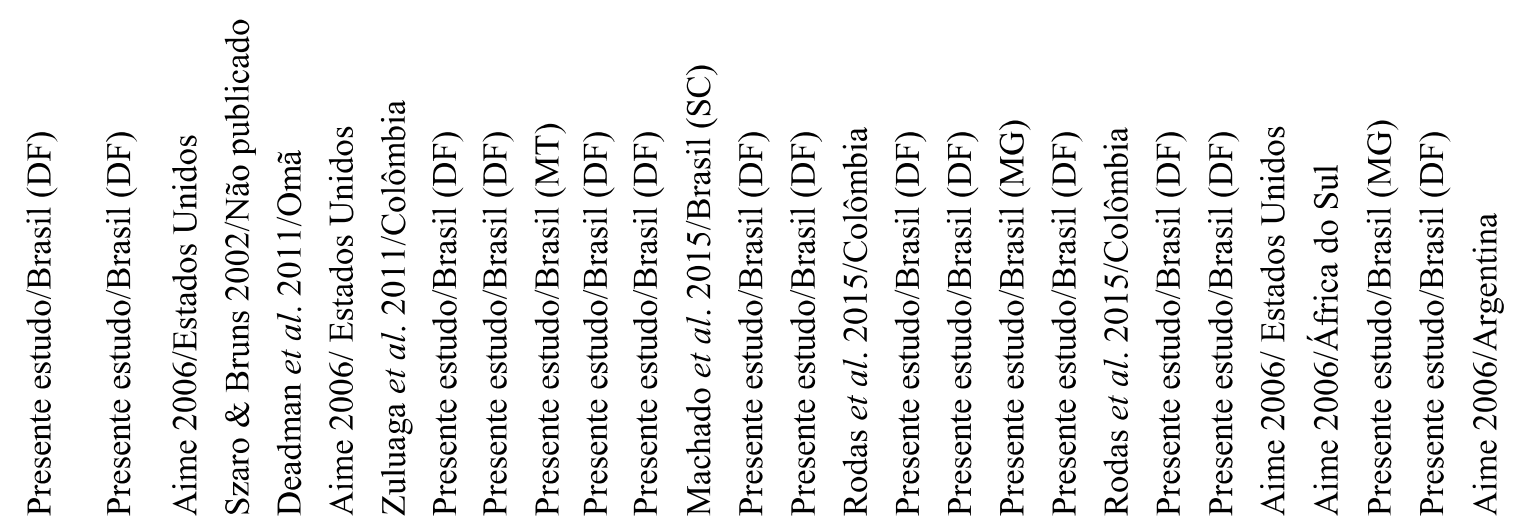

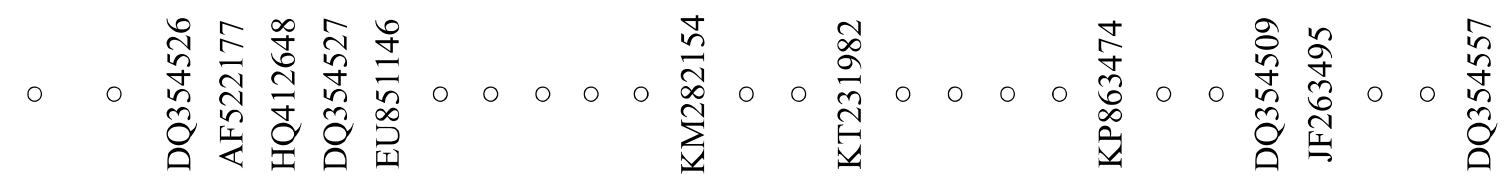
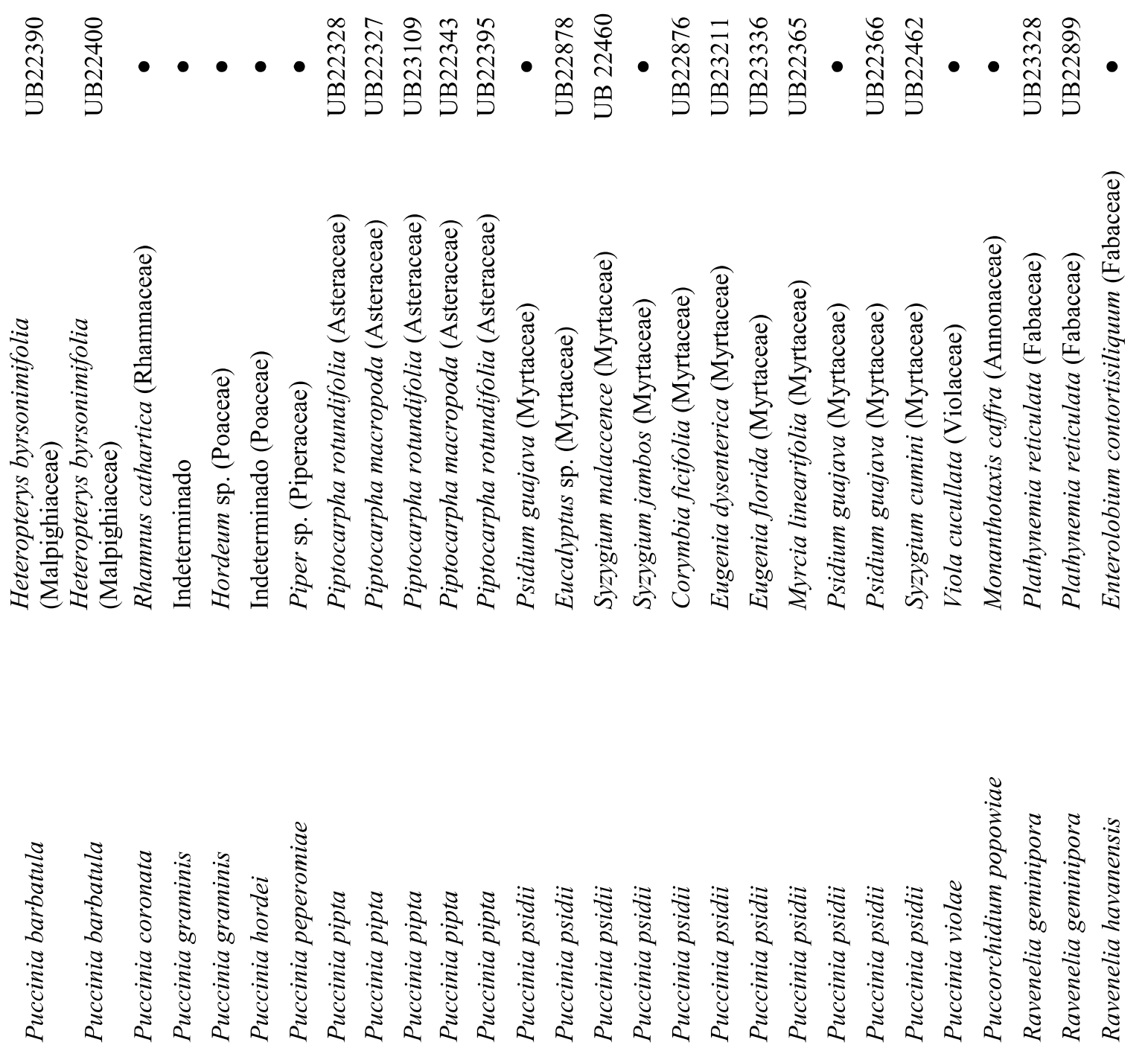


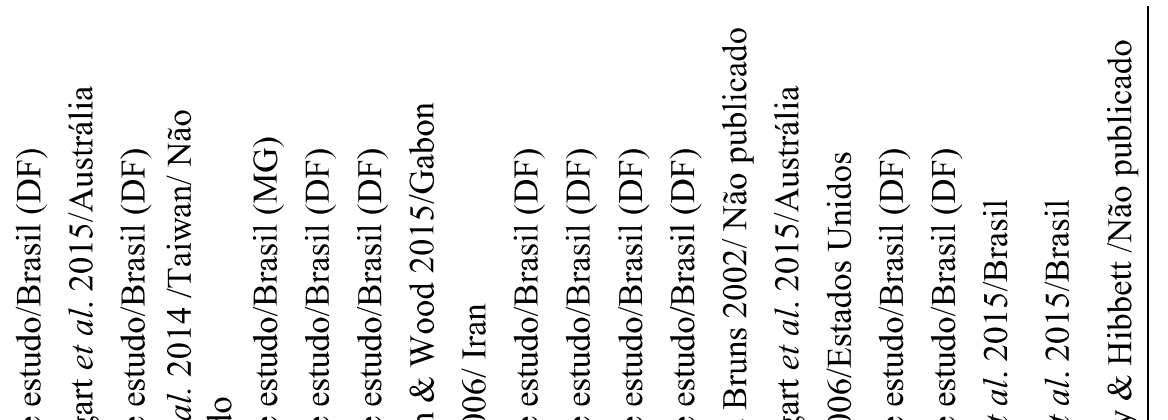
$\begin{array}{llll} & \\ 0\end{array}$

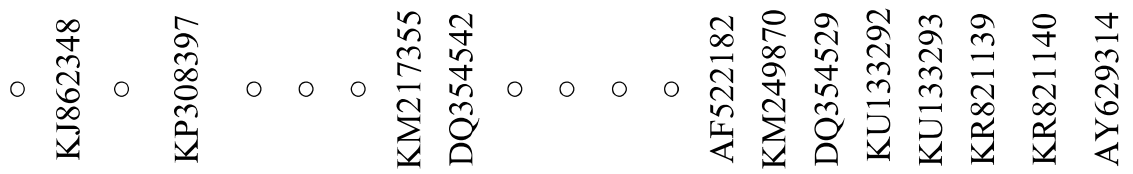

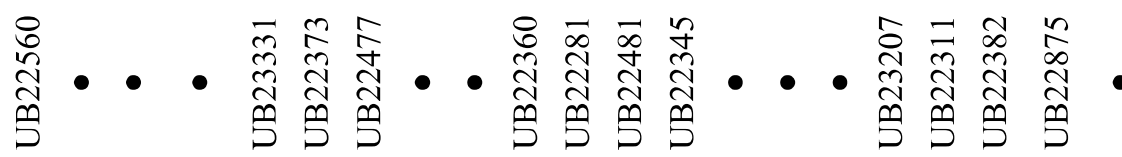

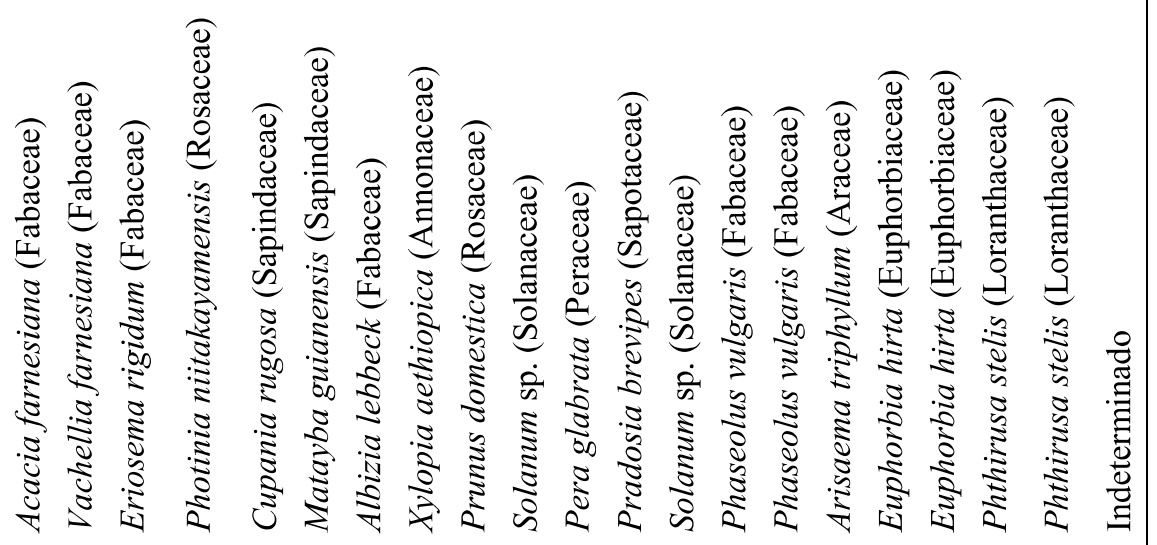




\section{Extração de DNA}

O material fúngico foi retirado das estruturas contidas nos tecidos vegetais frescos ou herborizados por meio de raspagem com bisturi, e transferidos com auxílio de pincéis de pintura e depositados previamente em uma folha de papel. Logo após, as amostras contendo estruturas fúngicas como esporos e espermácias, retirados de pícnios, écios, urédios ou télios, livres de contaminantes, foram transferidos e armazenados em tubos Eppendorf de 1,5 $\mathrm{ml}$ e congelados a $-20^{\circ} \mathrm{C}$ para posterior extração do DNA genômico.

A extração do DNA genômico foi realizada conforme o método CTAB, segundo o protocolo de Doyle \& Doyle (1990) adaptado. A modificação foi realizada durante a adição do $\mathrm{CTAB}$ pré-aquecido a $65^{\circ} \mathrm{C}$ ao macerado antes da incubação em banho-maria a mesma temperatura. Também foram realizadas tentativas de extração utilizando o método FenolClorofórmio de Reader \& Broda (1985) para algumas amostras.

Para a realização do método de extração CTAB o material fúngico foi macerado em Nitrogênio líquido com o auxílio de micropistilo em tubos de $1,5 \mathrm{~mL}$, ao qual foi adicionado $600 \mu \mathrm{L}$ de tampão CTAB a $2 \%\left(1,4 \mathrm{~mol} \mathrm{~L}^{-1}\right.$ de $\mathrm{NaCl}, 0,5$ mol L ${ }^{-1}$ de EDTA, $2 \%$ de CTAB, Polivinilpirrolidona -40 a 1\% e $1 \mathrm{M}$ de Tris- $\mathrm{HCl}-\mathrm{pH} 8,0$ ) e $\beta$-Mercaptoetanol a $1 \%$, previamente aquecido a temperatura de $65^{\circ} \mathrm{C}$. A suspensão foi homogeneizada manualmente por 30 segundos e incubada em banho-maria a $65^{\circ} \mathrm{C}$ por 30 minutos com agitação em intervalos de 10 minutos. Após este processo, foram adicionados às amostras, $600 \mu \mathrm{L}$ de Clorofórmio/Álcool Isoamílico (24:1) e homogeneizadas por 30 segundos, antes de serem centrifugadas a 12000 rpm por 10 minutos em temperatura ambiente. Após a centrifugação o sobrenadante foi retirado em frações de $200 \mu \mathrm{L}$ (média de duas vezes) e transferido para outro tubo. Em seguida o DNA contido no volume total adquirido foi precipitado com $54 \%$ do volume de Isopropanol gelado por no mínimo 1 hora a temperatura de $-20^{\circ} \mathrm{C}$. 
Posteriormente as amostras foram centrifugadas a $12000 \mathrm{rpm}$ por 15 minutos e o sobrenadante foi descartado. Ao precipitado foi adicionado $600 \mu \mathrm{L}$ de Etanol $70 \%$, para lavagem, e centrifugado novamente a $12000 \mathrm{rpm}$ por 10 minutos. Finalmente, o sobrenadante foi descartado e realizou-se uma última lavagem do precipitado com $600 \mu \mathrm{L}$ de Etanol 95\% e centrifugação a $12000 \mathrm{rpm}$ por 10 minutos.

A seguir, o precipitado foi secado em temperatura ambiente por 30 minutos, ressuspendido em $30 \mu \mathrm{l}$ de água milli-Q autoclavada sem RNase e armazenados à $-20^{\circ} \mathrm{C}$.

Algumas vezes o precipitado foi secado em speed vacuum (Eppendorf Concentrator Plus 2231 Humburg) à temperatura ambiente por 10 minutos e ressuspendido em $30 \mu 1$ de TE com $0,3 \mu \mathrm{L}$ de RNase $(10 \mathrm{mg} / \mathrm{mL})$, antes de armazenar o material à temperatura de $-20^{\circ} \mathrm{C}$.

\section{Amplificação e sequenciamento do DNA}

As reações de amplificações do DNA foram feitas via PCR (Polymerase Chain Reaction). A reação de PCR inicial foi realizada em um volume final de $25 \mu 1$, contendo DNA genômico (10 ng/ $\mu \mathrm{L})$, Tampão 1X para a Taq DNA Polimerase (Invitrogen) (10-50 mM TRIS$\mathrm{HCl}, \mathrm{pH} 8.3,50 \mathrm{mM} \mathrm{KCl}), \mathrm{MgCl}_{2}(1.5 \mathrm{mM})$, dNTPs (0,2 mM); Iniciadores ( $0,4 \mu \mathrm{M}$ cada), Taq DNA Polimerase Platinum (Invitrogen) (0.5 U) e Água Milli-Q esterilizada.

As amplificações foram executadas em um termociclador ESCO Swift ${ }^{\mathrm{TM}}$ MaxPro (Singapura). A reação foi submetida a um ciclo de desnaturação inicial do DNA a $94^{\circ} \mathrm{C}$ por quatro minutos; para a amplificação foram realizados 39 ciclos de desnaturação das fitas a $94^{\circ} \mathrm{C}$ por um minuto; para anelamento dos iniciadores, estes foram submetidos a temperaturas específicas contidas na Tabela 2, por um minuto e extensão das fitas sob $72^{\circ} \mathrm{C}$ por um minuto. Subsequentemente, foi procedida uma extensão final a $72^{\circ} \mathrm{C}$ por cinco minutos. 
Para a obtenção de fragmentos com tamanho suficiente, sequenciados pelo método Sanger, para análise filogenética foi necessário a amplificação de fragmentos utilizando quatro iniciadores, dois externos (Rustinv2/LR6) e dois internos (LR0R/RUST1) mostrados na Figura 1.

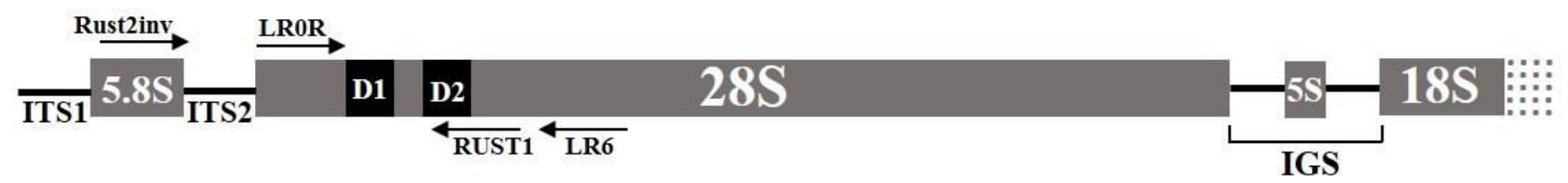

Figura 1. Localização dos iniciadores utilizados para amplificar uma região parcial do $28 \mathrm{~S}$ do rDNA.

Conforme pode ser observado também na Tabela 2, as amplificações resultaram em produtos de tamanhos de aproximadamente 1400 pares de base para os iniciadores externos (Rustinv2/LR6) e de 600 pares de bases para os iniciadores internos (LR0R/RUST1) e estes foram preparados para o sequenciamento conforme se segue.

A descrição dos iniciadores utilizados bem como as respectivas temperaturas de anelamento está listada na Tabela 2.

Tabela 2. Iniciadores utilizados para amplificação da região 28S do rDNA de Pucciniales.

\begin{tabular}{|c|c|c|c|c|c|c|}
\hline Região & Inici & ores & Sequências & $\begin{array}{c}\text { Temp. de } \\
\text { Anelamento }\end{array}$ & $\begin{array}{c}\text { Tamanho } \\
\text { (bp) }\end{array}$ & Referências \\
\hline \multirow{4}{*}{$\begin{array}{c}28 \mathrm{~S} \\
(\mathrm{LSU})\end{array}$} & Externer & Rust2inv & GATGAAGAACACAGTGAAA & \multirow{2}{*}{$55^{\circ} \mathrm{C}$} & \multirow{2}{*}{1400} & Aime (2006) \\
\hline & & LR6 & CGCCAGTTCTGCTTACC & & & Vilgalys \& Hester (1990) \\
\hline & \multirow{2}{*}{ Internos } & LR0R & ACCCGCTGAACTTAAGC & \multirow{2}{*}{$53^{\circ} \mathrm{C}$} & \multirow{2}{*}{600} & Moncalvo et al. (1995) \\
\hline & & RUST1 & GCTTACTGCCTTCCTCAATC & & & Kropp et al. (1997) \\
\hline
\end{tabular}




\section{Sequenciamento}

Os produtos de PCR da região $28 \mathrm{~S}$ do rDNA flanqueada pelos iniciadores Rust2inv/LR6, bem como LR0R/RUST1, foram tratados com Exonuclease I e Shrimp Alkaline Phosphatase (ExoSAP-IT PCR Product Cleanup). Para tanto adotou-se o seguinte protocolo: adicionou-se $2 \mu \mathrm{L}$ de ExoSAP e $5 \mu \mathrm{L}$ do produto de PCR em um microtubo de 0,6 mL, e incubou-se a $37^{\circ}$ por 15 minutos no primeiro ciclo $\mathrm{e}^{\circ} \mathrm{C}$ por 15 minutos no segundo ciclo.

Depois deste procedimento, parte do sequenciamento foi feito no Brasil no Centro de Pesquisa Renê Rachou da Fundação OsWaldo Cruz (FIOCRUZ) em Belo Horizonte, onde se utiliza o sequenciador ABI 3730 da Life Technologies por meio da tecnologia de sequenciamento Sanger, subsidiado pelo projeto Brazilian Barcode of Life (BrBOLhttp://brbol.org/pt-br) financiado pelo Conselho Nacional de Desenvolvimento Científico e Tecnológico (CNPq).

A outra fração do sequenciamento das amostras foi realizada, também pelo método Sanger, pela empresa ACTGene Análises Moleculares Ltda (Centro de Biotecnologia, UFRGS, Porto Alegre, RS) utilizando o sequenciador automático AB 3500 Genetic Analyzer.

\section{Alinhamento e Análise filogenética}

As sequências obtidas foram analisadas e editadas no software BioEdit 7.1.3.0 (Hall 2012) ou Geneious R8 (Kearse et al. 2012) realizando a remoção de segmentos com baixa qualidade e conferência e edição das bases de acordo com os eletroferogramas. As sequências foram obtidas a partir da fita consenso resultante do alinhamento das 4 fitas correspondentes aos iniciadores internos e externos da região 28S do rDNA utilizados (Tabela 2), e confirmadas por comparação no GenBank usando a ferramenta Blastn. 
Para criação do banco de dados foram utilizadas sequências depositadas no GenBank de taxa filogeneticamente relacionados com os espécimes coletados e espécies-tipo de gêneros e famílias da ordem Pucciniales. Adicionalmente, um grupo externo foi selecionado para o banco de dados.

O alinhamento múltiplo das sequências foi realizado por meio do software MEGA 6 (Tamura et al. 2013) com auxílio do programa Muscle (Edgar 2004 a e b), onde ajustes manuais foram realizados e o alinhamento checado. Os espaços vazios (gaps) foram considerados como dados ausentes.

As relações filogenéticas foram realizadas por Inferência Bayesiana usando o Mr Bayes v. 3.2 (Ronquist et al. 2012).

A análise por Inferência Bayesiana (BI) foi realizada empregando Cadeias de Markov, método de Monte Carlo (MCMC). Antes de executar a análise de BI, foi determinado o melhor modelo de substituição de nucleotídeos com MrModeltest 2.3 (Posada \& Buckley 2004). Uma vez que os valores de verossimilhança foram calculados, os modelos foram selecionados de acordo com o Critério de Informação de Akaike (AIC). O modelo selecionado foi o GTR + I + G.

A análise foi realizada no portal CIPRES (Miller et al. 2010) usando MrBayes v. 3.2 (Ronquist \& Heulsenbeck 2012). Quatro cadeias MCMC foram executadas simultaneamente, iniciando as árvores aleatoriamente até 10000000 gerações. As árvores foram amostradas a cada 1000 gerações, resultando em 10000 árvores. As primeiras 2500 árvores foram descartadas e a probabilidade posterior foi determinada a partir da árvore consenso gerada por meio das 7500 árvores remanescentes. A árvore foi enraizada com a espécie Platygloea disciformis, visualizada pelo programa Figtree (Rambaut 2009) e exportada para programas de edição. 


\section{RESULTADOS E DISCUSSÃO}

A família com o maior número de representantes foi a Pucciniaceae com sete espécies, sendo cinco de Puccinia spp. e duas de Uromyces spp; tendo como hospedeiras plantas das famílias Annonaceae, Myrtaceae, Malpighiaceae, Euphorbiaceae, Asteraceae, Sapindaceae e Loranthaceae. A família Phakopsoraceae foi representada por 12 espécimes pertencentes aos quatro gêneros: Phakopsora, Batistopsora, Catenulopsora e Crossopsora encontrados em plantas das famílias Annonaceae, Sapotaceae, Malpighiaceae, Fabaceae, Clusiaceae e Combretaceae. Na família Raveneliaceae três espécimes de Ravenelia, e um de Sphaerophragmium, Diorchidium e Esalque foram encontrados em hospedeiras da família Fabaceae. Em Uropyxidaceae foram coletadas amostras dos gêneros Dasyspora, Kimuromyces, Mimema, Porotenus e Prospodium em hospedeiras pertencentes a Annonaceae, Anacardiaceae, Fabaceae e Bignoniaceae. A família Chaconiaceae possui três espécies, sendo uma Aplopsora sp. e duas Chaconia sp., encontradas em hospedeiras de Vochysiaceae e Fabaceae. Uma Skierka, foi a única Pileolariaceae encontrada em uma Sapindaceae indeterminada. Também foram incluídas duas espécies de posicionamento incerto: Cerradoa palmaea em folhas de Syagrus flexuosa (Arecaceae) e Desmella sp. sobre uma Pteridophyta da família Thelypteridaceae, além de cinco formas assexuadas, um Aecidium sp. em Annonaceae e quatro Uredo spp., em plantas das famílias Lauraceae, Solanaceae e Sapotaceae (Tabela 1).

No total, 122 sequências da região 28S do rDNA (Tabela 1) foram utilizadas na análise filogenética, resultando em 1206 pb alinhadas, das quais 421 foram informativas para parcimônia, 525 foram variáveis e 664 foram conservadas.

A árvore filogenética é mostrada na Figura 2, onde as famílias da ordem Pucciniales são destacadas por cores. Os clados estão enumerados de 1 a 20 e a árvore foi subdividida em 6 setores para a ampliação e para facilitar a visualização (Figuras 3 a 9). 


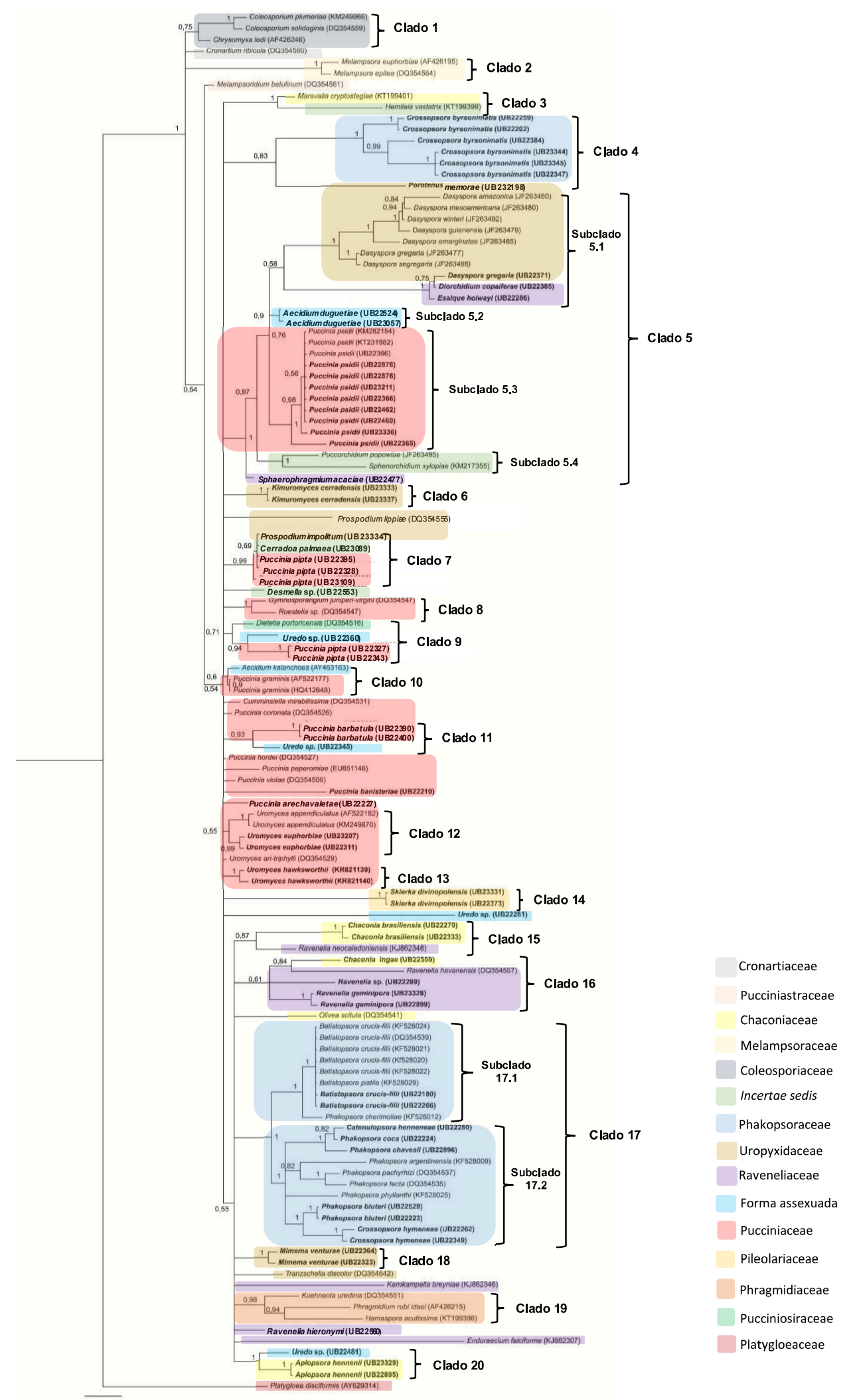

Figura 2. Árvore filogenética inferida a partir da análise de Inferência Bayesiana com base nas sequências da região 28S do rDNA de representantes da ordem Pucciniales. Os valores de probabilidades posterior acima de 0,50 são indicados nos nós. Os números de acessos dos espécimes depositados na CMHUB e dos acessos depositados no GenBank estão em parênteses. Os espécimes deste estudo são destacados em negrito. A árvore foi enraizada por Platygloea disciformis. 


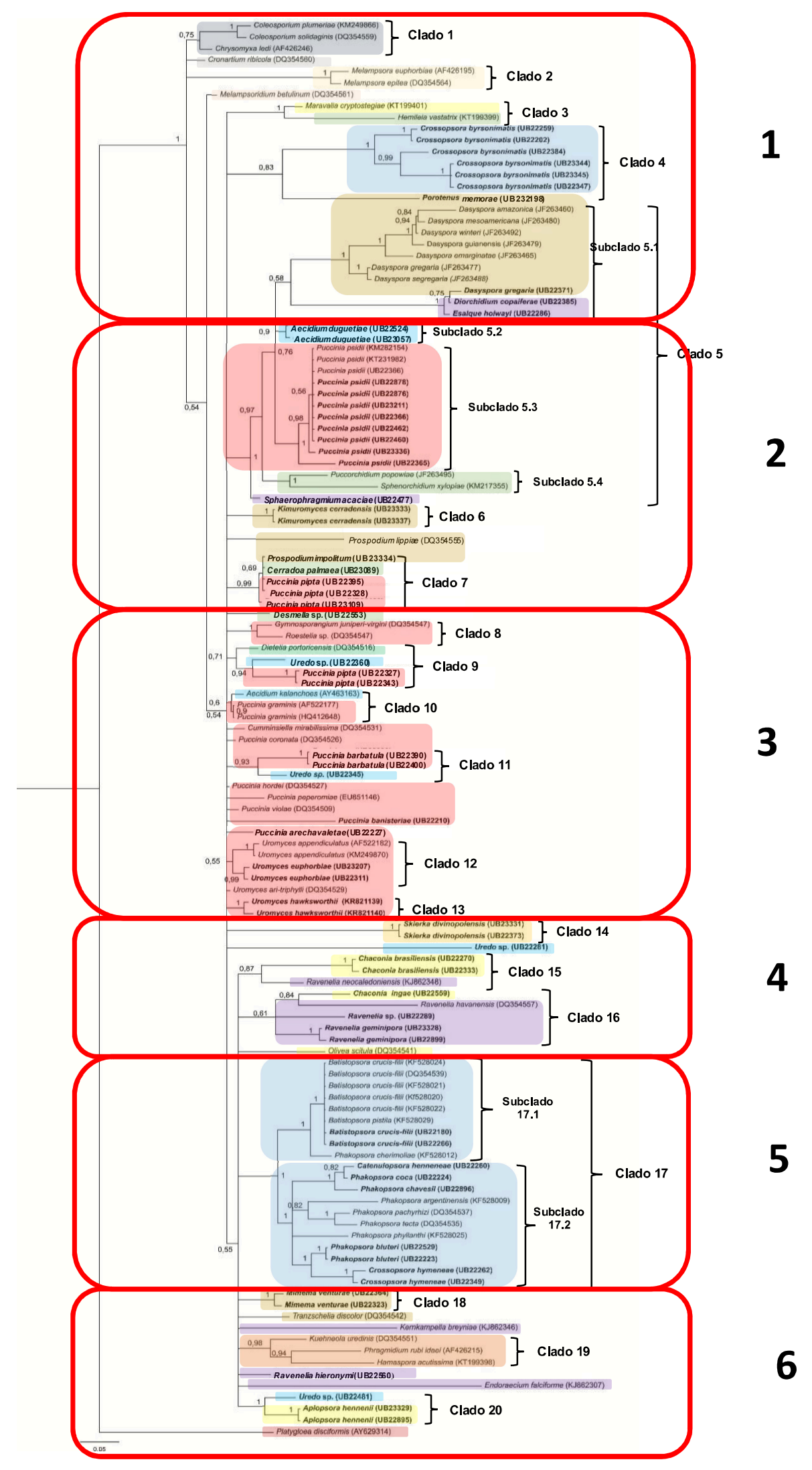

Figura 3. Representação da árvore filogenética de espécies da ordem Pucciniales subdividida em 6 setores. 
A ordem Pucciniales dentro do subfilo Pucciniomycotina, apresenta-se em condição monofilética, entretanto as famílias nela contidas são em grande parte polifiléticas, conforme mostrado na presente análise (Figura 2) e em estudos anteriores baseados nas regiões 28S e 18S do rDNA (Aime et al. 2006, Bauer et al. 2006, Aime et al. 2014).

De maneira geral este estudo possibilitou o esclarecimento das relações filogenéticas de alguns grupos de fungos que se apresentaram monofiléticos, como exemplo membros dos clados 4, 5, 6 e 17 (Figura 2) e a presença de gêneros polifiléticos como Puccinia (com espécies distribuídas nos clados 5, 7, 9 e 11) e Uromyces (com espécies nos clados 12 e 13) da família Pucciniaceae, ou mesmo de espécies com relacionamento filogenético indefinido. Nota-se também, evidentemente, a presença de politomias por toda a árvore. O fato deste estudo ter sido baseado em uma única região gênica (28S do rDNA), apesar de ser altamente recomendada por Hyde et al. (2014) para a discriminação efetiva de membros de fungos causadores de ferrugem, pode ter contribuído para a formação das mesmas. O ideal é que se utilize um maior número de marcadores na tentativa de se obter um melhor suporte e discriminação de taxa, principalmente quando se envolve muitos espécimes.

O relacionamento filogenético gerado a partir de dados da região $28 \mathrm{~S}$ do rDNA, de forma geral, não reflete a classificação taxonômica baseada na morfologia e desta maneira não seria amplamente recomendado para a discriminação dos membros em nível de família devido a grande quantidade de politomia existente. Porém, para algumas famílias como Phakopsoraceae (Figuras 4 [clado 4] e 8 [clado 17]) e Phragmidiaceae (Figuras 9 [clado19]) houve um suporte com elevado valor de probabilidade posterior.

A família Coleosporiaceae é aqui apresentada como componente basal (Figuras 2 e 4). Dado também observado por Aime (2006), Zualaga et al. (2011), Maier et al. (2003), Wingfield et al. (2004) e, mais recentemente por McTaggart et al. (2015). Maier et al. (2003) propôs que o gênero Melampsora representa uma linhagem primitiva dentro da Ordem Pucciniales. 


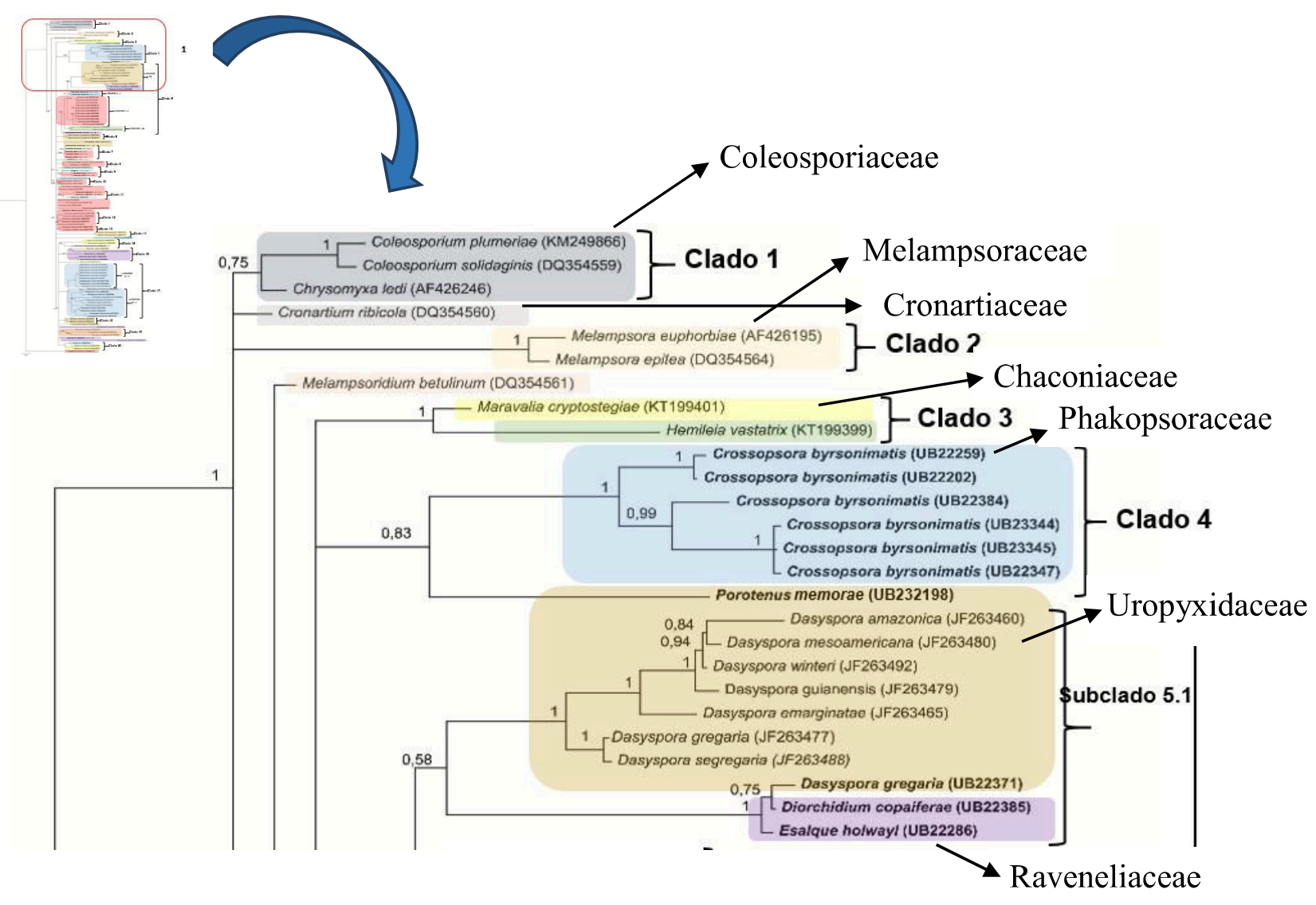

Figura 4. Setor $1 \mathrm{da}$ árvore filogenética mostrando em detalhe os clados de 1 a 4 e o subclado 5.1 do clado 5 .

No presente estudo a maioria das famílias de Pucciniales como Pucciniaceae, Raveneliaceae, Uropyxidaceae e Phakopsoraceae se mostraram polifiléticas, posicionadas em clados distintos (situação que pode ter ocorrido graças a politomia da árvore), conforme já observado em literatura por Wingfield et al. (2004) e Beenken (2012) (Figura 2). Van der Merve et al. 2007 e 2008, Dixon et al 2010, também constataram a relação polifilética entre os gêneros Puccinia e Uromyces dentro da família Pucciniaceae.

Quanto à análise filogenética da família Chaconiaceae, representada pelos gêneros Maravalia (Figura 4), Chaconia, Olivea (Figura 7), e Aplopsora (Figura 9), sabe-se que a 
família ainda não é suportada filogeneticamente, tornando-se necessário esclarecer ainda a afinidade entre alguns de seus gêneros e o relacionamento dos mesmos com membros da família Mikronegeriaceae (Zualaga et al. 2011). Recentemente confirmado por Aime (2006), que com base na análise de rDNA sugere que Hemileia, e pelo menos uma espécie do gênero Maravalia (M. cryptostegiae) deve ser localizado em Mikronegeriaceae, que de acordo com Aime (2006), também representa um grupo ancestral dentro da ordem dos fungos causadores de ferrugem.

Esta situação é mostrada no clado 3, setor 1 [Figura 4] como também por Zuluaga et al. (2011), onde a análise por Máxima Parcimônia realizada por eles não permitiu estabelecer uma estreita relação entre $H$. vastatrix (agente causal da ferrugem do cafeeiro) e $H$. colombiana, que infecta um membro de Apocynaceae, com outras espécies em Chaconiaceae como Olivea scitula e Maravalia guianensis. Este fato deve-se ao baixo sinal filogenético apresentado pelo gene correspondente a região $28 \mathrm{~S}$ do rDNA utilizado no presente estudo e por Zuluaga et al. (2011), havendo a necessidade da inclusão de outros marcadores para um melhor esclarecimento desta relação.

Pela primeira vez analisado filogeneticamente, o gênero Chaconia, representado pelas espécies $C$. ingae (clado 16, parte 4) e $C$. brasiliensis (clado 15, setor 4) [Figura 7], a priori, se constitui um gênero polifilético e relacionado com algumas espécies de Ravenelia.

Os espécimes de Aplopsora hennenii (Clado 20, setor 6) [Figura 9] se mostraram similares e ficaram muito próximos de Uredo sp. UB22481 que pode ser a forma assexuada de alguma espécie do gênero Aplopsora com urédios fortemente parafisados e urediniósporos reniformes, equinulados e marrons. Por outro lado, os isolados de $C$. brasiliensis e os de $C$. ingae (clados 15 e 16 da Figura 7) se posicionaram próximas às espécies de Ravenelia sp. podendo se suspeitar de algum relacionamento filogenético entre os dois gêneros, apesar de não possuir suporte filogenético, fato que merece pesquisa adicional, dadas as diferenças marcantes entre eles em termos morfológicos. 
A família Phakopsoraceae mostrou-se polifilética (Figura 2), assim como em estudos anteriores realizados por Wingfield et al. (2004) e foi a que apresentou a melhor resolução da afinidade filogenética entre os seus membros dispostos em dois clados (4 e 17) [Figuras 4 e 8 respectivamente], distantemente posicionados, envolvendo membros dos gêneros Batistopsora, Catenulopsora, Crossopsora e Phakopsora.

O clado 4 (setor 1) [Figura 4] está muito bem suportado (probabilidades posteriores $=1$ ) e compõem-se de seis espécimes pertencentes a $C$. byrsonimatis, parasitas de diferentes espécies de Byrsonima (Malpighiaceae). Os espécimes deste clado, que se mostrou monofilético, são aqui tratados como sendo da mesma espécie por não haver variação morfológica suficiente para separá-los, sendo considerados como espécies crípticas, porém é clara a variação genética intraespecífica entre eles. Os isolados de C. byrsonimatis, coletados em $B$. coccolobifolia (UB22259) e $B$. laxiflora (UB22202) ficaram próximos, o isolado de $B$. crassa (UB22384) apresentou-se separado dos demais, enquanto que os isolados de $B$. pachyphylla (UB23344 e UB23345) e B. verbascifolia ficaram juntos (Figura 4).

Esse grupo composto por espécimes de C. byrsonimatis (Figura 4, clado 4) se mostrou estreitamente relacionado com Porotenus memorae, membro da família Uropyxidaceae. Zualaga et al. 2011 também relataram a proximidade filogenética de uma outra espécie membro de Uropyxidaceae (Prospodium lippiae) com a família Phakopsoraceae e é sabido que os teliósporos de Prospodium e Porotenus são completamente diferentes dos de Phakopsoraceae que são imersos no tecido da hospedeira. Esta relação requer uma análise mais aprofundada com um maior número de representantes do gênero da família Uropyxidaceae.

A discussão sobre a relação de Crossopsora com o gênero Cronartium, com télios de formato semelhante (colunares em ambos os gêneros), chegando a ser tratados como sinônimos (Index Fungorum 2016), contrariando claras diferenças biológicas em termos de origem geográfica, parasitismo e aspectos básicos de morfologia da fase assexuada. Assim, a presente 
análise demonstra claramente a existência de uma ampla distância filogenética entre eles, ora posicionados em clados distintos e distantes entre si. (Crossopsora byrsonimatis no clado 4 , setor 1 e Cronartium ribicola (Cronartiaceae) próximo ao clado 1, setor 1, em posição mais basal (Figura 4).

Espécies de Phakopsoraceae também foram encontradas em outro clado distante deste anteriormente discutido. Neste caso o clado 17 (Subclado 17.1, setor 5) [Figura 8], onde os espécimes de Batistopsora crucis-fillii, encontrados em Annona tomentosa (Annonaceae), de várias regiões do país se mantiveram unidos, incluindo-se espécimes coletados no cerrado no Distrito Federal (UB22180 e UB22266) e outra espécie, B. pistila parasita de outra espécie de Annona (A. spraguei), próximas de outras espécies de Phakopsora e Crossopsora.

Recentemente Beenken (2014), através de estudos filogenéticos baseados no mDNA (CO3), recombinou Batistopsora em Phakopsora. Nossos dados mostram que se trata de dois gêneros próximos filogeneticamente (Figura 7). Entretanto, a espécie Batistopsora separa-se claramente de Phakopsora, graças ao formato característico dos urédios com paráfises periféricas em paliçada o que não é encontrado em Phakopsora.

O clado 17 (setor 5) [Figura 8] também composto por membros da família Phakopsoraceae, se estabeleceu como monofilético e muito bem suportado (probabilidades posteriores $=1$ ) subdividido em dois subclados. As relações filogenéticas entre outras espécies (subclado 17.2) encontradas no cerrado como Catenulopsora henneneae relatada em Pouteria torta (Sapotaceae), Phakopsora coca encontrada em Erythroxylum deciduum e P. chavesii em Terminalia argenteae (Combretaceae) não foram determinadas uma vez que apresentaram baixo suporte filogenético (Figura 8 subclado 17.2). Além dessas espécies, é incluída neste clado (subclado 17.2) uma espécie do gênero Crossopsora (com membros também posicionados no clado 4), C. hymeneae parasita de Hymenaeae stignocarpa (Fabaceae) que se mostrou próxima da espécie $P$. bluterii encontrada em folhas de Kilmeyera coriacea 
(Clusiaceae) com boa resolução apresentando valores de probabilidades posteriores $=1$ (Figura 8).

A família Uropyxidaceae, reconhecida como polifilética (Wingfield et al. 2004, Zuluaga et al. 2011, Beenken 2012, Beenken et al. 2014) foi aqui representada por espécies dos gêneros Dasyspora, Kimuromyces, Mimema, Porotenus e Prospodium distribuídos nos clados 5 (subclado 5.1, setor 1) e 6 (setor 2) [Figura 4].

Conforme já comentado acima, Porotenus memorae (Figura 4, clado 4) apresentou alguma proximidade com membros da família Phakopsoraceae (C. byrsonimatis) e agora também é mostrada situação semelhante em relação a membros de Raveneliaceae. Nesse caso, Dasyspora gregaria (UB22371) se agrupou, com baixo suporte filogenético, juntamente com outros dois membros de Raveneliaceae (Diorchidium copaiferae e Esalque holwayi) em clado basal (Figura 4, subclado 5.1) que deu suporte ao clado composto apenas por espécies de Dasyspora (Figura 4). O gênero Dasyspora encontrado em espécies hospedeiras pertencentes a Annonaceae, trata-se de um grupo monofilético (Beenkeen et al. 2012, Beenken 2014), aqui representado por sete espécies: D. amazonica, D. emarginatae, D. gregaria (JF263477), D. guianensis, D. mesoamericana, $D$. segregaria e $D$. winteri com alto valor de suporte (probabilidades posteriores $=1$ ) para o clado. Diante disso, apesar de um dos isolados de $D$. gregaria (UB22371) ter se posicionado fora do clado, ainda assim, considera-se válida aceitarse a monofilia do gênero, apesar dessa ausência discrepante de suporte estatístico mostrada pela análise filogenética.

No entanto, outros membros de Uropyxidaceae foram alocados no clado 6 (setor 2) com dois espécimes idênticos de Kimuromyces cerradencis coletados em Astronium flaxinifolium (Anacardiaceae) em Goiás (UB23337) e UB23333 na mesma hospedeira em Minas Gerais (Figura 5). Trata-se de um gênero monotípico, pela primeira vez sequenciado e analisado filogeneticamente. 


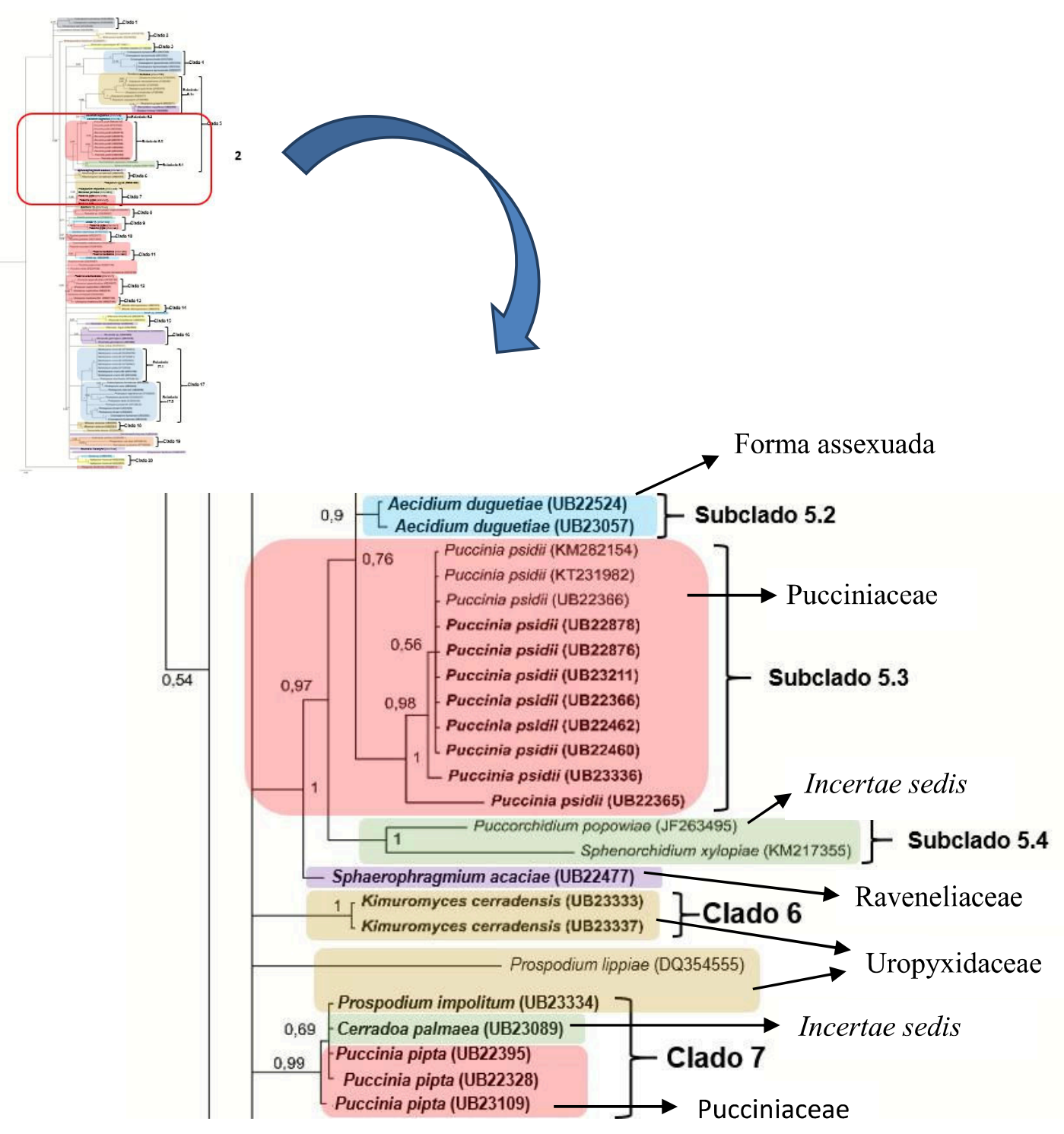

Figura 5. Setor 2 da árvore filogenética ampliado mostrando em detalhe os subclados 5.2, 5.3 e 5.4 do clado 5. Além disso também são mostrados os clados 6 e 7 .

O relacionamento filogenético das espécies de Prospodium não ficou claro, uma vez que a espécie P. lippiae (acesso obtido do GenBank) encontrado em Aloysia polystachya (Verbenaceae) não estabeleceu relação alguma com outros taxa conforme mostrado entre os clados 6 e 7 (setor 2) [Figura 5]. Já, P. impolitum (UB23334), parasitando Pyrostegia venusta (Bignoniaceae) em Minas Gerais, agrupou-se em um clado formado por membros da família 
Pucciniaceae (Figura 5), e, apesar dos dados se apresentarem robustos (probabilidades posteriores $=0,99$ ), a situação requer revisão e reanálise, com a inclusão de outros marcadores que possibilitem a necessária discriminação entre os espécimes estudados.

Por outro lado, Mimema venturae, pela primeira vez caracterizada molecularmente, foi incluída em um clado (Figura 9, clado 18, setor 6) formado independentemente sem relação com outros taxa e mostrou grande proximidade filogenética entre os isolados possivelmente se tratando da mesma espécie (com o valor de probabilidade posterior $=1$ ), coletados em folhas de Dalbergia miscolobium no Distrito Federal (Figura 8). Além disso, Mimema venturae mostrouse relativamente próxima de Tranzchelia discolor (Uropyxidaceae).

Pucciniaceae, a maior família da ordem Pucciniales (Cummins \& Hiratsuka 2003, Aime 2006, Zualaga et al. 2011, Aime et al. 2014), foi representada nesta análise por espécimes dos gêneros Cumminsiella, Gymnosporangium, Puccinia, Roestelia e Uromyces.

Trata-se de família sabidamente polifilética (Maier et al. 2003, Wingfield et al. 2004, Zualaga et al. 2011, Aime et al. 2014) e seus componentes foram aqui distribuídos em 7 clados (5 [5.3], 7, 8, 9,11, 12,13), com alguns espécimes sem possibilidade de ter sua filogenia esclarecida (Figura 2). No entanto o clado 5 (subclado 5.3, setor 2) [Figura 5] mostrou-se coerente sendo composto exclusivamente por um grupo de materiais de Puccinia psidii provenientes de diferentes espécies de Myrtaceae (Psidium guajava (KM282154) e (UB22366), Syzygium jambos (KT231982), Eucalyptus sp. (UB22878), Corymbia ficifolia (UB22876), Eugenia dysenterica (UB23211), E. florida (UB22336), S. cumini (UB22462), S. malaccence (UB22460) e Myrcia linearifolia (UB22365), confirmando a condição monofilética da espécie assim como observado por Machado et al. (2015). O clado está muito bem suportado pelos principais ramos (probabilidades posteriores acima de 0,98) e mostra o espécime que infecta M. linearifolia (UB22365) como basal em relação aos outros contidos no clado. Recentemente, Machado et al. (2015) epitipificaram a espécie (isolado incluído nesta análise [KM282154]) 
com um espécime encontrado em Santa Catarina, local originalmente coletado sobre Psidium sp. Buys et al. (2016) tentaram desenvolver um DNA barcode para discriminar variantes intraespecíficos de P. psidii, parasitas de distintas hospedeiras, sem no entanto, chegar a uma definição.

Beenken \& Wood (2015) e McTaggart et al. (2015) em estudo sobre fungos causadores de ferrugens em espécies de hospedeiras em Annonaceae, relacionam $P$. psidii como associada filogeneticamente com espécies de Dasyspora e dois novos gêneros por eles estabelecidos (Puccorchidium e Sphenorchidium). No presente trabalho essa relação se mostrou apenas para Puccorchidium e Sphenorchidium, porém espécies de Dasyspora se posicionaram em clados distintos e distantes filogeneticamente (subclado 5.1 do clado 5) [Figura 5].

Esta é a primeira vez que espécimes de $P$. psidii do Cerrado são incluídas em uma análise de filogenia molecular, como é o caso de E. florida (UB22336) e M. linearifolia (UB22365), bem como aqui se relatou a ocorrência de $P$. psidii em $C$. ficifolia e $S$. malaccence.

Os gêneros Puccinia e Uromyces como esperado, mostraram-se polifiléticos (Figura 2), conforme indicam van Der Merwe et al. (2007) com base em regiões gênicas $\beta$ tub e EF, e Maier et al. (2007) baseados em análises de sequências da na região 28S do rDNA.

Os materiais de $P$. pipta em folhas de Piptocarpha rotundifolia (UB22328 e UB22395) [Figura 5], ficaram separados dos exemplares da mesma espécie parasita de Piptocarpha macropoda (UB22327 e UB22343), com esses últimos com relação relativamente próxima de Uredo sp. (UB22360) encontrada sobre Solanum sp. (Solanaceae) [Figura 6]. 


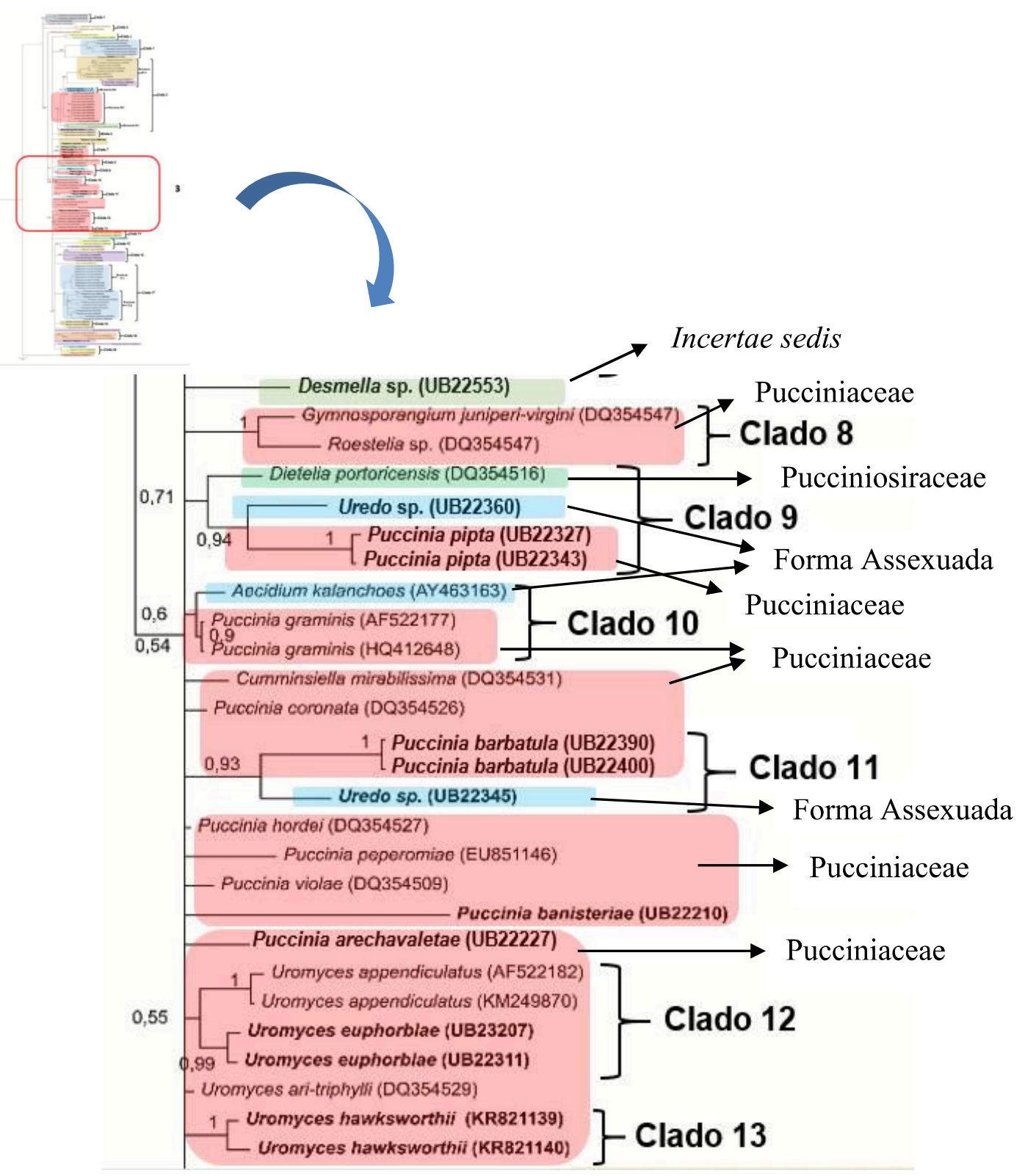

Figura 6. Setor 3 da árvore filogenética ampliado mostrando em detalhe os clados de 8 a 13 .

O clado 8 (setor 3), composto por Pucciniaceae dos gêneros Gymonsporangium e Roestelia sp. não mostraram proximidade filogenética com os outros taxa usados na análise (Figura 6).

A espécie $P$. barbatula (clado 11) representada pelos isolados (UB22390 e UB22400) encontrados em Heteropterys byrsonimifolia (Malpighiaceae) no Distrito Federal, apresentou 
estreita relação com Uredo sp. (UB22345]) coletados em folhas de Solanum sp. no Distrito Federal (Figura 6).

Outras espécies de Puccinia coletadas no cerrado e aqui analisadas (próximas ao clado 12, setor 3) são a $P$. banisteriae (UB22210) de folhas de Banisteriopsis gardneriana (Malpighiaceae) e P. arechavaletae (UB UB22227) parasita de Serjania lethalis (Sapindaceae) que mostraram uma relação filogenética indefinida com relação a outros membros incluídos na análise (Figura 6).

Duas espécies de Uromyces coletadas no Cerrado foram aqui analisadas. U. euphorbiae tanto a fase ecídica (UB2320) como a télica (UB22311) encontradas em Euphorbia hirta (Euphorbiaceae), se alocaram próximas aos materiais de Uromyces appendiculatus (AF522182 e KM249870), patógeno de Phaseolus vulgaris (Fabaceae). Esta relação mostrou-se bem suportada com probabilidades posteriores $=1$, conforme mostrada no clado 12, setor 3 (Figura 6). Já o segundo Uromyces do Cerrado, U. hawksworthii (KR821139 e KR821140), posicionouse em um clado independente (clado 13, setor 3) porém bem suportado (probabilidades posteriores $=1$ ), no qual o seu posicionamento filogenético não foi esclarecido, embora próximo de outras espécies de Uromyces presentes na árvore (Figura 6).

A família Raveneliaceae, aqui representada pelos gêneros Diorchidium, Endoraecium, Esalque, Kernkampella, Ravenelia e Sphaerophragmium é comprovadamente polifilética (Maier et al. 2003, Wingfield et al. 2004, Zualaga et al. 2011, Aime et al. 2014). 
Os resultados alocaram seus membros em três clados $(5,15$ e 16) mostrados nas figuras 4 e 6.

O clado 5 é composto por três raveneliáceos encontrados no cerrado. Diorchidium copaiferae (UB22385) e Esalque holwayi (UB22286) ambas em Fabaceae, ficaram agrupados no mesmo subclado (5.1) apresentando bom suporte filogenético (probabilidades posteriores =1) com relação a espécie de Diorchidium. Entretanto, apresentaram relação filogenética com uma espécie de Dasyspora (Uropyxidaceae), repetindo o resultado de Beenken et al. (2012). Neste caso um clado contendo Diorchidium polyalthiae que se apresentou como suporte para um clado com várias espécies de Dasyspora. Além disso, Aime (2006) encontrou estreito grau de parentesco entre Prospodium lippiae (Uropyxidaceae) e espécies do gênero Ravenelia, Endoraecium e Racospermyces.

Outra espécie de Raveneliaceae, Sphaerophragmium acaciae (UB22477), alocado no clado 5 (setor 2) é parasita de uma fabácea exótica, Albysia lebbeck. Essa espécie apresentou um posicionamento filogenético bem suportado (probabilidades posteriores=1) mostrando-se como base para todo o clado 5 que compõe, além de membros em Raveneliaceae, membros de Pucciniaceae e Phakopsoraceae (Figura 5). Se faz necessário uma análise envolvendo mais espécies de Sphaerophragmium para um posicionamento mais seguro do gênero.

Além disso, várias espécies de Ravenelia se agruparam próximas das espécies de Chaconia. Assim, no clado 16 (setor 4) [Figura 7], por exemplo, podemos observar a relação entre três membros do gênero Ravenelia com Chaconia ingae (UB22559). Ravenelia geminipora representada por dois isolados idênticos (UB23328 e UB22899) coletados em Minas Gerais e Distrito Federal respectivamente, ambas em Plathynemia reticulata; Ravenelia sp. (UB22289) proveniente da hospedeira Eriosema rigidum do Distrito Federal e R. havensis (obtida do GenBank, acesso DQ354557) coletada de folhas de Enterolobium contortisiliquum, se agruparam em posições próximas com C. ingae proveniente de Inga 
sessilis (Figura 7). Todos esses espécimes possuem hospedeiras em Fabaceae, fator que pode ter contribuído para essa aproximação filogenética.

Espécies como R. hieronymi (UB22560) coletada em Acacia farnansiana (Fabaceae), espécie exótica proveniente da América Central, Kernkampella breynie (KJ862346) proveniente de Breynia cernua (Phyllanthaceae) e Endoraecium falciforme (KJ862307) de Acacia falciformis (Fabaceae) não tiveram um posicionamento de forma a esclarecer a sua relação com outros taxa (Figura 9).

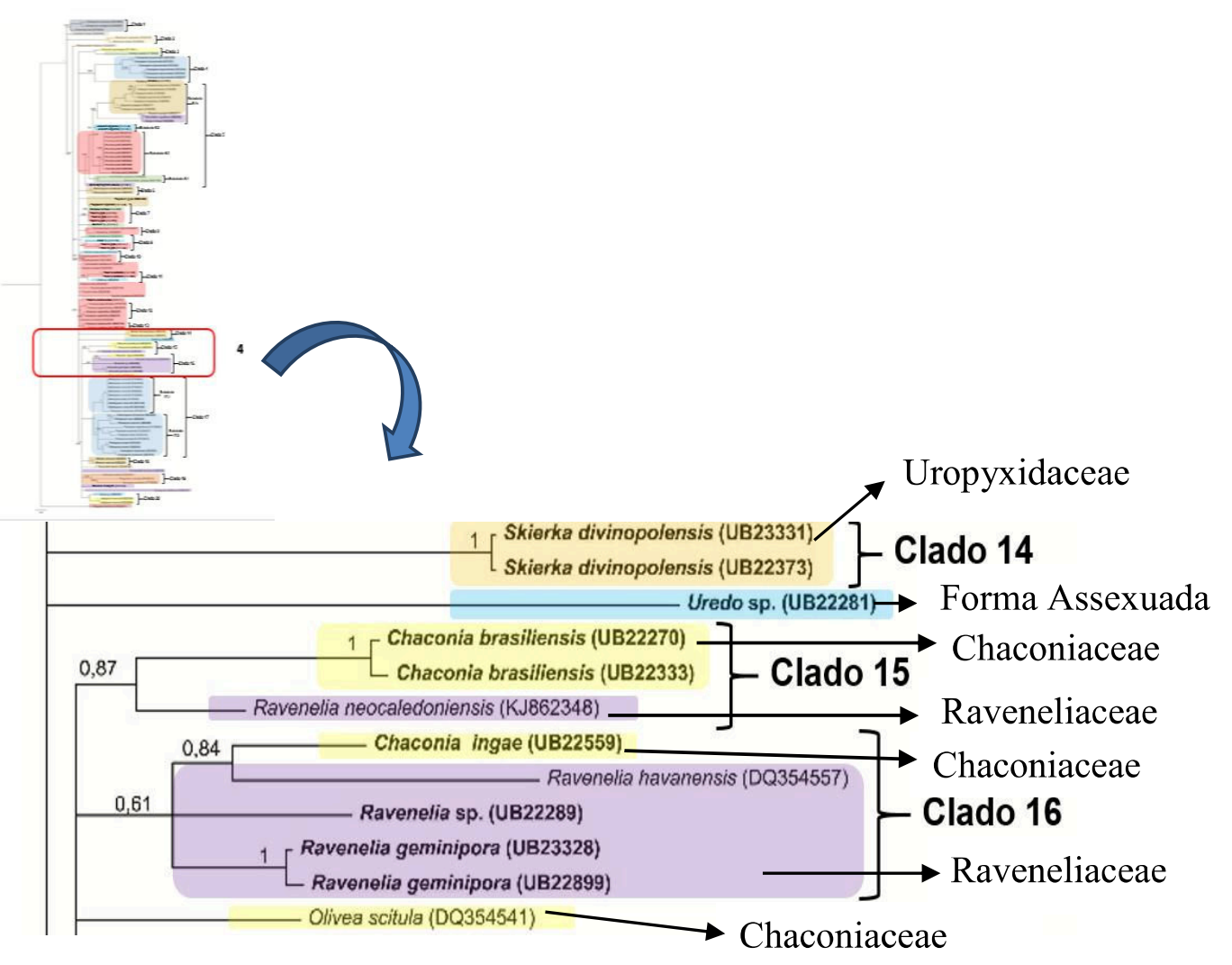

Figura 7. Setor 4 da árvore filogenética ampliado mostrando em detalhe os clados 14 a 16.

Assim como as outras famílias, Pileolariaceae também se comportou como um grupo polifilético (Aime 2006, Beenken et al. 2012) mostrado na figura 2. Wingfield et al. (2004) observou que espécies do gênero Uromycladium (Pileolariaceae) se mostraram como 
monofiléticas. A família é aqui representada por uma única espécie, Skierka divinipolensis com dois isolados: um (UB23331) encontrado em Cupania rugosa em Minas Gerais e outro (UB22373) proveniente de Matayba guianensis coletado no Distrito Federal, ambas em Sapindaceae.

A análise com bom suporte filogenético (probabilidades posteriores=1) mostrou que os dois isolados pertencem à mesma espécie, apesar de serem coletados em hospedeiras e locais distintos (Figura 7). Entretanto, não foi possível determinar com clareza o seu posicionamento filogenético em relação a outros taxa.

Foram incluídas nesta análise dois espécimes que não possuem inserção taxonômica bem estabelecida. Cerradoa palmaea (UB23089), um membro de Pucciniales encontrado em folhas de Syagrus flexuosa coletado no Distrito Federal e outro corresponde a Desmella sp. (UB22553) obtido de folhas de uma pteridófita, Thelypteris sp. (Thelypteridaceae). O primeiro se agrupou em um clado (clado 7, setor 2) composto por membros da família Pucciniaceae e por Prospodium impolitum (Uropyxidaceae), ambos coletados no cerrado (Figura 5). Apesar de atualmente o gênero Cerradoa, agora pela primeira vez sequenciado, não estar alocado em nenhuma família definida (Index Fungorum 2016), Cummins \& Hiratsuka (2003), ele tem sido aceito como membro de Uropyxidaceae juntamente com membros do gênero Edythea. $\mathrm{O}$ suporte deste clado (probabilidades posteriores inferiores a 0.9) não foi suficiente para afirmar com clareza as relações filogenéticas dentro do clado.

No caso de Desmella sp. (UB22553) a situação não é muito diferente, uma vez que se posicionou de maneira indefinida impossibilitando a definição do seu posicionamento filogenético (Figura 6).

Diante dos dados apresentados, entende-se que há a necessidade de mais pesquisas relacionadas a filogenia de fungos membros da ordem Pucciniales, envolvendo além de análise por Inferência Bayesiana, outras análises como Máxima Parcimônia e 
Verossimilhança para efeito de comparação e esclarecimento de quais métodos podem ser mais robustos e expressivos para esclarecer as relações filogenéticas deste grupo fúngico. Além disso outras regiões gênicas e intergênicas podem ser utilizadas na tentativa de melhorar a resolução das relações e posicionamento filogenético.

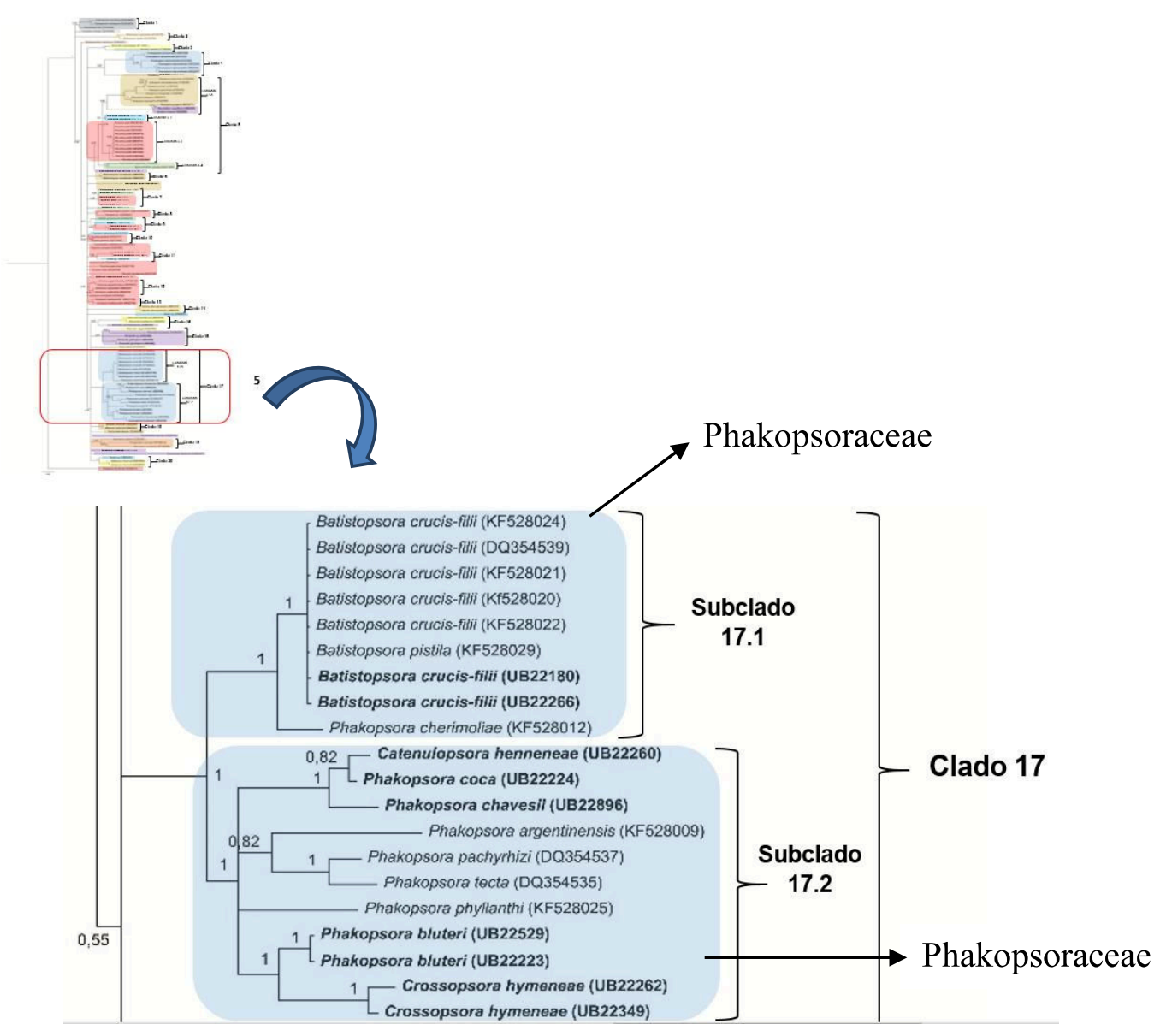

Figura 8. Setor 5 da árvore filogenética ampliado mostrando em detalhe o clado 17. 


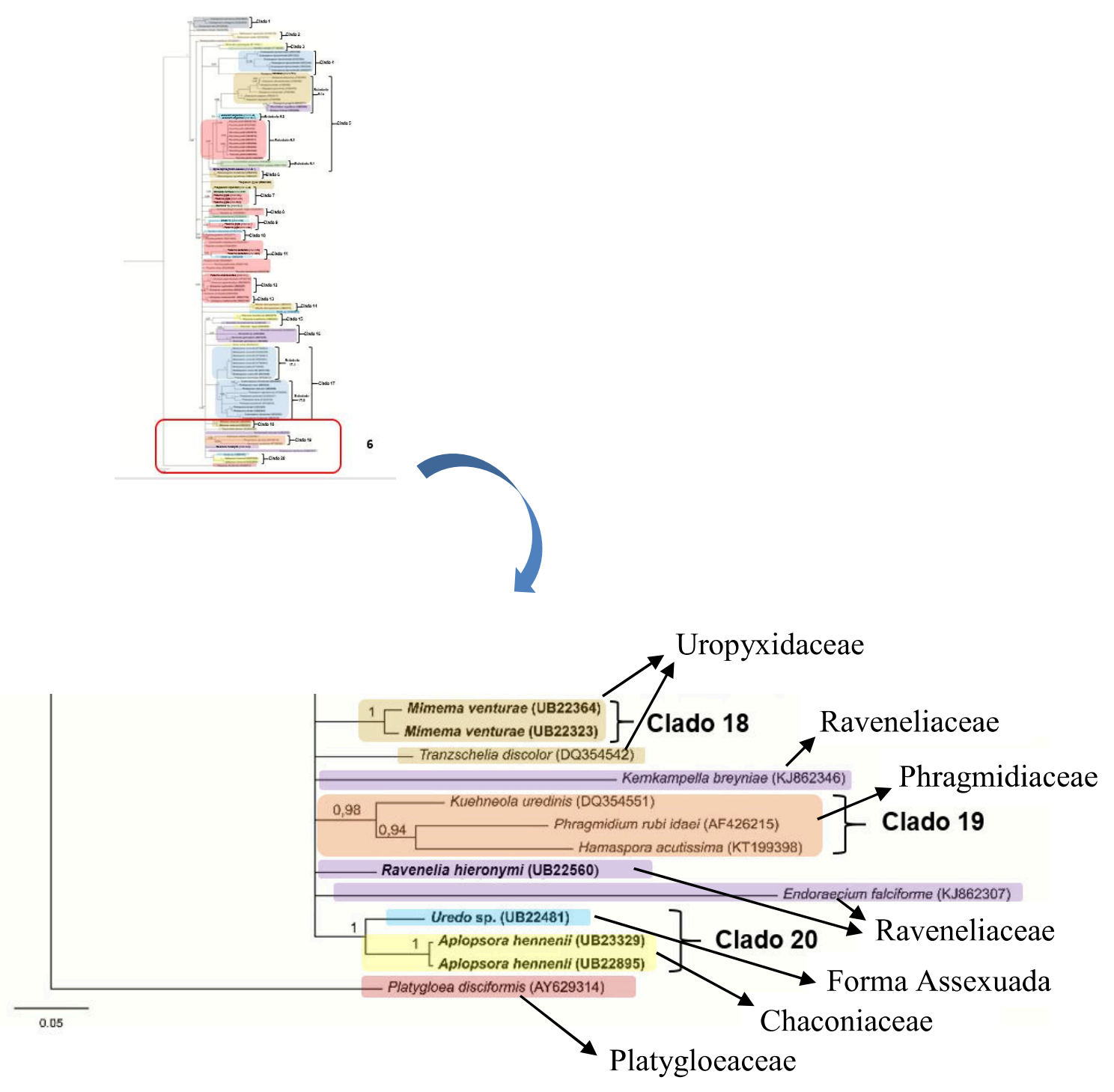

Figura 9. Setor 6 da árvore filogenética ampliado mostrando em detalhe os clados 18 a 20. 


\section{REFERÊNCIAS}

Aime MC (2006) Toward resolving family-level relationships in rust fungi (Uredinales). Mycoscience. v.47: 112-122. Aime MC, Toome M, McLaughlin DJ. 2014. Pucciniomycotina. In: McLaughlin DJ, Spatafora JW, eds. The Mycota, systematics and evolution, 2 ed, 7A. Berlin, Germany: Springer-Verlag, in press.

Bauer, R., D. Begerow, J.P. Sampaio, M. Weiß \& F. Oberwinkler (2006) The simple-septate basidiomycetes: a synopsis. Mycological Progress. 5: 41-66.

Beenken L, Zoller S, Berndt R (2012) Rust fungi on Annonaceae II: The genus Dasyspora. Mycologia. v.104(3):659-681.

Beenken L. (2014). Pucciniales on Annona (Annonaceae) with special focus on the genus Phakopsora Mycological Progress. v. 13(3):791-809.

Beenken L, Wood AR (2015) Puccorchidium and Sphenorchidium, two new genera of Pucciniales on Annonaceae related to Puccinia psidii and the genus Dasyspora. Mycological Progress. 14 1-13.

Buys MH, Flint HJ, Miller EM, Yao H, Caird AR, Ganley, RJ (2016) Preparing for the invasion: efficacy of DNA barcoding to discern the host range of myrtle rust (Puccinia psidii) among species of Myrtaceae. Forestry, 17.

Cummins GB \& Hiratsuka Y (2003) Illustrated genera of rust fungi. 3 ed. The American Phytopathological Society, St. Paul. 225p.

Deadman ML, Al Sadi AM, Al Maqbali YM, Farr DF, Aime MC (2011) Additions to the rust fungi (Pucciniales) from northern Oman. Sydowia 63: 155-168.

Dianese JC, Santos LTP (1999) Aplopsora hennenii sp. nov., the first rust fungus recorded from Vochysiaceae. Mycological Research. 99:914-916.

Dixon LJ, Castlebury LA, Aime MC, Glynn NC, Comstock JC (2010) Phylogenetic relationships of sugarcane rust fungi. Mycological Progress 9: 459-468. 
Doyle JJ \& Doyle JL. (1990) Isolation of plant DNA from fresh tissue. Focus 12: 13-15.

Edgar RC (2004) MUSCLE: a multiple sequence alignment method with reduced time and space complexity. BMC Bioinformatics 5: 113.

Hall T (2012) BioEdit v 7.0.9: Biological sequence alignment editor for Win95/98/2K/XP/7.

Hennen JF, Figueiredo MB, Carvalho Jr. AA, Hennen, PG (2005) Catalogue of plant rust fungi (Uredinales) of Brazil.

Hyde KD, Nilsson RH, S Alias A, Ariyawansa AH, Blair E et al. (2014) One stop shop: backbones trees for important phytopathogenic genera: I (2014). Fungal Diversity 67: 21125 .

Index Fungorum (2016) Disponível em: www.indexfungorum.org. Acessado em dezembro de 2016.

Kearse M, Moir R, Wilson A, Stones-Havas S, Cheung M, Sturrock S, Buxton S, Cooper A, Markowitz S, Duran C, Thierer T, Ashton B, Meintjes P, Drummond A (2012) Geneious Basic: an integrated and extendable desktop software platform for the organization and analysis of sequence data. Bioinformatics. 15; 28: 1647-9.

Kropp BR, Hansen DR, Wolf PG, Flint KM, Thomson SV. (1997) A study on the phylogeny of the dyer's woad rust fungus and other species of Puccinia from Crucifers. Phytopathology 87: 565-571.

Machado PDS, Glen M, Pereira OL, Silva AA, Alfenas AC (2015) Epitypification of Puccinia psidii, causal agent of guava rust. Tropical Plant Pathology. 40: 5-12.

Maier W, Begerow D, Weiss M, Oberwinkler F (2003) Phylogeny of the rust fungi: an approach using nu

clear large subunit ribosomal DNA sequences. Canadian Journal of Botany v. 81: 12-23.

Maier W, Wingfeld BD, Mennicken M, Wingfeld MJ (2007) Polyphyly and two emerging lineages in the rust genera Puccinia and Uromyces. Mycological Research 111: 176-185. 
McTaggart AR, Geering ADW, Shivas RG (2014) Uredinopsis pteridis and Desmella aneimiae, the first rust fungi (Pucciniales) reported on ferns (Pteridophyta) in Australia. Australasian Plant Disease Notes 9: 149.

McTaggart AR, Shivas RG, Nest MA, Roux J, Wingfield BD, Wingfield MJ (2016) Host jumps shaped the diversity of extant rust fungi (Pucciniales). New Phytologist. 209: 1149-1158.

Miller MA, Pfeiffer W, Schwartz T (2010) Creating the CIPRES Science Gateway for inference of large phylogenetic trees. Proceedings of the Gateway Computing Environments Workshop (GCE), 14 Nov. 2010, New Orleans, LA: 1-8. Moncalvo JM, Wang HH, Hseu RS (1995) Phylogenetic relationships in Ganoderma inferred from the internal transcribed spacers and 25S ribosomal DNA sequences. Mycologia 87: 223-238.

Minnis AM, McTaggart AR, Rossman AY, Aime MC (2012) Taxonomy of mayapple rust: the genus Allodus resurrected. Mycologia. 104: 942-950.

Moncalvo JM, Wang HH, Hseu RS (1995) Phylogenetic relationships in Ganoderma inferred from the internal transcribed spacers and 25S ribosomal DNA sequences. Mycologia 87: 223-238.

Padamsee M, McKenzie EH. (2014) A new species of rust fungus on the New Zealand endemic plant, Myosotidium, from the isolated Chatham Islands. Phytotaxa, 174, 223230.

Posada D, Buckley T. (2004) Model selection and model averaging in phylognetics: advantages of Akaike information criterion and Bayesian approaches over likelihood ratio tests. Systematic Biology 53: 793-808.

Rambaut A (2009) FigTree. Version 1.2.3. Edinburgh: Institute of Evolutionary Biology, University of Edinburgh.

Rodas CA, Roux J, Maier W, Granados GM, Bolaños MD, McTaggart AR, Wingfield, MJ. (2015) First report of Puccinia psidii on Corymbia citriodora and Eucalyptus in Colomedgarbia. Forest Pathology. 45: 534-536. 
Ronquist F, Teslenko M, Van Der Mark P, Ayres DL, Darling A, Ohna SH, Larget B, Liu L, Suchard MA, Huelsenbeck JP (2012) Mrbayes 3.2: Efficient Bayesian phylogenetic inference and model choice across a large model space. SystBiol v. 61:539-542.

Souza ESC, Chaves ZM, Soares WR, Pinho DB \& Dianese JC (2015) Uromyces hawksworthii nom. nov. for Aecidium goyazense, on Phthirusa stelis (Loranthaceae) from the Brazilian Cerrado. IMA fungus 6: 155-162.

Swofford DL (2002) PAUP*. Phylogenetic Analyses using parsimony (*and other methods), version 4.0. Sinauer Associates, Inc., Sunderland.

Tamura K, Peterson D, Peterson N, Stecher G, Nei M, Kumar S (2013) Mega 6: molecular evolutionary genetics analysis using maximum likelihood, evolutionary distance, and maximum parsimony methods. Mol. Biol. Evol. v. 28, n.10, p.2731-2739.

Thirumalachar MJ, B.B. Mundkur. (1949) Genera of rust ii. ind. Phytopathol. 2: 65-101.

Van Der Merwe MM, Walker J, Ericson L, Burdon JJ (2008) Coevolution with higher taxonomic host groups within the Puccinia/Uromyces rust lineage obscured by host jumps. Mycological research 112: 1387-1408.

Van der Merwe M, Ericson L, Walker J, Thrall PH, Burdon JJ (2007) Evolutionary relationships among species of Puccinia and Uromyces (Pucciniaceae, Uredinales) inferred from partial protein coding gene phylogenies. Mycological research 111, 163175.

Vilgalys R, Hester M. (1990) Rapid genetic identification and mapping of enzymatically amplified ribosomal DNA from several Cryptococcus species. J Bacteriol. v. 172:42384246.

Wingfield GD, Ericson L, Szaro T, Burdon JJ (2004) Phylogenetic patterns in the Uredinales. Australasian Plant Pathology 33: 327-335.

Yang T, Tian, CM, Lu HY, Liang YM, Kakishima, M. (2015) Two new rust fungi of Thekopsora on Cornus (Cornaceae) from western China. Mycoscience, 56(5), 461-469. 
Zuluaga C, Buriticá P, Marín M (2011) Filogenia de hongos roya (Uredinales) en la zona andina colombiana mediante el uso de secuencias del ADN ribosomal 28S. Revista de Biología Tropical. 59: 517-5402011 San José, Costa Rica.

Zuluaga CM, Céspedes PB, Marín-Montoya, M. (2008) Generalidades de los Uredinales (Fungi: Basidiomycota) y de sus relaciones filogenéticas. Acta Biológica Colombiana, $14,41$. 


\section{CAPÍTULO 3}

Este Capítulo consiste na versão em português do trabalho publicado no periódico IMA Fungus, editado pela International Mycological Association, Utrecht, Holanda.

\section{Uromyces hawksworthii UM NOVO NOME PARA Aecidium goyazense EM Phthirusa stelis (LORANTHACEAE) DO CERRADO BRASILEIRO (*)}

Autores: Érica S.C. Souza, Zuleide M. Chaves, William R.O. Soares, Danilo B. Pinho, and José C. Dianese (2105)

Uromyces hawksworthii nom. nov. for Aecidium goyazense, on Phthirusa stelis

(Loranthaceae) from the Brazilian Cerrado. IMA Fungus 6: 155-162

\section{(PDF no Anexo 1)}

\section{RESUMO}

A forma sexual de Aecidium goyazense coletada no Cerrado Brasileiro foi morfologicamente caracterizada por Microscopia de luz e por Microscopia Eletrônica de Varredura, e mostrou-se como sendo uma espécie de Uromyces o qual foi nomeada de Uromyces hawksworthii. A amostra aqui renomeada foi introduzida e designada como o seu epitipo. Este fungo foi comparado morfologicamente com outras espécies de Uromyces conhecidas para a família Loranthaceae. O DNA genômico foi recuperado a partir de eciósporos, bem como de teliósporos. As sequências de DNA foram geradas a partir das regiões ITS e 28S (LSU) do rRNA e as reconstruções filogenéticas foram geradas por Inferência Bayesiana para posicionar o táxon, quando comparado com outras espécies relacionadas filogeneticamente. Esta é a segunda espécie de Uromyces sp. conhecida infectando o gênero tropical Phthirusa (Loranthaceae).

Palavras chave: Basidiomycota, Fungos Neotropicais, Pucciniaceae, Pucciniomycotina 
(*) Trabalho já publicado: Souza ESC, Chaves Z, Soares WRO, Pinho DB, Dianese JC (2015) Uromyces hawksworthii nom. nov. for Aecidium goyazense, on Phthirusa stelis (Loranthaceae) from the Brazilian Cerrado. IMA Fungus 6: 155-162. (o artigo encontrase no anexo 1). 
Hennen e colaboradores em 2005 catalogaram os fungos causadores de ferrugem em Loranthaceae no Brasil, incluindo Aecidum goyazense e Uromyces circunscriptus, U. loranthi, e U. urbanianus.

Perdomo-Sánchez \& Piepenbring (2014) revisaram as espécies de Uromyces conhecidas para Loranthaceae, a saber: U. euphlebius, U. evastigatus, U. loranthi, $U$. nilagiricus, U. ornatipes, U. phthirusae, U. socius, e a adição de dois novos taxa, U. bahiensis do Brasil e U. struthanthi do Panamá.

O fungo Aecidium goyazense era conhecido apenas como uma fase ecial sem uma conexão com uma fase telial. A fase telial comprova morfologicamente que o fungo em questão pertence ao gênero Uromyces e esta é descrita e ilustrada aqui.

As duas fases (ecial e telial) também são caracterizadas molecularmente e filogeneticamente a partir de sequências de rDNA como um código de barras para identificação das espécies. 
Folhas de Phthirusa stelis com galhas características de fungos causadores de ferrugem foram coletadas em Brasília, Distrito Federal.

As galhas marrons estavam cobertas de estruturas eciais cilíndricas para cônicas, écios pálidos a amarelados e télias erumpentes castanhas escuras cobertas por uma camada de esporos marrom escuros.

As estruturas ecídica e telial foram submetidas a cortes histológicos de 15-20 mm de espessura com um criomicrótomo modelo Micron ${ }^{\circledR}$. Preparações de lâminas contendo écios, eciósporos e teliósporos das galhas foram examinadas microscopicamente por contraste de interferência diferencial Nomarski sob um microscópio de luz modelo Leica DM $2500^{\circledR}$ acoplado com uma câmera digital Leica DFC $490^{\circledR}$; captura de imagens e medidas foram feitas com o software Leica QWin $\mathrm{V}^{\circledR}$.

Algumas amostras foram coradas com azul de algodão ou com lacto-glicerol e as lâminas seladas com esmalte para unhas.

Um mínimo de 25 repetições de esporos e de células estruturais foram medidas. Porções desidratadas de galhas contendo as fases de écio e de télio foram fixadas em blocos de cobre de 10 milímetros de diâmetro usando fita dupla face de carbono e revestida com ouro $25 \mathrm{~mA}, 1,10^{2} \mathrm{mbar}$, durante 2,5 minutos para análise em microscópio eletrônico de varredura Modelo JEOL JSM-700 1F ${ }^{\circledR}$.

Os espécimes foram registrados e estão depositados na coleção micológica da Universidade de Brasília (UB). 


\section{Extração, Amplificação por PCR e sequenciamento de DNA}

Para obter esporos e prevenir a contaminação por outros fungos, soros foram examinados sob um microscópio estereoscópico. Massas contendo eciósporos e teliósporos foram removidas com uma agulha e colocadas separadamente em microtubos de $1,5 \mathrm{ml} \mathrm{e}$ armazenados a temperatura de $-20^{\circ} \mathrm{C}$. As amostras ainda nos microtubos foram congeladas com nitrogênio líquido e maceradas com auxílio de micropistilos até a obtenção de um pó fino.

A extração do DNA foi realizada pelo método CTAB (Cetiltrimetil Brometo de Amônio), procedimento estabelecido por Doyle \& Doyle (1990).

As reações de PCRs incluíram os seguintes componentes para cada reação em um volume final de $25 \mu \mathrm{L}: 0,5 \mathrm{U}$ de Taq DNA polimerase Platinum ${ }^{\circledR}, 0,2 \mu \mathrm{M}$ de cada nucleotídeo, $5 \mathrm{~mL}$ de Tampão $10 \mathrm{X}, 1,5 \mathrm{mM}$ de $\mathrm{MgCl}_{2}, 0,4 \mu \mathrm{M}$ de cada um dos iniciadores; além de 10 ng/ $\mu \mathrm{L}$ de DNA genômico e água livre de nuclease para completar o volume total.

Iniciadores ITS4-rust e ITS5-u foram utilizados para amplificar a região espaçadora transcrita interna (ITS) do rRNA (Pfunder et al. 2001). A região LSU foi amplificada com iniciadores externos, Rust2inv e LR6 (Aime 2006 Vilgalys \& Hester 1990), enquanto que os iniciadores LR0R e Rust1 (Moncalvo et al. 1995, Kropp et al.1997) foram utilizados como iniciadores para amplificar a região interna de interesse.

O ciclo térmico consistiu de $94^{\circ} \mathrm{C}$ durante 4 minutos seguido por 30 ciclos de $94^{\circ} \mathrm{C}$ durante 1 minuto para a desnaturação, $54^{\circ} \mathrm{C}$ durante 1 minuto para emparelhamento, $72^{\circ} \mathrm{C}$ durante 1 minuto para elongação e $72^{\circ} \mathrm{C}$ durante 5 minutos para a extensão final.

Os produtos de PCR foram analisados por eletroforese em gel de agarose a $1 \%$ e corados com brometo de etídio num tampão TAE $1 \mathrm{X}$ e visualizados sob luz ultravioleta para verificar a amplificação e a pureza dos amplicons. 
Os produtos da PCR foram tratados com as enzimas ExoSAP-IT ${ }^{\circledR}$ (USB) e sequenciados em um sequenciador Applied Biosystems Modelo ABI3130xl da Universidade Católica de Brasília.

As sequências de nucleotídeos foram editadas com o software BioEdit (Hall 2012). Todas as sequências foram verificadas manualmente e nucleotídeos com posições ambíguas foram conferidos através de ambas as sequências dos iniciadores.

As novas sequências foram depositadas no GenBank (http://www.ncbi.nlm.nih.gov/GenBank/) e os acessos são mostrados na Tabela 1. 
Tabela 1. Números de acessos do GenBank de Uromyces hawkswothii e de todas as outras espécies incluídas no estudo.

\begin{tabular}{|c|c|c|}
\hline ESPÉCIES & Acessos GenBank (LSU)* & FONTE E PAÍ́S \\
\hline Uromyces hawksworthii UB22382 & KR821139 & Neste estudo, Brasil \\
\hline Uromyces hawksworthii UB22875 & KR821140 & Neste estudo, Brasil \\
\hline Cumminsiella mirabilissima & DQ354531 & Aime (2006) Alemanha \\
\hline Cumminsiella mirabilissima & AF426206 & Maier et al. (2003) Alemanha \\
\hline Puccinia coronata & DQ354526 & Aime (2006) EUA \\
\hline Puccinia coronata & EU851141 & Zuluaga et al. (2011) \\
\hline Puccinia graminis & AF522177 & Bruns et al. (1992) \\
\hline Puccinia graminis & HQ412648 & Deadman et al. (2011) \\
\hline Puccinia hemerocallidis & GU058020 & Dixon et al. (2010) EUA \\
\hline Puccinia hemerocallidis & DQ354519 & Aime (2006) EUA \\
\hline Puccinia heucherae & DQ359701 & Henricot et al. (2007) UK \\
\hline Puccinia heucherae & DQ359702 & Henricot et al. (2007) UK \\
\hline Puccinia hordei & DQ354527 & Aime (2006) EUA \\
\hline Puccinia melanocephala & KP201838 & Wang et al. Não publicado (2014) China \\
\hline Puccinia melanocephala & KP201839 & Wang et al. Não publicado (2014) China \\
\hline Puccinia nakanishikii & GU058002 & Dixon et al. (2010) EUA \\
\hline Puccinia peperomiae & EU851146 & Zuluaga et al. (2011) Colômbia \\
\hline Uromyces acuminatus & GU109282 & Yun et al. (2010) Inglaterra \\
\hline Uromyces appendiculatus & KM249870 & McTaggart (2014) Austrália \\
\hline Uromyces appendiculatus & AY745704 & Matheny et al. Não publicado (2005) \\
\hline Uromyces ari-triphylli & DQ354529 & Aime (2006) EUA \\
\hline Uromyces ixiae & DQ917738 & Maier et al. (2007) África do Sul \\
\hline Uromyces ixiae & DQ917739 & Maier et al. (2007) África do Sul \\
\hline Uromyces pisi & $\mathrm{AF} 426201$ & Maier et al. (2003) Europa Central \\
\hline Uromyces striatus & HQ412652 & Deadman et al. (2011) Omã \\
\hline Uromyces striatus & HQ317512 & Liu et al. (2015) Canadá \\
\hline Uromyces trifoli & GU936634 & Zuluaga et al. (2011) Colômbia \\
\hline Uromyces viciae-fabae & KJ716343 & Padamsee \& McKenzie (2014) Nova Zelândia \\
\hline Uromyces viciae-fabae & AF426199 & Maier et al. (2003) Europa Central \\
\hline $\begin{array}{l}\text { Uromyces vignae } \\
\text { Melampsora larici-populina } \\
\text { (grupo externo) }\end{array}$ & $\begin{array}{l}\mathrm{AB} 115649 \\
\mathrm{JQ} 042250\end{array}$ & $\begin{array}{l}\text { Chung et al. (2004) Japão } \\
\text { Busby et al. (2012) EUA }\end{array}$ \\
\hline
\end{tabular}

*LSU: rDNA large subunit 


\section{Análise Filogenética}

As sequências consenso foram comparadas com as sequências do banco de dados do GenBank usando a ferramenta Mega BLAST. Com base nos resultados BLASTn, as sequências foram selecionadas para este estudo de acordo com as de maior similaridade e com os dados de estudos filogenéticos recentes focados em Pucciniaceae (Bruns et al. 1992, Maier et al. 2003, Chung et al. 2004, Aime 2006, Matheney et al. 2006, Henricot et al. 2007, Maier et al. 2007, Yun et al. 2010 e Dixon et al. 2010, Deadman et al. 2011, Zuluaga et al. 2011, Busby et al. 2012, McTaggart 2014, Padamse \& McKenzie 2014, Liu et al. 2015).

Após a seleção, as sequências foram baixadas em formato FASTA e alinhadas através do programa de alinhamento de múltipla sequência Muscle ${ }^{\circledR}$ (Edgar 2004) construído no software MEGA v.6 (Tamura et al. 2011). Os alinhamentos foram verificados e ajustes manuais foram realizados quando necessário. Os gaps foram tratados como dados ausentes.

O alinhamento resultante foi depositado no TreeBASE (http://www.treebase.org/), número de acesso 17667.

A análise por Inferência Bayesiana (BI) foi realizada empregando Cadeias de Markov, método de Monte Carlo (MCMC) apenas com as sequências de LSU. Antes de executar a análise de BI, foi determinado o melhor modelo de substituição de nucleotídeos com MrModeltest 2.3 (Posada \& Buckley 2004).

Uma vez que os valores de verossimilhança foram calculados, os modelos foram selecionados de acordo com o Critério de Informação de Akaike (AIC). Foi utilizado o modelo de tempo reversível geral da evolução incluindo estimativa de sítios invariáveis e assumindo uma discreta distribuição gama com seis categorias de tarifa (GTR + I + G).

A análise filogenética do conjunto de dados foi realizada através do portal web CIPRES (Miller et al. 2010) usando MrBayes v. 3.2 (Ronquist \& Heulsenbeck 2012). Quatro cadeias MCMC foram executadas simultaneamente, começando a partir de árvores aleatórias 
para 10000000 gerações. Árvores foram amostradas a cada geração de 1000 totalizando em 10000 árvores.

As primeiras 2500 árvores foram descartadas de cada análise. Probabilidades posteriores foram determinadas a partir de uma árvore consenso gerada com o restante das 7500 árvores. A árvore foi enraizada pela espécie Melampsora larici-populina e visualizada por meio do programa Figtree (Rambaut 2009) e exportada para programa de edição. 


\section{Filogenia}

A amplificação e o sequenciamento das regiões LSU e ITS rDNA foram bemsucedidos para as duas amostras obtidas tanto da fase ecial (UB22382) quanto da telial (UB22875).

A amplificação parcial da região LSU e da região ITS resultou em sequências com 1500 e 450 pb, respectivamente (números de acesso LSU: UB22382 = KR821139, UB22875 $=$ KR821140 e ITS: UB22382 = KR821137, UB22875 = KR821138). As sequências de LSU obtidas a partir de eciósporos e teliósporos mostraram-se idênticas (Figura1).

A região LSU foi selecionada para a identificação filogenética molecular do fungo uma vez que este marcador molecular é amplamente recomendado para a identificação de gênero e em nível de espécie para os fungos causadores de ferrugem (Hyde et al. 2014). As sequências ITS foram depositadas no GenBank e no UNITE (Nilsson et al. 2014).

Com base nos resultados a partir da matriz de dados primários de LSU (árvore não mostrada) e no conjunto de dados para fungos que causam ferrugem (árvore não mostrada) de Hyde et al. (2014), 31 taxa foram selecionados a partir de toda a amplitude das árvores filogenéticas derivadas de LSU. O conjunto de dados totalizou 1037 bp de posições alinhadas, dos quais 97 foram parcimônia informativos, 211 foram variáveis e 810 foram conservados. 


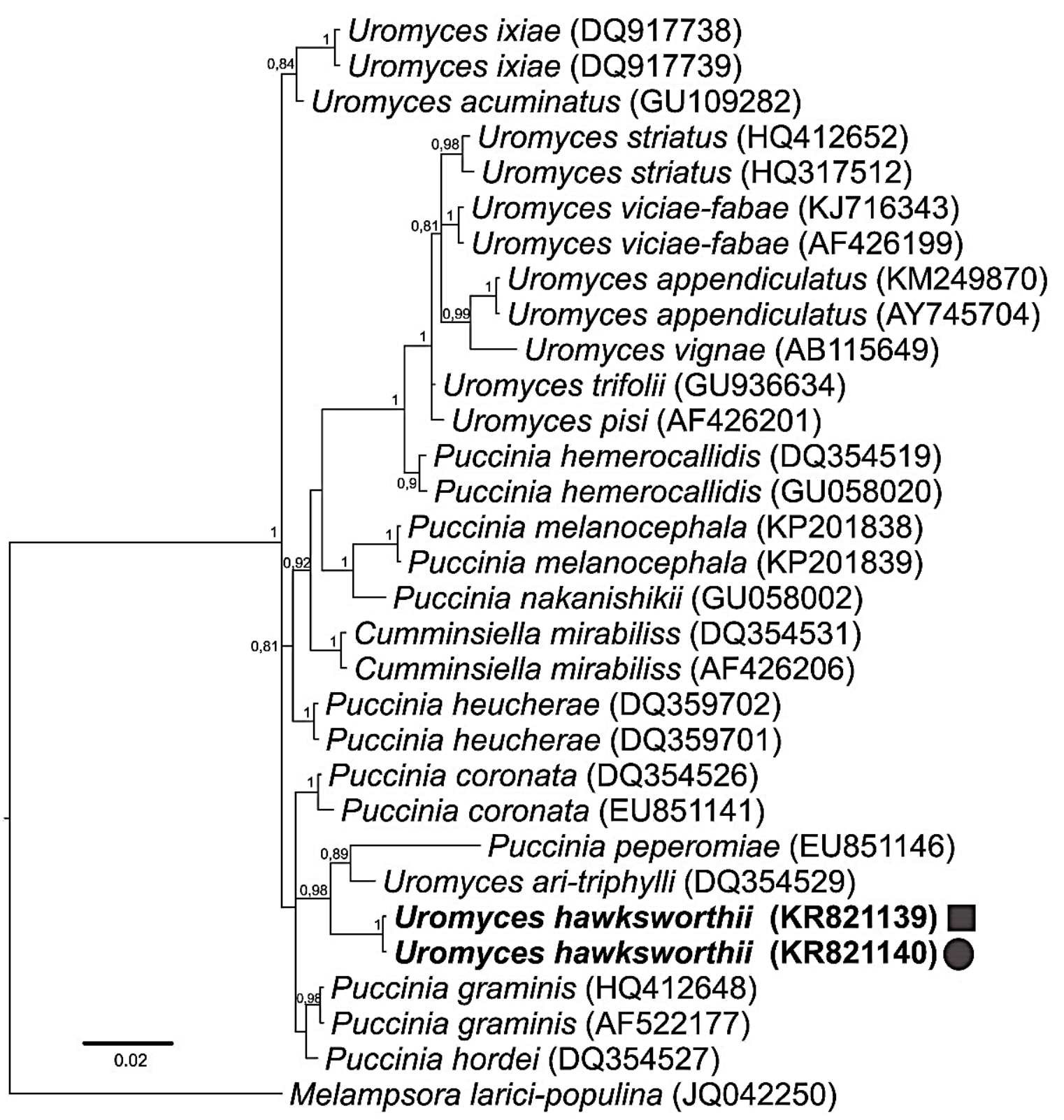

Figura 1. Árvore filogenética inferida a partir da análise Bayesiana com base nas sequências de LSU de Uromyces e taxa relacionados. A análise Bayesiana com valores de probabilidades posteriores acima de 0,75 são indicados nos nós. Os números de acesso do GenBank estão em parênteses. Os espécimes neste estudo são destacados em negrito. Quadrados e círculos pretos indicam sequências de DNA obtidas a partir de eciósporos e teliósporos, respectivamente. A árvore foi enraizada com Melampsora larici-populina. 
Espécime Tipo analisado: Brasil: Goiás, Serra dos Pirineus, em Phthirusa stelis (em Loranthus sp.), agosto de 1892, Ule 1909 (B 2945 - holótipo); Brasília, Guará I, Associação

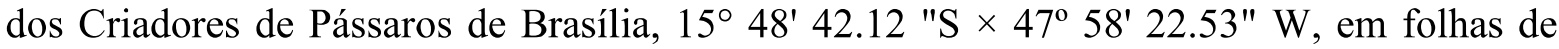
Phthirusa stelis, 09 de fevereiro de 2014, J.C. Dianese (UB Mycol. Col. 22875 - epitipo designado aqui, registro de acesso MBT 201.535).

Outros espécimes examinados: (em folhas de Phthirusa stelis): Brasil: Brasília, Guará I, Associação dos Criadores de Pássaros de Brasília, 18 de maio de 2014, J.C. Dianese (UB Mycol 22879.); Asa Norte, Campus Universidade de Brasília, próximo ao restaurante universitário, 17 de setembro de 2012, E.S.C. Souza (UB Mycol 22.389.); Parque Olhos D'Água, 12 Setembro 2012, E.S.C. Souza (UB Mycol 22382.); Lago Sul, Brasília Jardim Botânico, 23 de abril de 2012, E.S.C. Souza (UB Mycol. 22184); Asa Norte, Avenida L4, Estação Experimental de Biologia, Universidade de Brasília, 29 de setembro de 2009, M.D.M. Santos (UB Mycol. 21084); Vargem Bonita, Fazenda Água Limpa, Universidade de Brasília, 12 de setembro de 2007, N.M. Toledo Souza (UB Mycol 20651.); Asa Norte, Campus Universidade de Brasília, próximo à Reitoria, 9 de Maio. 2007, Z.M. Chaves (UB Mycol 20569.); Super Quadra Norte 410, próximo ao Bloco N, 18 de agosto de 2003, R.C.P. Carvalho (UB Mycol 19398.); Brasília Parque Nacional, 27 de setembro de 1995, Z.M. Chaves (UB Mycol. 10125).

Descrição: Espermogônios não vistos. Écios 5-6 mm de comprimento x 300-400 $\mu \mathrm{m}$ de largura, anfígenos, principalmente epífilos, gregários, inicialmente subepidermais, erumpentes, cilíndricos, cônicos, amarelo brilhante, agrupados em uma área hemisférica pulvinada castanho clara para marrom de $0,5-1 \mathrm{~cm}$ de diâmetro antes da emergência dos écios, atingindo 1,2 cm de diâmetro na maturidade; células peridiais 30-(36) 21-57 x (22)-35 $\mu \mathrm{m}$, 
oblongo a romboidal, parede exterior áspera, hialina ou levemente amarelada. Eciósporos (24) $25-29(-35) \times(17-) 21-25(-27,5) \mu \mathrm{m}$, angulares, romboides, subglobosos, ovoides, catenulados, verrugosos, hialinos a amarelos pálidos; paredes $2-3,5(-4,5) \mu \mathrm{m}$. Urédias não vistas. Télias 1- (2) -3 mm diam, manchas circulares marrons, anfígenas, subepidermais, erumpentes, pulverulentas, marrom escuras, anfígenas, achatadas a ligeiramente cupulares, aparafisadas, mas mostrando um grande número de pedicelos longos dos teliósporos.

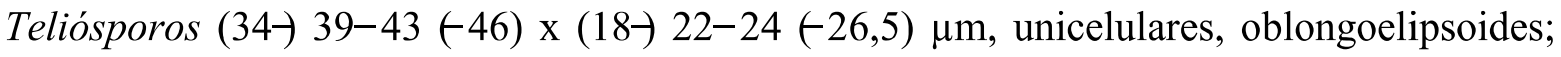
paredes pálidas a castanhas/marrons, reticuladas em MEV, poros germinativos não observados; parede lateral 2,5-3 (-4) mm grossa, parede apical 5-6 (-7) $\mu \mathrm{m}$ de espessura, pedicelos longos (48-) 84-143(-157) x (4- ) 5-6 (-7) $\mu \mathrm{m}$, raramente persistentes em teliósporos maduros, cilíndricos, flexuosos, lisos, paredes finas e hialinas. As fases, ecídica e telial são ilustradas nas figuras 2 e 3 , respectivamente.

\section{Chave de identificação para espécies de Uromyces em Loranthaceae}

1. Teliósporos de parede lisa, 30-45 x 21-30 $\mu \mathrm{m}$, parede distal com $8 \mu \mathrm{m}$ de espessura

U. nilagiricus.

Teliósporos de paredes não lisas 2

2(1). Teliósporos quase sempre inferiores a $40 \mu \mathrm{m}$ de comprimento 3

Teliósporos principalmente com mais de 40 um de comprimento 7

3(2). Teliósporos mostrando pedicelos ornamentados por anelações conspícuas

U. ornatipes.

Teliósporos com pedicelos não ornamentados por anelações conspícuas 4

4(3). Teliósporos com parede reticulada-estriada ou reticulada

Teliósporos com parede não como anteriormente 
5(4). Teliósporos com parede apical espessa.

U. circumscriptus.

Teliósporos com parede medindo uniformemente $2 \mu \mathrm{m}$ de espessura

U. bahiensis.

6(4). Teliósporos suaves para ligeiramente verrugosos; urédias parafisadas, urediniósporos equinulados, espinhos abundantes

U. loranthi.

Teliósporos longitudinalmente estriados; urédias aparafisadas, urediniósporos

equinulados

U. socius.

7(2). Teliósporos de pedicelos curtos, pedicelos com $50 \mu \mathrm{m}$ de comprimento 8

Teliósporos de pedicelos longos, pedicelos atingindo de 90-60 $\mu \mathrm{m}$ de comprimento

8(7). Teliósporos mostrando ornamentações muito finas sobre uma disposição reticulada, urediniósporos grosseiramente reticulados; eciósporos verrugosos, subtuberculados U. phthiruzae.

Teliósporos diferentes dos descritos acima, eciósporos minunciosamente verrugosos para verrugosos 9

9(8). Teliósporos verrugosos-estriados; eciósporos verrugosos

U. urbanianus.

Teliósporos reticulados, eciósporos minuciosamente verrugosos

U. evastigatus.

10(7). Teliósporos reticulados-foveado; eciósporos equinulados.

U. struthanthi.

Teliósporos, não reticulados-foveado; eciósporos verrugosos

U. hawksworthii. 

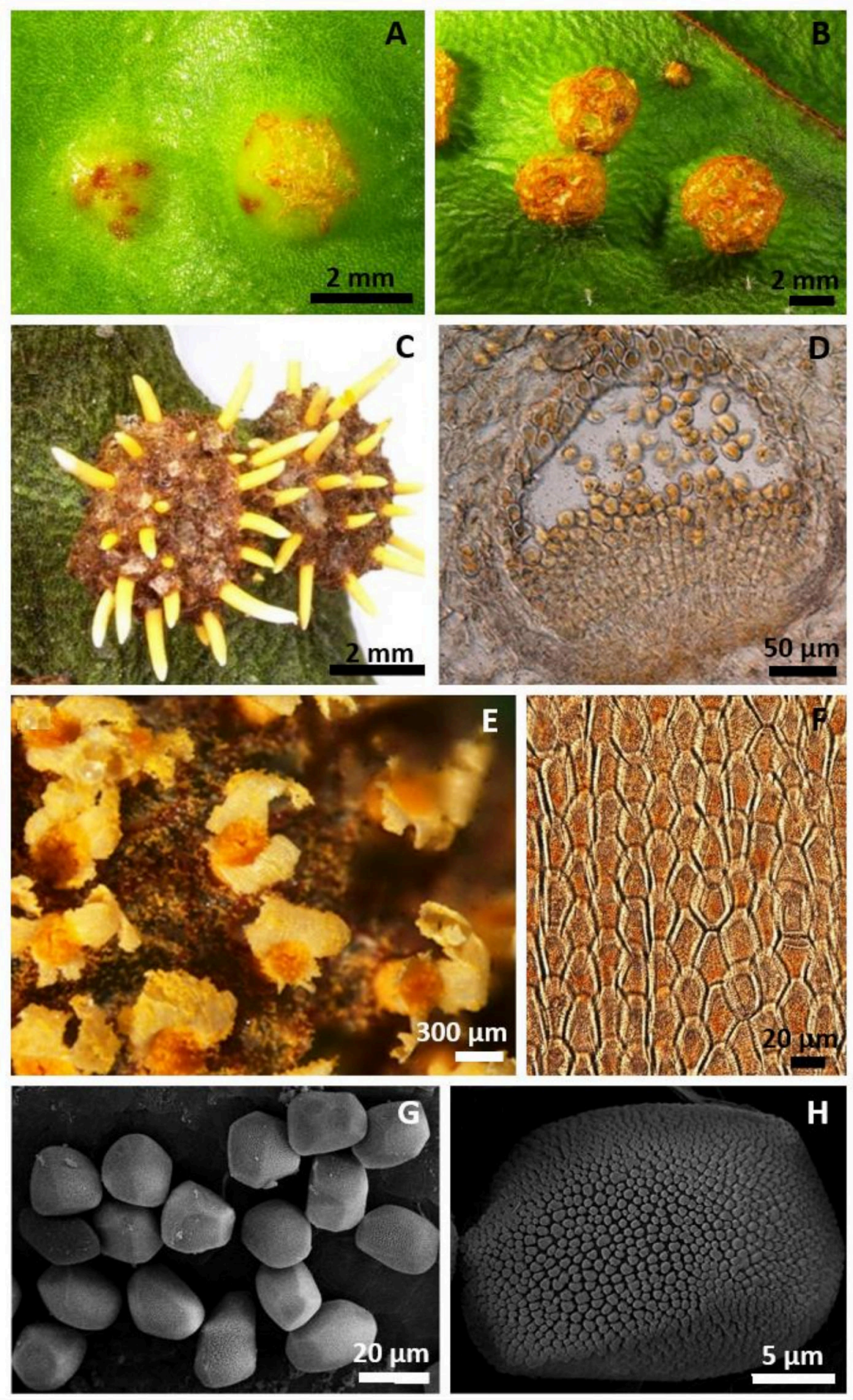

Figura 2. Fase ecídica de Uromyces hawksworthii em folhas de Phthirusa stelis Desenvolvimento de galhas ecidiais e morfologia do écio: $\mathbf{A}$. Fase inicial de formação. B. Estágio intermediário de duas galhas. C. Duas galhas maduras tendo numerosos écios colunares. D. Corte transversal de um écio em desenvolvimento. E. Écios após o lançamento de eciósporos. F. Textura interna da parede do perídio. G. Eciósporos. H. Detalhe da parede do eciósporo. 

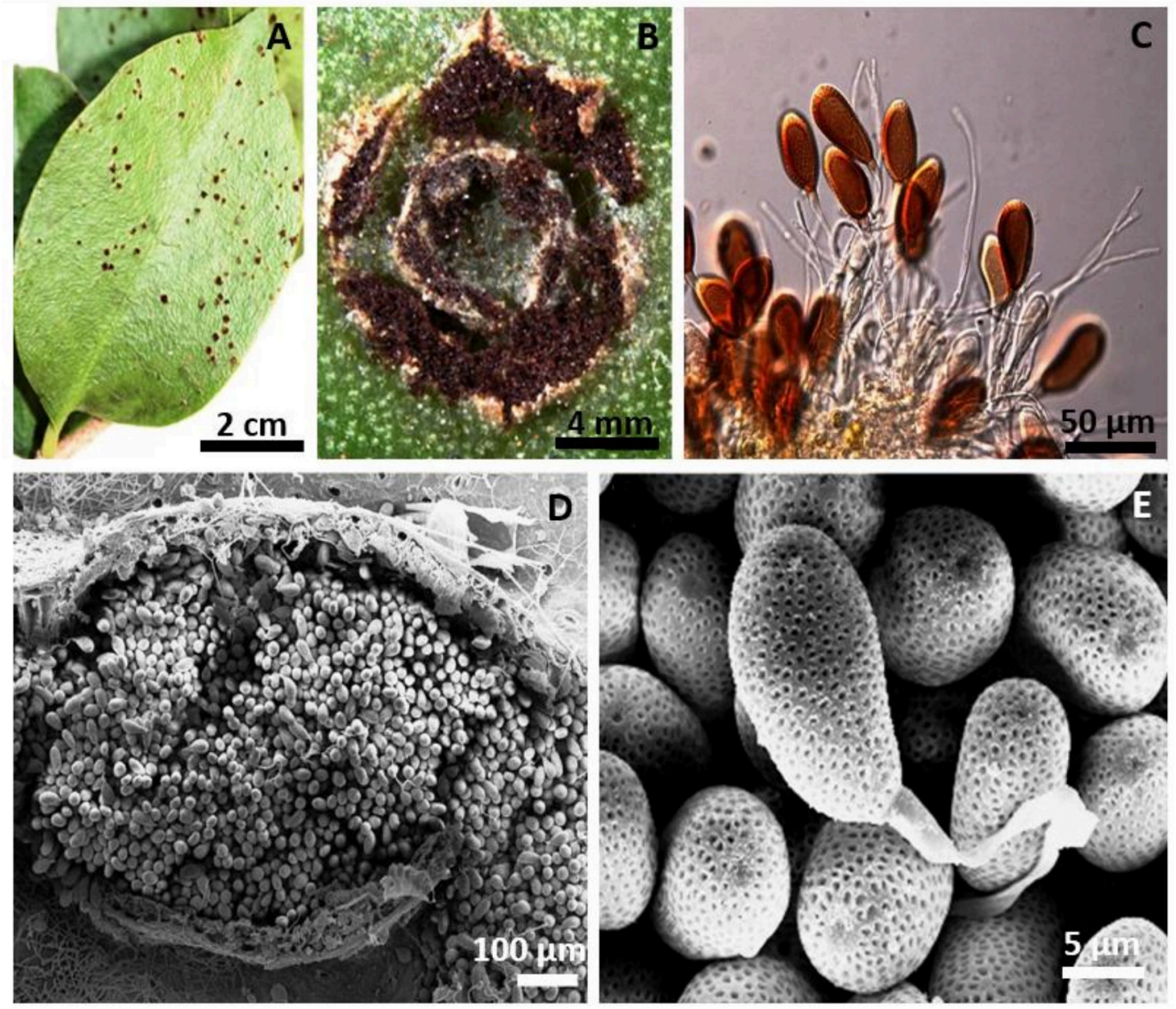

Figura 3. Fase telial de Uromyces hawksworthii (UB Mycol Col. 22875.) em folhas

de Phthirusa stelis: A. Télias circulares castanho escuras irregulares na face adaxial. B. Detalhe da télia erumpente. C. Grupo de teliósporos maduros e vários pedicelos longos similares a paráfises. D. Télio visto em MEV. E. Teliósporos mostrando parede reticulada em MEV. 
Uromyces hawksworthii é morfologicamente diferente das outras espécies relatadas no Brasil em Loranthaceae, pois apresenta écios eretos em forma de colunas cilíndricas a cônicas com 3,5 mm de altura, localizado em discos pulvinados bem definidos ou galhas subglobosas castanhas (Figura 2).

Além disso, U. hawksworthii é filogeneticamente distinta dos outros taxa obtidos do GenBank (Figura 1).

Com base na busca comparativa por meio da ferramenta Blastn do GenBank, os isolados mais próximos usando sequência de LSU foram: Puccinia heucherae RHS5296/05 (GenBank DQ359702), U. acuminatus CT-V080623-3 (GenBank GU109282), U. aritriphylli U637 (GenBank DQ354529), Puccinia graminis L-674 (GenBank HQ412648) e P. hordei AFTOL ID-1402 (GenBank DQ354527), todas com 98\% identidade.

Além disso, tanto a fase ecial como a telial dos espécimes de Uromyces hawksworthii examinados neste estudo se mostraram idênticos e formaram um clado robusto (probabilidade posterior $=0,98)$ juntamente com Uromyces ari-triphylli e Puccinia peperomiae (Figura 1).

Os dois espécimes de U. hawksworthii formaram um grupo irmão com outros taxa incluídos. Como os fungos causadores de ferrugem da América do Sul são pouco caracterizados molecularmente, dados adicionais de sequência de DNA serão necessários para esclarecer a filogenia desses fungos dos trópicos.

A forma ecídica deste fungo foi descrita como Aecidium goyazense (Hennings 1895), entretanto a fase telial nunca havia sido relatada. O binômio Uromyces goyazensis já se encontra ocupado por um fungo Pucciniales encontrado em Bauhinia sp. (Hennings 1895), o que significa que o nome Aecidium goyazense não pode ser recombinado em Uromyces pois isso criaria um homônimo a ser rejeitado (art. 53.1 do Código de Nomenclatura para Plantas, 
Algas e Fungos). Consequentemente, foi dado o novo nome Uromyces hawksworthii para o fungo aqui estudado em homenagem ao pesquisador David Leslie Hawksworth, presidente honorário da Associação Internacional de Micologia.

Duas chaves de identificação para espécies de Uromyces sobre Loranthaceae estão disponíveis (Hennen et al. 2005, Perdomo-Sánchez \& Piepenbring 2014). Em cada chave as espécies foram separadas pela forma e pela ornamentação dos teliósporos, écios, eciósporos, presença ou ausência da fase uredínica e espécies hospedeiras.

Perdomo-Sánchez \& Piepenbring (2014) revisaram e ilustraram por microscopia de luz e por MEV espécimes de Uromyces sobre Loranthaceae ao redor do mundo, com exceção de $U$. nilagiricus, uma espécie relatada em Loranthus sp. da Índia, para os quais o material tipo não estava disponível. Esta é a única espécie encontrada fora da América Latina distinguida por teliósporos lisos (Ramakrishnam \& Ramakrishnam 1950).

Com base em características da parede dos teliósporos, as espécies de Uromyces na família Loranthaceae são distribuídas em dois grupos bem definidos. Um tem teliósporos com superfície verrugosa ou marcadamente estriada, incluindo $U$. euphlebius, $U$. ornatipes, $U$. loranthi, U. phthirusae e U. socius (Sydow 1920, Arthur 1915, 1918, Perdomo-Sánchez \& Piepenbring 2014).

O outro grupo possui teliósporos não verrugosos com a superfície foveada, incluindo U. bahiensis, U. circumscriptus, U. evastigatus, U. loranthi, U. phthirusae, U. struthanthi, e U. urnabianus. Neste último grupo de espécies, apenas a $U$. loranthi (fase ecídica desconhecida, teliósporos verrugosos) e $U$. phthirusae (teliósporos estriados) têm uma fase uredínica conhecida.

Este trabalho aqui realizado já foi publicado em forma de artigo em 2015 e a publicação original encontra-se no anexo 1 . 


\section{REFERÊNCIAS}

Aime MC (2006) Toward resolving family-level relationships in rust fungi (Uredinales). Mycoscience. 47: 112-122.

Arthur JC (1915) New species of Uredineae IX. Bulletin of Torrey Botanical Club. 42: 585593.

Arthur JC (1918) Uredinales of Guatemala based on collections by WWD. Holway - II. Aecidiaceae, exclusive of Puccinia and form genera. American Journal of Botany. 5: 420446.

Bruns TD, Vilgalys R, Barns SM, Gonzalez D, Hibbett DS, et al. (1992) Evolutionary relationships within the fungi: analyses of nuclear small subunit rRNA sequences. Molecular Phylogenetics and Evolution. 1: 231241.

Busby PE, Aime MC, Newcombe G (2012) Foliar pathogens of Populus angustifolia are consistent with a hypothesis of Beringian migration into North America. Fungal Biology. 116: 792-801.

Chung WH, Tsukiboshi T, Ono Y, Kakishima M (2004) Morphological and phylogenetic analyses of Uromyces appendiculatus and U. vignae on legumes in Japan. Mycoscience. 45: 233-244.

Deadman ML, Al Sadi AM, Al Maqbali YM, Farr DF, Aime MC (2011) Additions to the rust fungi (Pucciniales) from northern Oman. Sydowia. 63: 155-168.

Dixon LJ, Castlebury LA, Aime MC, Glynn NC, Comstock JC (2010) Phylogenetic relationships of sugarcane rust fungi. Mycological Progress. 9: 459-468.

Doyle JJ, Doyle JL (1990) Isolation of plant DNA from fresh tissue. Focus. 12: 13-15.

Edgar RC (2004) MUSCLE: a multiple sequence alignment method with reduced time and space complexity. BMC Bioinformatics. 5: 113.

Hall T (2012) BioEdit v 7.0.9: Biological sequence alignment editor for Win95/98/2K/XP/7. 
Hennen JF, Figueiredo MB, Carvalho Jr. AA, Hennen PG (2005) Catalogue of the species of plant rust fungi (Uredinales) of Brazil. Instituto de Pesquisas, Jardim Botânico do Rio de Janeiro Rio de Janeiro, Brazil.

Hennings P (1895) Fungi goyazenses. Hedwigia. 34: 88-112.

Henricot BA, Denton GA, Lane CB (2007) First report of Puccinia heucherae on Heuchera spp. in the UK. Plant Pathology. 56: 352.

Hyde KD, Nilsson RH, Alias SA, Ariyawansa AH, Blair E, et al. (2014) One stop shop: backbones trees for important phytopathogenic genera: I (2014). Fungal Diversity. 67: 21-125.

Kropp BR, Hansen DR, Wolf PG, Flint KM, Thomson SV (1997) A study on the phylogeny of the dyer's woad rust fungus and other species of Puccinia from Crucifers. Phytopathology. 87: 565-571.

Liu M, McCabe E, Chapados JT, Carey J, Wilson SK, et al. (2015) Detection and identification of selected cereal rust pathogens by TaqMan ${ }^{\circledR}$ real-time PCR. Canadian Journal of Plant Pathology. 37: 92-105.

Maier W, Begerow D, Weiss M, Oberwinkler F (2003) Phylogeny of the rust fungi: an approach using nuclear large subunit ribosomal DNA sequences. Canadian Journal of Botany. 81: 12-23.

Maier W, Wingfield BD, Mennicken M, Wingfield MJ (2007) Polyphyly and two emerging lineages in the rust genera Puccinia and Uromyces. Mycological Research. 111: 176-185.

Matheny PB, Gossmann JA, Zalar P, Kumar TKA, Hibbett DS (2006) Resolving the phylogenetic position of the Wallemiomycetes: an enigmatic major lineage of Basidiomycota. Canadian Journal of Botany. 84: 1794-1805.

McTaggart AR, Geering ADW and Shivas RG (2014) Uredinopsis pteridis and Desmella aneimiae, the first rust fungi (Pucciniales) reported on ferns (Pteridophyta) in Australia. Australasian Plant Disease. Notes 9: 149. 
Miller MA, Pfeiffer W, Schwartz T (2010) Creating the CIPRES Science Gateway for inference of large phylogenetic trees. Proceedings of the Gateway Computing Environments Workshop (GCE), 14 Nov. 2010, New Orleans, LA: 1-8.

Moncalvo JM, Wang HH, Hseu RS (1995) Phylogenetic relationships in Ganoderma inferred from the internal transcribed spacers and 25S ribosomal DNA sequences. Mycologia. 87: 223-238.

Nilsson RH, Hyde KD, Pawłowska J, Ryberg M, Tedersoo L, et al. (2014) Improving ITS sequence data for identification of plant pathogenic fungi. Fungal Diversity. 67: 11-19.

Padamsee M, McKenzie EHC (2014) A new species of rust fungus on the New Zealand endemic plant, Myosotidium, from the isolated Chatham Islands. Phytotaxa. 174: 223230.

Perdomo-Sánchez O, Piepenbring M (2014) Species of Uromyces (Puccinilaes, Basidiomycota) on Loranthaceae. Tropical Plant Pathology. 39: 141-153.

Pfunder M, Schürch S, Roy BA (2001) Sequence variation and geographic distribution of pseudoflower-forming rust fungi (Uromyces pisi s. lat.) on Euphorbia cyparissias. Mycological Research. 105: 57-66.

Posada D, Buckley T (2004) Model selection and model averaging in phylognetics: advantages of Akaike information criterion and Bayesian approaches over likelihood ratio tests. Systematic Biology. 53: 793-808.

Ramakrishnam TS, Ramakrishnam K (1950) Additions to fungi of Madras VIII. Proceedings of the Indian Academy of Science. B 3: 102-110.

Rambaut A (2009) FigTree. Version 1.2.3. Edinburgh: Institute of Evolutionary Biology, University of Edinburgh.

Ronquist F, Teslenko M, van der Mark P, Ayres DL, Darling A, Höhna S, Larget B, Liu L, Suchard MA, Huelsenbeck JP (2012) Mrbayes 3.2: efficient Bayesian phylogenetic inference and model choice across a large model space. Systematic Biology. 61: 539-542.

Sydow HP (1920) Novae fungorum species. Annales Mycologici. 18: 154-160. 
Tamura K, Peterson D, Peterson N, Stecher G, Nei M, Kumar S (2011) Mega 5: molecular evolutionary genetics analysis using maximum likelihood, evolutionary distance, and maximum parsimony methods. Molecular Biology and Evolution. 28: 2731-2739.

Vilgalys R, Hester M (1990) Rapid genetic identification and mapping of enzymatically amplified ribosomal DNA from several Cryptococcus species. Journal of Bacteriology. 172: $4238-4246$.

Yun HY, Minnis AM, Dixon LJ, Castlebury LA (2010) First report of Uromyces acuminatus on Honckenya peploides, the endangered sea beach sandwort. Plant Disease. 94: 279.

Zuluaga C, Buriticá P, Marín M (2011) Filogenia de hongos/roya (Uredinales) em la zona andina colombiana mediante el uso de secuencias del DNA ribosomal 28S. Revista de Biología Tropical. 59: 517-540. 


\title{
CAPÍTULO 4
}

Esse Capitulo consiste na versão em português do trabalho submetido para publicação no dia 26 de novembro de 2016, no peródico Fungal Biology, editado via Elsevier pela British Mycological Society

\section{INTERAÇÃO ENTRE Colletotrichum truncatum E Uromyces euphorbiae EM}

\section{FOLHAS DE Euphorbia hirta (*)}

\author{
AUTORES: Érica S.C. Souza, Helson M.M. Vale, Rita C. Pereira-Carvalho, William R.O. \\ Soares, Robert G.N. Miller, José C. Dianese
}

(PDF no Anexo 2)

\section{RESUMO}

Euphorbia hirta (Euphorbiaceae) ocorre na maioria das regiões tropicais e subtropicais do mundo, incluindo no Brasil, Austrália, Índia e EUA. Em Brasília, plantas infectadas com Uromyces euphorbiae mostraram lesões características de pústulas de ferrugem (485-220 $\mu \mathrm{m}$ diâmetro) delimitadas por um centro necrótico e circundada por uma borda marromavermelhada contendo urediniósporos e teliósporos. Em $74 \%$ das lesões foliares, foram produzidos acérvulos setosos de uma espécie de Colletotrichum, exclusivamente dentro da área necrótica e ao redor das pústulas. A caracterização morfológica e molecular confirmaram a espécie Colletotrichum truncatum, com conídios tipicamente curvados (31)-27-23 x 3-4 $\mu \mathrm{m}$ ) acérvulos medindo $86-44 \mu \mathrm{m}$, formados por uma paliçada de setas negras e longas (até $140 \times 5 \mu \mathrm{m})$. Acérvulos de Colletotrichum truncatum não foram encontrados apenas em $26 \%$ das pústulas, e não foram observados nas áreas da folha onde U. euphorbiae não ocorre. 
Isolamento de áreas saudáveis das folhas e das folhas sem infecção por ferrugem, revelou que o fungo associado tratava-se de uma espécie endofítica. Os sequenciamentos das regiões parciais dos genes ITS, TUB2, GAPDH e HIS3 revelou que os espécimes, endofítico e acervular próximos às pústulas, pertenciam à mesma espécie e são membros do complexo $C$. truncatum. O fungo causador de ferrugem foi pela primeira vez sequenciado (regiões LSU e ITS do rDNA) e ilustrado em Microscopia Eletrônica de Varredura. Pesquisas adicionais são necessárias para esclarecer o aspecto fisiológico da interação entre $U$. euphorbiae e o fungo endofítico C. truncatum.

Palavras chave: Fungos Neotropicais, Identificação Morfo-molecular, Pucciniales, Glomerelalles 
Entre 2011 e 2016, foram encontrados na Estação Experimental de Biologia da Universidade de Brasília plantas da espécie Euphorbia hirta, uma erva daninha comum em terrenos baldios e plantios agrícolas nas regiões tropicais e subtropicais do mundo, incluindo o Brasil, Austrália, Índia e EUA (CABI 2016). As plantas mostraram manchas de folhas contendo pústulas de fungo causador de ferrugem devido a infecção por uma espécie de Uromyces, na maioria cercada por acérvulos setosos castanho escuros de uma espécie de Colletotrichum.

Assim, o objetivo deste trabalho foi caracterizar morfologicamente e molecularmente ambos os fungos e discutir o significado dessa interação. 


\section{MATERIAL E MÉTODOS}

\section{Morfologia}

As lesões foliares contendo espécie de Colletotrichum e o fungo causador da ferrugem foram inicialmente estudadas sob um microscópio estereoscópico, seguido por observações de lâminas contendo as estruturas fúngicas e cortes histológicos de 15-20 $\mu \mathrm{m}$ de espessura obtidos utilizando um criomicrótomo Leica ${ }^{\circledR}$.

As características morfológicas de ambos os fungos foram descritas, mensuradas e fotografadas usando um estereomicroscópio Leica M 206C® e um microscópio de luz Leica DM 2500® juntamente com uma câmera digital Leica DFC 490® acoplada a um computador.

A captura de imagens, edição e mensurações foram feitas usando o software Leica QWIN® V3. Em alguns casos, as amostras foram coradas com lacto-glicerol algodão azul e as lâminas seladas com esmalte para unhas, no entanto a maior parte do trabalho fotográfico foi feito sem coloração utilizando Nomarski óptica.

Um mínimo de 20 repetições de esporos e estruturas celulares foram medidas. Parte de folhas secas que continham acérvulos e pústulas da ferrugem com urediniósporos e teliósporos foram fixados sobre blocos de bronze de $10 \mathrm{~mm}$ de diâmetro com fita dupla face de carbono, e tratada com ouro a $25 \mathrm{~mA}, 1,10-2$ mbar, durante 2,5 minutos para o estudo detalhado da morfologia das estruturas fúngicas em Microscopia Eletrônica de Varredura (MEV) modelo JEOL JSM-700® 1F.

As amostras de plantas contendo os fungos associados foram herborizadas e depositadas na Coleção Micológica do Herbário UB com os seguintes códigos: UB21591, UB22311, UB23207 e UB23305. 


\section{Cultura, Extração de DNA, Amplificação por PCR e Sequenciamento de DNA}

Os espécimes de Colletotrichum foram diretamente isolados a partir dos acérvulos em torno das lesões da ferrugem, e, também, a partir de áreas assintomáticas das folhas da planta superficialmente desinfestadas por lavagem em série em $2 \%$ de hipoclorito, $70 \%$ de etanol e água destilada esterilizada para verificar a possível presença do fungo endofítico.

Os isolados foram cultivados em placas de Petri contendo batata-dextrose-ágar (BDA) durante sete dias antes da obtenção de culturas monospóricas utilizadas para os estudos morfológicos, e para a extração do DNA genômico necessária para a caracterização molecular das espécies.

Os isolados obtidos foram armazenados em água destilada esterilizada (Dhingra \& Sinclair 1995) com o código de acesso CCUB 29 para o isolado acervular e CCUB 30 para o endofítico.

O DNA genômico da ferrugem foi extraído a partir de pústulas mistas com urediniósporos e teliósporos da ferrugem, e, também separadamente, a partir dos eciósporos. Para todas as amostras de ambas as espécies, Colletotrichum e Uromyces, a extração do DNA genômico foi feita usando o método CTAB (Brometo de Cetiltrimetil Amônio), seguindo Doyle \& Doyle (1990).

Quatro regiões gênicas parciais foram sequenciados para ambos isolados de Colletotrichum: ITS; $\beta$-tubulin2 (TUB2); GAPDH e Histona H3 (Tabela 1).

No caso do fungo causador de ferrugem, a região ITS e LSU do rDNA foram sequenciadas usando os iniciadores contidos na Tabela 1.

As PCRs para ambas as espécies de Uromyces e de Colletotrichum foram realizadas usando os seguintes reagentes para um volume total de $25 \mu \mathrm{L}$ por reação: $0,5 \mathrm{U}$ de Taq DNA polimerase Platinum ${ }^{\circledR}, 0,2 \mathrm{mM}$ de cada nucleotídeo, Tampão 10X (10-50 mM de Tris-HCl, $\mathrm{pH} 8,3, \mathrm{KCl} 50 \mathrm{mM}), 1,5 \mathrm{mM}$ de $\mathrm{MgCl} 2,0,4 \mu \mathrm{M}$ de cada um dos iniciadores sensu e anti- 
sensu (Tabela 1); além de um máximo de $10 \mathrm{ng} / \mathrm{mL}$ de DNA genômico. O ciclo térmico consistiu em $94^{\circ} \mathrm{C}$ durante 4 min, seguido por 30 ciclos de $94^{\circ} \mathrm{C}$ durante 1 min (desnaturação), temperatura de anelamento de acordo com a tabela 1 durante $1 \mathrm{~min}, 72^{\circ} \mathrm{C}$ durante $1 \mathrm{~min}$ (elongação) e $72^{\circ} \mathrm{C}$ durante 5 min (extensão final).

Tabela 1. Iniciadores e respectivas temperaturas de anelamento utilizadas na PCR.

\begin{tabular}{|c|c|c|c|c|c|}
\hline $\begin{array}{l}\text { Espécie } \\
\text { fúngica } \\
\end{array}$ & $\begin{array}{l}\text { Região ou } \\
\text { gene }\end{array}$ & Primer & Sequência & $\begin{array}{c}\text { Temp. } \\
\text { Anelamento } \\
\end{array}$ & Referências \\
\hline \multirow{8}{*}{$\begin{array}{l}\text { Colletotrichum } \\
\text { truncatum }\end{array}$} & \multirow{2}{*}{ ITS } & ITS5 & GGAAGTAAAAGTCGTAACAAGG & \multirow{2}{*}{$55^{\circ} \mathrm{C}$} & White et al. (1990) \\
\hline & & ITS4 & TCCTCCGCTTATTGATATGC & & White et al. (1990) \\
\hline & \multirow{2}{*}{ GAPDH } & GDF1 & GCCGTCAACGACCCCTTCATTGA & \multirow{2}{*}{$58^{\circ} \mathrm{C}$} & Templeton et al. (1992) \\
\hline & & GDR1 & GGGTGGAGTCGTACTTGAGCATGT & & Templeton et al. (1992) \\
\hline & \multirow{2}{*}{ HIS } & CYlH3F & AGGTCCACTGGTGGCAAG & \multirow{2}{*}{$58^{\circ} \mathrm{C}$} & Crous et al. (2004) \\
\hline & & CY1H3R & AGCTGGATGTCCTTGACTG & & Crous et al. (2004) \\
\hline & \multirow[b]{2}{*}{ TUB2 } & $\mathrm{T} 1$ & AACATGCGTGAGATTGTAAGT & \multirow[b]{2}{*}{$62^{\circ} \mathrm{C}$} & Glass \& Donaldson (1995) \\
\hline & & $\mathrm{Bt} 2 \mathrm{~b}$ & ACCCTCAGTGTAGTGACCCTTGGC & & $\begin{array}{c}\text { O'Donnell \& Cigelnik } \\
\text { (1997) }\end{array}$ \\
\hline \multirow{6}{*}{$\begin{array}{l}\text { Uromyces } \\
\text { euphorbiae }\end{array}$} & \multirow[t]{2}{*}{ ITS } & $\begin{array}{l}\text { ITS4- } \\
\text { rust }\end{array}$ & CAGATTACAAATTTGGGCT & \multirow{2}{*}{$55^{\circ} \mathrm{C}$} & Pfunder et al. (2001) \\
\hline & & ITS5-u & AAGGTTTCTGTAGGTG & & Pfunder et al. (2001) \\
\hline & \multirow{4}{*}{ LSU } & Rust2inv & GATGAAGAACACAGTGAAA & \multirow{2}{*}{$55^{\circ} \mathrm{C}$} & Aime (2006) \\
\hline & & LR6 & CGCCAGTTCTGCTTACC & & Vilgalys \& Hester (1990) \\
\hline & & LR0R & ACCCGCTGAACTTAAGC & \multirow{2}{*}{$53^{\circ} \mathrm{C}$} & Moncalvo et al. (1995) \\
\hline & & Rust1 & GCTTACTGCCTTCCTCAATC & & Kropp et al. (1997) \\
\hline
\end{tabular}

Os produtos de PCR foram analisados por eletroforese em géis de agarose a $1 \%$ corado com brometo de etídio em tampão TAE 1X e visualizados sob luz UV para verificar o tamanho e pureza dos amplicons. Os produtos da PCR foram tratados com ExoSAP-IT ${ }^{\circledR}$ (USB) e sequenciados em um sequenciador da Applied Biosystems (modelo ABI3130xl) do Laboratório de Biotecnologia da Universidade Católica de Brasília. 


\section{Análise Filogenética}

As sequências dos nucleotídeos foram editadas usando BioEdit (Hall 2012) e Geneious-R8 (Kearse et al. 2012). Todas as sequências foram verificadas manualmente, e os nucleotídeos com posições ambíguas foram esclarecidas usando ambas as sequências dos iniciadores. As novas sequências foram depositadas no GenBank (http://www.ncbi.nlm.nih.gov/genbank/) e os seus números de acesso estão listados nas Tabelas 2 e 3.

Sequências consenso de todos os segmentos amplificados pertencentes às duas espécies de fungos foram comparados com aqueles do GenBank através da ferramenta BLASTn. Foram selecionadas sequências que mostraram similaridade para as análises filogenéticas enfatizando aquelas que ocorrem em hospedeiras pertencem na família Euphorbiaceae.

No caso do estudo envolvendo Colletotrichum também foram considerados estudos filogenéticos recentes centrados em espécies de conídios curvados para a seleção de espécies a serem incluídas nessas análises (Damm et al. 2009, Hyde et al. 2014, Yang et al. 2014).

Após a seleção, as sequências foram baixadas do GenBank em formato FASTA sendo ITS, TUB2, GAPDH e HIS3 de espécies de Colletotrichum e apenas ITS e LSU para Uromyces. Os alinhamentos foram realizados por Muscle ${ }^{\circledR}$ (Edgar 2004), no MEGA v.6 (Tamura et al. 2013), checados e ajustados manualmente quando necessário. Os gaps foram tratados como dados ausentes.

Os alinhamentos referentes a cada marcador utilizado para as análises filogenéticas das espécies de Colletotrichum foram analisados separadamente e após concatenados por meio do programa Mesquite v.3.10 (Maddison \& Maddison 2016).

Os alinhamentos resultantes da análise das espécies fúngicas foram depositados no TreeBASE (http://www.treebase.org/), número de acesso 19554. 
As relações filogenéticas para ambas as espécies de fungos foram realizadas sob Máxima Verossimilhança, em inglês Maximum Likelihood (ML) e sob Inferência Bayesiana, em inglês Bayesian Inference (BI) utilizando os softwares PAUP * v. $4.0 \mathrm{~b} 10$ (Swofford 2002) e Mr. Bayes v. 3.2.1 (Ronquist et al. 2012). Antes de lançar o ML e BI, o melhor modelo de substituição dos nucleotídeos foi determinado com MrMODELTEST 2.3 (Posada \& Buckley 2004). Uma vez que os valores de probabilidade foram calculados, os modelos foram selecionados de acordo com o Critério de Informação Akaike (AIC).

O método de ML baseou-se no modelo GTR + I + G e a árvore foi desenhada com comprimentos dos ramos sendo mensurados o número de substituições por sítio. A estabilidade dos clados das árvores ML foi calculada por meio de análise de bootstrap com 1000 repetições.

A análise por Inferência Bayesiana (BI) foi realizada empregando Cadeias de Markov, método de Monte Carlo (MCMC). Uma vez que as probabilidades para verossimilhança foram calculadas, os modelos foram selecionados de acordo com o Critério de Informação de Akaike (AIC).

Utilizou-se o modelo de tempo-reversível geral da evolução incluindo estimativa de sítios invariáveis e assumindo uma distribuição gama discreta com seis categorias de tarifa $(\mathrm{GTR}+\mathrm{I}+\mathrm{G})$. Quatro cadeias MCMC foram executadas simultaneamente, a partir de árvores aleatórias para 10.000.000 gerações. Árvores foram amostradas a cada geração das 1.000th gerando um total de 10.000 árvores. As primeiras 2500 árvores foram descartadas de cada análise. As probabilidades posteriores foram determinadas a partir de uma árvore consenso gerada com as 7500 árvores remanescentes.

As árvores foram enraizadas com as espécies Colletotrichum lindemuthianum para análise filogenética das espécies de Colletotrichum e Melampsora larici-populina para a análise filogenética envolvendo as espécies de Uromyces. Em seguida foram visualizadas no 
Figtree (Rambaut 2009) e exportaddas para programa de edição. Os filogramas gerados pelos métodos (ML e BI) são apresentados nas Figuras 1 e 2. 
Ambos os isolados de Colletotrichum associados com as pústulas de ferrugem causada por uma espécie de Uromyces sobre E. hirta, e ocorrendo como endofítico em folhas saudáveis, foram identificados como sendo a mesma espécie e pertencentes ao complexo $C$. truncatum.

O fungo causador de ferrugem foi identificado como U. euphorbiae. A identificação de $C$. truncatum e $U$. euphorbiae infectando E. hirta foi baseada em análises moleculares e morfológicas, como se segue.

No caso de $C$. truncatum, amplificação e sequenciamento da região ITS do rDNA, e genes TUB2, GAPDH e HIS3 foram realizados para ambos os isolados (acervular e endofíticos).

A matriz gerada usando os quatro marcadores de forma concatenada para 31 taxa, incluindo aqueles selecionados de GenBank (Tabela 2), resultou em um conjunto de dados de 1277 pb de posições alinhadas, sendo 373 para parcimônia informativos, 400 variáveis e 877 conservados, e usados para as análises de Máxima Verossimilhança e Inferência Bayesiana.

Além disso, a analise molecular (Figura 1) mostrou que tanto o isolado acervular e o isolado endofítico são, de fato, membros da mesma espécie, C. truncatum. 
Tabela 2. Acessos do GenBank de Colletotrichum truncatum (Endofítico e Acervular) e todas as outras espécies incluídas neste estudo.

\begin{tabular}{|c|c|c|c|c|c|}
\hline \multicolumn{6}{|c|}{ Números de acessos do GenBank } \\
\hline ESPÉCIES & ITS & TUB2 & GAPDH & HIS3 & FONTE \\
\hline C. truncatum CCUB 2239 (Endofítico) & KT955900 & KT955902 & KT955906 & KT955904 & Presente estudo \\
\hline C. truncatum CCUB 2242 (Acervular) & KT955901 & KT955903 & KT955907 & KT955905 & Presente estudo \\
\hline C. anthrisci CBS 125334 & GU227845 & GU228139 & GU228237 & GU228041 & Damm et al. (2009) \\
\hline C. chlorophyti IMI 103806 & GU227894 & GU228188 & GU228286 & GU228090 & Damm et al. (2009) \\
\hline C. circinans CBS 22181 & GU227855 & GU228149 & GU228247 & GU228051 & Damm et al. (2009) \\
\hline C. dematium CBS 12525 & GU227819 & GU228113 & GU228211 & GU228015 & Damm et al. (2009) \\
\hline C. fructi CBS 34637/CCT 4806 & GU227844 & GU228138 & GU228236 & GU228040 & Damm et al. (2009) \\
\hline C. incanum ATCC 64682a & KC110789 & KC110816 & KC110807 & KC110798 & Yang et al. (2014), Tu (1990) \\
\hline C. incanum IL6A/NRRL 62592/CBS133485 & KC110787 & KC110814 & KC110805 & KC110796 & Yang et al. (2014) \\
\hline C. lilii CBS 18630 & GU227811 & GU228105 & GU228203 & GU228007 & Damm et al. (2009) \\
\hline C. lineola CBS 125337 & GU227829 & GU228123 & GU228221 & GU228025 & Damm et al. (2009) \\
\hline C. liriopes CBS 119444 & GU227804 & GU228098 & GU228196 & GU228000 & Damm et al. (2009) \\
\hline C. phaseolorum CBS 15736 & GU227896 & GU228190 & GU228288 & GU228092 & Damm et al. (2009) \\
\hline C. rusci CBS 119206 & GU227818 & GU228112 & GU228210 & GU228014 & Damm et al. (2009) \\
\hline C. spaethianum CBS 16749/BBA 4804 & GU227807 & GU228101 & GU228199 & GU228003 & Damm et al. (2009) \\
\hline C. spinaciae CBS 12857 & GU227847 & GU228141 & GU228239 & GU228043 & Damm et al. (2009) \\
\hline C. tofieldiae CBS 49585 & GU227801 & GU228095 & GU228193 & GU227997 & Damm et al. (2009) \\
\hline C. trichellum CBS 118198 & GU227813 & GU228107 & GU228205 & GU228009 & Damm et al. (2009) \\
\hline C. truncatum CBS 125328 & GU227885 & GU228179 & GU228277 & GU228081 & Damm et al. (2009) \\
\hline C. truncatum CBS 15135 (Tipo) & GU227862 & GU228156 & GU228254 & GU228058 & Damm et al. (2009) \\
\hline C. truncatum CBS 18252 & GU227866 & GU228160 & GU228258 & GU228062 & Damm et al. (2009) \\
\hline C. truncatum CBS 19532 & GU227865 & GU228159 & GU228257 & GU228061 & Damm et al. (2009) \\
\hline C. truncatum CBS 66788 & GU227891 & GU228185 & GU228283 & GU228087 & Damm et al. (2009) \\
\hline C. truncatum CBS 71070 & GU227864 & GU228158 & GU228256 & GU228060 & Damm et al. (2009) \\
\hline C. truncatum CBS34570 & GU227867 & GU228161 & GU228259 & GU228063 & Damm et al. (2009) \\
\hline C. truncatum IL15B & KC110790 & KC110817 & KC110808 & KC110799 & Yang et al. (2014) \\
\hline C. truncatum IL16D & KC110791 & KC110818 & KC110809 & KC110800 & Yang et al. (2014) \\
\hline C. verruculosum IMI 45525 & GU227806 & GU228100 & GU228198 & GU228002 & Damm et al. (2009) \\
\hline C. lindemuthianum CBS15128 (grupo externo) & GU227800 & GU228094 & GU228192 & GU227996 & Damm et al. (2009) \\
\hline
\end{tabular}




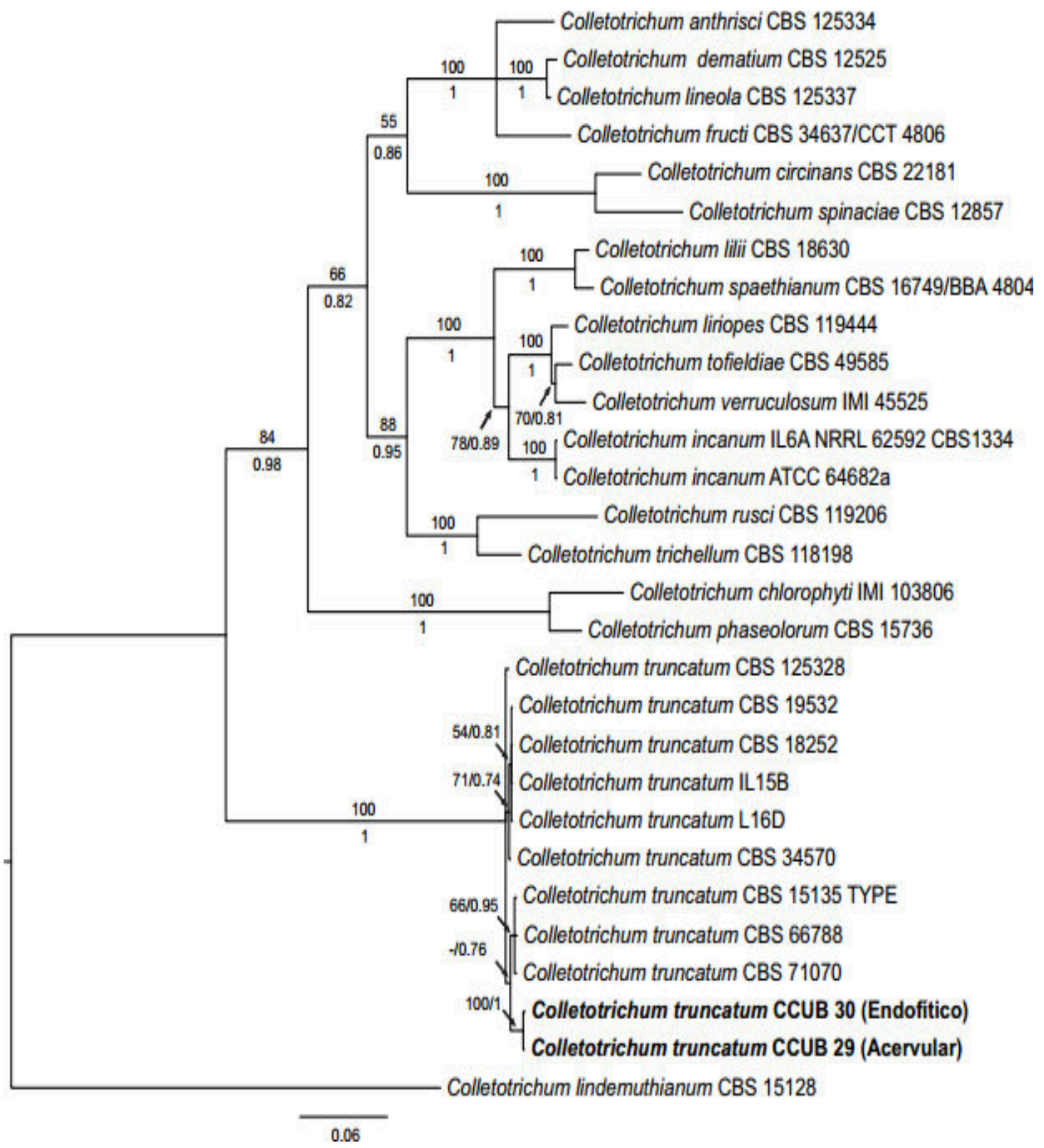

Figura 1. Árvore filogenética inferida a partir da análise de Máxima Verossimilhança e sob Inferência Bayesiana com base nas sequências concatenadas de ITS, TUB2, GAPDH e HIS de espécies do complexo C. truncatum e de espécies de Colletotrichum com conídios curvados. A análise de Máxima Verossimilhança com os valores de suporte de bootstrap (1000 repetições) acima de 50\% são mostrados nos nós. Valores de probabilidades posteriores em Bayesiana acima de 0,75 são indicados nos nós. Códigos de identificação dos isolados estão em parênteses. Os espécimes deste estudo são destacados em negrito. A árvore foi enraizada com Colletotrichum lindemuthianum. 
Pela primeira vez, foi realizado o sequenciamento da região ITS e LSU do rDNA de U. euphorbiae com sucesso para as duas amostras obtidas a partir dos eciósporos e de pústulas mistas contendo urediniósporos e teliósporos. Com base nos nossos dados moleculares $U$. euphorbiae, número de acesso UB23207 é considerado como espécime de referência.

Outras sequências de LSU de espécies de Uromyces foram selecionadas do GenBank e utilizadas para a identificação filogenética molecular do fungo, como extensamente recomendada para identificação em nível de gênero e espécies de fungos causadores de ferrugem (Hyde et al. 2014).

Com base nos resultados a partir da matriz de dados da região LSU, 34 taxa (Tabela 3) foram selecionados para as reconstruções filogenéticas. O conjunto de dados totalizou 509 bp de posições alinhadas, dos quais 59 foram parcimônia informativos, 120 foram variáveis e 389 foram conservados, usados para as análises ML e BI.

Os dados mostraram que as sequências de U. euphorbiae obtidas a partir de pústulas mistas (contendo teliósporos e urediniósporos) e de pústulas apenas com eciósporos, eram idênticas.

A espécie foi posicionada em um clado juntamente com outros membros patogênicos para Euphorbiaceae ou mesmo para Fabaceae. Os dados da filogenia baseada nas sequências, permitiram, assim, uma caracterização molecular e o posicionamento seguro das espécies claramente separadas dos outros componentes em outros clados (Figura 2). 
Tabela 3. Acessos do GenBank de Uromyces euphorbiae e de todas as outras espécies incluídas neste estudo.

\begin{tabular}{|c|c|c|c|}
\hline ESPÉCIES & HOSPEDEIRA (FAMÍLIA) & $\begin{array}{l}\text { Número de acessos } \\
\text { do GenBank } \\
\text { (LSU)* }\end{array}$ & FONTE E PAÍS \\
\hline Uromyces euphorbiae UB23207 (Ecial) & Euphorbia hirta (Euphorbiaceae) & KU133292 & Neste estudo, Brasil \\
\hline Uromyces euphorbiae UB22311 (Telial/Uredinial) & Euphorbia hirta (Euphorbiaceae) & KU133293 & Neste estudo, Brasil \\
\hline Cumminsiella mirabilissima & Mahonia aquifolium (Berberidaceae) & DQ354531 & Aime (2006) Alemanha \\
\hline Cumminsiella mirabilissima & Mahonia aquifolium (Berberidaceac) & AF426206 & Maier et al. (2003) Alemanha \\
\hline Endophyllum euphorbiae-sylvaticae & Euphorbia amygdaloides (Euphorbiaceae) & AF426200 & Maier et al. (2003) Alemanha \\
\hline Puccinia balsamorrhizae & Balsamorhiza sagittata (Asteraceae) & JN204182 & Bruckart et al. (2012) EUA \\
\hline Puccinia coronata & Rhamnus cathartica (Rhamnaceae) & DQ354526 & Aime (2006) EUA \\
\hline Puccinia graminis & Hordeum sp. (Poaceae) & HQ412648 & Deadman et al. (2011) \\
\hline Puccinia heucherae & Heuchera sp. (Saxifragaceae) & DQ359702 & Henricot et al. (2007) Inglaterra \\
\hline Puccinia malvacearum & Alcea rosea (Malvaceae) & AF426205 & Maier et al. (2003) Alemanha \\
\hline Puccinia melanocephala & Saccharum sp. (Poaceae) & KP201838 & Wang et al. Não publicado (2014) \\
\hline Puccinia peperomiae & Piper sp. (Piperaceae) & EU851146 & Zuluaga et al. (2011) Colômbia \\
\hline Uromyces acuminatus & Honkenya peploides (Caryophyllaceae) & GU109282 & Yun et al. (2010) Inglaterra \\
\hline Uromyces appendiculatus & Phaseolus vulgaris (Fabaceae) & KM249870 & McTaggart (2014) Austrália \\
\hline Uromyces ari-triphylli & Arisaema triphyllum (Araceae) & DQ354529 & Aime (2006) EUA \\
\hline Uromyces ficariae & Ranunculus ficaria (Ranunculaceae) & AF426204 & Maier et al. (2003) Alemanha \\
\hline Uromyces gageae & Gagea lutea (Liliaceae) & AF426208 & Maier et al. (2003) Alemanha \\
\hline Uromyces galegae & Galega officinalis (Fabaceae) & DQ250133 & Aime (2006) EUA \\
\hline Uromyces ixiae & Babiana tubulosa (Iridaceae) & DQ917738 & Maier et al. (2007) África do Sul \\
\hline Uromyces ixiae & Babiana cf. sambucina (Iridaceae) & DQ917739 & Maier et al. (2007) África do Sul \\
\hline Uromyces junci & Pulicaria dysenterica (Asteraceae) & AF426203 & Maier et al. (2003) Alemanha \\
\hline Uromyces phaseoli & Pisum sp. (Fabaceae) & HQ317516 & Não publicado \\
\hline Uromyces striatus & Medicago sp. (Fabaceae) & HQ412652 & Deadman et al. (2011) Omã \\
\hline Uromyces striatus & Euphorbia sp. (Euphorbiaceae) & HQ317512 & Liu et al. (2015) Canadá \\
\hline Uromyces trifolii & Trifolium repens (Fabaceae) & GU936634 & Zuluaga et al. (2011) Colômbia \\
\hline Uromyces viciae-fabae & Vicia faba (Fabaceae) & KJ716343 & $\begin{array}{l}\text { Padamse and McKenzie (2014) } \\
\text { Nova Zelândia }\end{array}$ \\
\hline Uromyces viciae-fabae & Vicia pannonica (Fabaceae) & AF426199 & Maier et al. (2003) Europa Central \\
\hline Uromyces viciae-fabae & Não publicado & AY745695 & $\begin{array}{l}\text { Matheny \& Hibbet Não publicado } \\
(2004)\end{array}$ \\
\hline Uromyces vignae & Vigna unguiculata (Fabaceae) & $\mathrm{AB} 115649$ & Chung et al. (2004) Japão \\
\hline Uromyces hawksworthii & Phthirusa stelis (Loranthaceae) & KR821139 & Souza et al. (2015) Brasil \\
\hline Uromyces hawksworthii & Phthirusa stelis (Loranthaceae) & KR821140 & Souza et al. (2015) Brasil \\
\hline Uromyces pisi & Euphorbia cyparissias (Euphorbiaceae) & AF426201 & Maier et al. (2003) Europa Central \\
\hline Uromyces scutellatus & Euphorbia cyparissias (Euphorbiaceae) & DQ917713 & Maier et al. (2007) África do Sul \\
\hline Melampsora larici-populina (grupo externo) & Populus $\mathrm{x}$ canadensis (Salicaceae) & JQ042250 & Busby et al. (2012) EUA \\
\hline
\end{tabular}

* LSU: rDNA large subunit 


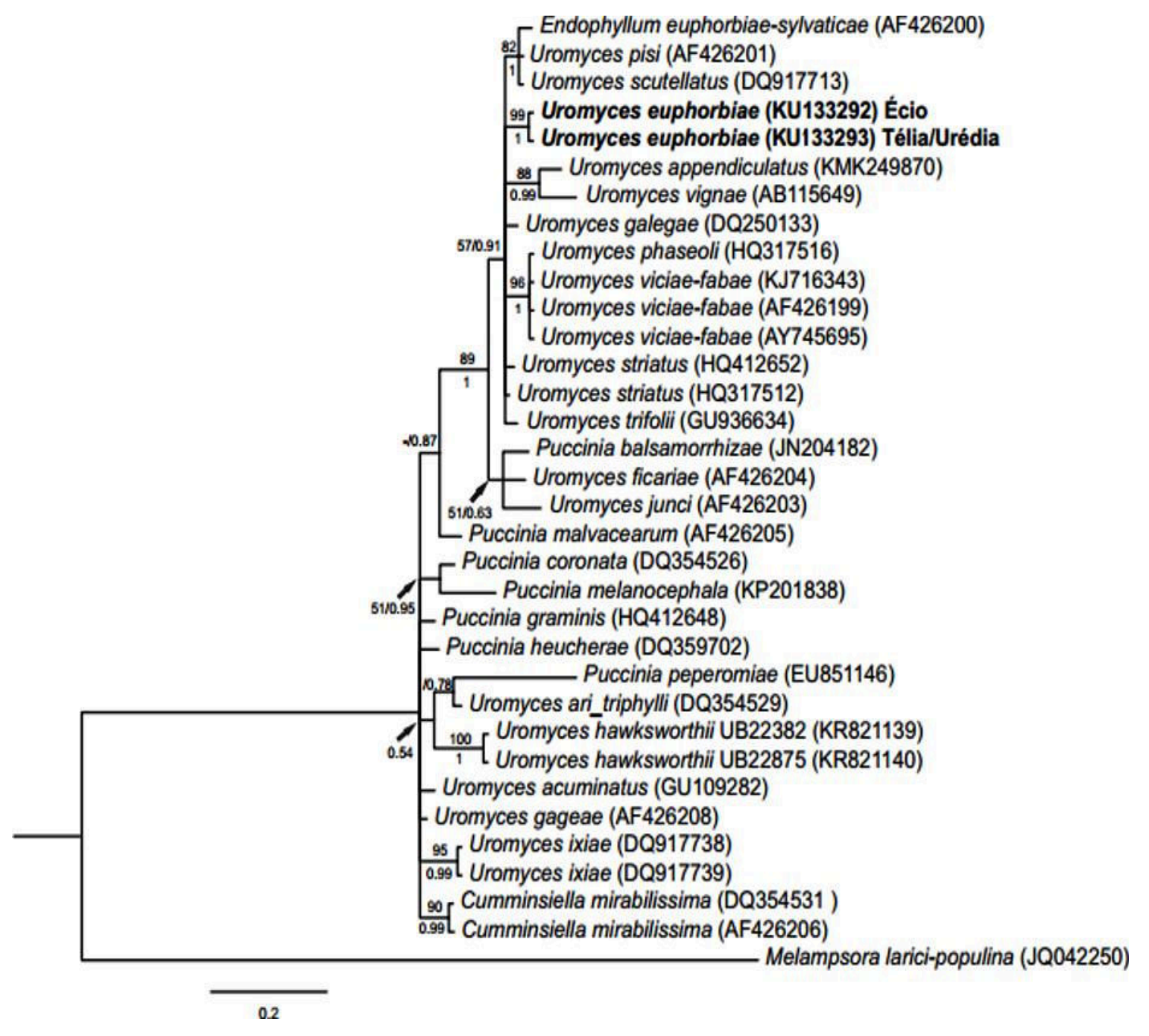

Figura 2. Árvore filogenética inferida a partir da análise de Máxima Verossimilhança e sob Inferência Bayesiana com base nas sequências de LSU de Uromyces e taxa relacionados. A análise de Máxima Verossimilhança com os valores de suporte de bootstrap (1000 repetições) acima de 50\% são mostrados nos nós. Os valores de probabilidades posteriores em Bayesiana acima de 0,75 são indicados nos nós. Os números de acesso do GenBank estão em parênteses. Os espécimes deste estudo são destacados em negrito. A árvore foi enraizada por Melampsora larici-populina. 
Damm et al. (2009) descreveram C. truncatum sobre espécies de Anthriscus sp. (Apiaceae) como um típico representante da espécie em uma amostra de herbário. As variações de dimensão entre a amostra em estudo e a espécie descrita por Damm et al. (2009) estão dentro dos limites estabelecidos para a espécie. Contudo, mais recentemente Crous et al. (2013) relataram a descrição de C. euphorbiae Damm \& Crous em Euphorbia sp., uma espécie não relacionada fora do complexo de C. truncatum, mostrando conídios retos não falcados e claramente gutulados em vez de não-gutulados.

Embora o C. truncatum seja conhecido em três espécies de Euphorbia (E. maculata, E. neriifolia e E. pulcherrima), este é o primeiro registro do fungo associado a Euphorbia hirta (Farr e Rossman, 2016).

Os espécimes de Colletotrichum em Euphorbia hirta apresentaram morfologia que se enquadra na descrição de C. truncatum conforme Damm et al. (2009): Conidiomas 44-90 $\mu \mathrm{m}$ de diâmetro, setosos, acervulares; Setas (até $140 \times 5 \mu \mathrm{m}$ ) de comprimento, marrom escuras a negras, lisas, septadas (de 1 a 3 septos), afinando em direção ao ápice ligeiramente agudo com a ponta arredondada, base cilíndrica a cônica; Conidióforos 70-81 (76) × 2-4 (3) $\mu \mathrm{m}$ de comprimento, castanho claros, septados, ramificados, densamente agrupados; Células conidiogênicas 11-20 (16) × 2-4 (3) $\mu$ m, enteroblástica, fialídica com aberturas medindo 11,5 $\mu \mathrm{m}$ de diâmetro, hialinas a castanho claras, cilíndricas, colarete presente, espessamento periclinal visível; Conídios 27-23 (31) × 3-4 $\mu \mathrm{m}$, hialinos, paredes lisas, asseptados, normalmente falcados, parte central de conídios longa, em geral ligeiramente curvados com paredes paralelas, terminando em ponta redonda e base subtruncada, protoplasma nãogutulados. Além disso, a Figura 3 ilustra a amostra aqui estudada. 

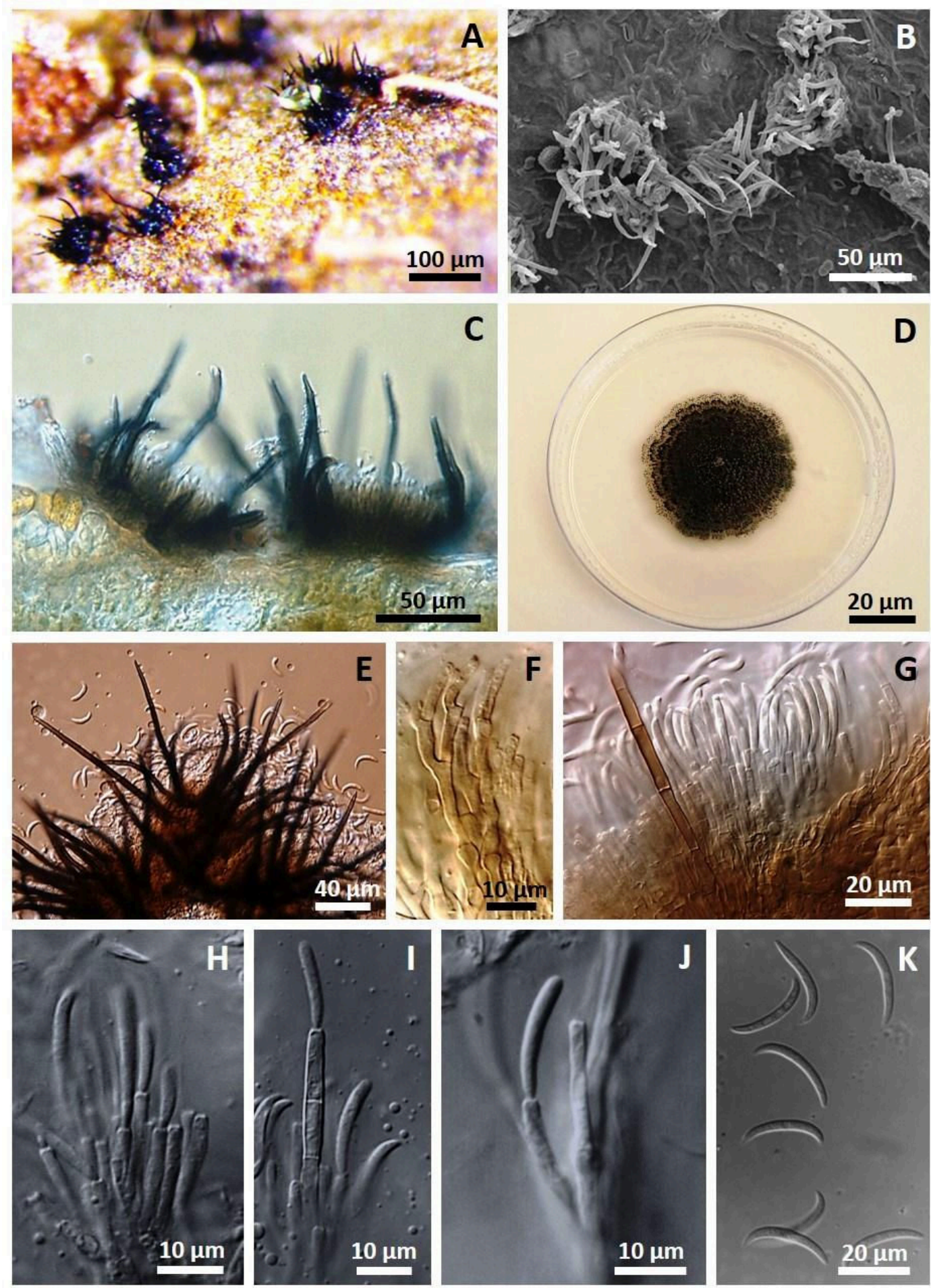

Figura 3. Principais características de Colletotrichum truncatum em

Euphorbia hirta. A. Conidiomas setosos, acervulares e negros vistos em microscopia de luz. B. Conidiomas setosos acervulares vistos em MEV. C. Acérvulos setosos e escuros. D. Colônia, em BDA. E. Setas e massa de conídios. F. Conidióforos ramificados em cultura. G, H, I e J. Células conidiogênicas fialídicas com conídios ainda presos. K. Conídios hialinos, asseptados e falcados/curvados. 
O espécime de U. euphorbiae mostrou: Espermogônios inconspícuos. Écios abaxiais, cilíndricos, campanulares a cupulares, densamente distribuídos, perídio incolor mostrando ápice pouco recurvado, Células peridiais 17,5-30 × 12-20,5 $\mu \mathrm{m}$, cuboides, poliédricos, parede de 4-7 $\mu \mathrm{m}$ de espessura, finamente verrugosas. Eciósporos 15-20 × 13-17 $\mu \mathrm{m}$, globoides a elipsoides, catenulados, paredes com $1 \mu \mathrm{m}$ de espessura, densamente verrugosos, amarelados, pálidos ou incolores, com 2-3 poros germinativos. Soros frequentemente mistos contendo teliósporos e urediniósporos; Urédias anfígenas, 485- (350) -220 $\mu \mathrm{m}$ de diâmetro, dispersas ou em grupos, geralmente circulares, erumpentes, pulverulentas, coloração canelamarrom; Urediniósporos 19-25 × 17-22,5 $\mu \mathrm{m}$, asseptados, globoides ou amplamente elipsoides; parede 1,5-2 $\mu \mathrm{m}$, moderadamente a pouco equinulados, marrom-dourados; 3-6 poros germinativos dispersos; Télias anfígenas, 485- (350) -220 $\mu \mathrm{m}$ de diâmetro, dispersas ou em grupos, geralmente circulares, erumpentes, escuras de coloração marrom-chocolate; Teliósporos 18-27 × 12-19,5 $\mu \mathrm{m}$, asseptados, obovoides a amplamente elipsoides, papila cônica sobre a poro germinativo, parede com 1,5 $\mu \mathrm{m}$ de espessura, coloração canela-marrom, pouco mais clara, verrugosos, por vezes, dispostos em fileiras circulares; pedicelos curtos, caducos e incolores. A espécie $U$. euphorbiae pela primeira vez é mostrada detalhadamente nas Figuras 4 e 5 vistos em microscopia de luz e em MEV.

Como U. euphorbiae não foi anteriormente ilustrada em detalhe, as Figuras 4 e 5 mostram uma vista do fungo em microscopia de luz e em MEV.

A espécie Uromyces euphorbiae é relatada infectando mais de sessenta espécies do gênero Euphorbia. Distribuída em quase todo o mundo, no Brasil foi encontrada em Euphorbia heterophylla, Euphorbia hirta e Euphorbia pilulifera. 

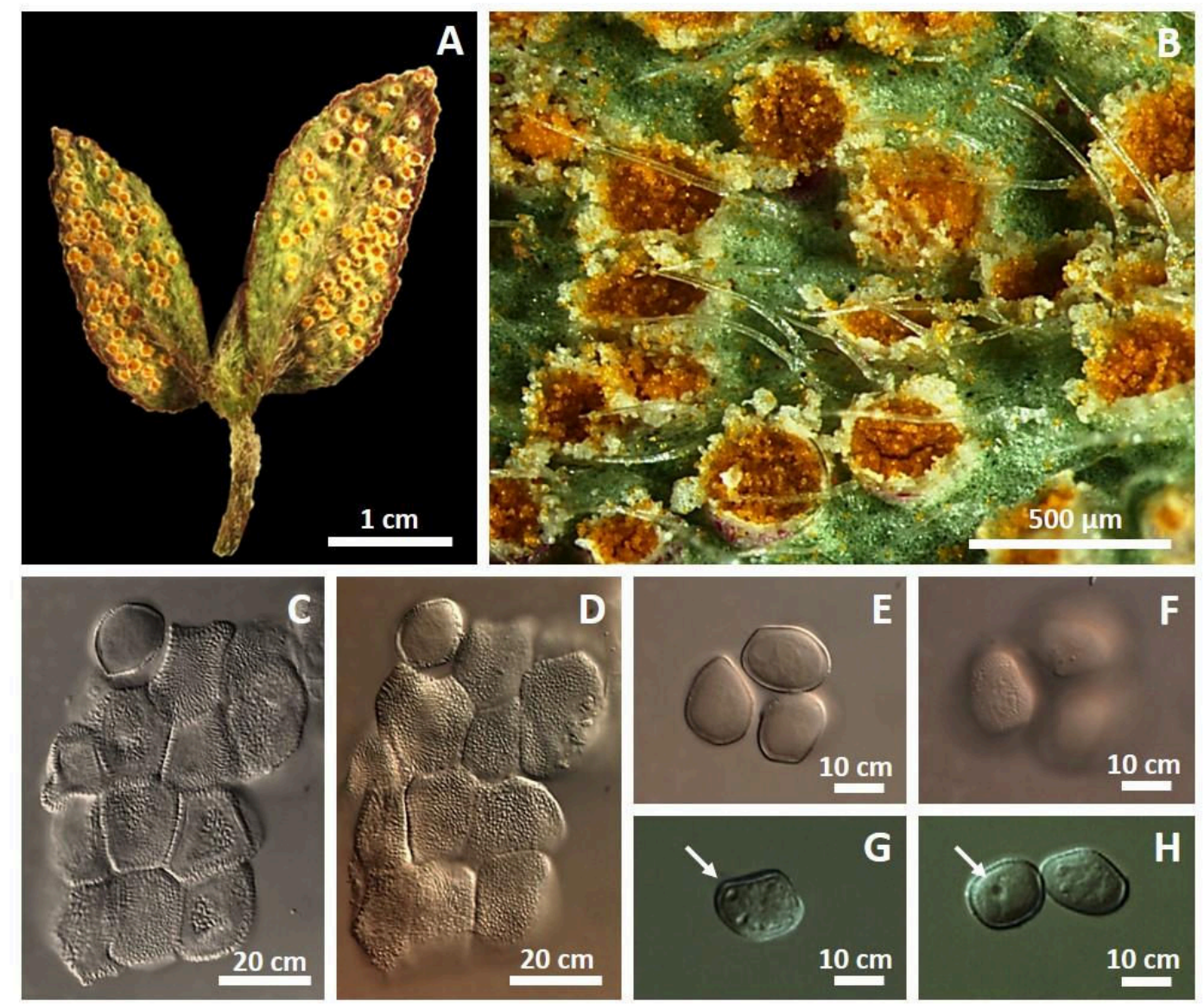

Figura 4. Fase ecial de Uromyces euphorbie em folhas de Euphorbia hirta. A

e B. Écios densamente distribuídos na face abaxial das folhas da hospedeira. C e D. Eciósporo e parte do perídio com parede verrugosa em duas profundidades de foco. $\mathbf{E}$ e $\mathbf{F}$. Eciósporos focados em duas profundidades diferentes. $\mathbf{G}$ e $\mathbf{H}$. Eciósporos com poros germinativos (setas). 

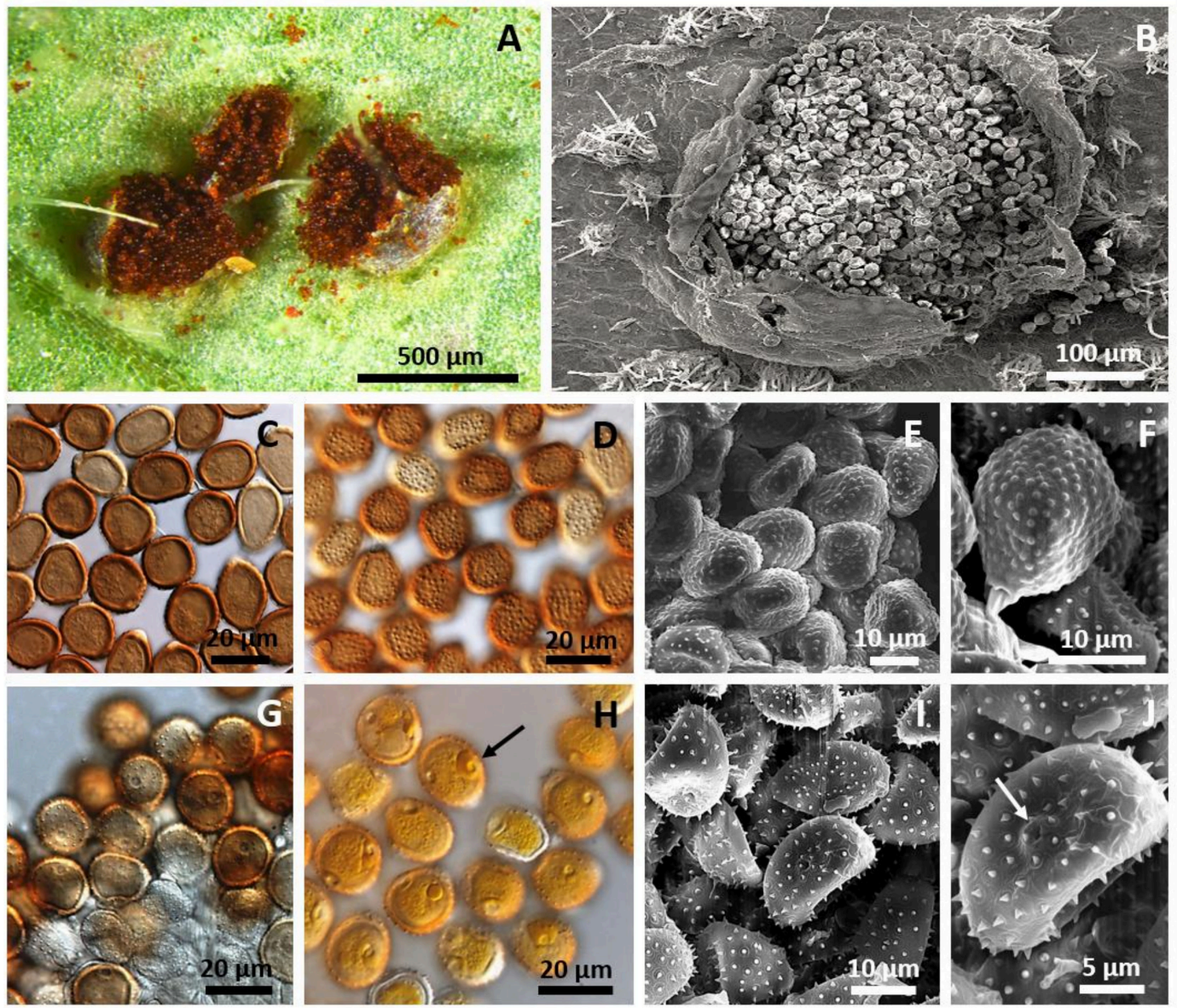

Figura 5. Uromyces euphorbiae em folhas de Euphorbia hirta. A. Pústulas mistas irrompentes contendo teliósporos e urediniósporos. B. Pústula mista visualizada em MEV. C e D. Teliósporos verrugosos levemente papilados. E e F. Detalhe da verrugosidade disposta em linhas circulares dos teliósporos visualizados no MEV. G. Urediniósporos. H. Detalhe do poro germinativo dos urediniósporos (seta). I e J. Superfície equinulada e poro germinativo (seta) dos urediniósporos visualizados no MEV. 
Ao considerar a interação entre C. truncatum e U. euphorbiae em folhas de E. hirta, à primeira vista, indicou que $74 \%$ das pústulas de ferrugem presente, eram rodeadas por um anel contendo acérvulos setosos escuros de Colletotrichum, resultando em manchas foliares anfígenas de bordas avermelhadas a marrons e centros de coloração marrom clara (Figura 6). No entanto, os acérvulos nunca estavam presentes na ausência das pústulas de U. euphorbiae. Isto indica que a infecção da planta pelo fungo da ferrugem promoveu alterações fisiológicas que levaram a uma necrose limitada do tecido foliar ao redor das pústulas, onde se formou a frutificação da espécie de Colletotrichum, como fase final da sua condição endofítica.

Espécies de Colletotrichum são hemibiotróficas (Munch et al. 2008) que carregam um grande número de genes de enzimas-carboidratos-ativas normalmente expressos antes da penetração e após a transição para necrotrofia (O'Connell et al. 2012).

Estas espécies apresentam uma fase biotrófica que é assintomática, que ocorre durante o crescimento do fungo endofítico. Pellier et al. (2003) indicaram que o interruptor da fase biotrófica para necrotrófica em C. lindemuthianum está ligada ao metabolismo de amônia / Lglutamina.

Outros estudiosos (Alkan et al. 2013, Miyara et al. 2012, Prusky \& Yakoby 2003, Shnaiderman et al. 2013) sugerem que o sinal para iniciar a fase de necrotrofia está relacionado com a alcalinização devido a secreção de amônia liberada através da atividade de protease e desaminação de aminoácidos.

No presente caso, como a ação necrotrófica de C. truncatum, conduziu a uma produção abundante de acérvulos, ocorrendo apenas em torno das pústulas do fungo causador de ferrugem, é necessário investigar as alterações metabólicas ocorridas nessa área específica para esclarecer esse fato. 
No entanto, a alta concentração de nutrientes em torno das pústulas de ferrugem está bem documentada como um grande aumento nos fosfatos de glicose, frutose e hexose, devido à atividade da invertase (Voegele et al., 2006, Walters \& McRoberts 2006).

Assim, hipoteticamente, isso forneceria os nutrientes necessários para o crescimento micelial e reprodução de $C$. truncatum associado as pústulas de $U$. euphorbiae.

Pesquisas adicionais são necessárias para esclarecer o aspecto fisiológico da interação entre $U$. euphorbiae e o fungo endofítico envolvido, C. truncatum.

Este trabalho aqui realizado já foi publicado em forma de resumo em congresso internacional e está em preparação final para submissão como artigo. 

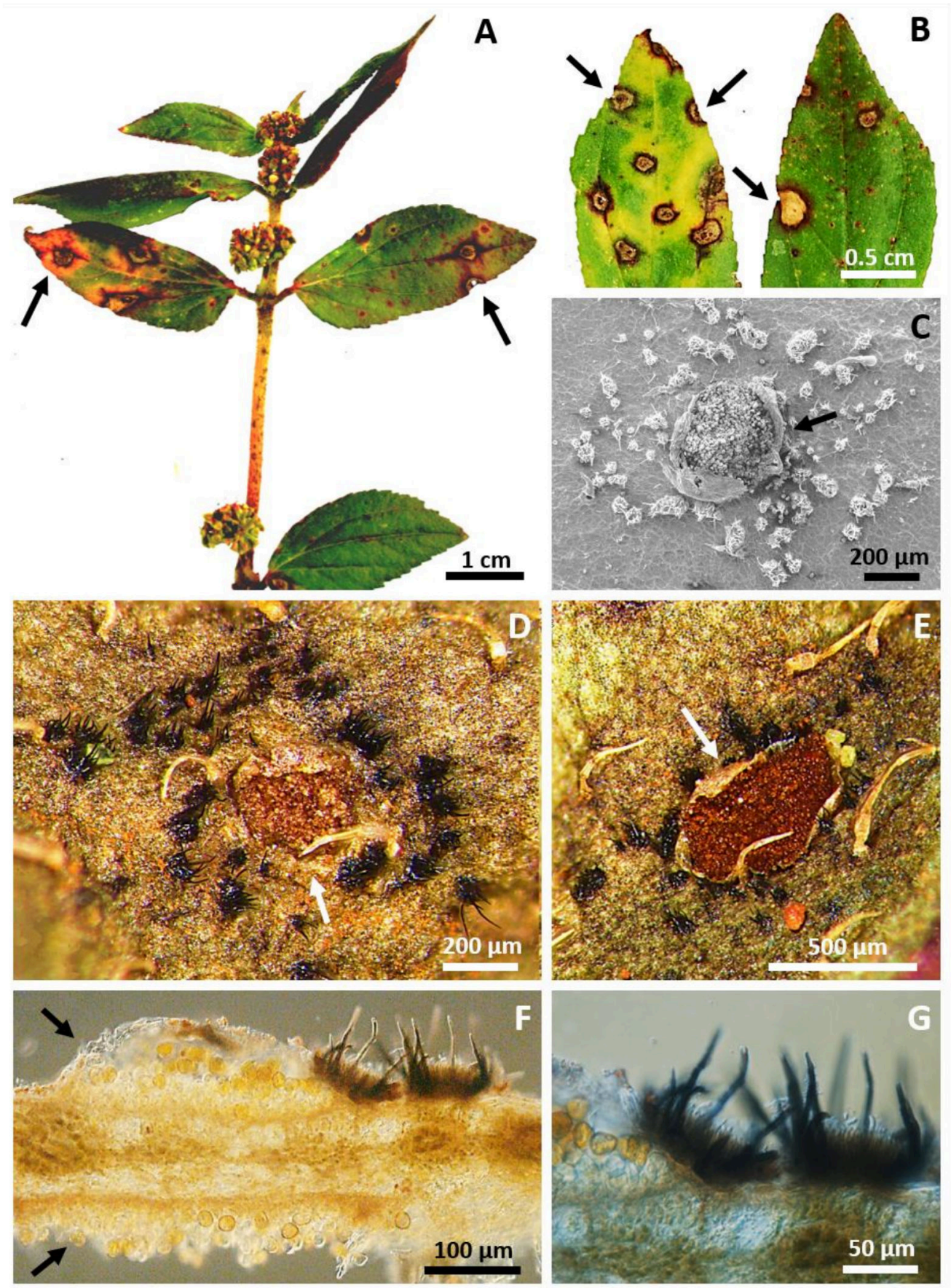

Figura 6. Colletotrichum truncatum e Uromyces euphorbiae em folhas de Euphorbia hirta.

A e B. Manchas foliares com bordas marrons avermelhadas e centros de cor castanha clara. C. Disposição dos acérvulos de C. truncatum em torno da pústula (seta) de $U$. euphorbiae visualizada em MEV. D e E. Detalhe das pústulas marrons-avermelhadas (setas) de $U$. euphorbiae circundadas poe acérvulos setosos de C. truncatum. F. Pústulas anfígenas (setas) de $U$. euphorbiae associadas com acérvulos setosos epífilos de C. truncatum. G. Detalhe da pústula subepidérmica de $U$. euphorbiae ao lado de acérvulos setosos irrompentes de $C$. truncatum. 


\section{REFERÊNCIAS}

Aime MC (2006) Toward resolving family-level relationships in rust fungi (Uredinales). Mycoscience. 47: 112-122.

Alkan N, Espeso EA, Prusky D (2013) Virulence regulation of phytopathogenic fungi by $\mathrm{pH}$. Antioxid Redox Signal. 19:1012-1025.

Bruckart III WL, Eskandari FM, Berner DK, Aime MC (2012) Comparison of Puccinia acroptili from Eurasia and the USA. Botany. 90: 465-471.

Busby PE, Aime MC, Newcombe G (2012) Foliar pathogens of Populus angustifolia are consistent with a hypothesis of Beringian migration into North America. Fungal Biology. 116: $792-801$.

Chung WH, Tsukiboshi T, Ono Y, Kakishima M (2004) Morphological and phylogenetic analyses of Uromyces appendiculatus and U. vignae on legumes in Japan. Mycoscience. 45: 233-244.

Crous PW, Groenewald JZ, Risede JM, Hywel-Jones NL (2004a) Calonectria species and their Cylindrocladium anamorphs: species with sphaeropedunculate vesicles. Studies in Mycology. 50: 415-430.

Damm U, Woudenberg JHC, Cannon PF and Crous PW (2009) Colletotrichum species with curved conidia from herbaceous hosts. Fungal Diersity. 39: 45-87.

Deadman ML, Al Sadi AM, Al Maqbali YM, Farr DF, Aime MC (2011) Additions to the rust fungi (Pucciniales) from northern Oman. Sydowia. 63: 155-168.

Dhingra OD, Sinclair JB (1995) Basic plant pathology methods. 2th ed. Boca Raton: CRC Press. 434.

Doyle JJ, Doyle JL (1990) Isolation of plant DNA from fresh tissue. Focus. 12: 13-15.

Edgar RC (2004) MUSCLE: a multiple sequence alignment method with reduced time and space complexity. BMC Bioinformatics. 5: 113. 
Farr DF, Rossman AY (2016) Fungal Databases, Systematic Mycology and Microbiology Laboratory, ARS, USDA. Access in July 2016, available at http: //nt.ars grin.gov/fungaldatabases/.

Glass NL, Donaldson GC (1995) Development of primer sets designed for use with the PCR to amplify conserved genes from filamentous ascomycetes. Applied and Environmental Microbiology. 61: 1323-1330.

Hall T (2012) BioEdit v 7.0.9: Biological sequence alignment editor for Win95/98/2K/XP/7.

Henricot BA, Denton GA, Lane CB (2007) First report of Puccinia heucherae on Heuchera spp. in the UK. Plant Pathology. 56: 352.

Hyde KD, Nilsson RH, Alias SA, Ariyawansa HA, Blair JE, Cai L, de Cock AWAM, Dissanayake AJ, Glockling SL, Goonasekara ID, Gorczak M, Hahn M, Jayawardena RS, van Kan JAL, Laurence MH, Lévesque CA, Li XH, Liu JK, Maharachchikumbura SSN, Manamgoda DS, Martin FN, McKenzie EHC, McTaggart AR, Mortimer PE, Nair PVR, Pawłowska J, Rintoul TL, Shivas RG, Spies CFJ, Summerell BA, Taylor PWJ, Terhem RB, Udayanga D, Vaghefi N, Walther G, Wilk M, Wrzosek M, Xu JC, Yan JY, Zhou N (2014) One stop shop: backbones trees for important phytopathogenic genera: I. Fungal Diversity. 67:21-125.

Kearse M, Moir R, Wilson A, Stones-Havas S, Cheung M, Sturrock S, Buxton S, Cooper A, Markowitz S, Duran C, Thierer T, Ashton B, Mentjies P and Drummond A (2012) Geneious Basic: an integrated and extendable desktop software platform for the organization and analysis of sequence data. Bioinformatics. 28: 1647-1649.

Kropp BR, Hansen DR, Wolf PG, Flint KM, Thomson SV (1997) A study on the phylogeny of the dyer's woad rust fungus and other species of Puccinia from Crucifers. Phytopathology. 87: 565-571.

Liu M, McCabe E, Chapados JT, Carey J, Wilson SK, Tropiano R, Redhead SA, Lévesque CA, Hambleton S (2015) Detection and identification of selected cereal rust pathogens by TaqMan® real-time PCR. Can J Plant Pathology. 37:92-105.

Maddison WP, Maddison DR (2016) Mesquite: a modular system for evolutionary analysis. Version 3.10. Acesso em abril de 2016. Disponível em: http://mesquiteproject.org. 
Maier W, Begerow D, Weiss M, Oberwinkler F (2003) Phylogeny of the rust fungi: an approach using nuclear large subunit ribosomal DNA sequences. Canadian Journal of Botany. 81: 12-23.

Maier W, Wingfield BD, Mennicken M, Wingfield MJ (2007) Polyphyly and two emerging lineages in the rust genera Puccinia and Uromyces. Mycological Research. 111: 176-185.

McTaggart AR, Geering ADW and Shivas RG (2014) Uredinopsis pteridis and Desmella aneimiae, the first rust fungi (Pucciniales) reported on ferns (Pteridophyta) in Australia. Australasian Plant Disease Notes. 9: 149.

Miyara I, Shnaiderman C, Meng X, Vargas WA, Díaz-Minguez JM, Thon M, Sherman A, Prusky D (2012) Role of nitrogen-metabolism genes expressed during pathogenicity of the alkalinizing Colletotrichum gloeosporioides and their differential expression in acidifying pathogens. Molecular Plant-Microbe Interactions. 25:125-163.

Moncalvo JM, Wang HH, Hseu RS (1995) Phylogenetic relationships in Ganoderma inferred from the internal transcribed spacers and 25S ribosomal DNA sequences. Mycologia. 87: 223-238.

Munch S, Lingner U, Floss DS, Ludwig N, Sauer N, Deising HB (2008) The hemibiotrophic lifestyle of Colletotrichum species. Jornal Plant Physiology. 165:41-51.

O’Donnell, E. Cigelnik (1997) Two different intragenomics rDNA ITS2 types within a monophyletic lineage of the fungus Fusarium are nonorthologous. Molecular Phylogenetics Evolution. 7:103-116.

O'Connell RJ, Thon MR, Hacquard S, Amyotte SG, Kleemann J, Torres MF, Damm U, Buiate EA, Epstein L, Alkan N, Altmüller J, Alvarado-Balderrama L, Bauser CA, Becker C, Birren BW, Chen Z, Choi J, Crouch JA, Duvick JP, Farman MA, Gan P, Heiman D, Henrissat B, Howard, M Kabbage, C Koch, B Kracher, Y Kubo, AD Law, M Lebrun, YH Lee RJ, Miyara I, Moore N, Neumann U, Nordström K, Panaccione DG, Panstruga R, Place M, Proctor RH, Prusky D, Rech G, Reinhardt R, Rollins JA, Rounsley S, Schardl CL, Schwartz DC, Shenoy N, Shirasu K, Sikhakolli UR, Stüber K, Sukno SA, Sweigard JA,Takano Y, Takahara H, Trail F, van der Does HC, Voll LM, Will I, Young S, Zeng Q, Zhang J, Zhou S, Dickman MB, Schulze-Lefert P, van 
Themaat EVL, Ma LJ, Vaillancourt LJ (2012) Lifestyle transitions in plant pathogenic Colletotrichum fungi deciphered by genome and transcriptome analyses. Nature Genetic. 44:1060-65.

Padamsee M, McKenzie EHC (2014) A new species of rust fungus on the New Zealand endemic plant, Myosotidium, from the isolated Chatham Islands. Phytotaxa. 174: 223230.

Pellier AL, Lauge R, Veneault-Fourrey C, Langin T (2003) CLNR1, the AREA/NIT2-like global nitrogen regulator of the plant fungal pathogen Colletotrichum lindemuthianum is required for the infection cycle. Molecular Microbiology. 48:639-655.

Pfunder M, Schürch S, Roy BA (2001) Sequence variation and geographic distribution of pseudoflower-forming rust fungi (Uromyces pisi s. lat.) on Euphorbia cyparissias. Mycological Research. 105: 57-66.

Posada D, Buckley T (2004) Model selection and model averaging in phylognetics: advantages of Akaike information criterion and Bayesian approaches over likelihood ratio tests. Systematic Biology. 53: 793-808.

Prusky D, Yakoby N (2003) Pathogenic fungi: leading or led by ambient pH? Molecular Plant Pathology. 4:509-16.

Rambaut A (2009) FigTree. Version 1.2.3. Edinburgh: Institute of Evolutionary Biology, University of Edinburgh.

Ronquist F, Teslenko M, van der Mark P, Ayres DL, Darling A, Höhna S, Larget B, Liu L, Suchard MA, Huelsenbeck JP (2012) Mrbayes 3.2: efficient Bayesian phylogenetic inference and model choice across a large model space. Systematic Biology. 61: 539-542.

Shnaiderman C, Miyara I, Kobiler I, Sherman A, Prusky D (2013) Differential activation of ammonium transporters during the accumulation of ammonia by Colletotrichum gloeosporioides and its effect on appressoria formation and pathogenicity. Molecular Plant-Microbe Interaction. 26:345-355. 
Souza ESC, Chaves ZM, Soares WR, Pinho DB, Dianese JC (2015) Uromyces hawksworthii nom. nov. for Aecidium goyazense, on Phthirusa stelis (Loranthaceae) from the Brazilian Cerrado. IMA fungus. 6: 155-162.

Swofford DL (2002) PAUP*. Phylogenetic Analyses using parsimony (*and other methods), version 4.0. Sinauer Associates, Inc., Sunderland.

Tamura K, Stecher G, Peterson D, Filipski A, Kumar S (2013) MEGA 6: molecular evolutionary genetics analysis version 6.0. Molecular biology and evolution. 30: 27252729.

Templeton MD, Rikkerink EH, Solon SL, Crowhurst RN (1992) Cloning and molecular characterization of the glyceraldehyde-3-phosphate dehydrogenase-encoding gene and cDNA from the plant pathogenic fungus Glomerella cingulata. Gene. 122: 225-230.

Tu JC (1990) First report of anthracnose caused by Glomerella cingulata on white beans in Ontario, Canada. Plant Disease. 74:394.

Vilgalys R, Hester M (1990) Rapid genetic identification and mapping of enzymatically amplified ribosomal DNA from several Cryptococcus species. Journal of Bacteriology. 172: $4238-4246$.

Voegele RT, Wirsel S, Möll U, Lechner M, Mendgen K (2006) Cloning and characterization of a novel invertase from the obligate biotroph Uromyces fabae and analysis of expression patterns of host and pathogen invertases in the course of infection. Molecular PlantMicrobe Interactions. 19: 625-634.

Walters DR, McRoberts N (2006) Plants and biotrophs: a pivotal role for cytokinins? Trends in Plant Sciences. 11: 581-586.

White TJ, Burns T, Lee S, Taylor J (1990) Amplification and direct sequencing of fungal ribosomal RNA genes for phylogenetics. In: Innis MA, Gelfand DH, Sninsky JJ, White TJ, editors. PCR protocols: A guide to methods and applications. San Diego (California). Academic Press. 315-322.

Yang H-C, Haudenshield JS, Hartman GL (2014) Colletotrichum incanum sp. nov., a curvedconidial species causing soybean anthracnose in USA. Mycologia. 106: 32-42. 
Yun HY, Minnis AM, Dixon LJ, Castlebury LA (2010) First report of Uromyces acuminatus on Honckenya peploides, the endangered seabeach sandwort. Plant Disease. 94: 279.

Zuluaga C, Buriticá P, Marín M (2011) Filogenia de hongos/roya (Uredinales) em la zona andina colombiana mediante el uso de secuencias del ADN ribosomal 28S. Revista de Biología Tropical. 59: 517-540. 
Este trabalho muito contribuiu para a ampliação do estudo em aspectos morfológicos dos fungos causadores de ferrugens (Pucciniales) ocorrentes em diversas famílias de hospedeiras e locais de ocorrência do bioma cerrado no que diz respeito a atualização nomenclatural, bem como a melhoria das ilustrações das espécies já conhecidas. Além de aumentar as informações sobre as espécies já conhecidas, o trabalho resultou em novos relatos de ocorrência de membros das Pucciniales em nova hospedeiras e novos locais, prováveis espécies novas, relatos de fase ou fases do ciclo de vida até então inéditas e, finalmente, algumas atualizações nomenclaturais e taxonômicas.

Pela primeira vez foi realizado um estudo baseado em análises moleculares filogenéticas de Pucciniales do cerrado numa dimensão ampla, envolvendo membros representantes de várias famílias. Aqui foi apresentada de forma inédita a caracterização molecular de vários espécimes fúngicos pertencentes a ordem Pucciniales encontradas em plantas endêmicas e introduzidas no cerrado que enriquecerá o banco de dados do NCBI e muito contribuirá para o estudo e compreensão da filogenia da ordem em estudos posteriores.

De forma geral, os dados obtidos possibilitaram o entendimento do posicionamento filogenético de apenas alguns grupos em níveis de gênero e espécies como o caso de membros componentes da família Phakopsoraceae. Entretanto, os dados obtidos não foram suficientes para o esclarecimento das relações filogenéticas dos membros causadores de ferrugem do Cerrado em níveis hierárquicos maiores como família dentro da ordem, havendo a necessidade de aprofundamento das análises filogenéticas principalmente com os grupos mais esclarecidos como o caso de exemplares correspondentes a Crossopsora byrsonimatis e atualização nomenclatural de alguns espécimes com classificação taxonômica indefinida como Cerradoa e Edythea. 
Em primeira instância faz-se necessário a realização de análises filogenéticas das famílias separadamente na tentativa da obtenção de dados robustos que possibilitem um melhor detalhamento e entendimento do relacionamento filogenético dos membros representantes de cada família e esclarecimento do posicionamento filogenético dos gêneros e espécies representantes.

Diante dos dados apresentados, entende-se que há a necessidade de mais pesquisas relacionadas a filogenia de fungos membros da ordem Pucciniales, envolvendo além de análise por Inferência Bayesiana, outras análises como Máxima Parcimônia e Verossimilhança para efeito de comparação e esclarecimento de quais métodos podem ser mais robustos e expressivos para esclarecer as relações filogenéticas deste grupo fúngico. Além disso, outras regiões gênicas como: $18 \mathrm{~S}$ do Rdna, $\beta$-tubulina, Fator de Elongação, e CO3 do mDNA; e regiões intergênicas como ITS podem ser utilizadas na tentativa de melhorar a resolução das relações e posicionamento filogenético dos fungos causadores de ferrugens ocorrentes no bioma Cerrado. 
ANEXO 1 


\title{
Uromyces hawksworthii nom. nov. for Aecidium goyazense, on Phthirusa stelis (Loranthaceae) from the Brazilian Cerrado
}

\author{
Érica S.C. Souza' ${ }^{1}$, Zuleide M. Chaves ${ }^{1}$, William R.O. Soares ${ }^{1}$, Danilo B. Pinho', and José C. Dianese ${ }^{1}$
}

1Departamento de Fitopatologia, Instituto de Ciências Biológicas, Universidade de Brasília, 70910-900 Brasília, DF, Brazil; corresponding author e-mail: jcarmine@gmail.com

\begin{abstract}
The sexual morph of Aecidium goyazense collected in the Brazilian Cerrado was morphologically characterized by light microscopy and SEM, and shown to be a species of Uromyces, for which the name Uromyces hawksworthii nom. nov. is introduced, and designated as its epitype. This is the second Uromyces species known to infect the tropical genus Phthirusa (Loranthaceae). DNA sequences were generated from the ITS and 28S rRNA (LSU) regions of DNA recovered from aeciospores as well as teliospores. This fungus is compared with other Uromyces species known from Loranthaceae.
\end{abstract}

\author{
Key words: \\ Basidiomycota \\ Neotropical fungi \\ Pucciniaceae \\ Pucciniomycotina \\ rust fungi \\ Urediniomycetes
}

Article info: Submitted: 23 May 2015; Accepted: 3 June 2015; Published: 9 June 2015.

\section{INTRODUCTION}

Hennen et al. (2005) catalogued the rust fungi on Loranthaceae in Brazil, including Aecidum goyazense, Uromyces circumscriptus, $U$. loranthi, and $U$. urbanianus. Perdomo-Sánchez \& Piepenbring (2014) revised the Uromyces species known from Loranthaceae, namely, $U$. euphlebius, $U$. evastigatus, $U$. loranthi, $U$. nilagiricus, $U$. ornatipes, $U$. phthirusae, $U$. socius, and $U$. urbanianus, adding two new taxa, $U$. bahiensis from Brazil, and $U$. struthanthi from Panama. They omitted $A$. goyazense as it was known only as an aecial morph without a connection to a telial stage. The telial stage proves morphologically to belong to Uromyces, and this is described and illustrated here, and also characterized by analysis of DNA sequences to provide a barcode for identification of the species.

\section{MATERIALS \& METHODS}

Leaves of Phthirusa stelis with a gall rust were collected in Brasilia, Distrito Federal. The brown galls were covered in cylindrical to conical/subulate pale yellow aecia, and erumpent dark brown telia covered by a layer of dark brown spores. Aecidia and telia were sectioned at 15-20 $\mu \mathrm{m}$ thickness with a Micron freezing microtome. Squash preparations of aecia, aeciospores, and teliospores from the galls were examined microscopically by Nomarski differential interference contrast under a Leica DM 2500 microscope coupled with a Leica DFC 490 digital camera; image capture and measurements were made with Leica QWin V3 software. Some samples were stained with lacto-glycerol Cotton blue and the slides sealed with nail polish. A minimum of 25 replicates of spore and aecial structural cells were measured. Portions of dried galls with aecia and telia were fixed onto $10 \mathrm{~mm}$ diam copper stubs using double-sided carbon tape, and coated with gold at $25 \mathrm{~mA}, 1.10^{-2} \mathrm{mbar}$, for $2.5 \mathrm{~min}$. for examination with a JEOL JSM-700 1F Model scanning electron microscope. Voucher specimens are deposited in the Mycological Collection of the Universidade de Brasilia (UB).

\section{DNA extraction, PCR amplification, and DNA sequencing}

To obtain spores and prevent contamination by other fungi, sori were examined under a stereomicroscope. Aeciospore and teliospore masses were removed with a needle, and placed separately in micro-centrifuge tubes $(1.5 \mathrm{~mL})$ stored at $-20^{\circ} \mathrm{C}$. Tissue samples were frozen with liquid nitrogen and ground into a fine powder with a micro-centrifuge tube pestle. DNA extraction followed the standard CTAB (cetyltrimethyl ammonium bromide) procedure (Doyle \& Doyle 1990). PCRs included the following ingredients for each $25 \mu \mathrm{L}$ reaction volume: $0.5 \cup$ Taq DNA Polymerase Platinum, $0.2 \mu \mathrm{M}$ of each nucleotide, $5 \mathrm{~mL} 10 \mathrm{X}$ buffer, $1.5 \mathrm{mM} \mathrm{MgCl}_{2}, 0.4 \mu \mathrm{M}$ of each of the forward and reverse primers; plus a maximum of $10 \mathrm{ng} /$ $\mu \mathrm{L}$ of genomic DNA; nuclease-free water completed the total volume. Primers ITS4-rust and ITS5-u were used to amplify the internal transcribed spacer region (ITS) of the rRNA (Pfunder et al. 2001). The LSU was amplified with a primer pair, Rust2inv and LR6 (Aime 2006, Vilgalys \& Hester 1990), while LROR and Rust1 (Moncalvo et al. 1995, Kropp et al. 1997) were used as internal sequence primers. The thermal cycle consisted of $94^{\circ} \mathrm{C}$ for $4 \mathrm{~min}$, followed by 30 cycles of 94 ${ }^{\circ} \mathrm{C}$ for $1 \mathrm{~min}$ (denaturation), $54{ }^{\circ} \mathrm{C}$ for $1 \mathrm{~min}$ (annealing), $72{ }^{\circ} \mathrm{C}$ for $1 \mathrm{~min}$ (elongation), and $72{ }^{\circ} \mathrm{C}$ for $5 \mathrm{~min}$ (final extension). PCR products were analyzed by $1 \%$ agarose electrophoresis

\section{2015 International Mycological Association}

You are free to share - to copy, distribute and transmit the work, under the following conditions:

Attribution: $\quad$ You must attribute the work in the manner specified by the author or licensor (but not in any way that suggests that they endorse you or your use of the work).

Non-commercial: $\quad$ You may not use this work for commercial purposes.

No derivative works: You may not alter, transform, or build upon this work.

For any reuse or distribution, you must make clear to others the license terms of this work, which can be found at http://creativecommons.org/licenses/by-nc-nd/3.0/legalcode. Any of the above conditions can be waived if you get permission from the copyright holder. Nothing in this license impairs or restricts the author's moral rights. 
Table 1. GenBank accession numbers of Uromyces hawksworthii, and of all other species included in the study.

\begin{tabular}{|c|c|c|}
\hline Species & GenBank accession numbers (LSU)* & Source and Country \\
\hline Uromyces hawksworthii UB22382 & KR821139 & Present study, Brazil \\
\hline Uromyces hawksworthii UB22875 & KR821140 & Present study, Brazil \\
\hline Cumminsiella mirabilissima & DQ354531 & Aime (2006) Germany \\
\hline Cumminsiella mirabilissima & AF426206 & Maier et al. (2003) Germany \\
\hline Puccinia coronata & DQ354526 & Aime (2006) USA \\
\hline Puccinia coronata & EU851141 & Zuluaga et al. (2011) \\
\hline Puccinia graminis & AF522177 & Bruns et al. (1992) \\
\hline Puccinia graminis & HQ412648 & Deadman et al. (2011) \\
\hline Puccinia hemerocallidis & GU058020 & Dixon et al. (2010) USA \\
\hline Puccinia hemerocallidis & DQ354519 & Aime (2006) USA \\
\hline Puccinia heucherae & DQ359701 & Henricot et al. (2007) UK \\
\hline Puccinia heucherae & DQ359702 & Henricot et al. (2007) UK \\
\hline Puccinia hordei & DQ354527 & Aime (2006) USA \\
\hline Puccinia melanocephala & KP201838 & Wang et al. Unpubl. (2014) China \\
\hline Puccinia melanocephala & KP201839 & Wang et al. Unpubl. (2014) China \\
\hline Puccinia nakanishikii & GU058002 & Dixon et al. (2010) USA \\
\hline Puccinia peperomiae & EU851146 & Zuluaga et al. (2011) Colombia \\
\hline Uromyces acuminatus & GU109282 & Yun et al. (2010) England \\
\hline Uromyces appendiculatus & KM249870 & McTaggart (2014) Australia \\
\hline Uromyces appendiculatus & AY745704 & Matheny et al. Unpubl. (2005) \\
\hline Uromyces ari-triphylli & DQ354529 & Aime (2006) USA \\
\hline Uromyces ixiae & DQ917738 & Maier et al. (2007) South Africa \\
\hline Uromyces ixiae & DQ917739 & Maier et al. (2007) South Africa \\
\hline Uromyces pisi & AF426201 & Maier et al. (2003) Central Eur. \\
\hline Uromyces striatus & HQ412652 & Deadman et al. (2011) Oman \\
\hline Uromyces striatus & HQ317512 & Liu et al. (2015) Canada \\
\hline Uromyces trifoli & GU936634 & Zuluaga et al. (2011) Colombia \\
\hline Uromyces viciae-fabae & KJ716343 & Padamsee \& McKenzie (2014) New Zealand \\
\hline Uromyces viciae-fabae & AF426199 & Maier et al. (2003) Central Eur. \\
\hline Uromyces vignae & AB115649 & Chung et al. (2004) Japan \\
\hline Melampsora larici-populina (outgroup) & JQ042250 & Busby et al. (2012) USA \\
\hline
\end{tabular}

${ }^{*}$ LSU: rDNA large subunit

gels stained with ethidium bromide in a $1 \mathrm{X}$ TAE buffer and visualized under UV light to check for amplification size and purity. PCR products were treated using ExOSAP-IT® (USB) and sequenced in an Applied Biosystems (ABI3130xI Model) apparatus at the Catholic University of Brasília.

The nucleotide sequences were edited with BioEdit software (Hall 2012). All sequences were checked manually, and nucleotides with ambiguous positions were clarified by both primer direction sequences. New sequences were deposited in GenBank (http://www.ncbi.nlm.nih.gov/ genbank/) (Table 1).

\section{PHYLOGENETIC ANALYSIS}

Consensus sequences were compared against GenBank's database using Mega BLAST. Based on the BLASTn results, sequences were selected for the greatest similarity, and data from recent phylogenetic studies focused on
Pucciniaceae (Bruns et al. 1992, Maier et al. 2003, Chung et al. 2004, Aime 2006, Matheny et al. 2006, Henricot et al. 2007, Maier et al. 2007, Yun et al. 2010, Dixon et al. 2010, Deadman et al. 2011, Zuluaga et al. 2011, Busby et al. 2012, McTaggart 2014, Padamse and McKenzie 2014, Liu et al. 2015). After selection, the sequences were downloaded in FASTA format and aligned by the multiple sequence alignment program MUSCLE $®$ (Edgar 2004), built in MEGA v. 6 software (Tamura et al. 2011). Alignments were checked and manual adjustments were made when necessary. Gaps were treated as missing data. The resulting alignment was deposited into TreeBASE (http://www.treebase.org/), accession no. 17667. Bayesian inference (BI) analysis employing a Markov Chain Monte Carlo method was performed only with LSU sequences. Before launching the $\mathrm{BI}$, the best nucleotide substitution model was determined with MrMODELTEST 2.3 (Posada \& Buckley 2004). Once the likelihood scores were calculated, the models were selected according to the Akaike Information Criterion (AIC). 
The general time-reversible model of evolution including estimation of invariable sites and assuming a discrete gamma distribution with six rate categories $(G T R+I+G)$ was used. The phylogenetic analysis of the dataset was performed through the CIPRES web portal (Miller et al. 2010) using MrBayes v. 3.2 (Ronquist \& Heulsenbeck 2012). Four MCMC chains were run simultaneously, starting from random trees for 10000000 generations. Trees were sampled every 1,000 th generation for a total of 10000 trees. The first 2500 trees were discarded as the burn-in phase of each analysis. Posterior probabilities were determined from a majority-rule consensus tree generated with the remaining 7500 trees. Trees rooted to Melampsora larici-populina were visualized by FigTree (Rambaut 2009), and exported to graphic programs.

\section{RESULTS}

\section{Phylogeny}

Amplification and sequencing of the LSU and ITS rDNA regions were successful for two specimens obtained from both the aecidial (UB22382) and telial (UB22875) morphs. The amplification of the partial 28S rDNA and ITS revealed sequences of ca. 1500 and $450 \mathrm{bp}$, respectively (Accession Numbers, LSU: UB22382=KR821139, UB22875=KR821140 and ITS: UB22382=KR821137, UB22875=KR821138). The LSU and ITS sequences obtained from aeciospores and teliospores were identical. The partial large subunit of rDNA (LSU) was selected for molecular phylogenetic identification of the fungus because this molecular marker is widely recommended for genus and species level identification of all rust fungi (Hyde et al. 2014). The ITS sequences were lodged in GenBank and UNITE (Nilsson et al. 2014). Based on the results from the primary LSU data matrix (tree not shown) and the dataset for rust fungi (tree not shown) from Hyde et al. (2014), 31 taxa were selected from across the breadth of the LSU derived phylogenetic trees. The dataset totaled $1037 \mathrm{bp}$ of aligned positions, 97 of which were parsimony informative, 211 were variable and 810 were conserved.

\section{TAXONOMY}

Uromyces hawksworthii E.S.C. Souza, Z.M. Chaves, W.R.O. Soares, D.B. Pinho \& Dianese, nom. nov. MycoBank MB812738

(Figs 1-2)

Replaced synonym: Aecidium goyazense P. Henn., Hedwigia 34: 101 (1895).

Non Uromyces goyazensis P. Henn., Hedwigia 34: 89 (1895)

Etymology: Named after David Leslie Hawksworth, Honorary President of the International Mycological Association.
Diagnosis: A Uromyces species on Phthirusa stelis (Loranthaceae) with elongate aecidia on the surface of pulvinate corticoid leaf galls up to $1.2 \mathrm{~cm}$ diam, and characteristically long-pedicellate teliospores.

Type: Brazil: Goiás, Serra dos Pyreneos, on Phthirusa stelis [as Loranthus sp.], Aug. 1892, Ule 1909 (B 2945 - holotype); Brasília, Guará I, Associação dos Criadores de Pássaros de Brasília, $15^{\circ} 48^{\prime} 42.12^{\prime \prime} S \times 47^{\circ} 58^{\prime} 22.53^{\prime \prime} \mathrm{W}$, on leaves of Phthirusa stelis, 9 Feb 2014, J. C. Dianese (UB Mycol. Col. 22875 - epitype designated here, MBT 201535).

Description: Spermogonia not seen. Aecidia 5-6 mm long $\times$ 300-400 $\mu \mathrm{m}$ wide, amphigenous, mostly epiphyllous, gregarious, initially subepidermal, erumpent, cylindrical, conical/subulate, bright yellow, grouped on a light brown to brown hemisphaerical to pulvinate area, $0.5-1 \mathrm{~cm}$ diam before emergence of the aecidia, to $1.2 \mathrm{~cm}$ diam at aecidial maturity; peridial cells 30-(36)-57 x 21-(22)-35 $\mu \mathrm{m}$, oblong to rhomboidal, outer wall rough, hyaline or slightly yellow. Aecidiospores (24-)25-29(-35) × (17-)21-25(-27.5) $\mu \mathrm{m}$, angular, rhomboidal, subglobose, ovoid, catenulate, verrucose, hyaline to pale yellow; walls 2-3.5(-4.5) $\mu \mathrm{m}$. Uredinia not seen. Telia 1-(2)-3 mm diam, on circular light brown spots, amphigenous, subepidermal, erumpent, pulverulent, dark brown, amphigenous, flattened to slightly domed, aparaphysate, but showing large numbers of paraphysis-like long teliospore pedicels. Teliospores (34-) 39-43(-46) × (18-) 22-24 (-26.5) $\mu \mathrm{m}, 1$-celled, oblongellipsoidal; wall pale to chestnut brown, reticulate, pitted in SEM, germ pores not observed; lateral wall 2.5-3(-4) $\mu \mathrm{m}$ thick, apical wall 5-6(-7) $\mu \mathrm{m}$ thick, long-pedicellate; pedicels (48-)84-143(-157) × (4-)5-6(-7) $\mu \mathrm{m}$, seldom persistent in mature teliospores, cylindrical, smooth, thin-walled, hyaline, flexuous.

Other specimens examined (on leaves of Phthirusa stelis): Brazil: Brasília, Guará I, Associação dos Criadores de Pássaros de Brasília, 18 May 2014, J. C. Dianese (UB Mycol. 22879); Asa Norte, Campus Universidade de Brasília, near University Restaurant, 17 Sep. 2012, E. S. C. de Souza (UB Mycol. 22389); Parque Olhos D’Água, 12 Sep. 2012, E. S. C. de Souza (UB Mycol. 22382); Lago Sul, Brasília Botanical Garden, 23 Apr. 2012, E. S. C. de Souza (UB Mycol. 22184); Asa Norte, L4 Avenue, Estação Experimental de Biologia, Universidade de Brasília, 29 Sep. 2009, M. D. M. dos Santos (UB Mycol. 21084); Vargem Bonita, Fazenda Água Limpa, Universidade de Brasília, 12 Sep. 2007, N. M. Toledo de Souza (UB Mycol. 20762); Planaltina-DF, Estação Ecológica de Águas Emendadas, 11 Jun. 2007, V. R.Rodrigues (UB Mycol. 20651); Asa Norte, Campus Universidade de Brasília, near the Rector's office, 9 May. 2007, Z. M. Chaves (UB Mycol. 20569); Super Quadra Norte 410 near the $N$ Bloc, 18 Aug. 2003, R. C. P. Carvalho (UB Mycol. 19398); Brasília National Park, 27 Sep. 1995, Z. M. Chaves (UB Mycol. 10125). 
A
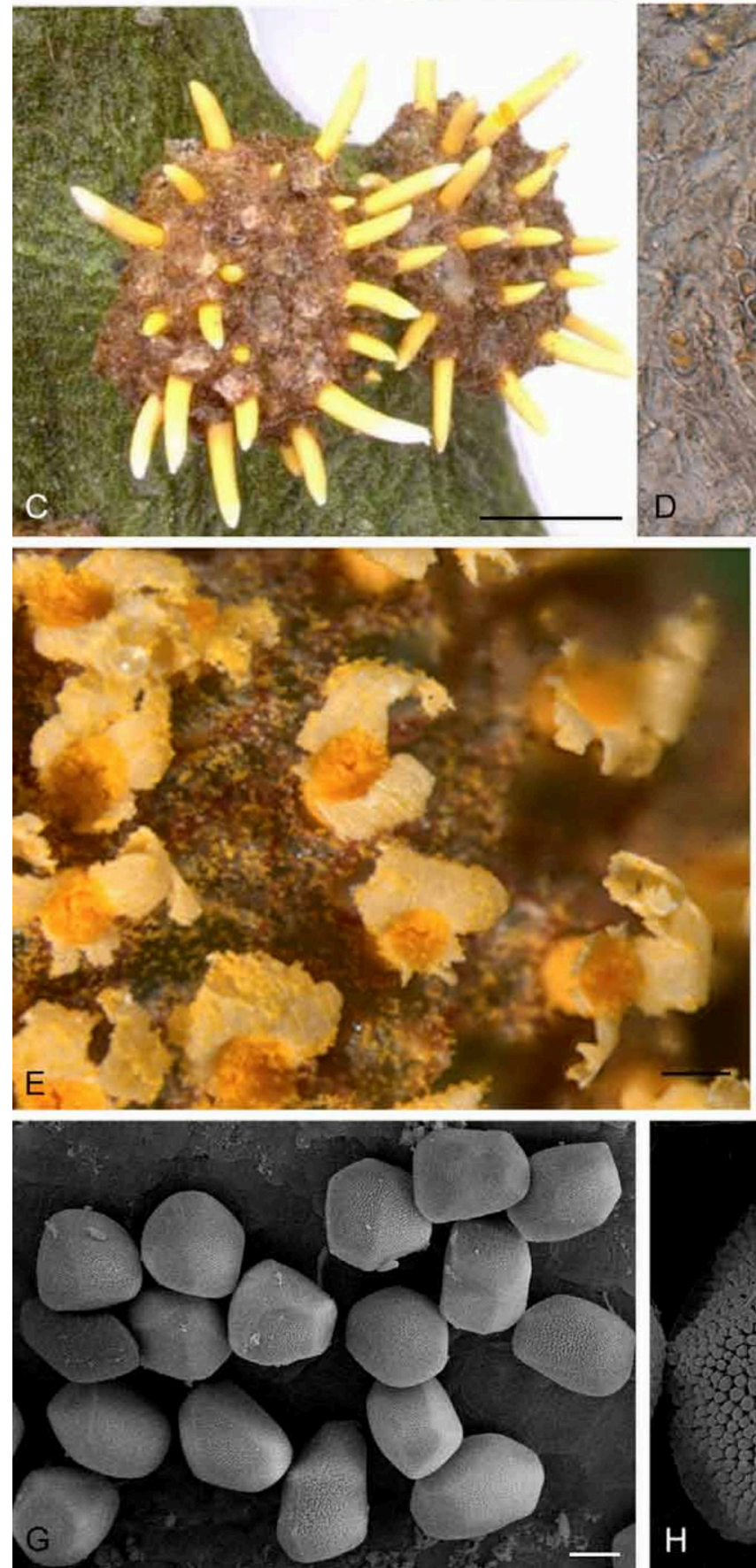
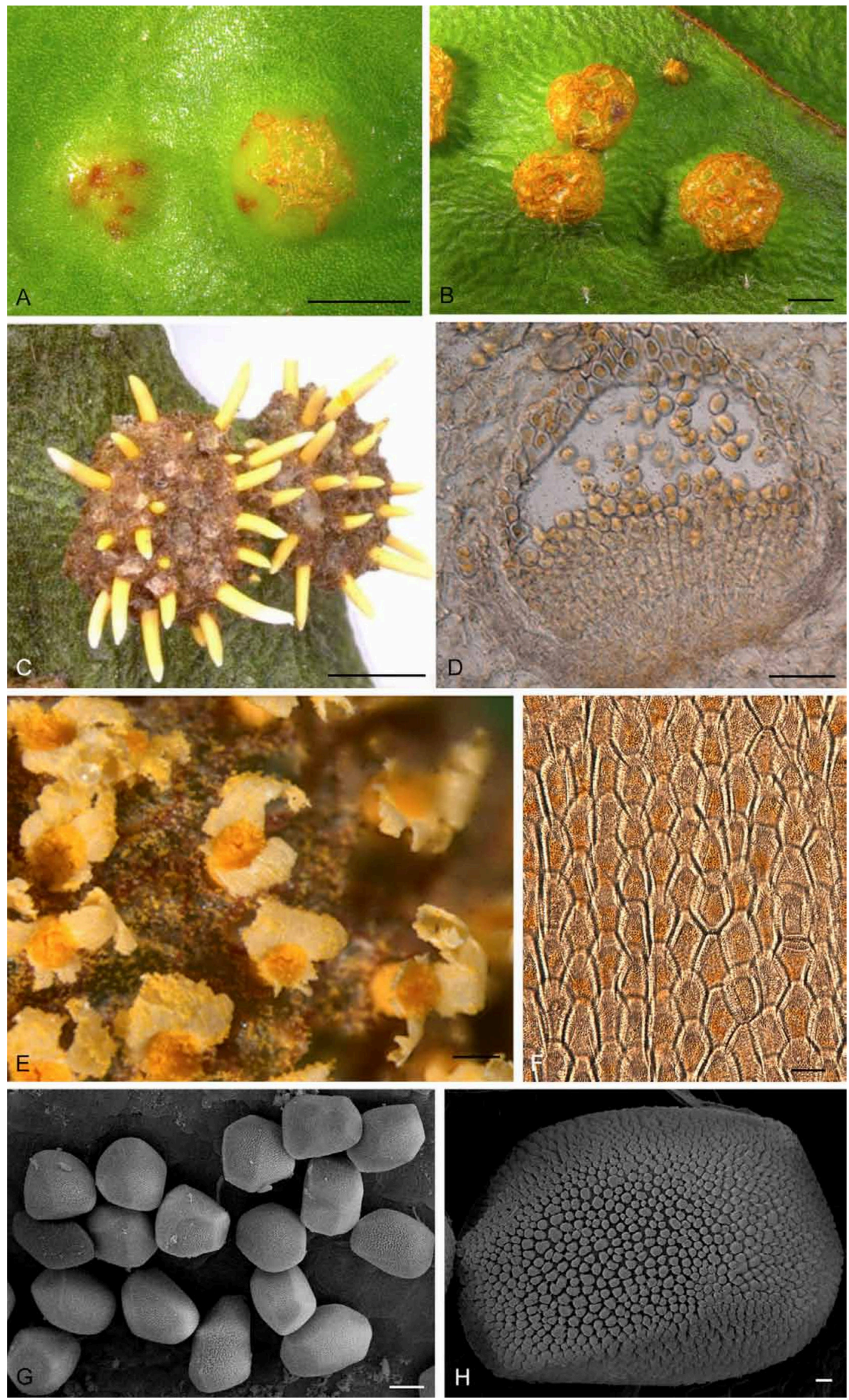

Fig. 1. A-H. Uromyces hawksworthii (UB Mycol. Col. 22875): aecidial gall development and morphology of the aecia, A. Early stage of gall formation. B. Intermediate stage of two galls. C. Two mature galls bearing numerous aecidia. D. Cross section through a developing aecidium. E. Aecidia after aeciospore release. F. Peridium internal texture. G. Aeciospores. H. Detail view of the aeciospore wall. Bars: $A-C=2 \mathrm{~mm}, \mathrm{D}=$ $50 \mu \mathrm{m}, \mathrm{E}=300 \mu \mathrm{m}, \mathrm{F}=20 \mu \mathrm{m}, \mathrm{G}=10 \mu \mathrm{m}, \mathrm{H}=1 \mu \mathrm{m}$. 


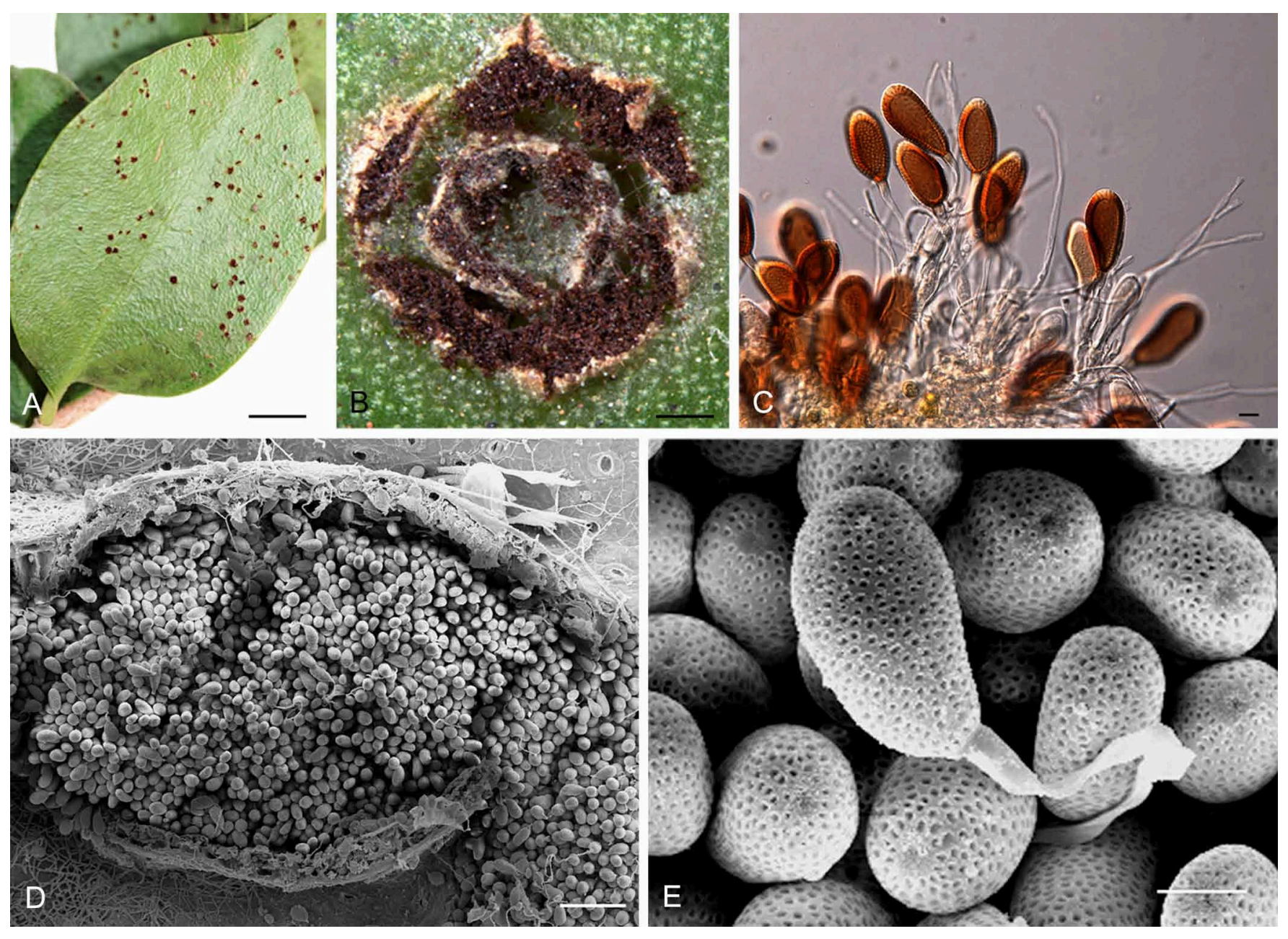

Fig. 2. A-E. Uromyces hawksworthii (UB Mycol. Col. 22875): A. Circular to irregular dark brown telia on the adaxial face. B. Erumpent telium. C. A group of mature teliospores and several long paraphysis-like pedicels. D. Telium seen in SEM. E. Teliospores showing the characteristically pitted wall in SEM. Bars: $A=1 \mathrm{~cm}, \mathrm{~B}=2 \mathrm{~mm}, \mathrm{C}=10 \mu \mathrm{m}, \mathrm{D}=100 \mu \mathrm{m}, \mathrm{E}=5 \mu \mathrm{m}$.

\section{Key to Uromyces species on Loranthaceae}

1 Teliospores smooth-walled, $30-45 \times 21-30 \mu \mathrm{m}$, distal wall to $8 \mu \mathrm{m}$ thick

U. nilagiricus

Teliospores not smooth-walled

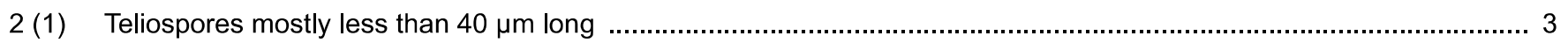

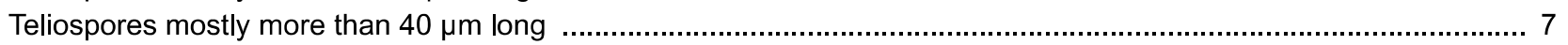

3 (2) Teliospores showing pedicels ornamented by conspicuous annelations ............................................... U. ornatipes

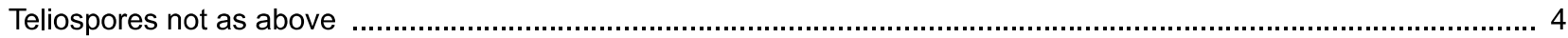

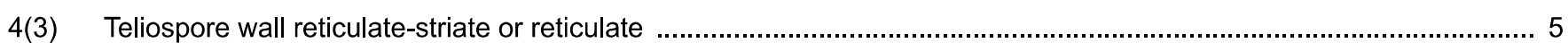

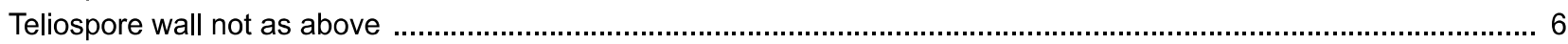

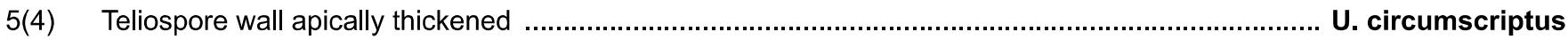

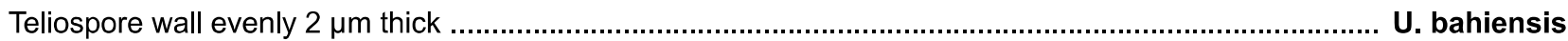

6(4) Teliospores smooth to finely verrucose; uredinia paraphysate, urediniospores echinulate, spines abundant

U. Ioranthi

Teliospores longitunally striate; uredinia aparaphysate, urediniospores echinulate

U. socius

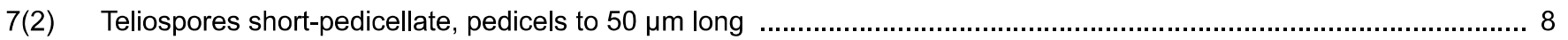

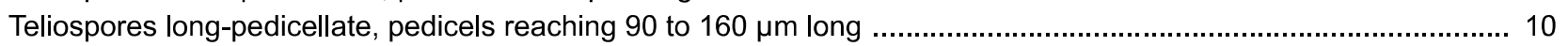




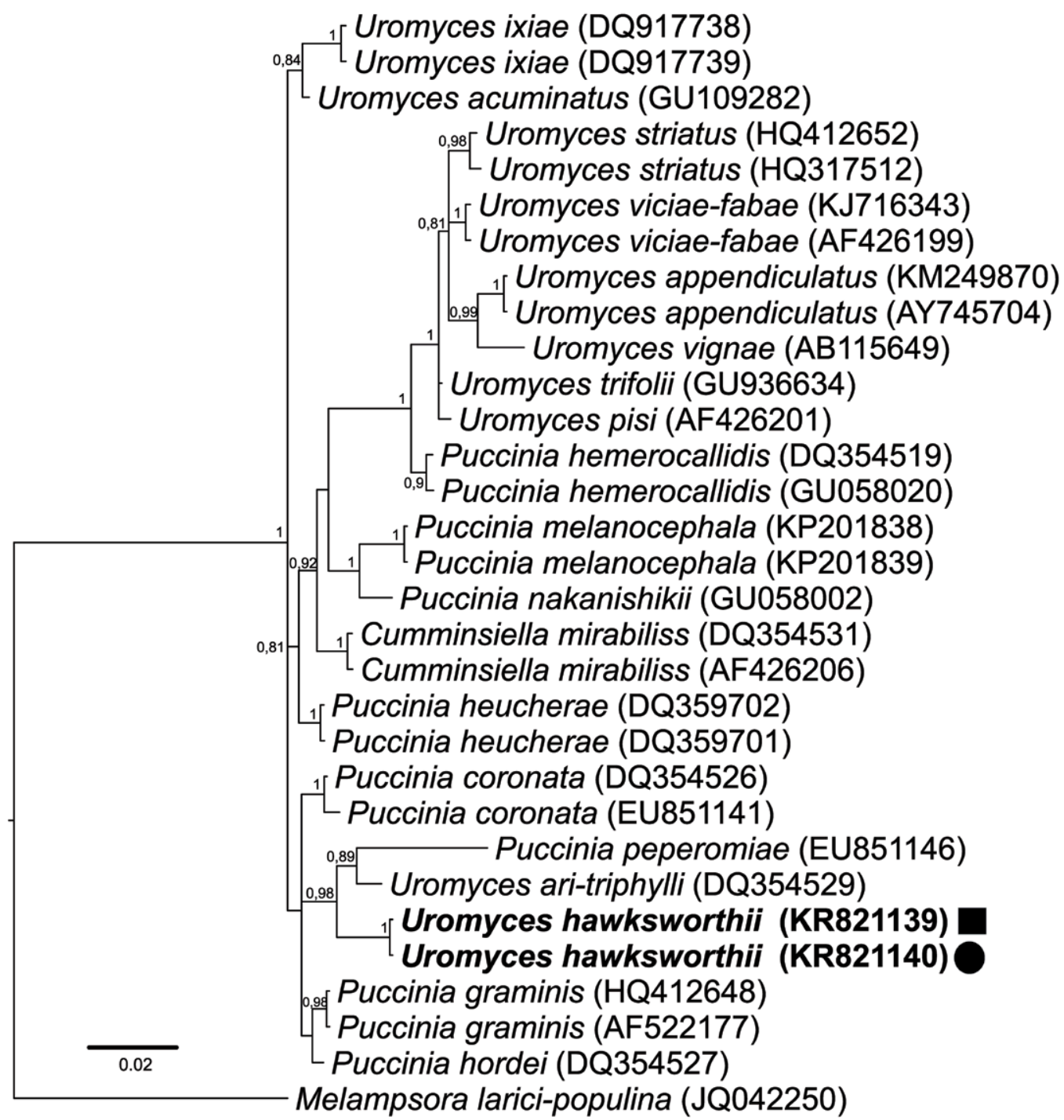

Fig. 3. Phylogenetic tree inferred from the Bayesian analysis based on the LSU sequences of Uromyces and related taxa. The Bayesian posterior probability values above 0.75 are indicated at the nodes. GenBank accession numbers are in parentheses. The specimens in this study are highlighted in bold. Black squares and circles indicate DNA sequences obtained from aeciospores and teliospores, respectively. The tree was rooted to Melampsora larici-populina.

8(7) Teliospores showing very fine ornamentations on a reticulate disposition, urediniospores coarsely reticulate; aecidiospores verrucose, subtuberculate

U. phthiruzae

Teliospores not as above, aecidiospores minutely verrucose to verrucose 9

9(8) Teliospores verrucose-striate; aecidiospores verrucose U. urbanianus Teliospores reticulate, aecidiospores minutely verrucose U. evastigatus

10 (7) Teliospores reticulate-foveate; aecidiospores spinose-echinulate U. struthanthi Teliospores, non reticulate-foveate; aecidiospores verrucose U. hawksworthii

\section{DISCUSSION}

Uromyces hawksworthii is morphologically different from other species reported from Brazil on Loranthaceae, in that it has erect cylindrical to conical or subulate aecia to $3.5 \mathrm{~mm}$ tall, located on well-defined hard pulvinate to subglobose brown galls. Furthermore, U. hawksworthii is phylogenetically distinct from the taxa presently accommodated in GenBank. Based on a megablast search of GenBank, the closest hits using the LSU sequence are Puccinia heucherae RHS5296/05 (GenBank DQ359702; Identities $(98 \%)=1036 / 1060, U$. acuminatus CT-V080623-3 (GenBank GU109282; Identities (98\%) = 1035/1059, U. ari-triphylli U637 (GenBank DQ354529; Identities $(98 \%)=1034 / 1057$, Puccinia graminis U-674 (GenBank HQ412648; Identities $(98 \%)=1023 / 1048$, and 
P. hordei AFTOL-ID 1402 (GenBank DQ354527; Identities $(98 \%)=1017 / 1043$. Additionally, both aecidial and telial specimens of Uromyces hawksworthii examined in this study were similar and formed a clade with Uromyces ari-triphylli and Puccinia peperomiae (Fig. 3). Within this strongly supported clade (posterior probability $=0.98$ ), the two specimens of $U$. hawksworthii formed a sister clade with other taxa included. As rust fungi from South America are poorly characterized molecularly, additional DNA sequence data will be needed to further clarify the phylogeny of rust fungi from tropics.

The aecidial morph of this fungus was described as Aecidium goyazense (Hennings 1895), but the telial morph has not been previously reported. The binomial Uromyces goyazensis is pre-occupied by a rust fungus found on Bauhinia (Hennings 1895), which means that the name Aecidium goyazense cannot be recombined into Uromyces as this would create an homonym to be rejected (Art. 53.1). Consequently, we have given the fungus the new name Uromyces hawksworthii here.

Two identification keys for Uromyces species on Loranthaceae are available (Hennen et al. 2005, PerdomoSánchez \& Piepenbring 2014). In each key the species were separated by the shape and ornamentation of the teliospores, aecia, aeciospores, presence or absence of the uredinial phase, and host species. Perdomo-Sánchez \& Piepenbring (2014) revised and illustrated by light microscopy and SEM, the type specimens of Uromyces on Loranthaceae around the world, except for $U$. nilagiricus, a species reported on Loranthus sp. from India, for which type material was not available. This is the only species found outside Latin America distinguished by smooth teliospores (Ramakrishnam \& Ramakrishnam 1950). Based on teliospore wall characteristics, the Uromyces species on Loranthaceae are distributed in two well-defined groups. One has superficially verrucose or markedly striate teliospores, including $U$. euphlebius, $U$. ornatipes, $U$. loranthi, U. phthirusae, and U. socius (Sydow 1920, Arthur 1915, 1918, Perdomo-Sánchez \& Piepenbring 2014). The other group has teliospores with pitted to foveate surfaces, including $U$. bahiensis, $U$. circumscriptus, $U$. evastigatus, $U$. loranthi, $U$. phthirusae, $U$. struthanthi, and $U$. urnabianus. In the latter group of species, only $U$. loranthi (aecidia unknown, teliospore walls verrucose) and $U$. phthirusae (teliospore walls striate) have a known uredinial phase.

\section{ACKNOWLEDGEMENTS}

We thank Mariza Sanchez, Robert N.G. Miller, and Dirceu Macagnan for support and help. Thanks are also due to CNPq/Brazil for financial support through the PPBIO-Cerrado Project.

\section{REFERENCES}

Aime MC (2006) Toward resolving family-level relationships in rust fungi (Uredinales). Mycoscience 47: 112-122.

Arthur JC (1915) New species of Uredineae IX. Bulletin of Torrey Botanical Club 42: 585-593.
Arthur JC (1918) Uredinales of Guatemala based on collections by WWD. Holway - II. Aecidiaceae, exclusive of Puccinia and form genera. American Journal of Botany 5: 420-446.

Bruns TD, Vilgalys R, Barns SM, Gonzalez D, Hibbett DS, et al. (1992) Evolutionary relationships within the fungi: analyses of nuclear small subunit rRNA sequences. Molecular Phylogenetics and Evolution 1: 231-241.

Busby PE, Aime MC, Newcombe G (2012) Foliar pathogens of Populus angustifolia are consistent with a hypothesis of Beringian migration into North America. Fungal Biology 116: 792-801.

Chung WH, Tsukiboshi T, Ono Y, Kakishima M (2004) Morphological and phylogenetic analyses of Uromyces appendiculatus and $U$. vignae on legumes in Japan. Mycoscience 45: 233-244.

Deadman ML, AI Sadi AM, AI Maqbali YM, Farr DF, Aime MC (2011) Additions to the rust fungi (Pucciniales) from northern Oman. Sydowia 63: 155-168.

Dixon LJ, Castlebury LA, Aime MC, Glynn NC, Comstock JC (2010) Phylogenetic relationships of sugarcane rust fungi. Mycological Progress 9: 459-468.

Doyle JJ, Doyle JL (1990) Isolation of plant DNA from fresh tissue. Focus 12: 13-15.

Edgar RC (2004) MUSCLE: a multiple sequence alignment method with reduced time and space complexity. BMC Bioinformatics 5: 113.

Hall T (2012) BioEdit v 7.0.9: Biological sequence alignment editor for Win95/98/2K/XP/7.

Hennen JF, Figueiredo MB, de Carvalho Jr. AA, Hennen PG (2005) Catalogue of the species of plant rust fungi (Uredinales) of Brazil. Instituto de Pesquisas, Jardim Botânico do Rio de Janeiro Rio de Janeiro, Brazil.

Hennings $P$ (1895) Fungi goyazenses. Hedwigia 34: 88-112.

Henricot BA, Denton GA, Lane CB (2007) First report of Puccinia heucherae on Heuchera spp. in the UK. Plant Pathology 56: 352.

Hyde KD, Nilsson RH, S. Alias A, Ariyawansa AH, Blair E, et al. (2014) One stop shop: backbones trees for important phytopathogenic genera: I (2014). Fungal Diversity 67: 21-125.

Kropp BR, Hansen DR, Wolf PG, Flint KM, Thomson SV (1997) A study on the phylogeny of the dyer's woad rust fungus and other species of Puccinia from Crucifers. Phytopathology 87: 565-571.

Liu M, McCabe E, Chapados JT, Carey J, Wilson SK, et al. (2015) Detection and identification of selected cereal rust pathogens by TaqMan® real-time PCR. Canadian Journal of Plant Pathology 37: 92-105.

Maier W, Begerow D, Weiss M, Oberwinkler F (2003) Phylogeny of the rust fungi: an approach using nuclear large subunit ribosomal DNA sequences. Canadian Journal of Botany 81: 12-23.

Maier W, Wingfield BD, Mennicken M, Wingfield MJ (2007) Polyphyly and two emerging lineages in the rust genera Puccinia and Uromyces. Mycological Research 111: 176-185.

Matheny PB, Gossmann JA, Zalar P, Kumar TKA, Hibbett DS (2006) Resolving the phylogenetic position of the Wallemiomycetes: an enigmatic major lineage of Basidiomycota. Canadian Journal of Botany 84: 1794-1805.

McTaggart AR, Geering ADW and Shivas RG (2014) Uredinopsis pteridis and Desmella aneimiae, the first rust fungi (Pucciniales) reported on ferns (Pteridophyta) in Australia. Australasian Plant Disease Notes 9: 149.

Miller MA, Pfeiffer W, Schwartz T (2010) Creating the CIPRES Science Gateway for inference of large phylogenetic trees. Proceedings of the Gateway Computing Environments Workshop (GCE), 14 Nov. 2010, New Orleans, LA: 1-8. 
Moncalvo JM, Wang HH, Hseu RS (1995) Phylogenetic relationships in Ganoderma inferred from the internal transcribed spacers and 25S ribosomal DNA sequences. Mycologia 87: 223-238.

Nilsson RH, Hyde KD, Pawłowska J, Ryberg M, Tedersoo L, et al. (2014) Improving ITS sequence data for identification of plant pathogenic fungi. Fungal Diversity 67: 11-19.

Padamsee M, McKenzie EHC (2014) A new species of rust fungus on the New Zealand endemic plant, Myosotidium, from the isolated Chatham Islands. Phytotaxa 174: 223-230.

Perdomo-Sánchez O, Piepenbring M (2014) Species of Uromyces (Puccinilaes, Basidiomycota) on Loranthaceae. Tropical Plant Pathology 39: 141-153.

Pfunder M, Schürch S, Roy BA (2001). Sequence variation and geographic distribution of pseudoflower-forming rust fungi (Uromyces pisi s. lat.) on Euphorbia cyparissias. Mycological Research 105: 57-66.

Posada D, Buckley T (2004) Model selection and model averaging in phylognetics: advantages of Akaike information criterion and Bayesian approaches over likelihood ratio tests. Systematic Biology 53: 793-808.

Ramakrishnam TS, Ramakrishnam K (1950) Additions to fungi of Madras VIII. Proceedings of the Indian Academy of Science, B 3: $102-110$.
Rambaut A (2009) FigTree. Version 1.2.3. Edinburgh: Institute of Evolutionary Biology, University of Edinburgh.

Ronquist F, Teslenko M, van der Mark P, Ayres DL, Darling A, et al (2012) Mrbayes 3.2: efficient Bayesian phylogenetic inference and model choice across a large model space. Systematic Biology 61: 539-542.

Sydow HP (1920) Novae fungorum species. Annales Mycologici 18 : 154-160.

Tamura K, Peterson D, Peterson N, Stecher G, Nei M, Kumar S (2011) Mega 5: molecular evolutionary genetics analysis using maximum likelihood, evolutionary distance, and maximum parsimony methods. Molecular Biology and Evolution 28: 27312739.

Vilgalys R, Hester M (1990) Rapid genetic identification and mapping of enzymatically amplified ribosomal DNA from several Cryptococcus species. Journal of Bacteriology 172: 4238-4246.

Yun HY, Minnis AM, Dixon LJ, Castlebury LA (2010) First report of Uromyces acuminatus on Honckenya peploides, the endangered seabeach sandwort. Plant Disease 94: 279.

Zuluaga C, Buriticá P, Marín M (2011) Filogenia de hongos/roya (Uredinales) em la zona andina colombiana mediante el uso de secuencias del ADN ribosomal 28S. Revista de Biología Tropical 59: $517-540$. 
ANEXO 2 
Manuscript Number:

Title: Interaction between Colletotrichum truncatum and Uromyces euphorbiae on leaves of Euphorbia hirta

Article Type: Original Research

Keywords: Endophyte/Rust Interaction

Neotropical Fungi

Morfomolecular Identification

Brazil

Pucciniales

Glomerelalles.

Corresponding Author: Professor JOSE Carmine DIANESE, PhD

Corresponding Author's Institution: Universidade de Brasília

First Author: ERICA S SOUZA, MSC, PhD Student

Order of Authors: ERICA S SOUZA, MSC, PhD Student; HELSON M VALE, DSC; RITA C PEREIRA-CARVALHO, DSC; WILLIAM R SOARES, MSC, PhD Student; ROBERT N MILLER, PhD; JOSE Carmine DIANESE, PhD

Abstract: Euphorbia hirta (Euphorbiaceae) grows widely in most tropical and subtropical regions of the world including in Brazil, Australia, India, and several states in USA. In Brasilia, plants infected with Uromyces euphorbiae characteristically show rust pustules (485-220 $\mu \mathrm{m}$ diam.) delimited by a necrotic band surrounded by a reddish-brown border showing showing epiphyllous sori with both urediniospores and teliospores, and sometimes hypophyllous aecia with aeciospores. In 74\% of the leaf lesions, setose acervuli of a Colletotrichum species were produced, but exclusively within the necrotic area. Morphological and molecular characterization indicated that Colletorichum trucatum was the species, with typically curved conidia (31-(27)-23 × 3-4 $\mu \mathrm{m})$ in acervuli measuring 86-44 $\mathrm{m}$, bordered by a palisade of long black setae (up to 140 $\times 5(\mathrm{~m})$. Colletotricum truncatum acervuli were not shown in $26 \%$ of the pustules, and were never formed in areas of the leaf where U. euphorbiae was not present. Isolation from healthy areas of the leaves and from leaves showing no rust infection, revealed that the associated fungus was indeed an endophyte. Sequencing of rDNA segments amplified using ITS, TUB2, GAPDH and HIS3 primers revealed that the endophyte and the pustuleinfecting fungus belonged in the same species and are members of the $C$. truncatum complex. The rust fungus was for the first time sequenced (segments LSU and ITS of the rDNA), and SEM illustrated. Phylogenetic analyzes were carried out by Maximum Likelihood and Bayesian Inference for the identification of both fungi. Further research is needed to clarify the physiological aspect of the interaction between $U$. euphorbiae and the endophytic C. truncatum involved.

Suggested Reviewers: Mary C Aime PhD Professor, Botany and Plant Pathology/Arhur Fungarium, Purdue University maime@purdue.edu 
She is an world expert on the taxonomy of rust fungi, and for sure would be able to contribute with a positive criticism of our paper.

PAUL F CANNON PhD

SENIOR MYCOLOLGIST, Kew Gardens, UK

p.cannonekew.org.uk

Senior and corresponding author of a recent classical paper on

Colletotrichum, published by Studies in Mycol. 2012 Sep 15; 73(1): 181213.

For sure an authority on the genus.

Mary C Aime PhD

Professor, Botany and Plant Pathology/Arhur Fungarium, Purdue University maime@purdue.edu

She is an world expert on the taxonomy of rust fungi, and for sure would be able to contribute with a positive criticism of our paper.

Paul F CANNON PhD

SENIOR MYCOLOGIST, Kew Gardens, UK

p.cannonakew.org.uk

Senior author of the classical paper,"Colletotrichum - current status and future directions, IN:Studies in Mycology (2012) 73(1): 181-213. A well

known authority when it comes to colletotrichum.

Robert W. Barreto PhD, Univ. Reading-UK

Professor, FITOPATOLOGIA, UNIV. fEDERAL DE VIÇOSA, MG, BRAZIL

rbarretodufv.br

Dr. Barreto is an authority on plant pathogenic fungi with an important contribution to the use of fungi as weed biocontrol tools. For many years engaged in cooperative work with Dr. Harry C. Evans (CABI-UK). Very important Brazilian mycologist/plant pathologist. 
To:

Prof. J.W. Spatafora

Senior Editor

FUNGAL BIOLOGY

Dear Prof. Spatafora,

I am submitting for publication in Fungal Biology a MS entitled "Interaction between Colletotrichum truncatum and Uromyces euphorbiae on leaves of Euphorbia hirta", where we run a morphological identification of both interacting fungi, and the at the same time we had them molecularly identified.

This is part of our effort to always include molecular support to our taxonomic studies, now that we finally have the available tools and materials to do such a job.

In over 40 years working with plant-associated fungi, this is the first time I had the opportunity to observe a clear stimulus to sporulation of hemibiotroph/endophyte by a rust fungus. I consider Fungal Biology the right place to publish this paper, and hope that I am correct.

Yours sincerely,

José Carmine Dianese

Universidade de Brasília 
Interaction between Uromyces euphorbiae and an endophytic Colletotrichum truncatum on leaves of Euphorbia hyrta

\section{Leaf lesions}

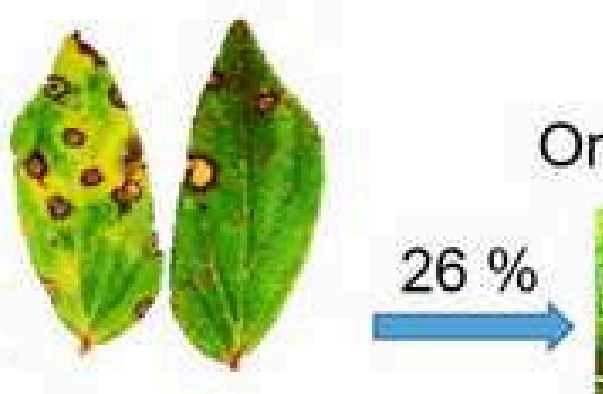

\section{$74 \%$}

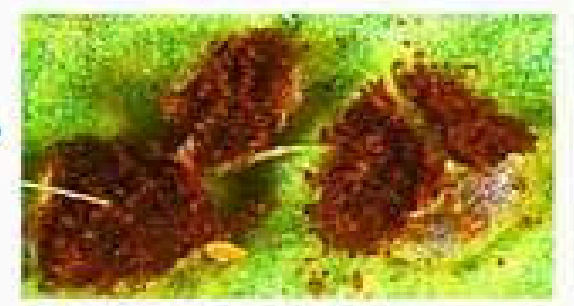

U. euphorbiae sori surrounded by

C. trucatum setose acervuli

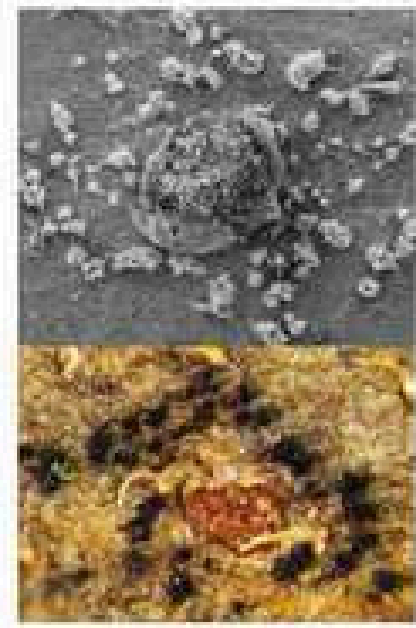

Morphological identification of both fungi was confirmed by phylogenetic analyses using Maximum Likelihood and Bayesian Inference, for the first time in the case of $U$. euphorbiae. 


\section{Highlights}

- Periphery of Uromyces euphorbiae sori was shown to be the only sites of acervular formation by an endophytic C. truncatum, on leaves of Euphorbia hirta.

- Only in $26 \%$ of the rust pustules the acervuli were lacking

- Morphology and molecular identification, and phylogeny of endophytic and acervular Colletotrichum specimens in E. hirta showed that they were identical and both belong to the species $C$. truncatum. The phylogeny based on Maximum Likelihood (ML) and Bayesian Inference (BI) analyses, using sequences of four genomic loci of both isolates (ITS; $\beta$-tubulin2 gene (TUB2); GAPDH gene, and Histone $\mathrm{H} 3$ gene).

- Uromyces euphorbiae was for the first time illustrated in detail using both light microscopy and SEM illustration of its telia/uredia and aecia.

- For the first time $U$. euphorbiae had its LSU sequences used for phylogenetic characterization by ML and BI analyses. 


\title{
Interaction between Colletotrichum truncatum and Uromyces euphorbiae on leaves of Euphorbia hirta
}

\author{
Érica S.C. Souza ${ }^{\mathrm{a}}$, Helson M.M. Vale ${ }^{\mathrm{b}}$, Rita C. Pereira-Carvalho ${ }^{\mathrm{b}}$, William R.O. Soares ${ }^{\mathrm{b}}$, \\ Robert N.G. Miller ${ }^{\mathrm{a}}$, José C. Dianese \\ ${ }^{a}$ Departamento de Biologia Celular, Pós-graduação em Biologia Microbiana, Universidade \\ de Brasília, Campus Darcy Ribeiro, 70910-900 Brasília, Distrito Federal, Brazil. \\ ${ }^{\mathrm{b}}$ Departamento de Fitopatologia, Universidade de Brasília, Campus Darcy Ribeiro, 70910- \\ 900 Brasília, Distrito Federal, Brazil.
}

Corresponding author:

Prof. José Carmine Dianese

Departamento de Fitopatologia, Universidade de Brasília, Campus Darcy Ribeiro, 70910900 Brasília, Distrito Federal, Brazil.

Tel: +55-061-999858695

E-mail: jcarmine@unb.br

Received ii July 2016, Revised ee July 2016, Accepted xx ??? 2016, Available online yy ??? 2016

\begin{abstract}
Euphorbia hirta (Euphorbiaceae) grows widely in most tropical and subtropical regions of the world including in Brazil, Australia, India, and several states in USA. In Brasilia, plants infected with Uromyces euphorbiae characteristically show rust pustules (485-220 $\mu \mathrm{m}$ diam.) delimited by a necrotic band surrounded by a reddish-brown border showing showing epiphyllous sori with both urediniospores and teliospores, and sometimes hypophyllous aecia with aeciospores. In $74 \%$ of the leaf lesions, setose acervuli of a Colletotrichum species were produced, but exclusively within the necrotic area. Morphological and molecular characterization indicated that Colletorichum trucatum was the species, with typically curved conidia $(31-(27)-23 \times 3-4 \mu \mathrm{m})$ in acervuli measuring $86-44 \mu \mathrm{m}$, bordered by a palisade of long black setae (up to $140 \times 5 \mu \mathrm{m}$ ).
\end{abstract} Colletotricum truncatum acervuli were not shown in $26 \%$ of the pustules, and were never 
formed in areas of the leaf where U. euphorbiae was not present. Isolation from healthy areas of the leaves and from leaves showing no rust infection, revealed that the associated fungus was indeed an endophyte. Sequencing of rDNA segments amplified using ITS, TUB2, GAPDH and HIS3 primers revealed that the endophyte and the pustule-infecting fungus belonged in the same species and are members of the C. truncatum complex. The rust fungus was for the first time sequenced (segments LSU and ITS of the rDNA), and SEM illustrated. Phylogenetic analyzes were carried out by Maximum Likelihood and Bayesian Inference for the identification of both fungi. Further research is needed to clarify the physiological aspect of the interaction between $U$. euphorbiae and the endophytic $C$. truncatum involved.

\section{Keywords:}

Endophyte/Rust Interaction, Neotropical Fungi, Morfomolecular Identification, Brazil, Pucciniales, Glomerelalles.

\section{Introduction}

Between 2011 and 2016, plants of Euphorbia hirta, a weed common in wastelands, and associated with cultivated crops throughout the tropical and subtropical regions of the world (CABI 2016), found at the Biological Experiment Station of the University of Brasilia showed leaf spots containing rust pustules due to infection by an Uromyces species, mostly surrounded by dark brown setose acevuli of a Colletotrichum species. Thus, the aim of this work was to morphologically and molecularly characterize and identify both fungi, and discuss the meaning of such interaction.

\section{Materials and Methods}

\subsection{Morphology}

Leaf lesions containing both the Colletotrichum species and the rust fungus were initially studied under a stereomicroscope, followed by observations of slides containing squash preparations, or $15-20 \mu \mathrm{m}$ thick sections obtained using a Leica ${ }^{\circledR}$ freezing microtome. The morphological features of both fungi were described, measured, and documented using both a Leica M $206 \mathrm{C}^{\circledR}$ stereomicroscope and a Leica DM $2500^{\circledR}$ light microscope coupled with a Leica DFC $4900^{\circledR}$ digital camera connected to a microcomputer. Image capture, editing, and structural measurements were done using a Leica QWin ${ }^{\circledR}$ V3 
software. In some cases, the samples were stained with lacto-glycerol Cotton Blue and the slides sealed with nail polish, however most of the photographic work was done without staining using Nomarski optics. A minimum of 20 spores and structural cells replicates were measured. Portions of dry leaves that contained acervuli and rust sori with urediniospores and teliospores were fixed on top of $10 \mathrm{~mm}$ diam. bronze stubs using double face carbon tape, and treated with gold at $25 \mathrm{~mA}, 1.10^{-2} \mathrm{mbar}$, for $2.5 \mathrm{~min}$. for SEM study. A JEOL JSM-700 ${ }^{\circledR} 1 \mathrm{~F}$ Model scanning electron microscope was used for detailed morphological view of the fungal components. Herbarium vouchers (UB-Mycol. Coll. 21591, UB-Mycol. Coll. 22311, UB-Mycol. Coll. 23207 and UB-Mycol. Coll. 23305) containing both associated fungi were deposited in the Mycological Collection of the Herbarium UB.

\subsection{Culturing, DNA extraction, PCR amplification, and DNA sequencing}

The Colletotricum specimens were directly isolated from the acervuli around the rust lesions, and also from healthy areas of plant leaves superficially disinfested by serially washing in $2 \%$ hypochlorite, $70 \%$ ethanol and sterile distilled water to verify the possible endophytic presence of the fungus. The isolates were cultured on PDA plates for seven days before obtaining monoconidial cultures used for the morphological studies, and for DNA extraction. The isolates obtained were preserved in sterile distilled water (Dhingra \& Sinclair 1995) under accession numbers CCUB 29 for the acervular isolate, and CCUB 30 for the endophyte, both deposited at the Fungal Culture Collection of the Herbarium UB.

Genomic DNA was extracted from a mixture of urediniospores and teliospores present on sori of the rust fungus, and separately from a mass of aeciospores. For all samples of both Colletotrichum and Uromyces species, genomic DNA extraction followed the CTAB protocol (Doyle \& Doyle 1990).

Four genomic loci were sequenced for both Colletotricum isolates: ITS; $\beta$-tubulin2 gene (TUB2); GAPDH gene, and Histone H3 gene, however in the case of the rust fungus the seuqences were limited to the ITS and LSU segments (Table 1).

The PCRs for both Colletotrichum and Uromyces species, included the following reagents for each $25 \mu \mathrm{L}$ reaction volume: $0.5 \mathrm{U}_{\text {Taq DNA Polymerase Platinum }}{ }^{\circledR}, 0.2 \mathrm{mM}$ of each nucleotide, $10 \times$ buffer $(10-50 \mathrm{mM}$ TRIS-HCl, $\mathrm{pH} 8.3,50 \mathrm{mM} \mathrm{KCl}), 1.5 \mathrm{mM}$ $\mathrm{MgCl}_{2}, 0.4 \mu \mathrm{M}$ of each of the forward and reverse primers, plus a maximum of $10 \mathrm{ng} / \mu \mathrm{L}$ of genomic DNA. The thermal cycle, for both fungi, consisted of $94 \mathrm{C}$ for $4 \mathrm{~min}$, followed 
by 30 cycles of $94 \mathrm{C}$ for $1 \mathrm{~min}$ (denaturation), and the respective annealing temperatures, all lasting $1 \mathrm{~min}$ are shown in Table 1; elongation was done at $72 \mathrm{C}$ for $1 \mathrm{~min}$, and final extension at $72 \mathrm{C}$ for $5 \mathrm{~min}$.

PCR products were analyzed in 1\% agarose electrophoresis with gels stained with ethidium bromide in a $1 \times$ TAE buffer, and visualized under UV light to check for amplicon size and purity. PCR products were treated using ExoSAP-IT ${ }^{\circledR}$ (USB) and sequenced in an Applied Biosystems (ABI3130xl Model) apparatus at the Biotecnology Laboratory, of the Catholic University of Brasília.

\subsection{Phylogeny}

The nucleotide sequences were edited using BioEdit (Hall 2012) and Geneious-R8 (Kearse et al. 2012). All sequences checked manually, and nucleotides with ambiguous positions being clarified using both primer direction sequences. The new sequences of both fungi were deposited in GenBank (http://www.ncbi.nlm.nih.gov/genbank/) and their accession numbers are listed in Tables 1 and 2, and the phylograms generated are shown in Figures 1 and 2. Consensus sequences of all amplified segments belonging to both fungal species were compared with those in GenBank via BLASTn. In the case of the Colletotrichum isolates, sequences belonging to species infecting members of the family Euphorbiaceae were taken from GenBank for the phylogenetic analyses. Also recent phylogenetic studies focusing species with curved conidia were considered in the selection of species to be included in the analyses (Damm et al. 2009, Hyde et al. 2014, Yang et al. 2014). The sequences chosen were downloaded from GenBank in FASTA format being ITS, TUB2, GAPDH and HIS3 for Colletotrichum species; and single ones of ITS and LSU for Uromyces. The alignments were carried by MUSCLE ${ }^{\circledR}$ (Edgar 2004), built in MEGA v. 6 (Tamura et al. 2013), manual adjustments were made when necessary. Gaps were treated as missing data.

The alignments for each of the markers used for the phylogenetic analyses of the Colletotrichum sequences were done separately before being concatenated using Mesquite v.3.10 (Maddison \& Maddison 2016).

Phylogenetic relationships for both fungal species were carried out under Maximum Likelihood (ML) and Bayesian Inference (BI) using PAUP* v. $4.0 b 10$ (Swofford 2002) and $\mathrm{Mr}$ Bayes v. 3.2 (Ronquist et al. 2012). Before launching the ML and BI, the best nucleotide substitution model was determined with MrMODELTEST 2.3 (Posada \& Buckley 2004). 
The likelihood scores were calculated and the models selected according to the Akaike Information Criterion (AIC). Maximum Likelihood was based on the $(\mathrm{GTR}+\mathrm{I}+\mathrm{G})$ model, and the phylogenetic trees drawn based on branch lengths, with the number of substitutions per site being shown on a scale. Clade stability resulted from bootstrap analyses with 1,000 replicates.

Bayesian inference analysis employing a Markov Chain Monte Carlo method was performed for all sequences. The general time-reversible model of evolution including estimation of invariable sites and assuming a discrete gamma distribution with six rate categories $(\mathrm{GTR}+\mathrm{I}+\mathrm{G})$ was used. Four MCMC chains were run simultaneously, starting from random trees for $10,000,000$ generations. Trees were sampled every 1,000th generation for a total of 10,000 trees. The first 2500 trees were discarded as the burn-in phase of each analysis. Posterior probabilities were determined from a majority-rule consensus tree generated with the remaining 7500 trees.

Trees were rooted to $C$. lindemuthianum for the Colletotrichum species, and to Melampsora larici-populina for Uromyces, visualized by FigTree (Rambaut 2009), and exported to a graphic's program. The alignments of sequences belonging to both fungi were deposited in TreeBase (http://www.treebase.org/) under access number 19554.

\section{Results and Discussion}

Isolates of Colletotrichum species associated with the rust pustules caused by an Uromyces species on E. hirta, and occurring as endophyte in healthy leaves, were both shown to belong to the same species: $C$. truncatum. The rust fungus present was identified as U. euphorbiae.

The identification of $C$. truncatum and $U$. euphorbiae infecting E. hirta was based in morphological and molecular analyses, as follows.

In the case of $C$. truncatum, the matrix generated using four markers in a concatenated fashion for 31 taxa including those selected from GenBank (Table 2), resulted in a dataset of $1277 \mathrm{bp}$ of aligned positions, being 373 parsimony informative, 400 variable and 877 conserved, and used for ML and BI analyses.

Amplification and sequencing of a ITS rDNA segment, and genes TUB2, GAPDH and HIS3 were performed for both acervular and endophytic isolates of C. truncatum.

In addition, the molecular identification (Figure 1) leaves no doubt that both the acervular and the endophytic isolates are indeed members of the $C$. trucatum species complex. 
On the other hand, for the first time, amplification and sequencing of the LSU and ITS rDNA regions of $U$. euphorbiae were successful for samples obtained from an aeciospore mass, and from a mixture of teliospores and urediniospores. Considering our molecular and morphological data, U. euphorbiae, access number UB-Mycol. Coll. 23207 is herein accepted as reference specimen.

Other LSU sequences of Uromyces species were selected from GenBank, and used for molecular phylogenetic identification of the fungus, as widely recommended for genus and species identification of rust fungi (Hyde et al. 2014).

Based on the results from the primary LSU data matrix and the dataset for rust fungi indicated by Hyde et al. (2014), 34 taxa (Table 3) were selected from across the breadth of LSU derived phylogenetic trees. The dataset used for ML and BI analyses consisted of $509 \mathrm{bp}$ of aligned positions, 59 of which were parsimony informative, 120 were variable and 389 were conserved.

The data showed that sequences of $U$. euphorbiae obtained from mixed pustules (containing teliospores and urediniospores) and from aeciospores, were identical and placed the species in a clade where all other members were either pathogenic to euphorbiaceous or to fabaceous hosts. The sequence data thus allowed for a safe molecular characterization of the species clearly segregated from the other clade components (Figure 2).

Damm et al. (2009) described C. truncatum on Anthriscus species (Apiaceae) as a typical representative of the species on a herbarium voucher. The variations in dimension between our specimen and the one described by Damm et al. (2009) are within the limits set for the species. However, more recently Crous et al. (2013), reported on the description of C. euphorbiae Damm \& Crous on Euphorbia sp., an unrelated species outside of the $C$. truncatum complex, showing conidia straight not falcate, and clearly guttulate instead of non-guttulate.

Although C. truncatum is known on three Euphorbia species (E. maculata, E. neriifolia, and E. pulcherrima), this is the first record of the fungus associated with Euphorbia hirta (Farr and Rossman 2016).

Our Colletotrichum specimen showed on the host leaves a morphology that fits the description C. truncatum by Damm et al. (2009): conidiomata 44-90 $\mu \mathrm{m}$ diam., setose, acervular; setae (up to $140 \times 5 \mu \mathrm{m}$ ) long, dark brown to black, smooth, 1-3 septate, tapering towards slightly acute to roundish tip, base cylindrical to obconical; conidiophores 70-81 (76) $\times$ 2-4 (3) $\mu \mathrm{m}$ long pale brown, septate, branched, densely clustered; 
conidiogenous cells 11-20 (16) $\times 2-4$ (3) $\mu \mathrm{m}$, enteroblastic, phialidic with openings measuring 1-1.5 $\mu \mathrm{m}$ diam., hyaline to pale brown, cylindrical, collarete present, periclinal thickenings visible; conidia $(31-(27)-23 \times 3-4 \mu \mathrm{m}$, hyaline, smooth-walled, aseptate, typically falcate, long central part of conidia usually slightly curved with parallel walls, ending at round tip, and subtruncate base, non-guttulate protoplasm. Besides that, Figures 3 to 6 illustrate the morphology of both $C$. truncatum and $U$. euphorbiae, starting with the leaf symptoms, and details of the distribution of both fungi on the infected leaves (Figure 3 ), and morphological details of the both fungi (Figures $4,5,6$ ) are shown. Thus, light and SEM microscopic illustration of one of the C. trucatum isolates (Figure 4), and of the $U$. euphorbiae specimen (Figures 5, 6) are shown.

The morphology of our specimen of $U$. euphorbiae, agrees with the description shown in Hennen et al. (2005): spermogonia inconspicuous; aecia mostly abaxial, cylindrical, campanular to cupulate densely distributed, peridium showing somewhat recurved apex, peridial cells 17.5-30 × 12-20.5 $\mu \mathrm{m}$, cuboid, polyhedral, wall 4-7 $\mu \mathrm{m}$ thick, finely verrucose; aeciospores 15-20 × 13-17 $\mu \mathrm{m}$, globoid to broadly ellipsoid, catenate, wall ca $1 \mu \mathrm{m}$ thick, densely verrucose, pale yellow or colorless, with 2-3 germpores; sori frequently mixed showing both teliopores and urediniospores; uredinia amphigenous, 485-(350)-220 $\mu \mathrm{m}$ diam., scattered or sometimes in circular or crowded groups, erumpent, powdery, cinnamon-brown; urediniospores 19-25 × 17-22.5 $\mu \mathrm{m}$, aseptate, globoid or broadly ellipsoid; wall $1.5-2 \mu \mathrm{m}$, moderately and sparsely echinulate, golden-brown; 3-6 scattered germpores; telia amphigenous, 485-(350)-220 $\mu \mathrm{m}$ diam., scattered or sometimes in circular groups, erumpent, dark chocolate-brown; teliospores $18-27 \times 12-19.5 \mu \mathrm{m}$, aseptate, broadly ellipsoid obovoid, conical papilla over the germ pore, wall ca $1.5 \mu \mathrm{m}$ thick, cinnamon-brown, with a lighter colored, verrucose with verrucae sometimes arranged in circular rows; pedicel short, colorless, deciduous. Detailed view of $U$. euphorbiae is shown in Figures 5 and 6.

When considering the interaction between $C$. truncatum and $U$. euphorbiae on leaves of E. hirta, it must be emphasized that seventy-four percent of the rust pustules present, were encircled by a ring of setose Colletotrichum acervuli, resulting in leaf spots showing reddish-brown edges and light brown necrotic centers showing dark hairy acervuli (Figures 4). The distribution of the acervuli around the rust pustules, and the structural characteristics of both fungi are shown in Figures 5. However, the acervuli were never present in the absence of $U$. euphorbiae pustules. 
This indicates that the infection by the rust fungus promoted physiological changes that led to a limited necrosis of the leaf tissue around the pustules, where the fructification of the Colletotrichum species was formed, as a final phase of its endophytic condition. Colletotrichum species are hemibiotrophs (Munch et al. 2008) that carry a large number of carbohydrate-active-enzyme genes usually expressed prior to penetration and following the transition to necrotrophy (O'Connell et al. 2012). These species show a biotrophic phase that is symptomless, that occurs during the endophytic growth of the fungus. Pellier et al. (2003) indicated that the biotrophic to necrotrophic switch in $C$. lindemuthianum is connected to the ammonium/L-glutamine metabolism. Others (Alkan et al. 2013, Miyara et al. 2012, Prusky \& Yakoby 2003, Shnaiderman et al. 2013) suggested that the signal to start necrotrophy is related to alkalinization due to secretion of ammonia released through protease activity, and amino acid deamination.

In the present case, as $C$. truncatum necrotrophic action leading to abundant acervular production occurred only around the rust pustules, research on the metabolic changes occurring in that specific area are necessary to explain the fact. However, high nutrient concentration around rust pustules is well-documented with major increase in glucose, fructose and hexose phosphates due to invertase activity (Voegele et al. 2006, Walters \& McRoberts 2006). Thus, hypothetically, this would supply the needed nutrients for mycelial growth and reproduction of $C$. truncatum associated with $U$. euphorbiae pustules.

\section{Conflict of Interests}

The authors declare that there are no conflicts of interests.

Acknowledgment: The authors thank CAPES-MEC-BRAZIL for a fellowship to the senior author. Also thanks are given to $\mathrm{CNPq}$, and MCTI-CNPq/PPBIO-Fungos do Cerrado for financial support; Prof. Mariza Sanchez (in memoriam) for assistance with the herbarium work; and Profs. Paulo E.P.S. Câmara and Danilo B. Pinho, for reviewing the manuscript.

\section{References}


Aime MC, 2006. Toward resolving family-level relationships in rust fungi (Uredinales). Mycoscience 47: 112-122.

Alkan N, Espeso EA, Prusky D, 2013. Virulence regulation of phytopathogenic fungi by pH. Antioxid Redox Signal 19:1012-1025.

Bruckart III WL, Eskandari FM, Berner DK, Aime MC, 2012. Comparison of Puccinia acroptili from Eurasia and the USA. Botany 90: 465-471.

Busby PE, Aime MC, Newcombe G, 2012. Foliar pathogens of Populus angustifolia are consistent with a hypothesis of Beringian migration into North America. Fungal Biology 116: 792-801.

CABI, 2016. Invasive Species Compendium. Euphorbia hirta. Accessed at http://www.cabi.org/isc/datasheet/21355, on November 23, 2016.

Chung WH, Tsukiboshi T, Ono Y, Kakishima M, 2004. Morphological and phylogenetic analyses of Uromyces appendiculatus and $U$. vignae on legumes in Japan. Mycoscience 45: 233-244.

Crous PW, Wingfield MJ, Guarro J, Cheewangkoon R, van der Bank M, Swart WJ, Stchigel AM, Cano-Lira JF, Roux J, Madrid H, Damm U, Wood AR, Shuttleworth LA, Hodges CS, Munster M, de Jesus Yanez-Morales M, Zuniga-Estrada L, Cruywagen EM, De Hoog GS, Silvera C, Najafzadeh MJ, Davison EM, Davidson PJN, Barrett MD, Barrett RL, Manamgoda DS, Minnis AM, Kleczewski NM, Flory SL, Castlebury LA, Clay K, Hyde KD, 2013. Fungal Planet description sheets: 154213. Persoonia 31: 188-296.

Crous PW, Groenewald JZ, Risede JM, Hywel-Jones NL, 2004a. Calonectria species and their Cylindrocladium anamorphs: species with sphaeropedunculate vesicles. Studies in Mycology 50: 415-430.

Damm U, Woudenberg JHC, Cannon PF and Crous PW, 2009. Colletotrichum species with curved conidia from herbaceous hosts. Fungal Diersity 39: 45-87.

Deadman ML, Al Sadi AM, Al Maqbali YM, Farr DF, Aime MC, 2011. Additions to the rust fungi (Pucciniales) from northern Oman. Sydowia 63: 155-168. 
Dhingra OD, Sinclair JB, 1995. Basic plant pathology methods. 2nd edn. CRC Press, Boca Raton.

Doyle JJ, Doyle JL, 1990. Isolation of plant DNA from fresh tissue. Focus 12: 13-15.

Edgar RC, 2004. MUSCLE: a multiple sequence alignment method with reduced time and space complexity. BMC Bioinformatics 5: 113.

Farr DF, Rossman AY, 2016. Fungal Databases, Systematic Mycology and Microbiology Laboratory, ARS, USDA. Accessed at http://nt.ars grin.gov/fungaldatabases/ on November 23, 2016.

Glass NL, Donaldson GC, 1995. Development of primer sets designed for use with the PCR to amplify conserved genes from filamentous ascomycetes. Applied and Environmental Microbiology 61: 1323-1330.

Hall T, 2012. BioEdit v 7.0.9: Biological sequence alignment editor for Win95/98/2K/XP/7.

Henricot BA, Denton GA, Lane CB, 2007. First report of Puccinia heucherae on Heuchera spp. in the UK. Plant Pathology 56: 352.

Hyde KD, Nilsson RH, Alias SA, Ariyawansa HA, Blair JE, Cai L, de Cock AWAM, Dissanayake AJ, Glockling SL, Goonasekara ID, Gorczak M, Hahn M, Jayawardena RS, van Kan JAL, Laurence MH, Lévesque CA, Li XH, Liu JK, Maharachchikumbura SSN, Manamgoda DS, Martin FN, McKenzie EHC, McTaggart AR, Mortimer PE, Nair PVR, Pawłowska J, Rintoul TL, Shivas RG, Spies CFJ, Summerell BA, Taylor PWJ, Terhem RB, Udayanga D, Vaghefi N, Walther G, Wilk M, Wrzosek M, Xu JC, Yan JY, Zhou N, 2014. One stop shop: backbones trees for important pytopathogenic genera- I. Fungal Diversity 67:21-125.

Kearse M, Moir R, Wilson A, Stones-Havas S, Cheung M, Sturrock S, Buxton S, Cooper A, Markowitz S, Duran C, Thierer T, Ashton B, Mentjies P and Drummond A, 2012. Geneious Basic: an integrated and extendable desktop software platform for the organization and analysis of sequence data. Bioinformatics 28: 1647-1649. 
Kropp BR, Hansen DR, Wolf PG, Flint KM, Thomson SV, 1997. A study on the phylogeny of the dyer's wood rust fungus and other species of Puccinia from crucifers. Phytopathology 87: 565-571.

Liu M, McCabe E, Chapados JT, Carey J, Wilson SK, Tropiano R, Redhead SA, Lévesque CA, Hambleton S, 2015. Detection and identification of selected cereal rust pathogens by TaqMan ${ }^{\circledR}$ real-time PCR. Can J Plant Pathology 37:92-105.

Maddison WP, Maddison DR, 2016. Mesquite: a modular system for evolutionary analysis. Version 3.10. Accessed at http://mesquiteproject.org, on April 15, 2016.

Maier W, Begerow D, Weiss M, Oberwinkler F, 2003. Phylogeny of the rust fungi: an approach using nuclear large subunit ribosomal DNA sequences. Canadian Journal of Botany 81: 12-23.

Maier W, Wingfield BD, Mennicken M, Wingfield MJ, 2007. Polyphyly and two emerging lineages in the rust genera Puccinia and Uromyces. Mycological Research 111: 176185.

McTaggart AR, Geering ADW and Shivas RG, 2014. Uredinopsis pteridis and Desmella aneimiae, the first rust fungi (Pucciniales) reported on ferns (Pteridophyta) in Australia. Australasian Plant Disease Notes 9: 149.

Miyara I, Shnaiderman C, Meng X, Vargas WA, Díaz-Minguez JM, Thon M, Sherman A, Prusky D, 2012. Role of nitrogen-metabolism genes expressed during pathogenicity of the alkalinizing Colletotrichum gloeosporioides and their differential expression in acidifying pathogens. Molecular Plant-Microbe Interactions 25:125-163.

Moncalvo JM, Wang HH, Hseu RS, 1995. Phylogenetic relationships in Ganoderma inferred from the internal transcribed spacers and 25S ribosomal DNA sequences. Mycologia 87: 223-238.

Munch S, Lingner U, Floss DS, Ludwig N, Sauer N, Deising HB, 2008. The hemibiotrophic lifestyle of Colletotrichum species. Journal of Plant Physiology 165:41-51. 
O`Donnell, E. Cigelnik, 1997. Two different intragenomics rDNA ITS2 types within a monophyletic lineage of the fungus Fusarium are nonorthologous. Molecular Phylogenetics Evolution 7:103-116.

O'Connell RJ, Thon MR, Hacquard S, Amyotte SG, Kleemann J, Torres MF, Damm U, Buiate EA, Epstein L, Alkan N, Altmüller J, Alvarado-Balderrama L, Bauser CA, Becker C, Birren BW, Chen Z, Choi J, Crouch JA, Duvick JP, Farman MA, Gan P, Heiman D, Henrissat B, Howard, M Kabbage, C Koch, B Kracher, Y Kubo, AD Law, M Lebrun, YH Lee RJ, Miyara I, Moore N, Neumann U, Nordström K, Panaccione DG, Panstruga R, Place M, Proctor RH, Prusky D, Rech G, Reinhardt R, Rollins JA, Rounsley S, Schardl CL, Schwartz DC, Shenoy N, Shirasu K, Sikhakolli UR, Stüber K, Sukno SA, Sweigard JA,Takano Y, Takahara H, Trail F, van der Does HC, Voll LM, Will I, Young S, Zeng Q, Zhang J, Zhou S, Dickman MB, Schulze-Lefert P, van Themaat EVL, Ma LJ, Vaillancourt LJ, 2012. Lifestyle transitions in plant pathogenic Colletotrichum fungi deciphered by genome and transcriptome analyses. Nature Genetics 44:1060-65.

Padamsee M, McKenzie EHC, 2014. A new species of rust fungus on the New Zealand endemic plant, Myosotidium, from the isolated Chatham Islands. Phytotaxa 174: 223 230.

Pellier AL, Lauge R, Veneault-Fourrey C, Langin T, 2003. CLNR1, the AREA/NIT2-like global nitrogen regulator of the plant fungal pathogen Colletotrichum lindemuthianum is required for the infection cycle. Molecular Microbiology 48:639-655.

Pfunder M, Schürch S, Roy BA, 2001. Sequence variation and geographic distribution of pseudoflower-forming rust fungi (Uromyces pisi s. lat.) on Euphorbia cyparissias. Mycological Research 105: 57-66.

Posada D, Buckley T, 2004. Model selection and model averaging in phylognetics: advantages of Akaike information criterion and Bayesian approaches over likelihood ratio tests. Systematic Biology. 53: 793-808.

Prusky D, Yakoby N, 2003. Pathogenic fungi: leading or led by ambient pH? Molecular Plant Pathology 4:509-16. 
Rambaut A, 2009. FigTree. Version 1.2.3. Institute of Evolutionary Biology, University of Edinburgh, Edinburgh.

Ronquist F, Teslenko M, van der Mark P, Ayres DL, Darling A, Höhna S, Larget B, Liu L, Suchard MA, Huelsenbeck JP, 2012. Mrbayes 3.2: efficient Bayesian phylogenetic inference and model choice across a large model space. Systematic Biology 61: 539542.

Shnaiderman C, Miyara I, Kobiler I, Sherman A, Prusky D, 2013. Differential activation of ammonium transporters during the accumulation of ammonia by Colletotrichum gloeosporioides and its effect on appressoria formation and pathogenicity. Molecular Plant-Microbe Interaction 26:345-355.

Souza ESC, Chaves ZM, Soares WR, Pinho DB, Dianese JC, 2015. Uromyces hawksworthii nom. nov. for Aecidium goyazense, on Phthirusa stelis (Loranthaceae) from the Brazilian Cerrado. IMA fungus 6: 155-162.

Swofford DL, 2002. PAUP*. Phylogenetic Analyses using parsimony (*and other methods), version 4.0. Sinauer Associates, Inc., Sunderland.

Tamura K, Stecher G, Peterson D, Filipski A, Kumar S, 2013. MEGA 6: molecular evolutionary genetics analysis version 6.0. Molecular Biology and Evolution 30: 27252729.

Templeton MD, Rikkerink EH, Solon SL, Crowhurst RN, 1992. Cloning and molecular characterization of the glyceraldehyde-3-phosphate dehydrogenase-encoding gene and cDNA from the plant pathogenic fungus Glomerella cingulata. Gene 122: 225-230.

Tu JC, 1990. First report of anthracnose caused by Glomerella cingulata on white beans in Ontario, Canada. Plant Disease 74:394.

Vilgalys R, Hester M, 1990. Rapid genetic identification and mapping of enzymatically amplified ribosomal DNA from several Cryptococcus species. Journal of Bacteriology 172: $4238-4246$.

Voegele RT, Wirsel S, Möll U, Lechner M, Mendgen K, 2006. Cloning and characterization of a novel invertase from the obligate biotroph Uromyces fabae and 
analysis of expression patterns of host and pathogen invertases in the course of infection. Molecular Plant-Microbe Interactions 19: 625-634.

Walters DR, McRoberts N, 2006. Plants and biotrophs: a pivotal role for cytokinins? Trends in Plant Sciences 11: 581-586.

White TJ, Burns T, Lee S, Taylor J, 1990. Amplification and direct sequencing of fungal ribosomal RNA genes for phylogenetics. In: Innis MA, Gelfand DH, Sninsky JJ, White TJ (eds), PCR protocols: A guide to methods and applications. Academic Press, San Diego, pp. 315-322.

Yang H-C, Haudenshield JS, Hartman GL, 2014. Colletotrichum incanum sp. nov., a curved-conidial species causing soybean anthracnose in USA. Mycologia 106: 32-42.

Yun HY, Minnis AM, Dixon LJ, Castlebury LA, 2010. First report of Uromyces acuminatus on Honckenya peploides, the endangered seabeach sandwort. Plant Disease 94: 279.

Zuluaga C, Buriticá P, Marín M, 2011. Filogenia de hongos/roya (Uredinales) em la zona andina colombiana mediante el uso de secuencias del ADN ribosomal 28S. Revista de Biología Tropical 59: 517-540. 
Table 1. Primers and respective annealing temperatures used in the pcr amplification.

\begin{tabular}{|c|c|c|c|c|c|}
\hline Fungal species & $\begin{array}{l}\text { Region or } \\
\text { gene }\end{array}$ & Primers & Sequences & $\begin{array}{c}\text { Temp. } \\
\text { Annealing }\end{array}$ & References \\
\hline \multirow{8}{*}{$\begin{array}{l}\text { Colletotrichum } \\
\text { truncatum }\end{array}$} & \multirow{2}{*}{ ITS } & ITS5 & GGAAGTAAAAGTCGTAACAAGG & \multirow{2}{*}{$55^{\circ} \mathrm{C}$} & White et al. (1990) \\
\hline & & ITS4 & GGAAGTAAAAGTCGTAACAAGG & & White et al. (1990) \\
\hline & \multirow{2}{*}{ GAPDH } & GDF1 & GCCGTCAACGACCCCTTCATTGA & \multirow{2}{*}{$58^{\circ} \mathrm{C}$} & Templeton et al. (1992) \\
\hline & & GDR1 & GGGTGGAGTCGTACTTGAGCATGT & & Templeton et al. (1992) \\
\hline & \multirow{2}{*}{ HIS } & $\mathrm{CY} 1 \mathrm{H} 3 \mathrm{~F}$ & AGGTCCACTGGTGGCAAG & \multirow{2}{*}{$58^{\circ} \mathrm{C}$} & Crous et al. (2004) \\
\hline & & CYlH3R & AGCTGGATGTCCTTGACTG & & Crous et al. (2004) \\
\hline & \multirow{2}{*}{ TUB2 } & $\mathrm{T} 1$ & AACATGCGTGAGATTGTAAGT & \multirow{2}{*}{$62^{\circ} \mathrm{C}$} & Glass \& Donaldson (1995) \\
\hline & & $\mathrm{Bt} 2 \mathrm{~b}$ & ACCCTCAGTGTAGTGACCCTTGGC & & O’Donnell \& Cigelnik (1997) \\
\hline \multirow{6}{*}{$\begin{array}{l}\text { Uromyces } \\
\text { euphorbiae }\end{array}$} & \multirow{2}{*}{ ITS } & ITS4-rust & CAGATTACAAATTTGGGCT & \multirow{2}{*}{$55^{\circ} \mathrm{C}$} & Pfunder et al. (2001) \\
\hline & & ITS5-u & AAGGTTTCTGTAGGTG & & Pfunder et al. (2001) \\
\hline & \multirow{4}{*}{ LSU } & Rust2inv & GATGAAGAACACAGTGAAA & \multirow{2}{*}{$55^{\circ} \mathrm{C}$} & Aime (2006) \\
\hline & & LR6 & CGCCAGTTCTGCTTACC & & Vilgalys \& Hester (1990) \\
\hline & & LR0R & ACCCGCTGAACTTAAGC & \multirow{2}{*}{$53^{\circ} \mathrm{C}$} & Moncalvo et al. (1995) \\
\hline & & Rust1 & GCTTACTGCСТTCСТCAATC & & Kropp et al. (1997) \\
\hline
\end{tabular}


Table 2. GenBank accesses from Colletotrichum truncatum (Endophytic and Acervular) and all other species included in this study.

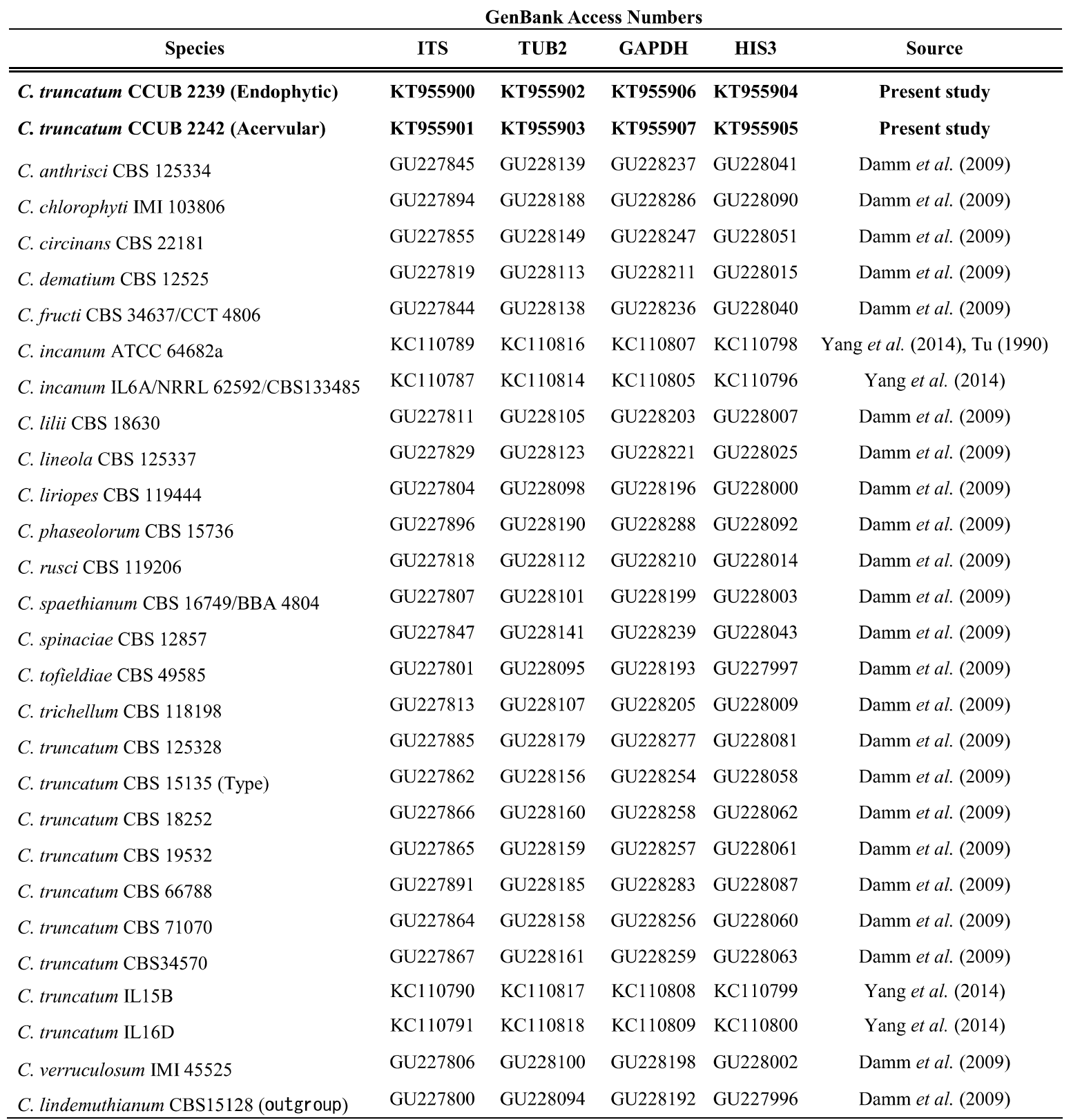


Table 3. GenBank accession numbers of Uromyces euphorbiae, and of all other species included in this study.

\begin{tabular}{|c|c|c|c|}
\hline Species & Host (Family) & $\begin{array}{c}\text { GenBank } \\
\text { Access Numbers } \\
\text { (LSU)* } \\
\end{array}$ & Source and Country \\
\hline Uromyces euphorbiae UB23207 (Ecial) & Euphorbia hirta (Euphorbiaceae) & KU133292 & Present study, Brazil \\
\hline Uromyces euphorbiae UB22311 (Telial/Uredinial) & Euphorbia hirta (Euphorbiaceae) & KU133293 & Present study, Brazil \\
\hline Cumminsiella mirabilissima & Mahonia aquifolium (Berberidaceae) & DQ354531 & Aime (2006) Germany \\
\hline Cumminsiella mirabilissima & Mahonia aquifolium (Berberidaceae) & AF426206 & Maier et al. (2003) Germany \\
\hline Endophyllum euphorbiae-sylvaticae & Euphorbia amygdaloides (Euphorbiaceae) & $\mathrm{AF} 426200$ & Maier et al. (2003) Germany \\
\hline Puccinia balsamorrhizae & Balsamorhiza sagittata (Asteraceae) & JN204182 & Bruckart et al. (2012) USA \\
\hline Puccinia coronata & Rhamnus cathartica (Rhamnaceae) & DQ354526 & Aime (2006) USA \\
\hline Puccinia graminis & Hordeum sp. (Poaceae) & HQ412648 & Deadman et al. (2011) \\
\hline Puccinia heucherae & Heuchera sp. (Saxifragaceae) & DQ359702 & Henricot et al. (2007) England \\
\hline Puccinia malvacearum & Alcea rosea (Malvaceae) & AF426205 & Maier et al. (2003) Germany \\
\hline Puccinia melanocephala & Saccharum sp. (Poaceae) & KP201838 & Wang et al. Unpubl. (2014) \\
\hline Puccinia peperomiae & Piper sp. (Piperaceae) & EU851146 & Zuluaga et al. (2011) Colombia \\
\hline Uromyces acuminatus & Honkenya peploides (Caryophyllaceae) & GU109282 & Yun et al. (2010) England \\
\hline Uromyces appendiculatus & Phaseolus vulgaris (Fabaceae) & KM249870 & McTaggart (2014) Australia \\
\hline Uromyces ari-triphylli & Arisaema triphyllum (Araceae) & DQ354529 & Aime (2006) USA \\
\hline Uromyces ficariae & Ranunculus ficaria (Ranunculaceae) & AF426204 & Maier et al. (2003) Germany \\
\hline Uromyces gageae & Gagea lutea (Liliaceae) & AF426208 & Maier et al. (2003) Alemanha \\
\hline Uromyces galegae & Galega officinalis (Fabaceae) & DQ250133 & Aime (2006) USA \\
\hline Uromyces ixiae & Babiana tubulosa (Iridaceae) & DQ917738 & Maier et al. (2007) South Africa \\
\hline Uromyces ixiae & Babiana cf. sambucina (Iridaceae) & DQ917739 & Maier et al. (2007) South Africa \\
\hline Uromyces junci & Pulicaria dysenterica (Asteraceae) & AF426203 & Maier et al. (2003) Germany \\
\hline Uromyces phaseoli & Pisum sp. (Fabaceae) & HQ317516 & Unpublished \\
\hline Uromyces striatus & Medicago sp. (Fabaceae) & HQ412652 & Deadman et al. (2011) Oman \\
\hline Uromyces striatus & Euphorbia sp. (Euphorbiaceae) & HQ317512 & Liu et al. (2015) Canada \\
\hline Uromyces trifolii & Trifolium repens (Fabaceae) & GU936634 & Zuluaga et al. (2011) Colombia \\
\hline Uromyces viciae-fabae & Vicia faba (Fabaceae) & KJ716343 & $\begin{array}{c}\text { Padamse \& McKenzie (2014) } \\
\text { New Zealand }\end{array}$ \\
\hline Uromyces viciae-fabae & Vicia pannonica (Fabaceae) & AF426199 & Maier et al. (2003) Central Europe \\
\hline Uromyces viciae-fabae & Unpublished & AY745695 & Matheny \& Hibbet Unpubl. (2004) \\
\hline Uromyces vignae & Vigna unguiculata (Fabaceae) & AB115649 & Chung et al. (2004) Japan \\
\hline Uromyces hawksworthii & Phthirusa stelis (Loranthaceae) & KR821139 & Souza et al. (2015) Brazil \\
\hline Uromyces hawksworthii & Phthirusa stelis (Loranthaceae) & KR821140 & Souza et al. (2015) Brazil \\
\hline Uromyces pisi & Euphorbia cyparissias (Euphorbiaceae) & AF426201 & Maier et al. (2003) Central Europe \\
\hline Uromyces scutellatus & Euphorbia cyparissias (Euphorbiaceae) & DQ917713 & Maier et al. (2007) South Africa \\
\hline Melampsora larici-populina (outgroup) & Populus $\mathrm{x}$ canadensis (Salicaceae) & JQ042250 & Busby et al. (2012) USA \\
\hline
\end{tabular}

* LSU: rDNA large subunit 


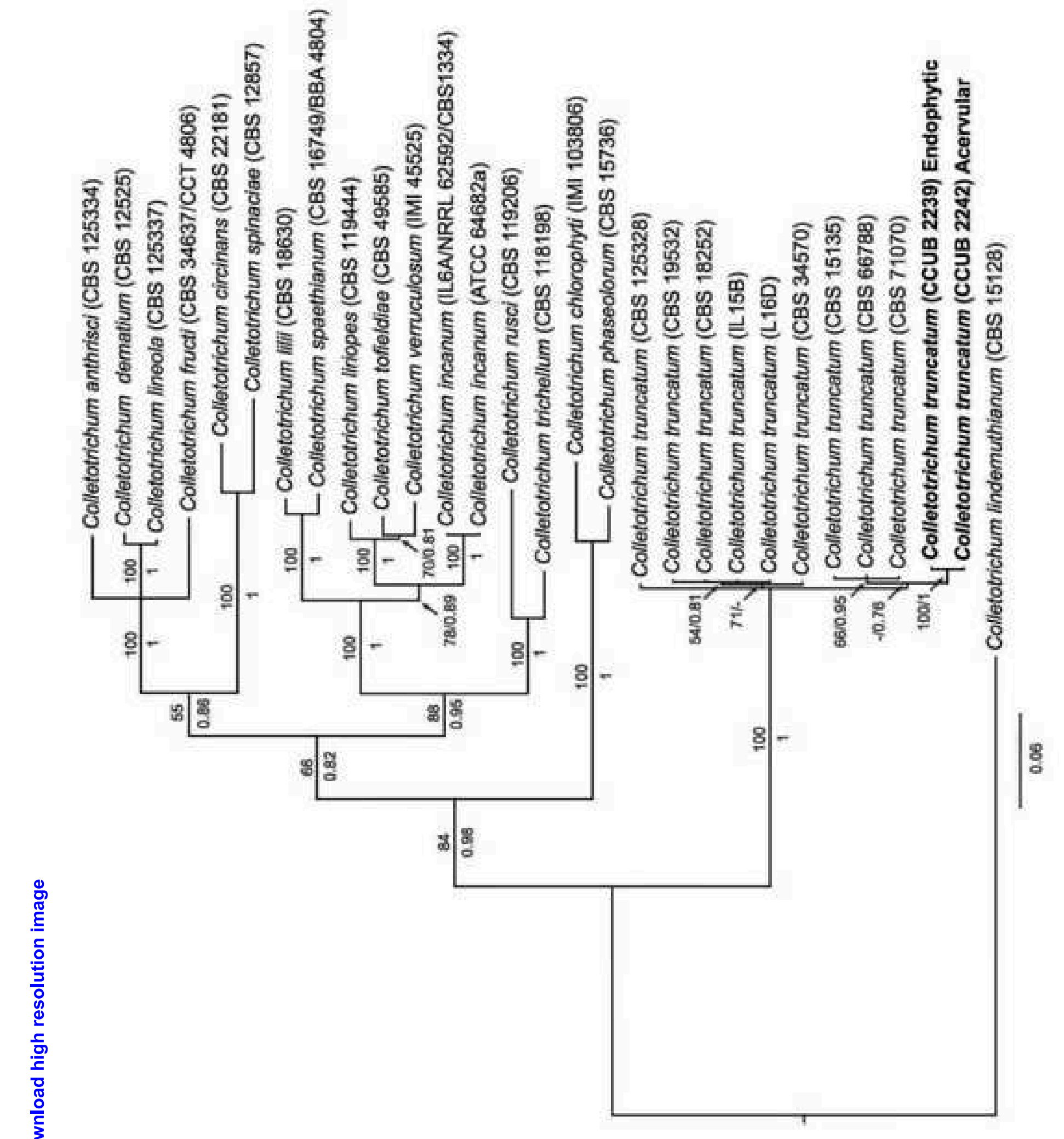




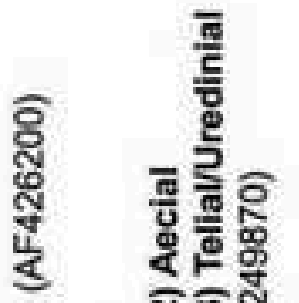

중ํำ

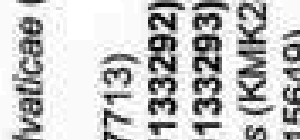

๘

कㅇํㅇ

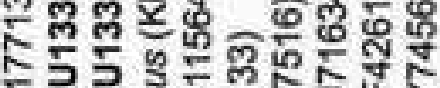

ส্

के

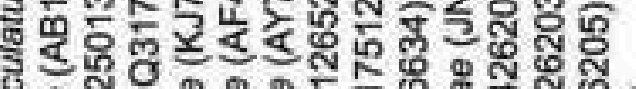

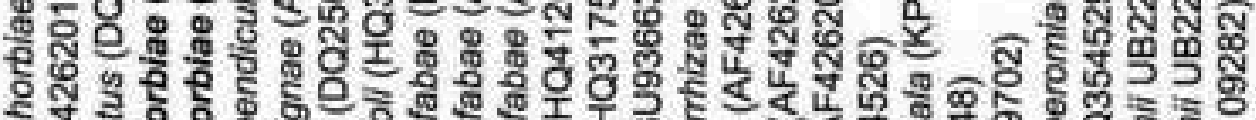



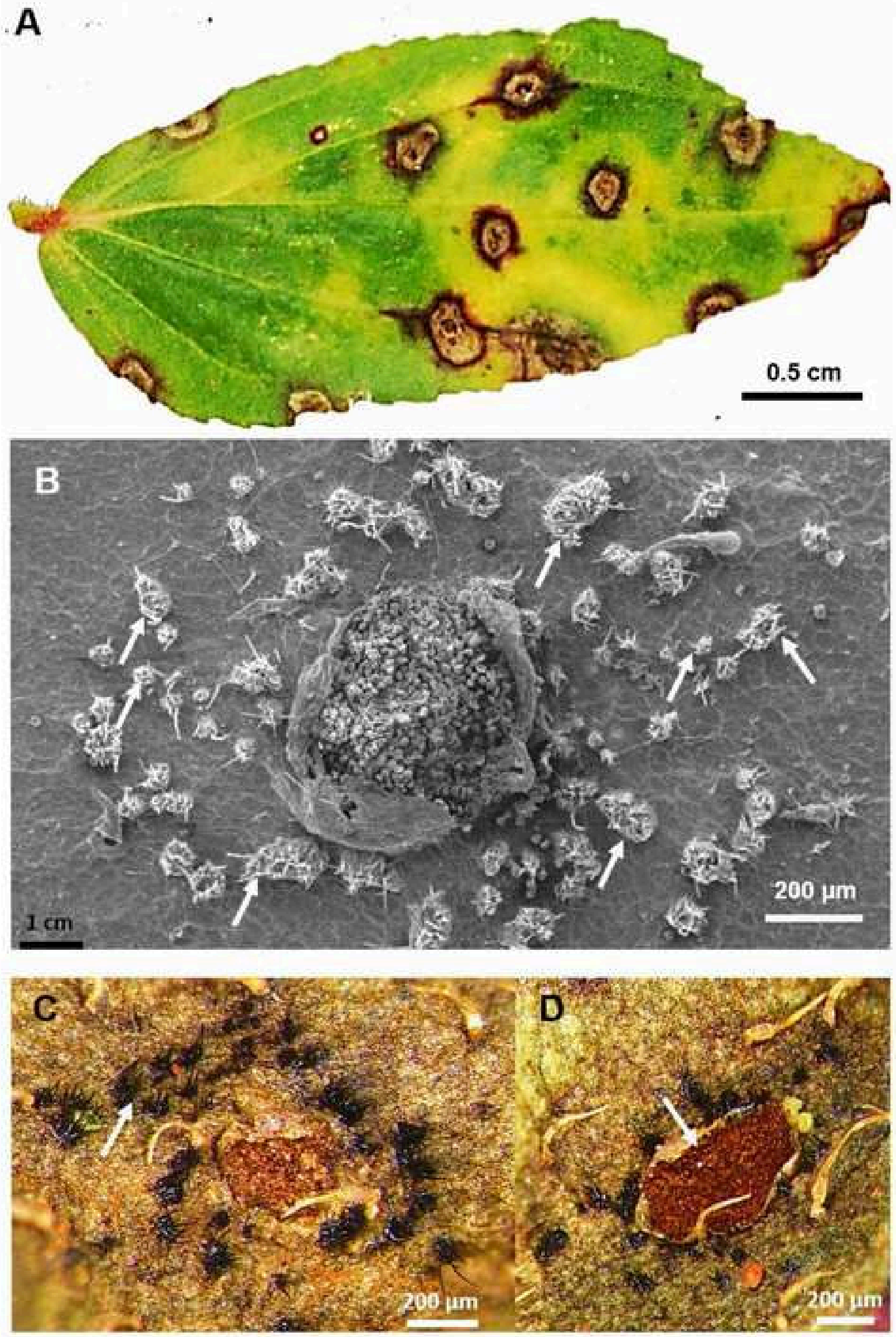


\section{Figure(s)}

Click here to download high resolution image
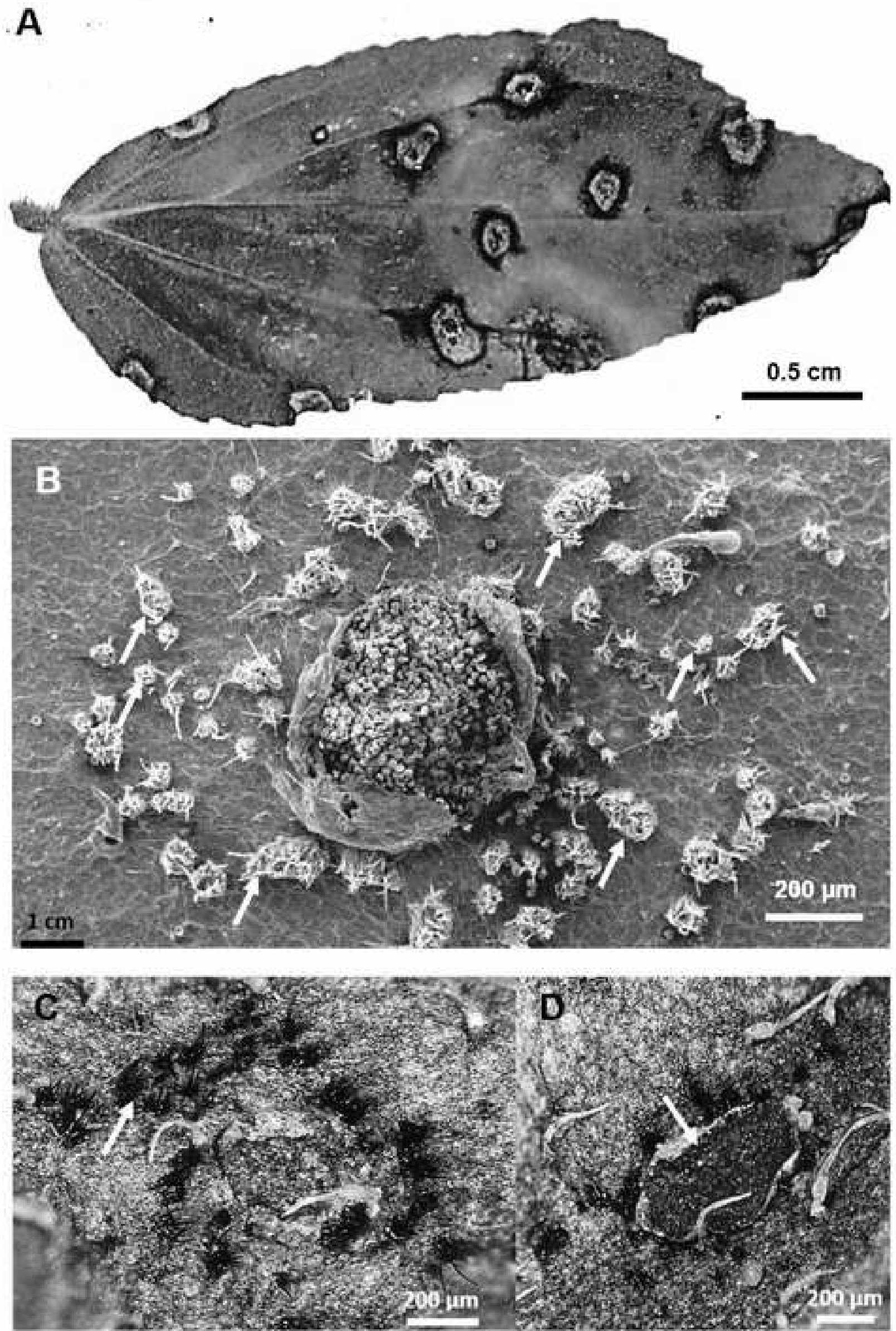


\section{Figure(s)}

Click here to download high resolution image
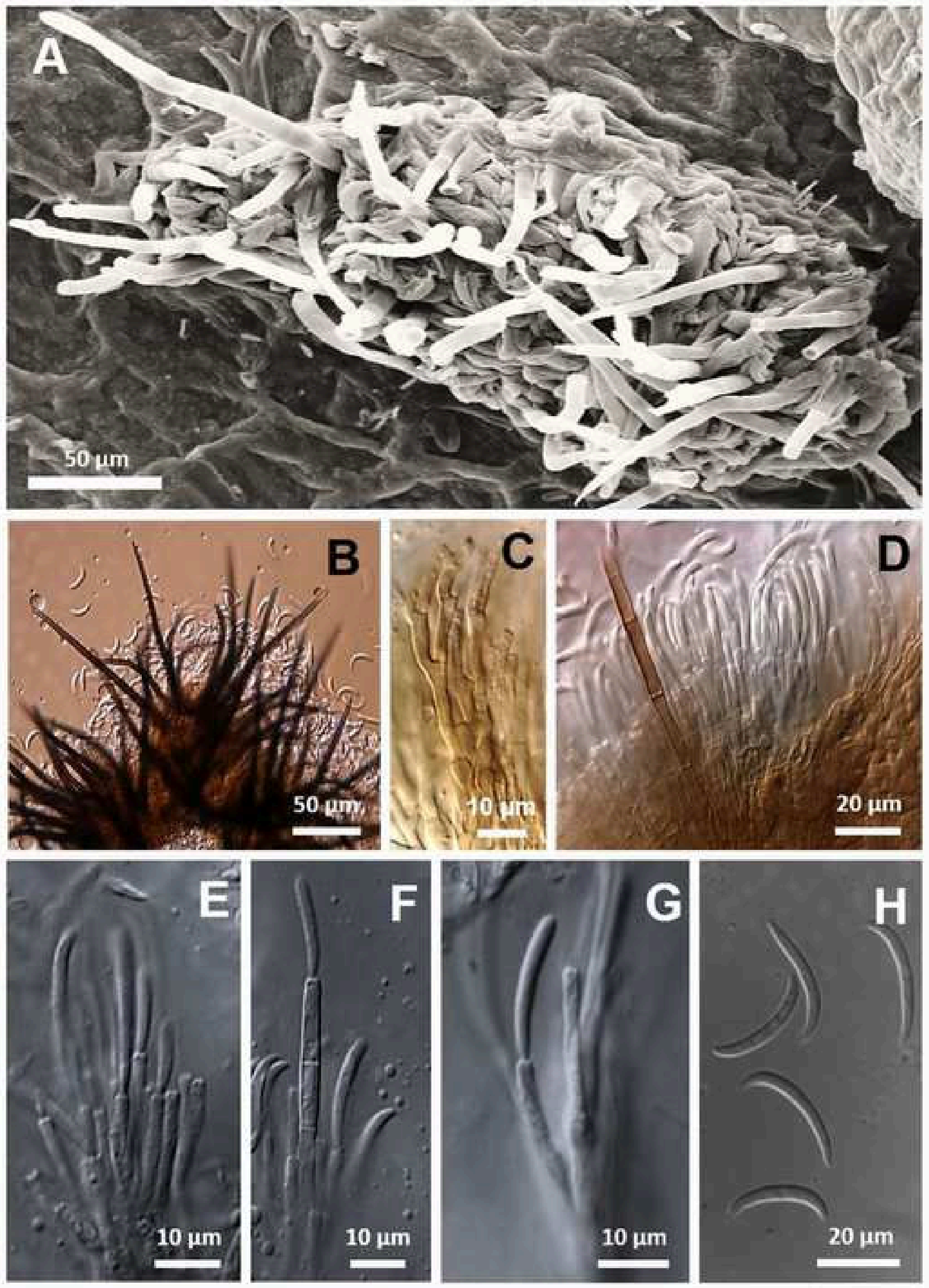


\section{Figure(s)}

Click here to download high resolution image
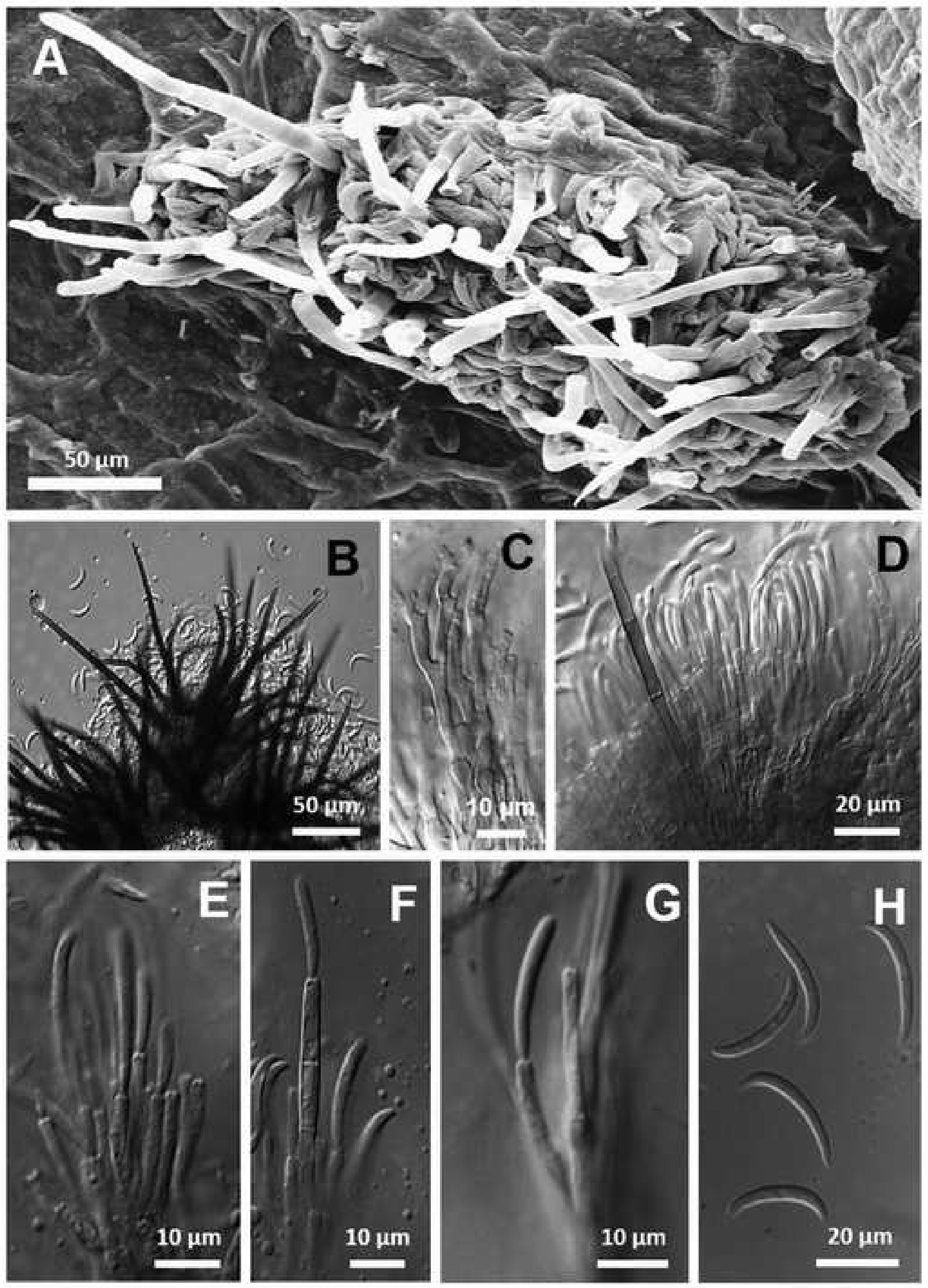

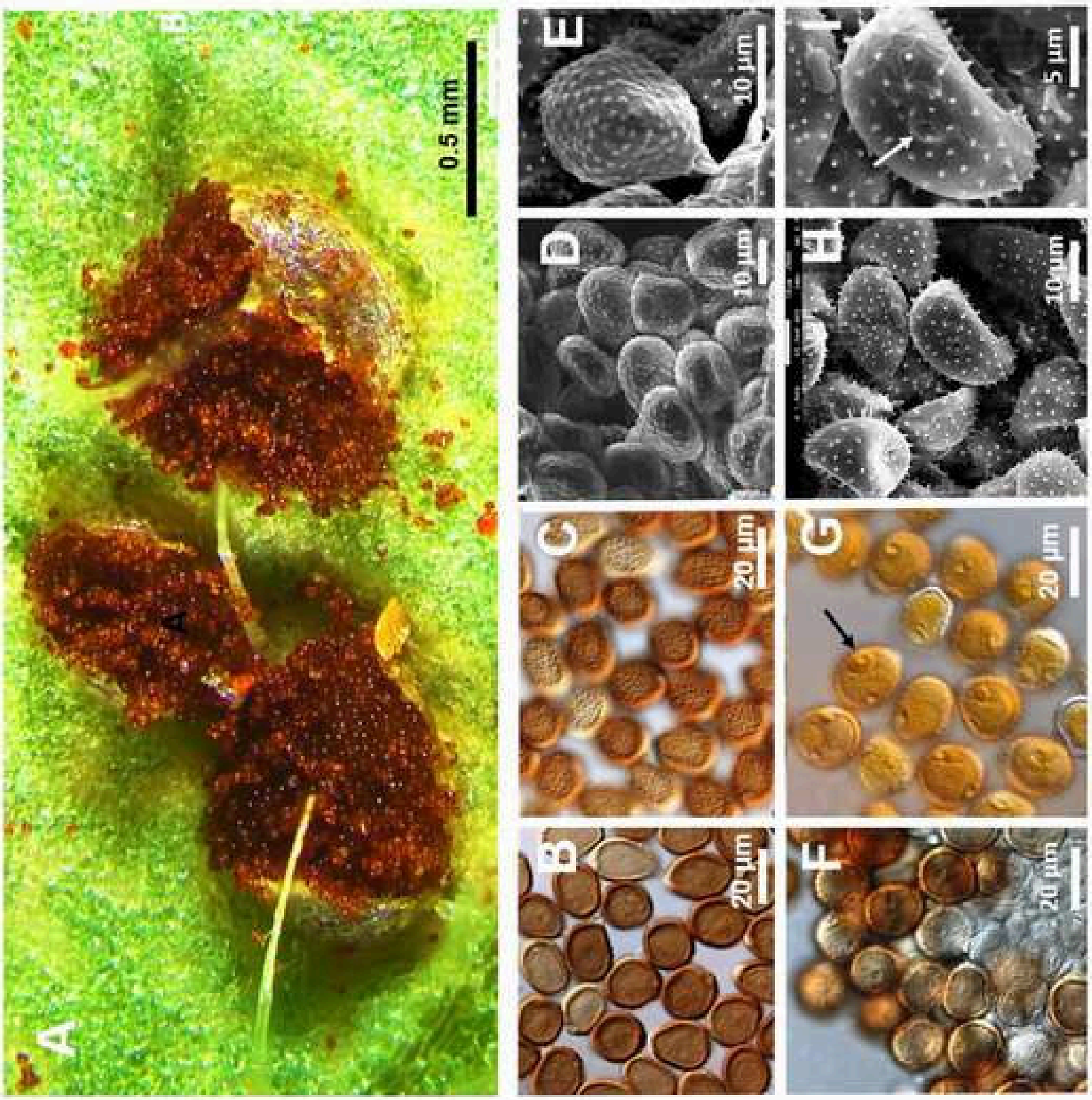

号 

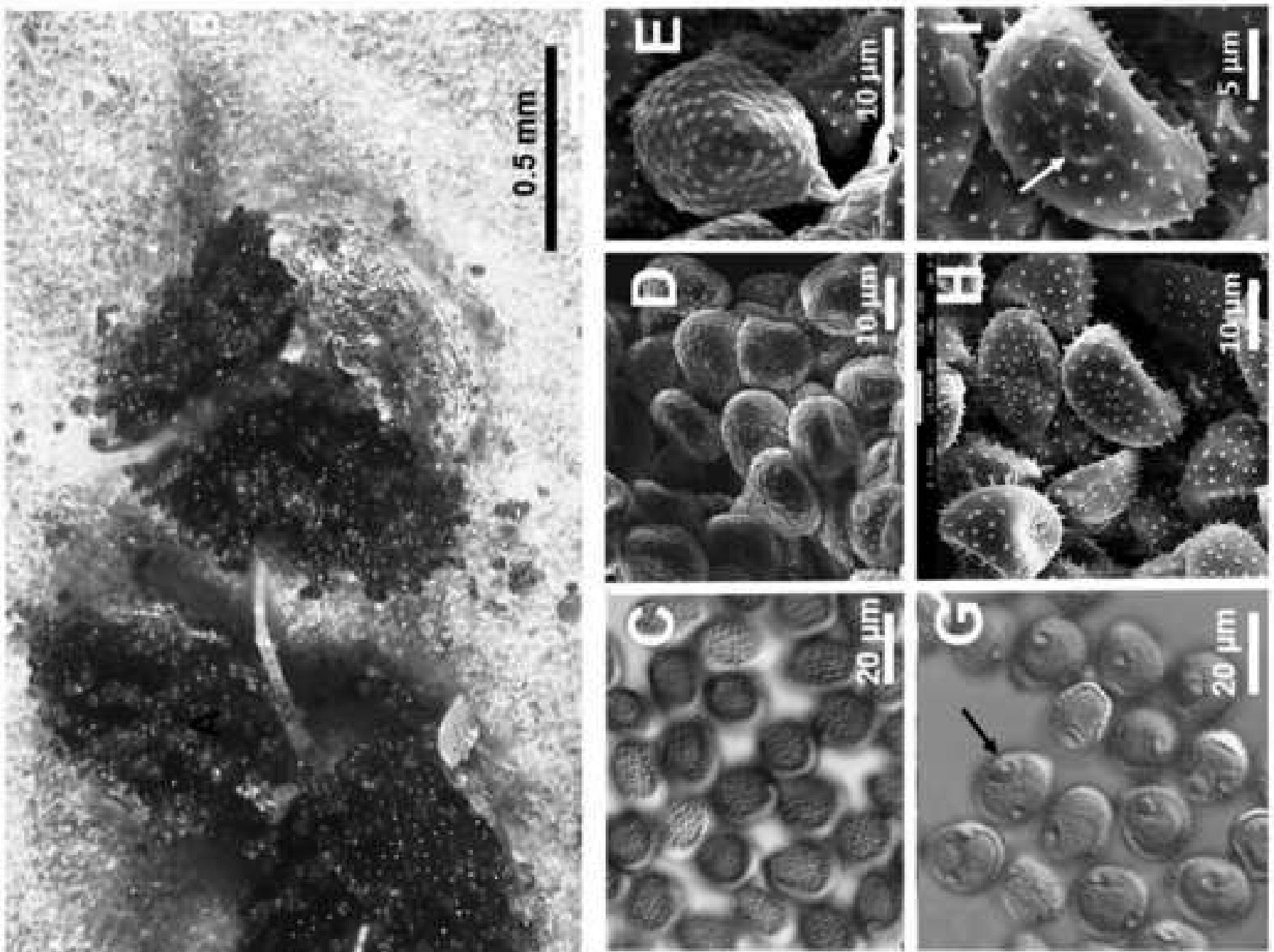

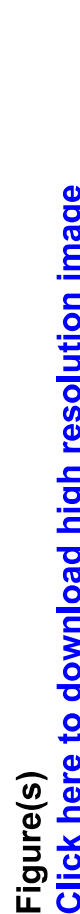
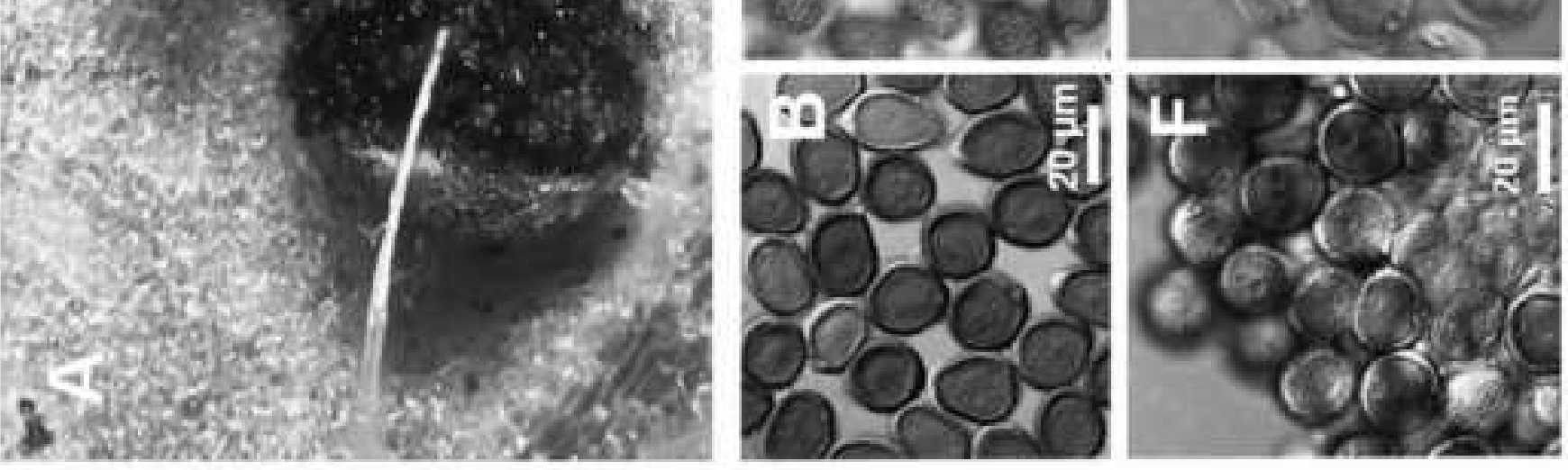

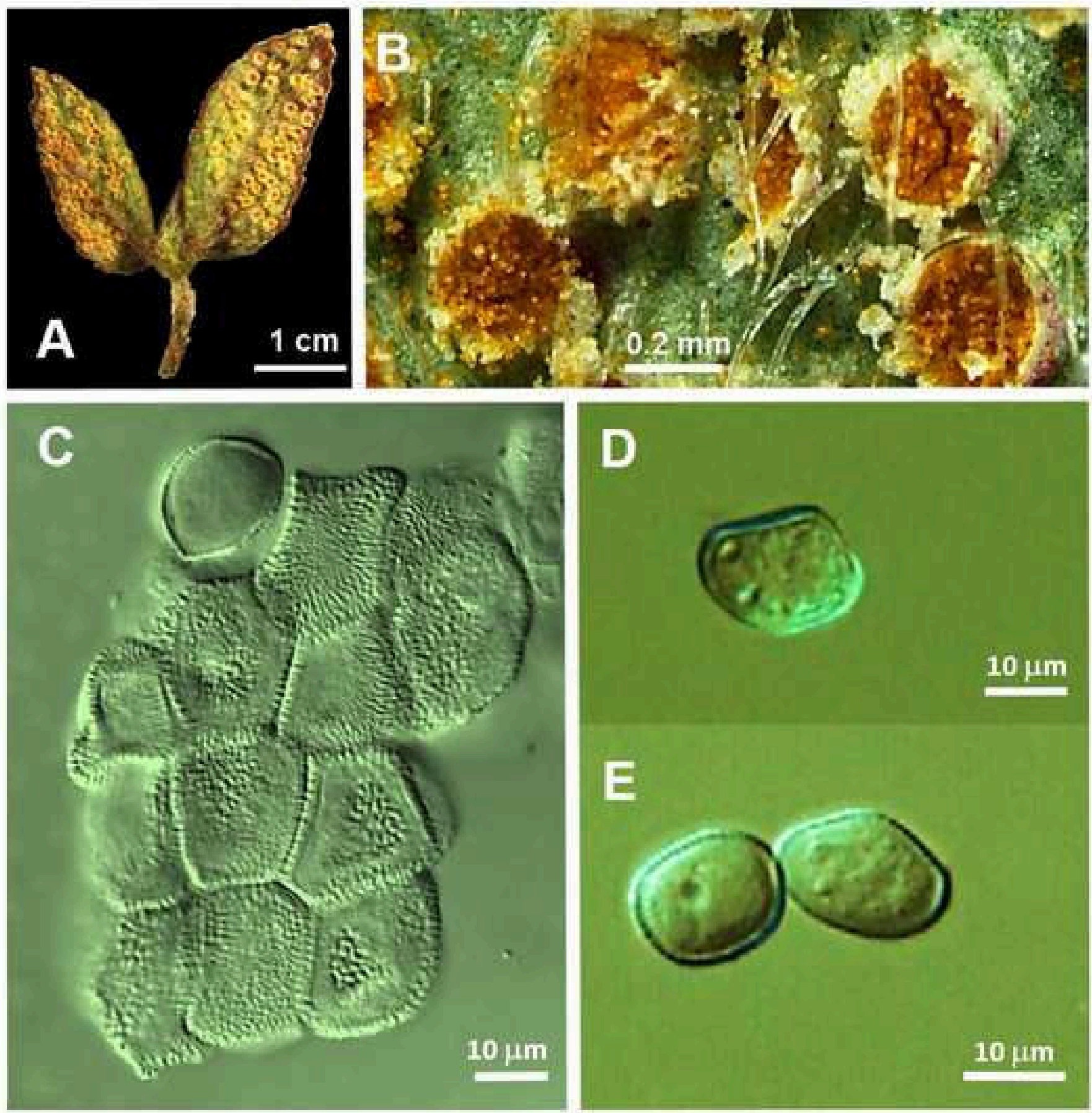

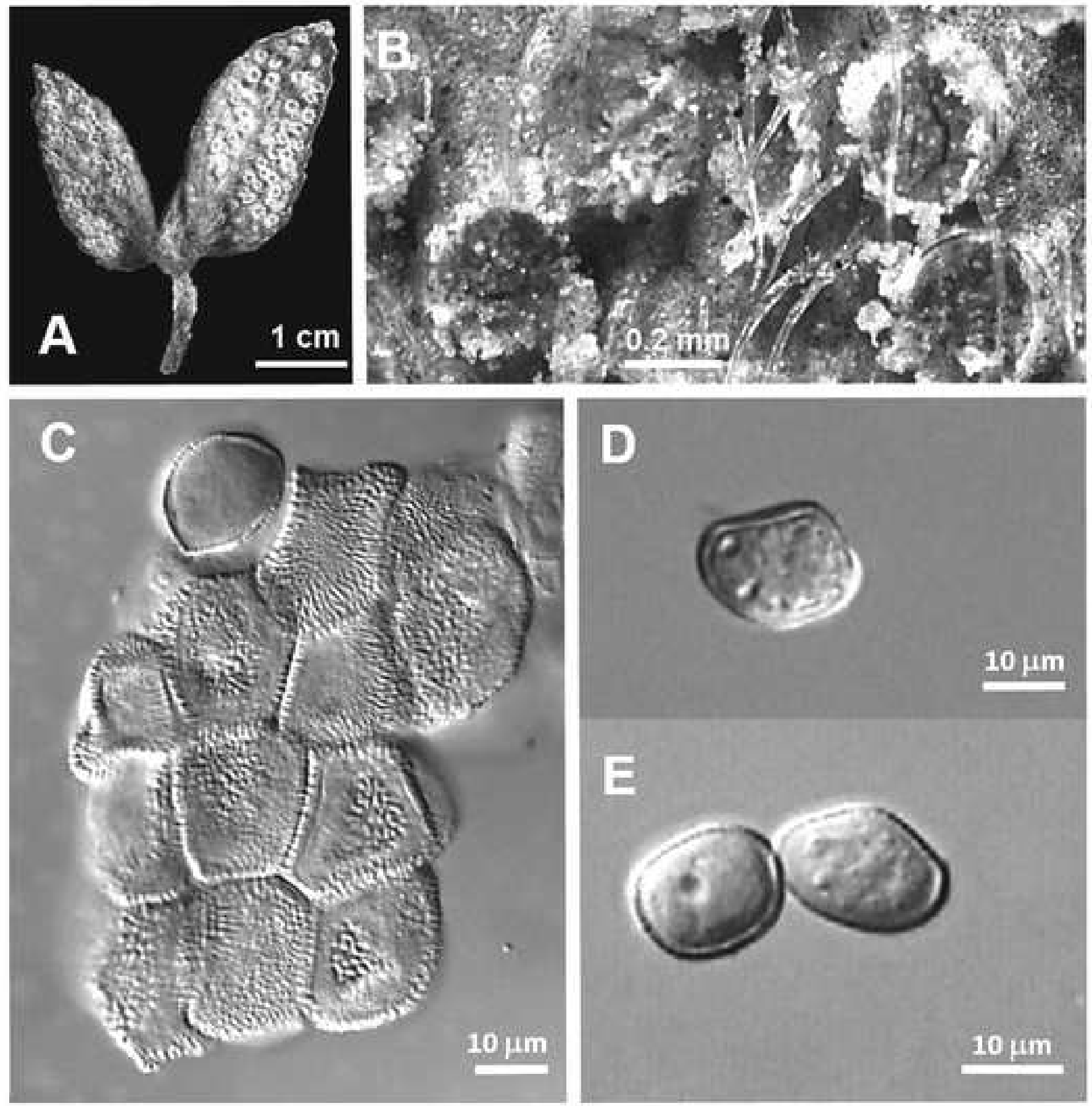